\title{
FINAL \\ ENVIRONMENTAL IMPACT STATEMENT FOR THE JEA CIRCULATING FLUIDIZED BED COMBUSTOR PROJECT
}

JACKSONVILLE, FLORIDA

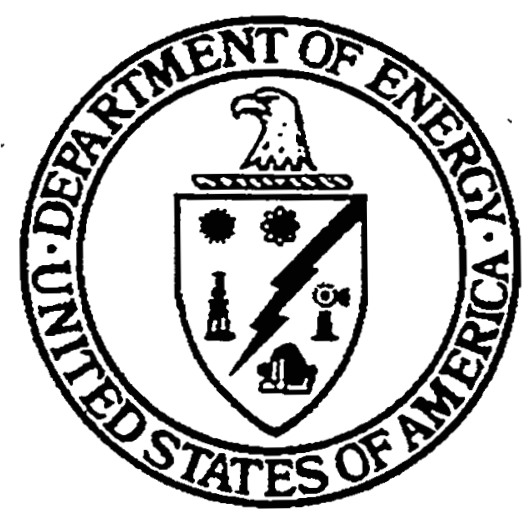

June 2000 


\section{DISCLAIMER}

This report was prepared as an account of work sponsored by an agency of the United States Government. Neither the United States Government nor any agency thereof, nor any of their employees, make any warranty, express or implied, or assumes any legal liability or responsibility for the accuracy, completeness, or usefulness of any information, apparatus, product, or process disclosed, or represents that its use would not infringe privately owned rights. Reference herein to any specific commercial product, process, or service by trade name, trademark, manufacturer, or otherwise does not necessarily constitute or imply its endorsement, recommendation, or favoring by the United States Government or any agency thereof. The views and opinions of authors expressed herein do not necessarily state or reflect those of the United States Government or any agency thereof. 


\section{DISCLAIMER}

Portions of this document may be illegible in electronic image products. Images are produced from the best available original document. 


\title{
RESPONSIBLE AGENCY
}

\author{
U.S. Department of Energy (DOE)
}

\section{TITLE}

Final Environmental Impact Statement for the JEA Circulating Fluidized Bed Combustor Project; Jacksonville, Duval County, Florida

\section{CONTACT}

Additional copies or information concerning this final environmental impact statement (EIS) can be obtained from Ms. Lisa K. Hollingsworth, National Environmental Policy Act (NEPA) Document Manager, U.S. Department of Energy, National Energy Technology Laboratory, 3610 Collins Ferry Road, P. O. Box 880, Morgantown, WV 26507-0880. Telephone: (304) 285-4992. Fax: (304) 285-4403. E-mail: lisa.hollingsworth@netl.doe.gov.

For general information on DOE's NEPA process, contact Ms. Carol M. Borgstrom, Director, Office of NEPA Policy and Assistance (EH-42), U.S. Department of Energy, 1000 Independence Avenue, SW, Washington, DC 20585. Telephone: (202) 586-4600, or leave a message at (800) 472-2756.

Fax: (202) 586-7031.

\section{ABSTRACT}

This EIS assesses environmental issues associated with constructing and demonstrating a project that would be cost-shared by DOE and JEA (formerly the Jacksonville Electric Authority) under the Clean Coal Technology Program. The project would demonstrate circulating fluidized bed (CFB) combustion technology at JEA's existing Northside Generating Station in Jacksonville, Florida, about 9 miles northeast of the downtown area of Jacksonville. The new CFB combustor would use coal and petroleum coke to generate nearly $300 \mathrm{MW}$ of electricity by repowering the existing Unit 2 steam turbine, a 297.5-MW unit that has been out of service since 1983. The proposed project is expected to demonstrate emission levels of sulfur dioxide $\left(\mathrm{SO}_{2}\right)$, oxides of nitrogen $\left(\mathrm{NO}_{x}\right)$, and particulate matter that would be lower than Clean Air Act limits while at the same time producing power more efficiently and at less cost than conventional coal utilization technologies. At their own risk, JEA has begun initial construction activities without DOE funding. Construction would take approximately two years and, consistent with the original JEA schedule, would be completed in December 2001. Demonstration of the proposed project would be conducted during a 2-year period from March 2002 until March 2004. In addition, JEA plans to repower the currently operating Unit 1 steam turbine about 6 to 12 months after the Unit 2 repowering without cost-shared funding from DOE. Although the proposed project consists of only the Unit 2 repowering, this EIS analyzes the Unit 1 repowering as a related action. The EIS also considers three reasonably foreseeable scenarios that could result from the no-action alternative in which DOE would not provide cost-shared funding for the proposed project. The proposed action, in which DOE would provide cost-shared funding for the proposed project, is DOE's preferred alternative.

The EIS evaluates the principal environmental issues, including air quality, traffic, noise, and ecological resources, that could result from construction and operation of the proposed project. Key findings include that maximum modeled increases in ground-level concentrations of $\mathrm{SO}_{2}$, nitrogen dioxide $\left(\mathrm{NO}_{2}\right)$, and particulate matter (for the proposed project alone or in conjunction with the related action) would always be less than $10 \%$ of their corresponding standards for increases in pollutants. For potential cumulative air quality impacts, results of modeling regional sources and the proposed project indicate that the maximum 24-hour average $\mathrm{SO}_{2}$ concentration would closely approach (i.e., 97\%) but not exceed the corresponding 
Florida standard. After the Unit 1 repowering, results indicate that the maximum 24-hour average $\mathrm{SO}_{2}$ concentration would be $91 \%$ of the Florida standard. Concentrations for other averaging periods and pollutants would be lower percentages of their standards. Regarding toxic air pollutants from the proposed project, the maximum annual cancer risk to a member of the public would be approximately 1 in 1 million; given the conservative assumptions in the estimate, the risk would probably be less. With regard to threatened and endangered species, impacts to manatees, gopher tortoises, and other species would be negligible or non-existent. Construction-induced traffic would result in noticeable congestion. In the unlikely event that all coal were transported by rail, up to 3 additional trains per week would exacerbate impacts associated with noise, vibration, and blocked roads at on-grade rail crossings. Additional train traffic could be minimized by relying more heavily on barges and ships for coal transport, which is likely to be a more economic fuel delivery mode. During construction of the proposed project, noise levels would increase from the current operational levels. Except possibly during steam blowouts and possibly during operation of equipment used to construct a nearby segment of a conveyor, construction noise should not appreciably affect the background noise of nearby residences or exceed local noise limitations. The preferred alternative for management of the combustion ash would be to sell it as a by-product to offsite customers. If more than approximately $70 \%$ of the ash could be sold over the 30-year lifetime of Northside Generating Station, the 40-acre storage site would be sufficient for complete containment.

\section{AVAILABILITY}

This final EIS and the draft EIS are available for inspection in the following public reading rooms.

- U.S. Department of Energy, Freedom of Information Reading Room, Room 1E-190, Forrestal Building, 1000 Independence Avenue SW, Washington, DC 20585

- U.S. Department of Energy, National Energy Technology Laboratory, 3610 Collins Ferry Road, P. O. Box 880, Morgantown, WV 26507-0880

- Highlands Branch Library, 1826 Dunn Avenue, Jacksonville, FL 32218

The EIS is also available on the internet at http://tis.eh.doe.gov/nepa/docs/docs.htm.

\section{PUBLIC PARTICIPATION}

DOE encourages public participation in the NEPA process. Accordingly, a public scoping meeting was held in Jacksonville, Florida, on December 3, 1997. The public was encouraged to provide oral comments at the scoping meeting and to submit written comments to DOE by the close of the scoping period on December 31, 1997. A public hearing on the draft EIS was held in Jacksonville, Florida, on September 30, 1999. The public was encouraged to provide oral comments at the hearing and to submit written comments to DOE by the close of the comment period on October 15, 1999. In preparing the draft and final EIS, DOE considered both oral and written comments.

\section{CHANGES FROM THE DRAFT EIS}

All changes, which have been made to improve the usefulness of the document to the decision maker and to be responsive to the public, are shown in a boldface italics font (as is this paragraph) except for Appendix $G$, which contains the comments and responses on the draft EIS.

Changes from the draft EIS are shown in a boldface italics font. 


\section{TABLE OF CONTENTS}

LIST OF FIGURES $\ldots \ldots \ldots \ldots \ldots \ldots \ldots \ldots \ldots \ldots \ldots \ldots \ldots \ldots \ldots \ldots \ldots \ldots \ldots \ldots \ldots$

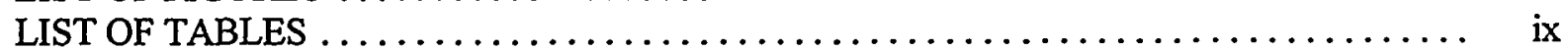

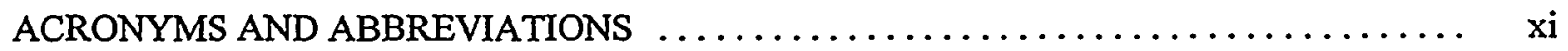

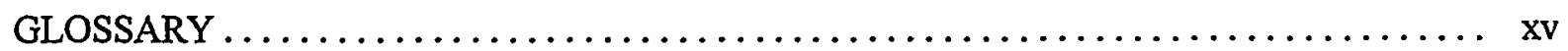

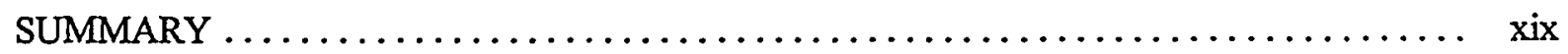

1. PURPOSE OF AND NEED FOR THE AGENCY ACTION $\ldots \ldots \ldots \ldots \ldots \ldots \ldots \ldots \ldots \ldots$.

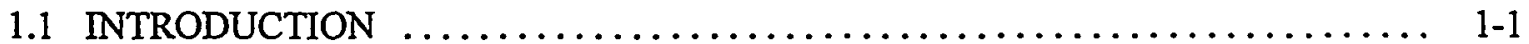

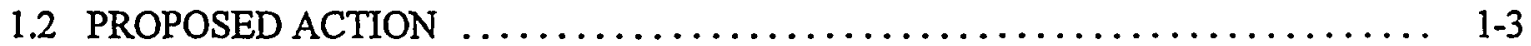

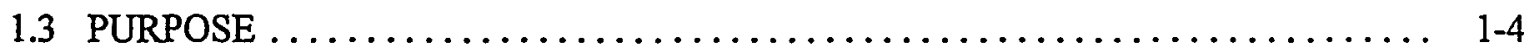

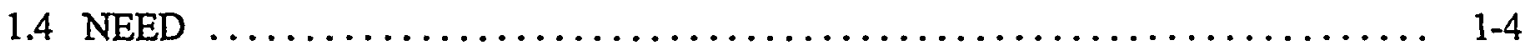

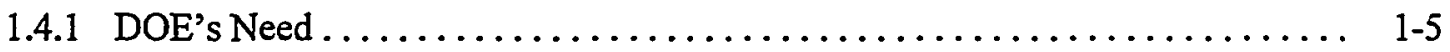

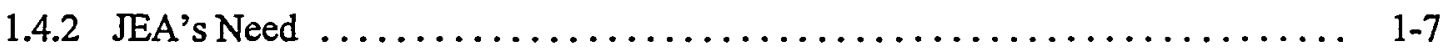

1.5 NATIONAL ENVIRONMENTAL POLICY ACT STRATEGY $\ldots \ldots \ldots \ldots \ldots \ldots \ldots$

1.6 SCOPE OF THE ENVIRONMENTAL IMPACT STATEMENT $\ldots \ldots \ldots \ldots \ldots \ldots \ldots 1-11$

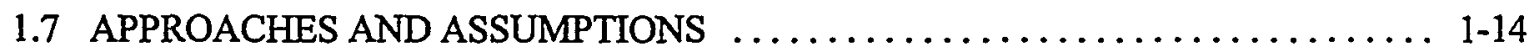

2. THE PROPOSED ACTION AND ALTERNATIVES $\ldots \ldots \ldots \ldots \ldots \ldots \ldots \ldots \ldots \ldots \ldots$

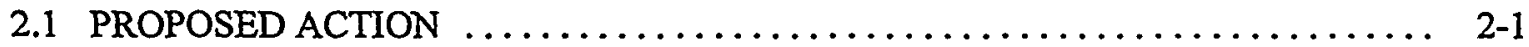

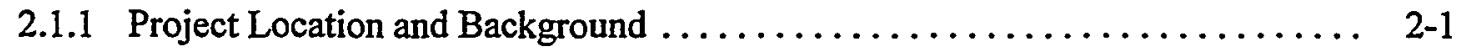

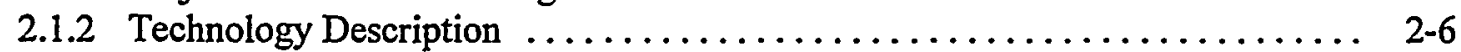

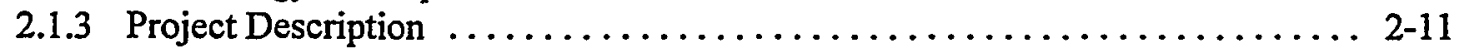

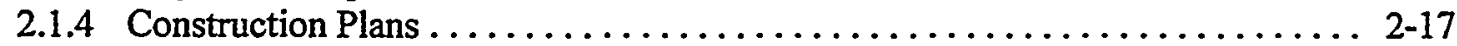

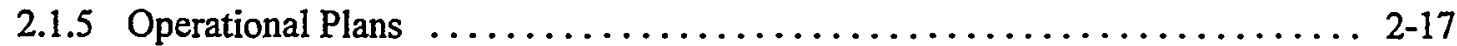

2.1.6 Resource Requirements ............................ 2-18

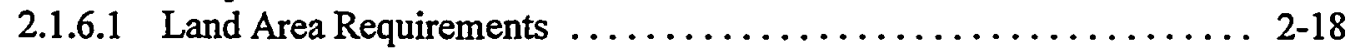

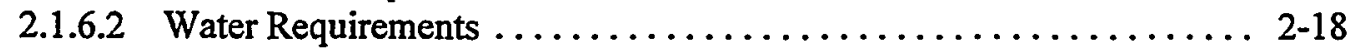

2.1.6.3 Fuel Requirements .......................... 2-22

2.1.6.4 Construction and Other Materials ................... 2-22

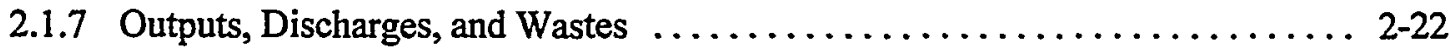

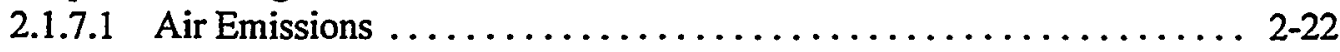

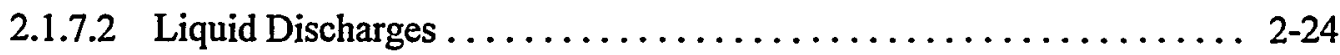

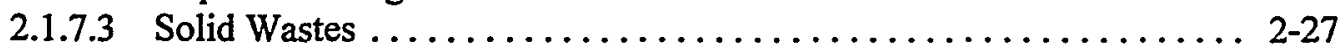

2.1.7.4 Toxic and Hazardous Materials .................... 2-27

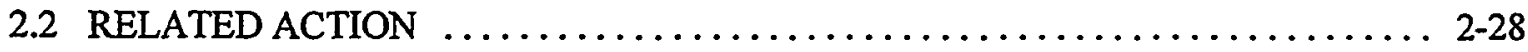

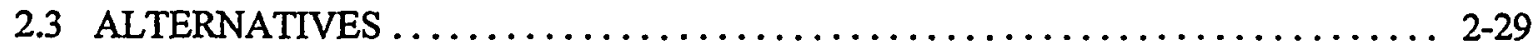

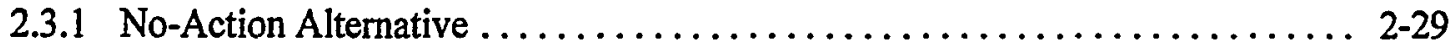

2.3.2 Alternatives Dismissed from Further Consideration .............. 2-31

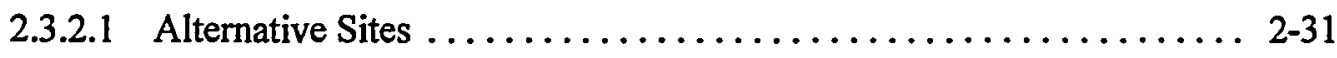

2.3.2.2 Alternative Technologies ...................... 2-43

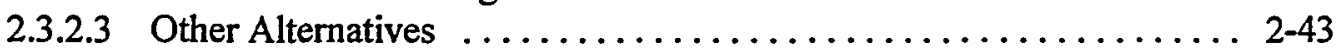

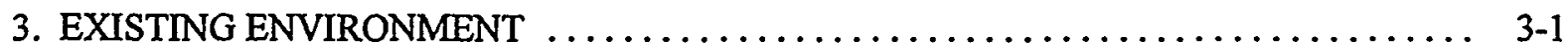

3.1 SITE DESCRIPTION, AESTHETICS, AND LAND USE $\ldots \ldots \ldots \ldots \ldots \ldots \ldots \ldots \ldots \ldots \ldots \ldots \ldots \ldots \ldots$

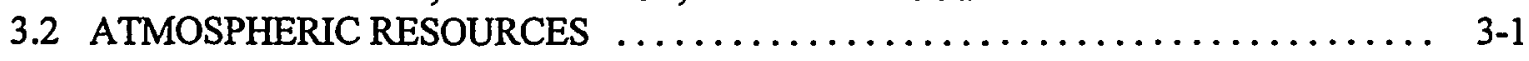

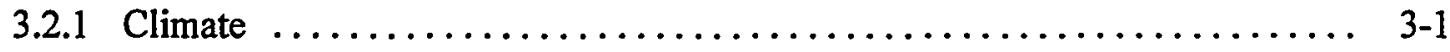




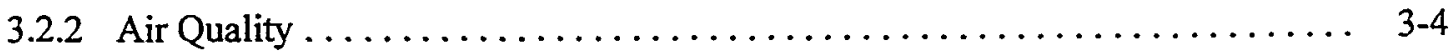

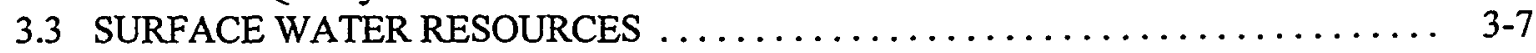

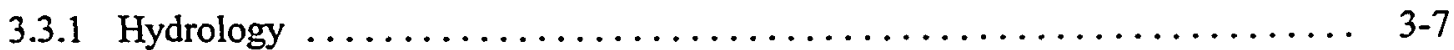

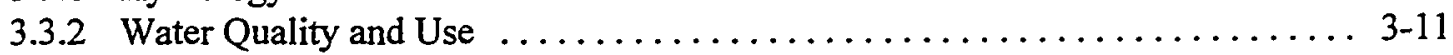

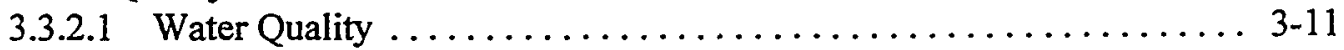

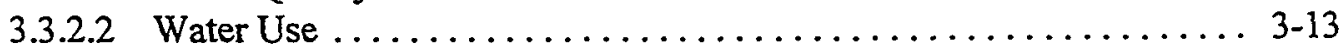

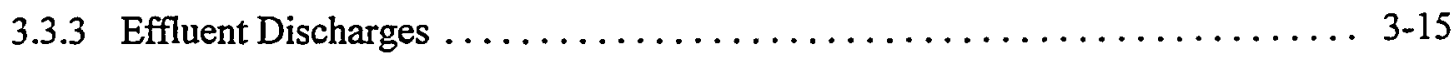

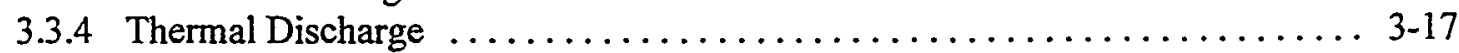

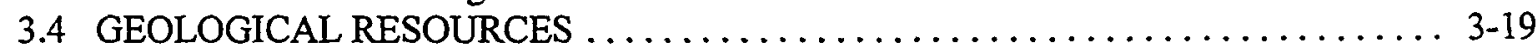

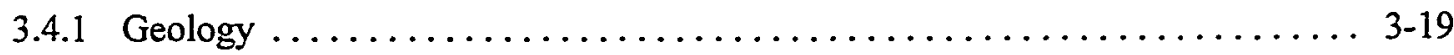

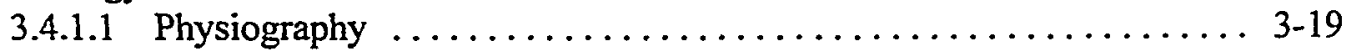

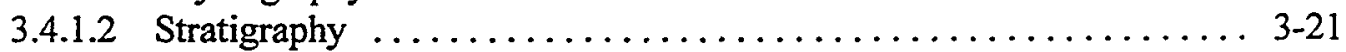

3.4.1.3 Chemical Properties .......................... 3-22

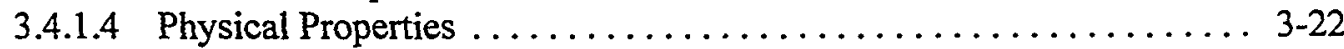

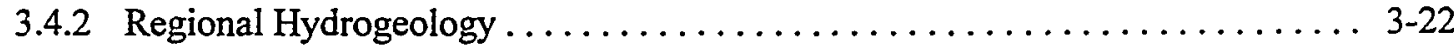

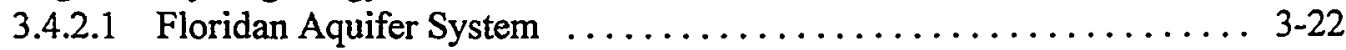

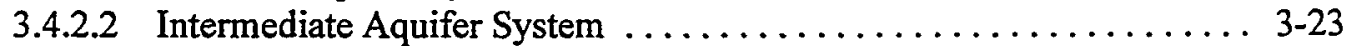

3.4.2.3 Surficial Aquifer System ...................... 3-24

3.4.3 Hydrogeology in the Vicinity of Northside Generating Station ......... 3-25

3.4.3.1 Production Wells .............................. 3-25

3.4.3.2 Surficial Aquifer Monitoring Wells .................. 3-25

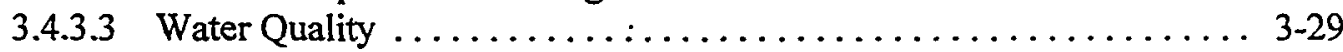

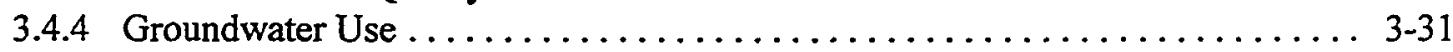

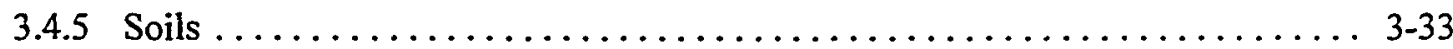

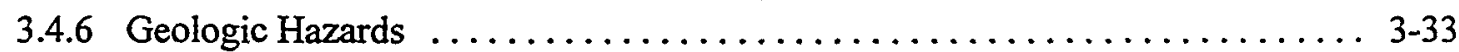

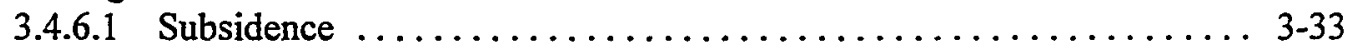

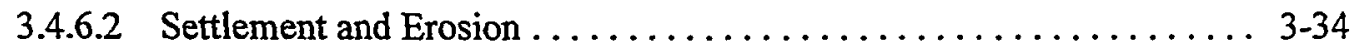

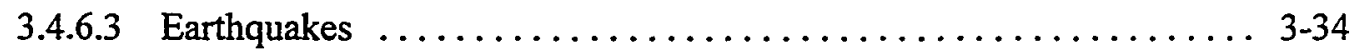

3.5 FLOODPLAINS, STORM SURGE, AND WETLANDS $\ldots \ldots \ldots \ldots \ldots \ldots \ldots \ldots .35$

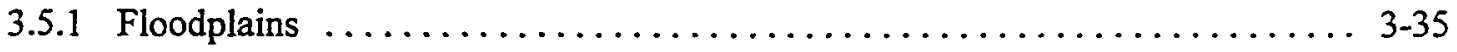

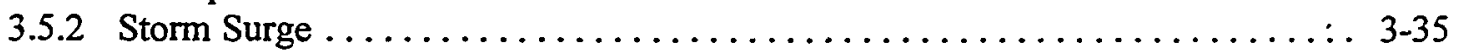

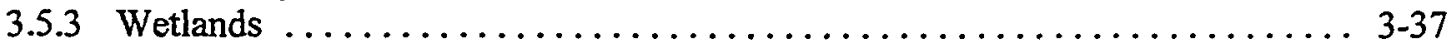

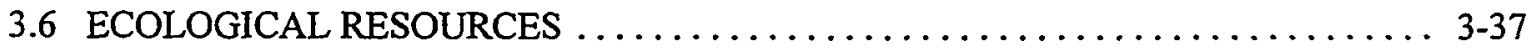

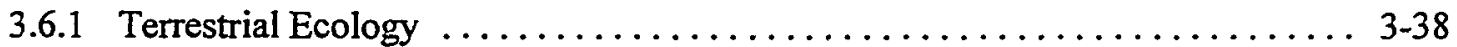

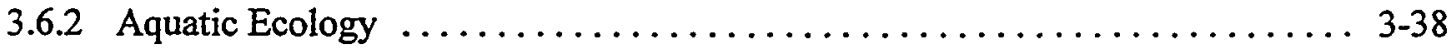

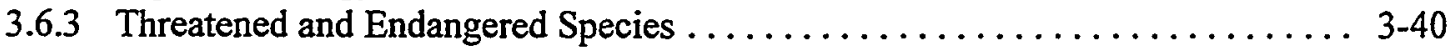

3.6 .4 Biodiversity . . . . . . . . . . . . . . . . . . . . . . . . . . 342

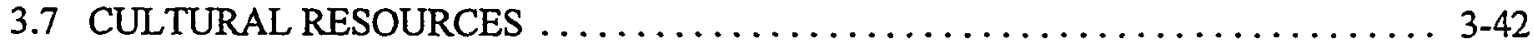

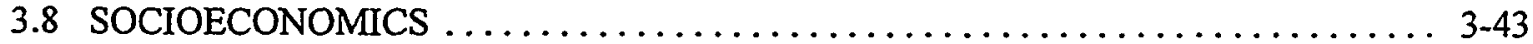

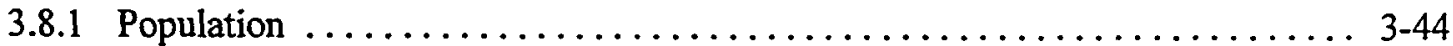

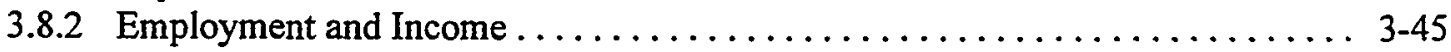

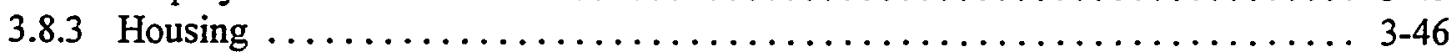

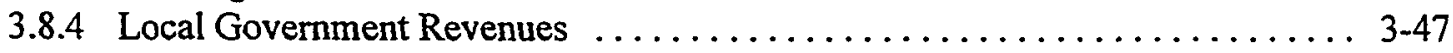

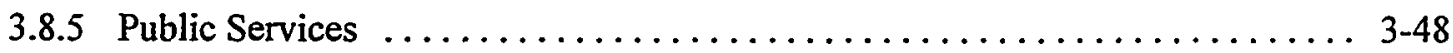

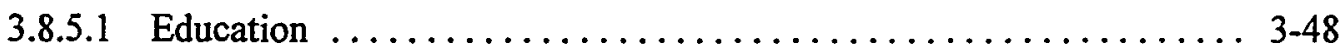

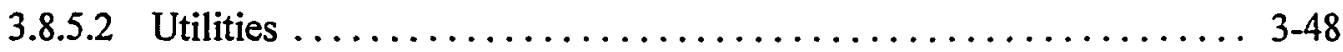

3.8.5.3 Police and Fire Protection $\ldots \ldots \ldots \ldots \ldots \ldots \ldots \ldots \ldots \ldots . \ldots \ldots . \ldots \ldots$

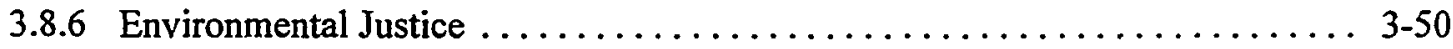

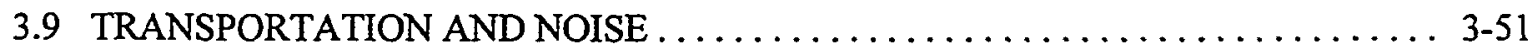

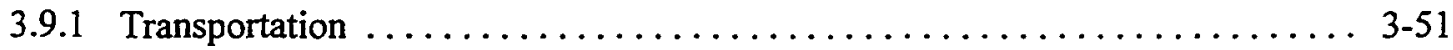


3.9.1.1 Roads ..................................... 3-51

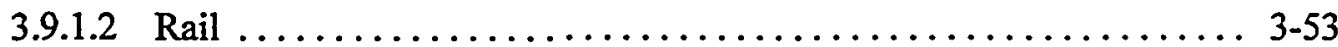

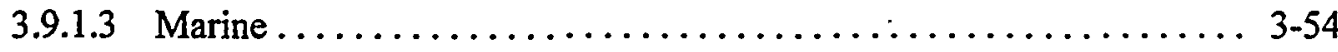

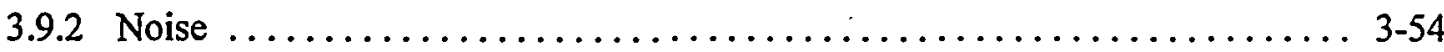

4. ENVIRONMENTAL CONSEQUENCES $\ldots \ldots \ldots \ldots \ldots \ldots \ldots \ldots \ldots \ldots \ldots \ldots \ldots \ldots$ 4-1

4.1 ENVIRONMENTAL IMPACTS OF THE PROPOSED PROJECT $\ldots \ldots \ldots \ldots \ldots \ldots$. $4-1$

4.1.1 Land Use and Aesthetics . . . . . . . . . . . .

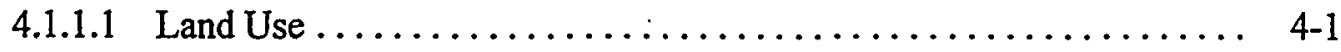

4.1.1.2 Aesthetics ................................ 4-3

4.1.2 Atmospheric Resources and Air Quality .................. 4-4

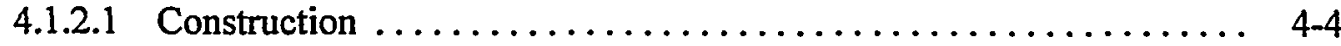

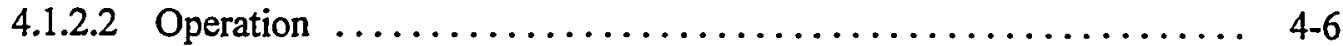

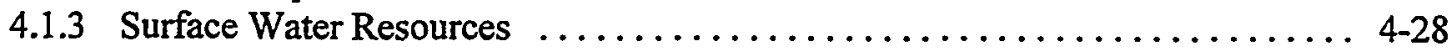

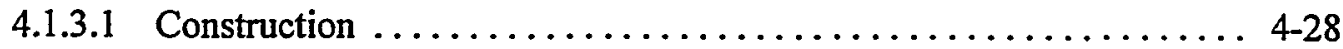

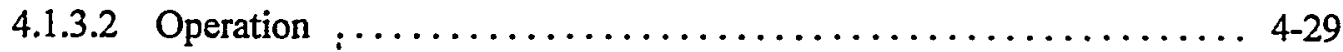

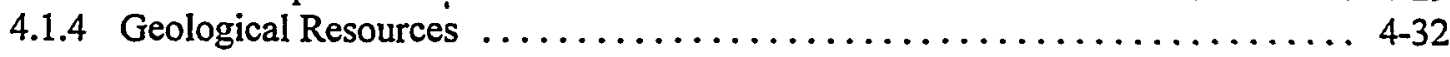

4.1.4.1 Groundwater ............................ 4-32

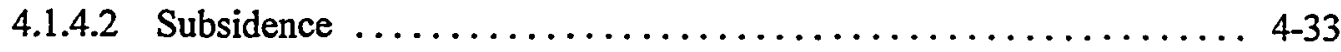

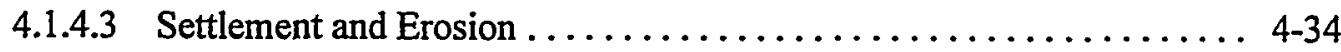

4.1.4.4 Earthquakes ............................ 4-34

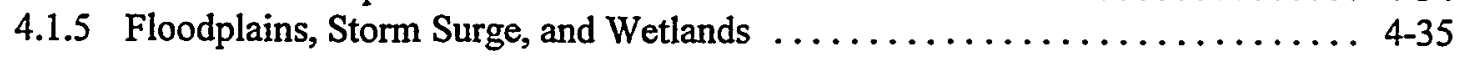

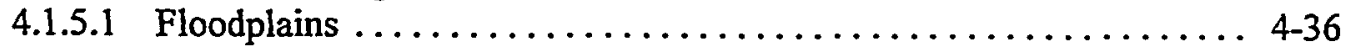

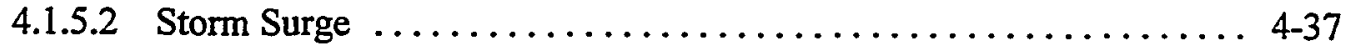

4.1.5.3 Wetlands ................................ 4-39

4.1.6 Ecological Resources $\ldots \ldots \ldots \ldots \ldots \ldots \ldots \ldots \ldots \ldots \ldots \ldots \ldots \ldots \ldots . \ldots \ldots 40 \ldots \ldots$

4.1.6.1 Terrestrial Ecology ........................ 4-40

4.1 .6 .2 Aquatic Ecology ............................. $4-41$

4.1.6.3 Threatened and Endangered Species ................... . 4-47

4.1.6.4 Biodiversity ............................. 4-50

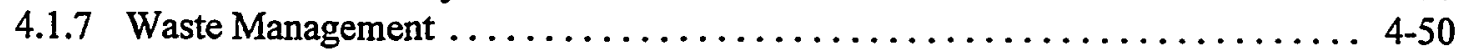

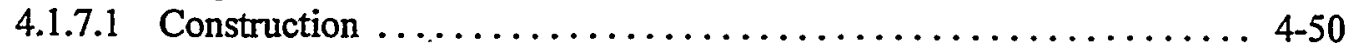

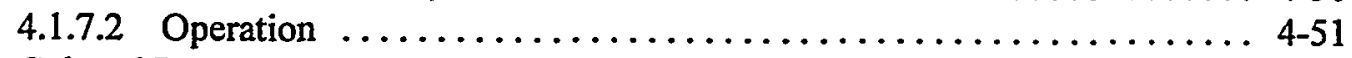

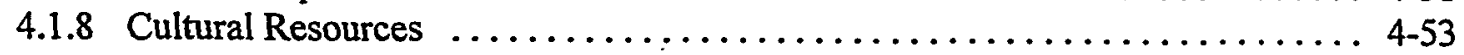

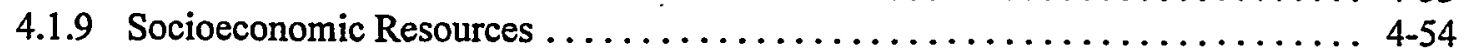

4.1.9.1 Population ............................ 4-57

4.1.9.2 Employment and Income $\ldots \ldots \ldots \ldots \ldots \ldots \ldots \ldots \ldots \ldots \ldots . \ldots \ldots$ 4-57

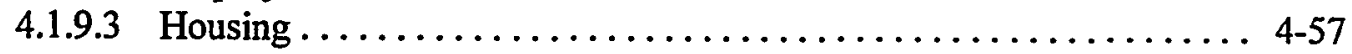

4.1.9.4 Local Government Revenues ................... 4-57

4.1.9.5 Public Services ............................ 4-58

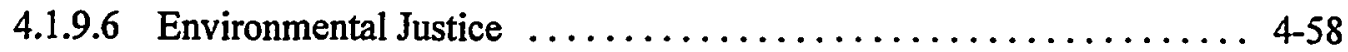

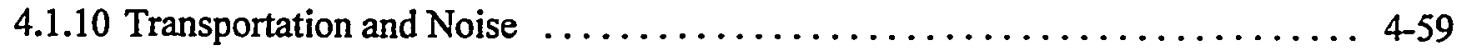

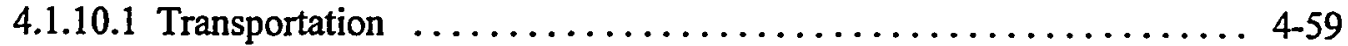

4.1 .10 .2 Noise ................................. 4-61

4.1.11 Electromagnetic Fields $\ldots \ldots \ldots \ldots \ldots \ldots \ldots \ldots \ldots \ldots \ldots . \ldots \ldots$ 4-64

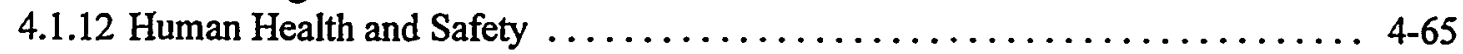

4.2 POLLUTION PREVENTION AND MITIGATION MEASURES $\ldots \ldots \ldots \ldots \ldots \ldots$ 4 $\ldots$ 4.66

4.3 ENVIRONMENTAL IMPACTS OF NO ACTION $\ldots \ldots \ldots \ldots \ldots \ldots \ldots \ldots \ldots \ldots \ldots$

5. IMPACTS OF COMMERCIAL OPERATION $\ldots \ldots \ldots \ldots \ldots \ldots \ldots \ldots \ldots \ldots \ldots \ldots$. 


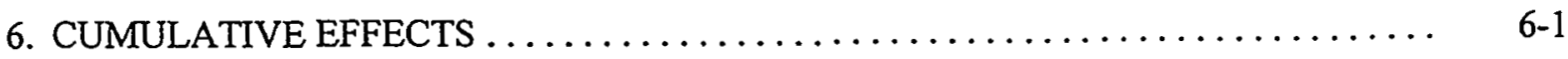

7. REGULATORY COMPLIANCE AND PERMIT REQUIREMENTS $\ldots \ldots \ldots \ldots \ldots$. $7-1$

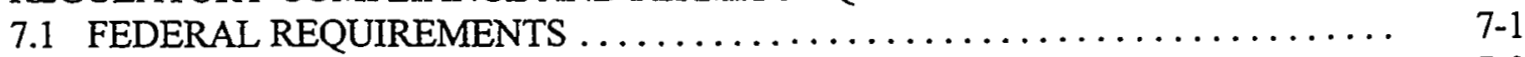

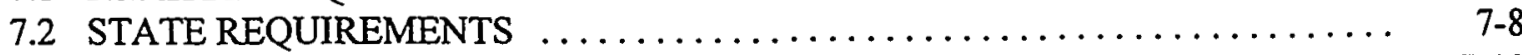

7.3 LOCAL REQUIREMENTS $\ldots \ldots \ldots \ldots \ldots \ldots \ldots \ldots \ldots \ldots \ldots \ldots \ldots \ldots \ldots \ldots \ldots \ldots \ldots \ldots, \quad 7-10$

8. IRREVERSIBLE OR IRRETRIEVABLE COMMITMENTS OF RESOURCES ....... 8-1

9. THE RELATIONSHIP BETWEEN SHORT-TERM USES OF THE

ENVIRONMENT AND LONG-TERM PRODUCTIVITY .................. $9-1$

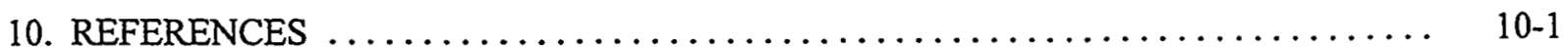

11. LIST OF PREPARERS $\ldots \ldots \ldots \ldots \ldots \ldots \ldots \ldots \ldots \ldots \ldots \ldots \ldots \ldots, 11-1$

12. LIST OF AGENCIES AND INDIVIDUALS CONTACTED $\ldots \ldots \ldots \ldots \ldots \ldots \ldots .12-1$

13. LIST OF AGENCIES, ORGANIZATIONS, AND PERSONS TO WHOM

COPIES OF THIS STATEMENT ARE SENT $\ldots \ldots \ldots \ldots \ldots \ldots \ldots \ldots \ldots \ldots, 13-1$

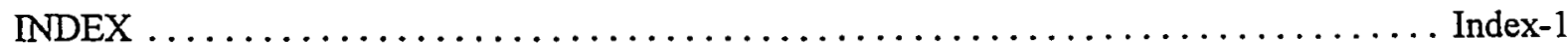

APPENDIX A CONSULTATION LETTERS UNDER SECTION 7

OF THE ENDANGERED SPECIES ACT $\ldots \ldots \ldots \ldots \ldots \ldots \ldots \ldots$ A-1

APPENDIX B CONSULTATION LETTERS UNDER SECTION 106 OF THE

NATIONAL HISTORIC PRESERVATION ACT $\ldots \ldots \ldots \ldots \ldots \ldots$ B-1

APPENDIX C CONSULTATION LETTERS ASSOCIATED WTTH THE

FLORIDA STATE CLEARINGHOUSE $\ldots \ldots \ldots \ldots \ldots \ldots \ldots \ldots, \mathrm{C}-1$

APPENDIX D CALCULATIONS OF HUMAN HEALTH RISK FROM

INHALATION OF TOXIC AND CARCINOGENIC

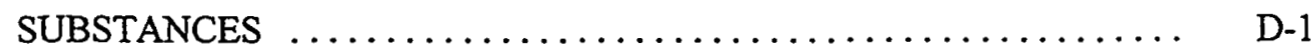

APPENDIX E ORGANIZATIONAL CONFLICT OF INTEREST STATEMENT ...... E-1

APPENDIX F ESSENTIAL FISH HABITAT ASSESSMENT ............... F-1

APPENDIX G TRANSCRIPT OF AND RESPONSES TO THE PUBLIC HEARING

AND PUBLIC COMMENT LETTERS AND RESPONSES......... G-1 


\section{LIST OF FIGURES}

2.1.1 Regional location map for the proposed circulating fluidized bed combustor project ... 2-2

2.1.2 Proposed site of the circulating fluidized bed combustor project $\ldots \ldots \ldots \ldots \ldots \ldots$

2.1.3 Location of the proposed circulating fluidized bed combustor project in relation to the existing Northside Generating Station power block $\ldots \ldots \ldots \ldots \ldots \ldots \ldots .2-5$

2.1.4 A generalized diagram of the primary components in the circulating fluidized bed

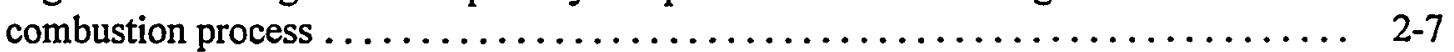

2.1.5 Artist's conception of key equipment for the circulating fluidized bed technology ... 2-9

2.1.6 A computerized drawing of the proposed facilities superimposed on a photograph of the existing Northside Generating Station with the existing Unit 1 combustor and stack removed (view is to the northeast) $\ldots \ldots \ldots \ldots \ldots \ldots \ldots \ldots .2-13$

2.1.7 Map showing the two options for handling the waterborne delivery of solid fuel and limestone and indicating delineated wetlands $\ldots \ldots \ldots \ldots \ldots \ldots \ldots \ldots$

2.1.8 Water flow diagram that depicts water requirements and discharges at Northside Generating Station after repowering both Units 1 and $2 \ldots \ldots \ldots \ldots \ldots$ 2-21

2.1.9 Water flow diagram that depicts water requirements and discharges at the existing Northside Generating Station $\ldots \ldots \ldots \ldots \ldots \ldots \ldots \ldots \ldots \ldots \ldots . \ldots \ldots$

3.2.1 Wind roses for (a) Jacksonville International Airport (1948-95) and

(b) a temporary monitoring site just north of the St. Johns River

Power Park (December 10, 1979-December 10, 1980) ................ 3-3

3.3.1 Map of the lower St. Johns River showing major tributaries and cities ......... 3-8

3.3.2 Local surface water hydrology in the vicinity of Northside

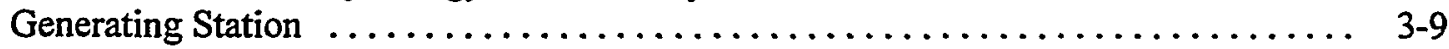

3.3.3 Water use diagram for Northside Generating Station and the St. Johns River Power Park ......................................... 3-14

3.3.4 Primary discharge points for Northside Generating Station $\ldots \ldots \ldots \ldots \ldots \ldots \ldots$ 3-16

3.4.1 Schematic cross-sectional view of the east flank of the Peninsular Arch ........ 3-20

3.4.2 Location map for upper Floridan aquifer production wells, surficial aquifer monitoring wells, and proposed ash storage area and runoff ponds $\ldots \ldots \ldots \ldots \ldots$ 3-26

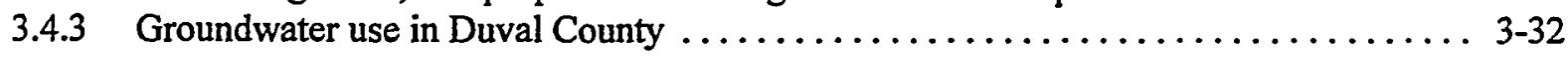

3.9.1 Location of ambient noise monitoring sites around

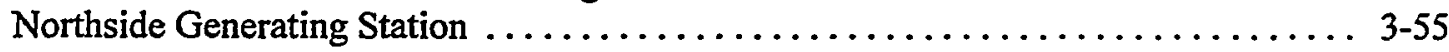

3.9.2 Equivalent noise levels (the average of each minute) for location 5, at the south boundary of the Northside property near several residences that are the closest to the plant

3.9.3 Communities that are concerned about train traffic and train noise in the area surrounding Northside Generating Station $\ldots \ldots \ldots \ldots \ldots \ldots \ldots \ldots . \ldots \ldots$

4.1.1 Principal land requirements for the proposed project at Northside Generating Station 


\section{LIST OF TABLES}

1.3.1 Chronological list of existing and planned circulating fluidized bed

combustors within and outside the United States with an electrical

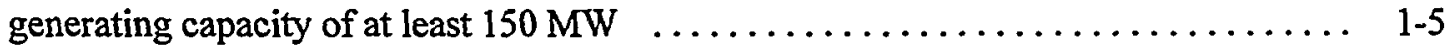

1.6.1 Issues identified for consideration in the environmental impact statement $\ldots \ldots \ldots \ldots 1-13$

2.1.1 Typical operating characteristics for the Northside Generating Station repowered

Unit 2, the combination of the repowered Units 1 and 2 , and the

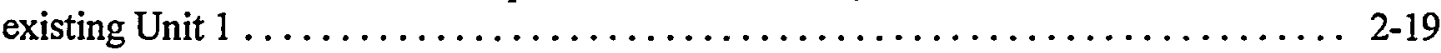

2.1.2 Analysis of the composition of coal and petroleum coke expected to

be received for the proposed project at Northside Generating Station $\ldots \ldots \ldots \ldots \ldots 2-23$

2.3.1 A comparison of potential impacts between the proposed project

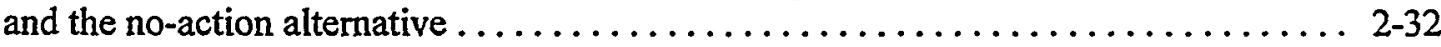

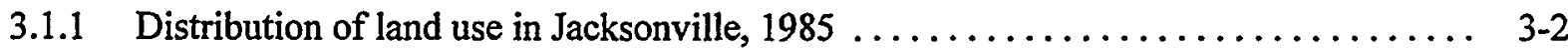

3.2.1 Summary of air quality data in Duval County for $1993-97 \ldots \ldots \ldots \ldots \ldots \ldots \ldots . . .5$

3.2.2 Allowable increments for Prevention of Significant Deterioration of air quality ..... 3-7

3.4.1 Water table elevations and concentrations of chemicals in 1993

and 1995 water samples from the surficial aquifer at

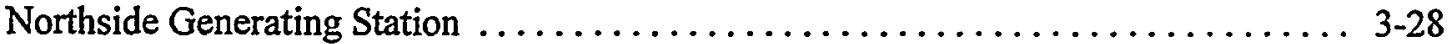

3.4.2 Hydraulic characteristics of the surficial aquifer in the vicinity

of the dredge spoil, tank farm, and combustion turbine areas . . . . . . . . . . 3-29

3.4.3 Upper Floridan aquifer water quality in production wells at

Northside Generating Station compared with wells located

10 miles east and west of the station $\ldots \ldots \ldots \ldots \ldots \ldots \ldots \ldots \ldots \ldots \ldots \ldots . \ldots \ldots \ldots .29$

3.4.4 Upper Floridan aquifer water quality in production wells at Northside

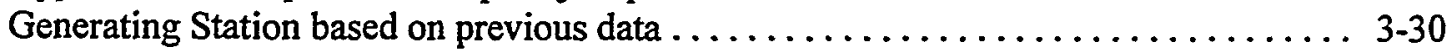

3.6.1 Sightings of manatees in the St. Johns River within 2 miles of the

Northside Generating Station intake and discharge area $\ldots \ldots \ldots \ldots \ldots \ldots . \ldots .41$

3.8.1 Current population and change over time for Duval County,

its municipalities, and Florida ............................. 3-44

3.8.2 Employment and income for residents of Jacksonville, Duval County,

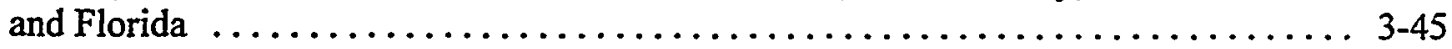

3.8.3 Employment by economic sector in Duval County, $1996 \ldots \ldots \ldots \ldots \ldots \ldots$......... 3-46

3.8.4 Housing data for Jacksonville and Duval County $\ldots \ldots \ldots \ldots \ldots \ldots \ldots \ldots \ldots \ldots \ldots \ldots$

3.8.5 Revenue by source for Duval County, fiscal year $1995 \ldots \ldots \ldots \ldots \ldots \ldots \ldots$. . . . . . . . .

3.8.6 Capacity and use of Jacksonville's potable water and

sewage treatment systems . . .............................. 3-49

3.8.7 Minority and low-income population residing in Duval County and Florida ...... 3-50

3.9.1 Key road segments in the vicinity of Northside Generating Station . . . . . . . . 3-52

4.1.1 Comparison of existing air emissions at Northside Generating Station

with emissions expected during the transition period after the Unit 2

repowering and emissions expected after the Unit 1 repowering $\ldots \ldots \ldots \ldots \ldots .4$

4.1.2 Prevention of Significant Deterioration (PSD) impact analysis for the proposed project and for the related action of repowering Unit $1 \ldots \ldots \ldots \ldots \ldots$ 4-11

4.1.3 Maximum improvements and maximum degradations in air quality that were modeled to result from the proposed project in conjunction with the related action of repowering Unit $1 \ldots \ldots \ldots \ldots \ldots \ldots .4-13$

4.1.4 Ambient air quality standards impact analysis for combined effects of regional sources and the proposed project $\ldots \ldots \ldots \ldots \ldots \ldots \ldots \ldots \ldots \ldots \ldots$ 4-16 
4.1.5 Beryllium and mercury concentrations predicted to result from the proposed project compared with Florida Ambient Air Reference

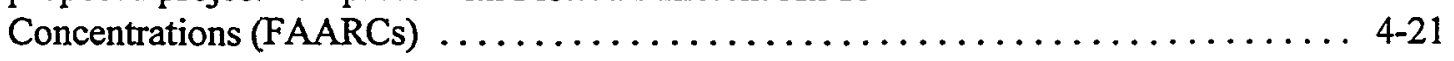

4.1.6 Changes in emissions of acid-rain precursors as a consequence of the

proposed project compared to emissions from all sources in Florida . . . . . . . . 4-26

4.1.7 Emissions of carbon dioxide $\left(\mathrm{CO}_{2}\right)$ from the proposed project by itself and

in conjunction with the related action of repowering the existing Unit 1

compared to U.S. and global emissions from combustion of fossil fuels . . . . . . . . 4-27

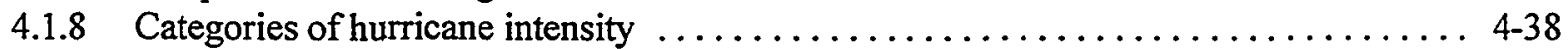

4.2.1 Pollution prevention and mitigation measures developed for the .

proposed project at Northside Generating Station .................. 4-67 


\section{ACRONYMS AND ABBREVIATIONS}

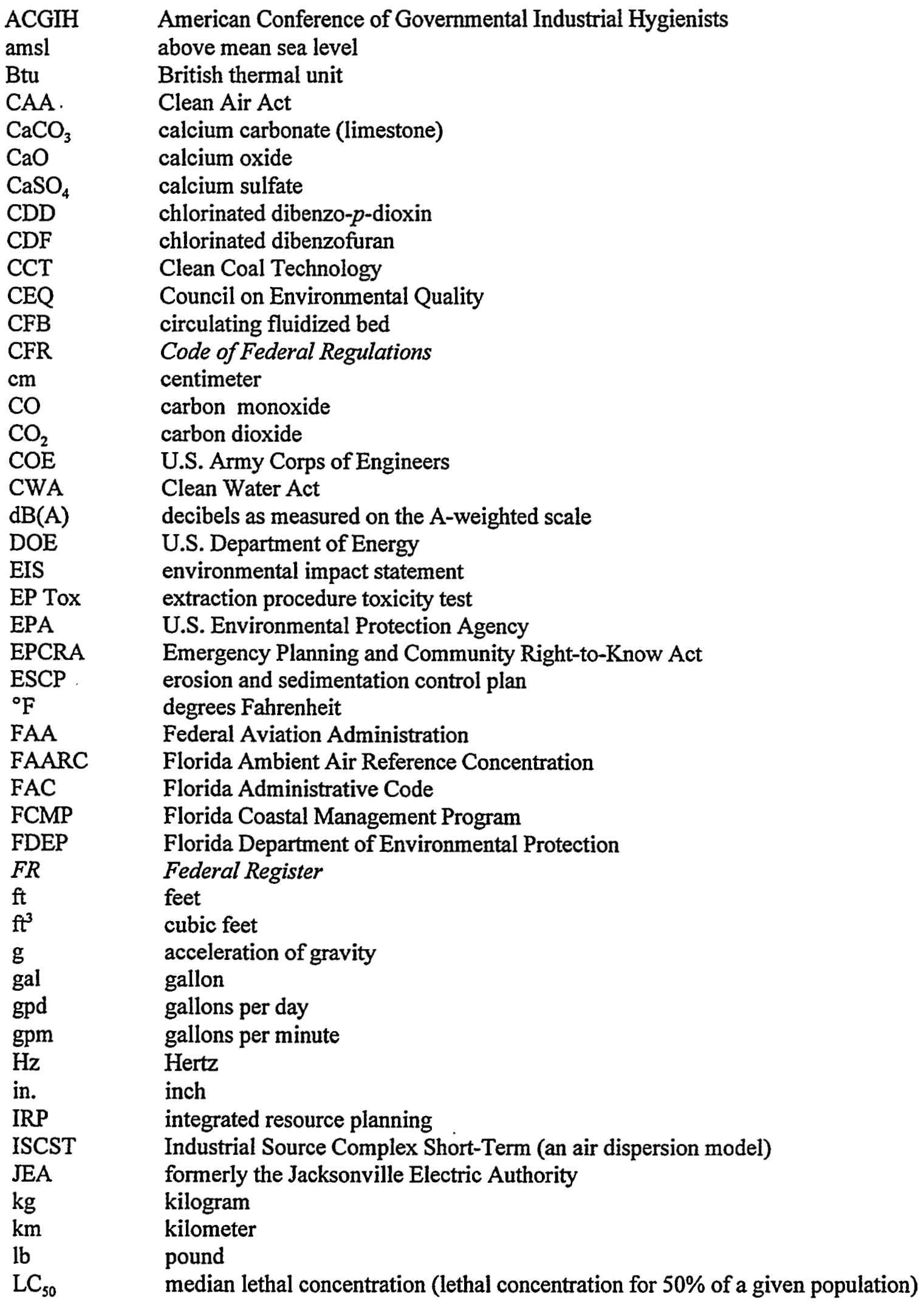


LOS

$\mathrm{m}$

$\mathrm{m}^{3}$

$\mu \mathrm{g}$

$\mu \mathrm{m}$

$\mu$ mho

$\mu \mathrm{rem}$

MBtu

$\mathrm{mCi}$

$\mathrm{mg}$

Mgal

Mgd

$\mathrm{mg} / \mathrm{L}$

mile ${ }^{2}$

$\min$

MMI

mph

mrem

MSL

MW

MWh

NAAQS

$\mathrm{NaBr}$

$\mathrm{NaOCl}$

NEPA

ng

$\mathrm{NO}_{2}$

$\mathrm{NO}_{x}$

NPDES

NSPS

NTU

$\mathrm{O}_{3}$

ORNL

OSHA

$\mathrm{Pb}$

$p C i / g$

PEIS

pg

PGA

$\mathrm{pH}$

PM-2.5

PM-10

ppm

PSD

Pub. L.

R\&D

$s$

SHPO

equivalent noise level (the energy-averaged sound level integrated over a measurement period)

level of service

meter

cubic meter

microgram

micrometer

micromho (a unit of conductance equal to the reciprocal of the ohm)

microroentgen equivalent in man

million British thermal units

millicurie

milligram

million gallons

million gallons per day

milligrams per liter

square mile

minute

modified Mercalli intensity

miles per hour

milliroentgen equivalent in man

mean sea level

megawatt

megawatt hour

National Ambient Air Quality Standards

sodium bromide

sodium hypochlorite

National Environmental Policy Act

nanogram

nitrogen dioxide

oxides of nitrogen

National Pollutant Discharge Elimination System

New Source Performance Standards

nephelometric turbidity units

ozone

Oak Ridge National Laboratory

Occupational Safety and Health Administration

lead

picocuries per gram

programmatic environmental impact statement

picogram

peak ground acceleration

hydrogen-ion concentration notation

particulate matter less than $2.5 \mu \mathrm{m}$ in aerodynamic diameter

particulate matter less than $10 \mu \mathrm{m}$ in aerodynamic diameter

parts per million

Prevention of Significant Deterioration

Public Law

research and development

second

State Historic Preservation Officer 
SJRWMD

SLERP

SLOSH

$\mathrm{SO}_{2}$

SPCCP

SPLP

TCLP

TEF

TEQ

TRC

UBC

UFA

USC

VOCs

yd

$\mathrm{yd}^{2}$

$\mathrm{yd}^{3}$
St. Johns River Water Management District

Submerged Lands \& Environmental Resource Permit

Sea, Lake, and Overland Surges from Hurricanes (model)

sulfur dioxide

spill prevention, control, and countermeasures plan

synthetic precipitation leaching procedure

toxic characteristic leaching procedure

toxicity equivalency factor

toxic equivalency

total residual chlorine

Uniform Building Code

Upper Floridan Aquifer

United States Code

volatile organic compounds

yard

square yard

cubic yard 


\section{GLOSSARY}

Aerodynamic diameter-A term used to describe particles with common aerodynamic properties: it avoids the complications associated with varying particle sizes, shapes, and densities. For example, PM-10 is defined in 40 CFR 50 as consisting of particles 10 micrometers or less in aerodynamic diameter, meaning particles that behave aerodynamically like spherical particles of unit mass (1 gram per cubic centimeter) having diameters of 10 micrometers or less.

Air dispersion model-computer program that incorporates a series of mathematical equations used to predict the ground-level concentrations resulting from emissions of a pollutant. Inputs to a dispersion model include the emission rate; characteristics of the emission release such as stack height, exhaust temperature, and flow rate; and atmospheric dispersion parameters such as wind speed and direction, air temperature, atmospheric stability, and mixing height.

Aquifer - a body of rock that can conduct groundwater and can yield significant quantities of groundwater to wells and springs.

Ash-The mineral content of a product remaining after complete combustion.

Baghouse-An air pollution control device that filters particulate emissions, consisting of a bank of bags that function like the bag of a vacuum cleaner; it intercepts particles that are mostly larger than 10 micrometers in aerodynamic diameter.

Baseline conditions-existing environmental conditions against which the potential impacts of a proposed action and its alternatives can be compared.

Benthic-of, relating to, or occurring at the bottom of a body of water.

Biocide-a substance (e.g., chlorine) that is toxic or lethal to many organisms and is used to treat water.

Blowdown-The portion of steam or water removed from a boiler at regular intervals to prevent excessive accumulation of dissolved and suspended materials.

Bottom ash-Non-airborne combustion residue that falls to the bottom of a boiler unit from where it can be physically removed.

Capacity factor-the percentage of electricity actually generated by a power plant during a year compared with the plant's maximum capacity.

Casing-undersized hollow steel tubing that is centered in a well hole and cemented in place. When a well is abandoned, the casing interior is plugged with cement to the surface to prevent further hydraulic communication between deep and shallow aquifers.

Circulating fluidized bed-a combustor in which coal or other fuels, air, and crushed limestone or other sorbents are injected into the lower portion of the combustor for initial burning of the fuel. The combustion occurs in a bed consisting of fuel, sorbent, and ash. The bed is fluidized by air nozzles in the bottom of the combustor. The air expands the bed, creates turbulence for enhanced mixing, and provides most of the air necessary for combustion of the fuel in the bed. As the fuel particles 
decrease in size through combustion and breakage, they are transported higher in the combustor where additional air is injected. As the particles continue to decrease in size, unreacted fuel, ash, and fine limestone particles are swept out of the combustor, collected in a particle separator, and recycled to the lower portion of the combustor. Drains in the bottom of the combustor remove a fraction of the bed composed primarily of ash while new fuel and sorbent are added.

Cold shock-depression of an animal's vital processes caused by a sudden drop in temperature (e.g., a decrease in water temperature by $5^{\circ} \mathrm{F}$ or more can kill some fish species).

Combustor-equipment in which coal or other fuel is burned at high temperatures.

Cooling water-water that is heated as a result of being used to cool steam and condense it to water.

Downwash-The downward movement of an elevated plume toward the area of low pressure created in the wake of a structure around which the air flows.

Electrostatic precipitator-A device that removes particles from a stream of exhaust gas; it imparts an electrical charge to the particles which causes them to adhere to metal plates that can be rapped to cause the particles to fall into a hopper for disposal.

Entrainment-an action in which organisms are inadvertently pulled through a water intake structure and through a water use facility.

\section{Essential Fish Habitat-waters and substrate required by fish for spawning, breeding, feeding, or growth to maturity.}

Fabric filter-A cloth device that intercepts particulate emissions. The simplest example is a vacuum cleaner bag; more complicated mechanisms are used to capture particulate matter from largescale industrial operations.

Floodplain - the strip of relatively level land adjacent to a river channel that will be covered with water if the river overflows its banks.

Flue gas-Residual gases after combustion, being vented to the atmosphere through a flue, or chimney.

Fly ash - fine solid particles of ashes, dust, and soot carried out from burning fuel (as coal or oil) by the draft.

Formation-the primary unit of formal geological mapping of an area. Formations possess distinctive geologic features and can be combined into "groups" or subdivided into "members."

Hydraulic gradient - refers to the flow of groundwater or surface water. Water flows from areas of higher energy (or hydraulic head) to areas of lower hydraulic head. The change in hydraulic head per unit distance is the hydraulic gradient. Upgradient areas are areas of higher hydraulic head and downgradient areas are areas of lower hydraulic head. Therefore, groundwater (and any contaminants moving with it) would flow from upgradient to downgradient areas. These terms are analogous to "upstream" and "downstream" flow of surface water. 
Ichthyoplankton-fish eggs and larvae.

Impingement - an action in which organisms are trapped inadvertently on the screens of a water intake structure.

Laydown area-material and equipment storage area for the construction phase of a project.

Leachate-solution or product produced by leaching.

Mixing height-the height within the lower atmosphere within which relatively vigorous mixing of pollutant emissions occurs.

Outfall—the outlet point for discharged or runoff water to a body of water or land area.

Plankton-the passively floating or weakly swimming animal and plant life of a body of water consisting chiefly of minute plants and animals but including also larger forms that have only weak powers of locomotion.

Potentiometric surface- (a) the surface to which the water from an aquifer will rise under its full head; (b) an imaginary surface that everywhere coincides with the static level of water in an aquifer.

Repower-the process of installing new steam generating equipment at a power plant site or industrial facility (as opposed to modifying or refurbishing existing equipment); repowering often involves installing an entirely different technology and may increase the electricity generating capacity by the plant.

Retrofit-the process of installing new equipment at an existing power plant or industrial facility to improve efficiency or pollution control without replacing the basic unit.

Rip-rap-Rocks or similar objects of various sizes placed over an area of soil for the purpose of preventing erosion.

Selective non-catalytic reduction-a system to reduce $\mathrm{NO}_{x}$ emissions by injecting a reagent such as urea into exhaust gas to convert $\mathrm{NO}_{x}$ emissions to nitrogen gas and water via a chemical reduction reaction.

Sorbent-Material that absorbs other substances, used to intercept pollutants before they would otherwise enter the air or water.

Superheat-(1) to heat a vapor not in contact with its own liquid so as to cause it to remain free from suspended liquid droplets (e.g., superheated steam); (2) to heat a liquid above its boiling point without converting it into vapor.

Supernatant - the usually clear liquid overlying material deposited by settling, precipitation, or centrifugation.

Thermal plume- area of a water body with elevated temperature as a result of discharged heated water. 
Transmission corridor - area used to provide separation between the transmission lines and the general public and to provide access to the transmission link for construction and maintenance.

Wetland-areas that are inundated by surface or groundwater with a frequency sufficient to support, and under normal circumstances do or would support, a prevalence of vegetative or aquatic life that requires saturated or seasonally saturated soil conditions for growth and reproduction. Wetlands generally include swamps, marshes, bogs, and similar areas (e.g., sloughs, potholes, wet meadows, river overflow areas, mudflats, natural ponds). "Jurisdictional wetlands" are those wetlands protected by the Clean Water Act. They must have a minimum of one positive wetland indicator from each parameter (i.e., vegetation, soil, and hydrology). The U.S. Army Corps of Engineers requires a permit to fill or dredge jurisdictional wetlands.

Wind rose-A graph in which the frequency of wind blowing from each direction is plotted as a bar that extends from the center of the diagram. Wind speeds are denoted by bar widths and shading; the frequency of wind speed within each wind direction is depicted according to the length of that section of the bar.

Zooplankton-The animal component of plankton (see Plankton). 


\section{SUMMARY}

This environmental impact statement (EIS) has been prepared by the U.S. Department of Energy (DOE), in compliance with the National Environmental Policy Act of 1969 (NEPA) as amended (42 USC 4321 et seq.), Council on Environmental Quality regulations for implementing NEPA (40 CFR Parts 1500-1508), and DOE NEPA regulations (10 CFR Part 1021). The EIS evaluates the potential environmental impacts associated with constructing and operating a project proposed by JEA (formerly the Jacksonville Electric Authority). The project would demonstrate circulating fluidized bed (CFB) combustion technology under the Clean Coal Technology (CCT) Program. The primary goal of the CCT Program is to make available to the U.S. energy marketplace a number of advanced, more efficient, economically advantageous, and environmentally responsible technologies for expanded coal utilization. The purpose of the proposed project is to generate technical, environmental, and financial data from the design, construction, and operation of facilities at a scale large enough to allow the power industry to assess the potential of CFB combustion technology for commercial application. In doing so, the proposed project would address the Congressional mandate in Pub. L. 99-190 for demonstrating environmentally sound technologies for the utilization of coal. The EIS will be used by DOE in making a decision on whether or not to provide approximately $\$ 73$ million (about $24 \%$ of the total cost of approximately $\$ 309$ million) in cost-shared funding to design, construct, and demonstrate the CFB technology proposed by JEA at their existing Northside Generating Station in Jacksonville, Florida. The proposed action is for DOE to provide the costshared funding.

Northside Generating Station occupies a 400-acre industrial site along the north shore of the St. Johns River about 9 miles northeast of the downtown area of Jacksonville. The local terrain is flat and there is a mix of industrial, commercial, residential, and agricultural land use in the vicinity. The property contains a number of wetland areas, especially in the perimeter areas. The industrial 1,650-acre St. Johns River Power Park borders Northside Generating Station to the northeast, and the 46,000-acre Timucuan Ecological and Historic Preserve borders the site to the east. Blount Island, located immediately to the southeast in the St. Johns River, is a major port with facilities for docking, loading, and unloading large ocean-going vessels. The proposed project would occupy a total of about 75 acres of land on the Northside Generating Station and St. Johns River Power Park property.

The proposed new CFB combustor would use bituminous coal and petroleum coke to generate nearly $300 \mathrm{MW}$ of electricity by repowering the existing Unit 2 steam turbine, a 297.5-MW unit that has been out of service since 1983. Piping and related infrastructure would be constructed to link the new CFB combustor with the existing Unit 2 steam turbine. CFB technology is an advanced method for burning coal and other fuels efficiently while removing air emissions inside the sophisticated combustor system. CFB technology provides flexibility in utility operations because a wide variety of solid fuels can be used, including high-sulfur, high-ash coal and petroleum coke. The proposed project is expected to demonstrate emission levels of sulfur dioxide $\left(\mathrm{SO}_{2}\right)$, oxides of nitrogen $\left(\mathrm{NO}_{x}\right)$, 
and particulate matter that would be lower than Clean Air Act limits while at the same time producing power more efficiently and at less cost than conventional coal utilization technologies.

At their own risk, JEA has begun initial construction activities without DOE funding. Construction would take approximately two years and, consistent with the original JEA schedule, would be completed in December 2001. Demonstration of the proposed project would be conducted during a 2-year period from March 2002 until March 2004. During the demonstration, Unit 2 would be operated on several different types and blends of coal and petroleum coke to explore the flexibility of the CFB technology. The coal would be transported by ship (from areas such as Columbia and Venezuela), by train (primarily from the central Appalachian region such as West Virginia and eastern Kentucky), and by a combination of train and ship (train from West Virginia and eastern Kentucky to Newport News, Virginia, and ship from Newport News to Jacksonville). The petroleum coke would be transported by ship from oil refineries in Venezuela and the Caribbean region. Limestone for the CFB combustor probably would be transported by ship from the Caribbean region and the Yucatan Peninsula of Mexico.

In addition to the proposed project, JEA plans to repower the currently operating Unit 1 steam turbine without cost-shared funding from DOE. The Unit 1 steam turbine would be essentially identical to the turbine for Unit 2 and would be repowered about 6 to 12 months after the Unit 2 repowering. Although the proposed project consists of only the Unit 2 repowering (because DOE would provide no funding for the Unit 1 repowering), this EIS evaluates the Unit 1 repowering as a related action.

JEA's management has established a target of a $10 \%$ reduction in annual stack emissions of each of 3 pollutants $\left(\mathrm{SO}_{2}, \mathrm{NO}_{x}\right.$, and particulate matter) from Northside Generating Station (Units 1, 2, and 3), as compared to emissions during a recent typical 2-year operating period (1994-95) of the station (Units 1 and 3). Also targeted for a 10\% reduction is the total annual groundwater consumption of Northside Generating Station, as compared to 1996 levels. These reductions are to be accomplished while increasing the total annual energy output of the station.

JEA, the project participant, plans to enter into a contract with Foster Wheeler Corporation, which would perform the design, engineering, procurement, and construction of the CFB combustor and air emissions control equipment.

DOE determined that providing cost-shared funding for the proposed CFB combustor project would constitute a major federal action that may significantly affect the quality of the human environment. Therefore, DOE has prepared this EIS to assess the potential impacts on the human and natural environment of the proposed action and reasonable alternatives. The EIS considers the proposed action (funding the demonstration) and the no-action alternative (not funding the demonstration), including scenarios reasonably expected to result as a consequence of the no-action alternative. Other alternatives to the proposed action have been examined and found not to be reasonable alternatives under NEPA. 
Potential impacts that could result from construction and operation of the proposed project were evaluated for resource areas including air quality, surface water, groundwater, floodplains and wetlands, ecological resources, noise, transportation, solid waste, and cultural and socioeconomic resources. During the public comment period on the draft EIS, the public was encouraged to provide DOE with oral and written comments. One person testified at the public hearing on the draft EIS, and 12 members of the public, interest groups, and federal, state, and local officials provided written comments. Altogether DOE received 60 comments, which helped to improve the quality and usefulness of the EIS. Among the topics or issues raised in the comments were concerns about

- reliability of CFB combustion technology in meeting expected air emissions rates for particulate matter and oxides of sulfur and nitrogen, in view of limited large-scale operating experience;

- air emissions of heavy metals, radionuclides, carcinogenic chemicals, and carbon dioxide;

- potential effects of cooling water discharge on the St. Johns River;

- potential entrainment of juvenile sea turtles, such as endangered green sea turtles, in the cooling water intake;

- potential effects on manatees and other endangered species;

- potential effects on Essential Fish Habitat, such as estuarine emergent wetlands;

- potential effects on cultural resources;

- disposal of ash, including whether the planned ash marketing would be successful;

- noise levels from construction, operation, and rail transportation;

- electromagnetic fields; and

- traffic congestion.

Generally, in responding to these comments, DOE revised the appropriate sections of the EIS to provide the requested information or further explore areas of potential impact. In addition, JEA has agreed to measures to mitigate potential impacts. For example, JEA has agreed to monitor traffic and provide a police officer or temporary traffic signal, as needed, to improve traffic flow. With respect to potential noise impacts, $J E A$ has agreed to monitor noise levels or install mufflers, as needed, to ensure that noise levels at the nearest residences conform to applicable Noise Pollution Control ordinance limits. The following sections further describe these measures and provide key findings for areas of potential concern.

\section{Potential Impacts}

Air Quality. A computer-based air dispersion model was used to estimate maximum increases in ground-level concentrations of $\mathrm{SO}_{2}$, nitrogen dioxide $\left(\mathrm{NO}_{2}\right)$, and particulate matter that would occur at any location as a result of emissions from the CFB combustor and limestone dryers for the proposed project (the Unit 2 repowering). Results indicate that maximum modeled increases are 
always less than $15 \%$ of their corresponding Prevention of Significant Deterioration (PSD) Class II increments (standards in the ambient air for increases in pollutant concentrations). One set of allowable increments exists for Class II areas, which cover most of the United States, and a much more stringent set of allowable increments exists for Class I areas, which include many national parks, monuments, and wilderness areas. Maximum concentrations generally occur at locations along, or very close to, the site boundary, often within 0.6 mile of the proposed CFB combustor stack. The PSD Class I area nearest to Northside Generating Station is the Okefenokee Wilderness Area, 38 miles to the west. The next nearest Class I area is Wolf Island Wilderness Area, 63 miles north of Northside Generating Station, on the Georgia coast. Dispersion of pollutants would reduce atmospheric concentrations at these Class I areas to only a small fraction of the maximum modeled increases near the site. The increases in pollutant concentrations at these Class I areas would be expected to be only small fractions of the corresponding Class I increments.

The combination of the proposed project and related action would result in emissions from the new 495- $\mathrm{ft}$ twin-flued stack that would be twice those considered in the analysis of the proposed project alone. However, the elimination of emissions from the existing $250-\mathrm{ft}$ stack serving Unit 1 would more than compensate for the added emissions. Compared to existing emissions at Northside Generating Station, a net decrease in maximum hourly emissions of $\mathrm{SO}_{2}, \mathrm{NO}_{x}$ and particulate matter would result from the addition of the repowered Unit 2 and the limestone dryers and the replacement of the existing Unit 1 with the repowered Unit 1. Therefore, a decrease in ground-level concentrations of these pollutants would be expected most of the time at most locations in the surrounding area (the overall effect would be beneficial). However, pollutant concentrations would not decrease for all averaging times at all locations; maximum ground-level concentrations at some locations could increase because the characteristics and location of the proposed new stack would be different from those of the stack currently serving Unit 1 . The net impacts could be positive or negative on any particular day at any particular location.

Air dispersion modeling was used to evaluate maximum adverse impacts possible from the proposed project in conjunction with the related action. Maximum modeled increases in ground-level concentrations are very similar to those for the proposed project alone. Maximum increases are always less than $15 \%$ of their corresponding Class II increments. Because the nearest PSD Class I areas are more than 30 miles away, pollutants from Northside Generating Station would be well mixed in the atmosphere, and stack characteristics would have little effect on ground-level pollutant concentrations in these areas. Therefore, a net decrease in pollutant emissions resulting from the proposed project in conjunction with the related action would be expected to improve air quality, albeit by a very small amount, at the nearest PSD Class I areas.

Regarding potential cumulative air quality impacts, results of modeling regional sources and the proposed project indicate that no exceedances of national or state ambient air quality standards would be expected if the proposed project were implemented. Florida standards are the same as the National Ambient Air Quality Standards (NAAQS) except for annual and 24-hour standards for $\mathrm{SO}_{2}$, 
for which the Florida standards are more stringent. However, during the 6- to 12-month transition period before the Unit 1 repowering, the 24-hour average $\mathrm{SO}_{2}$ concentration is predicted to be as high as $97 \%$ of the corresponding Florida standard. This large concentration results from aerodynamic downwash effects caused by the proposed 200 - $\mathrm{ft}$ tall combustor structure that would induce downward motion on the exhaust gas emitted from the 250 - $\mathrm{ft}$ stack serving the existing Unit 1 and the 350-ft stack serving the existing Unit 3 (exhaust gas from the proposed 495-ft CFB combustor stack would not be subjected to appreciable downwash because the stack is taller). During the 6- to 12-month transition period before the Unit 1 repowering, JEA has committed to reduce maximum hourly $\mathrm{SO}_{2}$ emissions from the existing Unit 1 by nearly $93 \%$ when operations commence for the proposed project. This reduction, which would be accomplished by using natural gas and fuel oil with an $\mathrm{SO}_{2}$ emission rate averaging no more than $0.143 \mathrm{lb} / \mathrm{MBtu}$ (effectively, a blend with a sulfur content averaging no more than $0.13 \%$ ), would assure that the maximum 24-hour average $\mathrm{SO}_{2}$ concentration would not exceed the Florida standard.

Estimated $\mathrm{SO}_{2}$ concentrations for other averaging periods are less than $60 \%$ of their respective standards. The annual average $\mathrm{NO}_{2}$ concentration is less than $40 \%$ of its NAAQS. The 24 -hour and annual averages of particulate matter are less than $65 \%$ of the NAAQS, even though ambient background particulate concentrations for both averaging periods are over $40 \%$ of the NAAQS.

Results of modeling regional sources and the proposed project in conjunction with the related action of repowering the existing Unit 1 indicate that maximum concentrations are always less than corresponding concentrations without the related action. For example, the 24-hour average $\mathrm{SO}_{2}$ concentration for regional sources and the proposed project in conjunction with the related action is $91 \%$ of the Florida standard, compared to $97 \%$ for regional sources and the proposed project without the related action.

Ozone $\left(\mathrm{O}_{3}\right)$ concentrations during 1993-97 at the nearest monitor located about 5 miles northnorthwest of Northside Generating Station were always less than $90 \%$ of the 1-hour NAAQS. Because changes in $\mathrm{NO}_{x}$ and volatile organic compound (VOC) emissions from the proposed project alone or in conjunction with the related action would be less than $1 \%$ of emissions in Duval County, they would not be expected to lead to any exceedances of the 1-hour NAAQS for $\mathrm{O}_{3}$ at that monitoring location.

DOE has performed a conformity review to assess whether a conformity determination ( $40 \mathrm{CFR}$ Part 93, Subpart B) is needed for the proposed project. Currently, no portion of Duval County is designated as a nonattainment area for any NAAQS or Florida standard, but Duval County is a maintenance area for $\mathrm{O}_{3}$. A maintenance area is an area that previously was a nonattainment area for a pollutant and which is striving to maintain attainment.with the standard(s) for the pollutant and comply with the state implementation plan. However, a conformity determination is not required [40 CFR Part 93.153(d)] because the precursors of $\mathrm{O}_{3}$ (VOCs and $\mathrm{NO}_{x}$ ) are evaluated in the PSD permit application. 
Regarding toxic air pollutants, findings indicate that the proposed project alone or in conjunction with the related action would not lead to any exceedances of, or close approaches to, guideline values for noncarcinogenic effects from toxic materials. When including both the inhalation and ingestion pathways, the maximum annual cancer risk to a member of the public resulting from dioxins, furans, and other carcinogenic substances emitted during operations was calculated to be approximately 1 in 1 million; given the upper-bound assumptions in the estimate, the risk would probably be less.

Water Resources. With regard to surface water resources, no change in the existing utilization or consumption of surface water would occur during the construction phase of the proposed project. All construction would be performed in accordance with an erosion and sedimentation control plan. Impacts attributable to construction-related runoff, turbidity-causing agents, erosion, and sedimentation would be negligible. Because Unit 2 has not operated since 1983, the proposed project (the repowering of Unit 2) would increase the demand for noncontact cooling water. After Unit 2 is repowered, the demand by the entire 3-unit plant would be approximately the same as when the three units operated together from approximately 1978 until 1980. The sustained flow of the back channel of the St. Johns River would not be depleted by this diversion because nearly all of the withdrawn cooling water would be returned to the river after passing through the condensers. The amount of heat discharged to the St. Johns River would also increase as a consequence of the proposed project. However, the size of the thermal plume would not increase because simultaneous operation of all three units would increase the discharge velocity and enhance mixing.

Operation of the proposed project would reduce groundwater consumption by Northside Generating Station by $10 \%$ from the upper Floridan aquifer, which would decrease the rate of decline of the potentiometric surface of that aquifer. As a result, more groundwater would be available to local users, and water quality of the aquifer would be improved because of reduced influx of brackish or saline groundwater from deeper aquifers.

Floodplains and Wetlands. No impacts from flooding would be expected to occur, and proposed activities would have a negligible effect on floodplain encroachment. A category 3, 4, or 5 hurricane in Jacksonville is a low-probability event that, if it occurred, would have serious consequences for Northside Generating Station. Although the inland location of Northside Generating Station, the presence of the beach ridge along the dune line, and Blount Island would partially mitigate the effects of storm surge and waves that would occur along the beaches, the first floor of the station could be inundated by this unlikely event.

Ecological impacts to wetlands from the proposed project would be minor because no more than 1.8 acres of isolated hardwood wetland habitat would be lost during construction of the ash storage area and disturbance of salt marsh habitats during construction of the solid fuel delivery system would be negligible. Wetlands associated with the upper salt marsh communities would not be measurably affected because nearly all of the conveyor system for solid fuel delivery would span these habitats using existing structures and would involve no clearing or earthmoving activities. Although some pilings could need to be installed at the upper fringes of the salt marsh and in San 
Carlos Creek, any impacts resulting from piling installation would be very localized and temporary and should not measurably affect the normal structural and functional dynamics of the salt marsh and nearby estuarine ecosystems.

As a mitigation measure to offset the loss of 1.8 acres of wetlands, JEA would purchase slightly greater than 3 acres of wetlands from an offsite mitigation bank and would restore 1 acre of salt marsh, which together would result in a net gain in the amount of wetlands. In addition, JEA plans to set aside and preserve 15 acres of undisturbed, uplands maritime oak hammock along the west bank of San Carlos Creek. By preserving the land, JEA would maintain habitat for wildlife, help protect the water quality of the creek, and leave a high-quality forested buffer area in a developing industrial area.

DOE has determined and the National Marine Fisheries Service concurs that the proposed project would not adversely affect Essential Fish Habitat.

Ecological Resources. With regard to threatened and endangered species, manatees are of the most concern. Impacts on this species from construction of a new fuel and limestone unloading dock are unlikely because manatees probably would not regularly frequent the dock area due to the paucity of submerged vegetation such as seagrasses and emergent cordgrasses in the immediate vicinity of the dock. Potential impacts resulting from operational activities such as docking of vessels would also be unlikely. The potential for manatees to be trapped and pinned between the dock and a vessel are minimal because the dock would be supported by widely spaced support pilings rather than consisting of one long continuous structure. Because manatees generally avoid swift currents and prefer slow-moving or stagnant water, they would not frequent the main discharge area in the back channel of the St. Johns River where currents are relatively swift. In addition, it is very unlikely that all units for both the St. Johns River Power Park and Northside Generating Station would be shut down simultaneously, thereby minimizing the probability that a cold shock event would occur. Moreover, the maximum size of the thermal discharge zone is relatively small ( 36 acres) for the $4^{\circ} \mathrm{F}$ temperature elevation (compared with ambient temperature). In summary, impacts to manatees from the proposed project would be minimal or non-existent because of a lack of preferred foraging habitat such as submerged seagrasses and a scarcity of emergent cordgrasses in the immediate site vicinity, because of the construction design of the docking facilities, and because manatees are not attracted to the thermal discharge.

Construction activities would be unlikely to occur where burrows of gopher tortoises have recently been observed. Because a large population of this species exists in Florida (including the site vicinity) and because any dislocation of individuals from their burrows as a result of construction activities would be temporary, re-population would be expected to occur relatively rapidly. A permit would be required from the Florida Game and Freshwater Fish Commission for relocation of gopher tortoises from any impacted areas. Prior to construction, a gopher tortoise survey would be conducted to identify burrows that must be manually excavated, and the animals would be relocated according to conditions of the collecting permit. 
Four or five juvenile loggerhead, Kemps Ridley, and/or green sea turtles were sighted in the Northside Generating Station intake basin on one occasion during summer 1997. In order to prevent any further occurrences of juvenile turtles entering the intake structure and subsequently becoming trapped, JEA installed on the intake trash rakes a finer grid of mesh bars (welded wire screen on 6-in. centers contrasted to the old 12 -in. centers). The denser grid has excluded turtles of sizes similar to those observed from entering the intake basin and becoming trapped. One potential problem with this change is that the finer grid could become more easily clogged with trash and attached marine organisms (e.g., barnacles), effectively reducing the cross-sectional area and increasing the water velocity at the intake. In turn, this would increase the vulnerability of free-swimming organisms to entrainment and/or impingement. Therefore, JEA regularly inspects the intake trash rakes to monitor any increased clogging and increases the frequency of cleaning if necessary.

Cultural Resources. Because the area in the vicinity of the proposed project is rich in archaeological resources and the excavation of undisturbed land could affect important archaeological artifacts, a cultural resources assessment survey of the proposed project site and a follow-up Phase II investigation were conducted. These studies found that there are no potentially significant historic or archaeological sites located in the area that would be disturbed by the proposed project. Under the terms of the Submerged Lands \& Environmental Resource Permit (SLERP) that would be issued by the Florida Department of Environmental Protection (FDEP), JEA would be required to notify the appropriate agencies [the St. Johns River Water Management District (SJRWMD), the FDEP, and the State Historic Preservation Officer (SHPO)] immediately upon discovery of any archaeological artifacts on the project site [Rule 62-330.200(2)(c), Florida Administrative Code].

Socioeconomic Resources and Environmental Justice. Construction and operation of the proposed project would not result in major impacts to population, employment, income, housing, local government revenues, or public services in Duval County. The percentage of Blacks and Asians in Duval County is greater than for Florida as a whole. Because there are relatively few people in poverty or Blacks and Asians living in the census tracts surrounding the proposed site, no disproportionately high and adverse impacts to low income or minority populations would occur. In particular, because of the relatively low number of minority and low-income residents in the vicinity of the proposed project, very few members of these groups would experience the adverse effects associated with increased road and rail traffic and related noise.

Transportation. Construction-induced traffic during the peak traffic hour would not exceed available capacity except for the section of Heckscher Drive from State Route 9A to Drummond Point (just west of Eastport Road). This segment currently has an available capacity of 89 trips per hour during its peak period. A recent traffic impact analysis performed for JEA predicts that $19 \%$ of peak hour project-related traffic would use this road segment during the construction period. Using the conservative assumption that all 820 workers would drive themselves and would all leave the plant during the peak traffic hour, an additional 156 vehicles would use this segment during its time 
of highest use, thereby exceeding its remaining capacity. The congestion experienced on this segment would represent a significant impact. Accordingly, JEA has agreed to encourage carpooling and suggest alternate routes to and from the site. In addition, the increased traffic would result in noticeable congestion on New Berlin Road, especially at the intersection of Ostner and New Berlin Roads. To avoid a significant impact, JEA has agreed to monitor traffic at the above-mentioned intersection and to place a police officer at the intersection to direct traffic during peak times, if needed. Should the presence of a police officer prove inadequate to control project-induced traffic, JEA has further agreed to pursue authorization of a temporary traffic signal at that intersection.

Based on current projections, marine transportation would be the most economic means of delivering solid fuel and limestone for the proposed project. Consequently, no more than one 90-car unit train per week would be required to transport coal for the proposed project, and this could be offset by decreased rail deliveries and corresponding increased waterborne deliveries for operations at the St. Johns River Power Park. However, in the less likely event that all necessary coal would be transported by rail, up to 3 additional trains per week would be required for a total of 6 new one-way trips by 90 -car unit trains. If all coal were transported by train, the 6 new one-way train trips per week would exacerbate impacts associated with noise, vibration, and blocked roads at on-grade rail crossings resulting from existing train traffic. These impacts are a source of concern for residents of Panama Park, North Shore, and San Mateo. The 6 additional one-way trips per week would increase total movement on the CSX line paralleling U.S. 17 by about $5 \%$ and would increase traffic on the spur line from U.S. 17 to the St. John River Power Park and Blount Island by approximately 8\%.

Noise. During construction of the proposed project, noise levels would increase from the present operational levels. Construction would primarily occur adjacent to the existing turbine building. The noisiest periods of construction would be during steam blowouts and during the operation of a pile driver and other construction equipment. Except possibly during steam blowouts and possibly during operation of equipment used to construct a nearby segment of a conveyor, construction noise should not appreciably affect the background noise of nearby residences, interfere with outside voice communications, or exceed the limitations of Rule 4, Noise Pollution Control, promulgated by the Jacksonville Environmental Protection Board (1995). This rule limits daytime construction noise levels to $65 \mathrm{~dB}(\mathrm{~A})$ at residential property.

JEA likely would perform continuous, low-pressure, high-velocity steam blowouts. Although this activity would be conducted around the clock, noise levels at the nearest residences should be below levels of concern with this type of blowout that uses low-pressure steam rather than highpressure steam. However, because JEA's steam blowout plan has not been finalized, JEA has committed to installing mufflers if high-pressure steam blowouts are conducted or, if mufflers are not installed, has committed to measuring the noise levels at the nearest residences to ensure that the levels would conform to the Noise Pollution Control ordinance limits.

The project-induced increased movement of trains through the local area (discussed in the transportation section) would be accompanied by high-decibel train whistles and rattling rail cars. 
Train noise is a source of concern for residents of Panama Park, North Shore, and San Mateo. One local resident has reported the level of train whistles as being $108 \mathrm{~dB}(\mathrm{~A})$ and the level of rattling rail cars as being up to $85 \mathrm{~dB}(\mathrm{~A})$. As mentioned in the transportation section, additional train noise could be minimized by relying more heavily on barges and ships for coal transport.

Waste Management. The preferred alternative for management of the combustion ash would be to sell it as a by-product to offsite customers. An aggressive marketing program would be implemented to maximize the quantity sold. If more than approximately $70 \%$ of the ash could be sold over the 30-year lifetime of Northside Generating Station, the 40-acre storage site would be sufficient for complete containment, and disposal of the material would not be an issue. Additional permanent disposal space would be required if JEA cannot sell over $70 \%$ of the ash. In the unlikely event that none can be sold, an additional 80 to 100 acres of disposal space would be required over the 30 -year operating life of the facility. If additional disposal space were required, the property directly north of the Northside property could be an option. Other alternatives include use of additional landfill capacity available at the St. Johns River Power Park or acquisition of other land that would be dedicated to disposing of the material. As a last resort, existing offsite landfills could be used to dispose of the ash. Four large landfill sites that are permitted to dispose of nonhazardous industrial waste have been identified in northeastern Florida and southeastern Georgia.

\section{No-Action Alternative}

Under the no-action alternative, DOE would not provide cost-shared funding for the proposed CFB combustor project. Consequently, three reasonably foreseeable scenarios could result. First, JEA could repower the existing Unit 2 steam turbine without DOE funding, thereby accepting more of the risk associated with demonstrating the CFB combustor. Construction materials and activities and project operations would be the same as for the proposed project. The same amount of electricity would be generated and environmental impacts would generally be very similar to those of the proposed project. Fuel requirements would be similar except that the blend of coal to petroleum coke might be slightly different, particularly during the first 2 years of operation. Under this scenario, more of the solid fuel used each year throughout the lifetime of the facility could be petroleum coke, which would be brought to the site by waterborne transport. If current projections about the economic advantages of marine transportation change and rail transport is the primary means of moving coal to the project site, the increased use of petroleum coke under this scenario would result in less train traffic and more ship traffic to deliver the fuel as compared with the proposed project. As a result, there would be fewer train trips through the neighborhoods in the vicinity of Northside Generating Station, which would reduce potential problems with noise, vibration, and blocked roads at on-grade rail crossings.

Under the second scenario, rather than repowering Unit 2, JEA could construct and operate a new gas-fired combined cycle facility at Northside Generating Station or at one of their other existing power plants. The natural gas would drive a gas combustion turbine, and the heat from combustion 
would be used to produce steam to drive a steam turbine. The facility would be expected to generate approximately $230 \mathrm{MW}$ of electricity.

Construction activities and operations would be similar to the proposed project but with notable differences related to fuel, sorbent, and ash handling and storage facilities. Under this scenario, no coal, petroleum coke, limestone, or lime would be used. Because the natural gas would be delivered by pipeline and no sorbent would be used, there would be no train, ship, or truck traffic associated with fuel and sorbent delivery. No combustion ash would be generated and there would be no truck traffic to remove ash from the site. Consequently, impacts related to traffic noise and disruptions would be minimized.

Air emissions would be expected to increase compared with historical levels because of the operation of the combined cycle facility in addition to the existing Northside units operating at the same or higher capacity factors. Therefore, air emissions under this scenario would generally be greater than those for the proposed project. Changes in concentrations of pollutants in the ambient air would depend on the location and project-specific nature of the facility (e.g., stack height and exit temperature and velocity).

Impacts to cultural resources could be less if there were less disruption to construct conveyors and other facilities on previously undisturbed land; conversely, impacts could be greater if more onsite and/or offsite land were disturbed because of a need to construct or upgrade a pipeline supplying natural gas to the facility.

Under the third scenario, rather than repowering Unit 2, JEA could purchase electricity from other utilities to meet JEA's projected demand. Consequently, no construction activities or changes in operations would be expected to occur within the JEA system of power plants, including Northside Generating Station. There would be no change in current environmental conditions at the site, and the impacts would remain unchanged from the baseline conditions. It is possible that existing Units 1 and 3 would operate at capacity factors greater than historical levels if JEA were unable to purchase sufficient electricity from other utilities. Consequently, annual air emissions and groundwater consumption would increase.

There could be construction activities or changes in operations at the other utilities providing electricity to JEA if the electricity were not readily available. Some impacts to resources could result in the geographical area of the other utilities, particularly if a new facility were built to meet the JEA demand or if additional fuel were transported to the other site or sites to generate additional electricity. The level of any such impacts would depend on the project-specific characteristics of any facility construction, the fuel required by the facility, and the affected resources in the area.

Table S.1 presents a comparison of key potential impacts between the proposed project and the three scenarios under the no-action alternative for resource areas of most concern (a more detailed comparison table is included in the body of the EIS). 


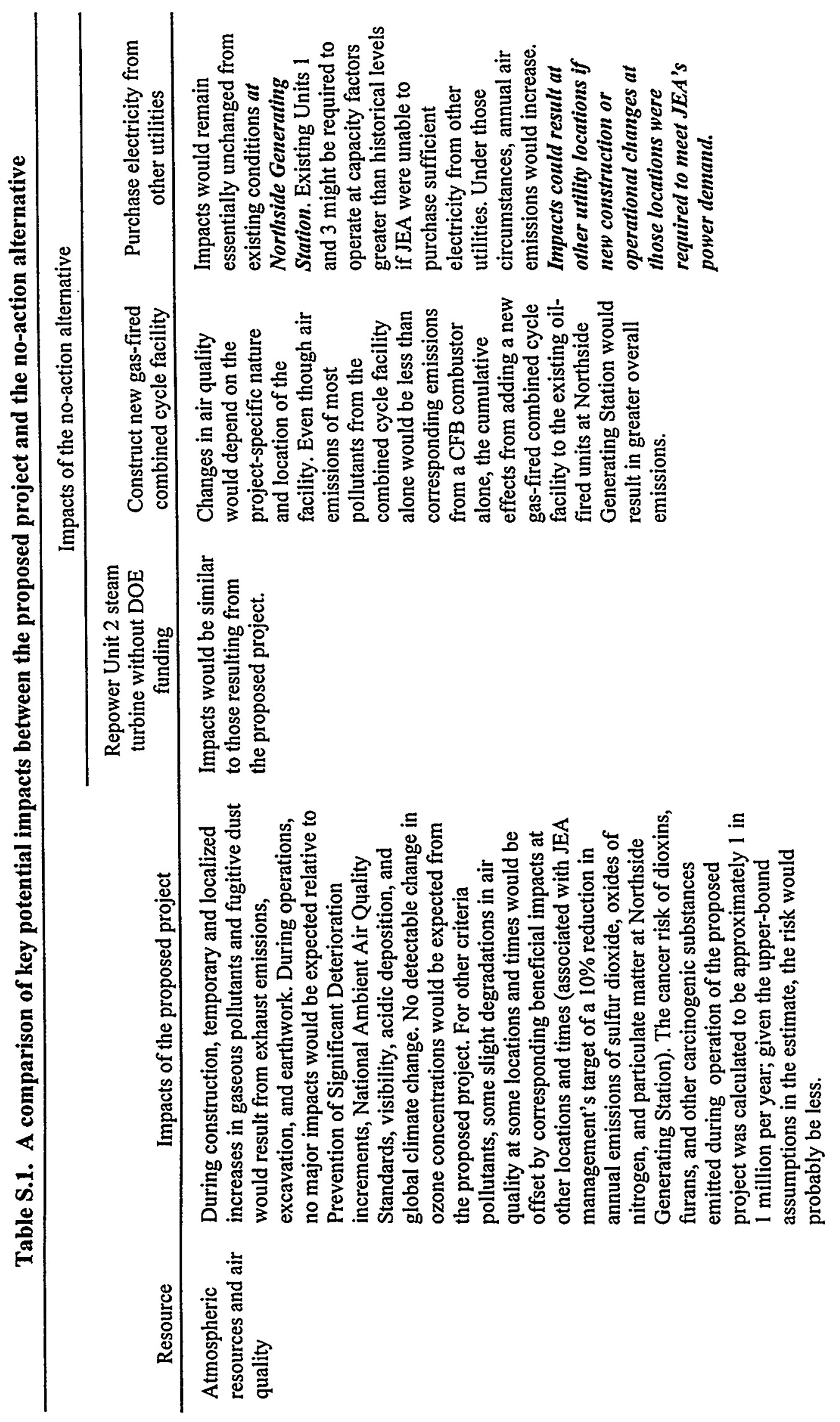




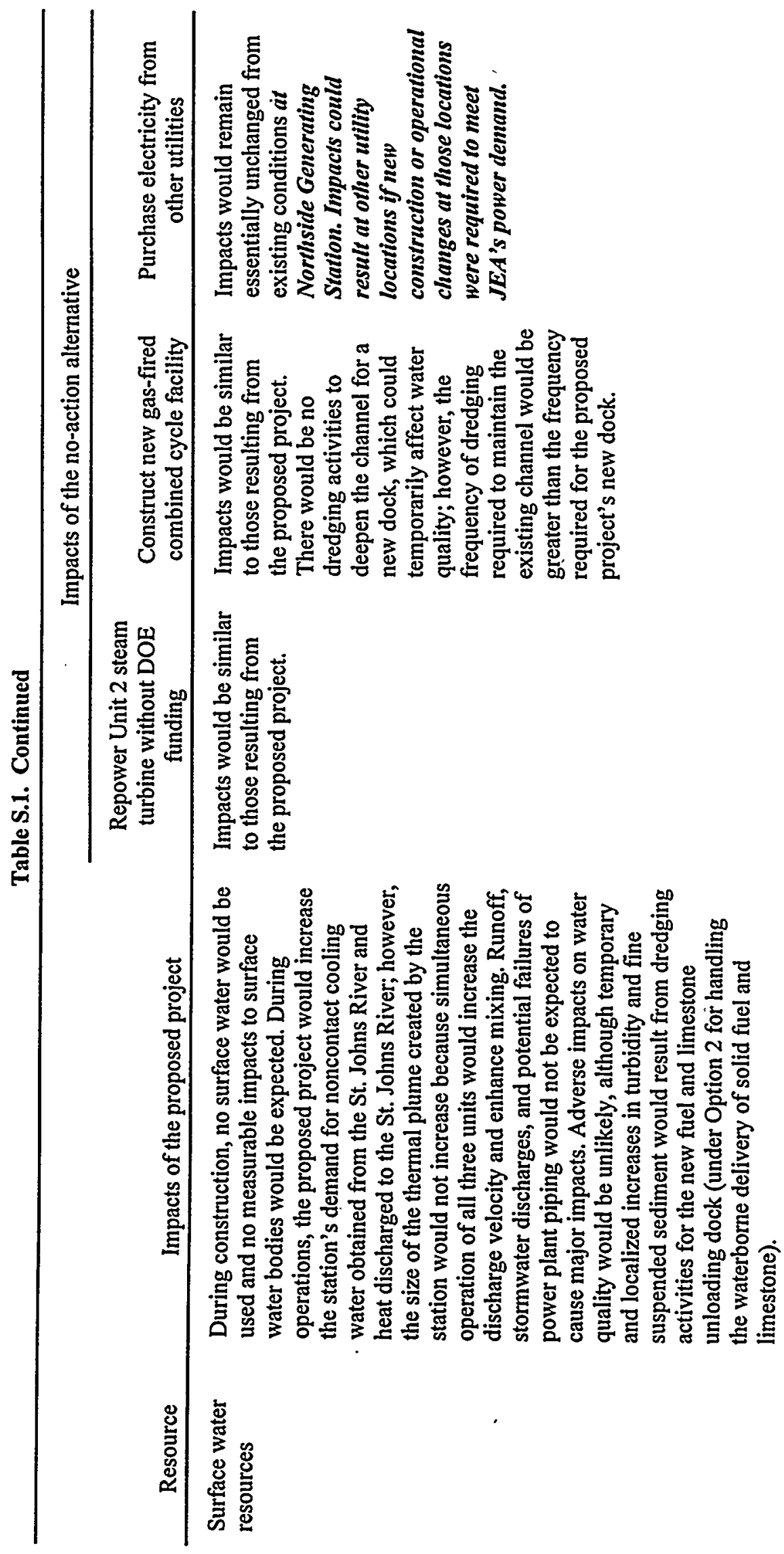

xxxi 


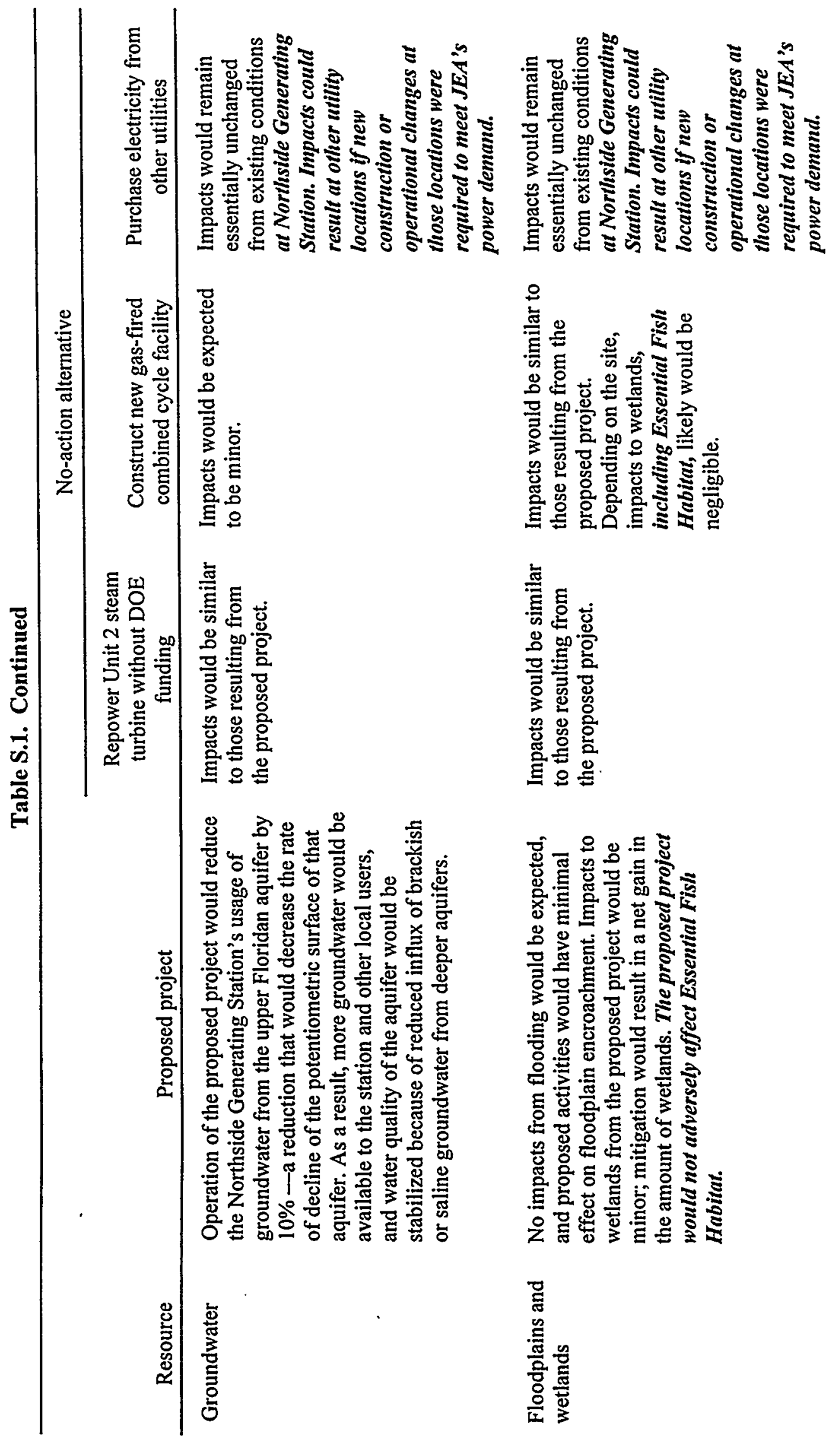




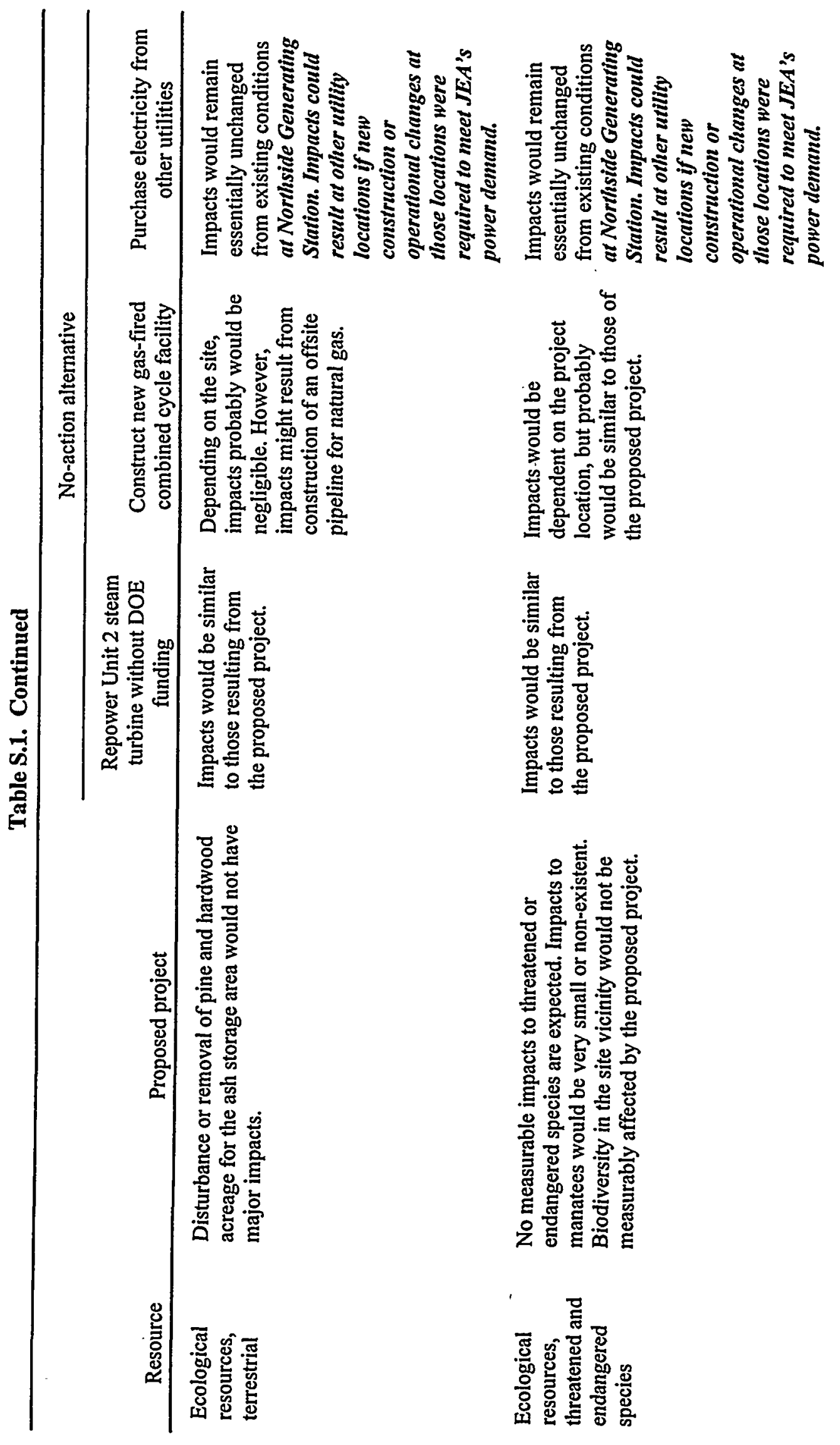




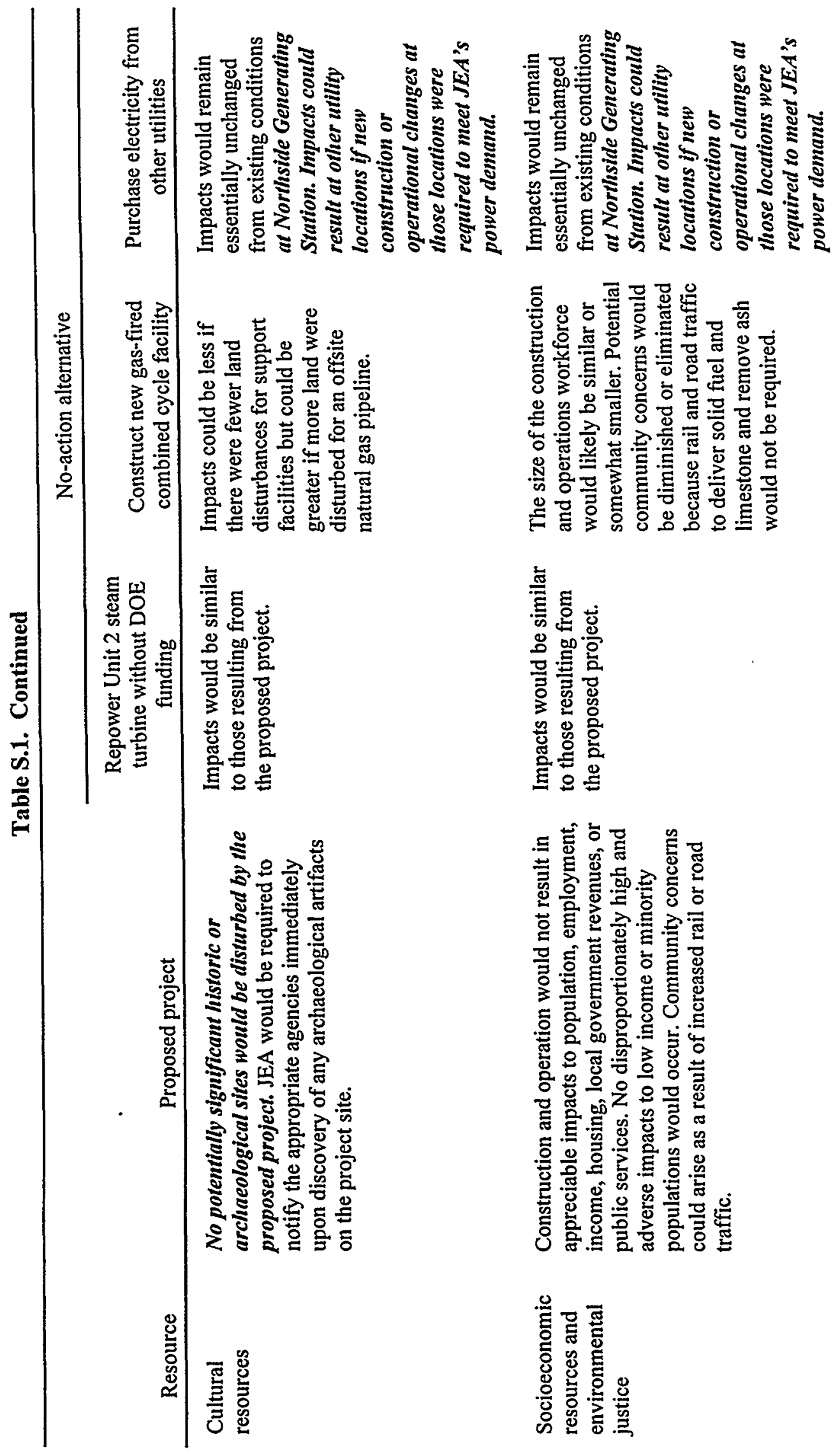




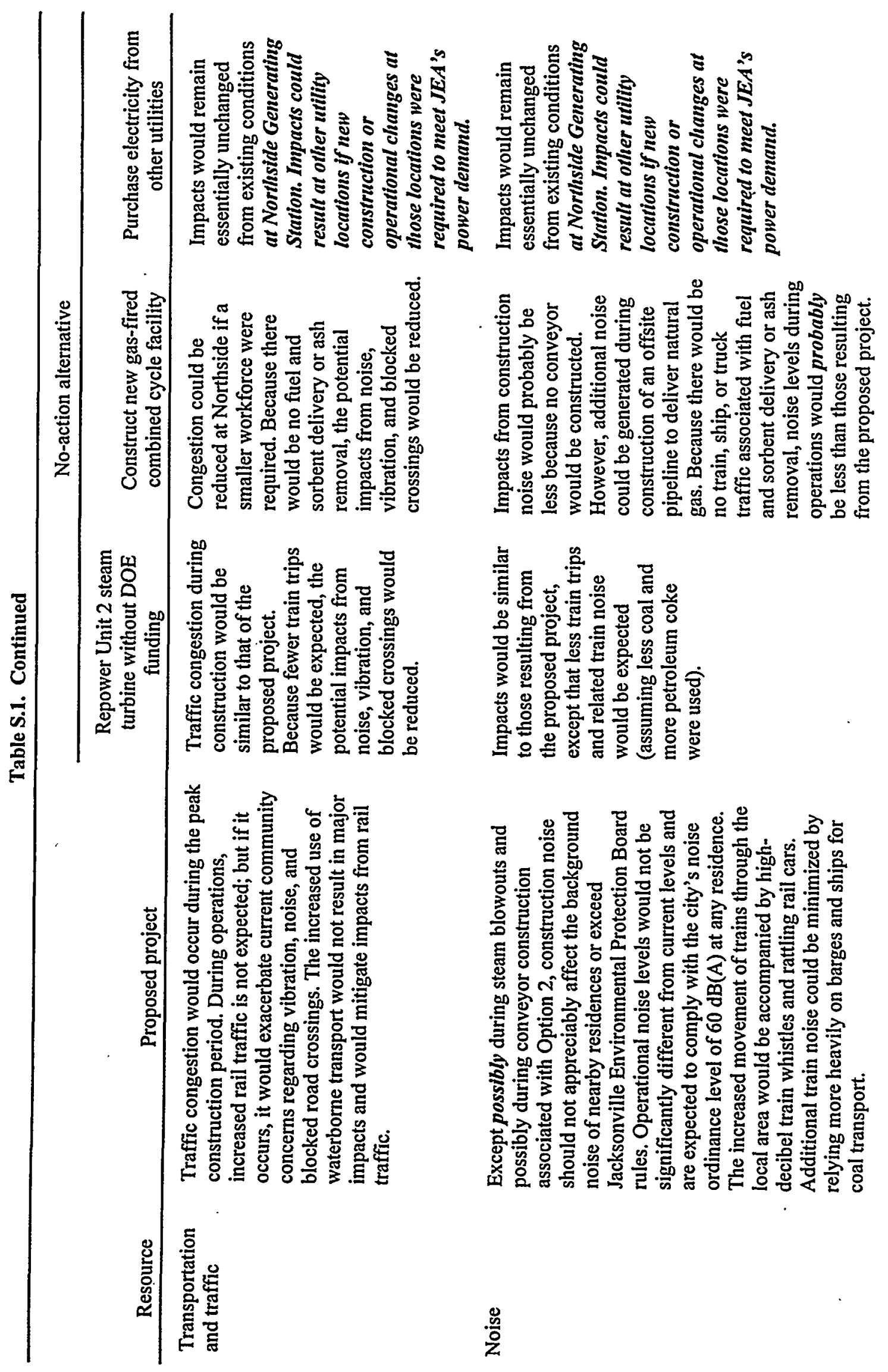




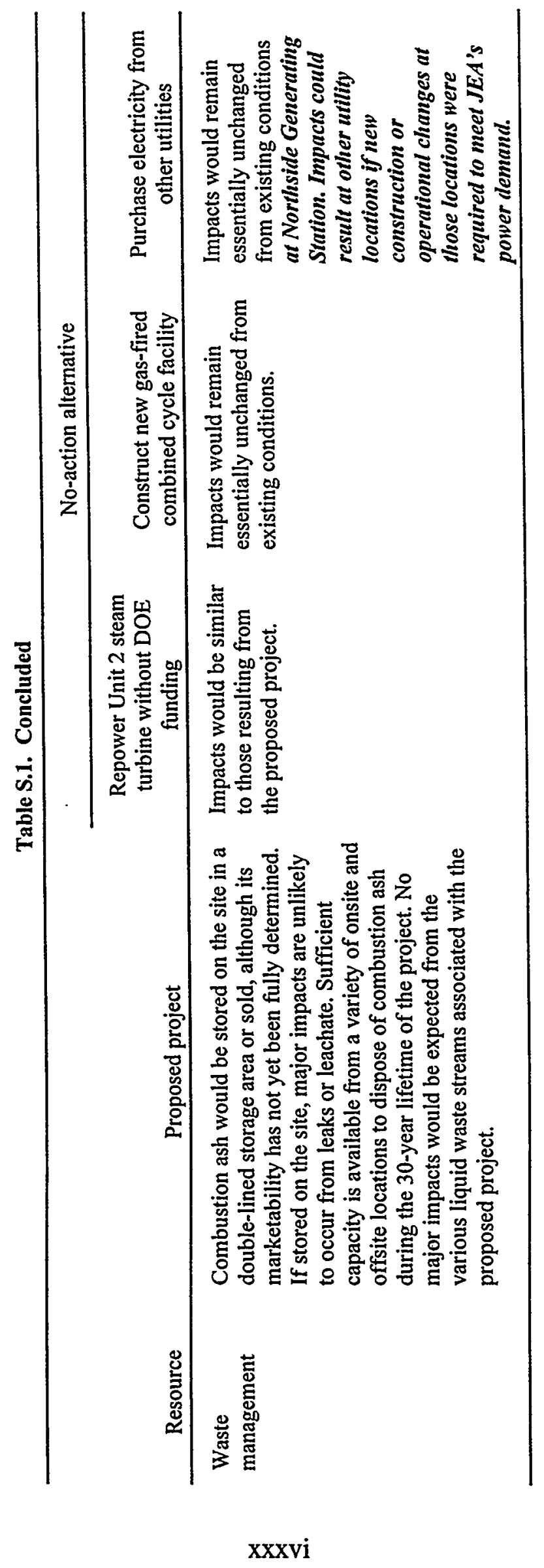




\section{PURPOSE OF AND NEED FOR THE AGENCY ACTION}

\subsection{INTRODUCTION}

This environmental impact statement (EIS) has been prepared by the U.S. Department of Energy (DOE), in compliance with the National Environmental Policy Act of 1969 (NEPA) as amended (42 USC 4321 et seq.), to evaluate the potential environmental impacts associated with constructing and operating a project proposed by JEA (formerly the Jacksonville Electric Authority). The project has been selected by DOE to demonstrate circulating fluidized bed (CFB) combustion technology under the Clean Coal Technology (CCT) Program. The EIS will be used by DOE in making a decision on whether or not to provide cost-shared funding to design, construct, and demonstrate the CFB technology proposed by JEA, the largest public power utility in Florida, at their existing Northside Generating Station in Jacksonville, Florida.

"Clean coal technologies" refer to a new generation of advanced coal utilization technologies that are environmentally cleaner and, in many cases, more efficient and less costly than conventional coal-using processes. These technologies contribute to a major objective of the national energy strategy to reduce U.S. dependence on potentially unreliable energy suppliers. Because the abundant domestic reserves of coal make it one of the nation's most important resources for sustaining a secure energy future, DOE has pursued a research and development (R\&D) program that has included increasing the use of coal while improving environmental quality. However, technologies that display potential at the proof-of-concept scale in an $R \& D$ program must be demonstrated at a larger scale before they are ready for commercialization. The CCT Program provides that essential step over the threshold between R\&D and commercial application of these technologies. The program takes the most promising technologies and moves them into the commercial marketplace through demonstration. Successful demonstrations also help position the United States to supply clean coal technologies, including CFB combustion, to a rapidly expanding world market for advanced coalfired combustion and pollution control technologies.

The CCT Program relies on substantial funding from sources other than the federal government, specifically, funds provided by the project participant (e.g., JEA for this proposed project).

Pub. L. 99-190, the Department of the Interior and Related Agencies Appropriations Act of 1986, introduced and defined cost sharing for the program. In addition, the U.S. Congress directed that projects in the CCT Program should be industry projects assisted by the government and not government-directed demonstrations.

In the CCT Program, the project participant (i.e., the non-federal-government participant) must finance at least $50 \%$ of the total cost of the project. The government assists the project participant by sharing in the project's cost, as detailed in a cooperative agreement negotiated between the project participant and DOE. The government also shares in the rewards of successful projects. The participant must agree to repay the government's financial contribution to ensure that taxpayers 
benefit from a successful project. The basis of the repayment is negotiated between the participant (or the technology provider) and the government.

The participant takes primary responsibility for designing, constructing, and demonstrating the project. During project execution, the government oversees project activities, provides technical advice, assesses progress by periodically reviewing project performance with the participant, and participates in decision making at major project junctures. In this manner, the government ensures that schedules are maintained, costs are controlled, project objectives are met, and the government's funds are repaid according to the terms in the cooperative agreements.

The CCT Program has committed funds to approximately 40 demonstration projects through 5 competitive solicitations. These solicitations have resulted in a combined commitment by the federal government and the project participants of about $\$ 5.7$ billion. DOE's cost share for these projects is roughly $\$ 1.9$ billion, or about $34 \%$ of the total. The project participants are providing the remaining $\$ 3.8$ billion, or approximately $66 \%$ of the total estimated cost, which exceeds their $50 \%$ minimum share mandated by Congress.

Technologies may be demonstrated at either new or existing facilities, but must be capable of repowering or retrofitting existing facilities. By definition, repowering technologies replace a major portion of an existing facility, not only to achieve a substantial emissions reduction, but also to increase facility capacity, extend facility life, and improve system efficiency. Repowering can increase capacity from 10 to $150 \%$ and may be more cost-effective than retiring older units and replacing them with new plants. It also offers the opportunity to efficiently and reliably integrate emissions control and power generation technologies. Repowering technologies include CFB combustion, pressurized fluidized bed combustion, and integrated gasification combined cycle.

By definition, retrofit technologies reduce sulfur dioxide $\left(\mathrm{SO}_{2}\right)$ and/or oxides of nitrogen $\left(\mathrm{NO}_{x}\right)$ emissions by modifying components of existing facilities or their present feedstocks. Retrofit technologies include advanced coal cleaning, advanced flue gas cleanup, coal liquefaction, and coal gasification.

In December 1985, Congress made funds available to DOE for conducting the first round of the CCT Program. Congress directed that this first solicitation (1) be open to all market applications of clean coal technologies, (2) apply to any segment of the U.S. coal resource base, and (3) apply to both new and existing facilities. On February 17, 1986, DOE issued a Program Opportunity Notice soliciting proposals to conduct cost-shared projects to demonstrate innovative, energy efficient, and economically competitive technologies. In response to the solicitation, 51 proposals were received and 9 projects were selected by DOE in July 1986 for negotiation. In addition, a list of alternate candidates was established from which replacement selection could be made should any of the original selections not proceed. JEA's proposed CFB combustor project has evolved through a series of site changes from a project that was selected by DOE in November 1990 from the alternate list for demonstration. 


\subsection{PROPOSED ACTION}

The proposed action is for DOE to provide support through cost-shared funding for the design, construction, and demonstration of CFB combustion technology for electric power generation at a size sufficient to allow utilities to make decisions regarding commercialization of the technology. Specifically, DOE will decide on providing approximately $\$ 73$ million (about $24 \%$ of the total cost of approximately $\$ 309$ million) to demonstrate CFB technology at JEA's Northside Generating Station in Jacksonville, Florida. The new CFB combustor would use coal and petroleum coke to generate nearly $300 \mathrm{MW}^{*}$ of electricity by repowering the existing Unit 2 steam turbine, a 297.5-MW unit that has been out of service since 1983. The project is expected to provide JEA with a low-cost, efficient, and environmentally sound source of additional electric generating capacity.

In addition, JEA plans to repower the currently operating Unit 1 steam turbine without costshared funding from DOE. The Unit 1 steam turbine would be essentially identical to the turbine for Unit 2 and would be repowered about 6 to 12 months after the Unit 2 repowering. Although the proposed project consists of only the Unit 2 repowering (because DOE would provide no funding for the Unit 1 repowering), this EIS evaluates the Unit 1 repowering as a related action (Section 2.2).

JEA, the project participant, plans to enter into a contract with Foster Wheeler Corporation, which would perform the design, engineering, procurement, and construction of the CFB combustor and air emissions control equipment. In addition, Black \& Veatch would provide the design and engineering for the solid fuel and limestone handling system, ash silos, ash storage area, site drainage areas, chemical waste treatment facility, and refurbishment and upgrades of existing equipment in the turbine building. Fluor Daniel would perform the procurement and construction for the solid fuel and limestone handling system and labor for the refurbishment of the existing steam turbine and generator. HB Zachry would perform the procurement and construction associated with remaining activities such as the ash silos, tanks, pumps, equipment refurbishment in the turbine building, and construction-related laydown, assembly of site-fabricated components, and facilities to be used by the construction workforce.

JEA and Foster Wheeler conceived and proposed the technology in response to the DOE solicitation; DOE's role is limited to providing the cost-shared funding for the proposed project and, therefore, DOE's decision is whether or not to fund the project. DOE's limited involvement influences the alternatives considered in the EIS (Section 2), and DOE will make its decision based on those alternatives.

*All electrical generating capacities presented in this EIS are gross rather than net; thus, the capacities include both the electricity used by consumers and the electricity consumed by the facilities themselves during operation. 


\subsection{PURPOSE}

The Clean Air Act (CAA) mandates that new and existing coal-fired power plants meet stringent emission levels. One of the goals of the CCT Program is to demonstrate promising coal utilization technologies that would not only help the power industry achieve mandated emission levels but would also result in plants operating even more cleanly than required by the CAA. As part of this goal, the proposed project was selected by $\mathrm{DOE}$ to demonstrate the combined removal of $\mathrm{SO}_{2}, \mathrm{NO}_{x}$, and particulate matter using CFB combustion technology, with the objective of achieving emission levels lower than CAA limits while at the same time producing power more efficiently and at less cost than conventional coal utilization technologies.

Fluidized bed combustors possess several advantages over conventional combustors. A CFB combustor can burn a wider variety of fossil fuels, especially low-quality fuels that contain high volumes of moisture and/or ash. Limestone in the bed removes $\mathrm{SO}_{2}$, thus eliminating the requirement for large, expensive scrubbers for $\mathrm{SO}_{2}$ emissions control. Because CFB technology operates at lower temperatures than conventional boilers, $\mathrm{NO}_{x}$ production is reduced. DOE expects the project to demonstrate that CFB technology has high potential for use in repowering existing plants and in new facilities in both the industrial and utility sectors.

The purpose of the proposed project is to generate technical, environmental, and financial data from the design, construction, and operation of facilities at a scale large enough to allow the power industry to assess the potential of CFB combustion technology for commercial application. Although there are many small, mostly industrial CFB combustors in the United States, CFB combustors on a scale of $200 \mathrm{MW}$ and larger are not yet accepted as commercial technology in the utility market. As indicated in Table 1.3.1, the size of the largest CFB combustor currently operating in the United States is $150 \mathrm{MW}$ and in the world is $250 \mathrm{MW}$ (Charles and Rezaiyan 1997). However, the conventional pulverized-coal boilers used today by electric utilities are predominantly units in the range of 250 to $400 \mathrm{MW}$. Electric utilities traditionally have installed these large units and will continue this practice to minimize the capital and operating costs of generating electricity (Charles and Rezaiyan 1997). A single large unit has economies of scale because it can be designed, constructed, and operated more cost effectively than two or more smaller units with the same total capacity. Factors contributing to the lower capital cost of a single large unit compared with multiple smaller units include reduced requirements for land, labor, and construction materials (e.g., concrete, structural steel, and piping). Factors contributing to the lower operating cost of a single large unit include reduced requirements for labor and auxiliary power. The proposed $297.5-\mathrm{MW}$ project would take the next step in size by evaluating the viability of CFB combustion technology within the range that is most desired by utilities ( 250 to $400 \mathrm{MW}$ ).

\subsection{NEED}

The need for the proposed CFB combustor project is twofold. First, cost-shared funding for the project addresses the Congressional mandate in Pub. L. 99-190 for demonstrating environmentally 
Table 1.3.1. Chronological list of existing and planned circulating fluidized bed combustors within and outside the United States with an electrical generating capacity of at least $150 \mathrm{MW}$

\begin{tabular}{|c|c|c|c|c|c|}
\hline Location & $\begin{array}{l}\text { Unit size } \\
\text { (MW) }\end{array}$ & $\begin{array}{l}\text { Number } \\
\text { of units }\end{array}$ & $\begin{array}{c}\text { Total } \\
\text { capacity } \\
(\mathrm{MW})\end{array}$ & Fuel & $\begin{array}{l}\text { Start-up } \\
\text { date }\end{array}$ \\
\hline \multicolumn{6}{|c|}{ United States } \\
\hline Robertson Co., Texas & 150 & 2 & 300 & Lignite & 1990 \\
\hline Taunton, Massachusetts & 150 & 1 & 150 & Coal & 1998 \\
\hline Cumberland, Maryland & 210 & 1 & 210 & Bituminous coal & 1999 \\
\hline Jacksonville, Florida & 297.5 & 2 & 595 & $\begin{array}{l}\text { Bituminous coal, } \\
\text { petroleum coke }\end{array}$ & 2002 \\
\hline \multicolumn{6}{|c|}{ Outside of the United States } \\
\hline Orebro, Sweden & 165 & 1 & 165 & Coal & 1990 \\
\hline Point Aconi, Canada & 165 & 1 & 165 & Coal & 1994 \\
\hline Grenoble, France & 250 & 1 & 250 & Coal & 1996 \\
\hline Turow, Poland & 235 & 2 & 470 & Brown coal, lignite & 1998 \\
\hline Tonghae, Korea & 220 & 1 & 220 & Anthracite & 1998 \\
\hline Tonghae, Korea & 220 & 1 & 220 & Anthracite & 1999 \\
\hline Guyama, Puerto Rico & 250 & 2 & 500 & Bituminous coal & 2000 \\
\hline
\end{tabular}

Source: Charles and Rezaiyan 1997.

sound technologies for the utilization of coal. Second, the project provides electricity for JEA's service area, thereby satisfying their future need for additional generating capacity. Although DOE recognizes that the need may be justified on either basis, its reason for selecting the proposed project is to support the demonstration of innovative, coal-based technology, not for power production or meeting demands for electricity. The cost-shared contribution by DOE for the demonstration would help reduce the risk to the JEA team in developing CFB technology to the level of maturity needed for decisions on commercialization.

\subsubsection{DOE's Need}

Since the early 1970 s, DOE and its predecessor organizations have pursued a broadly based coal $R \& D$ program for ensuring available and affordable energy supplies while improving environmental 
quality. This $R \& D$ program includes long-term activities that support the development of innovative, unproven concepts for a wide variety of coal technologies through the proof-of-concept stage. However, the availability of a technology at the proof-of-concept stage is not sufficient to ensure its continued development and subsequent commercialization. Before any technology can be seriously considered for commercialization, it must be demonstrated at a sufficiently large scale. Utilities generally are reluctant to demonstrate technologies at an unproven scale by themselves in the absence of strong economic incentives or legal requirements. The implementation of a technology demonstration program with cost-shared funding from the federal government has been endorsed by Congress and industry as a mechanism to accelerate the commercialization of innovative technology to meet near-term energy and environmental goals, to reduce risk to an acceptable level through costshared funding, and to provide the incentives necessary for continued R\&D directed at providing solutions to long-range energy supply problems.

The CCT Program includes a suite of technologies at varying levels of maturity. Because CFB technology is more mature than some of the others being demonstrated under the CCT Program, it tends to have a lower level of technological risk. The percentage of DOE funding provided for cost sharing is often used as a measure of the level of technological risk. The relatively small percentage $(24 \%)$ to be provided by DOE for the proposed project is indicative of the technology's relatively low risk.

The primary goal of the CCT Program, as funded by Congress in 1985 , is to make available to the U.S. energy marketplace a number of advanced, more efficient, economically advantageous, and environmentally responsible technologies for coal utilization. The CCT Program also addresses related energy issues including (1) long-range demand for additional electricity, (2) need for energy security, and (3) increased competitiveness in the international marketplace. The proposed CFB combustor project was selected for demonstration in the CCT Program as one of the projects that would best further the goals of the program.

Nearly $50 \%$ of current electrical generating capacity in the United States is over 30 years old. Thus, much replacement or refurbishment of aging facilities is anticipated over the next several decades to continue to meet current electricity demand, and new capacity will be needed to keep pace with rising demand for electricity. Currently, about $55 \%$ of U.S. electricity requirements are met by power plants fired with pulverized coal. As the most abundant domestic energy source, coal continues to represent an attractive option for future power plants, particularly through advanced technologies that have the potential to dramatically improve environmental performance and efficiency. The abundance of U.S. coal reserves makes it one of the nation's most important strategic resources for minimizing dependence on imported oil and sustaining a secure energy future. Using existing mining technology, recoverable reserves of coal in the United States could supply coal consumption at current levels for nearly 300 years. However, advanced coal utilization technologies such as those in the CCT Program must be successfully demonstrated if coal is to provide an environmentally acceptable and economically competitive source of energy into the 21 st century. 
As part of the CCT Program, the proposed project would meet DOE's need to demonstrate the commercial viability of using utility-scale CFB technology to generate electric power. The ability to show prospective domestic and overseas customers an operating facility rather than a conceptual or engineering prototype is expected to be a persuasive inducement to purchase American coal utilization technology. Data obtained on operational characteristics using a variety of coal sources during the demonstration would allow prospective customers to assess the potential of CFB technology for commercial application. Successful demonstration of CFB technology enhances prospects of exporting the technology to other nations and may provide the single most important advantage that the United States could have in the global competition for new markets. DOE is working closely with JEA and Foster Wheeler to develop plans for technology transfer and commercialization to help further the CFB technology and accelerate its commercialization.

\subsubsection{JEA's Need}

Following the recommendations of the Energy Policy Act of 1992, JEA adopted the use of the integrated resource planning (IRP) process for determining its future need for additional electric generating capacity. This technique takes into consideration the full range of alternatives available, including building new facilities, upgrading technology at existing facilities, improving efficiency at existing facilities, purchasing power from other utilities, using renewable energy resources to generate electricity, conserving energy to reduce the demand for electricity, and building cogeneration facilities (facilities that simultaneously provide steam to industrial users and generate electricity). For JEA's service area, the 1996 IRP analysis (JEA 1996a) indicated an annual growth in electrical demand of more than $3 \%$ and an annual growth in peak demand of over $4.5 \%$. JEA currently employs demand-side management to minimize annual growth by encouraging consumers to practice conservation and to reduce use during periods of peak demand. This effort includes three residential programs, one commercial/industrial program, and several educational programs.

The 1996 IRP analysis indicated-and the 1997 IRP update (JEA 1997a) confirmed-that new power supply resources would be needed by 1999 . About $135 \mathrm{MW}$ would be needed in 1999, with an increasing need of approximately $115 \mathrm{MW}$ per year through 2007 . This requirement for additional generating capacity is based on both the projected growth in electrical demand and plans by JEA to retire or shut down three oil- and gas-fired units with a history of equipment failure because of their age. The IRP study included detailed modeling of electrical demand on the JEA system, forecasts of fuel prices and availability, assessments of environmental factors, and evaluation of numerous facility construction and power purchase options. Screening analysis of over 60 alternatives led to a more detailed analysis of 12 alternatives involving construction and operation of electrical generating facilities and 6 alternatives involving power purchased from other utilities. An Electric Power Research Institute model called the Electric Generation Expansion Analysis System (EPRI 1996) was used to rank the alternatives according to cost. In addition to cost, environmental and land use considerations were factored into the resource plans to ensure that the least-cost plans selected by the 
model were socially and environmentally responsible. Based on all of these considerations, the most favorable plan to meet the future demand for electricity was the repowering of Units 1 and 2 at Northside Generating Station, combined with other options (i.e., new combustion turbines at other sites and power purchased from other utilities). JEA has adopted this plan as their preferred approach to meet demand.

\subsection{NATIONAL ENVIRONMENTAL POLICY ACT STRATEGY}

This EIS has been prepared for use by DOE decision makers in determining whether or not to fund the design, construction, and demonstration of the CFB combustor project proposed by JEA under the CCT Program. The EIS evaluates the environmental impacts of a range of reasonable alternatives and provides a means for the public to participate in the NEPA process.

An overall strategy for compliance with NEPA was developed for the CCT Program, consistent with the Council on Environmental Quality (CEQ) NEPA regulations and DOE regulations for compliance with NEPA, that includes consideration of both programmatic and project-specific environmental impacts during and after the process of selecting a project. This strategy, called tiering (40 CFR Part 1508.28), refers to the coverage of general issues in a broader EIS (e.g., for the CCT Program), followed by more focused statements or environmental analyses that incorporate by reference the general issues and concentrate on those issues specific to the proposal under consideration. Tiering eliminates repetitive discussions and evaluations of the same issues and focuses on the actual issues ripe for decision at each level of environmental review.

The DOE strategy has three principal elements. The first element involved preparation of a comprehensive Programmatic EIS (PEIS) for the CCT Program, published in November 1989 (DOE 1989), to address the potential environmental consequences of widespread commercialization of each of 22 successfully demonstrated clean coal technologies in the year 2010. The PEIS evaluated (1) a no-action alternative, which assumed that the CCT Program was not continued and that conventional coal-fired technologies with flue gas desulfurization controls would continue to be used for new plants or as replacements for existing plants that are retired or refurbished, and (2) a proposed action, which assumed that CCT Program projects were selected for funding and that successfully demonstrated technologies undergo widespread commercialization by 2010 .

The second element involved preparation of a preselection, project-specific environmental review of the proposed project based on project-specific environmental data and analyses that JEA supplied to DOE as part of the proposal. The review contained discussion of the site-specific environmental, health, safety, and socioeconomic issues associated with the project for use by DOE selection officials. The review analyzed the advantages and disadvantages of the proposed and alternative sites and/or processes reasonably available to JEA (DOE 1997).

The third element consists of preparing site-specific NEPA documents for each selected project. DOE determined that providing cost-shared funding for the proposed CFB combustor project would constitute a major federal action that may significantly affect the quality of the human environment. 
Therefore, DOE has prepared this EIS to assess the potential impacts on the human and natural environment of the proposed action and reasonable alternatives. As part of the overall NEPA strategy for the CCT Program, this EIS draws upon the PEIS and preselection environmental reviews that have already analyzed many alternatives and scenarios (e.g., alternative technologies and sites).

The Oak Ridge National Laboratory (ORNL) has assisted DOE in preparing this EIS and supporting documents for the proposed project. In independently assessing the issues and preparing the EIS, ORNL has utilized information provided by DOE; other federal, state, and local agencies; the JEA team; and others. DOE is responsible for the scope and content of the EIS and supporting documents and has provided direction to ORNL, as appropriate, in the preparation of these documents. The EIS has been prepared in accordance with Section 102(2)(C) of NEPA, as implemented under regulations promulgated by the CEQ ( 40 CFR Parts 1500-1508) and as provided in DOE regulations for compliance with NEPA (10 CFR Part 1021). The EIS is organized according to CEQ recommendations ( 40 CFR Part 1502.10).

A Notice of Intent to prepare the EIS and hold a public scoping meeting was published by DOE in the Federal Register on November 13, 1997 (62 FR 60889-92). The Notice of Intent invited comments and suggestions on the proposed scope of the EIS, including environmental issues and alternatives, and invited participation in the NEPA process. On November 24, 1997, an advertisement publicizing the public scoping meeting was printed in The Times-Union newspaper in Jacksonville, Florida, and the Notice of Intent was printed on November 26, 1997, in the "Legal Notices" section of the newspaper. The Notice of Intent and other information to announce the public scoping meeting were sent to 27 publications, radio stations, and television stations in Florida. Flyers announcing the meeting were distributed in the community. The Notice of Intent also was sent to stakeholders including federal, state, and local agencies, environmental groups, and a Native American tribal council for their information and comments on the proposed project.

Publication of the Notice of Intent initiated the EIS process with a public scoping period for soliciting public input to ensure that (1) significant issues are identified early and appropriately addressed, (2) issues of little significance do not consume time and effort, (3) the EIS is thorough and balanced, and (4) delays occasioned by an inadequate EIS are avoided (40 CFR Part 1501.7). DOE held the scoping meeting in Jacksonville, Florida, on December 3, 1997. The public was encouraged to provide oral comments at the scoping meeting and to submit additional comments in writing to DOE by the close of the EIS scoping period on December 31, 1997.

DOE received 3 oral responses and 20 written responses from members of the public, interested groups, and federal, state, and local officials. The responses assisted in establishing additional issues to be analyzed in the EIS and in determining the level of analysis required for each of the issues. Issues raised during public scoping are identified in Section 1.6.

On August 25, 1999, DOE issued a Notice of Availability in the Federal Register (64 FR 46363-64) to announce the availability of the draft EIS for public review and comment. The Notice of Availability announced a public hearing on the draft EIS and invited agencies, 
organizations, and individuals to present oral comments and submit written comments on the adequacy, accuracy, and completeness of the EIS. On September 23, 1999, and September 26, 1999, an advertisement publicizing the public hearing was printed in The Times-Union newspaper in Jacksonville, Florida. The Notice of Availability and other information to announce the public hearing were sent to 26 publications, radio stations, and television stations in Florida. Flyers announcing the meeting were distributed in the community. The draft EIS was sent to stakeholders including federal, state, and local agencies, environmental groups, and a Native American tribal council for their review and comment.

Publication of the Notice of Availability initiated the public comment period. DOE held the public hearing in Jacksonville, Florida, on September 30, 1999. The public was encouraged to provide oral comments at the hearing and to submit additional comments in writing to DOE by the close of the comment period on October 15, 1999. Testimony was presented by 1 person during the public hearing, and DOE received correspondence, from 12 members of the public, interested groups, and federal, state, and local officials. Altogether DOE received 60 comments, which helped to improve the quality and usefulness of the EIS. Among the topics or issues raised in the comments were concerns about

- reliability of CFB combustion technology in meeting expected air emissions rates for particulate matter and oxides of sulfur and nitrogen, in view of limited large-scale operating experience;

- air emissions of heavy metals, radionuclides, carcinogenic chemicals, and carbon dioxide $\left(\mathrm{CO}_{2}\right)$

- potential effects of cooling water discharge on the St. Johns River;

- potential entrainment of juvenile sea turtles, such as endangered green sea turtles, in the cooling water intake;

- potential effects on manatees and other endangered species;

- potential effects on Essential Fish Habitat, such as estuarine emergent wetlands;

- potential effects on cultural resources;

- disposal of ash, including whether the planned ash marketing would be successful;

- noise levels from construction, operation, and rail transportation;

- electromagnetic fields; and

- traffic congestion.

Generally, in responding to these comments, DOE revised the appropriate sections of the EIS to provide the requested information or further explore areas of potential impact. In addition, JEA has agreed to measures to mitigate potential impacts. For example, JEA has agreed to monitor traffic and provide a police officer or temporary traffic signal, as needed, to improve traffic flow. With respect to potential noise impacts, JEA has agreed to monitor noise levels or install mufflers, 
as needed, to ensure that noise levels at the nearest residences conform to applicable Noise Pollution Control ordinance limits. All comments and corresponding responses by DOE are contained in Appendix $G$ of this final EIS. Where responses to comments have initiated changes that appear in the final EIS, they have been so noted in the comment response.

\subsection{SCOPE OF THE ENVIRONMENTAL IMPACT STATEMENT}

This section summarizes the issues and alternatives associated with the proposed project that have been identified and considered by DOE and JEA. The following issues were initially identified as requiring analysis and assessment in the EIS and were included in the Notice of Intent:

1. Atmospheric Resources: potential air quality impacts resulting from air emissions during current and future operation of Northside Generating Station (e.g., effects of ground-level concentrations of criteria pollutants, and trace metals including mercury, on surrounding residential areas and the Timucuan Preserve (a National Park Service Class II ecological and historic preserve adjacent to the eastern edge of Northside Generating Station); potential effects of greenhouse gas emissions on global climate change;

2. Water Resources and Aquatic Ecology: potential effects on surface water and groundwater resources consumed and discharged; potential effects on estuarine salt marsh ecosystems and aquatic biota resulting from withdrawing and discharging cooling water from the St. Johns River (e.g., thermal discharge, entrainment or impingement of fish and invertebrate species);

3. Infrastructure and Land Use: potential effects resulting from the transport of coal, petroleum coke, and limestone required for the proposed project, including the development of land for infrastructure, storage, or waste disposal; affected resource areas including land (e.g., existing shoreline and wetlands), utilities, and transportation routes (e.g., train traffic to supply coal);

4. Solid Waste: pollution prevention and waste management practices, including solid waste impacts, caused by the generation, treatment, transport, storage, and disposal of solid wastes;

5. Construction: impacts associated with noise, traffic patterns, and construction-related emissions;

6. Aesthetics: impacts associated with a new stack that is taller than existing structures at Northside Generating Station;

7. Floodplains: potential impacts (e.g., impeding floodwaters, redirecting floodwaters, onsite and offsite property damage) of siting new buildings and infrastructure within floodplain and hurricane storm surge areas;

8. Wetlands: potential reduction of wetlands due to new construction (e.g., construction associated with infrastructure for receiving, conveying, and storing coal, petroleum coke, and limestone);

9. Community Impacts: impacts on public safety related to fire and emergency vehicle access to the Northside community of Jacksonville; impacts to local traffic patterns resulting from rail traffic; socioeconomic impacts on public services and infrastructure (e.g., police protection, schools, and 
utilities); noise associated with project operation; environmental justice with respect to the surrounding community; and

10. Cumulative Impacts: effects that result from the incremental impacts of the proposed project when added to other past, present, and reasonably foreseeable future actions (e.g., incremental discharge of cooling water affecting aquatic biota).

This list was developed partly on the basis of concerns identified by the public in response to an ongoing stakeholder outreach program conducted by JEA.

During the scoping process (Section 1.5), local residents and community organizations expressed concern about potential adverse effects that could be caused by the proposed project. The issue that probably has mobilized the largest number of people is the possible increase of train traffic in the vicinity of Northside Generating Station resulting from the need to transport coal to the plant. Currently, trains delivering coal to the St. Johns River Power Park use the same tracks that would be used by trains delivering coal for the proposed project.

At the public scoping meeting, a resident of a nearby neighborhood complained about past and continuing train traffic through the local area, specifically the communities of Panama Park, North Shore, and San Mateo (Figure 3.9.3). Stating that his concerns are shared by large numbers of his neighbors and documenting that assertion with reference to a recent petition drive, the speaker noted that large numbers of trains pass through the area at night (Section 3.9.1.2) and that these passages are routinely punctuated by high-decibel train whistles [which the speaker said he had measured at $108 \mathrm{~dB}(\mathrm{~A})$ at his property line] and loud rattling of the cars themselves [up to $85 \mathrm{~dB}(\mathrm{~A})$ ] that disturb the sleep of nearby residents. In a follow-up letter, this speaker also asserted that train traffic through the local area has resulted in vibration-induced structural damage to residences, can block access by emergency vehicles and others because of extended delays at on-grade rail crossings (Section 3.9.1.1), and could result in property devaluation. Similar concerns were also expressed at previous meetings between JEA and community groups such as the Northside Civic Association and the local umbrella organization calling itself Economic Development and Enhancement of the Northside. If local residents perceive that train traffic through their neighborhoods increases after the proposed project begins operations and attribute this increase to project operations, the level of their concerns could increase.

Other concerns expressed at the scoping meeting and at previous meetings between JEA and community groups are the potential effect of the project on air quality, the possible degradation of wetlands, and potential impacts to manatees and their habitat. Adverse impacts to these resources could increase the level of community concern. However, as discussed in Sections 4.1.2, 4.1.5.3, and 4.1.6.3, significant adverse impacts to these resources are not expected.

DOE used public input obtained during the scoping process to add to the list of issues requiring analysis and assessment. As discussions about the project progressed, DOE identified several other issues to be addressed. Table 1.6.1 lists the composite set of issues identified for consideration in the 
Table 1.6.1. Issues identified for consideration in the environmental impact statement

\section{Issues identified in the Notice of Intent}

Atmospheric resources

Water resources and aquatic ecology

Infrastructure and land use

Solid waste

Construction
Aesthetics

Floodplains

Wetlands

Community impacts

Cumulative impacts

\section{Additional issues identified during public scoping}

Noise and vibration-induced structural damage caused by rail traffic Hazardous air pollutants (e.g., sulfuric acid mist, fluorides, dioxins) Impacts to manatees and their habitat

Further issues identified by the U.S. Department of Energy

Cultural resources

Electromagnetic fields

Safety and health of workers and the public

Compliance with all applicable federal, state, and local statutes and regulations

EIS. Issues are analyzed and discussed in this EIS in accordance with their level of importance. The most detailed analyses focus on issues associated with train traffic and air quality impacts.

NEPA requires an EIS to include a discussion of reasonable alternatives to the proposed action. The purpose of and need for the proposed action determine the range of reasonable alternatives. Reasonable alternatives to the proposed CFB combustor project (i.e., approaches that are practical or feasible both technically and economically) that were considered initially as candidates for analysis in this EIS are identified and briefly described in the following bullets:

- No-action alternative. DOE would not provide funding to demonstrate CFB combustion technology. In the absence of DOE funding, there are three options that JEA could reasonably pursue: (1) JEA could construct the proposed project without DOE cost-shared funding; (2) JEA could construct a new gas-fired combined cycle facility at Northside Generating Station or at another location; and (3) JEA could purchase electricity from other utilities to meet JEA's projected demand.

- Alternative site. The CFB combustion technology would be demonstrated at another site. During its site selection process, JEA considered additional sites (i.e., the sites of their existing power plants and a hypothetical undeveloped site). An existing plant site was preferred because 


\section{JEA EIS}

the cost associated with construction of the project at an undeveloped site would be much higher, and the environmental impact likely would be much greater than at an existing facility.

- Alternative size. The CFB combustion technology would be demonstrated using a larger- or smaller-sized combustor. This alternative would not meet DOE's purpose (see Section 1.3).

- Alternative technologies. DOE would demonstrate other technologies. This alternative would not demonstrate CFB combustion technology and may not meet DOE's need to demonstrate advanced coal utilization technologies (see Section 1.4.1).

Of these alternatives, two were determined to require consideration in the EIS: the proposed project and the no-action alternative (including three reasonably foreseeable scenarios). Three alternatives were dismissed from further consideration: alternative site, alternative size, and alternative technologies. Alternatives and the basis for their consideration or dismissal are discussed in detail in Section 2.

\subsection{APPROACHES AND ASSUMPTIONS}

The following approaches are used and assumptions are made in this EIS:

- Potential environmental impacts are assessed for the surrounding environment (beyond the boundary of the facilities).

- Except as specifically noted in the text, potential environmental effects of the proposed project are based on the operating characteristics discussed in Section 2.

- One major exception to the above is that air quality impacts predicted by air dispersion modeling are based on the conservative assumption that the proposed facility operates at a $100 \%$ capacity factor rather than the expected $90 \%$ capacity factor.

- Potential environmental impacts of the proposed project during construction and operation during the demonstration period are assessed in Section 4. Section 5 addresses potential impacts of commercial operation following completion of the demonstration. 


\section{THE PROPOSED ACTION AND ALTERNATIVES}

This section discusses the proposed action, the no-action alternative (including three scenarios that are reasonably expected to result as a consequence of the no-action alternative), and alternatives dismissed from further consideration.

\subsection{PROPOSED ACTION}

The proposed action is for DOE to provide support through cost-shared funding for the design, construction, and demonstration of CFB combustion technology for electric power generation at a size sufficient to allow utilities to make decisions regarding commercialization of the technology. Specifically, DOE will decide on providing approximately $\$ 73$ million (about $24 \%$ of the total cost of approximately $\$ 309$ million) to demonstrate CFB technology at JEA's Northside Generating Station in Jacksonville, Florida. The new CFB combustor would use coal and petroleum coke to generate nearly $300 \mathrm{MW}$ of electricity by repowering the existing Unit 2 steam turbine, a 297.5-MW unit that has not operated since 1983. In doing so, the proposed project is expected to demonstrate emission levels of $\mathrm{SO}_{2}, \mathrm{NO}_{x}$ and particulate matter that would be lower than CAA limits while at the same time producing power more efficiently and at less cost than conventional technologies using coal. The proposed action as described in the following sections is DOE's preferred alternative.

\subsubsection{Project Location and Background}

The site for the proposed project is located in Jacksonville, Florida, about 9 miles northeast of the downtown area, at the existing Northside Generating Station (Figure 2.1.1). This 400-acre industrial site is situated along the north shore of the St. Johns River, approximately 10 miles west of the Atlantic Ocean. The local terrain is flat and there is a mix of industrial, commercial, residential, and agricultural land use in the vicinity. The most striking environmental feature associated with the area is the nearby presence of estuarine salt marsh backwaters of the St. Johns River.

The main entrance to Northside Generating Station is from Heckscher Drive, which runs eastwest along the site's southern border (Figure 2.1.2). Route 9A, a divided highway, runs north-south near the site's western border, and Interstate 95 and U.S. Highway 17, two major north-south thoroughfares, are located about 6 miles west of the site. The industrial 1,650-acre St. Johns River Power Park borders Northside Generating Station to the northeast, and the 46,000-acre Timucuan Ecological and Historic Preserve borders the site to the east. Blount Island, located immediately to the southeast in the St. Johns River, is a major port with facilities for docking, loading, and unloading large ocean-going vessels.

Existing steam generation units, combustion turbine units, and associated.infrastructure currently occupy about 200 acres of the 400 -acre Northside Generating Station property. The property contains a number of wetland areas, especially in the perimeter areas. The proposed project and related infrastructure would occupy about 75 acres of the property. The CFB combustor would be located immediately to the west of the existing Unit 3 on a section of the property that currently consists 


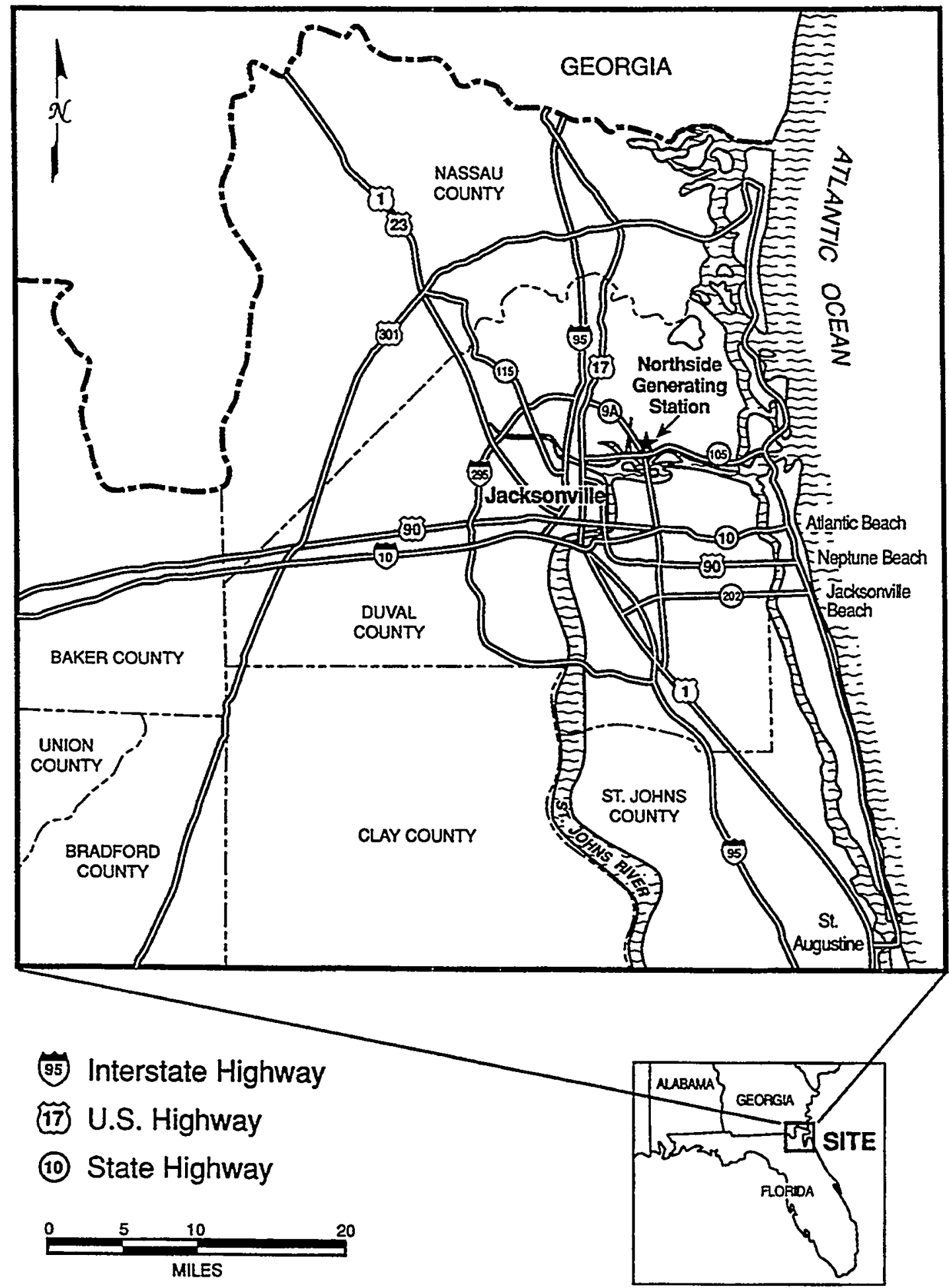

Figure 2.1.1. Regional location map for the proposed circulating fluidized bed combustor project. 


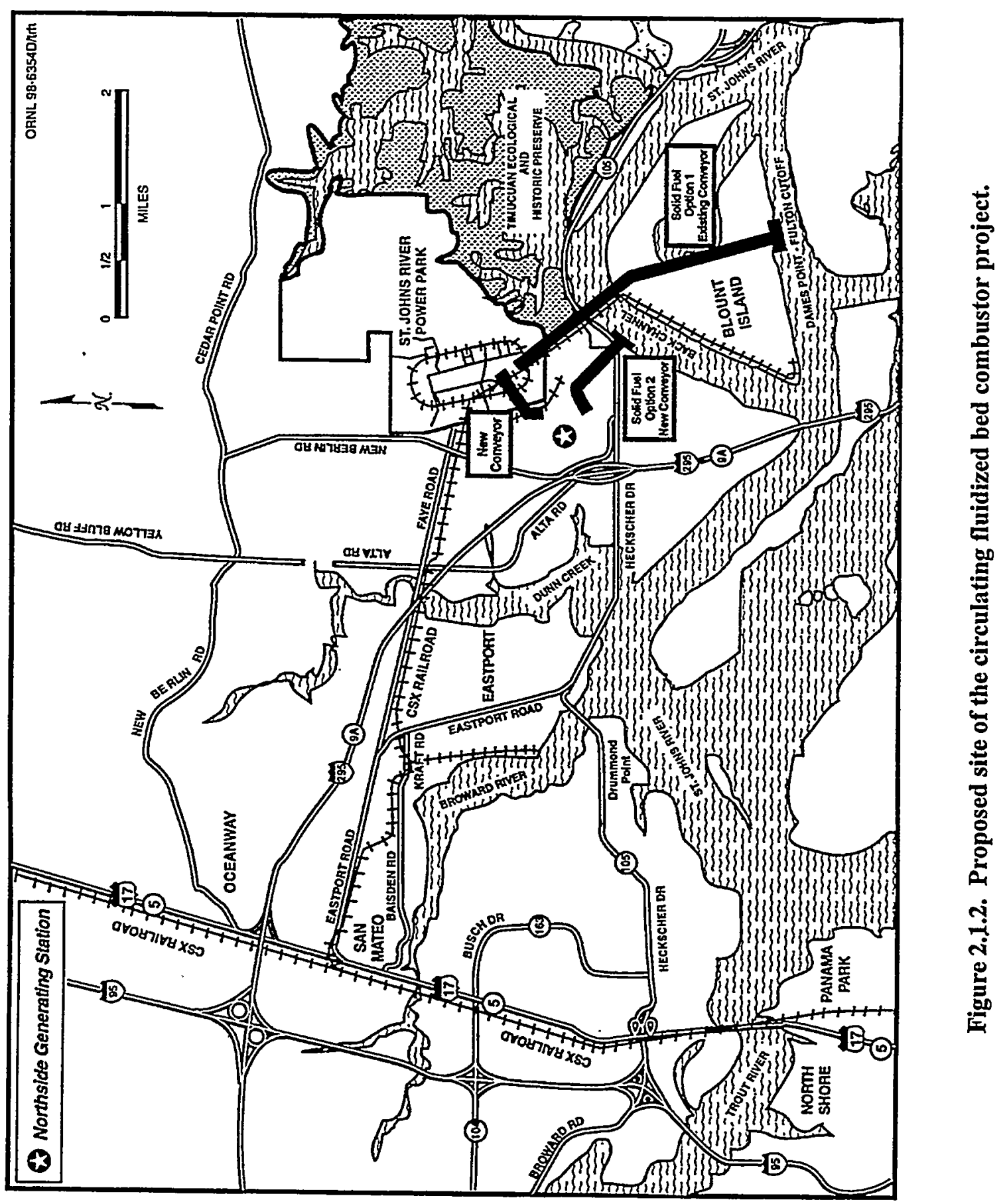


primarily of a covered parking lot for employees (Figure 2.1.3). Piping and related infrastructure would be constructed to link the new CFB combustor with the existing Unit 2 steam turbine.

Northside Generating Station has operated since November 1966 when the 297.5-MW Unit 1 came on-line. The 297.5-MW Unit 2 and the 564-MW Unit 3 started operation in March 1972 and June 1977, respectively. Unit 2 has been out of service since 1983 because of major boiler problems associated with the volume of its furnace being inadequate to accommodate the heat generated. The Unit 2 steam turbine is currently idle and the Unit 2 furnace and stack have recently been dismantled and removed. Units 1 and 3 currently operate at a capacity factor of between 30 and $40 \%$ because they are more costly to operate than other units in the JEA system. Northside Generating Station employs 265 people, including a pool of 105 operations workers and a pool of 126 maintenance workers who are stationed at Northside but are assigned daily tasks at other JEA facilities in addition to Northside. The remaining 34 workers at Northside are managers, engineers, and administrators for the JEA system of power plants.

All three units were designed with the capability of using both oil and natural gas for fuel. However, all units began operation with infrastructure capable of using No. 6 fuel oil only; Units 1 and 3 were modified later so that they can burn both natural gas and oil [No. 6 fuel oil or No. 2 fuel oil (diesel)]. Each unit has multiple burners that are capable of burning either natural gas or oil alone at any given time; fuel blending flexibility for each unit is attained by varying the number of burners using each fuel. Blending is dictated by economic and air emission considerations. Units 1 and 3 have no air pollution control with the exception of low- $\mathrm{NO}_{x}$ burners on Unit 3. Once-through cooling water is withdrawn from and discharged into the St. Johns River. In addition to Units 1 and 3 , 4 diesel-fired 52.5-MW combustion turbines that operate to meet peak demand are located at Northside Generating Station.

In the mid-1970s, the U.S. Army Corps of Engineers (COE) designed and constructed a 40-acre dredge spoil area on Northside Generating Station property (Figure 3.4.2). The COE has used this area to dispose of sediment dredged from the bottom of the back channel of the St. Johns River (Figure 2.1.2). Periodic dredging to maintain channel depth has been conducted at the existing Northside Generating Station fuel oil unloading dock.

The adjacent St. Johns River Power Park (Figure 2.1.2), a power plant which has operated since 1986, is a joint venture between JEA and Florida Power \& Light. JEA and Florida Power \& Light each receive approximately $50 \%$ of the electricity generated. The twin $660-\mathrm{MW}$ units are fueled with coal and petroleum coke, with coal comprising at least $80 \%$ of the fuel blend. The units were designed to use coal with a $4 \%$ sulfur content, but they currently are using $1 \%$ sulfur coal. Wet limestone scrubbers are used for $\mathrm{SO}_{2}$ control, and electrostatic precipitators are used for particulate control. Currently, all of the gypsum (generated by the scrubbers) and bottom ash (produced by the combustors) is sold, as is some of the fly ash (captured by the electrostatic precipitators). The Power Park uses two natural-draft cooling towers with a water discharge system that is integrated into the Northside Generating Station's system (i.e., make-up water needed by the cooling towers is drawn 

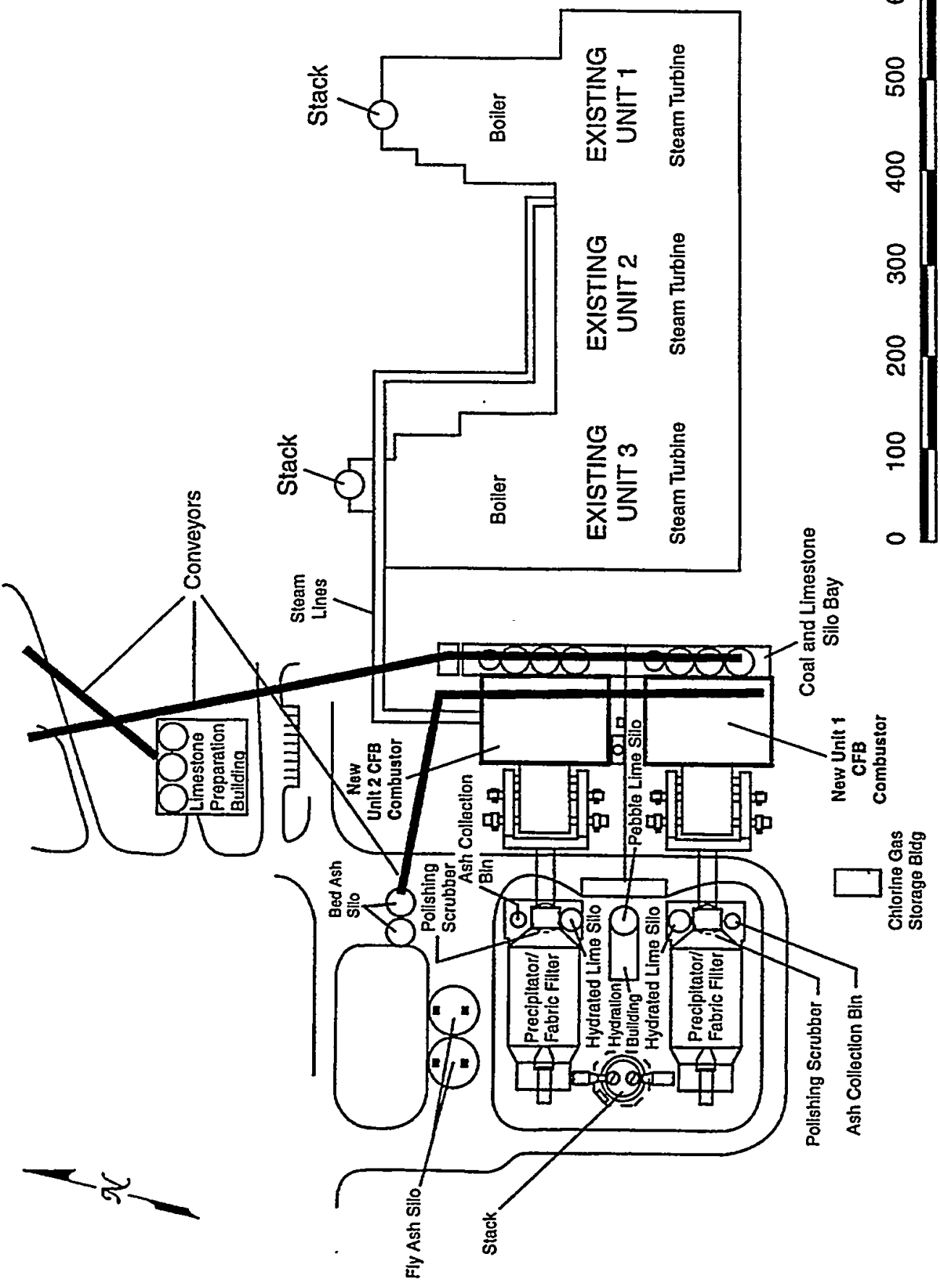

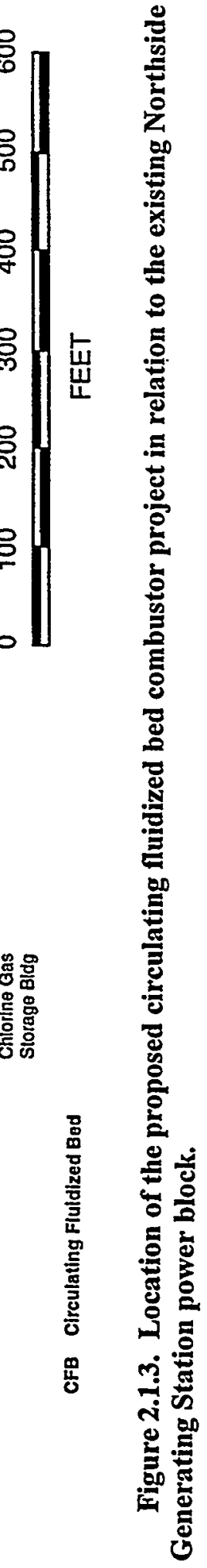




\section{JEA EIS}

from the Northside discharge of once-through cooling water, and blowdown from the cooling towers is added to the Northside discharge of once-through cooling water; circulating pumps direct the flow of water to prevent the blowdown from being recycled as make-up water).

\subsubsection{Technology Description}

CFB technology is an advanced method for burning coal and other fuels efficiently while removing air emissions inside the sophisticated combustor system. CFB technology provides flexibility in utility operations because a wide variety of solid fuels can be used, including high-sulfur, high-ash coal and petroleum coke. Figure 2.1.4 is a generalized diagram of the primary components in the CFB combustion process. Figure 2.1.5 is an artist's conception of key equipment for the technology.

In a CFB combustor, coal or other fuels, air, and crushed limestone or other sorbents are injected into the lower portion of the combustor for initial burning of the fuel. The combustion actually occurs in a bed of fuel, sorbent, and ash particles that are fluidized by air nozzles in the bottom of the combustor. The air expands the bed, creates turbulence for enhanced mixing, and provides most of the oxygen necessary for combustion of the fuel. As the fuel particles decrease in size through combustion and breakage, they are transported higher in the combustor where additional air is injected. As the particles continue to decrease in size, unreacted fuel, ash, and fine limestone particles are swept out of the combustor, collected in a particle separator (also called a cyclone), and recycled to the lower portion of the combustor. This is the "circulating" nature of the combustor. Drains in the bottom of the combustor remove a fraction of the bed composed primarily of ash while new fuel and sorbent are added. The combustion ash is suitable for beneficial uses such as road construction material, agricultural fertilizer, and reclaiming surface mining areas.

The limestone captures up to $98 \%$ of the sulfur impurities released from the fuel (DOE 1996). When heated in the $\mathrm{CFB}$ combustor, the limestone, consisting primarily of calcium carbonate $\left(\mathrm{CaCO}_{3}\right)$, converts to calcium oxide $(\mathrm{CaO})$ and $\mathrm{CO}_{2}$. The $\mathrm{CaO}$ reacts with the $\mathrm{SO}_{2}$ from the burning fuel to form calcium sulfate $\left(\mathrm{CaSO}_{4}\right)$, an inert material that is removed with the combustion ash. The combustion efficiency of the $\mathrm{CFB}$ combustor allows the fuel to be burned at a relatively low temperature of about $1,650^{\circ} \mathrm{F}$, thus reducing $\mathrm{NO}_{x}$ formation by approximately $60 \%$ compared with conventional coal-fired technologies (DOE 1996). Greater than $99 \%$ of particulate emissions in the flue gas are removed downstream of the combustor by either an electrostatic precipitator or a fabric filter (baghouse).

The heated combustor converts water in tubes lining the combustor's walls to high pressure steam. The steam is then superheated in tube bundles placed in the solids circulating stream and the flue gas stream. The superheated steam drives a steam turbine-generator to produce electricity in a conventional steam cycle.

A CFB combustor has several advantageous operating characteristics that differentiate it from more conventional technologies. Because the fuel and sorbent being added represent only a fraction 


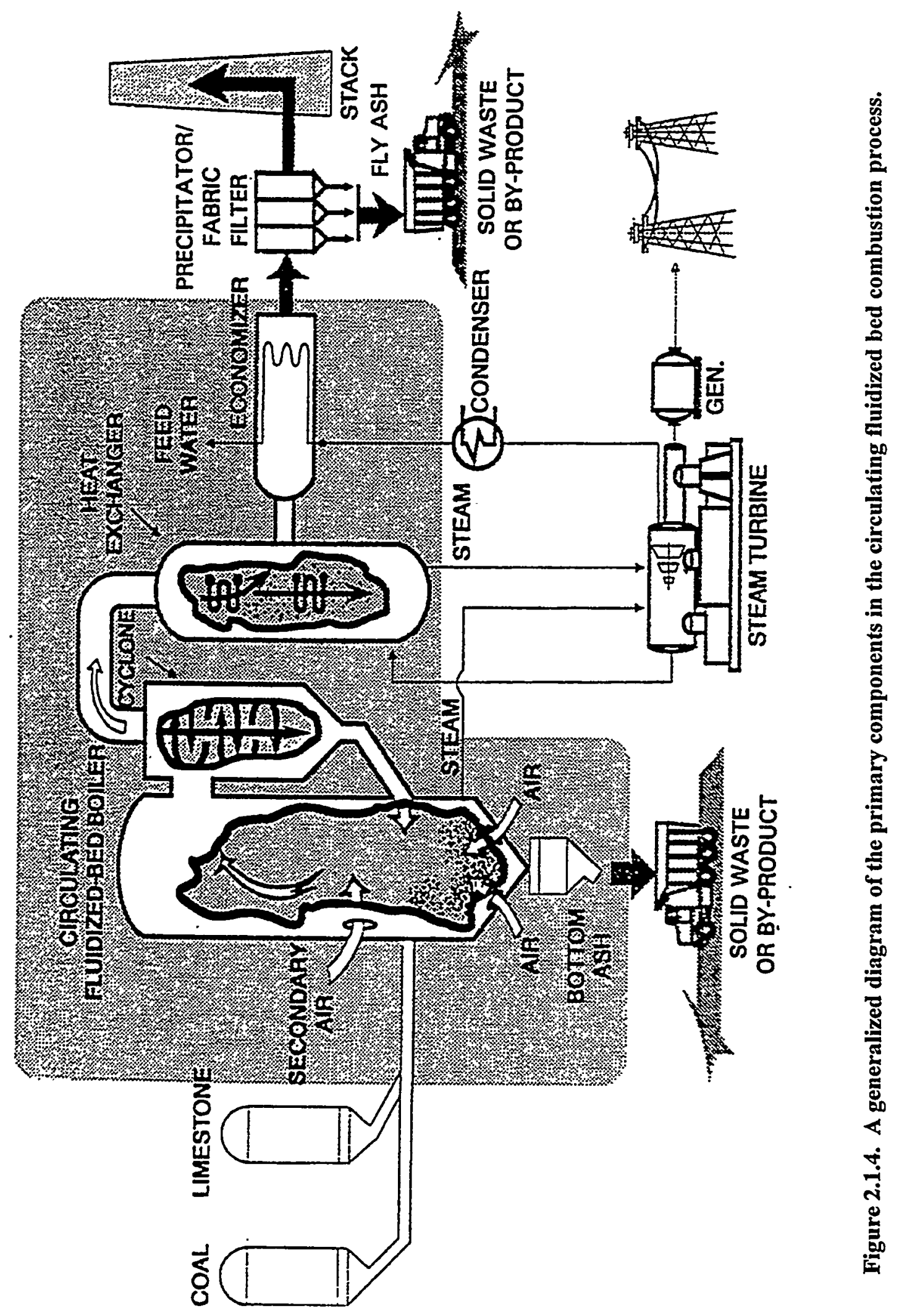




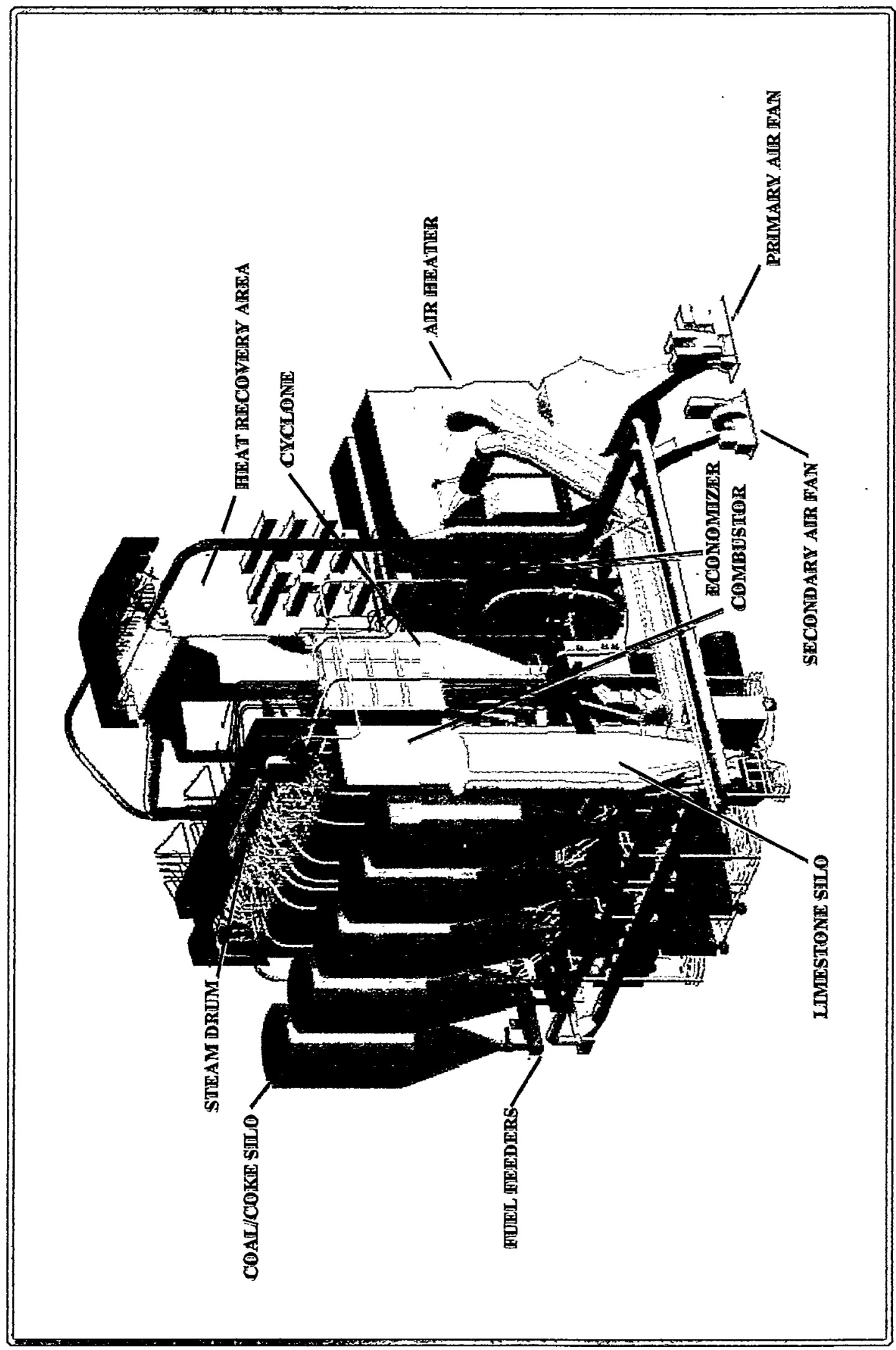

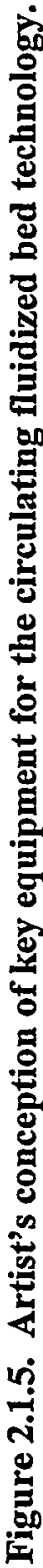



of the total fuel and sorbent available in the bed, the combustor reacts more slowly to variations in fuel or sorbent quality. Steam characteristics and furnace temperatures are more uniform, which usually results in easier operation, fewer upset conditions and emission spikes, and more consistency in the quality of combustion ash. As a consequence of bed fluidization and recycling of particles back to the lower portion of the combustor, enhanced mixing is achieved at more uniform temperatures, which allows more complete combustion and sorbent reaction. Another advantage of the combustor is the efficient transfer of heat due to the physical contact between the particles in the bed and the heat exchanger tubes in the walls. The technology also has lower operating and maintenance costs and a shorter "down time" for maintenance than conventional coal-fired technologies.

\subsubsection{Project Description}

The proposed CFB combustor project would incorporate the technology described in Section 2.1.2 into the repowering of the existing 297.5-MW Unit 2 steam turbine at Northside Generating Station. The related action of repowering the currently operating Unit 1 steam turbine is discussed in Section 2.2. One addition to the CFB technology described above is that the proposed project would use a polishing scrubber in combination with the CFB combustor to attain a $98 \% \mathrm{SO}_{2}$ removal rate. The polishing scrubber is a conventional scrubbing system that would use lime in a dry flue gas desulfurization process downstream of the combustor to convert $\mathrm{SO}_{2}$ chemically to calcium sulfite and calcium sulfate. It is called a polishing scrubber because the CFB combustor would remove $85-90 \%$ of the $\mathrm{SO}_{2}$ and the polishing scrubber would remove or "polish off" the remainder. This design is driven by economic rather than technical considerations (i.e., the CFB combustor alone could achieve a $98 \% \mathrm{SO}_{2}$ removal rate but the operating cost would be greater).

Another addition to the CFB combustion technology is that the proposed project would use a selective non-catalytic reduction system to further reduce $\mathrm{NO}_{x}$ emissions. Aqueous ammonia, the reagent for this system, would be injected into the CFB combustor exhaust gas to convert $\mathrm{NO}_{x}$ emissions to nitrogen gas and water via a chemical reduction reaction. Atmospheric emissions of ammonia can occur if the amount supplied to reduce $\mathrm{NO}_{x}$ in the flue gas is not used up (ammonia slip). However, excess ammonia in the stack gas can typically be reduced to a level in the parts per million by optimizing the amount of ammonia that is injected. For the proposed project, stack emissions of ammonia slip would not exceed $40 \mathrm{ppm}$. Based on technical, environmental, and economic considerations, JEA plans to decide on using an electrostatic precipitator or a fabric filter (baghouse) to remove at least $99.8 \%$ of particulate emissions for the proposed project.

The proposed project would generate $50 \%$ or less of the emissions allowed by New Source Performance Standards (NSPS). The project's $\mathrm{SO}_{2}$ limits (based on performance design) would be $0.15 \mathrm{lb} / \mathrm{MBtu}$ on a 30-day rolling average (for all periods of 30 consecutive days) and $0.2 \mathrm{lb} / \mathrm{MBtu}$ on a 24-hour block average (from midnight to midnight). By comparison, the corresponding NSPS for $\mathrm{SO}_{2}$ are $1.2 \mathrm{lb} / \mathrm{MBtu}$ with a $90 \%$ removal rate or $0.6 \mathrm{lb} / \mathrm{MBtu}$ with a $70 \%$ removal rate, on a 30 -day rolling average. The proposed project's $\mathrm{NO}_{x}$ limit would be $0.09 \mathrm{lb} / \mathrm{MBtu}$ on a 30 -day rolling 
average, compared to the NSPS of $1.6 \mathrm{lb} / \mathrm{MWh}$ (approximately $0.18 \mathrm{lb} / \mathrm{MBtu}$ ). The proposed particulate limit would be $0.011 \mathrm{lb} / \mathrm{MBtu}$ (verified by annual stack testing) compared to the NSPS of $0.03 \mathrm{lb} / \mathrm{MBtu}$, and the opacity limit would be $10 \%$ compared to the NSPS of $20 \%$.

The proposed project would use bituminous coal and petroleum coke to generate nearly $300 \mathrm{MW}$ of electricity. After satisfying the power requirements of Northside Generating Station, the power plant would provide electricity to the city of Jacksonville through the local power grid. During the 2-year demonstration, Unit 2 would be operated on several different types and blends of coal and petroleum coke to explore the flexibility of the CFB technology. The coal would be transported by ship (from areas such as Columbia and Venezuela), by train (primarily from the central Appalachian region such as West Virginia and eastern Kentucky), and by a combination of train and ship (train from West Virginia and eastern Kentucky to Newport News, Virginia, and ship from Newport News to Jacksonville). Either rail or ship transport would be capable of supplying all of the coal needs for the proposed project. The petroleum coke would be transported by ship from oil refineries in Venezuela and the Caribbean region. Petroleum coke is a high-sulfur, high-energy product having the appearance of coal. Refineries produce petroleum coke by heating and removing volatile organic compounds (VOCs) from the residue remaining after the refining process. Limestone for the CFB combustor would be transported by ship from areas such as the Caribbean region and the Yucatan Peninsula of Mexico to Northside Generating Station, or to the waterfront area of Jacksonville and then trucked to the station. With respect to the frequency of occurrence of the various modes of transportation, current economic projections indicate that marine transport would be the primary means of delivering solid fuel and limestone for the proposed project. The lime for the polishing scrubber would be trucked from a supplier within the southeastern United States.

Wherever possible, existing facilities and infrastructure located at Northside Generating Station would be used for the proposed project. These include the discharge system for cooling water to the St. Johns River, the wastewater treatment system, the water chlorination system, and the electric transmission lines and towers. The existing Unit 2 steam turbine would be refurbished prior to its return to service because it has not been used since 1983. Overhaul and/or modifications would also be performed to existing systems, such as the condensate and feedwater systems, circulating water systems, water treatment systems, plant electrical distribution systems, the switchyard, and the control systems. Unit 3 and the 4 combustion turbines would continue in operation without modification.

Major new facilities that would be constructed include the CFB combustor building, solid fuel delivery and storage facilities, limestone preparation and storage facilities, lime silo, polishing scrubber, 495-ft flue gas stack, and ash removal and storage facilities (Figure 2.1.3). A computerized drawing of the proposed CFB combustor facilities superimposed on a photograph of the existing Northside Generating Station is shown in Figure 2.1.6.

JEA is considering two options for handling the waterborne delivery of solid fuel and limestone (Figure 2.1.7). Option 1 is to construct a second unloader at the existing St. Johns River coal terminal 

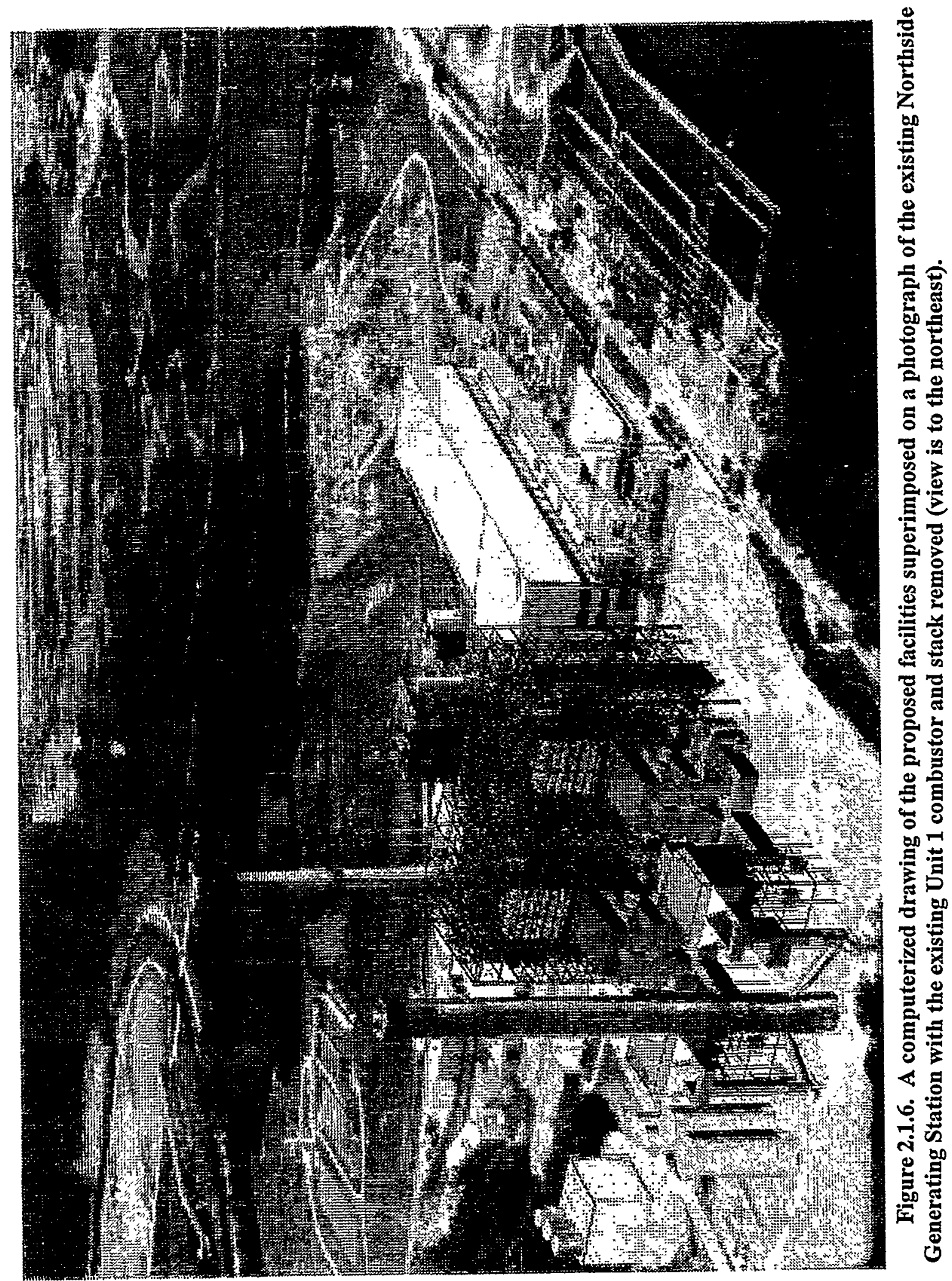

Final: June 2000

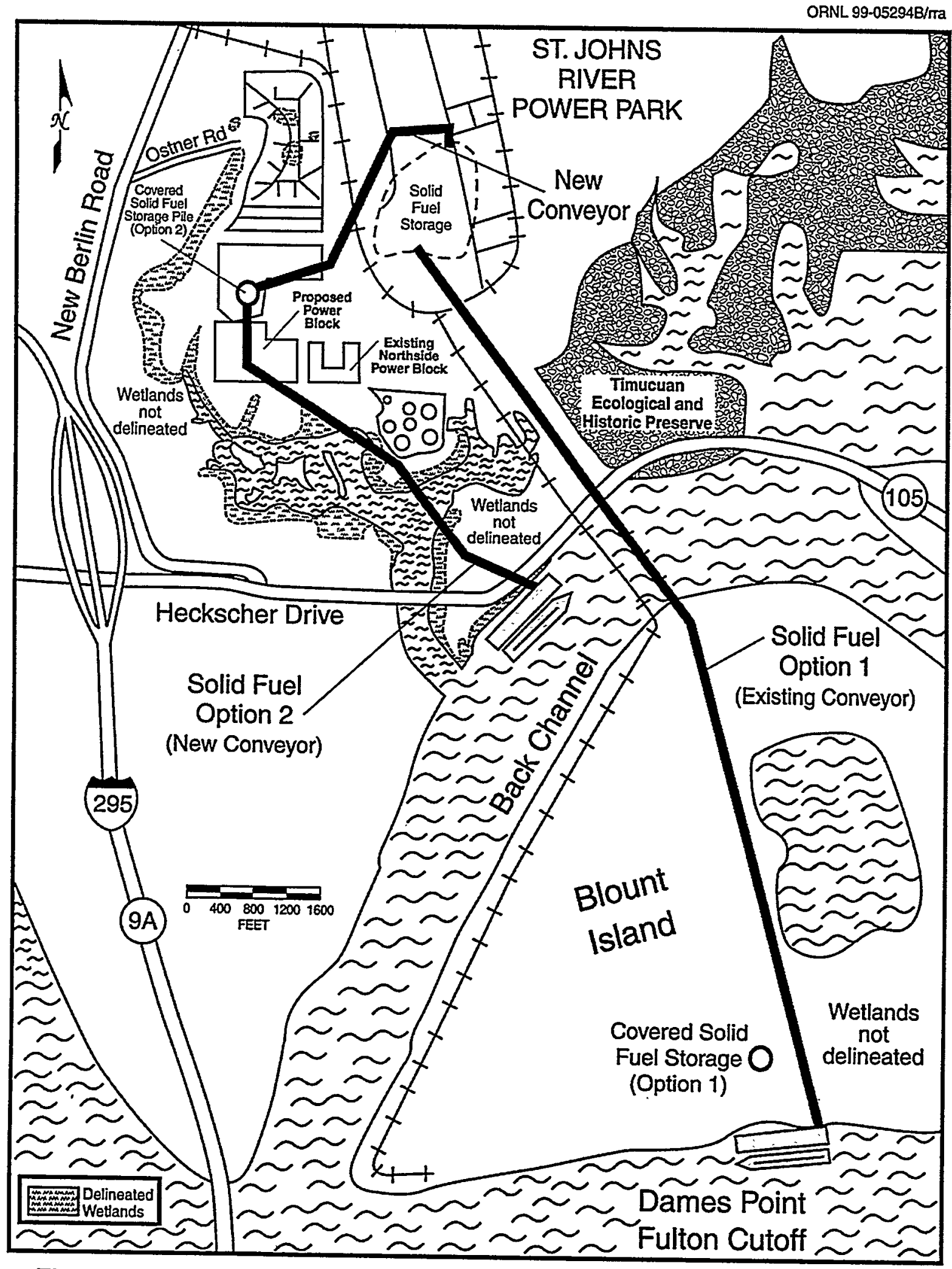

Figure 2.1.7. Map showing the two options for handling the waterborne delivery of solid fuel and limestone and indicating delineated wetlands. 


\section{JEA EIS}

that receives coal and petroleum coke delivered by ship and conveys the fuel to the St. Johns River Power Park. Two unloaders at the terminal would provide sufficient capacity to meet the future requirements of both the proposed project and the existing Power Park. Limestone delivered by ship to the coal terminal (rather than to the waterfront area of Jacksonville) would also be unloaded and transported by conveyor. The existing conveyor from the terminal to the Power Park transports solid fuel at a rate of 1,500 tons per hour. The speed of the conveyor's belt may be increased to 1,750 tons per hour to handle the additional fuel and/or limestone, but no additional conveyor would be constructed along this corridor. If the conveyor can't handle the additional fuel, new covered fuel storage would be added at the terminal. After the fuel and/or limestone are moved via the existing conveyor to the Power Park, the fuel would be stored at the existing solid fuel yard at the Power Park and then a new conveyor from the Power Park would transport the required fuel quantities to Northside Generating Station. The limestone would be transported on the new conveyor from the Power Park to Northside Generating Station (without storage at the Power Park) and stored as a new uncovered limestone pile. Under Option 1, no land would be purchased and most of the land has previously been disturbed. This option requires that JEA and Florida Power \& Light reach an agreement on the new facilities and that the existing conveyor from the terminal to the Power Park is deemed capable of handling the increased load.

Option 2 is to construct a new unloading terminal to receive coal, petroleum coke, and limestone delivered by ship, as part of an upgraded unloading facility that would replace Northside's existing fuel oil unloading dock. A small portion of the existing dock would be removed during construction of the new dock because it would interfere with construction. The remainder of the existing dock would be used during construction for access and staging of materials and then would be demolished following construction of the new dock. During facility operation, solid fuel, limestone, and fuel oil unloading would occur at the new dock, however, only one ship would dock at a time. Dredging associated with the new dock would deepen the channel by an average of $15 \mathrm{ft}$ from its current average depth of $25 \mathrm{ft}$. Because less siltation would occur at the new dock, located about $100 \mathrm{ft}$ farther from shore, the frequency of dredging required to maintain the depth of the new channel would be reduced compared to the existing dredging frequency. A new elevated conveyor would run adjacent to the existing oil pipelines to transport the solid fuel and limestone from the terminal to Northside Generating Station. A new covered solid fuel storage pile and a new uncovered limestone pile would be required at the station. Under Option 2, no land would be purchased and most of the land has previously been disturbed. All of the petroleum coke and limestone would be delivered by ship to the new unloading terminal. Under either Option 1 or 2 , coal delivered by train would be unloaded at the existing receiving facilities at the Power Park and a new conveyor from the Power Park to Northside Generating Station would be required.

JEA's management has established a target of a $10 \%$ reduction in annual stack emissions of each of 3 pollutants $\left(\mathrm{SO}_{2}, \mathrm{NO}_{x}\right.$ and particulate matter) from Northside Generating Station (Units 1, 2, and 3), as compared to emissions during a recent typical 2-year operating period (1994-95) of the 
station (Units 1 and 3). Also targeted for a 10\% reduction is the total annual groundwater consumption of Northside Generating Station, as compared to 1996 levels. These reductions are to be accomplished while increasing the total annual energy output of the station from $2,320,000 \mathrm{MWh}$ to $6,220,000 \mathrm{MWh}$.

Permits and other regulatory compliance issues for the proposed project are discussed in Section 7.

\subsubsection{Construction Plans}

\section{At their own risk, JEA has begun initial construction activities without DOE funding.} Construction would take approximately two years and, consistent with the original JEA schedule, would be completed in December 2001. Approximately 820 construction workers would be required during the peak construction period. Construction crews would probably work five 8-hour days with the option for four 10-hour days. Construction deliveries (e.g., concrete and small equipment) would normally be made by truck between 9 a.m. and 3 p.m. Major components of the proposed project would be delivered by train. Land requirements during construction and operation are discussed in Section 2.1.6.1.

\subsubsection{Operational Plans}

Demonstration of the proposed project, including performance testing and monitoring, would be conducted during a 2-year period from March 2002 until March 2004. Following the repowering of Unit 2 and the related action of repowering the existing Unit 1, the total number of employees at Northside Generating Station is expected to decrease by about $10 \%$ through attrition from the current level of 265 to about 238 workers (based on projected workforce requirements). Because existing employees would be used to operate and maintain the repowered units, no new employees would be hired by JEA, except for hiring of staff in future years of operation because of further attrition. Although JEA uses pools of employees for its facilities rather than dedicating personnel to particular units, it is expected that there would be a total of approximately 150 full-time equivalent workers at the 2 repowered units, including 74 for operations, 64 for maintenance, ard 12 for management, engineering, and administration. The facilities would be staffed with operations workers around the clock plus a maintenance crew working primarily during the daytime.

If the demonstration is successful, commercial operation would follow immediately (Section 5). During commercial operation, the facility would be used as a baseload unit operating 24 hours per day at the $297.5-\mathrm{MW}$ level for $90 \%$ of the time during the year. The facility would be designed for a lifetime of 30 years. 


\subsubsection{Resource Requirements}

Table 2.1.1 displays the operating characteristics, including resource requirements, for the proposed project in conjunction with the related action of repowering Unit 1 (Section 2.2) and those of the existing Unit 1 for comparison.

\subsubsection{Land Area Requirements}

Land that would be required temporarily during construction activities includes a total of about 15 acres for equipment/material laydown, storage, assembly of site-fabricated components, construction equipment access, and facilities to be used by the construction workforce (i.e., offices, sanitary facilities, and a construction parking lot). The 400-acre Northside Generating Station, half of which is currently occupied by facilities and infrastructure, should easily accommodate these land requirements.

During operation, the proposed facility would use a total of about 75 acres of land, including 40 acres for ash storage (Section 2.1.7.3). Stormwater and leachate storage ponds would occupy about 11 acres. Newly generated dredge spoil would be added to an existing onsite dredge spoil area (Figure 3.4.2).

The construction area associated with the major facilities for the proposed project's power block would be located on a nearly level 5-acre parcel of land that is partially grassed and has some temporary buildings and sheds that are used to store equipment (Figure 4.1.1). Part of this previously disturbed land also has been paved and is used as a covered parking lot for employees. Therefore, limited site clearing and grading would be required. Three new uncovered, asphalt parking lots occupying a total of about 2 acres would be built to replace the existing parking lot that would be removed prior to construction of the major facilities (Figure 4.1.1). A 10-vehicle lot would be constructed immediately north of the new CFB combustor building, while 30-vehicle and 130-vehicle lots would be built to the east of the existing Unit 1 . Under Option 1, about 7 acres of land would be required to expand the existing solid fuel yard at the Power Park and about 1.5 acres would be required for the new conveyor. Under Option 2, about 10 acres of land would be required for the covered solid fuel storage pile at Northside Generating Station and about 3 acres would be required for the new conveyors. Under either option, a new uncovered limestone storage pile would occupy about 2 acres.

\subsubsection{Water Requirements}

Water would be used during construction of the proposed project for various purposes including personal consumption and sanitation, concrete formulation and preparation of other mixtures needed to construct the facilities, equipment washdown, general cleaning, dust suppression, and fire protection. All water used during construction would be supplied from four deep wells that tap the upper Floridan aquifer. Combined potable and service water use during construction would average 
Table 2.1.1. Typical operating characteristics for the Northside Generating Station repowered Unit 2, the combination of the repowered Units 1 and 2, and the existing Unit 1

\begin{tabular}{|c|c|c|c|}
\hline Operating characteristics & $\begin{array}{l}\text { Repowered } \\
\text { Unit } 2\end{array}$ & $\begin{array}{l}\text { Repowered } \\
\text { Units } 1 \text { and } 2\end{array}$ & $\begin{array}{l}\text { Existing } \\
\text { Unit } 1\end{array}$ \\
\hline Generating capacity, MW & 297.5 & 595 & 297.5 \\
\hline Capacity factor, $\%^{a}$ & 90 & 90 & 39 \\
\hline Power production, $\mathrm{MWh} /$ year & $2,345,490$ & $4,690,980$ & $1,016,379$ \\
\hline Size of Northside Generating Station, acres & 400 & 400 & 400 \\
\hline Size of project site, acres & $75^{b}$ & 75 & - \\
\hline Coal consumption, tons/year ${ }^{c}$ & 912,100 & $1,824,200$ & - \\
\hline Petroleum coke consumption, tons/year ${ }^{d}$ & 715,820 & $1,431,640$ & - \\
\hline Limestone consumption, tons/year & 288,760 & 577,520 & - \\
\hline Lime consumption, tons/year & 3,900 & 7,800 & - \\
\hline Aqueous ammonia consumption, tons/year & 1,648 & 3,296 & - \\
\hline Natural gas consumption, $10^{6} \mathrm{ft}^{3} /$ year & $174^{e}$ & $348^{e}$ & $2,300^{f}$ \\
\hline Fuel oil consumption, $10^{6}$ gal/year & $0.03^{g}$ & $0.06^{g}$ & $43^{f}$ \\
\hline \multicolumn{4}{|l|}{ Water use } \\
\hline Noncontact cooling water, $10^{6} \mathrm{gal} / \mathrm{day}^{h}$ & 203 & 406 & 203 \\
\hline Treated groundwater, $10^{6} \mathrm{gal} /$ day & $0.57-0.64^{i}$ & $0.57^{j}$ & $0.64^{j}$ \\
\hline Chlorine gas consumption, tons/year & $11^{i}$ & $11^{j}$ & $11^{j}$ \\
\hline \multicolumn{4}{|l|}{ Air emissions } \\
\hline Sulfur dioxide $\left(\mathrm{SO}_{2}\right)$, tons/year & $1,650^{k}$ & $3,300^{k}$ & $5,528^{f}$ \\
\hline Oxides of nitrogen $\left(\mathrm{NO}_{x}\right)$, tons/year & $990^{k}$ & $1,980^{k, l}$ & $1,716^{f, l}$ \\
\hline Particulate matter (PM-10), tons/year & $121^{k}$ & $242^{k}$ & $394^{f}$ \\
\hline Carbon monoxide (CO), tons/year & $1,533^{m}$ & $3,066^{m}$ & $153^{f}$ \\
\hline Volatile organic compounds (VOCs), tons/year & $61^{m}$ & $122^{m}$ & $24^{f}$ \\
\hline Carbon dioxide $\left(\mathrm{CO}_{2}\right)$, tons/year & $2,293,100^{k}$ & $4,586,200^{k}$ & $743,400^{f}$ \\
\hline \multicolumn{4}{|l|}{ Effluents } \\
\hline $\begin{array}{l}\text { Wastewater discharged to St. Johns River, } \\
10^{6} \mathrm{gal} / \mathrm{day}\end{array}$ & $0.11-0.14^{i}$ & $0.14^{j}$ & $0.11^{j}$ \\
\hline $\begin{array}{l}\text { Wastewater discharged to evaporation/ } \\
\text { percolation ponds, } 10^{6} \text { gal/day }\end{array}$ & $0.027-0.41^{i}$ & $0.027^{j}$ & $0.41^{j}$ \\
\hline $\begin{array}{l}\text { Noncontact cooling water discharged to St. Johns } \\
\text { River, } 10^{6} \mathrm{gal} / \mathrm{day}^{n}\end{array}$ & 200 & 400 & 200 \\
\hline Heat rejected to St. Johns River, $10^{9}$ Btu/hour & 1.3 & 2.6 & 1.3 \\
\hline $\begin{array}{l}\text { Maximum permitted temperature rise above } \\
\text { ambient at the discharge outfall, }{ }^{\circ} \mathrm{F}\end{array}$ & 19 & 19 & $19^{\circ}$ \\
\hline \multicolumn{4}{|l|}{ Solid waste } \\
\hline Bottom ash, tons/year & $\begin{array}{l}105,880^{c}- \\
170,411^{d}\end{array}$ & $\begin{array}{l}211,760^{c}- \\
340,822^{d}\end{array}$ & - \\
\hline Fly ash, tons/year & $\begin{array}{l}57,012^{c}- \\
109,352^{d}\end{array}$ & $\begin{array}{l}114,024^{c}- \\
218,704^{d}\end{array}$ & - \\
\hline
\end{tabular}




\section{Table 2.1.1. Concluded}

\footnotetext{
${ }^{a}$ Capacity factor is the ratio of the energy output during a period of time to the energy that would have been produced if the equipment had operated at its maximum power during that period.

${ }^{b}$ Includes the footprint for the new facilities associated with the repowered Unit 1.

'Based on using typical coal alone for the entire year.

${ }^{d}$ Based on using typical petroleum coke alone for the entire year.

${ }^{{ }^{*}}$ Based on 3 cold starts and 5 warm starts per year, plus consumption by the limestone dryer of $20,000 \mathrm{ft} /$ hour.

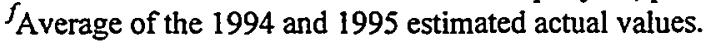

${ }^{8}$ Based on 1 cold start and 1 warm start per year.

${ }^{h}$ Unthrottled. Represents allocated portions (based upon generator nameplates) of station 3-unit total flow of $827 \mathrm{Mgd}$.

'Includes existing Units 1 and 3. Changes in groundwater consumption and wastewater discharges at Northside Generating Station would only be partially realized during the period after Unit 2 is repowered but before Unit 1 is repowered.

$j_{\text {Includes existing Unit } 3 .}$

${ }^{k}$ Assumed to be $90 \%$ of the potential emissions, thereby incorporating the capacity factor. Emissions would be nearly independent of fuel type because emissions controls would be adjusted based on fuel type to achieve the same level of emissions.

'JEA is committed to achieving a $10 \%$ reduction in annual $\mathrm{NO}_{x}$ emissions at Northside Generating Station. If the reduction is not achieved by the repowering of Units 1 and 2, JEA would attain the reduction by using one or more of the following methods at Unit 3: (1) using more natural gas and less oil; (2) reducing the hours of operation; and (3) installing additional $\mathrm{NO}_{x}$ emission controls.

${ }^{m}$ Because the maximum emission rates occur at minimum load, a proposed annual cap is given rather than incorporating the capacity factor.

${ }^{n}$ Unthrottled. Represents allocated portions (based upon generator nameplates) of station 3-unit discharge to St. Johns River of $815 \mathrm{Mgd}$.

${ }^{\circ}$ During 1997 and 1998, the average temperature rise at Northside Generating Station was $9^{\circ} \mathrm{F}$ and the maximum measured temperature rise was $16.6^{\circ} \mathrm{F}$.
}

$0.001 \mathrm{Mgd}$ (about $1 \mathrm{gpm}$ ). Drinking water also would be provided using bottled water. Portable toilets would minimize requirements for additional sanitary water.

Water for plant operation would be supplied from both the St. Johns River and the four deep wells that tap the upper Floridan aquifer. The total flow of once-through, noncontact cooling water required to operate Northside Generating Station (all 3 units) at full load would average $827 \mathrm{Mgd}$ $(574,000 \mathrm{gpm})$. This cooling water would be drawn from the back channel of the St. Johns River and then $815 \mathrm{Mgd}(566,000 \mathrm{gpm})$ would be returned to the river after passing through the condensers (Figure 2.1.8).

Service water, potable water, process water for generating steam such as boiler makeup, and other Northside Generating Station high-quality water needs would be obtained from the four deep wells. Based on 1996 levels, current average daily consumption of groundwater by both of the existing Units 1 and 3 is $0.64 \mathrm{Mgd}$ (444 gpm). After Units 1 and 2 are repowered, JEA has committed to a $10 \%$ reduction in groundwater consumption (based on an annual average as compared to 1996 levels).

The estimated total supply of surface water and groundwater that would be required to operate Northside Generating Station (all 3 units) after repowering is about $827.57 \mathrm{Mgd}$ (575,000 gpm). On an annual basis, the total volume of water that would be supplied is 271,860 million gallons assuming a $90 \%$ capacity factor. 


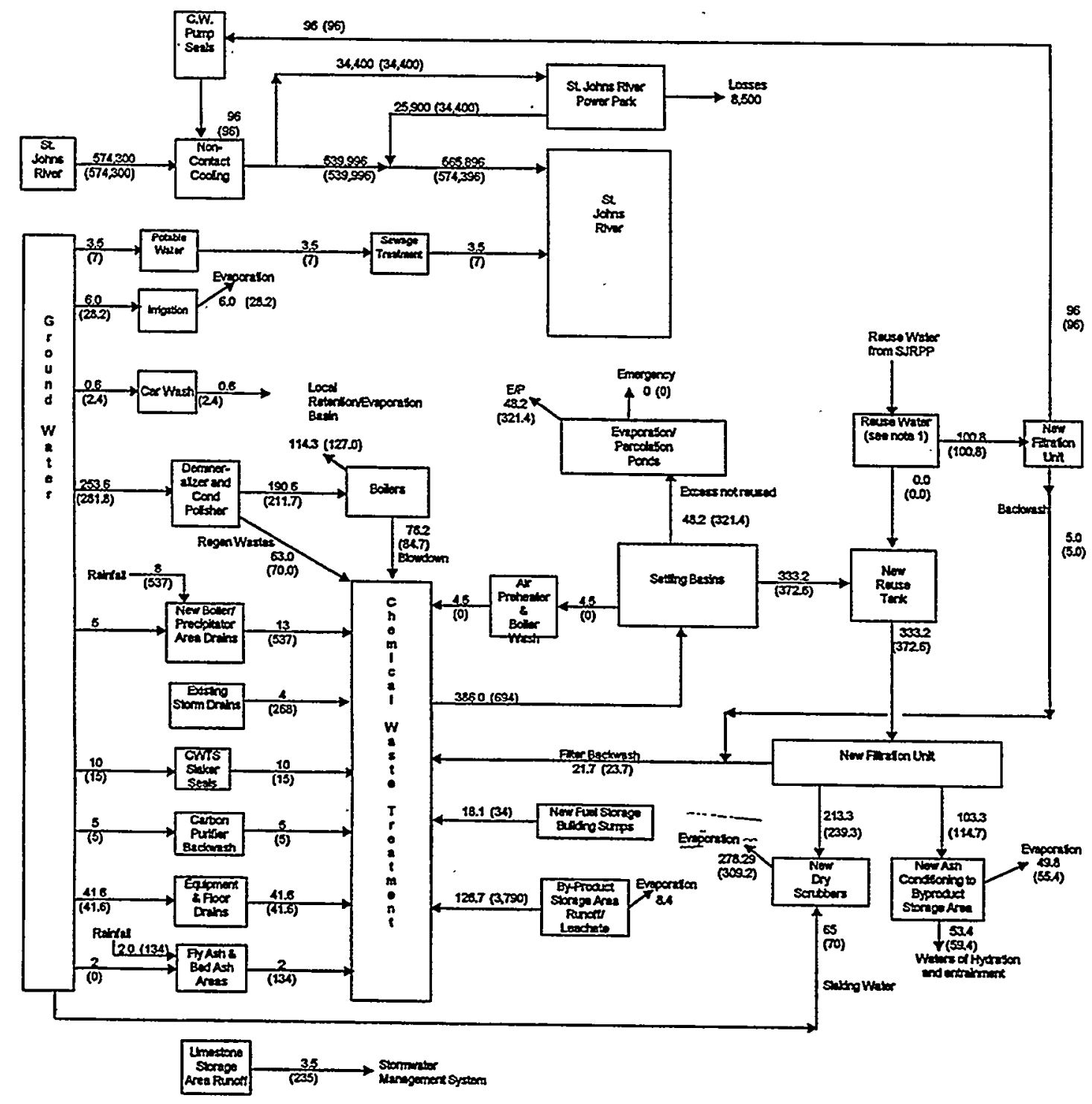

Ground Water Todal $\left(A_{\text {gg }}\right)=565,485$ opd

Ground Water Total (Peak) $=657,083$ apd

Northside Generating Station Water Balance (Flows in gpm)

After Repowering, Cells 1 and 2 of Byproduct Storage Area

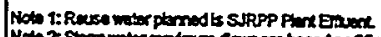

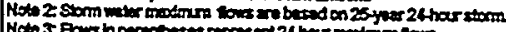

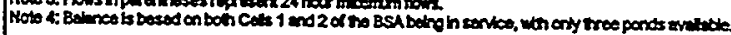

Figure 2.1.8. Water flow diagram that depicts water requirements and discharges at Northside Generating Station after repowering both Units 1 and 2. 


\subsubsection{Fuel Requirements}

The proposed project would be fueled with bituminous coal and petroleum coke. Table 2.1.2 presents an analysis of the composition of the coal and petroleum coke expected to be received for the proposed project. The heating value is expected to be at least.10,000 Btu/lb for the coal and at least 13,000 Btu/lb for the petroleum coke. The percentage of sulfur would range between 0.5 and $4.5 \%$ for the coal and between 3 and $8 \%$ for the petroleum coke. Assuming a $90 \%$ capacity factor and the use of a single fuel (i.e., either coal or petroleum coke alone), the Unit 2 combustor would consume coal at a rate of about 912,100 tons per year or petroleum coke at a rate of about 715,820 tons per year. Each of these amounts would be reduced by $50 \%$ by assuming both of these fuels are used equally during the year, including blends of the fuels. Natural gas would be the primary fuel used during cold starts. About 3,120,000 $\mathrm{ft}^{3}$ would be consumed during a 12-hour startup prior to beginning the switch to coal and/or petroleum coke. Alternatively, about 23,100 gal of No. 2 fuel oil, the backup start-up fuel, would be consumed during the 12-hour start-up. Approximately four cold starts are expected annually (three cold starts using natural gas and one cold start using No. 2 fuel oil).

\subsubsection{Construction and Other Materials}

Locally obtained construction materials would include crushed stone, sand, and lumber for the proposed facilities and temporary structures such as enclosures, forming, and scaffolding. The facilities would be built using large quantities of structural steel, piping, and concrete. Assuming a $90 \%$ capacity factor, annual consumption of limestone, injected into the lower portion of the CFB combustor to remove $\mathrm{SO}_{2}$, would be approximately 288,760 tons. The maximum annual consumption of lime, used by the polishing scrubber for additional $\mathrm{SO}_{2}$ removal, would be 3,900 tons. The selective non-catalytic reduction system would inject a maximum of 2,138 tons per year of $\mathrm{NO}_{x}$ reagent into the $\mathrm{CFB}$ combustor exhaust gas to convert $\mathrm{NO}_{x}$ emissions to nitrogen gas and water.

\subsubsection{Outputs, Discharges, and Wastes}

Table 2.1.1 includes a summary of discharges and wastes for the proposed project during the demonstration. Also presented in the table are the discharges and wastes for the proposed project in conjunction with the related action (Section 2.2) and those of the existing Unit 1 for comparison.

\subsubsection{Air Emissions}

Based on a $90 \%$ capacity factor, air emissions from the proposed project would include approximately 1,650 tons per year of $\mathrm{SO}_{2}, 990$ tons per year of $\mathrm{NO}_{x}, 121$ tons per year of particulate matter, 1,533 tons per year of carbon monoxide (CO), and 61 tons per year of VOCs. Emissions would be nearly independent of fuel type because emissions controls would be adjusted (i.e., tightened or relaxed) based on fuel type to achieve the same level of emissions. Trace emissions of other pollutants would include beryllium, sulfuric acid mist, mercury, hydrochloric acid, 


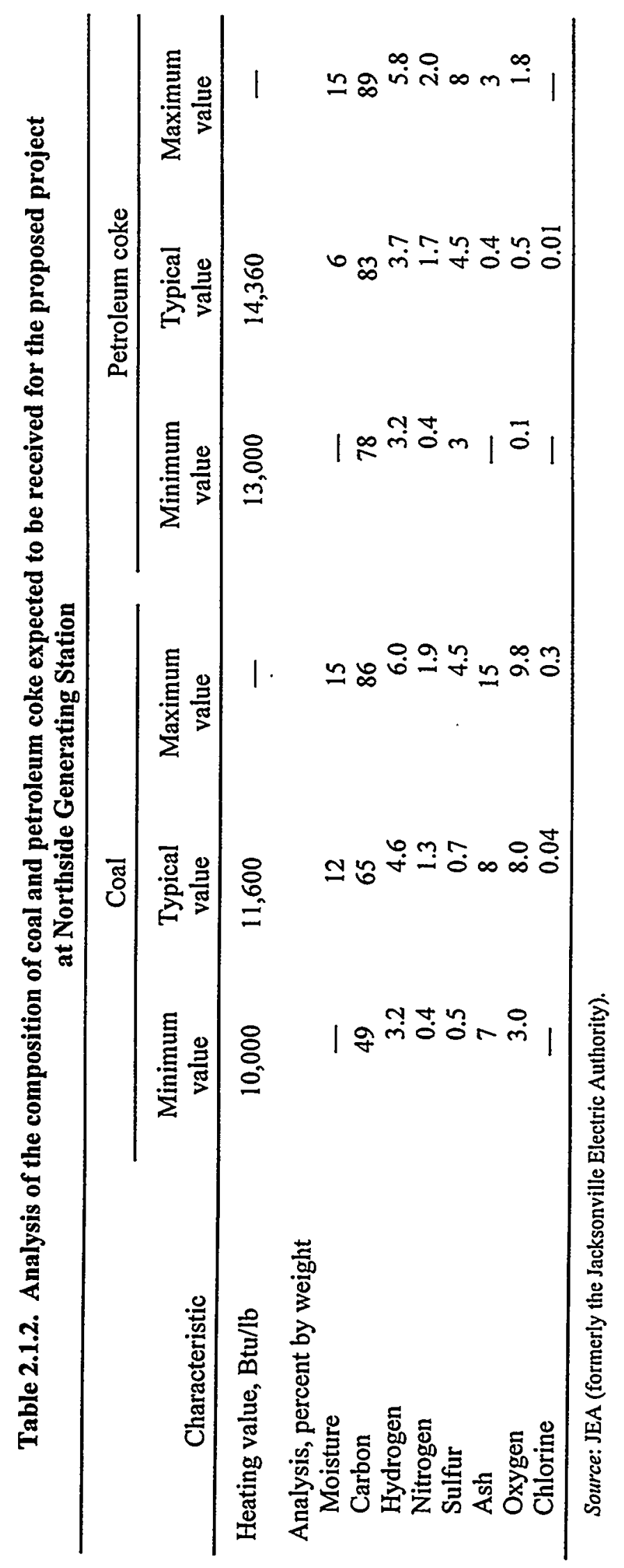


hydrofluoric acid, benzene, arsenic, and various heavy metals. The project also would emit about $2,293,100$ tons per year of $\mathrm{CO}_{2}$. Although $\mathrm{CO}_{2}$ is not considered an air pollutant, it is a contributor to the greenhouse effect that is suspected to cause global warming and climate change (Mitchell 1989).

\subsubsection{Liquid Discharges}

\section{Condenser Cooling Water}

The total flow of once-through, noncontact cooling water required to operate Northside Generating Station (all 3 units) at full load would average $827 \mathrm{Mgd}(574,000 \mathrm{gpm})$. This cooling water would be drawn from the back channel of the St. Johns River and then $815 \mathrm{Mgd}(566,000 \mathrm{gpm})$ would be returned to the river after passing through the condensers (Figure 2.1.8). Prior to circulating through the condensers, the cooling water would be treated intermittently ( 2 hours or less per day) with sodium hypochlorite $(\mathrm{NaOCl})$ or sodium bromide $(\mathrm{NaBr})$, which are biocides to prevent biological growth on heat exchanger tubes.

\section{Circulating Water Pumps, Irrigation, and Car Wash}

Groundwater from the upper Floridan aquifer currently is used to lubricate the seals and bearings of the circulating water pumps, to irrigate plants and grass as required, and to clean vehicles.

Vehicles that are parked at Northside Generating Station are placed in covered areas and/or routinely rinsed to avoid the possibility of accelerated corrosion resulting from existing facility emissions into the moist ocean air. The freshwater effluents associated with these uses are discharged untreated into the estuarine St. Johns River. During the demonstration, the circulating water pumps at Northside Generating Station would use a total of $0.14 \mathrm{Mgd}(96 \mathrm{gpm})$ for lubrication of the seals. Rather than being obtained directly from groundwater (as is the current practice), this water would be reused by Northside after use by the adjacent St. Johns River Power Park. This water would not come into contact with oil or grease and would be discharged at this same rate into the back channel of the St. Johns River after passing through the pumps. Approximately $90 \%$ of the groundwater used for irrigation and to wash cars either transpires or evaporates into the atmosphere, respectively. Untreated effluent resulting from irrigation and car washing enters the St. Johns River at a rate of $0.001 \mathrm{Mgd}$ (about $1 \mathrm{gpm}$ ). The proposed project would have no effect on the effluent discharges associated with irrigation and rinsing of cars. In a change unrelated to the proposed project, JEA plans to modify the car wash drains to divert them from the St. Johns River. This effluent would be sent to a retention basin, from which it would either evaporate or be reused for irrigation.

\section{Wastewater Streams}

Northside Generating Station would continue to treat wastewater streams to reduce metals, oil and grease, and suspended solids and to adjust $\mathrm{pH}$. Wastewater from the following activities would be routed to the chemical waste treatment facility: demineralizer regeneration, boiler blowdown, storm drains from the power block area, waste streams from the ash storage area, seal water, carbon 
purifier backwash, equipment and floor drains, fuel storage building sumps, and air preheater and boiler wash (Figure 2.1.8). The wastewater is currently discharged to evaporation/percolation ponds after being processed through the chemical waste treatment facility; however, the system would be modified so that most of the water from the system would be reused within the scrubber and ash conditioning systems. Supernatant from lined settling ponds would be directed to the reuse tank for use in the scrubber system. Approximately $3 \%$ of the treated wastewater in the existing system would be recirculated and reused as air preheater and boiler wash.

The supernatant from the settling basins would be collected in a reuse tank. A filtration unit would receive the water collected in the reuse tank and designated reuse water received from the St. Johns River Power Park. Most of the filtered water exiting the filtration unit would be directed to the polishing scrubber, while the remaining water would be used to hydrate and moisten the ash for easier handling. The reused water used in the polishing scrubber would either evaporate and exit through the stack into the atmosphere, or combine with anhydrite to form solid gypsum combustion by-products. Most of the reused water for ash conditioning would also combine with calcium oxide and anhydrite to form hydrated compounds. The cleaning water for the filtration unit would be routed to the head of the chemical waste treatment system. A separate filtration unit would be used to treat the water recycled from the St. Johns River Power Park for the circulating water pump seals. The cleaning water from this unit would also be routed to the head of the chemical waste treatment system.

Northside Generating Station currently treats an average of $0.42 \mathrm{Mgd}(293 \mathrm{gpm})$ of wastewater at the chemical waste treatment system (Figure 2.1.9). During normal conditions, all of the wastewater [except $0.01 \mathrm{Mgd}(7 \mathrm{gpm}$ ) that is recycled for boiler wash] discharges to the surficial aquifer through the unlined settling basins and the evaporation/percolation ponds. During abnormal overflow conditions, surface water may discharge to the San Carlos Creek from an overflow spillway on the evaporation/percolation ponds and/or a riser in the settling basins. After repowering, the only effluent that would normally be routed to the evaporation/percolation ponds would be $0.07 \mathrm{Mgd}$ (48 gpm) from the chemical waste treatment system (Figure 2.1.8). However, the evaporation/ percolation ponds would receive overflow of chemical waste treatment effluent from the lined settling basins if the reuse tank were full (e.g., during periods of abnormally high wastewater production or periods of low demand from the polishing scrubber).

\section{Sanitary Wastewater}

Northside Generating Station currently discharges $0.005 \mathrm{Mgd}$ (4 gpm) of treated sanitary effluent into the back channel of the St. Johns River (Figure 2.1.9). There would be no change in this operation as a result of the proposed project. 


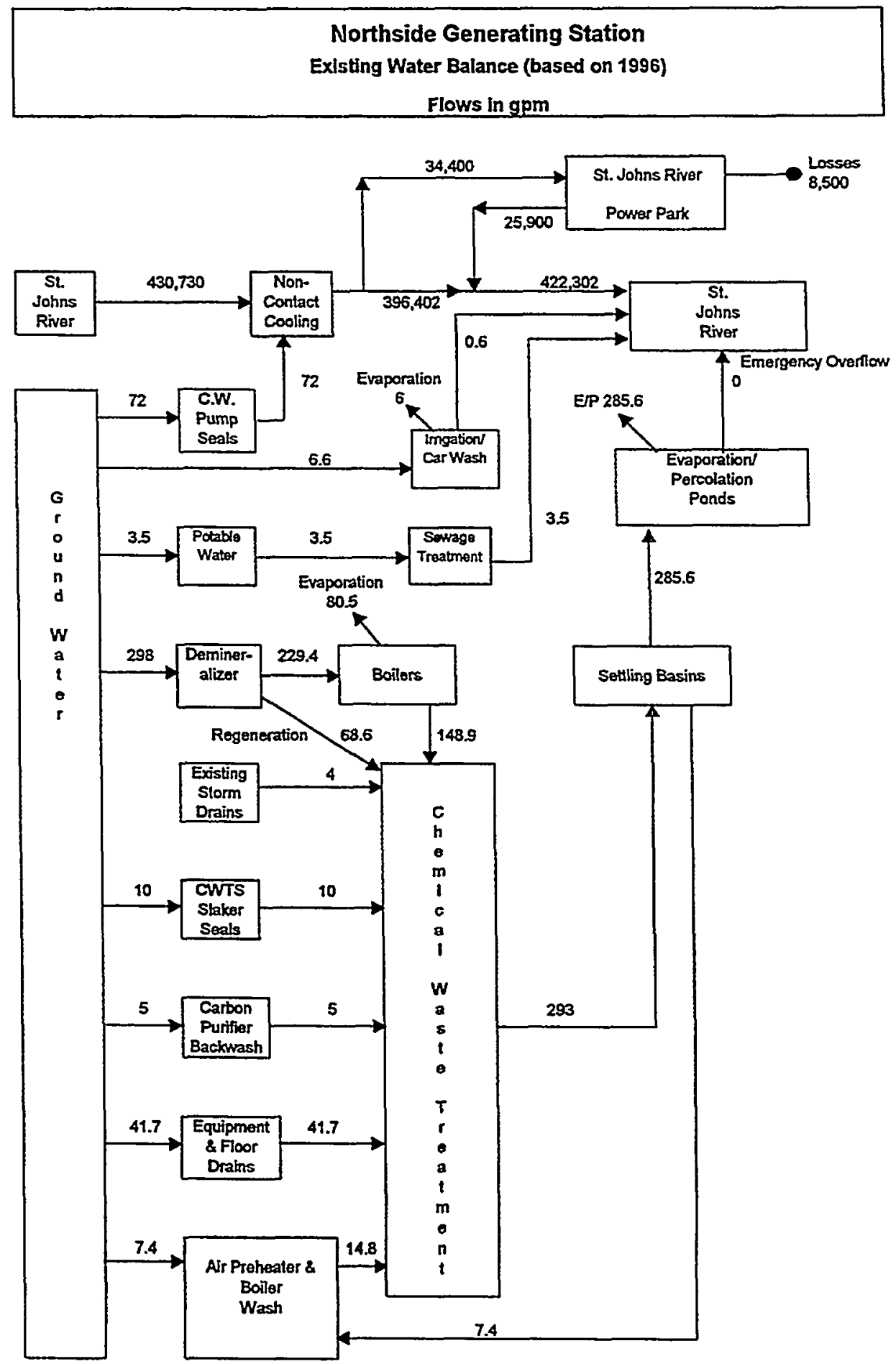

Ground Water Total $=\quad 639,650 \mathrm{gpd}$

Figure 2.1.9. Water flow diagram that depicts water requirements and discharges at the existing Northside Generating Station. 


\subsubsection{Solid Wastes}

During construction, the existing covered parking lot would be dismantled and removed. Asphalt from the parking lot would be recycled in Jacksonville and metal would be sold as scrap. Assuming a $90 \%$ capacity factor during operation, the proposed project would generate about 57,012 tons per year of fly ash and 105,880 tons per year of bottom ash if coal were used alone for an entire year or 109,352 tons per year of fly ash and 170,411 tons per year of bottom ash if petroleum coke were used alone for an entire year. Because both fuels would be used during the course of a year, actual amounts would be between this range. Collected fly ash would be recirculated to the polishing scrubber for further use in $\mathrm{SO}_{2}$ removal. The calcium sulfite and calcium sulfate generated by the polishing scrubber would be captured as fly ash by the particulate collector (the electrostatic precipitator or fabric filter). Therefore, the given fly ash amounts include fly ash captured by the particulate collector from both the CFB combustor and the polishing scrubber. The fly ash and bottom ash would be stored in separate silos at the site and periodically hauled by truck to the adjacent 40 -acre storage area in the northwest corner of the Northside Generating Station property (Figure 3.4.2). At this storage area, the fly ash and bottom ash would be commingled to make a saleable by-product:

The preferred alternative for management of this combustion ash would be to sell it as a byproduct and transport it by truck to offsite customers. If markets cannot be established, excess material would be disposed of either on the site or off the site in accordance with appropriate solid waste disposal requirements (Section 5).

There would be no waste generated by the selective non-catalytic reduction system (Section 2.1.3). Because the system would be non-catalytic, there would be no need to replace a catalyst.

\subsubsection{Toxic and Hazardous Materials}

Several materials considered toxic or hazardous would be required for or generated by the proposed project. These materials, which are currently used at Northside Generating Station (primarily for water chlorination and for maintenance and cleaning activities), would be transported by truck to and from the station. Approximately 11 tons per year of chlorine gas would be used at Northside Generating Station to treat the potable and process water that would be withdrawn from the four deep wells that tap the upper Floridan aquifer. Approximately 1,648 tons per year of aqueous ammonia would be used as reagent for the selective non-catalytic reduction system. The ammonia would be stored in a 40,000-gal horizontal cylindrical tank with secondary containment of sufficient volume to hold the entire contents of the tank in the unlikely event of a rupture. A Spill Prevention, Control, and Countermeasures Plan (SPCCP) (40 CFR Part 112) would be developed, and the ammonia storage would comply with Emergency Planning and Community Right-to-Know Act (EPCRA) notification requirements. 
On an annual basis, the other materials would include an estimated eight 55-gal drums of paint product, three 55-gal drums of paint solvent, 30 gal of chlorinated solvents, two 55-gal drums of laboratory solvents and rags, and $2,500 \mathrm{lb}$ of Safety-Kleen solvent. All chemicals would be properly labeled and stored according to local fire codes and Occupational Safety and Health Administration (OSHA) requirements. Wastes from these materials would be transported and disposed of in approved offsite waste disposal areas by licensed disposal contractors.

\subsection{RELATED ACTION}

In addition to the proposed project of repowering Unit 2, JEA plans to repower the currently operating Unit 1 steam turbine without cost-shared funding from DOE. More precisely, the DOE cost-shared funding would be applied to the cost of systems distinct to Unit 2, plus $50 \%$ of the cost associated with systems common to Units 1 and 2; DOE cost-shared funding would not be applied to the cost of systems distinct to Unit 1 .

The repowered Unit 1 would be essentially identical to the repowered Unit 2. The CFB combustor for the repowered Unit 1 would be located immediately to the west of the existing Unit 3 on the section of the property that currently consists primarily of a covered parking lot for employees and immediately to the south of the Unit 2 CFB combustor (Figure 2.1.3). Piping and related infrastructure would be constructed to link the Unit 1 CFB combustor with the existing Unit 1 steam turbine. Common systems for Units 1 and 2 include the solid fuel delivery and storage facilities, limestone preparation building, ash storage facilities, and electrical substation. Separate systems include the CFB combustor buildings, limestone silos, air heaters, lime silos, polishing scrubbers, ash collection bins, and baghouses or electrostatic precipitators. The repowered units would be served by a single new 495-ft stack with separate flues for each unit.

Construction on the repowered Unit 1 would lag construction on the repowered Unit 2 by about 4-6 months overall. Craft workers would work on Unit 2 first and then move over to Unit 1 . This approach is very efficient because the workers can immediately start work on Unit 1 upon completion of their tasks on Unit 2 without going to another job site between tasks. Construction on many items, such as foundations, would proceed on both units nearly simultaneously. The existing Unit 1 would continue in operation as the demonstration commences on the repowered Unit 2 . Unit 1 would burn a blend of natural gas and fuel oil with a sulfur content averaging no more than $0.13 \%$ to ensure that the maximum 24-hour average $\mathrm{SO}_{2}$ concentration would not exceed the corresponding Florida standard (see Section 4.1.2.2). The existing Units 1 and 3 would be operated to meet the target established by JEA's management of a $10 \%$ reduction in total annual emissions of $\mathrm{SO}_{2}, \mathrm{NO}_{x}$, and particulate matter from Northside Generating Station, starting with the year that the demonstration begins. About 6-12 months later, Unit 1 would cease operation and the new CFB combustor would be connected to repower the existing Unit 1 steam turbine. 
This EIS evaluates the Unit 1 repowering as a related action to the proposed project. The analyses of environmental consequences (Section 4 ) initially discuss the proposed project alone and then include an evaluation of the proposed project in conjunction with this related action.

\subsection{ALTERNATIVES}

Section 102(2)(C) of NEPA requires an EIS to include a discussion of reasonable alternatives to the proposed action. The term "reasonable alternatives" is not self-defining, but rather must be determined within the context of the proposed action. The goals of the federal action establish the limits of its reasonable alternatives. Congress established the CCT Program with a specific goal- - to make available to the U.S. energy marketplace a number of advanced, more efficient, economically feasible, and environmentally acceptable coal technologies. DOE's purpose in considering the proposed action (to provide cost-shared funding) is to demonstrate the CFB combustion technology's viability in achieving the goal for the program. Reasonable alternatives to this proposed action must be capable of meeting this purpose.

Congress also directed DOE to pursue the goals of the legislation by providing partial funding for projects owned and controlled by nonfederal-government participants. This statutory requirement places DOE in a much more limited role than if the federal government were the owner and operator of the project. In the latter situation, DOE would ordinarily be required to review a wide variety of reasonable alternatives to the proposed action. However, in dealing with a nonfederal applicant, the scope of alternatives is necessarily more restricted. It is appropriate in such cases for DOE to give substantial weight to the needs of the proposer in establishing reasonable alternatives to the proposed action. In addition, under the CCT Program, DOE's role is limited to approving or disapproving the project that JEA has proposed.

Thus, the only reasonable alternative to the proposed action is the no-action alternative, including three scenarios reasonably expected as a consequence of the no-action alternative (Section 2.3.1).

\subsubsection{No-Action Alternative}

Under the no-action alternative, DOE would not provide cost-shared funding for the proposed CFB combustor project. The PEIS for the CCT Program (DOE 1989) evaluated the programmatic consequences of no action (Section 1.5). Under the no-action alternative for the proposed project, three reasonably foreseeable scenarios could result.

First, JEA could repower the existing Unit 2 steam turbine without DOE funding, thereby accepting more of the risk associated with demonstrating the CFB combustor. JEA would also proceed with the related action of repowering Unit 1. Under this scenario, construction materials and activities and project operations would be the same as for the proposed project. Fuel requirements would be similar except that the blend of coal to petroleum coke might be slightly different, particularly during the first 2 years of operation. Under this scenario, more of the solid fuel used each year throughout the lifetime of the facility could be petroleum coke. Therefore, there could be less 
train traffic and more ship traffic to deliver the fuel. The same amount of electricity would be generated and environmental impacts would be very similar to those of the proposed project.

Related to this first scenario, JEA has proceeded with the proposed project, including commencing construction, at their own risk without $\mathrm{DOE}$ funding prior to the completion of the NEPA process. DOE will still independently make a decision on whether or not to provide costshared funding to design, construct, and demonstrate the proposed project. If DOE decides to provide cost-shared funding for the proposed project, then the proposed action would be implemented as construction continues. If DOE decides not to provide cost-shared funding for the proposed project, then JEA would continue construction and operation of the project as described in the first scenario.

Second, rather than repowering Unit 2, JEA could construct and operate a new gas-fired combined cycle facility at Northside Generating Station or at one of their other existing power plants. The natural gas would drive a gas combustion turbine and the heat from combustion would be used to produce steam that would drive a steam turbine. Based on modeling projections by JEA, the facility would be expected to generate approximately $230 \mathrm{MW}$ of electricity.

Under this scenario, Northside Unit 1 would remain in its current oil- and gas-fired configuration, and JEA would not proceed with the related action of repowering Unit 1. Based upon the projected cost of natural gas and the combined cycle unit efficiency, the cost of generating electricity at the new combined cycle facility was projected to be in the same range as the existing oil-fired units. This resulted in a projected capacity factor in the $60 \%$ range for the new combined cycle unit. The difference in generating output between the proposed combined cycle unit operating at a $60 \%$ capacity factor and the two proposed CFB combustors operating at a $90 \%$ capacity factor would be supplied by operating the existing units at higher capacity factors, by purchasing electricity from other utilities, or most likely by a combination of these two options. If the existing Northside units were to remain operating at their historical levels, then the addition of a combined cycle unit would result in an increase in JEA emissions. The more likely scenario is that the existing units would operate at higher capacity factors than in recent years, resulting in a larger increase in emissions compared with historical levels and an even larger increase of most pollutants compared with JEA emissions expected following the repowering of Units 1 and 2 with CFB combustors. Therefore, even though air emissions of most pollutants from the combined cycle facility alone would be less than corresponding emissions from a CFB combustor alone, the emissions from the existing oil-fired units would result in greater overall emissions under the combined cycle facility scenario.

Construction activities and operations would be similar for the gas-fired combined cycle facility and the CFB combustors but with notable differences related to fuel, sorbent, and ash handling and storage facilities. Under the combined cycle facility scenario, no coal, petroleum coke, limestone, or lime would be used. Because the natural gas would be delivered by pipeline and no sorbent would be used, there would be no train, ship, or truck traffic associated with fuel and sorbent delivery. No combustion ash would be generated and there would be no truck traffic to remove ash from the site. 
This scenario would not contribute to the CCT Program goal of demonstrating advanced, more efficient, economically feasible, and environmentally acceptable coal technologies.

Third, rather than repowering Unit 2, JEA could purchase electricity from other utilities to meet JEA's projected demand. Under this scenario, no construction activities or changes in current operations would occur within the JEA system of power plants, including Northside Generating Station. There would be no change in current environmental conditions at the site, and the impacts would remain unchanged from the baseline conditions. JEA would not proceed with the related action of repowering Unit 1 . There could be construction activities or changes in operations at the other utilities providing electricity to JEA if the electricity were not already available.

This scenario would not contribute to the CCT Program goal, would not provide employment for construction workers in the Jacksonville area, and would not result in reductions of atmospheric emissions or groundwater use at Northside Generating Station. Moreover, existing Units 1 and 3 might be required to operate at capacity factors greater than historical levels if JEA were unable to purchase sufficient electricity from other utilities. Under those circumstances, annual air emissions and groundwater consumption would increase.

Table 2.3.1 presents a comparison of potential impacts between the proposed project and the noaction alternative.

\subsubsection{Alternatives Dismissed from Further Consideration}

The following sections discuss alternatives that were initially identified and considered by DOE or JEA, and alternatives that were raised during the scoping process. The project as proposed by JEA and Foster Wheeler meets the needs outlined in the CCT solicitation's Program Opportunity Notice that was issued by DOE in February 1986 (Section 1.1). DOE's role is limited to providing the costshared funding for JEA's proposed project. As such, reasonable alternatives to the proposed project are narrowed and the following alternatives have been dismissed from further consideration.

\subsubsection{Alternative Sites}

During the site selection process for the proposed project, JEA considered the sites of their existing power plants and a hypothetical undeveloped site. JEA owns and operates four power plants: Northside, Southside, Kennedy, and the St. Johns River Power Park (a joint venture between JEA and Florida Power \& Light, as described in Section 2.1.1). Southside Generating Station is located in downtown Jacksonville and Kennedy Generating Station is located about 4 miles northeast of the downtown area.

The available infrastructure at the existing sites offers a considerable advantage. JEA eliminated the undeveloped site from further consideration because it was economically unattractive and the environmental impacts resulting from construction and operation of the project were expected to be considerably greater than impacts associated with repowering a unit at an existing site. 


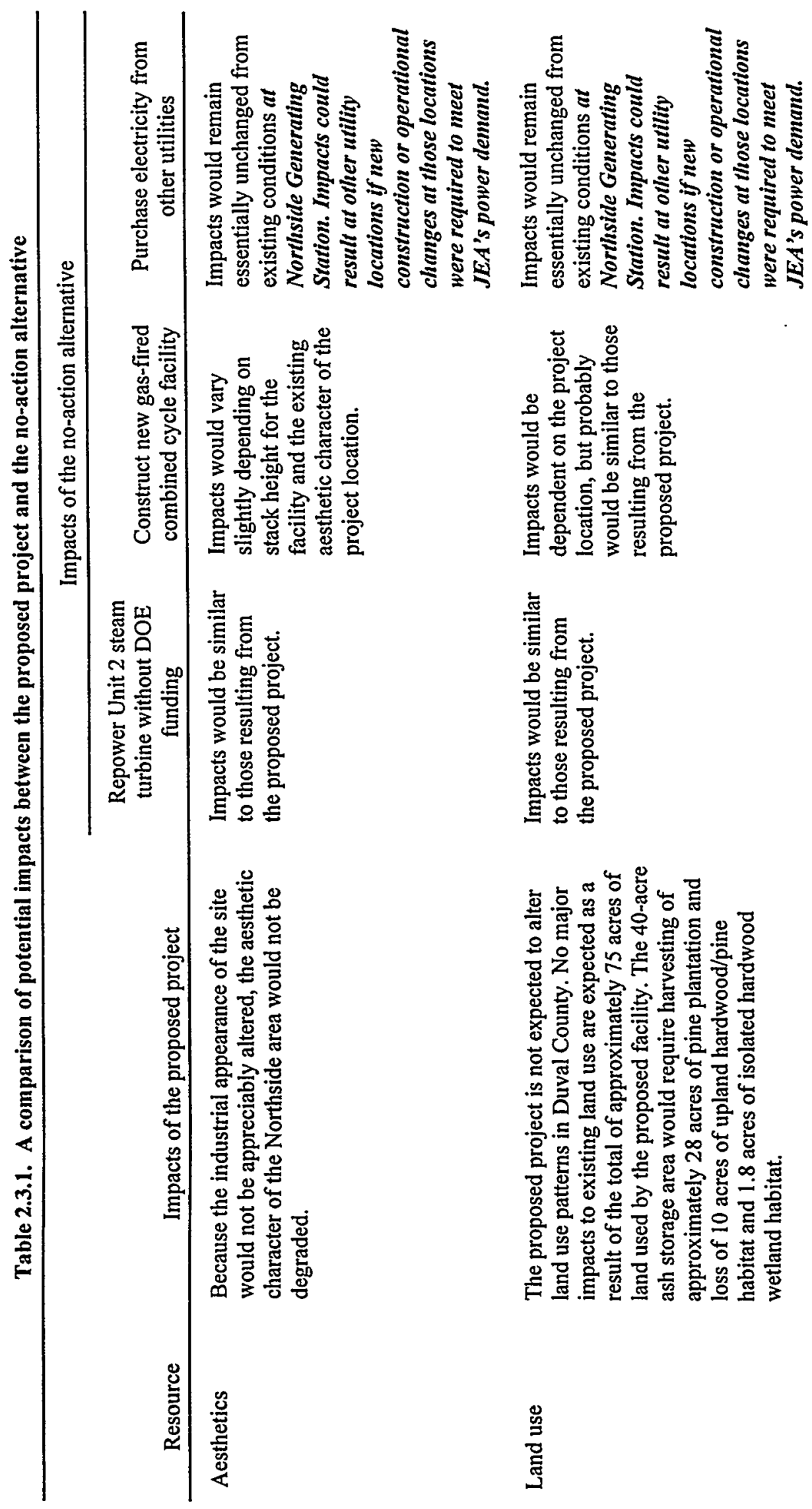




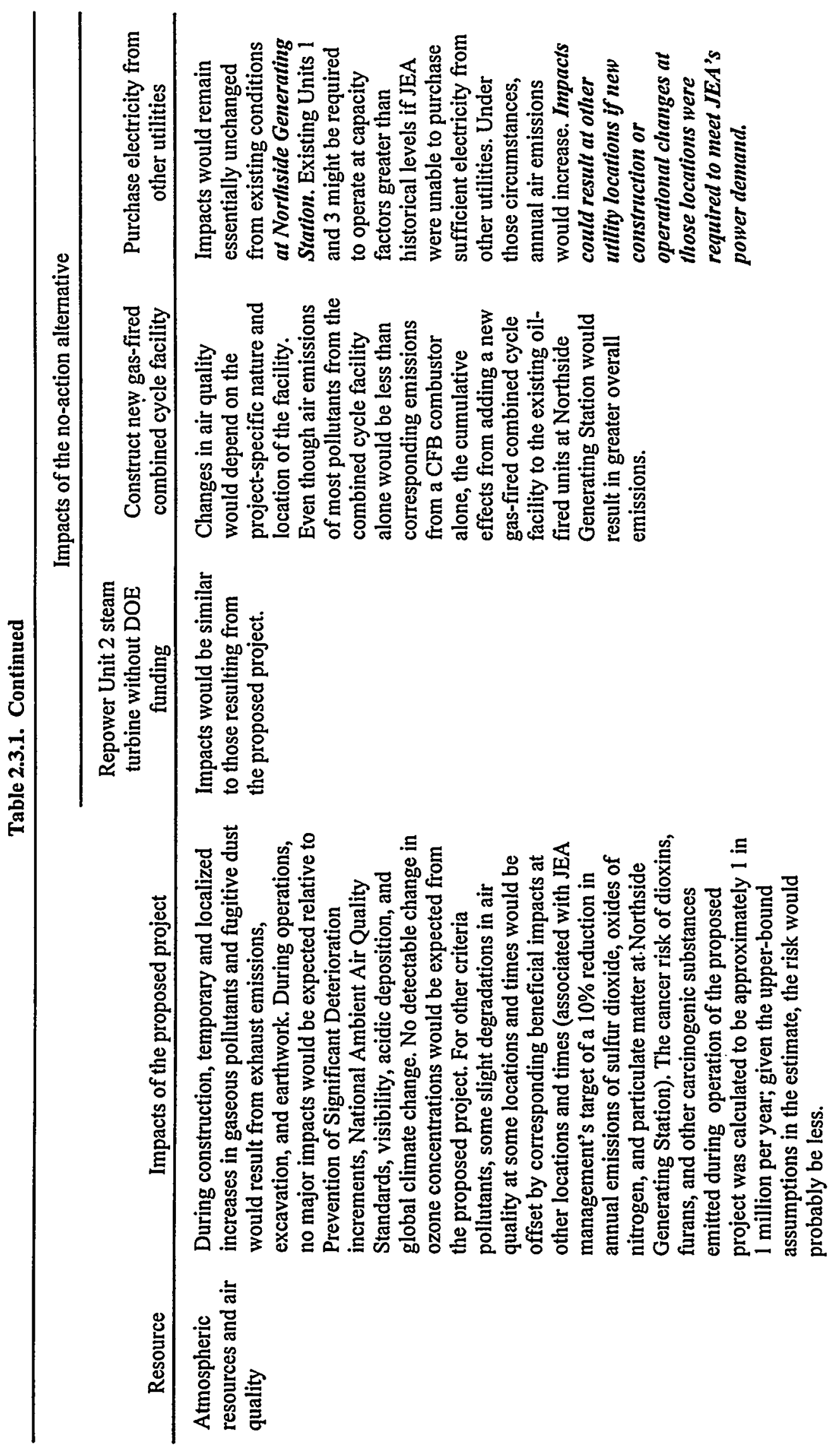




\section{JEA EIS}

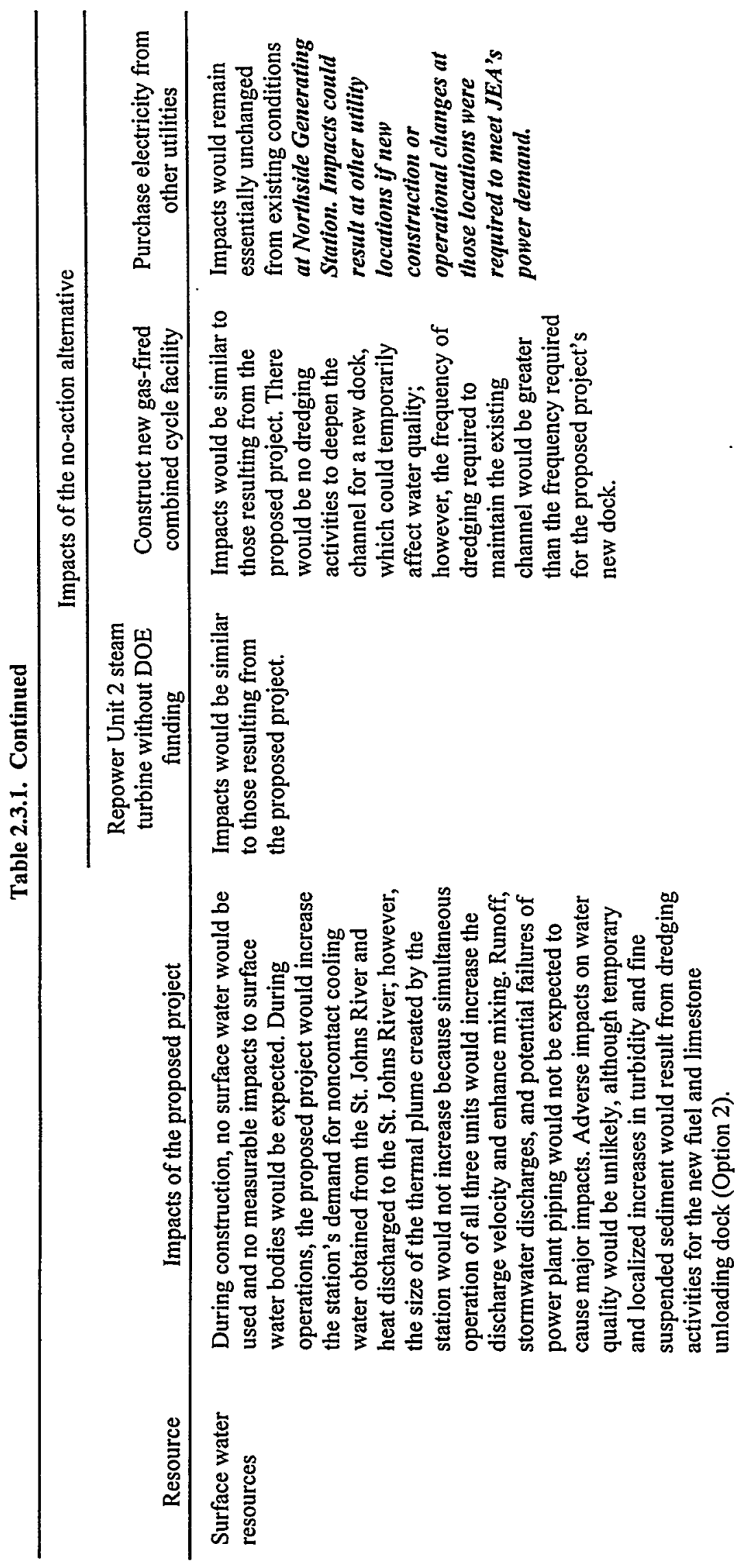




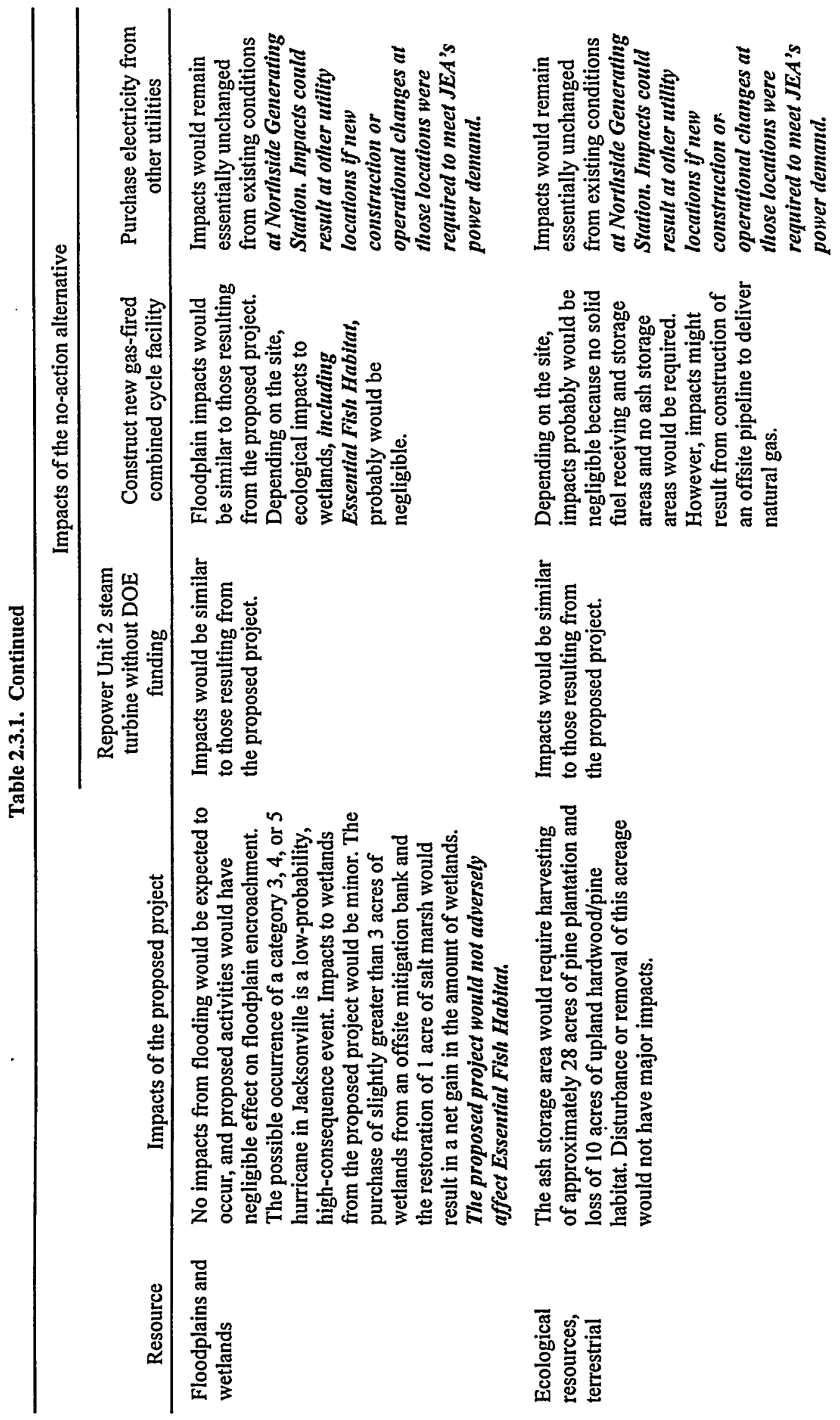




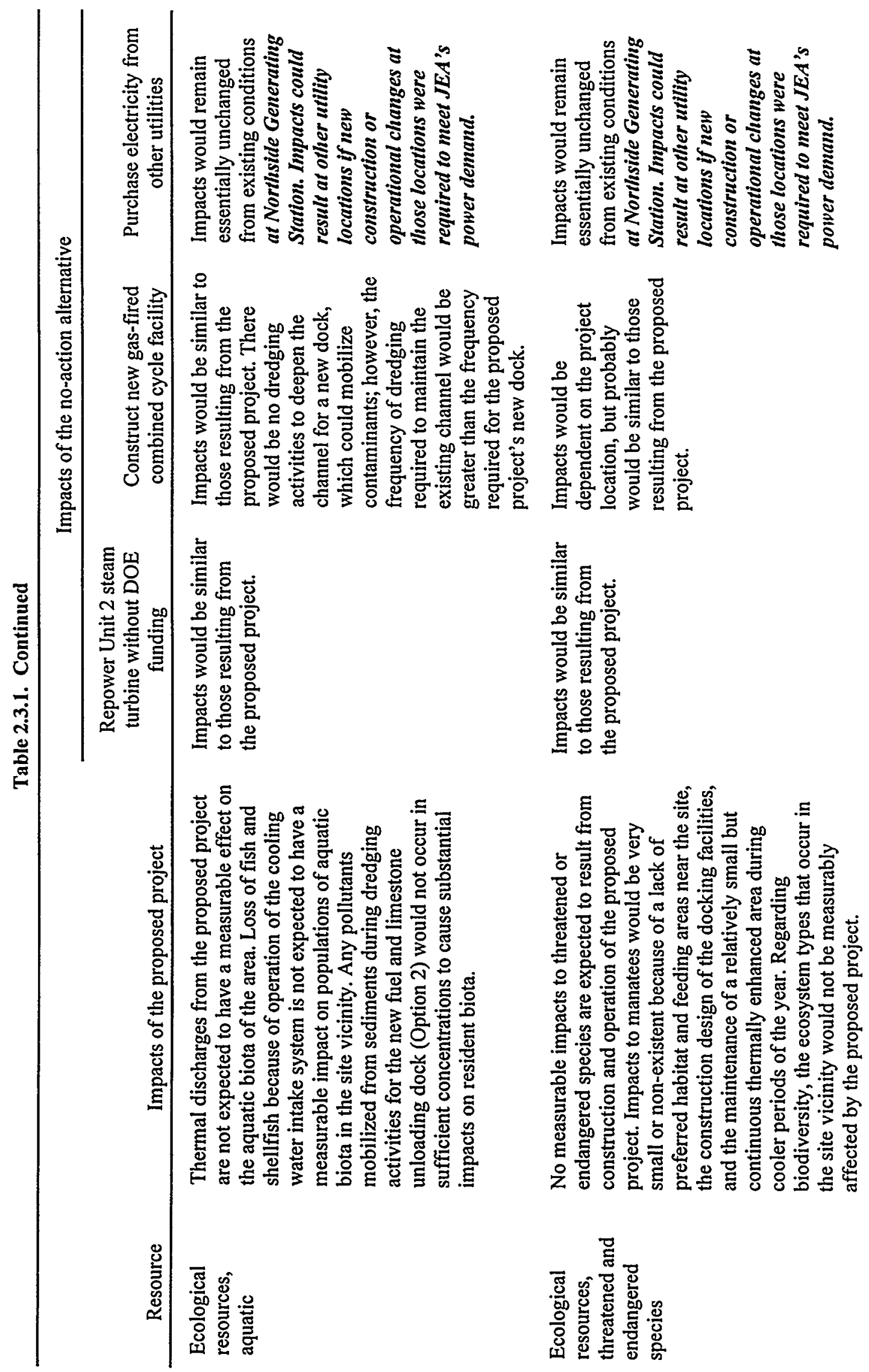




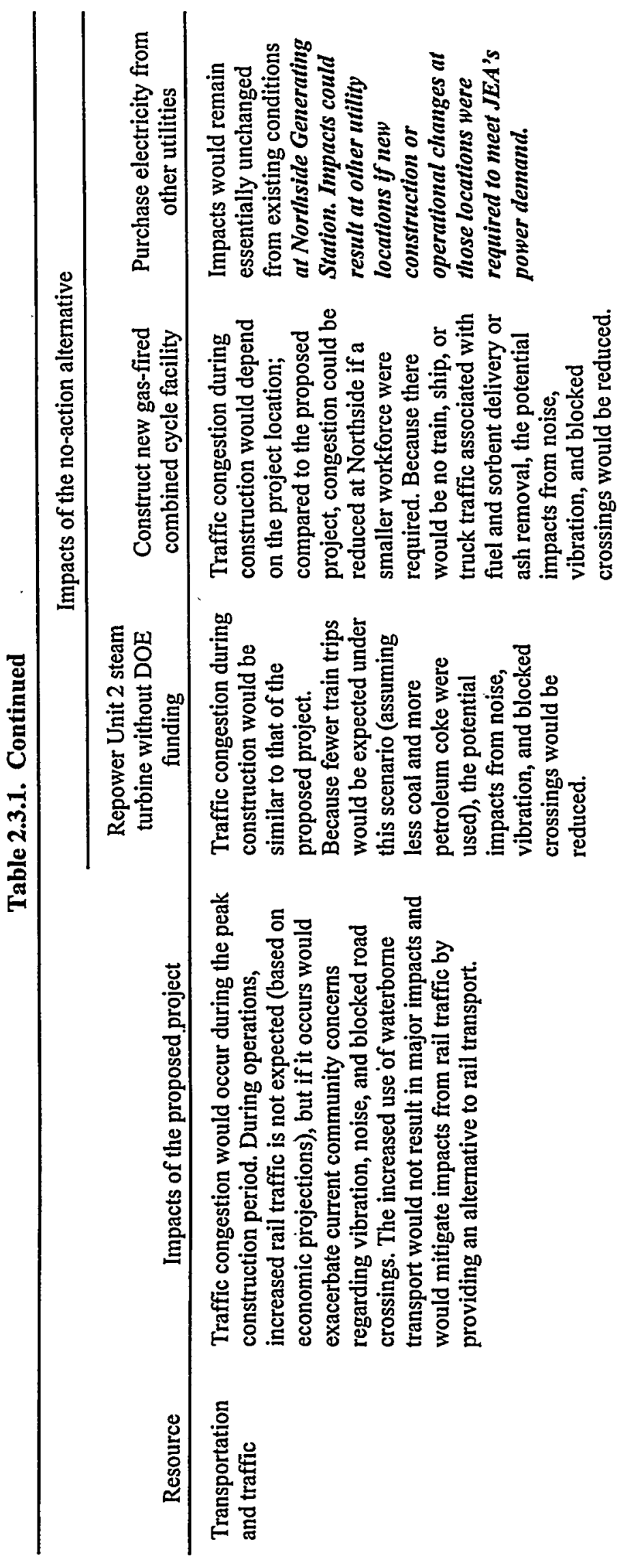




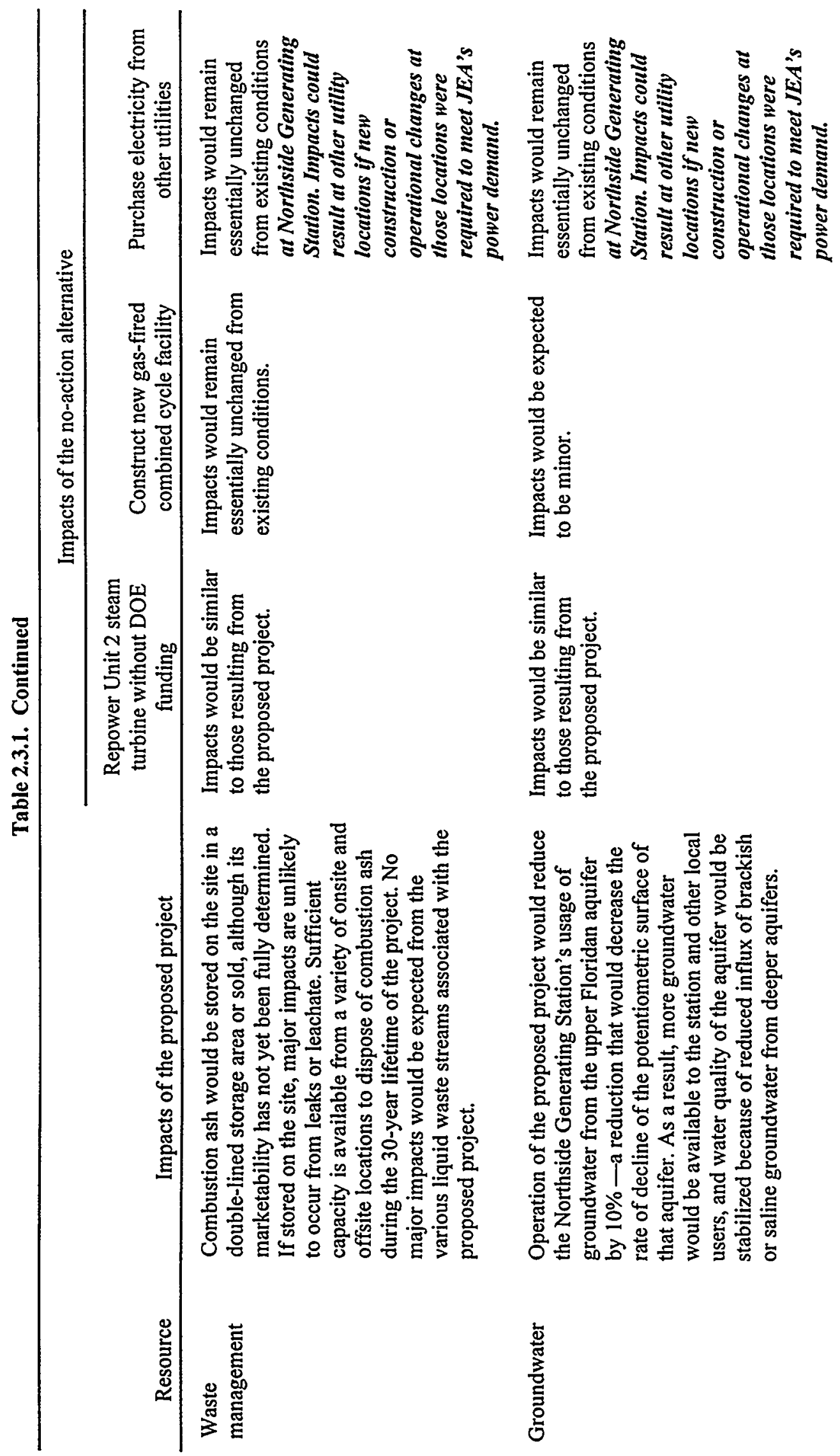




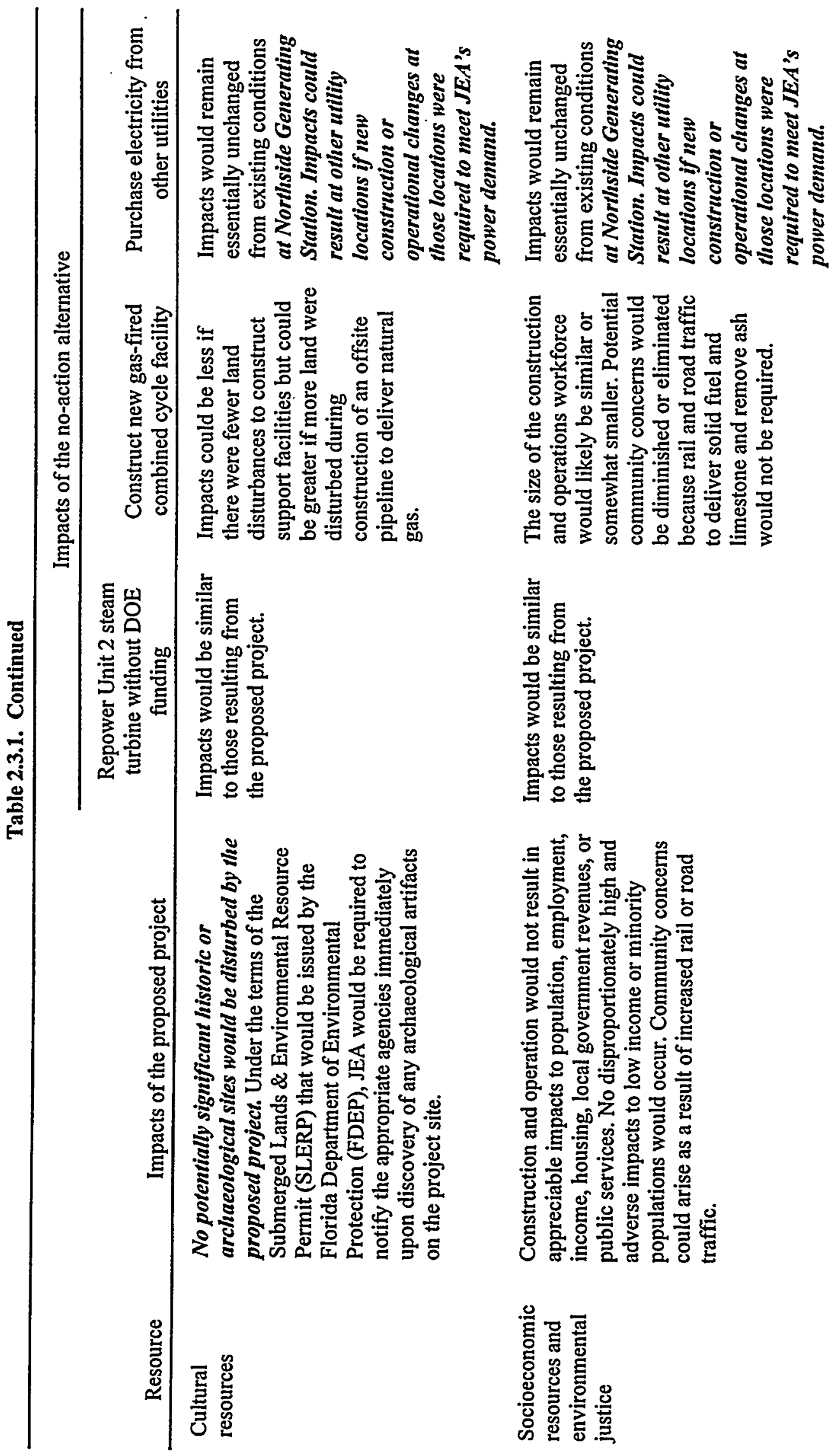




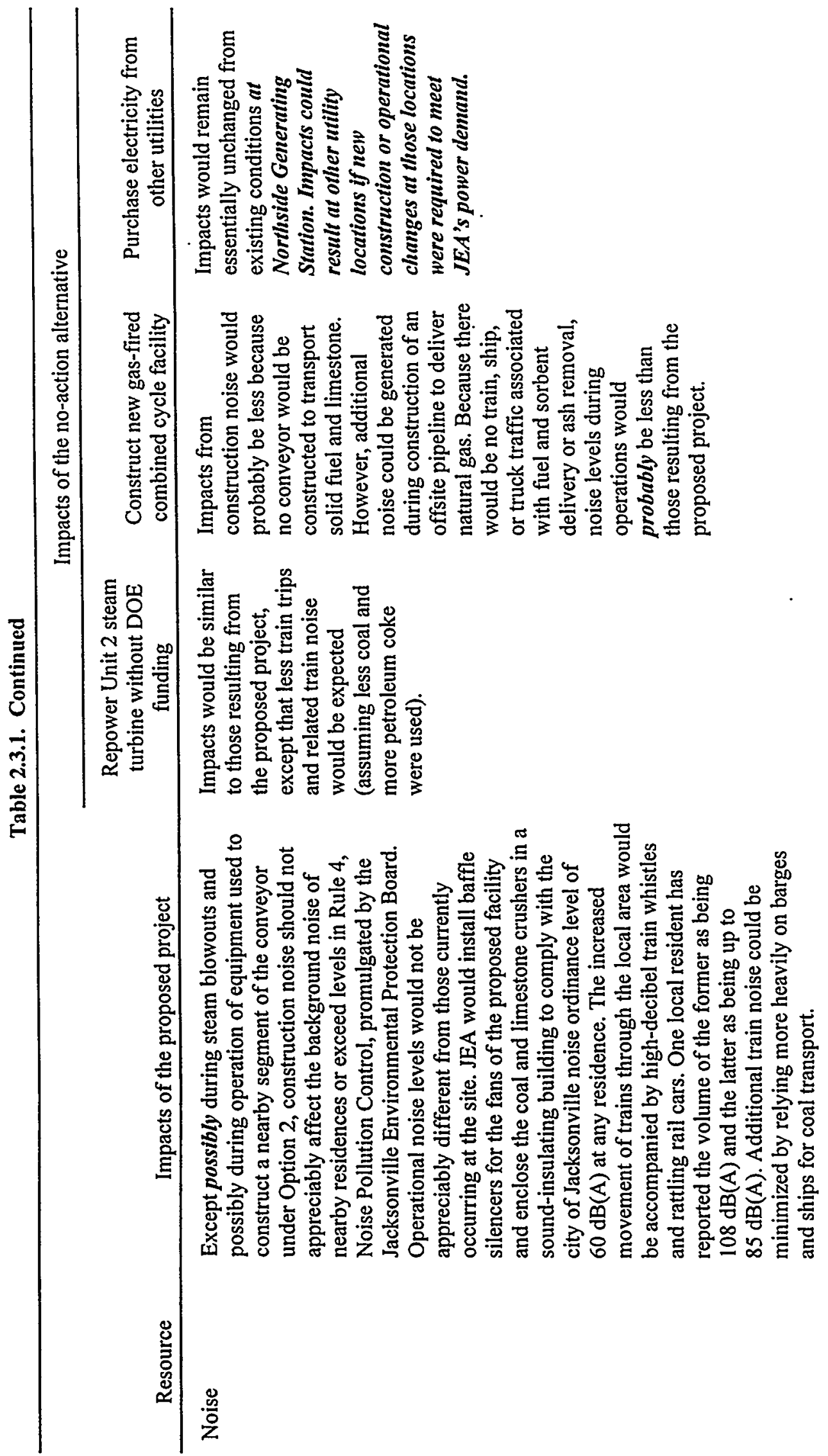




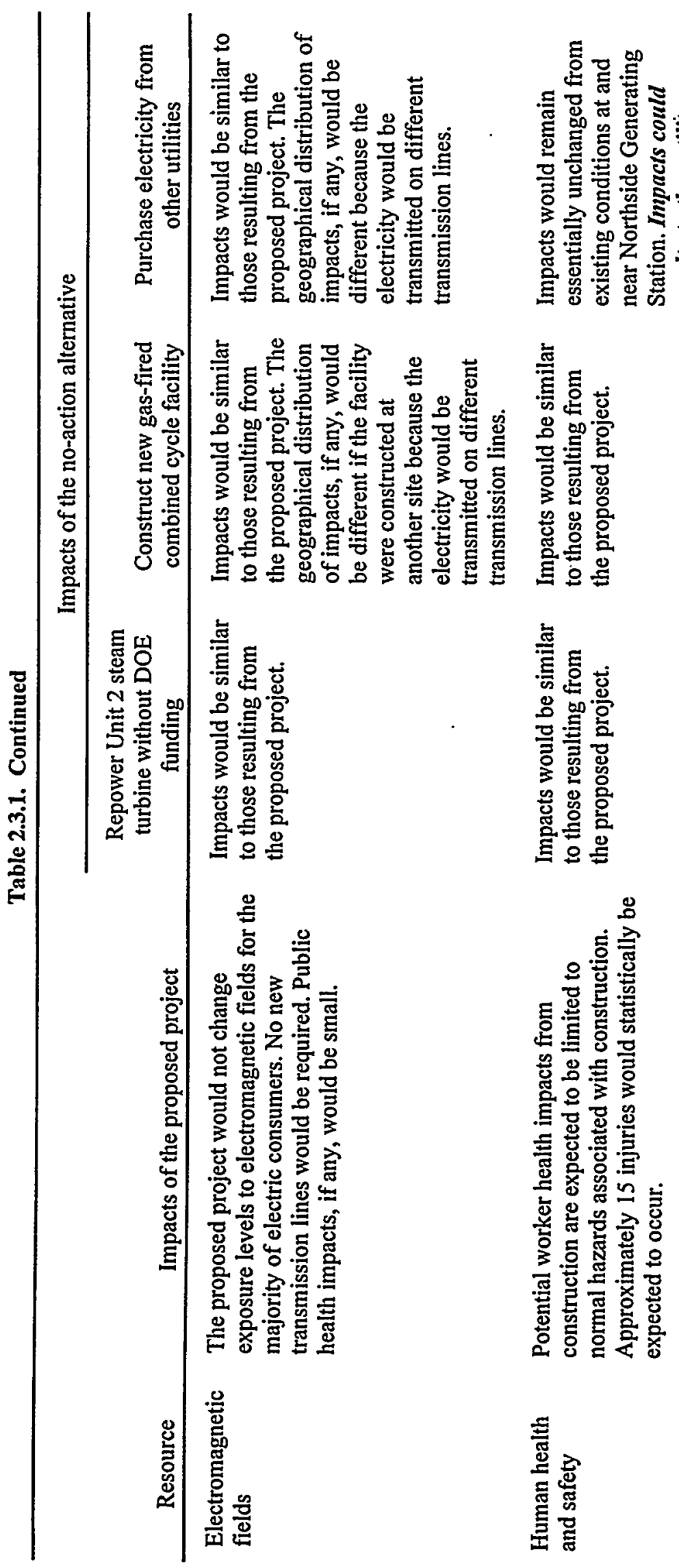




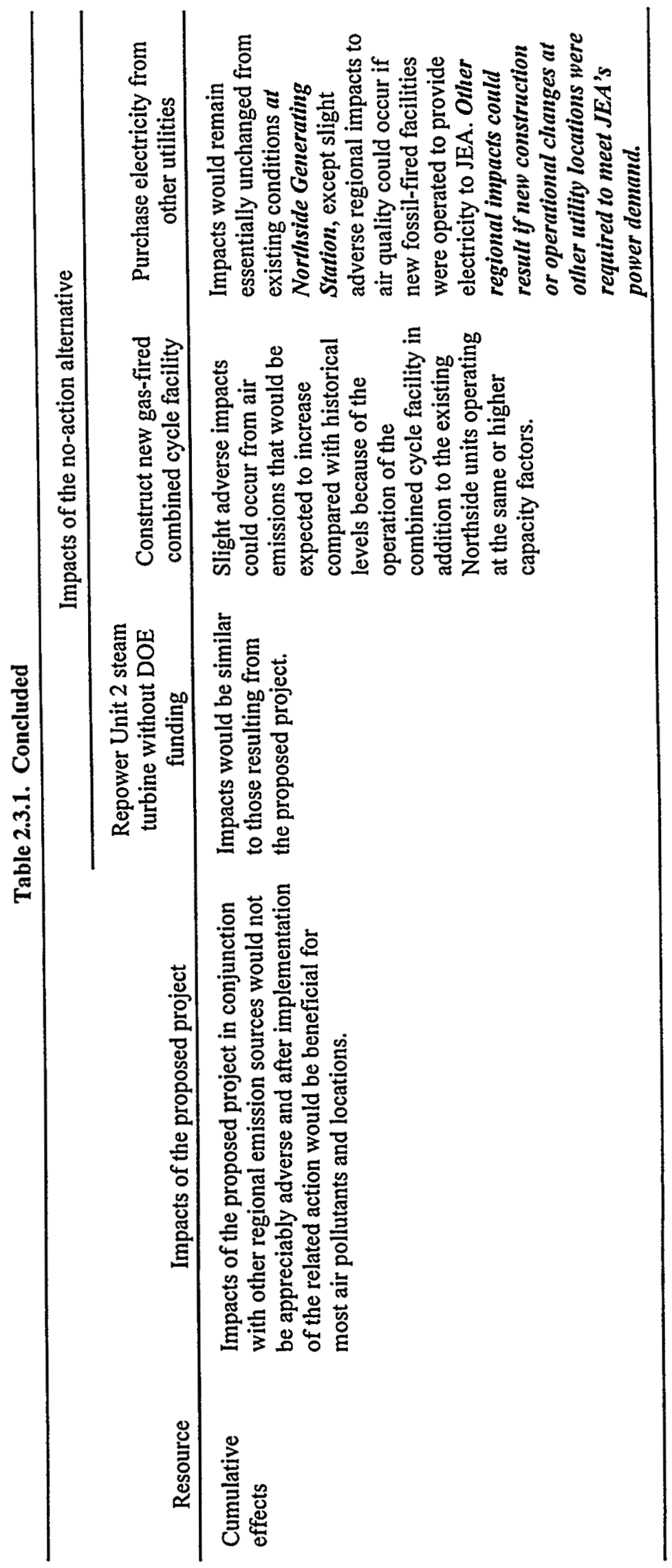


An important consideration during site selection was to meet DOE's purpose for the proposed project: to generate technical, environmental, and financial data from the design, construction, and operation of facilities at a sufficiently large enough scale to allow the power industry to assess the potential of CFB combustion technology for commercial application (Section 1.3). Specifically, the proposed project should take the next step in size by demonstrating the viability of the technology within the range of 250 to $400 \mathrm{MW}$. This consideration eliminated all sites except Northside Generating Station because the largest unit at Southside is $150 \mathrm{MW}$, the largest unit at Kennedy is $134 \mathrm{MW}$, and the twin units at the Power Park are each $660 \mathrm{MW}$. In addition, because the Power Park units are relatively new and efficient, they are not serious contenders for repowering. The idle 297.5-MW Unit 2 at Northside is an ideal candidate based on its size. Another advantage of Northside Generating Station over Southside and Kennedy is the availability of space for solid fuel and limestone storage facilities.

Based on the above considerations, JEA selected Northside Generating Station as the site for the proposed project. Other sites are not reasonably foreseeable alternatives and are not evaluated in this EIS.

\subsubsection{Alternative Technologies}

As discussed in Section 1.3, the proposed project was selected to demonstrate CFB combustion technology. Other CCT projects would not achieve this goal. The PEIS evaluated the potential environmental consequences of widespread commercialization of each of 22 successfully demonstrated clean coal technologies in the year 2010 (Section 1.5). The CCT preselection reviews included environmental comparisons of proposals submitted in response to each solicitation's Program Opportunity Notice (Section 1.5). The projects selected for demonstration are not considered alternatives to each other. As with other CCT projects, the use of other technologies and approaches which do not use coal (e.g., natural gas, wind power, solar energy, and conservation) to meet JEA's need for power (Section 1.4.2) would not achieve the goal of demonstrating CFB combustion technology.

\subsubsection{Other Alternatives}

Other alternatives, such as delaying or reducing the size of the proposed project, have been dismissed as not reasonable. Delaying the project would not result in any reduction of environmental impacts once the project is implemented but would adversely affect JEA's ability to meet the needs of its customers: The design size for the proposed project was selected because it is large enough to show utilities that the technology, once demonstrated at this scale, could be applied without further scale-up to many similar sized combustors (Section 1.3). 


\section{EXISTING ENVIRONMENT}

\subsection{SITE DESCRIPTION, AESTHETICS, AND LAND USE}

The proposed project would be located in an industrial setting in the city of Jacksonville along the north shore of the St. Johns River, approximately 10 miles west of the Atlantic Ocean. The local terrain is flat, and there is a mix of industrial, commercial, residential, and agricultural land use in the vicinity. The site property contains a number of wetlands, especially in the perimeter areas. The most striking environmental feature associated with the area is the nearby presence of estuarine salt marsh backwaters of the St. Johns River. The Timucuan Ecological and Historic Preserve borders the site to the east.

Because the site is located at Northside Generating Station, adjacent to the St. Johns River Power Park, the viewing landscape is conspicuously marked with combustor and steam turbine buildings, flue gas stacks, cooling towers, and associated infrastructure. Northside Generating Station has two stacks that are $250 \mathrm{ft}$ and $350 \mathrm{ft}$ tall. A 300 -ft stack at the station was dismantled and removed in early 1998. The Power Park has a 640-ft chimney and two 425-ft hyperbolic cooling towers.

Emissions from the Northside and Power Park stacks are occasionally visible, and plumes of water droplets from the Power Park cooling towers are frequently visible. In addition to these highly visible structures, there are numerous smaller structures, roadways, and parking areas. Blount Island, located immediately to the southeast in the St. Johns River, is a major port with loading and unloading cranes that are easily visible from nearby viewing points.

The city of Jacksonville encompasses nearly the entire land area of Duval County. Table 3.1.1 shows the distribution of various land uses within the Jacksonville city limits as of 1985 (the most recent year with reliable data). At that time, $40.8 \%$ of the land was vacant and another $26.2 \%$ was in agricultural use. Nearly $90 \%$ of the agricultural land was in planted pine, most of it under corporate ownership. Large portions of the city also were devoted to residential use (15.5\%) and to public buildings and facilities (11.5\%), with much smaller areas used for commercial, industrial, and other purposes. Rough estimates of current land use, calculated with population-based formulae contained in the Future Land Use Element of Jacksonville's comprehensive plan (JPDD 1996a), indicate that residential area has increased substantially since 1985, while there has been a slight decrease in agricultural usage and a more substantial decline in the amount of vacant land.

\subsection{ATMOSPHERIC RESOURCES}

\subsubsection{Climate}

Jacksonville's proximity to the Atlantic Ocean leads to a mild climate. Average July temperature is $82^{\circ} \mathrm{F}$, and average January temperature is $52^{\circ} \mathrm{F}$; the annual average is $68^{\circ} \mathrm{F}$. Precipitation is greatest during summer; about one-half of the annual amount typically occurs from June through September. August is the wettest month, averaging 7.9 in., and November is the driest month, averaging $2.2 \mathrm{in.}$ Average annual total precipitation is $51.3 \mathrm{in.}$ 
Table 3.1.1. Distribution of land use in Jacksonville, $\mathbf{1 9 8 5}^{a}$

\begin{tabular}{lc}
\hline \multicolumn{1}{c}{ Land use } & $\begin{array}{c}\text { Percent of } \\
\text { total land area }\end{array}$ \\
\hline Residential & 15.5 \\
Commercial & 1.4 \\
Industrial & 2.1 \\
Recreation/open space & 1.1 \\
Public buildings and facilities & 11.5 \\
Historic resources & $<0.1$ \\
Conservation & 1.3 \\
Agriculture & 26.2 \\
Vacant & 40.8 \\
$\quad$ Total & 100.0 \\
\hline
\end{tabular}

${ }^{a}$ The most recent year with reliable data.

Source: JPDD 1996a.

Hurricanes and lesser tropical cyclones can lead to appreciable precipitation for short periods. The estimated maximum 24-hour precipitation expected to be equaled or exceeded, on average, once in 100 years is 11 in.; this has not been achieved or exceeded in the 52-year period of record (1942-93). However, amounts greater than 10 in. during a 24-hour period occurred during September 1950 and July 1966.

Hurricane winds (having speeds of $74 \mathrm{mph}$ or greater) have been recorded only once in Jacksonville, when the center of Hurricane Dora passed just to the south and west of the city on September 9, 1964, producing a maximum sustained wind of $82 \mathrm{mph}$. Hurricanes in the region have generally traveled parallel to the coastline, either remaining far out to sea or losing much of their force over land to the south of Jacksonville before reaching the city.

Winds in the area average about $8 \mathrm{mph}$. There is no clearly dominant wind direction: northwesterly winds are most prevalent during the winter and southwesterly winds prevail in summer. Sea breezes are generally from the east and land breezes are generally from the west. Winds are least frequent from the south-southeast. The wind rose for Jacksonville International Airport, about 9 miles west-northwest of Northside Generating Station, for the period 1948-95 is shown in part (a) of Figure 3.2.1. Wind data for 1 year (December 10, 1979-December 10, 1980) have also been gathered at a location about 2 miles north-northeast of Northside Generating Station; these data are summarized in the wind rose shown in part (b) of Figure 3.2.1. The two wind roses are quite similar. The terrain in the area is relatively flat and homogeneous, free of appreciable obstacles that could reduce wind speed or alter its direction; therefore, wind patterns would be expected to be similar from one location to another nearby location. 


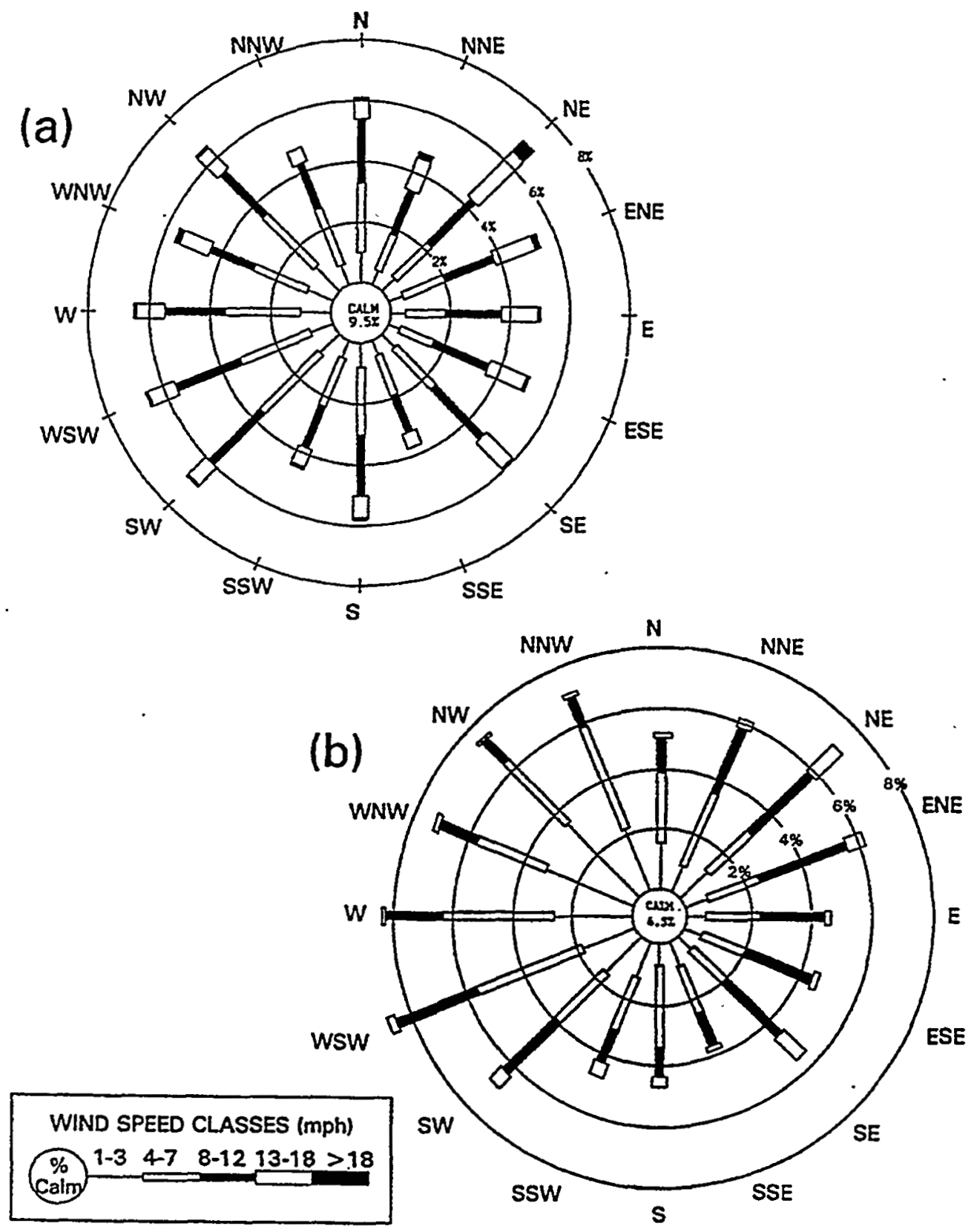

Figure 3.2.1. Wind roses for (a) Jacksonville International Airport (1948-95) and (b) a temporary monitoring site just north of the St. Johns River Power Park (December 10, 1979-December 10, 1980). The frequency of wind blowing from each direction is plotted as a bar that extends from the center of the diagram. Wind speeds are denoted by bar widths and shading; the frequency of wind speed within each wind direction is depicted according to the length of that section of the bar. Because the wind rose displays directions from which the wind blows, emissions would travel downwind in the opposite direction. 
The height above ground to which appreciable vertical atmospheric mixing occurs (the mixing height) is an important factor influencing atmospheric dispersion of pollutants. If mixing height and wind speed are both very low, atmospheric dispersion of pollutants is limited and the meteorological potential for air quality deterioration is high. Such conditions are rare in Jacksonville; according to Holzworth (1972), only about 1 day per year has a high meteorological potential for air quality deterioration.

Relative humidity is higher at Jacksonville than in most parts of the United States, averaging from 75 to $80 \%$ during most months; however, it is closer to $70 \%$ during the spring. Fog occurs about 5 days per month in winter, and about 1 day per month in summer.

\subsubsection{Air Quality}

Criteria pollutants are defined as those for which National Ambient Air Quality Standards (NAAQS) exist. These pollutants are sulfur dioxide $\left(\mathrm{SO}_{2}\right)$, nitrogen dioxide $\left(\mathrm{NO}_{2}\right)$, ozone $\left(\mathrm{O}_{3}\right)$, carbon monoxide $(\mathrm{CO})$, lead $(\mathrm{Pb})$, and particulate matter less than or equal to $10 \mu \mathrm{m}$ in aerodynamic diameter, designated PM-10. EPA has also promulgated NAAQS for particulate matter less than or equal to $2.5 \mathrm{\mu m}$ in aerodynamic diameter (PM-2.5) (62 FR 38652), and a new 8-hour $\mathrm{NAAQS}$ for $\mathrm{O}_{3}$ to replace the 1-hour $\mathrm{O}_{3}$ standard (62 $\mathrm{FR}$ 38856). However, an appellate court rendered these new NAAQS unenforceable (U.S. Court of Appeals 1999a,b). In response, EPA is currently seeking a review of that court's action by the U.S. Supreme Court (EPA 1999a). Because the outcome of that appeal is uncertain, further discussion in this document of the PM-2.5 standards and the 8-hour $\mathrm{O}_{3}$ standard will be limited. Moreover, the new standards are based on statistics requiring 3 years of data, which are currently incomplete and/or unofficial.

The NAAQS are expressed as concentrations of pollutants in the ambient air; that is, in the outdoor air to which the general public has access [40 CFR Part 501(e)]. Primary NAAQS define levels of air quality that the U.S. Environmental Protection Agency (EPA) deems necessary, with an adequate margin of safety, to protect human health. Secondary NAAQS are similarly designated to protect human welfare by safeguarding environmental resources (such as soils, water, plants, and animals) and manufactured materials. Primary and secondary standards are currently the same for all pollutants and averaging periods, with the exception that 3-hour $\mathrm{SO}_{2}$ averages have only a secondary standard. Florida standards are the same as the NAAQS except for annual and 24-hour standards for $\mathrm{SO}_{2}$, for which the Florida standards are more stringent. The applicable (most stringent) standards are presented in Table 3.2.1.

Currently, no portion of Duval County is designated as a nonattainment area for any NAAQS or Florida standard, but Duval County is a maintenance area for $\mathrm{O}_{3}$ (R. S. Pace, Jacksonville Regulatory \& Environmental Services Department, personal communication to R. L. Miller, ORNL, November 18,1998$)$. A maintenance area is an area that previously was a nonattainment area for a pollutant and which is striving to maintain attainment with the standard(s) for the pollutant and comply with the state implementation plan. Table 3.2.1 provides a recent 5-year (1993-97) summary 


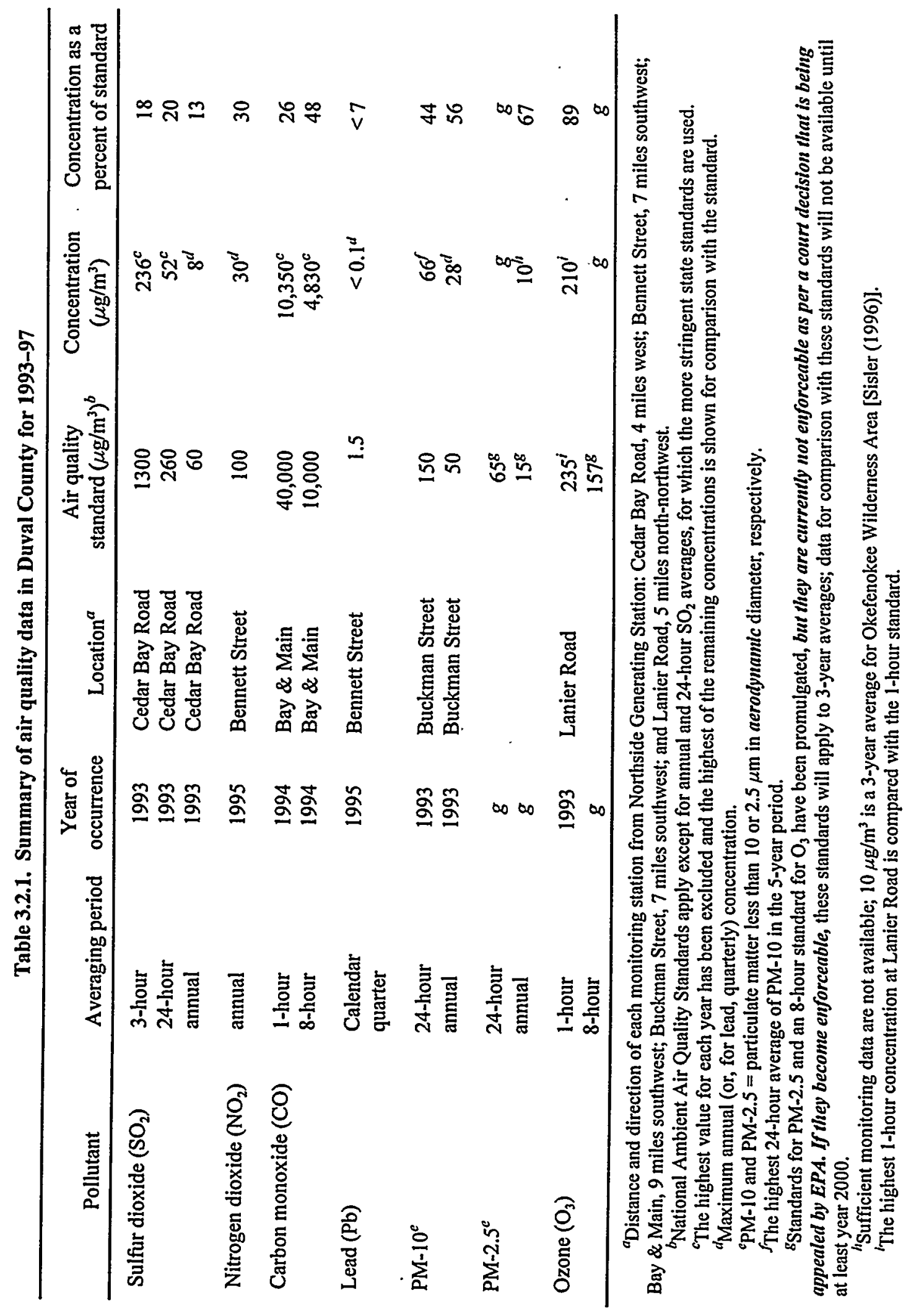


of air quality data in Duval County at the monitoring stations nearest to Northside Generating Station for pollutants regulated by NAAQS or by state standards. For comparison with the standards, the table gives the highest measured concentrations for averaging periods of greater than 24 hours. The long-term pollutant concentrations were well within the applicable standards (less than $70 \%$ of the standards for all pollutants, and $30 \%$ or less for all pollutants except particulate matter).

The standards for averaging periods of 24 hours or less include some allowance for occasional anomalous values. For comparison with the standards, the highest $\mathrm{SO}_{2}$ and $\mathrm{CO}$ measurement for each year was excluded and the table gives the highest of the remaining concentrations (the highest second-highest value) for 1993-97. All short-term $\mathrm{SO}_{2}$ and $\mathrm{CO}$ concentrations were well within the applicable standards (i.e., less than $50 \%$ of the standards).

Standards for PM-10 apply to statistical values derived from 3 years of data. However, because PM-10 measurements have traditionally been taken only every sixth day, the highest actual 24-hour concentrations might not be included in the data. Therefore, the table gives the highest measured 24-hour PM-10 concentration, which was less than $50 \%$ of the standards, rather than the highest second-highest value. As a rough indicator of annual average PM-2.5 concentrations in Duval County, a 3-year (March 1992-February 1995) average PM-2.5 concentration of $9.8 \mu \mathrm{g} / \mathrm{m}^{3}$ that was reported at Okefenokee Wilderness Area (Sisler 1996) can be used. That value (rounded up to 10) is given in Table 3.2.1; however, concentrations may be higher in the urban areas of Duval County.

Duval County was declared by EPA on March 6,1995, to be in attainment of the 1-hour $\mathrm{O}_{3}$ standard (i.e., Duval County is a maintenance area for $\mathrm{O}_{3}$ ). This standard allows for up to 3 exceedances over a 3-year period. Two exceedances occurred during 1995-97 at the monitoring site at the Naval Air Station, about 15 miles southwest of Northside Generating Station. No exceedances occurred at the monitoring site on Lanier Road, about 5 miles north-northwest of Northside Generating Station. The highest 1-hour concentration recorded at that monitor during 1993-97 was $210 \mu \mathrm{g} / \mathrm{m}^{3}$, which was less than $90 \%$ of the standard.

Contaminants other than the criteria pollutants are present in the atmosphere in varying amounts that depend on the magnitude and characteristics of the sources, the distance from each source, and the residence time of each pollutant in the atmosphere. In the ambient air, many of these pollutants are present only in extremely small concentrations, requiring expensive state-of-the-art equipment to measure them. Measurements of existing ambient air concentrations for many hazardous pollutants are, at best, sporadic. Regulation of these pollutants is attempted at the sources; emissions from specific source categories are regulated by the National Emissions Standards for Hazardous Air Pollutants (40 CFR Part 61; 40 CFR Part 63). However, electric utilities are not included among the specific source categories to which these regulations apply.

In addition to ambient air quality standards, which represent an upper bound on allowable pollutant concentrations, there are national air quality standards for the Prevention of Significant Deterioration (PSD) (40 CFR Part 51.166). The PSD standards differ from the NAAQS in that the NAAQS specify maximum allowable concentrations of pollutants, while PSD requirements provide 
maximum allowable increases in concentrations of pollutants for areas already in compliance with the NAAQS. PSD standards are therefore expressed as allowable increments in the atmospheric concentrations of specific pollutants. Allowable PSD increments currently exist for three pollutants $\left(\mathrm{NO}_{2}, \mathrm{SO}_{2}\right.$, and PM-10). PSD increments are particularly relevant when a major proposed action (involving a new source or a major modification to an existing source) could degrade air quality without exceeding the NAAQS, as would be the case, for example, in an area where the ambient air is very clean. One set of allowable increments exists for Class II areas, which cover most of the United States, and a much more stringent set of allowable increments exists for Class I areas, which include many national parks and monuments, wilderness areas, and other areas as specified in 40 CFR Part 51.166(e). Allowable PSD increments for Class I and Class II areas are given in Table 3.2.2.

Table 3.2.2. Allowable increments for Prevention of Significant Deterioration of air quality

\begin{tabular}{llcc}
\hline & & \multicolumn{2}{c}{$\begin{array}{c}\text { Allowable increment } \\
\left(\mu \mathrm{g} / \mathrm{m}^{3}\right)\end{array}$} \\
\cline { 3 - 4 } \multicolumn{1}{c}{ Pollutant } & $\begin{array}{c}\text { Averaging } \\
\text { period }\end{array}$ & Class $\mathrm{I}^{a}$ & Class $\mathrm{I}^{\alpha}$ \\
\hline Sulfur dioxide $\left(\mathrm{SO}_{2}\right)$ & 3-hour & 25 & 512 \\
& 24-hour & 5 & 91 \\
annual & 2 & 20 \\
Nitrogen dioxide $\left(\mathrm{NO}_{2}\right)$ & annual & 2.5 & 25 \\
Particulate matter less than $10 \mu \mathrm{m}$ & 24-hour & 8 & 30 \\
in aerodynamic diameter & annual & 4 & 17 \\
\hline
\end{tabular}

${ }^{a}$ Class I areas are specifically designated areas (e.g., national parks greater than 6,000 acres in area) in which the degradation of air quality is to be severely restricted. Class II areas (which include most of the United States) have a less stringent set of allowable increments.

The PSD Class I area nearest to Northside Generating Station is the Okefenokee Wilderness Area, 38 miles to the west. The next nearest Class I area is Wolf Island Wilderness Area, 63 miles north of Northside Generating Station, on the Georgia coast.

\subsection{SURFACE WATER RESOURCES}

\subsubsection{Hydrology}

Northside Generating Station lies within the drainage basin of the lower St. Johns River, 10 miles upstream from the river's mouth (Figure 3.3.1). The station is located 0.5 mile north of the back channel of the St. Johns River (previously known as the Blount Island Channel) and across from Blount Island (Figure 3.3.2) (USGS 1992b). The back channel of the St. Johns River conveys 30 to $50 \%$ of the river's total flow (JEA 1976; EVSC 1983). The site drains into the San Carlos Creek 
ORNL 97-129928Arra

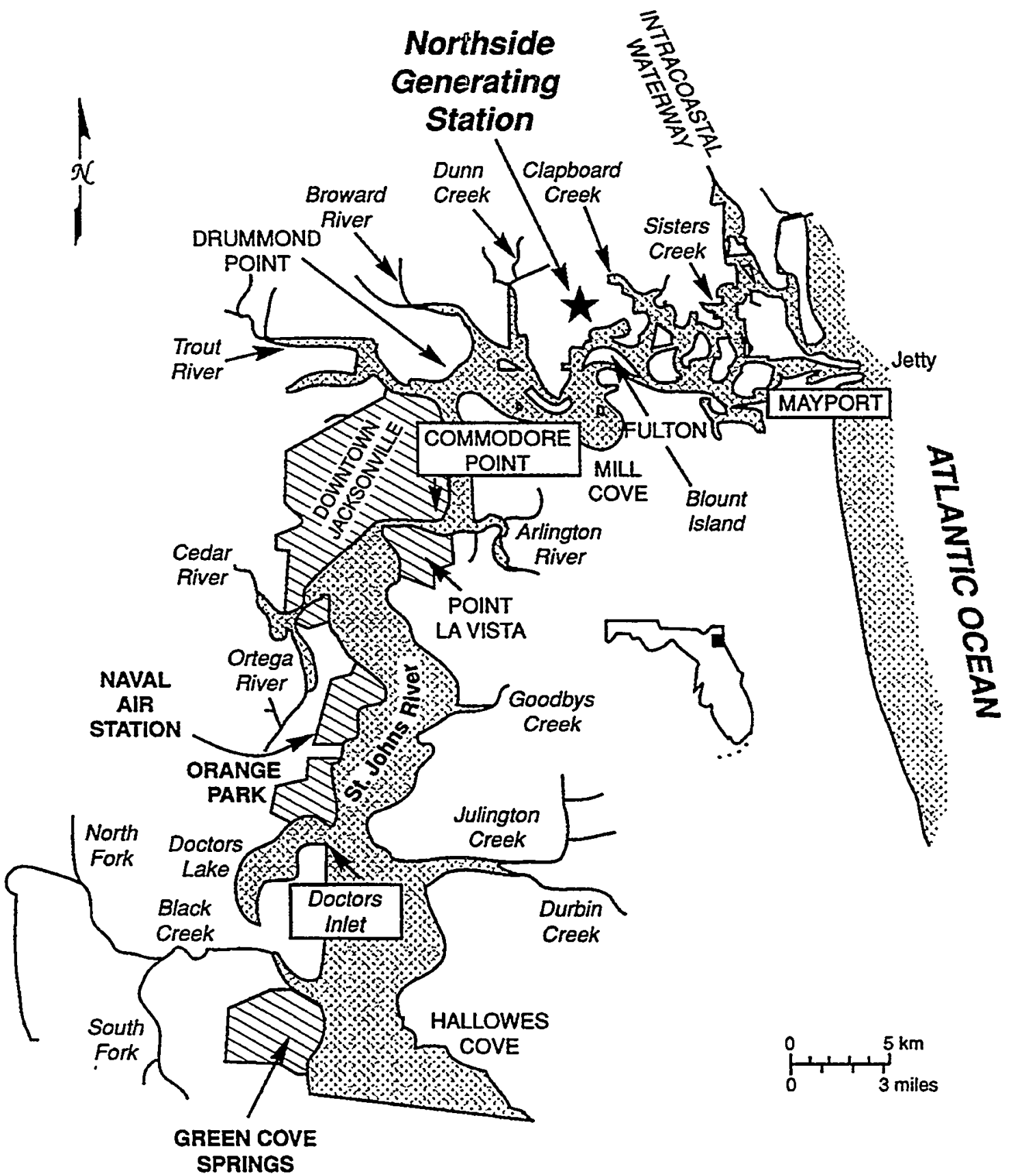

Figure 3.3.1. Map of the lower St. Johns River showing major tributaries and cities. Source: DeMort 1991. 

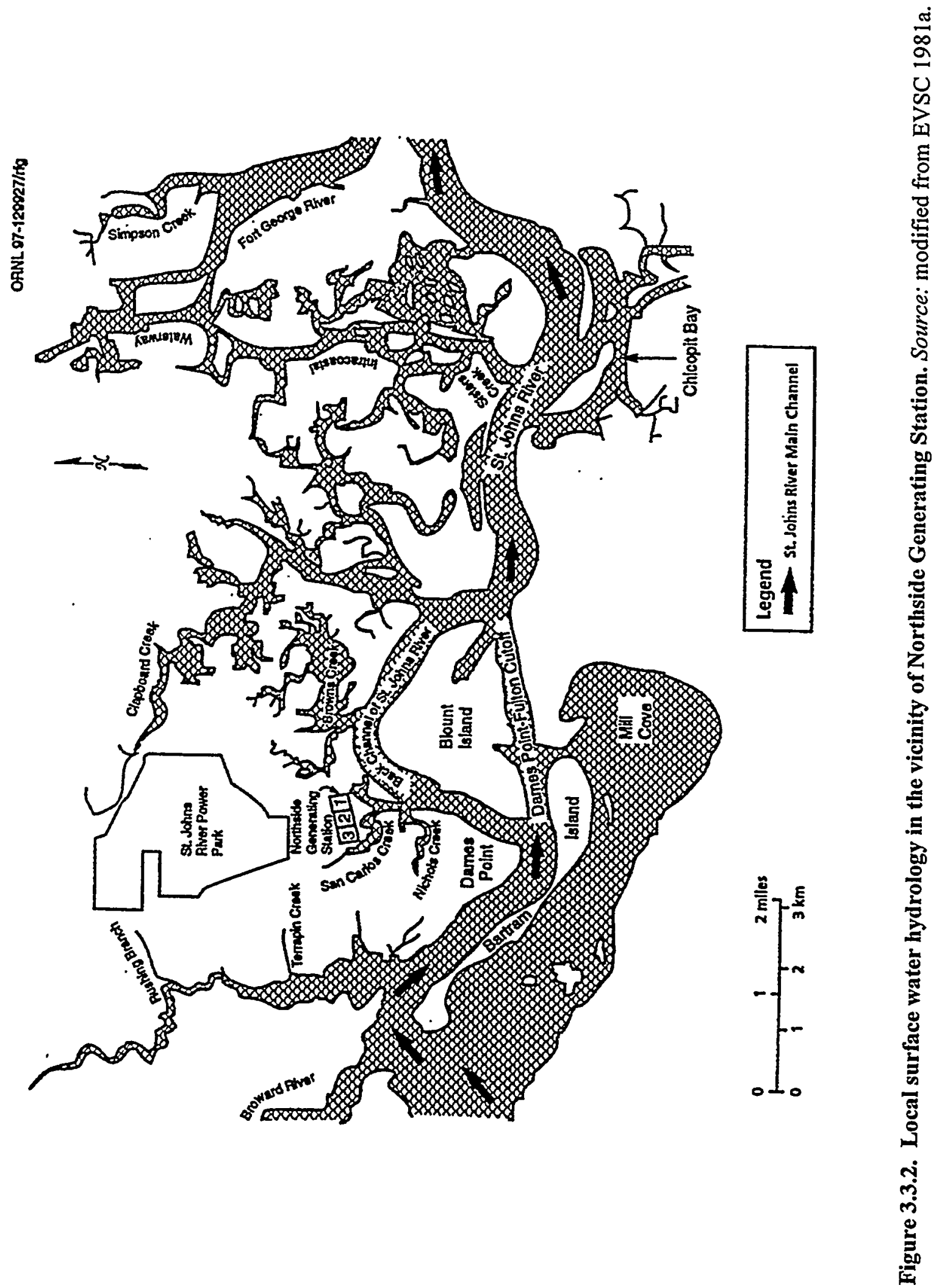
watershed which in turn empties into the back channel of the St. Johns River, which was the original channel of the river. The Dames Point-Fulton Cutoff along the southern side of Blount Island was constructed in 1947 and is now the main course of the river. Blount Island is a major port with facilities for docking, loading, and unloading large ocean-going vessels.

The St. Johns River is the longest river entirely within the state of Florida, having a length of 300 miles (Patrick 1994a). This coastal plain river drains one-fifth of Florida's land area, approximately 9,000 mile (DeMort 1991). The river's headwaters form in the St. Johns marsh around Hellen Blazes and Sawgrass lakes in Brevard County, 15 miles west of Melbourne, and to the southeast of Orlando (Grolier, Inc. 1993). The northward flow of the river is rare among larger U.S. rivers. The river gradually turns eastward at Jacksonville, flowing for 15 miles before emptying into the Atlantic Ocean at Mayport (USGS 1992a). The St. Johns River Water Management District (SJRWMD) has jurisdiction over the entire St. Johns River basin (Campbell et al. 1984).

Rodman Dam, about 80 miles upstream from Northside Generating Station, forms Lake Oklawaha (also known as Rodman Reservoir) (DMC 1989). The Lake Oklawaha standard project flood elevation is $23.2 \mathrm{ft}$ above mean sea level (amsl), while the maximum recorded lake water surface elevation of $20.7 \mathrm{ft}$ amsl occurred on February 4, 1970 (USGS 1997). In the lower part of the St. Johns River basin between Palatka ( 86 miles from the river's mouth) and Jacksonville, the main channel widens from 0.9 to 3 miles, with depths averaging less than $10 \mathrm{ft}$ (DeMort 1991). At Jacksonville, the channel narrows and deepens to $30 \mathrm{ft}$. Some areas east of the Acosta bridge in Jacksonville are tidally scoured or dredged, and have depths exceeding $60 \mathrm{ft}$. The St. Johns River is navigable by large ocean-going ships for 15 miles, or as far as the downtown area of Jacksonville (Grolier, Inc. 1993).

The St. Johns River is an estuarine river that is influenced by tidal motion and saline ocean water (Patrick 1994a). Normally the river is tidal for at least 80 miles from its mouth, and the influence of tides can extend as far as $\mathbf{2 8 3}$ miles inland during the spring. The great penetration of seawater is made possible by the low hydraulic gradient (i.e., low slope) of the river. The streambed of the St. Johns River drops only $26 \mathrm{ft}$ in elevation from source to mouth (DeMort 1991).

The St. Johns estuary is a river-dominated, moderately stratified system (DeMort 1991). In the Mayport area, there is a horizontal as well as a vertical salinity wedge. The river is regularly brackish during high tide as far south as Orange Park, with high tide salinities ranging from 2,000 to $5,000 \mathrm{mg} / \mathrm{L}$. During low flow years when the average annual rainfall is decreased, the saltwater mixing zone may extend south as far as Walaka. Low tide salinities in the Mandarin area north of Orange Park typically are less than $1,000 \mathrm{mg} / \mathrm{L}$.

The hydrology of the St. Johns River is influenced by the presence of numerous wetlands in the drainage basin and limestone sinks, fissures, springs, and subsurface rivers, some of which are saline (Patrick 1994a). There are 51 first-magnitude (having a discharge exceeding $100 \mathrm{ft}^{3} / \mathrm{s}$ ) springs and approximately 1,000 flowing artesian wells within the SJRWMD (Campbell et al. 1984). Freely flowing wells can seriously degrade groundwater quality by causing the upward leakage of salt 
water. The SJRWMD maintains a program to find and properly close abandoned wells and wells requiring remediation.

The net flow of the St. Johns River is negative over part of a 24-hour period (Patrick 1994a). During the tidal cycle, the river actually flows upstream more than it flows downstream. The U.S. Geological Survey operates a gaging station (station number 02246500) at the Main Street Bridge in Jacksonville, 22.7 miles upstream from the mouth of the river (USGS 1997). The average discharge for 23 years of record (water years 1955-74, 1981, 1988, and 1991) was 6,105 $\mathrm{ft}^{3} / \mathrm{s}$. The maximum daily discharge flowing into the ocean of $64,000 \mathrm{ft}^{3} / \mathrm{s}$ was recorded on June 20, 1972, while the maximum inland reverse flow of $-62,700 \mathrm{ft}^{3} / \mathrm{s}$ was recorded on October 20,1972 (the negative sign on the numerical value indicates a reverse flow, in which water moves upstream from the ocean).

The following average daily tidal stages were measured in the back channel of the St. Johns River adjacent to Northside Generating Station between November 1979 and October 1980 (EVSC 1983): (1) a high water level elevation of $2.24 \mathrm{ft}$ amsl, (2) a low water level elevation of $-1.28 \mathrm{ft}$ below mean sea level, and (3) a mean water level elevation of approximately $0 \mathrm{ft}$ (i.e., at mean sea level). Similar average daily tidal stages recorded between November 1980 and October 1981 were as follows: (1) a high water level elevation of $1.80 \mathrm{ft}$ amsl, (2) a low water level elevation of $-0.92 \mathrm{ft}$ below mean sea level, and (3) a mean water level elevation of approximately $0.18 \mathrm{ft}$ amsl.

\subsubsection{Water Quality and Use}

\subsubsection{Water Quality}

Surface water quality in the lower St. Johns River is influenced by a variety of natural and manmade sources. Tidal flushing, which involves an average of four tidal exchanges each day, provides an important mechanism for removal and dilution of contaminants and other pollutants that enter the river upstream of the site. Because the St. Johns River at the Northside Generating Station site is downstream from the urban core of Jacksonville, the water quality at this site would be affected by upstream inputs of industrial and domestic pollutants (approximately $25 \%$ of the land use in Duval County is urban-industrial). The major contributors to impaired water quality in the lower St. Johns River are sewage effluents, urban runoff, pulp mill effluents, and a variety of other industrial discharges (DeMort 1991). There currently are 33 industrial sources, 13 municipal sources, and 63 other permitted sources (including JEA sources) in the lower St. Johns River (M. Cadenhead, Florida Department of Environmental Protection, personal communication to R. L. Miller, ORNL, December 11, 1998). Another factor that influences surface water quality in the lower St. Johns River is a vertical salinity density gradient, which is typical of tidally influenced reaches of the St. Johns River in the vicinity of the site.

The waters in the vicinity of Northside Generating Station are classified by the state of Florida as Class III waters, which are designated for recreation and the propagation of well-balanced fish and wildlife populations. For discharges into these waters, the state water quality criteria apply beyond a 
designated mixing zone. In addition, at the point of discharge, the concentration of any toxic pollutant must be less than the 96 -hour $\mathrm{LC}_{50}$ for any important ecological species. Based on water quality data collected in the St. Johns River during the St. Johns River Power Park pre-application monitoring program (EPA 1981), the following nine pollutants exceeded the state water quality standards for Class III marine waters: aluminum, total residual chlorine, copper, total coliform, cyanide, iron, mercury, oil and grease, and silver. However, the Florida Department of Environmental Protection (FDEP) determined in 1996 that all the above pollutants except mercury and copper meet the Class III criteria and no longer require a variance. Because ambient levels of mercury and copper are currently within the state water quality standards, a request by Power Park staff to remove these parameters from the list requiring a variance was submitted to the FDEP in March 1997; however, there has been no final action taken to date on this request.

Surface water quality resulting from the operation of Northside Generating Station is regulated primarily by a National Pollutant Discharge Elimination System (NPDES) permit (FL0001031) that requires JEA to monitor a number of physicochemical parameters in the St. Johns River and San Carlos Creek. Specifically, NPDES limitations or reporting requirements have been established for the following liquid process streams: (1) once-through cooling water discharged via pipeline into the St. Johns River-volumetric flow, discharge temperature, temperature rise, total residual oxidants, intake water temperature, and acute whole effluent toxicity; (2) sewage treatment plant discharge via the pipeline into the St. Johns River- volumetric flow, carbonaceous 5-day biochemical oxygen demand, total suspended solids, $\mathrm{pH}$, and fecal coliform bacteria; (3) potable water storage tank overflow into San Carlos Creek-volumetric flow; and (4) non-chemical and chemical metal cleaning wastes, boiler blowdown, and other-low-volume wastes at the emergency overflow into San Carlos Creek-volumetric flow, total suspended solids, oil and grease, arsenic, cadmium, chromium, copper, total iron, lead, total manganese, mercury, nickel, selenium, zinc, $\mathrm{pH}$, and total hardness as calcium carbonate. No discharge of floating solids or visible foam in other than trace amounts is permitted in these effluents.

As a required component of the St. Johns River Power Park NPDES permit, a bioassay test program was developed for the combined Northside Generating Station/St. Johns River Power Park effluent discharge to determine if plant operation affects the water quality of the St. Johns River. This program consisted of three components, (1) measurement of the water quality at the intake and discharge points, (2) bioaccumulation studies on oysters to determine potential uptake of methylmercury and copper, and (3) aquatic toxicity tests to determine the effect of discharge water on the survival of two species of estuarine animals (mysid shrimp and silverside fish). These studies were conducted during a 2-year period (1986-88) and consisted of two phases-a pre-operational component to determine baseline conditions and a post-operational component to assess potential changes in baseline water quality as a result of facility operation.

Bioassays with caged oysters and toxicity testing on mysid shrimp and silverside fish have been conducted to determine the effects of water quality (primarily mercury and copper) on representative 
biota in the site vicinity (JEA 1989). Bioconcentration studies on native and caged oysters exposed for 3,6, and 12 months were performed in 1986 throughout the first year of operation of the St. Johns River Power Park. Placement of oyster cages was such that the combined discharge of the St. Johns River Power Park and Northside Generating Station was monitored. All methylmercury concentrations in oyster tissue were found to be below analytical detection levels in the reference and experimental oysters following exposure to the discharge effluents. Even though copper was detected in all oysters, including the reference individuals, there were no statistically significant differences in levels of heavy metals between the reference and effluent-exposed oysters after 3-9 months of exposure. The quarterly toxicity bioassays also demonstrated that the combined St. Johns River Power Park/Northside Generating Station discharge effluent was not acutely toxic to the mysid shrimp or the Atlantic silverside. The results of the bioaccumulation and toxicity tests demonstrated, therefore, that operation of the St. Johns River Power Park/Northside Generating Station facilities had no detectable effect on the water quality of the St. Johns River as reflected by toxicity to representative biota.

\subsubsection{Water Use}

Water is obtained from the back channel of the St. Johns River to cool the Northside Generating Station condensers and it is returned to the back channel (Figure 3.3.3). An elevated intake flume delivers the water from the back channel to the station condensers. This cooling water does not mix with other liquid process streams while in contact with the condensers. Because Unit 2 has been out of service since 1983, the actual demand for cooling water by Northside Generating Station at full load since that time has been approximately $620 \mathrm{Mgd}(430,700 \mathrm{gpm})$ to operate Units 1 and 3 (Figure 2.1.9). Operation of the entire 3-unit plant occurred only from about 1978 until 1980. During that time, the demand for cooling water was approximately $827 \mathrm{Mgd}(574,000 \mathrm{gpm})$ (JEA 1976, 1997b; EVSC 1983): (1) $24.5 \%$ for Unit 1, (2) $24.5 \%$ for Unit 2, and (3) $51 \%$ for Unit 3 . This amount of surface water supplied to the station was approximately $10 \%$ of the average flow passing through the back channel of the St. Johns River (JEA 1976).

Before passing through the condensers, noncontact cooling water at Northside Generating Station is treated intermittently with a biocide to prevent biological growth on the heat exchanger tubes. Sodium hypochlorite $(\mathrm{NaOCl})$ and occasionally sodium bromide $(\mathrm{NaBr})$ are used (JEA 1997b). Treatment occurs no more than 2 hours per day per operating unit.

The St. Johns River Power Park taps into the discharge side of the Northside Generating Station condensers to obtain cooling tower makeup (Figure 3.3.3). The average surface water flow supplied to the Power Park heat rejection system is $50 \mathrm{Mgd}(34,400 \mathrm{gpm}$ ) (Figure 2.1.9). Approximately 25\% of this surface water evaporates into the atmosphere from the cooling towers. Cooling tower blowdown is routed back into Northside Generating Station's discharge collector basin. The daily average temperature of the cooling tower blowdown is limited to $96^{\circ} \mathrm{F}$ (FDER 1981). 


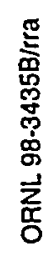

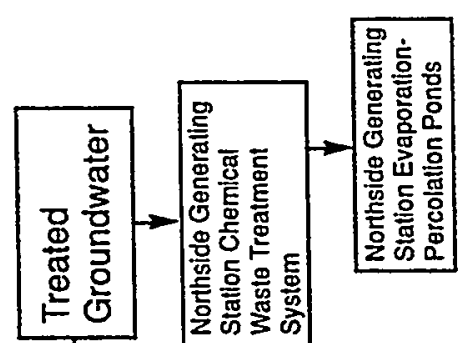


Recreation and commercial navigation constitute the primary uses of surface water in the vicinity of the station (EVSC 1981a). Recreational activities include boating, water skiing, swimming, fishing, and shellfish harvesting. The navigable channel serves both domestic and foreign cargo lines at the Port of Jacksonville, including Blount Island immediately south of the station.

The salinity of the estuarine water precludes using the lower St. Johns River as either a drinking water supply or a source of water for the irrigation of crops without prior treatment. Water is used by industries such as the pulp and paper industry for cooling and process use. The industrial consumption of surface water from the lower St. Johns River was approximately $25 \mathrm{Mgd}$ in 1980 and is expected to increase by about 50\% to $38 \mathrm{Mgd}$ by 2020 (EVSC 1981a). Surface water use (including once-through cooling) required for the generation of electricity is currently about $923 \mathrm{Mgd}$ (M. Cadenhead, FDEP, personal communication to R. L. Miller, ORNL, December 11, 1998).

\subsubsection{Effluent Discharges}

All discharges from Northside Generating Station are regulated under limits specified in an NPDES permit (FL0001031) (JEA 1997b). The NPDES permit renewal application currently under

- review by the FDEP addresses effluent discharges associated with the existing units and proposed outfalls and discharges that would occur after Units 1 and 2 are repowered.

The primary discharge from the station occurs at outfall 001 , located just offshore in the back channel of the St. Johns River (Figure 3.3.4). A pipeline buried beneath San Carlos Creek conveys the effluent from the elevated discharge collector basin located on the bank of San Carlos Creek to a submerged pair of diffuser pipes having a $Y$-configuration.

The discharge collector basin is an integrated system that receives and mixes discharges from both Northside Generating Station and the St. Johns River Power Park (Figure 3.3.3). During the operation of all 3 units at Northside (i.e., from approximately 1978 until 1980), effluents entering the discharge collector basin from Northside included $827 \mathrm{Mgd}(574,000 \mathrm{gpm})$ of heated noncontact cooling water exiting the condensers (JEA 1976, 1997b; EVSC 1983) and $0.005 \mathrm{Mgd}$ (4 gpm) from the sewage treatment plant (outfall 007) (JEA 1997b). Because Unit 2 has not been used since 1983, the current amount of heated Northside cooling water entering the collector basin is about $620 \mathrm{Mgd}$ (430,700 gpm) (Figure 2.1.9). Approximately $50 \mathrm{Mgd}(34,400 \mathrm{gpm})$ of the heated Northside cooling water is drawn from the collector basin and used at the Power Park as make-up water to replace cooling tower blowdown and water that evaporates into the atmosphere from the cooling towers. The Power Park returns about $37 \mathrm{Mgd}(25,900 \mathrm{gpm})$ of cooling tower blowdown and effluent from its sewage treatment plant and central wastewater treatment system. The total permitted flow discharged into the back channel of the St. Johns River at outfall 001 is $815 \mathrm{Mgd}(566,000 \mathrm{gpm})$, based on the operation of all 3 units at Northside (i.e., from approximately 1978 until 1980) and both units at the Power Park. The current discharge is approximately $608 \mathrm{Mgd}(422,300 \mathrm{gpm})$, which approximately equals $620 \mathrm{Mgd}(430,700 \mathrm{gpm})$ entering the collector basin minus $50 \mathrm{Mgd}(34,400 \mathrm{gpm})$ sent to the Power Park plus $37 \mathrm{Mgd}$ (25,900 gpm) returned from the Power Park (Figure 2.1.9). 

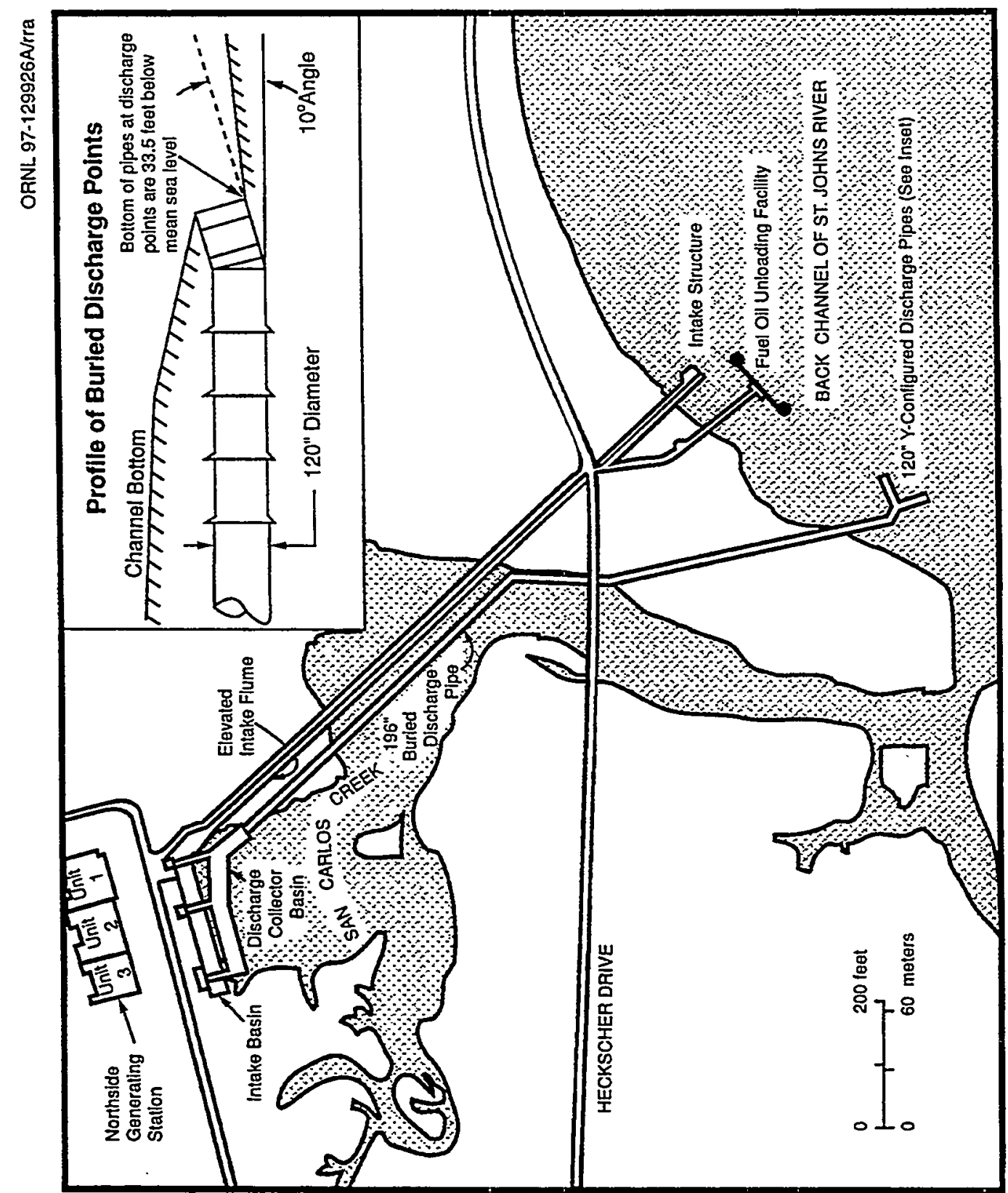

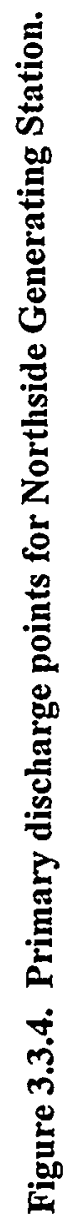


Three Northside Generating Station outfalls that drain into San Carlos Creek are regulated under requirements specified in the NPDES permit (JEA 1997b). Outfalls 009, 010, and 011 are located at the elevated tank used to store treated groundwater, the emergency overflow for the chemical waste treatment system percolation pond, and the emergency overflow for the south lime settling basin, respectively. Discharges from these outfalls seldom occur. These emergency outfalls are associated with flow control devices that prevent the tank, pond, and basin from overfilling. Stormwater discharges at Northside Generating Station are regulated in accordance with a general permit (FLR00B341) issued by EPA (JEA 1997b).

\subsubsection{Thermal Discharge}

Because Unit 2 has been out of service since 1983, the actual heat rejected by Northside Generating Station at full load since that time has been approximately $4 \times 10^{9} \mathrm{Btu} /$ hour from the condensers of Units 1 and 3. Operation of the entire 3-unit plant occurred only from about 1978 until 1980. During that time, the heat rejected by the condensers was approximately $5.3 \times 10^{9} \mathrm{Btu} / \mathrm{hour}$ at full load (EVSC 1983): (1) $24.5 \%$ for Unit 1, (2) $24.5 \%$ for Unit 2, and (3) $51 \%$ for Unit 3 . The temperature rise of $19^{\circ} \mathrm{F}$ (at the design flows quoted in Section 3.3.2) was the same for each condenser (JEA 1976; EVSC 1983).

The heat rejected by the condensers is dissipated by the tidal waters of the back channel of the St. Johns River. A thermal plume extends both upstream and downstream from the $Y$-configured pair of submerged discharge pipes (outfall 001) in response to flow reversals created by the flood and ebb (i.e., high and low) tides, respectively. If, because of reduced load, less electricity is generated and correspondingly the heat rejected by the condensers decreases, the flow of cooling water may also decrease because one of the four circulating water pumps may be taken out of service. The mixing that occurs in the St. Johns River is a function of both the heat rejected by the condensers and the exit velocity of the cooling water at the outlet of the submerged discharge pipes.

The temperature and total area of the thermal plume are regulated by limits specified in the NPDES permit (FL0001031), which includes three units (even though Unit 2 has been out of service) (JEA 1997b):

1. The daily (i.e., 24-hour) average effluent temperature at the point of discharge into the back channel of the St. Johns River cannot exceed $104^{\circ} \mathrm{F}$.

2. The daily average effluent temperature at the point of discharge cannot exceed the daily average ambient water temperature of the back channel of the St. Johns River by more than $19^{\circ} \mathrm{F}$. (During 1997 and 1998, the average temperature rise at Northside Generating Station was $9^{\circ} \mathrm{F}$ and the maximum measured temperature rise was $16.6^{\circ} \mathrm{F}$.)

3. The thermal discharge cannot cause the water temperature of the back channel of the St. Johns River, as measured $3.3 \mathrm{ft}$ below the water surface, to exceed $2^{\circ} \mathrm{F}$ above the natural water temperature outside of a 275 -yd wide mixing zone extending no more than $1,800 \mathrm{yd}$ from the 
point of discharge. The permitted surface area enclosed by this $2^{\circ} \mathrm{F}$ rectangular thermal discharge zone is 102 acres.

4. The thermal discharge cannot cause the water temperature of the back channel of the St. Johns River, as measured $3.3 \mathrm{ft}$ below the water surface, to exceed $4^{\circ} \mathrm{F}$ above the natural water temperature outside of a 133-yd wide mixing zone extending no more than 1,300 yd from the point of discharge. The permitted surface area enclosed by this $4^{\circ} \mathrm{F}$ rectangular thermal discharge zone is 36 acres.

The thermal discharge limitations specified in the NPDES permit were formulated using results from thermal plume mathematical modeling studies that assessed and substantiated the preoperational design of the station's heat rejection system (JEA 1976).

Northside Generating Station operates under a variance from thermal effluent limitations promulgated in Florida Administrative Code (FAC) 62-302.520 as provided for in the Clean Water Act Section 316 (a), otherwise referred to as a "316 (a) variance." The 316 (a) variance is a part of the NPDES permit renewal that includes the proposed project and would require EPA approval for continuance. A 316 Demonstration for the existing station has verified compliance with cooling water criteria promulgated under Chapter 17-3 of the FAC (JEA 1976). The extent of the thermal plume was measured during temperature mapping surveys that were performed on September 3-4, 1980; February 27, 1981; and May 20, 1981 (EVSC 1983). Results obtained during the monitoring program demonstrated that the extent of the thermal plume as defined by the area of the $2^{\circ} \mathrm{F}$ thermal discharge zone was approximately one order of magnitude smaller than (i.e., one-tenth the size of) the 102-acre plume permitted by NPDES limits. The largest plume, which occurred during the slack of ebb tide (no flow), measured 7 acres. Continuous water temperature measurements recorded near the mouth of San Carlos Creek under all tidal conditions also verified that the thermal plume did not penetrate into the creek.

When all three units were in service, Northside Generating Station operated in one of five different modes in response to demand for electricity (EVSC 1983). For instance, only Unit 3 might operate if peaking power were not needed. Modeling simulations of the thermal plume were performed with mathematical models to determine which operating mode produced the largest thermal plume (EVSC 1983). The largest thermal plume occurred when the flow through the condensers was approximately $400 \mathrm{Mgd}(280,000 \mathrm{gpm})$ (e.g., if Unit 3 were operating alone at full load with the flow reduced to $400 \mathrm{Mgd}$ ). At higher flow rates, the increased velocity at the submerged discharge promoted rapid mixing and heat dissipation; at lower flow rates, the corresponding decrease in heat load was large enough to reduce the size of the thermal plume. Thus, the thermal plume was smaller when all three units were operating at full capacity from approximately 1978 until 1980 because the increased velocity of the discharge promoted more rapid mixing. 
The mathematical modeling predicted a maximum extent for the $2^{\circ} \mathrm{F}$ thermal discharge zone of $1,000 \mathrm{yd}$ and an areal extent of 17 acres; the modeling confirmed compliance with NPDES permit limitations of length, width, and area under all operating conditions for the station. The maximum width predicted by the thermal plume modeling was about $82 \mathrm{yd}$. The maximum width of the $2^{\circ} \mathrm{F}$ thermal discharge zone allowed by the NPDES permit is $275 \mathrm{yd}$. The width of the back channel of the St. Johns River is approximately 530 yd near outfall 001 (JEA 1976). Therefore, a large zone of passage for aquatic organisms exists in the back channel around the plume during all operating conditions. Because the zone of passage remains at the ambient river temperature, it provides a pathway for aquatic species to move past the thermal discharge without being stressed.

\subsection{GEOLOGICAL RESOURCES}

\subsubsection{Geology}

This section discusses geological characteristics and properties in the area of the proposed project.

\subsubsection{Physiography}

The topography of eastern Duval County is controlled by a series of Pliocene and Pleistocene marine terraces. These terraces were formed during intervals when the sea level was higher than it is today. When the sea level fell, sedimentary deposits formerly on the sea floor emerged as a gently sloping terrace. A subtle wave-cut bench (scarp) developed on the seaward side of the terrace. Northside Generating Station is located on one such terrace.

Surface elevations at Northside Generating Station vary from $4 \mathrm{ft}$ amsl near the confluence of the east and west branches of San Carlos Creek to $13 \mathrm{ft}$ amsl about $330 \mathrm{ft}$ north of the 40-acre dredge spoil site. The water table is at or near the surface at the lower end of the terrace, and wetlands are prevalent on the lower end. The subsurface consists of medium to fine sand with lesser amounts of silt and even less clay to depths of at least $20 \mathrm{ft}$.

The main geologic structure in northern Florida is the Peninsular Arch (Phelps and Spechler 1997) which trends south-southeast from southeastern Georgia to central Florida. The crest of this arch is about midway between the east and west coasts in northern Florida and near the Atlantic coast in central Florida.

The Ocala Group (Eocene) is exposed at the surface along the crest of the arch in central and western Florida. Eocene strata dip generally to the east and are buried beneath 400-600 ft of successively younger strata in Duval County in extreme northeastern Florida (Phelps and Spechler 1997). Figure 3.4.1 shows schematic subsurface stratigraphic sections from west to east.

Leve (1978) used geological and geophysical logs of water wells to map the top of the buried Ocala Group in Duval County and discovered large vertical variations $(50-200 \mathrm{ft})$ in the elevations of the top of the Ocala Group. The somewhat linear trend of these variations led Leve to postulate the 

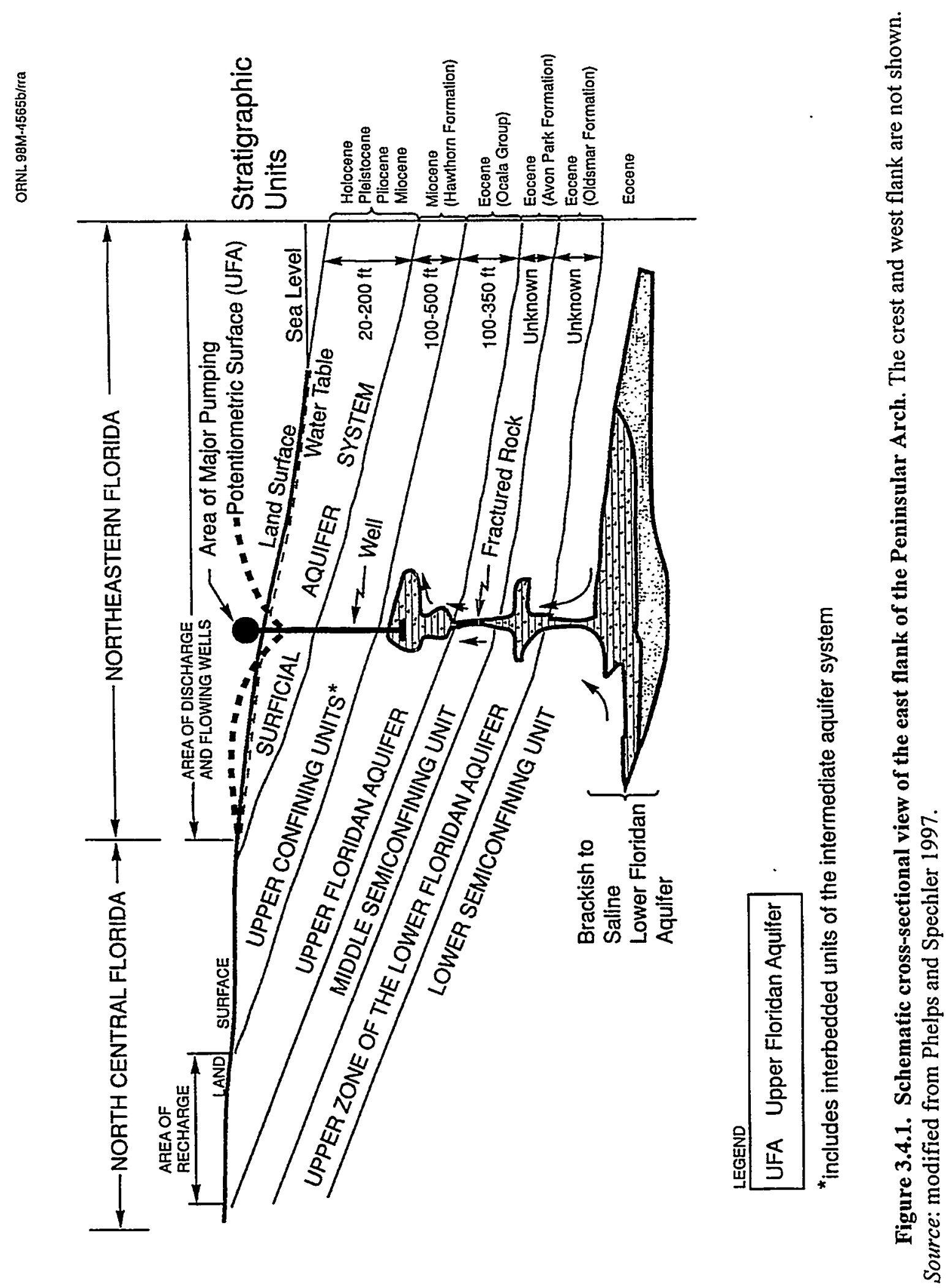
presence of two buried north-south striking faults. One of these faults lies near Northside Generating Station and the other lies a few miles to the west.

There is no evidence that the postulated faults near Northside Generating Station reach the surface. A subsurface drilling program (Leve 1978) failed to find similar variations in vertical relief at the top of the Hawthorn Formation (Miocene), which directly overlies the Ocala Group. The range of Hawthorn elevations was less than $20 \mathrm{ft}$. The absence of offsets in the Hawthorn Formation suggests that most of the activity on these faults ended by the close of Oligocene time (about 25 million years ago). An alternative interpretation for the observed topographic relief at the top of the buried Ocala Group is that the relief may have been caused by paleokarst development (ancient sinkholes) (Phelps and Spechler 1997) rather than by faults as proposed by Leve.

\subsubsection{Stratigraphy}

In this section, stratigraphic units are discussed in order, beginning with the deepest strata (Eocene) penetrated by water wells in Duval County and moving through successively younger and shallower units.

Eocene strata are more than $820 \mathrm{ft}$ thick in Duval County. All these strata were originally deposited as shallow marine carbonate (now limestone and dolomite) sediments. The deepest Eocene units have not been penetrated by water wells in Duval County. The deepest penetrated strata in Duval County are in the Oldsmar Formation (the upper zone of the lower Floridan aquifer). The next shallower strata are in the Avon Park Formation and the Ocala Group which comprise the upper Floridan aquifer (Phelps and Spechler 1997). A confining bed in the lower part of the Avon Park Formation separates the lower Floridan aquifer from the upper Floridan aquifer as shown in Figure 3.4.1.

The Ocala Group comprises the thickest part of the upper Floridan aquifer (more than $200 \mathrm{ft}$ thick in Duval County). The Ocala consists of interbedded hard crystalline limestone, dolomitic limestone, and soft, chalky, limestone. The upper surface of the Ocala Group is highly irregular (Section 3.4.1.1). Solution cavities, pipes, and sinks are common in some parts of the Ocala Group.

Strata above the Ocala Group (from the base of the Hawthorn to the surface) have lithologic characteristics, depositional environments, and stratigraphic characteristics that contrast sharply with the Eocene strata that underlie them. Whereas Eocene strata are carbonate rocks of marine (offshore) origin, the overlying Miocene to Holocene strata are unconsolidated sands, silts, mudstones and isolated lens-shaped beds of carbonate rocks. Miocene to Holocene strata were deposited in mostly terrigenous (at or above the shoreline) environments. Deposition of these sediments occurred in a wide variety of environments such as floodplains, river deltas and channels, lakes (formed in sinkholes in the Ocala), tidal lagoons, and beaches.

Whereas Eocene marine carbonates are thick and widespread, Miocene to Holocene lithologic units come in a wide variety of shapes and sizes. Most individual lithologic units are thin and discontinuous. Collectively, however, Miocene to Holocene strata cover a large area of northeastern 
Florida from the Atlantic shoreline to central Florida. The collective thickness ranges from 0 at the exposed Ocala-Hawthorn contact in central Florida to 400-600 ft in Duval County. Sediments that overlie the Ocala Group are about $500 \mathrm{ft}$ thick at Northside Generating Station.

\subsubsection{Chemical Properties}

Chemical properties of Miocene to Holocene strata contrast sharply with those of Eocene strata in northeastern Florida. Eocene strata are relatively soluble in rainwater and tend to form solution cavities near the water table. Generally, Miocene and Holocene strata are insoluble. Solution cavities do not form in these strata except in isolated carbonate lenses.

\subsubsection{Physical Properties}

Physical properties also contrast sharply between Eocene and younger strata in northeastern Florida. Whereas most Eocene strata are difficult to penetrate with a percussion drill, younger strata offer variable resistances to such drilling activity (depending on depth of burial and sand/silt versus clay content). Sediments rich in loose sand are prevalent on the terrace where Northside Generating Station is located. Sands are cohesionless and yield readily to penetration. Loose sand and silt located below the water table may settle during strong and sustained vibratory motion of heavy machinery or during an earthquake. This phenomenon is referred to as liquefaction.

\subsubsection{Regional Hydrogeology}

There are three aquifer systems in northeastern Florida. The Floridan aquifer system is $400-600 \mathrm{ft}$ deep and provides all municipal and most industrial potable water supplies in Duval County. The Floridan aquifer system is inaccessible to most private users because of the high cost of well completions. The surficial and intermediate aquifers provide potable water for rural residences that are not connected to municipal water supplies. The surficial aquifer is also a major source of nonpotable water for irrigation and livestock use. The intermediate aquifer is a less important source of groundwater in northeastern Duval County where the proposed project is located.

\subsubsection{Floridan Aquifer System}

The recharge area of the Floridan aquifer system is in the central part of the northern end of the Florida peninsula. This system is at the surface and is unconfined in its recharge area (Figure 3.4.1). Wells in the outcrop area of north central Florida are nonflowing because the potentiometric surface coincides with the shallow water table.

The Floridan aquifer system is confined in northeastern Florida. Confining clays and silts are in the overlying Hawthorn Formation (Phelps and Spechler 1997). The confining strata prevent upward flow and cause the hydrostatic pressure to increase within the Floridan aquifer system. The potentiometric surface of the Floridan aquifer system rises above the confining strata and above the ground surface in many places. At isolated locations, hydraulic connection may be established with 
the surface and cause water to flow up the connection and into overlying strata or even to the surface (depending on the height of the potentiometric surface in relation to the land surface).

The Floridan aquifer system is divided into upper and lower parts. The upper Floridan aquifer is separated from the lower Floridan aquifer by confining strata. Locally, hydraulic connection exists along solution channels and by wells that are screened in both units.

The potentiometric surface of the upper Floridan aquifer was much higher prior to development (over 100 years ago). According to Phelps and Spechler (1997), the potentiometric surface has been declining at rates between 0.33 and $0.75 \mathrm{ft}$ per year in northeastern Florida. Vergara (1998) estimates that the potentiometric surface in Duval County will decline an additional 3 to $15 \mathrm{ft}$ between 1995 and 2020 (based on projected increased groundwater use). The largest declines would be experienced south and east of the St. Johns River.

Discharge from the upper Floridan aquifer occurs to wells and springs in eastern Florida and offshore on the continental shelf beneath the Atlantic Ocean. The most prominent springs in eastern Florida are south of Duval County (German 1997). Many of these springs occur along the St. Johns River from St. Johns County to Seminole County. Limited discharge occurs to the overlying intermediate and surficial aquifers at locations where some degree of hydraulic connection exists (Phelps and Spechler 1997). Most of the industrial and municipal wells penetrate only the upper Floridan aquifer in Duval County. The lower Floridan aquifer is under-utilized because of its greater depth and relatively low water quality in Duval County.

Water quality in the upper Floridan aquifer meets EPA and Florida secondary water standards (less than $250 \mathrm{mg} / \mathrm{L}$ for chloride and sulfate and less than $500 \mathrm{mg} / \mathrm{L}$ for total dissolved solids) in most of Duval County (Huff and McKenzie-Arenberg 1990). Water quality in northern Duval County is well below these maximum concentration limits.

A few municipal wells in Jacksonville exceed maximum recommended secondary drinking water standards for total dissolved solids. Furthermore, the chloride concentration has been rising in a number of wells for several decades. Phelps and Spechler (1997) believe the rising chloride concentration is in response to the decline in the potentiometric surface of the upper Floridan aquifer and subsequent upward leakage of saline or brackish water from the upper zone of the lower Floridan aquifer.

In contrast, water quality in the upper Floridan aquifer south of Duval County generally exceeds EPA drinking water standards. Total dissolved solids concentrations exceed $500 \mathrm{mg} / \mathrm{L}$ throughout the southern two-thirds of St. Johns County, nearly all of Flagler County, and the eastern third of Putnam County.

\subsubsection{Intermediate Aquifer System}

According to Toth (1993), the intermediate aquifer system is not extensive in area, but occurs in portions of Duval, St. Johns, Clay, Putnam, and Flagler counties. It ranges from less than 10 to about $300 \mathrm{ft}$ below mean sea level and varies in thickness from less than 1 to about $15 \mathrm{ft}$. The intermediate 
aquifer system consists of strata of the Hawthorn Group and undifferentiated post-Hawthorn Group sediments. The Hawthorn Group consists of early to middle Miocene clay and limestone that act as confining units between the underlying Floridan aquifer system and the overlying surficial aquifer system. Layers of interbedded sand and shell fragments (groundwater resources) lie within the Hawthorn Group. Generally, the intermediate aquifer system is slightly artesian and is recharged from below by the more artesian Floridan aquifer system through upward leakage via intervening confining strata. In a few locations, the intermediate aquifer system is nonartesian and may be recharged by the surficial aquifer also. The largest groundwater production from the intermediate aquifer system is in Clay County, which borders Duval County on the southwest side (Huff and McKenzie-Arenberg 1990).

\subsubsection{Surficial Aquifer System}

The surficial aquifer system is not a single continuous aquifer. Rather, it is a series of discontinuous and thin aquifers progressing in age from oldest (Miocene) in east central Florida to youngest (Pleistocene and Holocene) in eastern Duval County where Northside Generating Station is located.

In parts of Duval County a limestone unit is the principal water-bearing unit in the surficial aquifer system (Toth 1993). A series of high-standing Pliocene and Pleistocene beach deposits extends inland from the present-day coastline. The surficial aquifer consists of medium- to finegrained sand in these areas. In swampy lowland areas (e.g., at Northside Generating Station) the water table is at or near the land surface throughout most of the year.

According to Toth (1993), the surficial aquifer system is recharged by local rainfall, ditches, tributaries, septic tank effluent, and percolation pond effluent (a groundwater mound is sustained beneath percolation ponds by nearly continuous recharge by liquid wastes). Also, in areas where the elevation of the potentiometric surface of the Floridan aquifer system is above the water table (as it is at Northside Generating Station), upward leakage from the upper Floridan aquifer to the surficial aquifer system may occur. Reverse flow (discharge) occurs when the water table is higher than the above features. The St. Johns River may alternately recharge and discharge the aquifer during high tides and low tides, respectively, depending on the water table elevation.

The quality of water taken from the surficial aquifer at depths ranging up to $125 \mathrm{ft}$ is generally suitable for domestic, commercial, and industrial uses in most areas of Duval County (Phelps 1994). However, some wells are affected by water with high concentrations of chloride from the St. Johns River, other estuaries, and tidal marshes. Water in clean (low in clays and decaying vegetation) sandy zones is generally soft (total hardness less than $60 \mathrm{mg} / \mathrm{L}$ ) and slightly acidic. Water in shellbeds of limestone is generally hard (total hardness greater than $120 \mathrm{mg} / \mathrm{L}$ ) and slightly alkaline. Iron concentration generally exceeds EPA's secondary drinking water standards (which are guidelines rather than regulatory restrictions). The mean concentration of iron in the surficial aquifer is $1.5 \mathrm{mg} / \mathrm{L}$ compared to EPA's standard of $0.3 \mathrm{mg} / \mathrm{L}$. 


\subsubsection{Hydrogeology in the Vicinity of Northside Generating Station}

This section discusses production wells in the upper Floridan aquifer, groundwater monitoring wells in the surficial aquifer, and groundwater characteristics at Northside Generating Station.

\subsubsection{Production Wells}

There are four active deep production wells (D-1149, D-1150, D-1151, and D-1152) at Northside Generating Station and a fifth deep production well (D-228) that is on standby (Figure 3.4.2). Based on the following casing records, there is no interaction between the upper Floridan and surficial aquifer waters at the four active production wells. Each of these 16-in.-diameter wells was drilled to a depth of $1,104 \mathrm{ft}$ and cased to a depth of $520 \mathrm{ft}$ (USGS 1997). The casing exteriors were cemented to the surface. Cemented casings are periodically pressure-tested for leaks. When a leak is identified, a well is either repaired or the casing interior is plugged with cement and abandoned. Presumably the casings were placed at least $10 \mathrm{ft}$ into the upper Floridan aquifer and certainly below the confining . strata in the lower Hawthorn Formation. There is no published casing record for well D-228 that was drilled to $850 \mathrm{ft}$. Well D-228 appears to have casing that effectively seals off the surficial aquifer. The potentiometric surface had an average water level elevation of $25.1 \mathrm{ft}$ for well D-228 during the 1996 water year (USGS 1997). Well D-1152 (with a published casing record) had a lower average water level elevation ( $20.8 \mathrm{ft}$ ) during the same time interval. If all other influencing factors are equal, these data suggest that well D-228 may be as effective as well D-1152 in preventing leakage through the casing.

The 18-year historical record (1978-96) of potentiometric surface heights is inconclusive in terms of whether these heights are declining or recovering at Northside Generating Station. The potentiometric surface heights of wells D-228 and D-1152 have declined from their historically highest levels in 1983 (29.4 ft and $26.5 \mathrm{ft}$, respectively). In contrast, the heights of the potentiometric surfaces for wells D-1149, D-1150, and D-1151 reached their historically highest levels during the 1995-96 water year (36.4 ft, $42.0 \mathrm{ft}$, and $24.8 \mathrm{ft}$, respectively) (USGS 1997). Data collected during more recent water years have not yet been published.

\subsubsection{Surficial Aquifer Monitoring Wells}

JEA (1997b) reports the results of quarterly groundwater quality sample analyses for seven surficial aquifer monitoring wells to the FDEP, Northeast District, Jacksonville, Florida. Other wells are plugged and abandoned or utilized only for measuring the depth to the water table. The seven surficial aquifer monitoring wells are at scattered locations around Northside Generating Station (Figure 3.4.2).

A background well (NS19) is located about $375 \mathrm{ft}$ north (upgradient) from the dredge spoil pile. One well (NS14) is located on the inside edge of the L-shaped dredge spoil pile. Two more wells are located near the northwest and southwest corners of the northern tank farm (NS16 and NS27, respectively). The western boundary of this tank farm is about $500 \mathrm{ft}$ from the west fork of San 


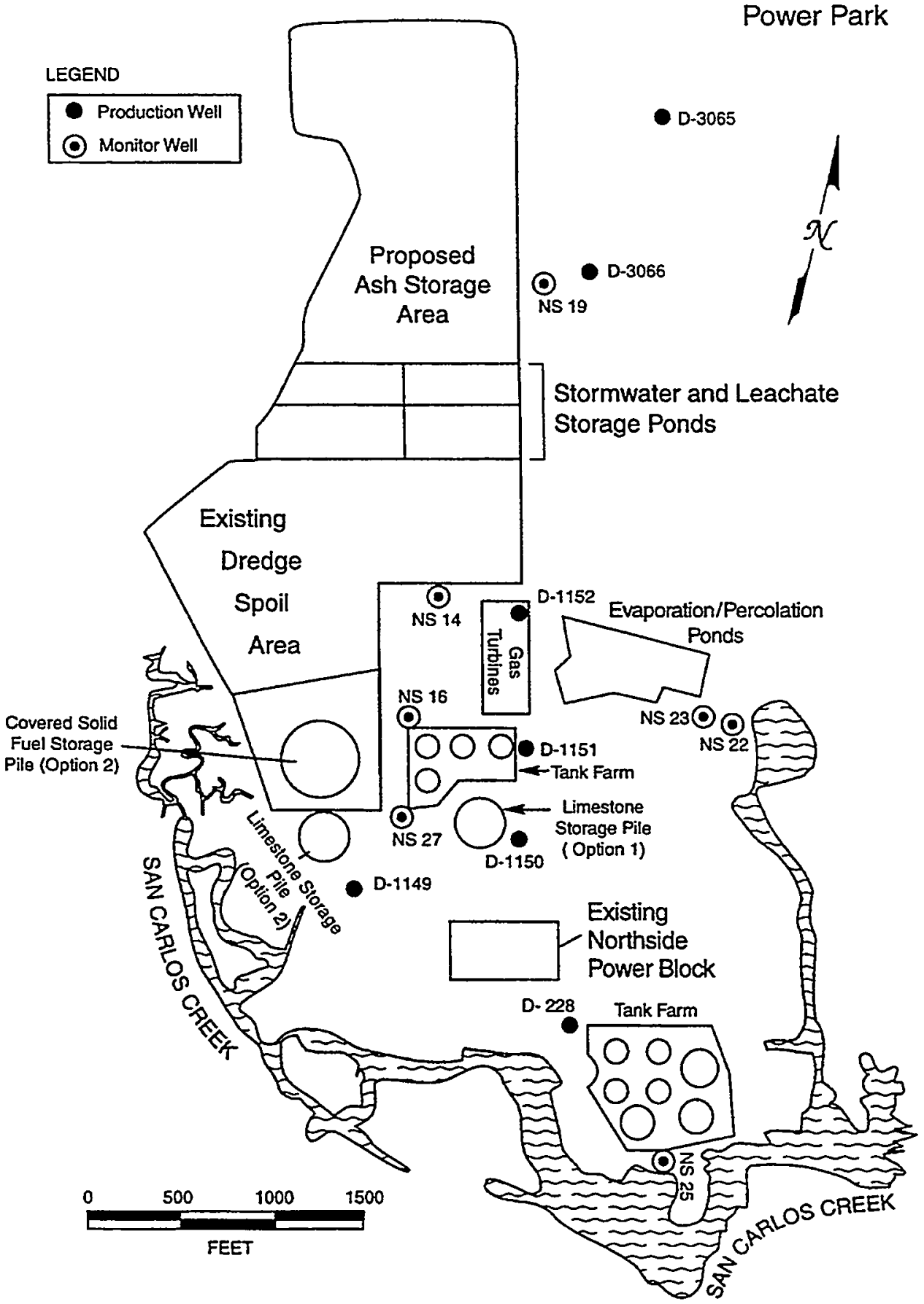

Figure 3.4.2. Location map for upper Floridan aquifer production wells, surficial aquifer monitoring wells, and proposed ash storage area and runoff ponds. 
Carlos Creek, a tributary to St. Johns River. Another two wells (NS22 and NS23) are located near the southeast corner of the evaporation/percolation ponds. Another well (NS25) is located on the south side of the fuel oil tank farm and adjacent to the confluence of the east and west forks of San Carlos Creek.

Well depths range from 11 to $20 \mathrm{ft}$. Fine, loose sand is the predominant sediment encountered in all the wells. Surface elevations range from 4.3 to $12.9 \mathrm{ft}$ amsl. Water table elevations range from 0.1 to $2.9 \mathrm{ft}$ amsl. Seasonal variations in water table elevations range from 3 to $6 \mathrm{ft}$. Higher water table elevations and greater water table fluctuations are associated with wells at higher surface elevations.

Five of the seven wells were monitored mainly for inorganic constituents, as shown in Table 3.4.1. Fourth-quarter analytical results for 1993 and 1995 are presented. These data are provided by JEA to the FDEP under terms of their groundwater permit. Water samples from two wells (NS22 and NS23) close to the evaporation/percolation ponds have high concentrations of sulfate, chloride, and total dissolved solids. The other three wells all meet EPA secondary drinking water standards for these constituents. Analyses did not detect the presence of metals above their detection limits. Iron was not included in these analyses. All water samples were slightly acidic (pH between 5 and 6), including samples from the background well (NS19).

The water quality was better in all five wells when the water table was high in 1995. When the water table is high as a result of infiltrating rainwater, the surficial aquifer discharges to San Carlos Creek, nearby ponds, and ditches. Conversely, when the water table is low, the surficial aquifer may be recharged by the creek, nearby ponds, and ditches.

Two compliance wells (NS25 and NS27) are adjacent to fuel oil tank farms. These wells were monitored for the presence of many organic compounds that are commonly associated with fuel oil. Analyses did not detect the presence of any of these compounds above their detection limits.

Three surficial aquifer studies were conducted for JEA from 1992 to 1995 in areas adjacent to one another. The first study (Law Engineering 1992) was initiated to support the development of a new groundwater monitoring plan for a proposed sludge disposal site on the dredge spoil berms. Law Engineering used existing surficial aquifer wells to characterize local groundwater conditions around the dredge spoil area. However, the proposed project was cancelled, and the new wells were never installed. Similar characterizations were completed in support of limited contamination assessments for the surficial aquifer immediately downgradient from the combustion turbines on the southeast side of the dredge spoil area (EMCON 1995), and the nearby tank farm (RBA 1995). Results of these three independent groundwater characterizations are presented in Table 3.4.2. Estimates of aquifer porosity, hydraulic conductivity, hydraulic gradient, and groundwater velocity varied by factors of 2 , 21,12 , and 20 , respectively. The wide variation in estimated groundwater velocities indicates contaminant travel times ranging from a few decades to over 100 years to reach San Carlos Creek. 


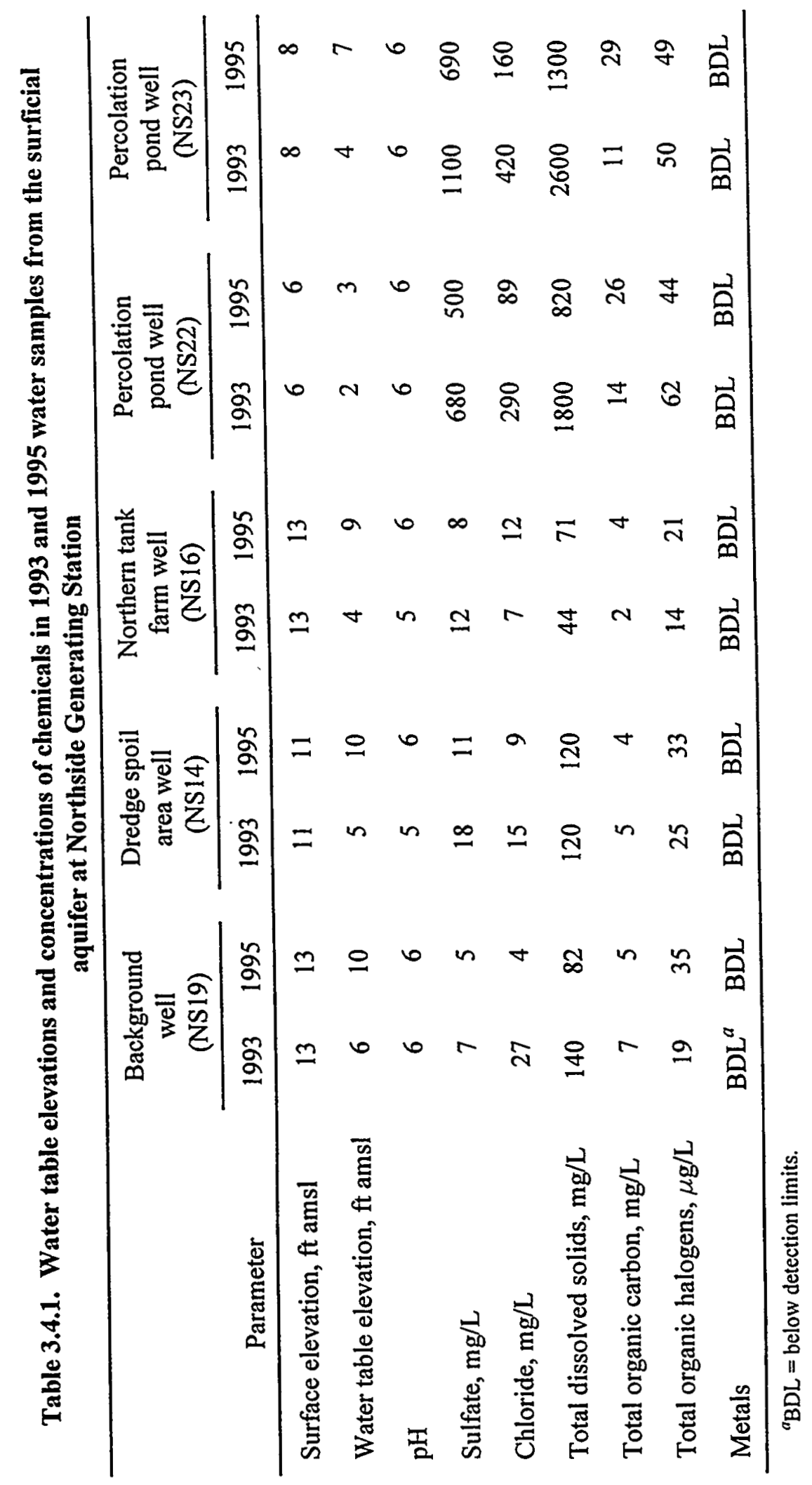


Table 3.4.2. Hydraulic characteristics of the surficial aquifer in the vicinity of the dredge spoil, tank farm, and combustion turbine areas

\begin{tabular}{lccc}
\hline & Dredge spoil $^{a}$ & Tank farm $^{b}$ & $\begin{array}{c}\text { Combustion }^{b} \\
\text { turbines }^{c}\end{array}$ \\
\hline Conductivity, ft/day & 5.7 & 0.27 & 4.5 \\
Gradient & 0.002 & 0.0036 & 0.0003 \\
Porosity & 0.15 & 0.25 & 0.30 \\
Groundwater velocity, ft/year & 28 & 1.4 & 1.6 \\
\hline \multicolumn{1}{c}{${ }^{{ }^{L} \text { Law Engineering 1992. }}$} & & & \\
$\quad{ }^{b}$ RBA 1995. \\
$\quad{ }^{c}$ EMCON 1995.
\end{tabular}

\subsubsection{Water Quality}

In 1996, chloride concentrations ranged from 20 to $36 \mathrm{mg} / \mathrm{L}$ for individual quarterly samples from the four active production wells (D-1149, D-1150, D-1151, and D-1152) at Northside Generating Station (USGS 1997). Similar samples of specific conductance ranged between 488 and $613 \mu \mathrm{mhos} / \mathrm{cm}$ at these wells. Two wells (D-3841, located 10 miles to the east, and D-1095, located 10 miles to the west) had concentrations ranging from 13 to $20 \mathrm{mg} / \mathrm{L}$ for chloride, 86 to $100 \mathrm{mg} / \mathrm{L}$ for sulfate, 296 to $338 \mathrm{mg} / \mathrm{L}$ for total dissolved solids, and 480 to $530 \mu \mathrm{mhos} / \mathrm{cm}$ (Phelps and Spechler 1997). Table 3.4.3 presents a compilation of annual average concentrations for four quarterly water

Table 3.4.3. Upper Floridan aquifer water quality in production wells at Northside Generating Station compared with wells located 10 miles east and west of the station ${ }^{a}$

\begin{tabular}{lcccccc}
\hline \multicolumn{1}{c}{} & \multicolumn{6}{c}{ Well } \\
\cline { 2 - 7 } \multicolumn{1}{c}{ Parameter } & $\begin{array}{c}\text { D-1095, } \\
10 \text { miles } \\
\text { west }\end{array}$ & $\begin{array}{c}\text { D-3841, } \\
10 \text { miles } \\
\text { east }\end{array}$ & $\begin{array}{c}\text { D-1149, } \\
\text { at the } \\
\text { station }\end{array}$ & $\begin{array}{c}\text { D-1150, } \\
\text { at the } \\
\text { station }\end{array}$ & $\begin{array}{c}\text { D-1151, } \\
\text { at the } \\
\text { station }\end{array}$ & $\begin{array}{c}\text { D-1152, } \\
\text { at the } \\
\text { station }\end{array}$ \\
\hline Chloride, $\mathrm{mg} / \mathrm{L}$ & 13 & 17 & 20 & 35 & 22 & 23 \\
Sulfate, $\mathrm{mg} / \mathrm{L}$ & 86 & 93 & & &. & 502 \\
$\begin{array}{l}\text { Specific conductance, } \\
\mu \text { mhos/cm }\end{array}$ & 480 & 520 & 514 & 589 & 537 & 502 \\
Total dissolved solids, $\mathrm{mg} / \mathrm{L}$ & 296 & 338 & & & & \\
\hline
\end{tabular}

${ }^{a}$ Well-head samples are from wells drilled to similar depths. Samples were collected from D-1095 and D-3841 in the 1994-95 water year (Phelps and Spechler 1997) and from the Northside Generating Station wells in the 1995-96 water year (USGS 1997). 


\section{JEA EIS}

samples from the four active production wells and the two offsite wells. Although total dissolved solids were not reported at Northside Generating Station, specific conductance is a good estimator of total dissolved solids. Based on a comparison of the maximum specific conductance at Northside Generating Station with the specific conductance at the two offsite wells and assuming a similar percentage increase in total dissolved solids at Northside Generating Station, total dissolved solids at station wells might exceed $400 \mathrm{mg} / \mathrm{L}$ at times.

Older data are available for comparison with these more recent data. Comprehensive water quality data for well D-1149 were collected in September 1978 (USGS 1980), while more limited data were collected in October 1976 for wells D-228, D-1150, and D-1151 (Table 3.4.4). A comparison of the more recent data in Table 3.4.3 with the older data in Table 3.4.4 suggests that chloride concentrations and specific conductance have increased by about 10 and $20 \%$, respectively, over the past 20 years in upper Floridan aquifer production wells at Northside Generating Station.

Table 3.4.4 Upper Floridan aquifer water quality in production wells at Northside Generating Station based on previous data ${ }^{a}$

\begin{tabular}{|c|c|c|c|c|}
\hline \multirow[b]{2}{*}{ Parameter } & \multicolumn{4}{|c|}{ Well } \\
\hline & D-228 & D-1149 & D-1150 & D-1151 \\
\hline $\begin{array}{l}\text { Specific conductance, } \\
\mu \mathrm{mhos} / \mathrm{cm}\end{array}$ & 415 & 425 & 440 & 460 \\
\hline Alkalinity, mg/L & & 160 & & \\
\hline Bicarbonate, $\mathrm{mg} / \mathrm{L}$ & & 190 & & \\
\hline Hardness, $\mathrm{mg} / \mathrm{L}$ & 204 & 250 & 212 & 240 \\
\hline Calcium, $\mathrm{mg} / \mathrm{L}$ & & 55 & & \\
\hline Magnesium, mg/L & & 27 & & \\
\hline Sodium, $\mathrm{mg} / \mathrm{L}$ & & 14 & & \\
\hline Potassium, $\mathrm{mg} / \mathrm{L}$ & & 2 & & \\
\hline Chloride, $\mathrm{mg} / \mathrm{L}$ & 18 & 24 & 20 & 20 \\
\hline Sulfate, $\mathrm{mg} / \mathrm{L}$ & & 80 & & \\
\hline Fluoride, $\mathrm{mg} / \mathrm{L}$ & & 1 & & \\
\hline
\end{tabular}

${ }^{a}$ Water samples from well D-1149 were collected in September 1978. All other water samples were collected in October 1976.

It is unlikely that the surficial aquifer would discharge into the upper Floridan aquifer at any time in the near future at Northside Generating Station. The only short-term scenario is one in which a casing fails while a deep cone of depression is developing around a producing upper Floridan aquifer 
well. However, well casings are periodically examined for leaks and, when necessary, the well casing is repaired or the well is plugged and abandoned. The potentiometric surface in shut-in wells would recover and-if a shut-in well has a failed casing-leakage would be upward from the upper Floridan aquifer to the surficial aquifer.

The following potentiometric data were obtained from four production wells (all drilled to a depth of 1,104 ft) at Northside Generating Station. In 1996, the potentiometric surface of the upper Floridan aquifer ranged from 17.0 to $41.7 \mathrm{ft}$ above the land surface elevation of $10 \mathrm{ft}$ amsl (USGS 1997). The potentiometric surface elevations were influenced by two factors [the time of the year and length of time since a particular well temporarily ceased production (i.e., was shut-in)]. The rate of potentiometric surface decline is between 0.33 and $0.75 \mathrm{ft}$ per year (Phelps and Spechler 1997). Using the lowest potentiometric surface observed in $1996(17 \mathrm{ft}$ ) and assuming that the water table coincides with the land surface, it would take between 21 and 50 years beyond 1999 for the potentiometric surface to fall below the land surface.

\subsubsection{Groundwater Use}

This section discusses groundwater use quantitatively for industrial, commercial, municipal, and private user categories in Duval County. Also, groundwater consumption at Northside Generating Station and its nearby neighbors (within 2 miles) is discussed.

Huff and McKenzie-Arenberg (1990) provides groundwater use data for Duval County from 1975 to 1988 , and more recent groundwater use data through 1996 are provided by individual SJRWMD annual water use surveys (Figure 3.4.3). Total groundwater use increased from $152 \mathrm{Mgd}$ in 1975 to $169 \mathrm{Mgd}$ in 1988 (Huff and McKenzie-Arenberg 1990), but decreased to $151 \mathrm{Mgd}$ in 1995 (Florence and Moore 1997). Total groundwater demand is expected to increase by $43 \mathrm{Mgd}$ between 1995 and 2020 (Vergara 1998).

A comparison of 1988 and 1995 data shows that public use is increasing while all other categories of use are declining. Public use of municipal wells in 1988 and 1995, respectively, was approximately 95 and $100 \mathrm{Mgd}$; domestic or household use of private wells was 15 and $12 \mathrm{Mgd}$; agricultural use was 15 and $3 \mathrm{Mgd}$; and industrial use or electric power generation was 44 and 30 Mgd.

Vergara (1998) identifies southeastern Duval County as a priority water resource caution area. Northside Generating Station and the St. Johns River Power Park are adjacent to the northern boundary of this caution area. Caution areas are regions where existing and reasonably anticipated sources of water and conservation efforts may not be adequate to (1) supply water for all existing legal uses and reasonably anticipated future needs and (2) sustain the water resources and related natural systems.

Northside Generating Station and the St. Johns River Power Park pump groundwater for processes and systems requiring potable water. Treated groundwater is used for domestic and sanitary needs, various washes, miscellaneous equipment, advanced water treatment, boiler 
ORNL 99-04721/rra

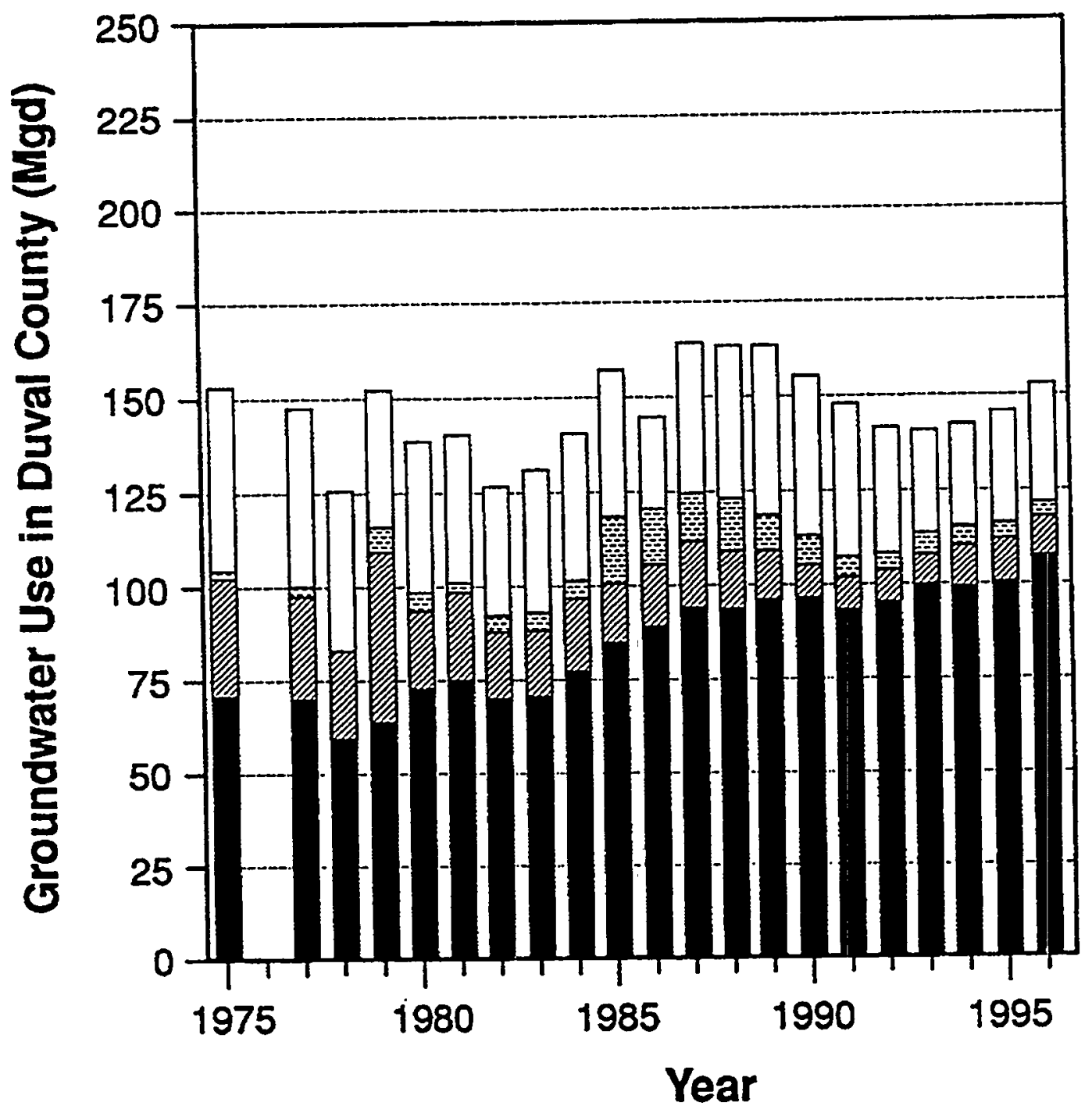

Public Supply

บ110 Domestic

Agricultural

$\square$ Industrial/Power

Figure 3.4.3. Groundwater use in Duval County. 
feedwater makeup, boiler and preheater washes, and fire protection. Although JEA is permitted to withdraw a maximum of $3 \mathrm{Mgd}$ from the four deep wells in the upper Floridan aquifer at Northside Generating Station, groundwater consumption averaged 0.64 Mgd in 1996. The maximum allowable annual usage for the Northside facility is $730 \mathrm{Mgal} / \mathrm{year}$, which is equivalent to $2 \mathrm{Mgd}$ for each day of the year. The consumptive use permit was issued in 1993 and expires in 2000. The permit was modified in December 1996, but the allocation for groundwater consumption was not changed in the 1996 modification. St. Johns River Power Park also obtains its groundwater from onsite wells. Groundwater consumption by the Power Park averaged 3.57 Mgd in 1995 (Florence and Moore 1997).

Gate Maritime Properties, Inc., and the Jacksonville Port Authority, located within 2 miles of Northside Generating Station, are currently permitted to withdraw groundwater from the upper Floridan aquifer from a total of eight wells. Collectively, these two facilities are permitted to withdraw $1.3 \mathrm{Mgal} / \mathrm{year}$, which is less than $1 \%$ of the permitted consumption rate at Northside Generating Station.

\subsubsection{Soils}

Where undisturbed by prior construction activity, soils in the area of Northside Generating Station are only slightly modified by weathering from the Pleistocene beach sands from which they were derived. They are predominantly unconsolidated, medium to fine quartz sand with lesser amounts of silt and even smaller amounts of clay to depths of greater than $20 \mathrm{ft}$. The water table is at or near the surface most of the year. Weathering processes such as oxidation and leaching are retarded where the soil is usually saturated. The only appreciable soil alteration results from the growth and decay of wetland vegetation.

\subsubsection{Geologic Hazards}

This section discusses the potential for subsidence, settlement, and erosion by storm surge. Also, the probability of damage from an earthquake and associated liquefaction is discussed.

\subsubsection{Subsidence}

Cover-collapse sinkholes are common to the west and south of Duval County, but they are rarely found at the surface in northeastern Florida (Beck and Sinclair 1986). Cover-collapse in central Florida and the southern reaches of the St. Johns River basin is a phenomenon where the near-surface Hawthorn and younger sands, silts, and clays collapse into solution cavities in the underlying Ocala Group. The size and severity of collapse at the surface is related to the thickness and bearing strength of the near-surface sediments. Collapse of the surface into buried Ocala Group sinkholes is possible but extremely rare in Duval County (Beck and Sinclair 1986). The greater thickness of the Miocene to Holocene sediments is believed to prevent cover-collapse sinkholes from propagating to the surface. When such features do reach the surface, they are not as severe. However, small-scale 
subsidence may occur over near-surface shell beds or limestone lenses of Miocene to Holocene age. One small topographic depression is located on the south side of the 40-acre dredge spoil site at Northside Generating Station. This depression may be a sinkhole or possibly a settlement feature caused by the loading of dredge spoil. Another small topographic depression that may have been caused by subsidence lies immediately south of the dredge spoil site.

\subsubsection{Settlement and Erosion}

Uniform sands in the vicinity of Northside Generating Station are not expected to experience long-term settlement or appreciable differential (uneven) settlement. Settlement occurs rapidly in free-draining sands. Unconsolidated sands that are located in critical areas may be eroded by infrequent storm-surge.

\subsubsection{Earthquakes}

The Northside Generating Station site contains medium- and fine-grained sands and silts below the water table that are susceptible to liquefaction (Seed and Idriss 1971). Such soils lose their strength under vibratory motion. There is a greater than normal risk of structural failure at such sites during a strong-motion earthquake.

Algermissen et al. (1990) used the entire history of earthquakes in eastern North America through 1988 to produce probabilistic ground motion estimates. These estimates are the basis for Uniform Building Code (UBC) guidelines. All of Northern Florida is located in seismic zone 1 of the UBC (ICBO 1995). Earthquakes have 10 and $63 \%$ probabilities of producing peak ground accelerations (PGAs) in excess of $0.05 \mathrm{~g}$ at least once in 50 and 500 years, respectively, on rock foundations anywhere in seismic zone 1. The UBC design PGA for seismic zone 1 is $0.075 \mathrm{~g}$.

There are no state of Florida or local seismic building codes. However, the Southern Building Codes Conference recently published a set of standard codes for the southeastern United States (SBCC 1997). A PGA of $0.05 \mathrm{~g}$ would produce minor damage to structures founded on rock and designed to resist earthquakes. Somewhat greater damage would occur to structures founded on unconsolidated sediments. Seed and Idriss (1971) consider a PGA of $0.05 \mathrm{~g}$ to be somewhere near the threshold of liquefaction in medium- to fine-grained and loose sand that is located below the water table.

The Charleston, South Carolina, earthquake of 1886 probably produced the strongest ground motion of record in northeastern Florida. The modified Mercalli intensity (MMI) of this earthquake was estimated at $\mathrm{V}$ to $\mathrm{VI}$ in Jacksonville, based on newspaper accounts of eye-witness perceptions (Bollinger 1986). Although an earthquake with an MMI of VI is capable of causing wide-spread panic, the only damage is likely to be fallen plaster and damaged chimneys.

There is a historical record of mild earthquakes in Florida (EVSC 1981a). An earthquake with an epicentral MMI of V struck near Jacksonville in August 1900. A similar earthquake in the future would be felt in the region surrounding Northside Generating Station. However, damage would be 
minor and confined to older, poorly constructed buildings. The largest earthquake in Florida struck Gainesville in 1879 with an MMI of VI in the epicentral area. Although this earthquake was widely felt along the Atlantic coast from Savannah, Georgia, to Daytona Beach, Florida, the only damage reported was plaster falls in a few older homes in St. Augustine.

\subsection{FLOODPLAINS, STORM SURGE, AND WETLANDS .}

\subsubsection{Floodplains}

The 100- and 500-year floodplains along the St. Johns River for the area including and surrounding Northside Generating Station have been identified by the Federal Emergency Management Agency (FEMA 1989). The elevations of the 100- and 500-year floodplains are 7 and $10 \mathrm{ft}$ amsl, respectively. Water storage provided by the vast array of tidal marshlands east and north of Jacksonville limits the extent of flooding that could occur along the lower St. Johns River near Northside Generating Station (COE 1961).

Most of the land for the existing and proposed power blocks is located above the 500-year floodplain because it is at an elevation that slightly exceeds $10 \mathrm{ft}$ amsl (USGS 1992b). A small portion of this land along the southern edge of the existing and proposed structures could be inundated by an approximate 100 - to 500-year flood to depths averaging less than $1 \mathrm{ft}$ (i.e., nuisance flooding).

The St. Johns River Power Park's coal conveyer that originates on Blount Island, the water intake flume, and the discharge collector basin are elevated structures that cross the floodplain. The coal conveyer is elevated above the 500-year floodplain. The intake flume and collector basin would be either partially or completely submerged during an approximate 500-year flood. The base of the vertical turbine pumps that supply cooling water to the condensers are above the 500-year floodplain.

The existing and proposed fuel and sorbent unloading facilities are located within the 100-year floodplain. These structures either have or would have the capability to moor and unload large ships and comply or would comply with all applicable regulations governing the design, installation, and maintenance of marine/harbor facilities. Some of the ancillary structures, piping, and equipment related to the operation of these facilities also are located either totally or partially within the 100-year floodplain.

\subsubsection{Storm Surge}

Florida is located in one of the most hurricane-prone regions of the United States. A hurricane is a tropical storm whose wind velocities equal or exceed $74 \mathrm{mph}$. Damage from hurricanes is caused by intense precipitation, extreme winds, and wind-induced tides and wave action known as storm surge, which can result in flooding, erosion, and washout. Hurricane Dora (September 1964) was the first hurricane north of Stuart, Florida, to strike perpendicular to the coast of Florida from the 
Atlantic Ocean since the Great Hurricane of 1880 (Rabon 1970; Williams and Duedall 1997). Damage at Jacksonville caused by Dora exceeded that of either Andrew (1992) or Hugo (1989).

Sustained winds attributed to hurricane Dora were $125 \mathrm{mph}$ at St. Augustine and $82 \mathrm{mph}$ at the Jacksonville airport (Rabon 1970; Williams and Duedall 1997). Rainfall during the 4-day storm exceeded 10 in. over a 10,000-mile ${ }^{2}$ area-an estimated 50-year, 4-day storm. A 10-ft storm tide caused extensive erosion and inundation of the beaches and coastline near Jacksonville. Beach roads were washed out and buildings were swept into the sea.

Hurricane Dora also caused considerable wind-induced flooding along the St. Johns River in Jacksonville (Rabon 1970; Williams and Duedall 1997). High winds caused massive utilities failure, and numerous trees were uprooted. Total damage was estimated at $\$ 250$ million dollars (more than $\$ 1$ billion in 1990 dollars).

The maximum water surface elevation recorded at the Main Street Bridge (22.7 miles upstream from the mouth of the river) in Jacksonville was $5.21 \mathrm{ft}$ amsl; this elevation occurred on September 10, 1964 during hurricane Dora (USGS 1997). Northside Generating Station is located approximately 10 miles upstream from the mouth of the river (EVSC 1981a). Using the storm tide elevation of $10 \mathrm{ft}$ amsl at the mouth of the St. Johns River as a reference, the maximum water surface elevation that occurred in the vicinity of the station during hurricane Dora was $7.9 \mathrm{ft}$ amsl (obtained using linear interpolation based on the relative distances from the mouth of the river). This amount is less than the elevation of approximately $10 \mathrm{ft}$ amsl at the base of Northside's existing turbine building.

Other hurricanes have caused elevated water surface along the St. Johns River at Jacksonville that were less than the storm surge observed during hurricane Dora (COE 1961): (a) $4.8 \mathrm{ft}$ amsl, October 13-21, 1944; (b) $3.0 \mathrm{ft}$ amsl, October 7-9, 1946; and (c) $4.7 \mathrm{ft}$ amsl, October 15-19, 1950. Waterfront areas in downtown Jacksonville experienced minor flooding during the 1944 and 1950 hurricanes.

The somewhat inland location of Northside Generating Station is partially protected from storm surge by the narrow coastal strip, comprising the beach and beach ridge, which lies between the Atlantic Ocean and Intracoastal Waterway (COE 1961). The beach ridge along the dune line has an average elevation in the range from 10 to $12 \mathrm{ft}$ amsl. Marshlands east and north of Jacksonville serve to absorb tides and limit the extent of flooding. Historically, hurricanes have tended to move parallel to the coast of Florida and bypass Jacksonville.

A design hurricane-tide elevation in the range from 4 to $6 \mathrm{ft}$ amsl has been quoted for the Jacksonville riverfront (COE 1961). This range does not include wave run-up and ponding on lands along the waterfront. The city of Jacksonville is preparing storm surge maps, which have not yet been issued.

The JEA has an emergency plan ready for implementation that provides for mobilization of the necessary resources to respond quickly and effectively to a major disaster such as a hurricane (JEA $1996 \mathrm{~b}, \mathrm{c})$. The advanced preparation and planned response protect personnel, minimize property 
damage, and minimize the time required to restore electrical service to the community if damage does occur.

\subsubsection{Wetlands}

The delineated wetlands in the vicinity of the proposed project are shown in Figure 2.1.7. The estuarine emergent wetlands in the project area have been identified by the National Marine Fisheries Service as Essential Fish Habitat (Letter No. 7 in Appendix G). The freshwater habitats that are an integral component of wetland ecosystems in the vicinity of Northside Generating Station consist of two creeks, their associated hardwood swamps, and small isolated gum swamps. Types of terrestrial habitat or communities within the hardwood swamps include cypress, bottomland hardwood, and bayhead. These freshwater systems are typical of similar habitats throughout the region where fluctuations in water levels and stream flow with time are the primary factors that determine or regulate the abundance and diversity of freshwater organisms residing in these systems. The hardwood swamps drain into the salt marsh via small streams and provide some nutrient and organic food sources for organisms in the upper salt marsh/tidal creek complex. The water level varies seasonally in these freshwater habitats with depths up to 20 in. occurring during wet seasons and with standing water restricted to local depressions in dry periods. The isolated gum swamps occur in the area as small depressions within the pine flatwood vegetation types. These swamps are important to the surrounding pine flatwoods in that they aid in drainage and in nutrient regeneration. Water retention in this community type is also seasonal, being prevalent during wetter months and subsiding dramatically during the drier periods. The fauna of these freshwater systems are adapted to the fluctuating water levels characteristic of these habitats. Within the hardwood swamp (which also includes the cypress, bottomland hardwood, and bayhead habitats and their associated creeks), 5 species of mammals, 12 bird species, 3 reptile species, and 9 species of amphibians (mostly frogs) have been observed. Some of the dominant herbaceous plant species in the hardwood and cypress swamps include bladderworts, duckweed, pickerelweed, and cattails.

\subsection{ECOLOGICAL RESOURCES}

This section summarizes and provides an overview of the ecological resources, including aquatic and terrestrial ecosystems, in the vicinity of Northside Generating Station. Of particular importance is the 46,000-acre Timucuan Ecological and Historic Preserve that borders the site to the east. Because detailed descriptions of the ecological resources, including extensive species lists, are available in other documents previously prepared for Northside Generating Station and the St. Johns River Power Park (EVSC 1981a,b; JEA 1976; EPA 1981), the purpose of this section is to identify the major ecological habitats and community types on and near the site, provide a brief description of the major aquatic and terrestrial resources associated with these habitat types, and discuss the functional relationships between these habitats and communities in terms of how they relate to each other as integrated ecological systems. The amount of detail provided for each of the ecological 
components described below generally reflects the potential level of effect that the proposed project could have on each of these components. For example, the proposed project is not anticipated to affect any of the terrestrial habitat types in the site vicinity; but the potential to impact aquatic resources is much higher. Therefore, more detail is provided for the aquatic systems.

\subsubsection{Terrestrial Ecology}

Northeastern Florida is categorized as southern mixed forest, which is characterized by tall forest with broadleaf deciduous and evergreen species. Nine major types of terrestrial habitat or communities occur in the vicinity of Northside Generating Station including pine flatwoods, grassy scrub, grassy scrub/pine flatwoods, hardwood swamp, hardwood hammock, bottomland hardwood, bayhead, and cypress swamp (EPA 1981). Isolated gum swamps also occur in the area as small depressions within the pine flatwoods. The salt marsh systems that border San Carlos Creek and other tidal estuaries in the area are also considered terrestrial communities; however, because they are transitional habitats between terrestrial and aquatic systems and because of their high ecological importance, the ecology of these systems is described in Section 3.6.2.

Both game and non-game species of wildlife are associated with these terrestrial and wetland communities in the vicinity of the site. Game species include whitetail deer, eastern gray squirrel, marsh rabbit, and bobwhite quail. Some of the more common non-game species include raccoons and opossums; river otters are observed less frequently.

\subsubsection{Aquatic Ecology}

The aquatic ecosystems in the vicinity of Northside Generating Station are typical of southeastern coastal ecosystems and consist of two major habitat or community types: the St. Johns River estuary and the tidal creeks and their associated salt marsh estuaries. These two ecosystems are relatively distinct in terms of their hydrodynamic, physicochemical, and biological character.

The tidal creek and salt marsh systems in the area of Northside Generating Station are contiguous with the extensive southeast coastal marsh system and are well recognized for their ecological and commercial importance. Salt marsh systems provide several ecological services to the surrounding estuarine communities. These habitats function as nursing, spawning, and/or feeding areas for several species of commercially and recreationally important fish and shellfish species such as shrimp, crabs, seatrout, and menhaden. The salt marsh system also (1) helps to filter and process pollutants, nutrients, and sediments; (2) functions as an aquifer recharge zone; and (3) helps to maintain a proper balance of salinity regimes in wetland areas.

Tidal flow and salinity regimes are the primary factors that dictate and regulate the structure and function of the biological communities of these salt marsh/tidal creek systems. Tidal flow provides nutrients and materials to organisms residing within the tidal creek/salt marsh complex and transports organic food sources and other nutrients to other areas of the estuarine system. Black needle rush and salt marsh cord grass are the predominant vegetation types that ultimately form the primary energy 
base of the food chain, particularly for many invertebrates and detritivore species (organisms that primarily eat decaying organic matter). The salt marsh systems that directly border the St. Johns River, such as those that occur along the river channel of the Blount Island area, are somewhat disturbed because of channelization, sea walls, and rip rap embankments. Extensive, relatively undisturbed tidal marshes, however, border San Carlos Creek in the vicinity of Northside Generating Station.

In addition to the emergent macrophytes (plants that extend above the water surface) such as black needle rush and cord grass, periphyton (algae attached on underwater rocks and pilings) also contribute to the organic matter base of the salt marsh/tidal creek food web. Periphyton serve, for example, as forage for grazers such as gastropod molluscs and fiddler crabs. On a seasonal basis, some of the organic matter production within the tidal creek/salt marsh complex is retained within the system, providing a food base for many invertebrate and some fish species. Submergent macrophytes (plants that do not extend above the water surface) such as seagrasses are generally absent in the back channel of the St. Johns River, primarily because of (1) unfavorable turbidity and salinity regimes which limit their distribution and (2) the disturbed shorelines and channelization which hinder their growth.

The benthic communities of the estuarine systems in the site vicinity are dominated by macroinvertebrates that are characteristic of southeastern estuarine ecosystems. There are two distinct assemblages of macroinvertebrates inhabiting the estuarine systems in the vicinity of Northside Generating Station: those associated with the fine mud and sand substrates of the tidal creeks, such as polychaetes and amphipods; and those residing in the silt and mud substrates of the St. Johns River, such as the small clam, Mulinia sp. Within the St. Johns River, many mollusc species have undergone severe reduction of potential habitat as a result of dredge and fill activities in construction and maintenance of the Intracoastal Waterway and the ship channel (Brody 1993). Densities of benthic invertebrates in both the St. Johns River and the tidal creeks/salt marsh systems are relatively low with scattered, high-density patches of several opportunistic species.(Brody 1993). The smaller invertebrates such as amphipods and polychaetes serve as forage for bottom-feeding fish such as spot and croaker while the macroinvertebrates such as shrimp and crabs are preferred by predators such as redfish, sea trout, black drum, and flounder. Also, of commercial importance, are the blue crab and three species of shrimp which utilize the tidal creek/salt marsh complex during much of their life history for feeding, growth, and protection from predators.

Even though zooplankton are not an important component of the food web in the tidal creeks and salt marshes, they are the dominant food source for most species of larval and juvenile fish in the St. Johns River estuary. Copepods, cladocerans, and larval forms of benthic organisms such as barnacles and polychaetes (meroplankton) are the dominant zooplankton in the St. Johns River. Whereas the base of the food chain in tidal salt marshes and wetlands is primarily detritus (decaying organic matter) and periphyton, the food chain in the St. Johns River is supported mainly by phytoplankton and zooplankton (Brody 1993). Phytoplankton and zooplankton are consumed by not 
only larval fishes, but zooplankton also serve as the primary food of some ecologically important adult species such as anchovy and silversides and the filter-feeding menhaden. These species, in turn, serve as important prey for intermediate-level predators such as seatrout and bluefish.

The St. Johns River estuary supports an abundant and varied fish community including seasonal and permanent residents (menhaden, weakfish, silver perch, spot, croaker, spotted seatrout), anadromous species (shad, striped bass), and occasional oceanic species that pass through the area (e.g., bluefish, jacks). Of the 113 fish species that have been identified in the area (EPA 1981), several are recreationally and commercially important and use the salt marsh/tidal creek areas near Northside Generating Station for feeding and nursery grounds.

Mean densities of total fish larvae, including shrimp and crab larvae, were found to be $16,000 / 1,000 \mathrm{~m}^{3}$ in the tidal creeks and about $10,000 / 1,000 \mathrm{~m}^{3}$ in the back channel of the St. Johns River (EVSC 1981a). The most common species of ichthyoplankton were weakfish, spot, menhaden, spotted seatrout, croaker, silver perch, and black drum. Both blue crabs and penaeid shrimp postlarvae are seasonally common constituents of the meroplankton (included in ichthyoplankton in terms of total densities) (JEA 1976; EVSC 1981a).

\subsubsection{Threatened and Endangered Species}

Although suitable habitat exists for 21 species of terrestrial and aquatic wildlife that are listed as threatened, endangered, or species of special concern by the U.S. Fish and Wildlife Service and the Florida Game and Fresh Water Fish Commission, species actually observed in the site vicinity include the shortnose sturgeon (federal and state endangered), green sea turtle (federal and state endangered), gopher tortoise (state, species of special concern) (detected indirectly by its burrows), snowy egret (state, species of special concern), tricolored heron (state, species of special concern), wood stork (federal and state endangered), brown pelican (state, species of special concern), and manatee (federal and state endangered) (Foster Wheeler 1998a).

West Indian manatees have been the subject of increasing scrutiny since the passage of the U.S. Marine Mammal Protection Act of 1972, as amended, and the Endangered Species Act of 1973. Manatees reside year-round in waters of southern Florida and in northern waters of the state during the summer. Manatees occupy a variety of marine, estuarine, and freshwater habitats and are found in both turbid and clear water in depths of at least $3 \mathrm{ft}$. In coastal areas, manatees tend to travel in water up to $20 \mathrm{ft}$ deep and typically avoid swift currents. Being herbivorous, manatees feed primarily on freshwater plants, submerged seagrasses, and plants along shorelines. Manatees are regularly observed in the site vicinity during warmer months and have occasionally been observed during the winter. The manatee population in the Jacksonville area consists of one group that remains in the area throughout the winter and another group that migrates south with the onset of cooler weather. The survival of the group that remains during the winter appears to be dependent on artificial thermal discharges in the Jacksonville area (Brody 1993). Based on aerial surveys from 1994 to 1996, manatees have been sighted on 11 occasions during the spring and summer in the St. Johns River 
within 2 miles of the Northside Generating Station intake and discharge area (Table 3.6.1); all but one of these sightings were upstream of the intake and discharge area. In addition, one unofficial sighting of manatees in San Carlos Creek during the summer of 1997 has been reported. Of the 11 official aerial sightings, manatees were traveling through the area on 8 occasions, were observed feeding on 2 occasions, and were resting on 1 occasion. Two of these observations included not only adults but also their calves.

Table 3.6.1. Sightings of manatees in the St. Johns River within 2 miles of the Northside Generating Station intake and discharge area

\begin{tabular}{lccl}
\hline \multicolumn{1}{c}{ Date } & Adults & Calves & Observed activity \\
\hline April 26, 1994 & 1 & 0 & Traveling \\
May 12, 1994 & 1 & 0 & Traveling \\
May 14, 1994 & 1 & 0 & Resting \\
May 26, 1994 & 1 & 0 & Traveling \\
June 11, 1994 & 1 & 1 & Traveling \\
May 16, 1995 & 1 & 0 & Feeding \\
May 30, 1995 & 2 & 0 & Traveling \\
August 8, 1995 & 1 & 0 & Traveling \\
June 21, 1996 & 1 & 0 & Feeding \\
July 29, 1996 & 1 & 0 & Traveling \\
August 19, 1996 & 1 & 1 & Traveling \\
\hline
\end{tabular}

Gopher tortoises reside on the Northside Generating Station site, and numerous burrows have recently been observed in the uplands area north of Ostner Road and east of the dredge spoil site around the combustion turbine tank farm. Preferred gopher tortoise habitats are dry, well-drained soils such as may occur within the xeric (dry) pine flatwoods areas or on sandy berms around dredge spoil and other sandy sloping structures. Burrows of gopher tortoises can harbor other protected species including eastern indigo snakes and gopher frogs, even though neither species has been observed on the site or in the site vicinity. Wood storks feed in the salt marshes next to the site, and snowy egrets and tricolored herons have been observed feeding along the shorelines of adjacent creeks and the St. Johns River. Brown pelicans frequent the site vicinity on a regular basis and also feed in the shallow estuarine systems adjacent to the site.

Although suitable habitat exists in the site vicinity for 26 protected plant species, only the hooded pitcher-plant (state threatened) is included in the Florida Natural Areas Inventory (Foster 
Wheeler 1998a). The preferred habitat of this species is acidic soil associated with pine savannas and bogs; this habitat is found in peaty-sandy ditches in the site vicinity.

\subsubsection{Biodiversity}

The biodiversity of an ecosystem or community is defined by the variety or richness of the natural biotic environment in terms of the number of habitat types and/or species. The biodiversity in the site vicinity can be characterized as relatively high because of the nature and variety of community types present and the presence and influence of several marine vertebrate and invertebrate species from the Atlantic Ocean via the St. Johns River. This variety of community and habitat types dictates that a large number and variety of organisms will also occur as a result of their adaptation to and their close association with each of these habitat types. Major community types that occur in the site vicinity are (1) the upland terrestrial systems including the freshwater wetlands and creeks, (2) the salt marsh/tidal creek systems which are major transitional zone systems between terrestrial and aquatic communities, and (3) the St. Johns River estuary complex. Each of these major ecosystems is relatively distinct in terms of its hydrodynamic and physiochemical character and, therefore, many of the organisms associated with these systems are unique in terms of their ecological adaptation and tolerance to existing environmental conditions. These three major ecosystem types in the site vicinity are linked hydrodynamically and ecologically, functioning as an integrated ecological ecosystem. For example, the upland freshwater wetlands provide freshwater (and therefore help to regulate the salinity regimes) and some nutrient and organic food (detrital) input into the salt marsh/tidal creek complex. The salt marsh system, in turn provides food, shelter, and breeding areas for several ecologically and commercially important fish and invertebrate species which migrate into the salt marsh and tidal creeks from the St. Johns River. Contributing to this rich biodiversity in the area are also the transient or occasional mammal and bird species that utilize these systems for feeding, breeding, or shelter.

\subsection{CULTURAL RESOURCES}

Seventy-five sites in Duval County are listed in the National Register of Historic Places; 72 of them are individual historic or archaeological sites and three are historic districts. Although the Northside Generating Station site had not been comprehensively surveyed for cultural resources at the time the CFB combustor project was proposed (F. Keel, Florida Division of Historical Resources, personal communication to S. Marshall, Foster Wheeler Environmental Corporation, January 21, 1998), four archaeological sites had previously been recorded as existing on the JEA property. They are identified as Du91 (San Carlos Creek A Site), Du101 (San Carlos West Site), DuI02 (San Carlos West Burial Mound Site), and DuI05 (Jacksonville Power Plant Site). The results of other studies indicate that the area in the vicinity of the proposed project is rich in archaeological resources. Nearby sites that have been identified include an extremely large (about $2,000 \times 660 \mathrm{ft}$ ) shell midden (a mound or pile of discarded materials typically consisting of food 
remains and various artifacts) on Pelotes Island, less than 3 miles east of Northside Generating Station; numerous sites around Browns Creek and Clapboard Creek, within 3 miles of Northside Generating Station; approximately 20 sites on the mainland north of Blount Island, less than 2 miles from Northside Generating Station; and over 30 prehistoric sites on Fort George Island, located about 9 miles east of Northside Generating Station (JPDD 1994).

Further corroboration of the potential for undiscovered archaeological resources at the proposed project site is provided by a study of the adjacent St. Johns River Power Park that was performed in 1980 prior to plant construction. A reconnaissance survey identified 11 archaeological sites and further investigation indicated that the sites are Orange Period (2000-1000 B.C.) and Savannah Period (700-1500 A.D.) middens (shell and nonshell) and that there were also two 19th century structures. According to the Florida State Historic Preservation Officer (SHPO), 8 of the 11 archaeological sites are eligible for the National Register of Historic Places as the St. Johns River Power Park Archaeological District because of their cultural significance. In late 1981, the Secretary of the Interior concurred that the St. Johns River Power Park Archaeological District is eligible for listing in the National Register (EPA 1981).

Because of the area's archaeological richness, JEA contracted Florida Archeological Services to perform a cultural resources assessment survey of the proposed site in the spring of 1999. That survey relocated the four archaeological sites mentioned above (Du91, Du101, Du102, and Du105) and found five previously-unrecorded archaeological deposits. The newly discovered sites are identified as Du13923 (Light Bulb Site), Du13924 (Hideaway Hammock Site), Du13925 (Headwaters Site), Du13926 (Pogo Site), and Du13927 (Broken Shovel Site). Taken as a whole, the nine sites represent a broad range of ages and past activities. According to the report documenting the survey (Florida Archeological Services 1999a), four of the sites (Du91, Du13924, Du13925, and Du13927) are culturally insignificant. However, four others (Du101, Du102, Du105, and Du13923) were judged to be potentially eligible for inclusion in the National Register of Historic Places. The final site (Du13926) was not thoroughly investigated because it lies outside the boundaries of the proposed project, leaving its significance unknown at this time.

Of the four sites known to have potential archaeological significance, three (Du101, Du102, and Du105) are situated in what JEA refers to as a conservation area and would not be disturbed by the proposed project. Because the fourth potentially significant site (Du13923) would likely be affected by the proposed project, it was subjected to a Phase II investigation to definitively determine its significance. That Phase II analysis concluded that Du13923 does not qualify for inclusion in the National Register of Historic Places.(Florida Archeological Services 1999b).

\subsection{SOCIOECONOMICS}

This discussion of existing socioeconomic conditions focuses on Duval County, in which Northside Generating Station is located (Figure 2.1.1). In addition to being the site of proposed construction and operations activities, this heavily populated county has more than enough housing 
and public services available to attract any workers that might move to the area as a result of the project. The city of Jacksonville and Duval County merged in the late 1960 s to form the consolidated city of Jacksonville, which encompasses nearly the entire land area of Duval County. The only portions of the county that are not part of the consolidated city are the three beach communities (Atlantic Beach, Jacksonville Beach, and Neptune Beach) located east of the Intracoastal Waterway and the small community of Baldwin in the far western portion of the county.

\subsubsection{Population}

Table 3.8.1 shows current population for Duval County and its five municipalities and how those numbers have changed over time. The consolidated city of Jacksonville, with nearly 712,000 residents, accounts for almost $95 \%$ of the county's total population. The other four municipalities house the remainder of the county's inhabitants, with Jacksonville Beach having the largest population of the four and Baldwin having by far the smallest. Between 1980 and 1990, Duval County experienced substantial growth, although it did not keep pace with Florida as a whole. Within the county, Atlantic Beach and Neptune Beach grew at a much greater rate than did the other municipalities and Duval County overall. Between 1990 and 1997, Duval County and Jacksonville continued to grow at roughly the same annual rate they had experienced throughout the $1980 \mathrm{~s}$, outstripping all the other municipalities in the county except for Jacksonville Beach and coming close to Florida's 1990-95 annual growth rate.

Table 3.8.1. Current population and change over time for Duval County, its municipalities, and Florida

\begin{tabular}{crcccc}
\hline \multicolumn{1}{c}{ Location } & \multicolumn{1}{c}{$\begin{array}{c}1980 \\
\text { population }\end{array}$} & $\begin{array}{c}1990 \\
\text { population }\end{array}$ & $\begin{array}{c}\text { Percent } \\
\text { change }\end{array}$ & $\begin{array}{c}1980-90 \\
\text { population }\end{array}{ }^{a}$ & $\begin{array}{c}\text { Percent change } \\
1990-95 / 97\end{array}$ \\
\hline Duval County & 571,003 & 672,971 & +17.9 & 754,048 & +12.0 \\
Atlantic Beach & 7,847 & 11,636 & +48.3 & 12,908 & +10.9 \\
Baldwin & 1,526 & 1,450 & -5.0 & 1,556 & +7.3 \\
Jacksonville & 540,898 & 635,230 & +17.4 & 711,933 & +12.1 \\
Jacksonville & 15,462 & 17,839 & +15.4 & 20,520 & +15.0 \\
Beach & & & & & +4.6 \\
Neptune Beach & 5,248 & 6,816 & +29.9 & 7,131 & +9.5 \\
\hline
\end{tabular}

${ }^{a}$ County and municipality populations are estimates by Jacksonville Planning and Development Department for April 1, 1997. State population is an estimate by the U.S. Bureau of the Census for 1995.

Sources: U.S. Bureau of the Census 1981; U.S. Bureau of the Census 1991; U.S. Bureau of the Census 1996; JPDD $1997 b$. 
According to projections made by Jacksonville's Planning and Development Department (JPDD 1996b), growth in Jacksonville and Duval County will continue for the remainder of this decade at roughly the same pace as it has since 1980 . At this rate, the consolidated city of Jacksonville will be home to nearly 735,000 residents in 2000 and Duval County's population will exceed 777,000 . The growth rate is expected to slow somewhat after that, but the city still predicts that the populations of Jacksonville and Duval County will be approximately 790,000 and 835,000, respectively, in 2010 . The ratio of city to overall county population is projected to remain essentially unchanged.

\subsubsection{Employment and Income}

In 1996, the average size of Duval County's resident labor force was 368,467 (Table 3.8.2), with nearly $94 \%$ of these people living in the consolidated city of Jacksonville. The unemployment rate in both Jacksonville and Duval County was 3.8\%, substantially below the statewide rate of $5.1 \%$.

Although Duval County residents did better than Floridians overall in terms of unemployment, their 1995 average per-capita income of $\$ 22,337$ was slightly less than the statewide average of $\$ 23,031$.

Table 3.8.2. Employment and income for residents of Jacksonville, Duval County, and Florida

\begin{tabular}{lccccc}
\hline Location & $\begin{array}{c}\text { Labor force, } \\
1996\end{array}$ & $\begin{array}{c}\text { Number } \\
\text { employed, } \\
1996\end{array}$ & $\begin{array}{c}\text { Number } \\
\text { unemployed, } \\
1996\end{array}$ & $\begin{array}{c}\text { Unemployment } \\
\text { rate, 1996 } \\
(\%)\end{array}$ & $\begin{array}{c}\text { Per-capita } \\
\text { income, } \\
1995 \\
(\$)\end{array}$ \\
\hline Jacksonville & 345,540 & 332,307 & 13,233 & 3.8 & N/A \\
Duval County & 368,467 & 354,629 & 13,838 & 3.8 & 22,337 \\
Florida & $6,938,000$ & $6,586,000$ & 352,000 & 5.1 & 23,031 \\
\hline
\end{tabular}

Source: University of Florida 1997.

Table 3.8.3 shows how employment within Duval County was distributed among key economic sectors in 1996. The services sector, which accounted for nearly $30 \%$ of all Duval County jobs, was by far the largest. Other important categories were retail trade ( $18.5 \%$ of all jobs) and the finance, insurance and real estate sector ( $11.8 \%$ of total employment). And when federal, state, and local government numbers are added together, they account for $12.8 \%$ of all jobs within the county. Because of the large number of people employed in Duval County, even a relatively small sector like construction (5.6\% of all workers) provides a large number of jobs $(22,179)$.

\subsubsection{Housing}

As of 1990 , there were over 257,000 occupied housing units in Duval County and more than 27,000 vacant units (Table 3.8.4). Almost $94 \%$ of these units were located within the Jacksonville 
Table 3.8.3. Employment by economic sector in Duval County, 1996

\begin{tabular}{lcc}
\hline \multicolumn{1}{c}{ Economic sector } & $\begin{array}{c}\text { Number } \\
\text { of workers }\end{array}$ & $\begin{array}{c}\text { Percent of } \\
\text { all workers }\end{array}$ \\
\hline Agriculture, forestry, and fishing & 2,985 & 0.8 \\
Mining & N/A & N/A \\
Construction & 22,179 & 5.6 \\
Manufacturing & 29,589 & 7.5 \\
Transportation, communications, and public utilities & 27,841 & 7.1 \\
Wholesale trade & 24,417 & 6.2 \\
Retail trade & 72,906 & 18.5 \\
Finance, insurance and real estate & 46,654 & 11.8 \\
Services & 116,912 & 29.6 \\
Federal government & 16,855 & 4.3 \\
State government & 7,189 & 1.8 \\
Local government & 26,384 & 6.7 \\
Other & 560 & 0.1 \\
Total & 394,675 & 100.0 \\
\hline
\end{tabular}

${ }^{a}$ These numbers describe all those working in Duval County, regardless of place of residence. Source: University of Florida 1997.

Table 3.8.4. Housing data for Jacksonville and Duval County ${ }^{a}$

\begin{tabular}{lcc}
\hline & Jacksonville & Duval County \\
\hline Number of occupied housing units & 241,384 & 257,245 \\
Percent of units occupied by owner & 62.1 & 62.0 \\
Percent of units occupied by renter & 37.9 & 38.0 \\
Number of vacant housing units & 25,764 & 27,428 \\
Number of vacant units for sale & 4,356 & 4,665 \\
Number of vacant units for rent & 13,377 & 14,049 \\
Median value owner-occupied unit, $\$$ & 62,900 & 64,000 \\
Median rent, $\$$ & 353 & 355 \\
\hline
\end{tabular}

${ }^{a}$ All data are for 1990 .

Source: U.S. Bureau of the Census 1991. 
city limits. Sixty-two percent of Duval County's occupied units were owner-occupied and the remaining $38 \%$ were occupied by renters. Of the vacant units countywide, 4,665 were for sale and 14,049 were for rent. The median value of an owner-occupied unit within Duval County was $\$ 64,000$ and the median monthly rent was $\$ 355$. Although precise updates are not available, it is likely that these cost figures have increased substantially since 1990. Data released by the Jacksonville Planning and Development Department (JPDD 1997a) indicate that the average construction value of all single family homes built in the city of Jacksonville during the first half of 1997 was slightly more than $\$ 110,000$; this number reflects material and labor costs but does not include land cost or profits.

Between April 1990 and April 1997, there was a net increase of 35,445 housing units in Duval County, with $94 \%$ of these located within the city of Jacksonville and the remainder in the county's other four municipalities (JPDD 1997b). Of the total units added countywide, just over $72 \%$ were single family dwellings, slightly more than $23 \%$ were multi-family units, and less than $5 \%$ were mobile homes. In the beach communities, there was a higher percentage of multi-family units and a much lower percentage of mobile homes than for the county as a whole. Although it is still too early to tell if it is a trend or an anomaly, the number of building permits issued for multi-family units countywide was substantially higher in 1996 and the first half of 1997 than it had been earlier in the decade (JPDD 1997a,c).

\subsubsection{Local Government Revenues}

Duval County received over $\$ 2.3$ billion in total revenues in fiscal year 1995, with the largest share (42.3\%) coming from charges for services (Table 3.8.5). Other important revenue sources were taxes and impact fees (15.6\%), state and other governments (7.0\%), and the broad category of "other sources and transfers" (33.2\%).

Table 3.8.5. Revenue by source for Duval County, fiscal year 1995

\begin{tabular}{lcc}
\hline \multicolumn{1}{c}{ Source } & $\begin{array}{c}\text { Revenue } \\
(\times \$ 1,000)\end{array}$ & $\begin{array}{c}\text { Percent of } \\
\text { total revenue }\end{array}$ \\
\hline Taxes and impact fees & 361,588 & 15.6 \\
Federal grants & 35,148 & 1.5 \\
State and other governments & 162,838 & 7.0 \\
Charges for services & 979,592 & 42.3 \\
Fines and forfeitures & 9,135 & 0.4 \\
Other sources and transfers & 769,023 & 33.2 \\
\multicolumn{1}{c}{ Total } & $2,317,324$ & 100.0 \\
\hline
\end{tabular}

Source: University of Florida 1997. 


\section{JEA EIS}

The tax revenues received by Duval County come from a variety of sources. Real property and tangible personal property in Duval County are taxed at the rate of approximately $\$ 2.22$ per $\$ 100$ of assessed value (FDR 1997). Property owned by government entities (such as JEA) is not subject to taxation, but JEA does make in-lieu-of-tax payments to the local government. Also, the interest of a private company in a public-private partnership (like the proposed project at Northside Generating Station) would be subject to taxation. In addition to the ad valorem property tax, there are several different sales taxes that benefit local communities. The state of Florida assesses a sales tax of $6.0 \%$, a portion of which is shared with the local jurisdictions in which sales are made. There also are a number of local option sales taxes in Duval County: a $0.5 \%$ transit system surtax on all sales up to $\$ 5,000$; a $4 \%$ Tourist Development Tax on short-term living accommodations; and a $2 \%$ Convention Development Tax on short-term living accommodations (FLCIR 1997). Although there is no personal income tax in Florida, there is a corporate income tax of $5.5 \%$ assessed by the state.

\subsubsection{Public Services}

\subsubsection{Education}

During the 1995-96 school year, Duval County's 158 public schools had a total enrollment of 120,898 students in kindergarten through grade 12 . The ratio of students to full-time-equivalent teachers was 24.89 to 1 in the elementary grades and 22.54 to 1 at the secondary level. The breakdown of public school teachers as of fall 1996 was as follows: 2,988 elementary school teachers; 2,204 secondary school teachers; 1,112 teachers for exceptional students; and 97 teachers in other categories (University of Florida 1997).

\subsubsection{Utilities}

The city of Jacksonville owns and operates two extensive potable water supply and distribution systems, known as the North Grid and the South Grid, as well as several small satellite systems. Since mid-1997, these city-owned facilities-as well as the city's wastewater treatment facilities-have been controlled and operated by JEA. There currently are about 8 functioning water treatment plants in the North Grid and 12 in the South Grid (F. Brown, JEA, personal communication to $M$. Schweitzer, ORNL, February 2, 1998). Table 3.8.6 shows that existing capacity exceeds average use in both the North and South Grids, leaving a substantial surplus in each. Nonetheless, the city plans to continue making improvements to its systems, as it has done in recent years, in order to meet future demand and improve water quality. In addition to the city facilities, there are some small investor-owned utilities operating in the city. Some rural portions of Jacksonville do not yet receive potable water from a centralized system, and residents of these areas get their water from individual wells. Outside of the Jacksonville city limits, the municipalities of Atlantic Beach, Baldwin, Jacksonville Beach, and Neptune Beach operate their own separate centralized water systems (JPDD 1993a). 
Table 3.8.6. Capacity and use of Jacksonville's potable water and sewage treatment systems [Units are million gallons per day (Mgd).]

\begin{tabular}{|c|c|c|c|}
\hline & Capacity & Average use & Surplus \\
\hline \multicolumn{4}{|c|}{ Potable water system (as of 12/31/97) } \\
\hline South grid & 86.53 & 36.69 & 49.84 \\
\hline North grid & 117.77 & 41.19 & 76.58 \\
\hline \multicolumn{4}{|c|}{ Sewage treatment system (as of 12/31/96) } \\
\hline District 1 & 52.50 & 31.82 & 20.68 \\
\hline District 2 & 10.00 & 3.79 & 6.21 \\
\hline District 3 & 10.00 & 5.83 & 4.17 \\
\hline District 4 & $11.00^{a}$ & 9.93 & 1.07 \\
\hline District 5 & $5.00^{b}$ & 4.59 & 0.41 \\
\hline
\end{tabular}

${ }^{a} A$ construction permit has been issued to expand the District 4 plant to a capacity of $15.00 \mathrm{Mgd}$.

${ }^{b} \mathrm{~A}$ construction permit has been issued to expand the District 5 plant to a capacity of at least $7.50 \mathrm{Mgd}$.

Source: F. Brown, JEA, personal communication to

M. Schweitzer, ORNL, February 2, 1998.

The city of Jacksonville operates five regional wastewater collection and treatment districts, covering all of the urbanized areas within the city limits. In addition, there are a number of investorowned utility companies operating in Jacksonville as well as several hundred private package treatment plants serving individual businesses (JPDD 1993b). Existing capacity and average use for each sewage treatment district are shown in Table 3.8.6. District 1 clearly has substantial surplus capacity, while average demand in Districts 4 and 5 is very close to existing treatment capacity. Construction permits have been issued for plant expansions in these last two districts. The city also plans to upgrade its District 3 plant, and it has the capacity to transfer up to $2 \mathrm{Mgd}$ from District 4 to the District 1 treatment plant ( F. Brown, JEA, personal communication to M. Schweitzer, ORNL, February 2, 1998). Jacksonville households and businesses that do not yet have centralized sewer service utilize individual septic systems. Outside the city, all four of Duval County's smaller municipalities have their own centralized sewage systems.

\subsubsection{Police and Fire Protection}

The Jacksonville Sheriff's Office, which has approximately 2,400 employees and an overall budget of over $\$ 160$ million, has jurisdiction over the consolidated city of Jacksonville. The Sheriff's Office has three directorates: Operations (which includes the Detective Division, Community Affairs 
Division, and two Patrol Divisions); Services; and Corrections (Jacksonville Sheriff's Office 1998). Each of the four smaller municipalities within Duval County has its own police department, which provides basic patrol services, but the Jacksonville Sheriff's Office provides these communities with specialized assistance such as detective services and crime lab operations ( $\mathrm{H}$. Reagan, Jacksonville Sheriff's Office, personal communication to M. Schweitzer, ORNL, January 30, 1998).

The Jacksonville Fire and Rescue Department has 49 fire stations, just over 1,000 employees, and a budget of nearly $\$ 70$ million. The department's resources include 45 engine companies, 7 ladder companies, 12 tanker trucks, and 23 rescue units (JFRD 1998). Each of Duval County's four smaller municipalities has its own fire department, but the available resources vary considerable from community to community. The city of Jacksonville has mutual aid agreements with all the other fire departments in the county and provides specialized services and equipment to some of those smaller communities ( $T$. Holmes, Jacksonville Fire and Rescue Department, personal communication to M. Schweitzer, ORNL, January 30, 1998).

\subsubsection{Environmental Justice}

Percentages of minority and low-income populations living in Duval County and Florida are provided in Table 3.8.7. Blacks are by far the largest minority group in Duval County, and the percentage of Blacks in the county is almost twice as large as in the state as a whole. There also is a higher percentage of Asians in Duval County than in Florida overall. However, 1990 Census data show that the percentages of Blacks and Asians living in the census tracts immediately surrounding the proposed site are much lower than in the state as a whole (between 0 and $1.9 \%$ for Blacks, and between 0 and $0.6 \%$ for Asians) (U.S. Bureau of the Census 1991). The percentage of people living

\begin{tabular}{|c|c|c|}
\hline Categories & Duval County & Florida \\
\hline Black & 27.5 & 15.1 \\
\hline Native American & 0.3 & 0.4 \\
\hline Asian & 2.8 & 1.7 \\
\hline Hispanic (all races) & 3.4 & 14.0 \\
\hline Poverty status & 15.2 & 15.9 \\
\hline
\end{tabular}


below the poverty level is slightly less in Duval County (15.2\%) than in all of Florida (15.9\%); furthermore, in the census tracts immediately surrounding the proposed site, the percentage of the population living in poverty is substantially less (between 5.9 and $11.7 \%$ ) than for either the county or the state. The percentage of Hispanics in Duval County is only about one-fourth of the statewide average.

\subsection{TRANSPORTATION AND NOISE}

\subsubsection{Transportation}

Figure 2.1.2 shows the major roads, rail lines, and water bodies in the vicinity of Northside Generating Station. These transportation features are discussed in the following subsections.

\subsubsection{Roads}

In Table 3.9.1, current peak hourly traffic, available capacity, and existing level of service (LOS) are listed for road segments that would probably be used by workers and truck drivers accessing Northside Generating Station during construction and operation of the proposed project. The main entrance to Northside Generating Station is on Heckscher Drive just east of State Route 9A. The back entrance, which would be used by all workers during the construction period, is on Ostner Road, a narrow two-lane road that intersects New Berlin Road about 1 mile north of Heckscher Drive (Figure 2.1.7). The back entrance to the St. Johns River Power Park is also located on Ostner Road, just north of the rear entrance to Northside Generating Station, while the main entrance to the Power Park is on New Berlin Road, a short distance north of its back entrance.

As Table 3.9.1 shows, existing LOS is Level C or better for all of the key segments except one, and substantial capacity is still available for those links. As defined in the Highway Capacity Manual (TRB 1994), an LOS of C is characterized by traffic flow that is at or near the posted speed but with maneuverability noticeably restricted. At LOS B, there is free flow with only slightly restricted maneuverability, while there is uninterrupted maneuverability at LOS A. The segment of Heckscher Drive slightly west of Northside Generating Station (from Drummond Point to State Route 9A) is currently operating at LOS E during its peak hour. At LOS E, flow is at or near capacity, maneuverability is severely restricted, and any disruption leads to flow breakdown and severe congestion, which is LOS F. This segment has available capacity for 89 vehicles per hour during its peak period.

Currently, about 200 passenger vehicles and 25 heavy trucks access Northside Generating Station daily. At the main entrance to the plant, Heckscher Drive is a four-lane divided highway. For vehicles accessing the plant from the west, there is a left turn lane on eastbound Heckscher directly across from the plant entrance, but there is no traffic signal. For vehicles accessing the plant from the east, there is no right turn lane into the plant from westbound Heckscher, but there is a paved shoulder that is wide enough to accommodate automobiles. When exiting Northside Generating Station onto 


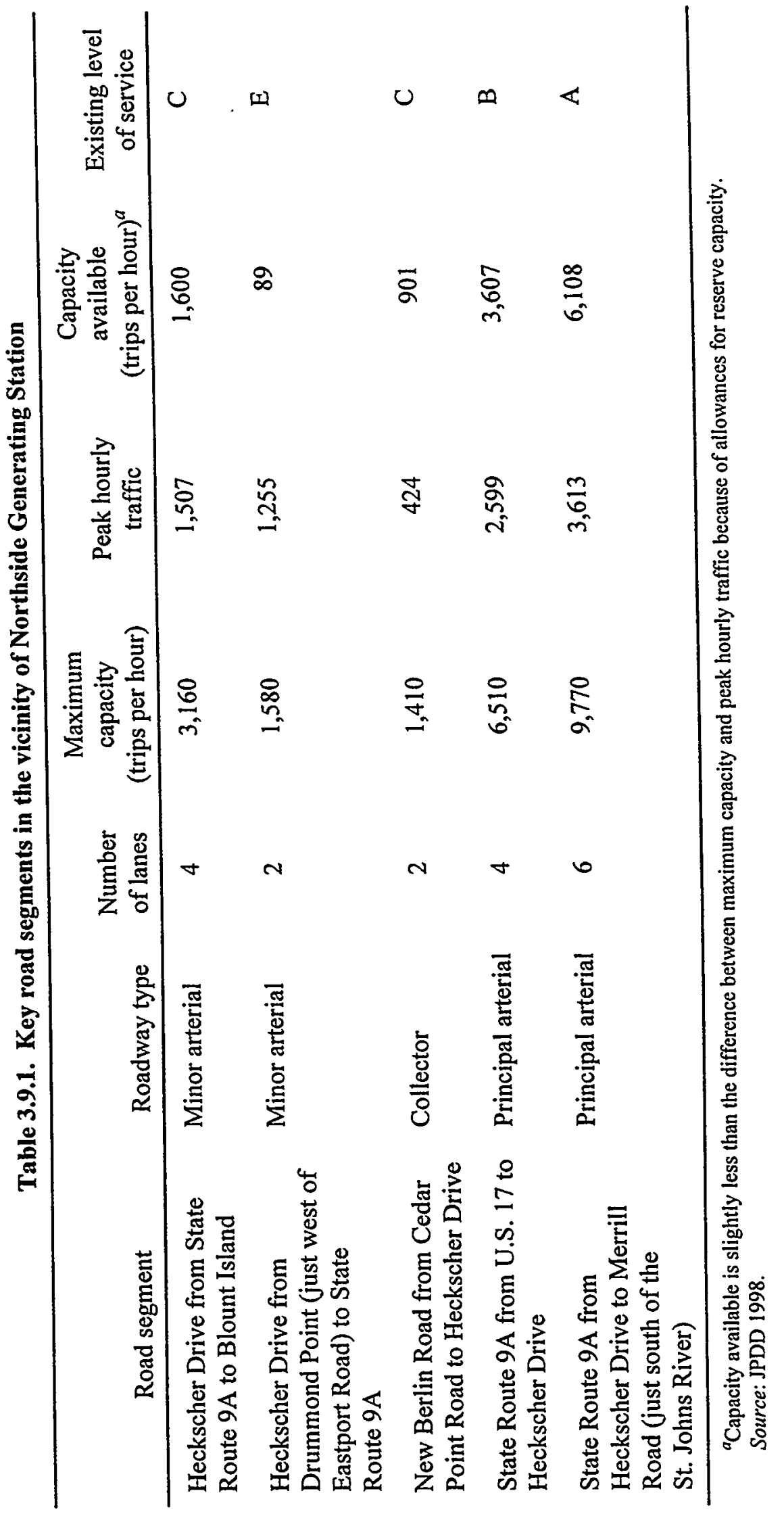


westbound Heckscher, there is no official acceleration lane, but the aforementioned shoulder is wide enough to serve as a defacto acceleration lane for automobiles. For vehicles exiting the plant onto eastbound Heckscher, there is no acceleration lane, so vehicles must wait for traffic to clear before merging.

Approximately 300 passenger vehicles access the Power Park daily, via its main entrance. About 65 heavy trucks (e.g., dump trucks bringing in limestone and container trucks hauling away fly ash) access the Power Park each day via its back entrance, just south of the main entrance.

At several places in the vicinity of Northside Generating Station, road traffic experiences periodic delays as a result of on-grade railroad crossings. Delays of 5 to $10 \mathrm{~min}$ are not uncommon, and these can last up to $30 \mathrm{~min}$ if trains are uncoupling and recoupling. One such on-grade crossing is on New Berlin Road, just north of the back entrances to Northside Generating Station and the St. Johns River Power Park and just south of the Power Park's main entrance. Other crossings in the vicinity of the plant include Alta Road just north of South Route 9A, Eastport Road just south of Faye Road and also just east of U.S. 17, Baisden Road just west of Eastport Road, Busch Drive just west of U.S. 17, and U.S. 17 just north of Eastport and also just south of the Trout River.

\subsubsection{Rail}

The St. Johns River Power Park currently receives an average of three to four train loads of coal each week, for a total of six to eight one-way trips. The coal is transported in 90 car unit-trains under contract with the CSX rail line. The main CSX line travels south from Georgia, running parallel to U.S. 1/U.S. 23 in the Jacksonville area. Trains bound for the Power Park continue to run parallel to U.S. 1 after it splits with U.S. 23, heading east and then veering north after crossing U.S. 17. The coal trains continue northward, running next to U.S. 17, through the communities of Panama Park and North Shore (Figure 2.1.2). Approximately 4 miles north of the Trout River, a spur line diverges from the north-south CSX line and takes the coal trains on the last leg of their journey to the Power Park. This spur line, which passes along the northern edge of the residential community of San Mateo, roughly parallels Eastport Road and then Faye Road. The spur line enters the St. Johns River Power Park just east of New Berlin Road and continues south beyond the Power Park to Blount Island, crossing Heckscher Drive and the back channel of the St. Johns River (Figure 2.1.2).

At the Power Park, there is a rail loop encircling much of the property. This loop can accommodate coal trains and allow them to uncouple and recouple without blocking New Berlin Road. In the past, however, it was not uncommon for CSX to uncouple and recouple trains outside the Power Park's boundaries, despite the presence of the onsite tracks, resulting in substantially longer delays of road traffic than would otherwise occur. CSX recently discontinued this practice, and the car change-outs are now conducted on the Power Park's property 24 hours per day. However, any resumption of offsite train uncoupling and recoupling would cause a resumption of the traffic delays. 
In addition to the rail loop that encircles the St. Johns River Power Park, there also is a short set of tracks that branches off from the spur line slightly north of Northside Generating Station and runs parallel to the eastern boundary of the Northside property. This short line is occasionally used to transport large equipment that cannot be moved by truck to Northside Generating Station. It has never been used for fuel deliveries and has no fuel-unloading facilities.

Total train traffic on the CSX line paralleling U.S. 17 currently averages about 115 one-way trips per week. On the spur line that runs from U.S. 17 to the St. Johns River Power Park and beyond to Blount Island, train traffic averages approximately 78 one-way trips per week. About seven of these trips are made by coal trains going to and from the Power Park and about the same number of trips are made by trains traveling to and from the Cedar Bay Plant, near Eastport Road. The remaining trains (approximately 64 trips) transport automobiles and other goods from Blount Island, where they arrive via water (Robinson Engineering Group 1998a).

\subsubsection{Marine}

In addition to the coal it receives by rail, the St. Johns River Power Park receives coal and petroleum coke by barge and ship. The waterborne solid fuel comes to an unloading facility on the south side of Blount Island and is transported from there to the Power Park via elevated conveyor (Figure 2.1.2). Although the existing facility is adequate to handle current shipment volumes, it would require expansion if the amount of solid fuel brought in by water were increased to serve the proposed project. Northside Generating Station currently receives waterborne shipments of fuel oil that come to the fuel terminal on the north shore of the St. Johns River back channel. From there, the fuel oil is piped to the fuel storage tank farm located southeast of the turbine building. The existing unloading facility is not adequate to accommodate solid fuel shipments in addition to the fuel oil it handles, and there currently is no conveyor to transport solid fuel from the back channel to the generating station.

\subsubsection{Noise}

A noise survey was performed to assess the existing noise environment in the vicinity of Northside Generating Station (JEA 1998a). The survey was conducted from noon on February 12 until noon on February 13, 1998, at four locations between 0.5 and 1 mile from Northside Generating Station (locations 1-4 in Figure 3.9.1). These locations are considered representative of noisesensitive receptors in different directions from the facility; locations 2 and 3 are adjacent to residences. During the survey, both Northside units (Units 1 and 3) and one of the two St. Johns River Power Park units were operating.

Data obtained from measurements during the 24-hour period included equivalent noise levels (Leq, the energy-averaged sound level integrated over each minute) and hourly values of the L10, $\mathrm{L} 50$, and $\mathrm{L} 90$ (the number following the " $\mathrm{L}$ " is the percent of time during the hour that a particular level is exceeded). Because of the averaging procedure, these data could include much louder, 


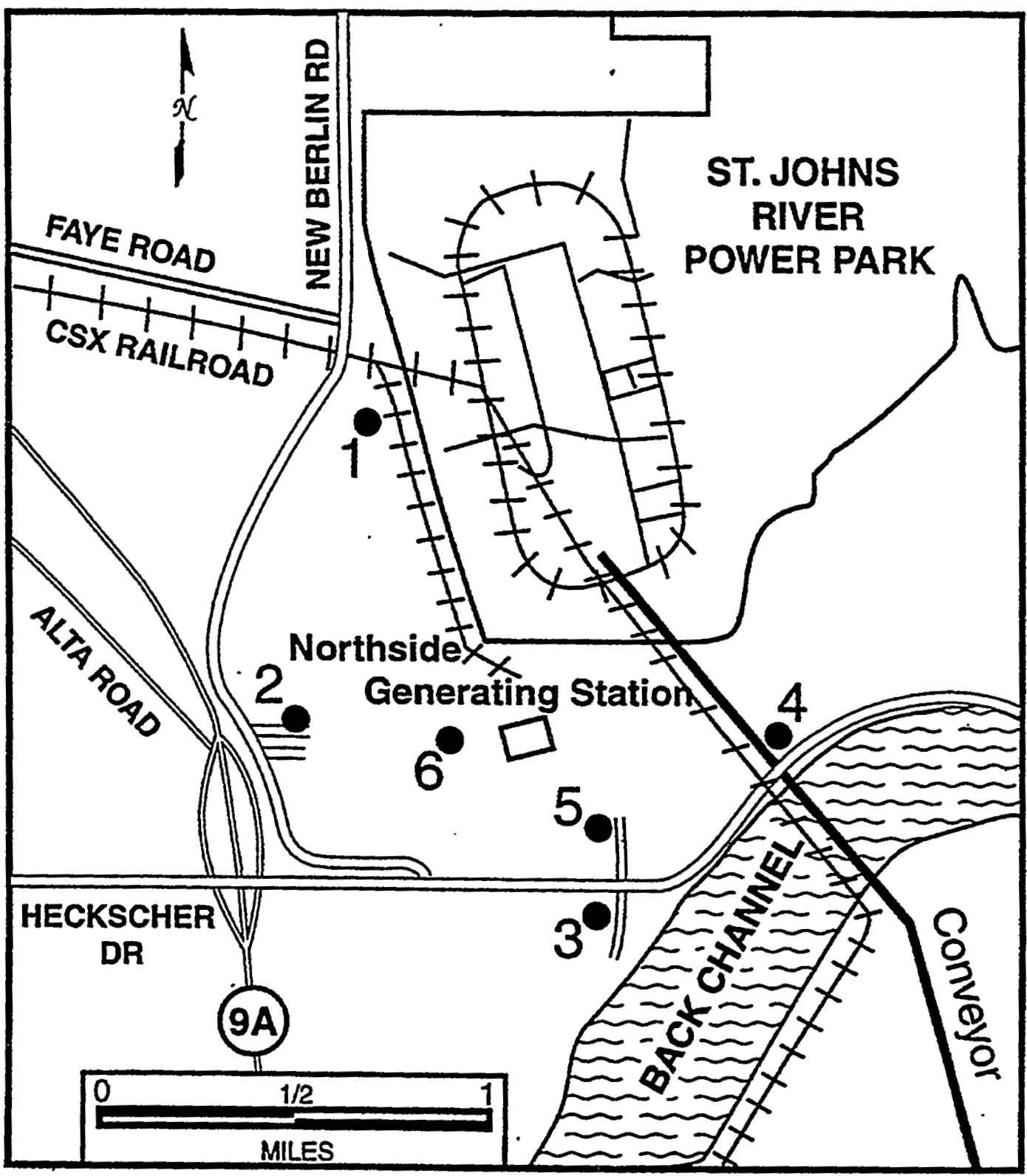

Figure 3.9.1. Location of ambient noise monitoring sites around Northside Generating Station. Locations 1, 2, and 4 were used in the February 1998 survey, locations 5 and 6 were used in the May 1998 survey, and location 3 was used in both. 


\section{JEA EIS}

very brief noises such as train whistles. In addition, three sets of ten different octave band levels were measured: one in the morning, one in the afternoon, and one between 1 a.m. and 3 a.m. when ambient levels were anticipated to be the lowest. The octave band measurements were short samples taken during the absence of intrusive sounds, such as noise generated from traffic. Therefore, they are representative of the background spectrum to which Northside Generating Station contributes. Because large power plant fans produce a hum at about $500 \mathrm{~Hz}$, measurement at this frequency when Northside Generating Station is operating at or near peak load and when other noise sources are minimized provides a good measure of the power plant's maximum contribution to the noise spectrum.

Because vehicular traffic was found to be the most substantial source of noise in the area, locations farther from the traffic were less noisy overall. Location 1 was the quietest of the four locations. Noise from Northside Generating Station was not distinguishable from that produced by the nearby St. Johns River Power Park. The octave band data appear typical of background spectra, with higher levels in the lower frequencies and lower levels in the higher frequencies. The only influence of the power plants that can be identified is in the $500-\mathrm{Hz}$ band at locations 1 and 3 . At these locations, the level in the 500-Hz band is slightly higher than those of the two adjacent bands at 250 and $1,000 \mathrm{~Hz}$, approximately 1 to $2 \mathrm{~dB}(\mathrm{~A})$ above that which would be expected. Typical $500-\mathrm{Hz}$ Leq levels were approximately $41-46 \mathrm{~dB}(\mathrm{~A})$ during the nighttime, while daytime levels were in the $55-60 \mathrm{~dB}(\mathrm{~A})$ range.

A supplemental noise survey was performed from noon on May 12 until noon on May 13, 1998, to document levels of existing noise at locations nearer Northside Generating Station than locations in the original survey and to provide the basis for the noise level to be used in the design of the proposed project (JEA 1998b). During this survey, both Northside units and both Power Park unitswere operating. Measurements were taken at three locations (locations 3, 5, and 6 in Figure 3.9.1), two of which (locations 5 and 6) were closer than locations in the first survey; location 3 used in the original survey was also used in the supplemental survey to provide a link between the two surveys (i.e., differences in levels measured at location 3 during the two surveys might explain unexpected results at the two new locations). Location 5 was at the south boundary of the Northside property near several residences that are the closest to the plant, approximately 0.3 mile $(1,600 \mathrm{ft})$ southeast of the existing turbine building. Atmospheric conditions during this survey were more variable than during the first survey, but the noise measurement procedures were the same.

Unlike the results of the first survey, analysis of the octave band spectra did not show the influence of the power plant. However, during calm winds and when traffic was minimally present, the contribution of the plant to background Leq levels was determined to be $51 \mathrm{~dB}(\mathrm{~A})$; daytime Leq levels were in the 55-60 $\mathrm{dB}(\mathrm{A})$ range. As an illustration, Figure 3.9.2 contains Leq levels (the average of each minute) for a 24-hour period at location 5 (at the south boundary of the Northside property near several residences that are the closest to the plant). The noisiest times are associated 


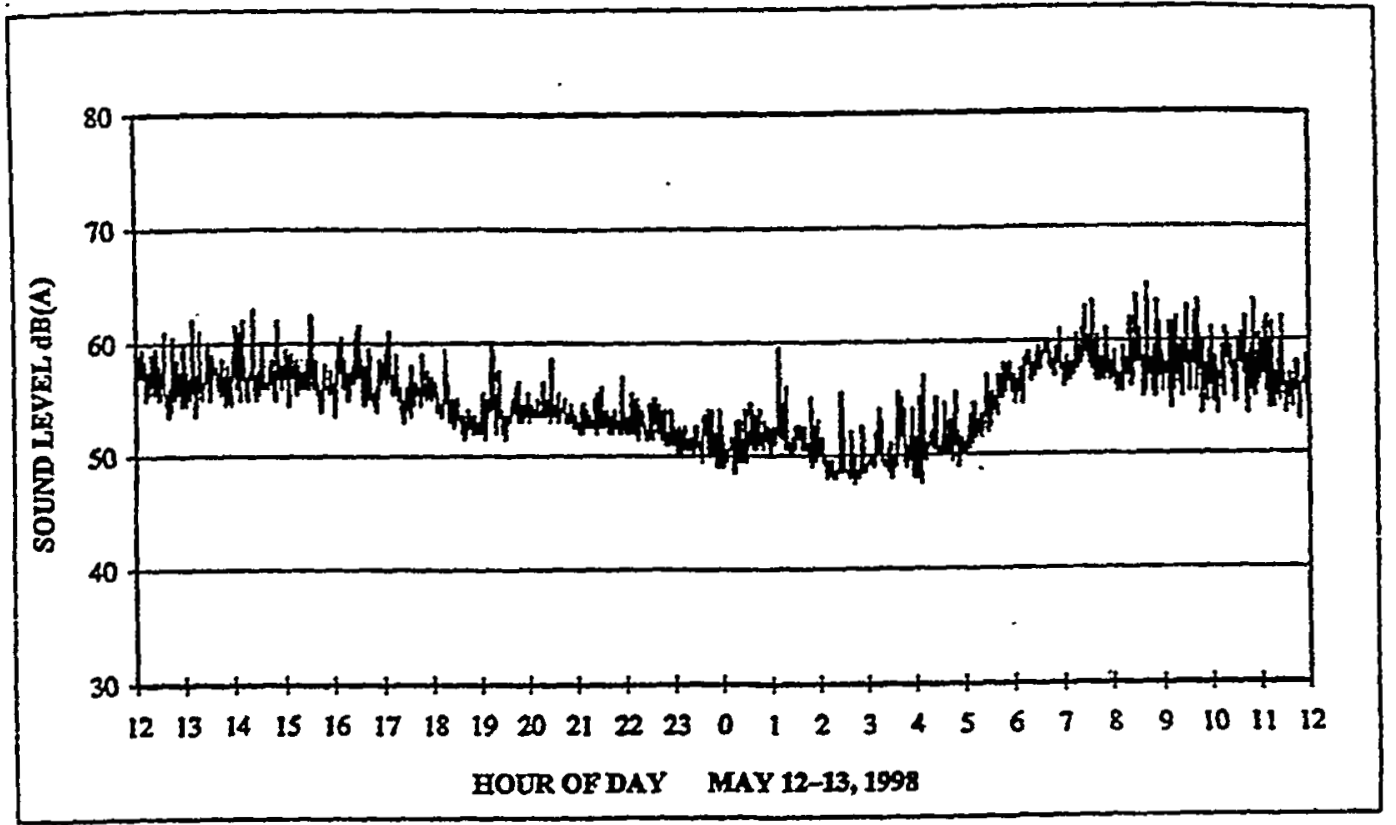

Figure 3.9.2. Equivalent noise levels (the average of each minute) for location 5 , at the south boundary of the Northside property near several residences that are the closest to the plant. Source: JEA $1998 \mathrm{~b}$.

with vehicular traffic along Heckscher Drive. During the late evening and early morning, when traffic is light, the Leq level is reduced to approximately $50 \mathrm{~dB}(\mathrm{~A})$. The pattern in Figure 3.9.2 is typical of all locations; variations at other-locations are primarily a function of their proximity to highway traffic. The results of the two noise surveys indicate that Northside Generating Station is operating within the Noise Pollution Control Rules of $60 \mathrm{~dB}(\mathrm{~A})$ for nighttime Leq levels (Jacksonville Environmental Protection Board 1995).

During the scoping process, local residents and community organizations expressed concern related to the existing noise associated with ongoing rail traffic through the local area, specifically the communities of Panama Park, North Shore, and San Mateo (Figure 3.9.3). The frequency of rail traffic through the area is described in Section 3.9.1.2. A local resident who spoke at the public at $108 \mathrm{~dB}(\mathrm{~A})$ at his property line and the volume of rattling train cars at up to $85 \mathrm{~dB}(\mathrm{~A})$ at his property line. scoping meeting held on December 3,1997, stated that he had measured the volume of train whistles at $108 \mathrm{~dB}(\mathrm{~A})$ at his property line and the volume of rattling train cars at up to $85 \mathrm{~dB}(\mathrm{~A})$ at his property line. 


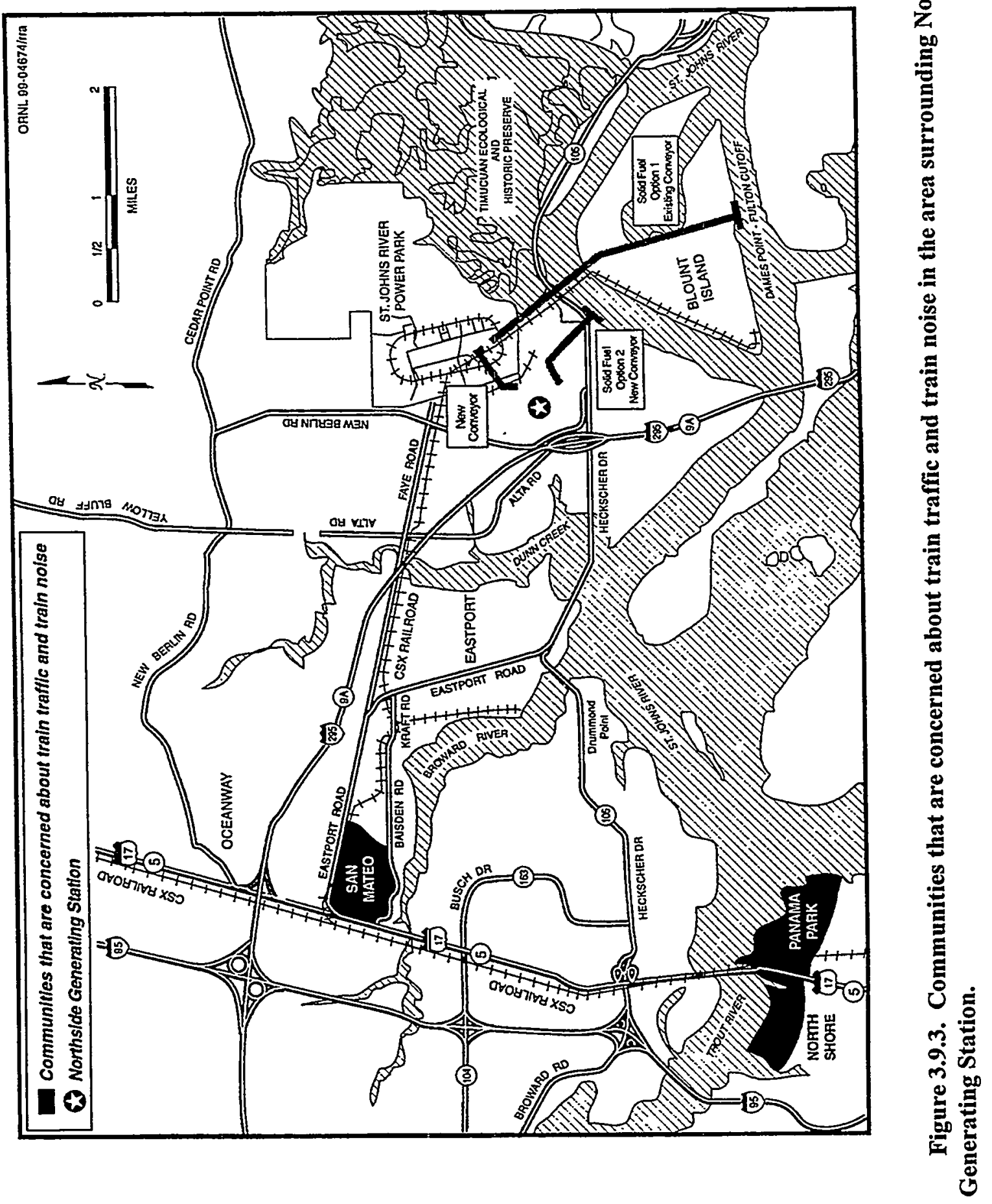




\section{ENVIRONMENTAL CONSEQUENCES}

This section analyzes the potential impacts to human and environmental resources resulting from construction and demonstration of the proposed CFB combustor project and for three reasonably foreseeable scenarios of no action. Potentially affected physical, biological, social, and economic resources are included. The analyses for no action focus on a comparison of impacts with those anticipated for the proposed project.

\subsection{ENVIRONMENTAL IMPACTS OF THE PROPOSED PROJECT}

\subsubsection{Land Use and Aesthetics}

\subsubsection{Land Use}

The proposed project would slightly change existing land use, which would not result in major adverse impacts. A total of approximately 75 acres of land would be required on the Northside Generating Station and adjacent St. Johns River Power Park property, including 5 acres of land for the proposed power block (Figure 4.1.1). This parcel of land for the power block is partially grassed and has some temporary buildings and sheds that are used to store equipment. Part of this land also has been paved and is used as a covered parking lot for employees. Much of the land already has been disturbed to some extent because of the presence of vehicular traffic and its proximity to the existing units. The 40-acre ash storage area in the northwest corner of the property would require harvesting of approximately 28 acres of pine plantation and loss of 10 acres of upland hardwood/pine habitat (Section 4.1.6.1) and 1.8 acres of isolated hardwood wetland habitat (Section 4.1.5.3). Much of the 10 acres of land for the covered solid fuel storage pile under Option 2 is currently being used as a dredge spoil area (Figure 3.4.2). Under either option, no more than about 10 acres of Power Park land would be required.

The proposed project would be constructed to minimize impacts to the number, density, and species types of trees. As a mitigation measure, the planting of trees to replace those removed during construction is required under the city of Jacksonville's tree protection regulations. JEA would supply replacement trees from their tree farm to the local civic association for the latter to use wherever needed to implement the community's beautification program. As part of the proposed project, JEA is planning to enhance the landscaping at the entrance to Northside Generating Station and extend landscaping along Heckscher Drive adjacent to the Northside property. JEA would plant 20 mature date palms, other trees, shrubs, and ground cover.

Implementation of the proposed project would not require any land off the Northside Generating Station site for water treatment or sewage treatment. All construction facilities and laydown/staging areas would be located on the site. Construction and operation of the repowered units would be consistent with existing use.

The proposed project would not alter the pattern of land use in Duval County because it would be confined to the existing Northside and Power Park property. The proposed project would be 
OANL 99-04673/ra

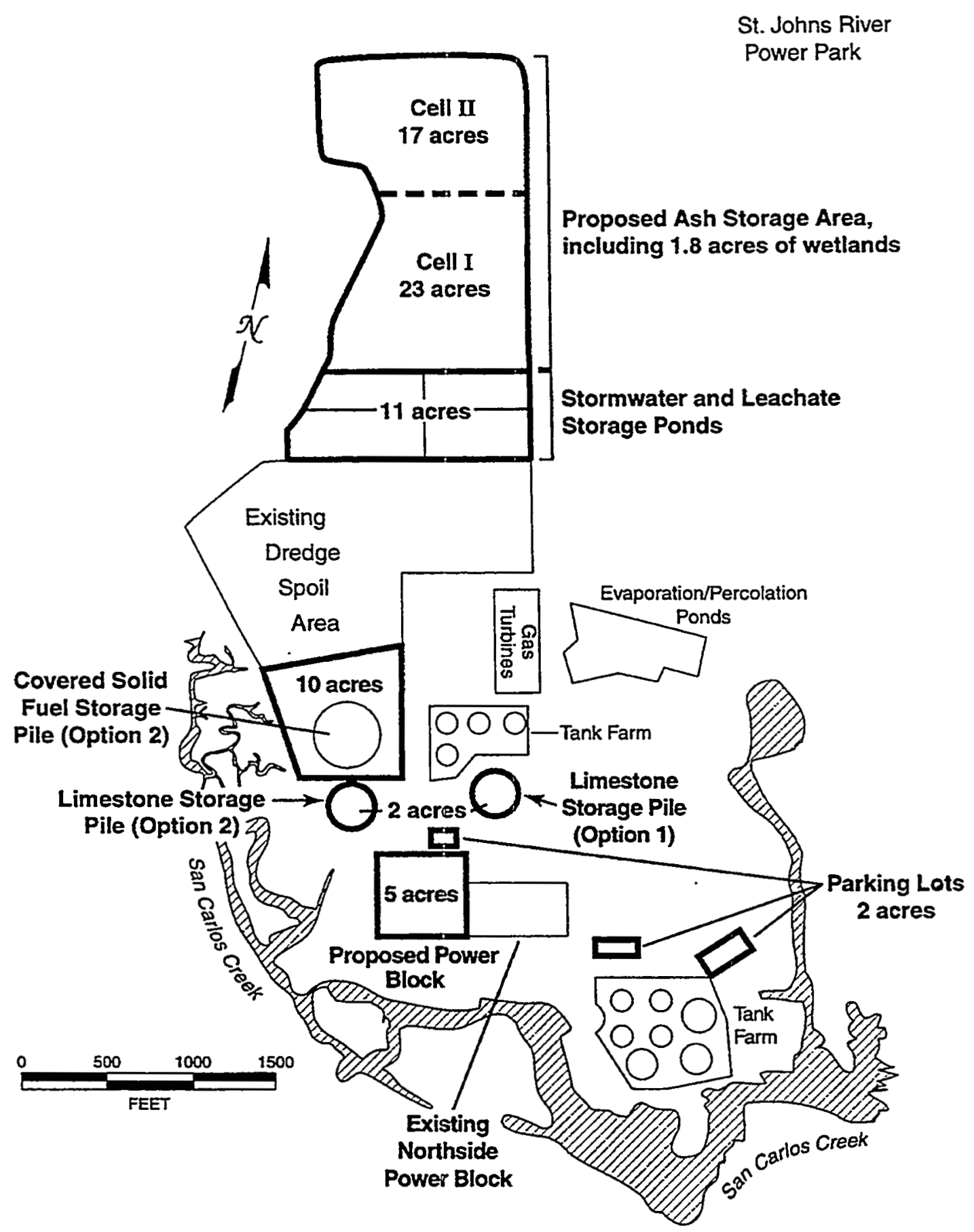

Figure 4.1.1. Principal land requirements for the proposed project at Northside Generating Station. 
consistent with existing land use plans and local zoning. Furthermore, any in-migration of workers that might occur during project construction and operations would not be large enough to increase the amount of land used for residential purposes (Section 4.1.9.3) or public service facilities (Section 4.1.9.5). Although some indirect and induced jobs would be created as a result of direct employment at the project site (Section 4.1.9), any increase in the amount of land devoted to commercial purposes in Duval County would be extremely small.

\subsubsection{Aesthetics}

As part of the proposed project, JEA would construct a single 495-ft twin-flued stack at Northside Generating Station. This new stack would be considerably taller than the two existing stacks ( $250 \mathrm{ft}$ and $350 \mathrm{ft}$ tall), so it would be visible from a greater distance. However, it would be nearly $150 \mathrm{ft}$ shorter than the stack at the adjacent St. Johns River Power Park and is much smaller in diameter than the Power Park's two 425-ft hyperbolic cooling towers, so it would not be the most highly visible feature in the area. Moreover, three stacks existed at Northside Generating Station until the 300-ft stack for Unit 2 was dismantled and removed in early 1998. As part of the related action of repowering Unit 1 , the existing 250 -ft stack would be dismantled and removed. The new CFB combustor buildings for each of the repowered units would be similar in size to the existing combustor and turbine buildings. If JEA were unsuccessful in marketing the ash generated by the proposed project, the height of the 40 -acre ash storage area would reach $100 \mathrm{ft}$ in 9 to 11 years (Section 5); however, this mound of ash should not be aesthetically displeasing and would be consistent with the area's industrial character. In general, the proposed project would not alter the industrial appearance of the site and, accordingly, would not degrade the aesthetic character of the Northside site and the surrounding area.

More specifically, the visual impact of the proposed project would be very minor on the Timucuan Ecological and Historic Preserve, located along the eastern border of Northside Generating Station (Figure 2.1.2). The Kingsley Plantation, Fort Caroline National Memorial, Ribault Monument, and Theodore Roosevelt Area are located within the Timucuan Ecological and Historic Preserve. Northside Generating Station is not visible from these four locations. There are two opportunities for viewing Northside Generating Station from the access road to the Kingsley Plantation, which is approximately 6 miles east of the station. These views are located in small open areas in the forested canopy along the dirt access road. The station is visible to people fishing in these areas. The duration of the viewing opportunity for people in moving vehicles is very brief.

The Federal Aviation Administration would make the final decision on the marking and lighting of temporary and permanent structures associated with the proposed project (Section 7.1). Generally, construction cranes and other elevated equipment require lighting if their height above the ground exceeds $200 \mathrm{ft}$. The 495 -ft stack would require medium- or high-intensity flashing white obstruction lights. The lights would operate at reduced intensity during the night. Because this type of lighting is 


\section{JEA EIS}

currently installed and operating on the Power Park's stack and cooling towers and on the Cedar Bay Generating Plant's stack, located about 2 miles west of the proposed facility, the additional lighting. would be consistent with the area's industrial appearance and would not degrade the aesthetic character of the area.

\subsubsection{Atmospheric Resources and Air Quality}

Potential impacts to atmospheric resources may result from construction or operation of the proposed facility. Section 4.1.2.1 discusses effects of construction, which primarily involve fugitive dust associated with earthwork and excavation. Section 4.1.2.2 discusses effects of operation; these result from a wider variety of pollutants that have effects at varying time and space scales. An introductory subsection summarizes air emissions from operation of the proposed project. This introduction is followed by an analysis of potential degradation of air quality and an analysis of potential cumulative impacts to air quality. Topics covered in the remainder of the section include noncriteria pollutants that may cause human health effects, radionuclide emissions, effects on visibility, regional-scale acidic deposition, and global climate change.

\subsubsection{Construction}

During construction of the proposed facility, temporary and localized increases in atmospheric concentrations of oxides of nitrogen $\left(\mathrm{NO}_{x}\right)$, carbon monoxide $(\mathrm{CO})$, sulfur dioxide $\left(\mathrm{SO}_{2}\right)$, volatile organic compounds (VOCs), and particulate matter would result from exhaust emissions of workers' vehicles, heavy construction vehicles, diesel generators, and other machinery and tools. Construction vehicles and machinery would be equipped with standard pollution-control devices to minimize emissions. These emissions would be very small compared to regulatory thresholds typically used to determine whether further air quality impact analysis is necessary.

Fugitive dust would result from excavation and earthwork. The impacts of this dust on offsite ambient air concentrations of particulate matter less than $10 \mu \mathrm{m}$ in aerodynamic diameter (PM-10) were modeled using the EPA-recommended Industrial Source Complex Short-Term (ISCST3) air dispersion model (EPA 1995). An average emission factor of 1.2 tons of total suspended particulate matter per acre per month was assumed (EPA 1985). Of these emissions, roughly $30 \%$ of the mass would consist of PM-10 (Kinsey and Cowherd 1992). It was further assumed that sprinkling with water would reduce fugitive dust by $50 \%$ (EPA 1985) and that construction would occur during daylight hours only.

The maximum area undergoing heavy construction at any one time was assumed to be 10 acres. This includes the area on which the proposed CFB combustors and adjacent facilities would be located (extending from the existing Unit 3 west toward San Carlos Creek) and an adjacent area to the south to be used for short-term staging and other temporary activities. Equally large areas farther from the site boundaries may be disturbed at other times. However, pollutant concentrations from 
nonbuoyant ground-level sources decrease as distance from the source increases; therefore, disturbance of areas farther from the site boundaries would have less effect on offsite PM-10 concentrations. Also, disturbances in areas away from the site of the proposed combustor facilities are likely to be less intense.

Five years (1984-88) of meteorological data from Jacksonville International Airport (about 9 miles west-northwest of Northside Generating Station), in conjunction with upper-air data from Waycross, Georgia (about 70 miles northwest of Northside Generating Station), were used for this analysis of construction impacts. Jacksonville International Airport is the nearest location at which quality-assured hourly meteorological data are archived. Because meteorological data from 1980 for a location nearer to Northside Generating Station were not archived on an hourly basis, those data are inappropriate for air dispersion modeling. Comparison of wind roses at the two locations confirmed that meteorological data from Jacksonville International Airport are generally representative of conditions at the site of the proposed project (Section 3.2.1). The 5-year period for modeling analysis was based largely on the availability of continuous meteorological data in a form suitable for model input. Although there is no overlap between that period and the 5 years (1993-97) of recent air quality data used in the analysis (Table 3.2.1), data from the 1980s are still indicative of meteorology in the region; however, air quality may have changed, which makes it necessary to use recent air quality data.

Waycross, Georgia, provides the nearest upper-air data; these data represent large-scale meteorological conditions and would therefore be expected to be relatively uniform between Waycross and Jacksonville. However, in coastal areas, some meteorological parameters may change appreciably as one moves closer to or away from the coastline. On warm and sunny days, when the land surface can be much warmer than the ocean surface, the height above ground to which convection causes appreciable vertical mixing (the mixing height) is typically highest over inland areas and decreases nearer the coast. In such cases, the mixing height at Northside Generating Station would tend to be lower than indicated by the upper-air data at Waycross; however, mixing heights at both locations would be high, favoring dispersion of pollutants and, correspondingly, lower pollutant concentrations. Under such conditions, vertical dispersion of fugitive dust would not be affected at locations near the source, such as the nearest site boundary or nearby offsite locations. Therefore, differences in mixing height between Northside Generating Station and Waycross would not affect the results.

Concentrations of PM-10 were modeled in each of 36 directions (at 10-degree intervals) in 328- $\mathrm{ft}$ increments from the center of the disturbed area. Maximum existing emissions of PM-10 from stacks at Northside Generating Station and the St. Johns River Power Park were included in the modeling to simulate construction activities occurring simultaneously with operation of the existing facilities. The total concentrations, obtained by adding maximum modeled concentrations to their corresponding background concentrations (Table 3.2.1), were compared with the NAAQS. Because 
construction emissions are temporary, the comparisons made in Section 4.1.2.2 with PSD increments were not made for construction activities.

During any major construction activity, it is typical that PM-10 concentrations exceed the NAAQS near the edge of a disturbed area; in this case, results indicated that exceedances of the 24-hour standard could occasionally occur up to $1,200 \mathrm{ft}$ from the nearest edge of the construction area if construction were as intense as that assumed in the modeling and lasted from 7:00 a.m. until 7:00 p.m. No exceedances would be expected at any residences because the nearest residences are approximately $1,600 \mathrm{ft}$ southeast of the existing turbine building. No exceedances of the 24-hour standard would be expected as far south as the St. Johns River, and no exceedances of the annual standard would be expected at distances greater than about $300 \mathrm{ft}$ from the nearest edge of the construction area.

Construction also would be required under the two options for the solid fuel delivery and handling system (Section 2.1.3). Option 1 is to construct a second unloader at the existing St. Johns River terminal on Blount Island, which is outside the site boundary; Option 2 is to construct a new solid fuel and limestone unloading terminal at the existing Northside Generating Station fuel oil unloading dock, which is adjacent to, but also outside of, the site boundary. For each option, emissions of fugitive dust from construction activities were modeled using the same approach as above, except that the construction area was assumed to be 2 acres with dimensions of $420 \times 210 \mathrm{ft}$, and no buffer area was assumed to exist between the construction area and the receptors (i.e., locations at which air quality effects were modeled). Emissions factors for fugitive dust were the same as those used previously. Results indicated no exceedances of the annual or 24-hour NAAQS for PM-10 at distances beyond $500 \mathrm{ft}$ from the nearest edge of the disturbed area. Therefore, no exceedances would be expected at any residences or other locations likely to be frequented by a member of the general public.

\subsubsection{Operation}

This section discusses potential air quality impacts resulting from operation of the proposed facility. New emissions of air pollutants would occur primarily from the 495 - $\mathrm{ft}$ twin-fiued CFB combustor stack. Table 4.1.1 summarizes annual emissions and maximum potential hourly emissions of $\mathrm{SO}_{2}, \mathrm{NO}_{x}$ and PM-10 from the existing and proposed units at Northside Generating Station. Specifically, Table 4.1.1 compares existing air emissions from Units 1 and 3 with emissions expected during the transition period after the Unit 2 repowering (the proposed project) and emissions expected after the Unit 1 repowering (the related action). Although the capacity factor for the repowered Units 1 and 2 would be $90 \%$ (Table 2.1.1), Table 4.1 .1 uses a 100\% capacity factor as an upper bound that matches the PSD air permit application.

The table shows that the repowering of Unit 2 and a corresponding reallocation of emissions among the three units would meet JEA management's target of a $10 \%$ reduction in annual emissions 


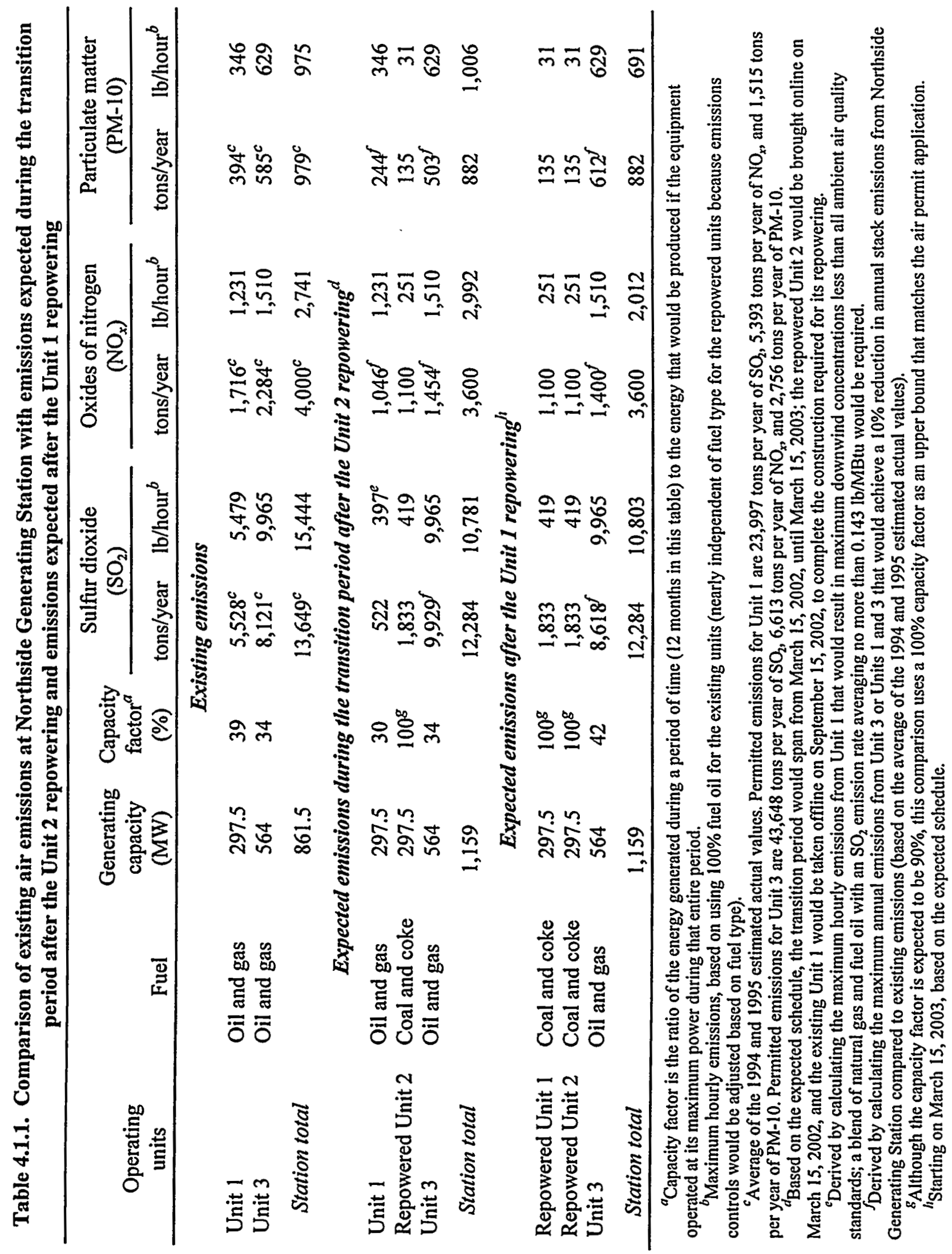


of each pollutant $\left(\mathrm{SO}_{2}, \mathrm{NO}_{x}\right.$, and $\left.\mathrm{PM}-10\right)$ from the three units collectively while at the same time increasing Northside's total generating capacity. The related action of repowering Unit 1 would allow that unit to operate a greater percentage of the time and consequently increase the total annual energy output of the station while maintaining the overall $10 \%$ reduction in annual $\mathrm{SO}_{2}, \mathrm{NO}_{x}$, and PM-10 emissions. Annual emissions from Units 1 and 3 (during the transition period after the Unit 2 repowering) and from Unit 3 (after the Unit 1 repowering) would be adjusted by using different blends of natural gas and fuel oil to meet the overall $10 \%$ reduction. Thus, the relationship between annual emissions and capacity factor is not proportional. For example, as indicated in the table, annual $\mathrm{SO}_{2}$ emissions from Unit 3 would decrease after the Unit 1 repowering from 9,929 to 8,618 tons per year because more natural gas and less fuel oil would be used, even though the capacity factor would increase from $34 \%$ to $42 \%$.

The combination of the proposed project and the related action would also reduce maximum potential hourly emissions from the three units collectively. Maximum hourly $\mathrm{SO}_{2}$ emissions would decrease by $30 \%$ after the Unit 2 repowering and would remain essentially unchanged from that lower level after the Unit 1 repowering. This reduction results from a commitment by JEA to use a blend of natural gas and fuel oil with an $\mathrm{SO}_{2}$ emission rate averaging no more than $0.143 \mathrm{lb} / \mathrm{MBtu}$ (effectively, a blend with a sulfur content averaging no more than $0.13 \%$ ) in Unit 1 during the transition period. Maximum hourly emissions of $\mathrm{NO}_{x}$ and $\mathrm{PM}-10$ would increase somewhat after Unit 2 is repowered because emissions from Units 1 and 3 would remain the same while emissions from Unit 2 would be added. Emissions would then decrease after the Unit 1 repowering; the net result compared to existing maximum hourly emissions at Northside Generating Station would be a decrease of $27 \%$ in $\mathrm{NO}_{x}$ emissions and $29 \%$ in PM-10 emissions.

In addition to the emissions summarized in Table 4.1.1, relatively small amounts of pollutants would be emitted from the 75-ft stacks serving the proposed limestone dryers. Maximum potential hourly emissions of $\mathrm{NO}_{x}$ from those stacks would be about $1 \%$ of $\mathrm{NO}_{x}$ emissions from the repowered Unit 2; hourly emissions of $\mathrm{SO}_{2}$ and PM-10 would be even smaller percentages compared to Unit 2 . Emissions from the dryers were conservatively assumed to be at their maximum hourly rate during the transition period after the Unit 2 repowering and to continue at that rate after the Unit 1 repowering.

Although emissions of $\mathrm{SO}_{2}, \mathrm{NO}_{x}$, and PM-10 from Northside Generating Station would decrease as a result of the proposed project and related action, the redistribution of pollutants in the atmosphere is a complex process that could result in increased ground-level concentrations at some locations and for some averaging periods. On any particular day, concentrations could be increased at some locations and decreased at others; at any particular location, concentrations could be increased on some days and reduced on others. Because emissions from the proposed limestone dryers would occur close to ground level, as compared with emissions from the boiler stacks, concentrations of pollutants emitted from the dryer stacks would be expected to increase near the site 
boundary; these increases would be greatest for $\mathrm{NO}_{2}$ because $\mathrm{NO}_{x}$ emissions from the dryer stacks exceed those of other pollutants. Thus, concentrations could be increased slightly near the site boundary while decreased at other locations.

Sources of air pollutants other than stacks would include plant vehicular traffic and personal commuter vehicles; this smail amount of traffic would not contribute appreciably to ambient air pollutant concentrations in the area, and therefore is not included in the following analysis.

Additional PM-10 would be generated from handling and transfer of coal, petroleum coke, and limestone at the site. To reduce these PM-10 emissions to acceptable levels, the proposed project would minimize the number of handling and transfer points, enclose the conveyors and material unloading points, use wetting systems for particulate suppression, and install collection devices such as baghouses. Air quality effects of these emissions are not included in the following analysis, but results of the evaluation in the PSD air permit application (JEA 1999) indicate that handling and transfer of materials would not generate particulate emissions that would exceed $85 \%$ of ambient air quality standards at the location of maximum impact outside the site boundary.

DOE has performed a conformity review to assess whether a conformity determination (40 CFR Part 93, Subpart B) is needed for the proposed project. Currently, no portion of Duval County is designated as a nonattainment area for any NAAQS or Florida standard, but Duval County is a maintenance area for $\mathrm{O}_{3}$ (Section 3.2.2). A maintenance area is an area that previously was a nonattainment area for a pollutant and which is striving to maintain attainment with the standard(s) for the pollutant and comply with the state implementation plan. However, a conformity determination is not required [40 CFR Part 93.153(d)] because the precursors of $\mathrm{O}_{3}\left(V O C s\right.$ and $\left.\mathrm{NO}_{x}\right)$ are evaluated in the PSD permit application (JEA 1999). Because emissions of these pollutants would be greater than PSD significance thresholds [40 CFR Part 93.153(b)], the application includes Best Available Control Technology analyses for these pollutants.

The following analysis first evaluates the changes in ambient air concentrations of pollutants expected to result from changes in stack emissions associated with the proposed project alone and in conjunction with the related action (PSD subsection); then the analysis examines potential cumulative air quality impacts from the proposed facility and from other regional sources (NAAQS subsection).

\section{Prevention of Significant Deterioration}

As discussed in Section 3.2.2, PSD increments are established to restrict the deterioration of air quality that could result from new pollutant sources (40 CFR Part 51.166). PSD increments are used in this analysis as standards by which to measure the significance of the changes in ambient air concentrations. There are two PSD Class I areas within 63 miles of Northside Generating Station (Section 3.2.2). All other areas are designated as Class II. 
Proposed project. The ISCST3 atmospheric dispersion model (EPA 1995) was used to estimate maximum increases in ground-level concentrations of $\mathrm{SO}_{2}, \mathrm{NO}_{2}$ and PM-10 that would occur at any location as a result of emissions from the CFB combustor and limestone dryers for the proposed project (the Unit 2 repowering). Meteorological data were the same as those used for the analysis of construction impacts in Section 4.1.2.1. Maximum potential hourly emissions and a 100\% capacity factor were used in the modeling. All $\mathrm{NO}_{x}$ emissions were conservatively assumed to be in the form of $\mathrm{NO}_{2}$ for comparison with the $\mathrm{NO}_{2}$ increment. Concentrations were modeled at 352 locations (receptors) along or outside the property boundary (boundary of the combined area occupied by Northside Generating Station and the adjoining St. Johns River Power Park) at distances of up to 6 miles from the proposed CFB combustor stack. For short-term averaging periods, PSD regulations allow for one anomalous exceedance of an increment per year (40 CFR Part 51.166); therefore, the highest modeled short-term concentrations at each receptor location for each year were excluded, and the highest remaining values for all 5 years modeled (1984-88) were included in the analysis.

Results indicate that maximum modeled increases are always less than $15 \%$ of their corresponding Class II increments (Table 4.1.2). Maximum concentrations generally occur at locations along, or very close to, the site boundary, often within 0.6 mile of the proposed CFB combustor stack. Because the nearest PSD Class I areas are more than 30 miles from the proposed facility (Section 3.2.2), pollutant concentrations estimated by the ISCST3 air dispersion model for those locations would be overly conservative. Dispersion of pollutants at such distances would reduce atmospheric concentrations to only a small fraction of the maximum modeled increases near the site. Because these maximum modeled increases are about equal to (for short-term $\mathrm{SO}_{2}$ and annual $\mathrm{NO}_{2}$ concentrations) or less than PSD Class $I$ increments at the locations of their maximum impact near Northside Generating Station, the increases in pollutant concentrations at the nearest PSD Class I areas would be expected to be only small fractions of the corresponding Class I increments (Table 3.2.2).

Proposed project and related action. The combination of the proposed project and related action would result in emissions from the new 495-ft twin-flued stack that would be twice those considered in the analysis of the proposed project alone. However, emissions from the stacks serving the proposed limestone dryers were assumed to be at their maximum value for the proposed project alone and were not increased in the analysis of the proposed project in conjunction with the related action. Furthermore, the elimination of emissions from the existing 250-ft stack serving Unit 1 would more than compensate for the added emissions. Compared to existing emissions at Northside Generating Station, a net decrease in maximum hourly emissions of $\mathrm{SO}_{2}, \mathrm{NO}_{x}$, and $\mathrm{PM}-10$ would result from the addition of the repowered Unit 2 and the limestone dryers and the replacement of the existing Unit 1 with the repowered Unit 1 (Table 4.1.1). Therefore, a decrease in ground-level 


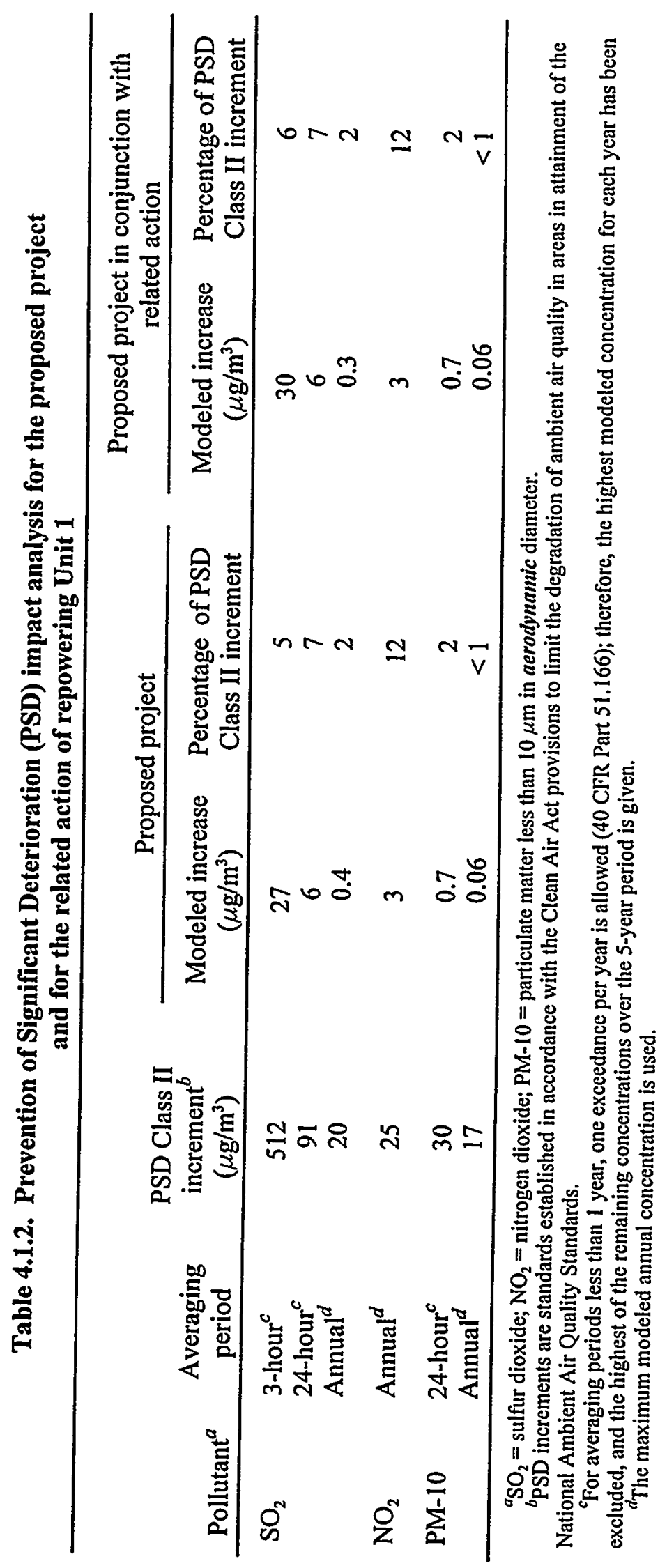


concentrations of these pollutants would be expected most of the time at most locations in the surrounding area.

However, pollutant concentrations would not decrease for all averaging times at all locations; maximum ground-level concentrations at some locations could increase because the characteristics and location of the proposed new stack would be different from those of the stack currently serving Unit 1. For example, the presence of a scrubber would result in a lower exit temperature for the exhaust gas from the new stack. This would tend to decrease the buoyancy of the exhaust gas, lower the height of the pollutant plume, decrease the vertical and horizontal spread of the plume, and increase ground-level concentrations. On the other hand, exhaust gas from the repowered Units 1 and 2 operating simultaneously would be emitted from adjacent flues, which increase the initial upward momentum and buoyancy of the exhaust gas. This larger initial lift would result in a greater plume height, a greater vertical and horizontal spread of the plume, and lower ground-level concentrations than would occur otherwise. The net result would be a complex redistribution of pollutant concentrations near Northside Generating Station. The net impacts could be positive or negative on any particular day at any particular location, but negative impacts would be expected to be less than the upper-bound estimates presented in this analysis.

Maximum modeled increases in ground-level concentrations for the proposed project in conjunction with the related action are very similar to those for the proposed project alone. Maximum increases are always less than $15 \%$ of their corresponding Class II increments (Table 4.1.2). This result is largely attributable to the dominance of the proposed limestone dryer stacks in determining maximum concentrations. Although emissions from the limestone dryer stacks would be less than $1 \%$ of emissions from the proposed twin-flued CFB combustor stack, the maximum modeled concentrations of the former are comparable to, and frequently larger than, maximum concentrations of the latter. Because the dryer stacks would only be $75 \mathrm{ft}$ tall, they would be subject to strong aerodynamic effects from surrounding structures. Under frequently occurring meteorological conditions (e.g., neutral atmospheric stability and moderate or high wind speeds), these effects could cause maximum impacts from the dryer stacks, which would occur about $500 \mathrm{ft}$ from their source, to be larger than maximum impacts from the CFB combustor stack, which would occur several miles from their source.

Because the nearest PSD Class I areas are more than 30 miles away, pollutants from Northside Generating Station would be well mixed in the atmosphere, and stack characteristics would have little effect on ground-level pollutant concentrations in these areas. Therefore, a net decrease in pollutant emissions resulting from the proposed project in conjunction with the related action (Table 4.1.1) would be expected to improve air quality, albeit by a very small amount, at the nearest PSD Class I areas.

Complete PSD analysis for regulatory applications considers other sources in the area that may be contributing to the degradation of air quality (40 CFR Part 51.166). However, expected effects of 
the proposed facility alone and in combination with the related action are small fractions of the corresponding PSD increments at locations close to Northside Generating Station (Table 4.1.2), and would be even smaller fractions of those increments at locations distant from Northside Generating Station. Similarly, pollution increments attributable to other sources would have their maximum values near their respective sources, and would be unlikely to approach $100 \%$ of PSD increments near the site of the proposed project. Therefore, other sources in the area were not included in this PSD analysis but were included in the modeling of cumulative effects discussed in the following subsection.

The foregoing discussion of air quality impacts near Northside Generating Station focused primarily on maximum degradation. Improvements would also be expected to result from the decrease in air emissions that would accompany implementation of the proposed project in conjunction with the related action (Table 4.1.1). Maximum modeled improvements in air quality were obtained by simultaneously modeling the emissions from the proposed CFB combustor stack and limestone dryer stacks with the elimination of emissions from the stack currently serving the existing Unit 1. Maximum improvements in air quality would occur at different times, and typically at different places, than would maximum degradations. Modeled maximum improvements and degradations are compared in Table 4.1.3. The improvements would generally be much greater than the degradations, reflecting primarily the net emissions decrease.

Table 4.1.3. Maximum improvements and maximum degradations in air quality that were modeled to result from the proposed project in conjunction with the related action of repowering Unit 1

\begin{tabular}{llcc}
\hline Pollutant & \multicolumn{1}{c}{$\begin{array}{c}\text { Averaging } \\
\text { period }\end{array}$} & $\begin{array}{c}\text { Maximum } \\
\text { improvement } \\
\left(\mu \mathrm{g} / \mathrm{m}^{3}\right)\end{array}$ & $\begin{array}{c}\text { Maximum } \\
\text { degradation } \\
\left(\mu \mathrm{g} / \mathrm{m}^{3}\right)\end{array}$ \\
\hline $\mathrm{SO}_{2}$ & 3-hour $^{c}$ & 157 & 30 \\
& 24-hour $^{c}$ & 42 & 6 \\
$\mathrm{NO}_{2}$ & Annual $^{d}$ & 3 & $<1$ \\
$\mathrm{PM}^{20}$ & Annual $^{d}$ & 1 & 3 \\
& 24-hour $^{c}$ & 3 & $<1$ \\
& Annual $^{d}$ & $<1$ & $<1$ \\
\hline
\end{tabular}

${ }^{a} \mathrm{SO}_{2}=$ sulfur dioxide; $\mathrm{NO}_{2}=$ nitrogen dioxide; $\mathrm{PM}-10=$ particulate matter less than $10 \mu \mathrm{m}$ in aerodynamic diameter.

${ }^{b}$ Same as the modeled increase shown in Table 4.1.2 resulting from the proposed project in conjunction with the related action of repowering the existing Unit 1.

'For averaging periods less than 1 year, one exceedance per year is allowed (40 CFR Part 51.166); therefore, the highest modeled concentration for each year has been excluded, and the highest of the remaining concentrations over the 5-year period is given.

${ }^{d}$ The maximum modeled annual concentration is used. 
In conclusion, concentrations of $\mathrm{SO}_{2}, \mathrm{NO}_{2}$, and PM-10 would be expected to increase by only a small fraction of their respective PSD increments as a result of the proposed project. Actual degradation of air quality should be even less than the relatively small amounts presented above as upper-bound estimates. When the related action of repowering Unit 1 is also considered, beneficial effects on air quality would be expected to outweigh the small adverse effects.

\section{National Ambient Air Quality Standards}

Pollutants for which National Ambient Air Quality Standards (NAAQS) exist (criteria pollutants) include $\mathrm{SO}_{2}, \mathrm{NO}_{2}, \mathrm{CO}, \mathrm{Pb}, \mathrm{O}_{3}$, and $\mathrm{PM}-10$ (Section 3.2.2). Concentrations of $\mathrm{CO}$ are of primary concern near major intersections in large cities, where the simultaneous idling of many vehicles can produce a large ground-level source, and air circulation is limited by surrounding highrise buildings. Concentrations of $\mathrm{CO}$ in downtown Jacksonville were always much less than their corresponding NAAQS during the 5-year period of analysis; therefore, $\mathrm{CO}$ emissions from the proposed project were not evaluated further. No appreciable $\mathrm{Pb}$ emissions would occur from operation of the proposed facility. Concentrations of $\mathrm{Pb}$ in recent years have been well below NAAQS (Table 3.2.1), largely because of the decreased use of leaded gasoline in automobiles. Therefore, the remainder of this section addresses $\mathrm{O}_{3}, \mathrm{SO}_{2}, \mathrm{NO}_{2}$, and PM-10.

Ozone. $\mathrm{O}_{3}$ is not emitted directly from a combustion source; instead, it is formed from photochemical reactions involving emitted VOCs and $\mathrm{NO}_{x}$. Because the reactions involved can take hours to complete, $\mathrm{O}_{3}$ can form far from the sources of its precursors (the VOCs and $\mathrm{NO}_{x}$ that initiate its formation). Therefore, the contribution of an individual source to $\mathrm{O}_{3}$ concentrations at any particular location cannot be readily quantified.

The proposed project and the corresponding decrease in emissions from Units 1 and 3 would result in a $10 \%$ decrease in $\mathrm{NO}_{x}$ emissions from Northside Generating Station (i.e., 400 tons per year) (Table 4.1.1), or less than $1 \%$ of the $\mathrm{NO}_{x}$ emissions in Duval County. Meanwhile, VOC emissions would increase by 61 tons per year (Table 2.1.1), or by less than $1 \%$ of VOC emissions in Duval County (including biogenic emissions). It is not clear whether the net effect of increasing one $\mathrm{O}_{3}$ precursor (VOCs) and decreasing another $\left(\mathrm{NO}_{x}\right)$ would tend to increase or decrease $\mathrm{O}_{3}$ concentrations; however, because the magnitudes of the changes in precursor emissions are so small compared to regional values, the magnitude of any resulting change in $\mathrm{O}_{3}$ concentrations is expected to be negligible.

The repowering of Unit 1 would not result in any additional change in the total annual $\mathrm{NO}_{x}$ emissions from Northside Generating Station (Table 4.1.1). Repowered Unit 1 would add 61 tons per year to the VOC emissions from Northside Generating Station, while the 24 tons per year currently emitted by the existing Unit 1 would be eliminated; the net result of the proposed project combined with the related action of repowering Unit 1 would be an increase of 98 tons per year (Table 2.1.1), or less than $1 \%$ of VOC emissions in Duval County. Therefore, the proposed project, either by itself 
or in combination with the related action, would be expected to have only negligible effects on $\mathrm{O}_{3}$ concentrations.

There are $2 \mathrm{O}_{3}$ monitors in Duval County: one is located about 5 miles north-northwest of Northside Generating Station and the other is located at the Naval Air Station, about 15 miles southwest of Northside Generating Station. During 1993-97, $\mathrm{O}_{3}$ concentrations at the nearest monitor were always less than $90 \%$ of the 1-hour NAAQS (Table 3.2.1); because changes in $\mathrm{NO}_{x}$ and VOC emissions from the proposed project alone or in conjunction with the related action would be less than $1 \%$ of emissions in Duval County, they would not be expected to lead to any exceedances of the 1-hour NAAQS for $\mathrm{O}_{3}$ at that monitoring location. It is possible (although very unlikely) that the changes in emissions could lead to concentrations greater than the 1-hour standard at the Naval Air Station because the station recorded concentrations in the 1990s equaling that former standard. It is more likely, however, that the changes in emissions would have no detectable effect at the station. It is not yet possible to assess the effect of the proposed project on compliance with the 8-hour standard (Section 3.2.2).

Other criteria pollutants. Potential cumulative air quality impacts of $\mathrm{SO}_{2}, \mathrm{NO}_{x}$, and PM-10 emissions from the proposed facility and from other regional sources were evaluated by estimating maximum increases in ground-level concentrations using the ISCST3 air dispersion model (EPA 1995) with the same meteorological input data discussed in Section 4.1.2.1. Modeling included emissions from the proposed project and from the existing stacks at Northside Generating Station, the St. John River Power Park, and several other sources within 30 miles of the proposed project that were expected to contribute to cumulative impacts (e.g., Cedar Bay Cogeneration, Inc., and the Stone Container Corporation). Maximum potential hourly emissions and a $100 \%$ capacity factor were used in the modeling. All NO comparison with the $\mathrm{NO}_{2}$ standard. Concentrations were modeled at 352 locations (receptors) within 6 miles of the proposed CFB combustor stack excluding the Northside Generating Station and the St. Johns River Power Park properties. Maximum modeled concentrations during the 5-year period of meteorological data were added to the corresponding monitored background concentrations (Table 3.2.1), and the totals are compared to NAAQS or Florida standards, as appropriate, in Table 4.1.4.

The modeling of existing nearby sources assures inclusion of their effects on air quality near the site of the proposed project; these effects may not be fully represented at the nearest monitoring location because the instrument may be located relatively distant from Northside Generating Station. Adding monitored background concentrations to the modeling results assures inclusion of contributions from sources that were not modeled (e.g., natural sources, vehicles, and utilities or industrial sources that were not modeled because of their small size and/or large distance from the proposed facility). Adding modeled and monitored concentrations is conservative because it "double counts" any modeled effects that are included in the monitoring data. The use of maximum potential 


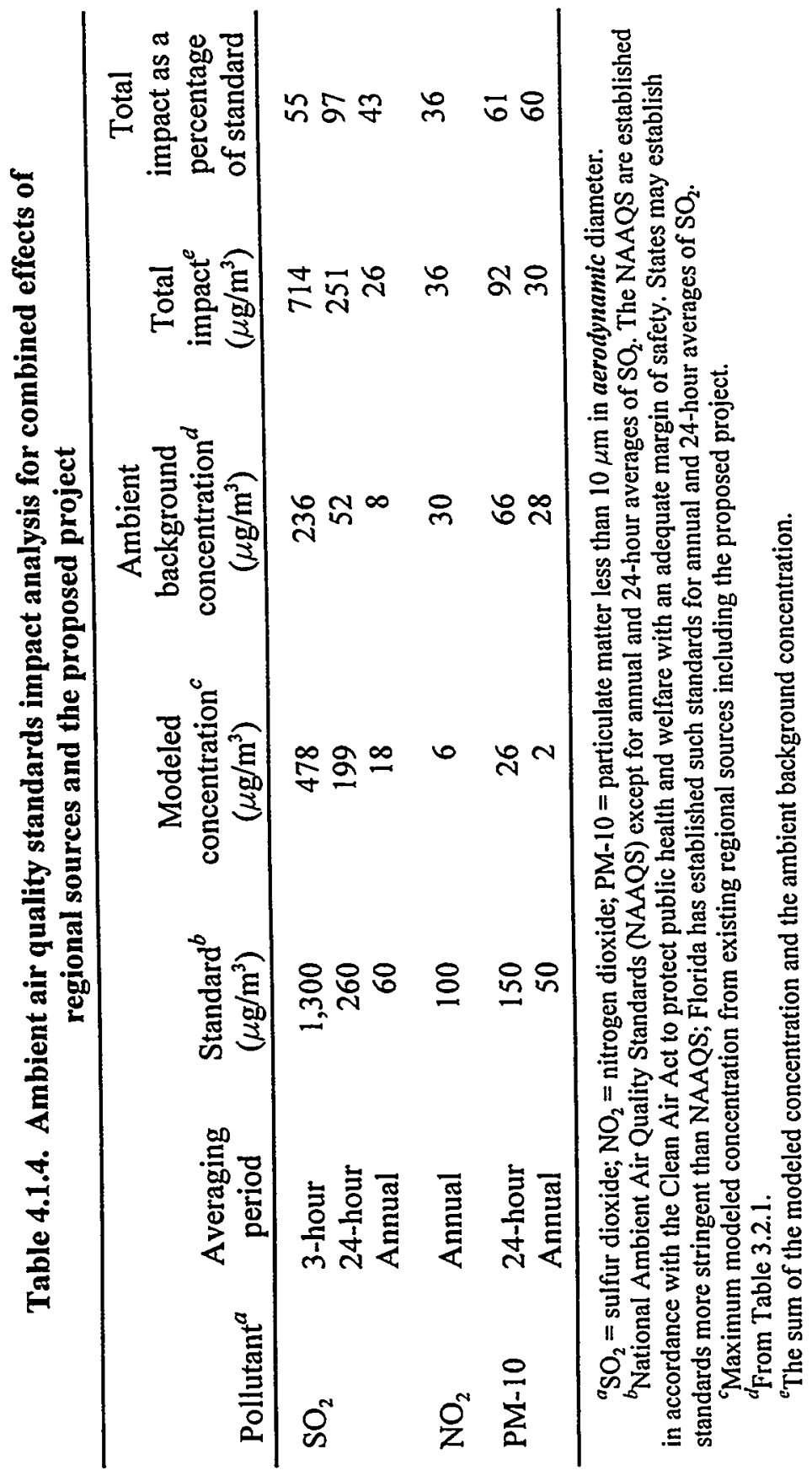


hourly emissions from all sources, rather than the smaller actual emissions, adds conservatism to analysis. Therefore, the estimates of total impacts and their percentages of corresponding standards in Table 4.1.4 represent upper-bound values; they could conceivably occur, but are higher than the amounts that would be expected.

Results of modeling regional sources and the proposed project indicate that no exceedances of national or state ambient air quality standards would be expected if the proposed project were implemented (Table 4.1.4). However, the 24-hour average $\mathrm{SO}_{2}$ concentration would be $97 \%$ of the corresponding Florida standard, and all $\mathrm{SO}_{2}$ concentrations would increase appreciably compared with the ambient background concentrations. Particularly for the short-term concentrations, these large values result from aerodynamic downwash effects caused by the proposed 200 - $\mathrm{ft}$ tall combustor structure that would induce downward motion on the exhaust gas emitted from the 250 - $\mathrm{ft}$ stack serving the existing Unit 1 and the 350-ft stack serving the existing Unit 3. Exhaust gas from the proposed 495-ft CFB combustor stack would not be subjected to substantial downwash because the stack is taller. Downwash leads to substantial, localized increases in ground-level concentrations near the site boundary compared with concentrations that would result from an identical situation without downwash. These effects are complicated; in general, maximum ground-level concentrations are redistributed as greater concentrations within about a mile of the source and smaller concentrations at greater distances (compared with an identical situation without downwash). During the 6- to 12-month transition period before the Unit 1 repowering, JEA has committed to reduce maximum hourly $\mathrm{SO}_{2}$ emissions from the existing Unit 1 by nearly $93 \%$ when operations commence for the proposed project (Table 4.1.1). This reduction, which would be accomplished by using natural gas and fuel oil with a sulfur content averaging no more than $0.13 \%$, would assure that the maximum 24-hour average $\mathrm{SO}_{2}$ concentration would not exceed the Florida standard, as indicated in the modeling presented in Table 4.1.4.

Estimated $\mathrm{SO}_{2}$ concentrations for other averaging periods are less than $60 \%$ of their respective standards. The annual average $\mathrm{NO}_{2}$ concentration is less than $40 \%$ of the NAAQS. The 24 -hour and annual averages of PM-10 are less than $65 \%$ of the NAAQS, even though ambient background PM-10 concentrations for both averaging periods are over $40 \%$ of the NAAQS.

Results of modeling regional sources and the proposed project in conjunction with the related action of repowering the existing Unit 1 indicate that maximum concentrations are always less than corresponding concentrations without the related action. For example, the 24-hour average $\mathrm{SO}_{2}$ concentration for regional sources and the proposed project in conjunction with the related action is $91 \%$ of the Florida standard, compared to $97 \%$ for regional sources and the proposed project without the related action. This decrease is attributable to several factors. First, the repowered Unit 1 would emit pollutants through a 495 -ft stack rather than the 250 -ft stack serving the existing Unit 1 . The taller stack would allow more dilution of the pollutant plume before it reaches ground level. Second, elimination of emissions from the existing shorter stack would be augmented by the corresponding 
elimination of aerodynamic downwash affecting those emissions. Third, although the Unit 1 repowering would increase the maximum potential hourly emissions from the twin-flued 495-ft stack by a factor of two, the exhaust gas would be emitted from adjacent flues, which would add buoyancy and upward momentum to the plume, so that ground-level concentrations of pollutants emitted from that stack alone would increase by much less than a factor of two. Finally, compared to the transition period after the Unit 2 repowering, the Unit 1 repowering would be accompanied by appreciable reductions in maximum hourly emissions of $\mathrm{NO}_{x}$ and $\mathrm{PM-10}$; maximum hourly emissions of $\mathrm{SO}_{2}$ would remain almost the same (Table 4.1.1). The net effect would be that expected maximum ground-level concentrations would decrease appreciably for $\mathrm{NO}_{2}$ and $\mathrm{PM}-10$ and would decrease slightly for $\mathrm{SO}_{2}$ compared with the modeling performed without the Unit 1 repowering.

\section{Human Health Effects from Noncriteria Pollutants}

In addition to the criteria pollutants listed in 40 CFR Part 50, other contaminants are present in the atmosphere; however, their concentrations are typically very small and are therefore difficult to measure (Section 3.2.2). Nonetheless, even in very small concentrations some of these contaminants may be health hazards because of their toxicity and/or carcinogenic (cancer-causing) potential. Because of the lack of background measurements for most toxic substances in the atmosphere, the following analysis deals only with modeled ambient air concentrations resulting from the proposed project.

Two approaches were taken to estimate potential impacts of hazardous materials that would be released to the atmosphere from the proposed project alone. The first approach was based on EPA reference doses and carcinogenic potency concepts; it was applied generally (Appendix D) to several metals, organic compounds (including dioxins and furans), and acid gases (including hydrogen fluoride) that could be emitted in small quantities from the proposed project. In the second approach, two metals (beryllium and mercury) that may be emitted at significant rates (40 CFR Part 51.166) were further evaluated by comparing maximum modeled increases in atmospheric concentrations to Florida Ambient Air Reference Concentrations (FAARCs), which are guideline concentration values established to protect human health.

Both approaches were based on maximum modeled increases in ambient air concentrations obtained by applying the ISCST3 air dispersion model (in the same manner as for the criteria pollutants) to estimated emissions from the proposed project using coal or petroleum coke as fuel. Both approaches assumed that the project would be operating at a $100 \%$ capacity factor. Estimated emissions tend to be conservative (form an upper bound) because no control measures were assumed in calculating the emission rates. For both approaches, modeled concentrations are presented for the location of maximum impacts, about 1.6 miles east of the proposed project, near the southern boundary of the Timucuan Ecological and Historic Preserve. This location is different than the 
location of maximum impacts for the criteria pollutants because the limestone dryer stacks were excluded in this modeling, since they would have negligible emissions of these contaminants.

General analysis based on EPA reference doses and cancer-risk measures.

Reference doses and cancer-risk measures are available for use in defining maximum ambient air concentrations of various substances for the protection of human health. Reference doses, which apply to noncarcinogenic effects, are available for most of the noncarcinogenic substances that would be emitted from the proposed facility (EPA 1989). These doses were used to calculate corresponding guideline values of maximum contaminant concentrations in the ambient air for the protection of human health, based on the assumption that air is inhaled at a rate of $26 \mathrm{yd}^{3}$ per day by a person weighing $154 \mathrm{lb}$. In some cases, only an oral reference dose was available and this was used without modification for the inhalation dose (i.e., $100 \%$ absorption was assumed); this procedure tends to overestimate potential impacts. Comparisons of the maximum modeled contaminant concentrations in the ambient air with their guideline maximum values for the protection of human health indicated that the concentration of chromium would be less than $2 \%$ of its guideline maximum value (its percentage of the EPA reference dose is 1.36 in the seventh column of Table D.1); for other substances, the corresponding percentages would be much less than $1 \%$ (Table D.1). These results indicate that the public would be adequately protected with respect to noncarcinogenic effects resulting from the proposed project.

Cancer potency slopes taken from EPA (1998a) were compared with the anticipated emissions of dioxins, furans, and other carcinogenic substances from the proposed project. Calculated risk values indicate that the cumulative cancer risk from inhalation would be less than 2 in 10 million per year $\left(1.42 \times 10^{-7}\right.$ in the ninth column of Table D.1). Except for dioxins and furans (which are discussed specifically in the following subsection), the cancer risk from ingestion of these substances would be much less than 1 in 1 million per year. Cancer risk is consistently discussed in the EIS on a "per year" basis. Because the facility would be designed for a lifetime of 30 years, the risk from a 30-year period of exposure during the lifetime of the facility can be approximated by multiplying each corresponding annual risk by 30.

Dioxins and furans. The health effects of dioxins and furans (which are closely related to dioxins in chemical structure and health effects) were included in the analysis of cancer risk. However, because dioxins were raised as an issue during public scoping, additional discussion of dioxins is presented below.

The production of dioxins and furans is of concern wherever fuels are burned, especially if a source of chlorine is present. There are 210 structurally related forms (congeners) of chlorinated dibenzo-p-dioxins (CDDs) and chlorinated dibenzofurans (CDFs), and several congeners are typically released from a combustion source. The dioxin-like compounds are often found in complex mixtures. To assist in risk assessment, a toxicity equivalency procedure has been developed to characterize the cumulative toxicity of these mixtures (EPA 1989). This procedure involves 
assigning individual toxicity equivalency factors (TEFs) to the $2,3,7,8$ substituted CDD/CDF congeners. These TEF values are estimates of the toxicity of dioxin-like compounds relative to the toxicity of 2,3,7,8-TCDD, which is assigned a TEF of 1.0. Calculating the toxic equivalency (TEQ) of a mixture involves multiplying the concentrations of individual congeners by their respective TEFs. The sum of the TEQ concentrations for the individual congeners is the TEQ concentration for the mixture. If the TEQ is expressed as a mass of material produced per mass of coal burned (an emission factor) for a coal-fired utility boiler, it would typically be less than $0.84 \mathrm{lb}$ per billion tons of coal burned (NATO 1988), which is less than $1 \mathrm{lb}$ per 1,000 years of operation of the proposed project at full capacity.

The average daily intake of dioxins for people in North America is approximately $119 \mathrm{pg}$ TEQ/day for all exposure pathways combined (EPA 1994). Ingestion of dioxins from meat and dairy products accounts for the vast majority of exposure (about $100 \mathrm{pg}$ TEQ/day), while inhalation accounts for about $2.2 \%$ or $2.6 \mathrm{pg} \mathrm{TEQ} /$ day. By comparison, cigarette smokers receive exposure to approximately $10 \mathrm{pg}$ TEQ per pack (EPA 1998b). Dioxin emissions from the proposed project would be similar whether the facility burns coal and/or petroleum coke (Table D.1). Results of calculations indicated an exposure to about $0.01 \mathrm{pg} \mathrm{TEQ} /$ day for the maximum exposed person, weighing $154 \mathrm{lb}$ and inhaling air at a rate of $26 \mathrm{yd}^{3}$ per day. Thus, the proposed project would add 4 parts per thousand of TEQ exposure via inhalation ( $0.01 \mathrm{pg} \mathrm{TEQ/day} \mathrm{added} \mathrm{to} 2.6 \mathrm{pg} \mathrm{TEQ} /$ day).

The combined risk of cancer from inhalation of dioxins and furans emitted by the proposed project was calculated to be about 2 in 100 million ( 0.2 in 10 million) per year ( $1.87 \times 10^{-8}$ in the ninth column of Table D.1). The total cancer risk from inhalation of dioxins, furans, and other carcinogenic substances emitted by the proposed project was calculated to be less than 2 in 10 million per year $\left(1.42 \times 10^{-7}\right.$ in the ninth column of Table D.1).

With regard to the ingestion pathway, specific source-receptor relationships are not well known for dioxins. Because dioxins attach primarily to very small particles, most dioxins are deposited far from their sources. However, because there is agricultural land in the Northside vicinity (including a dairy about 2 miles north-northwest of Northside Generating Station), an estimate was made that links the ingestion pathway for dioxins with air emissions from the proposed project. This estimate conservatively assumed that agricultural land such as the dairy would be exposed to the maximum modeled concentrations (even though the location of the maximum modeled concentrations, 1.6 miles east of the proposed project, is not agricultural land). The estimate also assumed that dioxins in milk and meat produced on the agricultural land would increase proportionally to the increase in airborne dioxins and that a person would consume $100 \%$ of his or her meat and dairy products from that land.

In North America, the average human intake of dioxins and furans is roughly 40 times greater via ingestion than inhalation (for dioxins, about $100 \mathrm{pg} \mathrm{TEQ/day} \mathrm{versus} \mathrm{about} 2.6 \mathrm{pg} \mathrm{TEQ/day).}$ Consequently, the ingestion of dioxins from the proposed project's emissions would be 
approximately 40 times the value of $0.01 \mathrm{pg} \mathrm{TEQ/day} \mathrm{for} \mathrm{inhalation} \mathrm{by} \mathrm{the} \mathrm{maximum} \mathrm{exposed}$ person, or $0.4 \mathrm{pg} \mathrm{TEQ} /$ day. Considering both ingestion and inhalation, the daily intake of dioxins resulting from the proposed project would be $0.41 \mathrm{pg} \mathrm{TEQ} /$ day.

The total cancer risk from inhalation and ingestion of dioxins and furans emitted by the proposed project was calculated to be about 8 in 10 million ( 0.8 in 1 million) per year $\left(7.7 \times 10^{-7}\right)$ by multiplying $1.87 \times 10^{-8}$ (in the ninth column of Table D.1) by 41 to account for both inhalation $\left(1.87 \times 10^{-8}\right)$ and ingestion (40 times $\left.1.87 \times 10^{-8}\right)$. The sum of the cancer risk from inhalation of dioxins, furans, and other carcinogenic substances $\left(1.42 \times 10^{-7}\right.$ in the ninth column of Table D.1) and from ingestion of dioxins and furans (40 times $\left.1.87 \times 10^{-8}\right)$ was calculated to be about 9 in 10 million ( 0.9 in 1 million) per year $\left(8.9 \times 10^{-7}\right)$. Given the upper-bound assumptions in the estimates, the risks would probably be less than these values.

Beryllium and mercury. Except for mercury emissions from burning petroleum coke, the proposed project could emit more beryllium and mercury (Table 4.1.5) than the amounts specified as significant in 40 CFR Part 51.166 (0.0004 tons per year for beryllium and 0.1 tons per year for mercury). In addition, mercury was raised as a pollutant of concern during public scoping. Therefore, further analysis is presented for these metals.

Table 4.1.5. Beryllium and mercury concentrations predicted to result from the proposed project compared with Florida Ambient Air Reference Concentrations (FAARCs)

\begin{tabular}{clccc}
\hline Element & Fuel type & $\begin{array}{c}\text { Emissions } \\
\text { (tons/year) }\end{array}$ & $\begin{array}{c}\text { Maximum 24-hour } \\
\text { average concentration } \\
\left(\mathrm{NG} / \mathrm{m}^{3}\right)^{a}\end{array}$ & $\begin{array}{c}\text { Maximum 24-hour } \\
\text { average concentration } \\
\text { as a percentage of } \\
\text { FAARC }\end{array}$ \\
\hline Beryllium & Coal & 0.008 & 0.02 & 0.5 \\
& Petroleum coke & 0.003 & 0.01 & 0.2 \\
Mercury & Coal & 0.10 & 0.28 & 1.4 \\
& Petroleum coke & $0.02^{b}$ & 0.06 & 0.3 \\
\hline
\end{tabular}

Nanograms per cubic meter; a nanogram is $10^{-9}$ grams, or one billionth of a gram.

${ }^{b}$ Emissions were not significant (40 CFR Part 51.166).

Beryllium is listed as a known carcinogen (cancer-causing substance) by the American Conference of Governmental Industrial Hygienists (ACGIH) (ACGIH 1997). It can also have chronic noncancerous effects such as berylliosis (noncancerous growths in the lungs) and acute effects which primarily affect the lungs. Mercury can cause ulceration, particularly within the digestive system, liver, and kidneys. Mercury may also disrupt endocrine function, which is of particular significance during fetal development and early childhood, when organ development is most rapid. 
Ambient air quality standards do not exist for beryllium and mercury; guideline concentrations are typically obtained either by back-calculating from EPA reference doses (Appendix D) or by adjusting time-weighted (8-hour) averages specified by ACGIH (1997) as maximum allowable concentrations for healthy workers, as follows. The first adjustment to the standards for healthy workers is made because they typically spend an average of 40 hours per week at their workplace rather than 168 hours (around the clock); therefore, the maximum allowable concentration for workers is divided by $4.2(168 / 40)$. The resulting concentration is then divided by 10 because the tolerance of an individual during their years as a healthy adult worker would be greater than for their entire lifetime, especially during childhood and old age. The resulting concentration value is divided again by 10 to account for differing sensitivities to environmental exposures experienced by members of the general population, including the infirm. The final result is a guideline maximum ambient air concentration; for concentrations below the guideline value, it is expected that the public would be protected from adverse impacts. Such guideline values (sometimes referred to as "no-threat levels") are commonly used as maximum permissible ambient air concentrations of substances regulated by 29 CFR Part 1910.1000 (Patrick 1994b); for beryllium and mercury, they are given in this analysis as 24-hour average FAARCs.

Maximum modeled ambient concentrations of beryllium and mercury that would result from the proposed project are compared to the FAARCs in Table 4.1.5. Beryllium concentrations would be less than $1 \%$ of the corresponding FAARC. The mercury concentration would also be less than $1 \%$ of its FAARC if petroleum coke is used as fuel and less than $2 \%$ of its FAARC if coal is used as fuel. These results corroborate the results obtained using the reference dose approach in the previous analysis (Appendix D) that beryllium and mercury emissions from the proposed project would pose no threat to human health.

The nearest PSD Class I areas are more than 30 miles from the site of the proposed project; the ISCST3 air dispersion model is not recommended at such distances (EPA 1995). However, because increased concentrations of beryllium and mercury at those distances would be only small fractions of the increases near the site of the proposed project, impacts to Class I areas would be negligible.

With regard to deposition, much uncertainty exists regarding the spatial distribution of mercury deposition downwind of emissions sources. Likewise, source identification and attribution based on measurements of mercury deposition (i.e., working in the reverse direction to identify sources of measured deposition) have proven difficult. Moreover, not all emissions are produced by human activity, and lack of reliable data about the speciation of mercury in source emissions further contributes to assessment difficulties (Hanisch 1998). Controversy exists regarding the magnitude of the local impact from sources such as power plants. Global and regional models suggest that about 50\% of manmade mercury emissions are transported globally, while the remaining 50\% deposit on a local or regional scale (EPRI 1994; Bullock, Brehme, and Mapp 1998). Another study has indicated that mercury is more of a global or regional problem than one 
Final: June 2000

of local concern because computer modeling has shown that most mercury emissions from power plants are transported over 60 miles away (Constantinou, Wu, and Seigneur 1995). However, some field measurements of oxidized, inorganic mercury appear to contradict this finding. This species normally represents only about 3\% of total gaseous mercury, but is expected to account for a major portion of mercury dry deposition. On the basis of measurements near the ground in close vicinity to power plants, a study concluded that cutting a local emissions source of oxidized, inorganic mercury could result in some local reduction of deposition (Lindberg and Stratton 1998). Similar uncertainty exists for deposition of other heavy metals.

Radionuclides. Fossil fuels and limestone contain trace quantities of naturally occurring radionuclides, primarily uranium-238, thorium-232, and their decay products. During the burning of fossil fuels, inert material either falls to the bottom of the combustor as bottom ash or becomes entrained in the gaseous combustion products as fly ash. This ash contains radionuclides originally present in the fuel and/or limestone. Fly ash not captured by pollution control equipment is emitted into the atmosphere as particulate matter. In addition, two radioactive noble gases, radon-220 and radon-222, are emitted from the combustor as gases. The quantities of naturally occurring radionuclides vary according to fuel type and its geographical location; coal typically contains the greatest total quantity per unit mass.

For a proposed facility very similar to the proposed project, detailed dose pathway analyses were performed for radionuclides in coal and limestone using two different approaches: measurement of radioactive species at an operating plant (Weston 1995) and calculations based on coal analysis coupled with emission factors (DOE 1995). The estimated radionuclide emission rates for the similar facility were approximately 10 times greater than the estimated radionuclide emission rates of $6 \mathrm{mCi} / y e a r$ for the proposed project. Not including radon gas, a lifetime cancer risk to the maximum exposed person in a range of 2 in 10 million $\left(2 \times 10^{-7}\right)$ to 2 in 1 million $\left(2 \times 10^{-6}\right)$ was obtained using the two approaches. Given that emissions from the proposed project would be about 10 times lower and that typical risks would be proportionally lower, the lifetime cancer risk for the maximum exposed person would be in the range of 2 in 100 million $\left(2 \times 10^{-8}\right)$ to 2 in 10 million $\left(2 \times 10^{-7}\right)$.

Because radon is a noble gas that is not captured in particulate filters, it is often treated separately. Using an upper limit for radon of approximately $175 \mathrm{mCi} / y e a r$ (DOE 1995) and an estimated dilution at the location of maximum exposure of about $6 \times 10^{-9} \mathrm{~s} / \mathrm{m}^{3}$ (the ratio of the maximum annual ground-level concentration in the ambient air calculated by the ISCST3 air dispersion model to the air emission rate), the dose is estimated to be approximately $3 \times 10^{-4} \mu \mathrm{rem}$ per year, which is about 2 billionths of the 160 mrem value given by EPA (1999b) for the dose from radon in the natural background. This small additional dose is associated with a lifetime risk of 1 in 100 billion $\left(1 \times 10^{-11}\right)($ ICRP 1991).

Sulfuric acid mist. Air emissions of sulfuric acid mist from the proposed project were identified as an issue during public scoping. The proposed project would emit about 5 tons per year 
of sulfuric acid mist. By comparison, the amount specified as significant in 40 CFR Part 51.166 is 7 tons per year. Consequently, emissions of sulfuric acid mist would be less than the level of concern. Furthermore, following the related action of repowering Unit 1, there would be a net decrease of about 187 tons per year of sulfuric acid mist because the existing Unit 1 annually emits about 197 tons while each of the repowered units would annually emit about 5 tons.

Proposed project and related action. The related action of repowering the existing Unit 1 would approximately double the emissions of toxic air pollutants from Northside Generating Station that were evaluated in Tables D.1 and 4.1.5. Although emissions from the existing Unit 1, which uses natural gas and/or fuel oil, would be replaced by the related action, those existing emissions of toxic air pollutants are likely to be small in comparison with those from the repowered Unit 1 , which would use coal and/or petroleum coke. Therefore, simply doubling the effects of the proposed project produces ground-level ambient concentrations that are similar, although somewhat higher, than concentrations obtained if credit were taken for (1) the elimination of emissions from the existing Unit 1, and (2) a greater initial upward momentum and buoyancy of the exhaust gas from the two repowered units operating simultaneously. Doubling the effects of the proposed project would not lead to any exceedances of, or close approaches to, any of the previously discussed guideline values for noncarcinogenic effects from toxic materials. The total cancer risk would be approximately 1.8 in 1 million per year (for the sum of the cancer risk from inhalation of dioxins, furans, and other carcinogenic substances and from ingestion of dioxins and furans), which is calculated for the location of maximum exposure. Given the upper-bound assumptions in the estimate, the risk would probably be less than this value at this location and even lower at other locations.

\section{Visibility}

Visibility, or background visual range, is defined as the maximum distance a large, black object can be observed on the horizon. The scenic quality of natural landscapes and their color, contrast, and texture, are improved by good visibility. Visibility, as a measure of clarity of the atmosphere, has been established as an important air-quality-related value of national parks and wilderness areas that are designated as PSD Class I areas.

Effects of the proposed project on visibility in the Okefenokee Wilderness Area, the nearest PSD Class I area (38 miles to the west), were analyzed using a conservative (upper-bound) screening procedure provided in Appendix B of a report prepared by the Interagency Workgroup on Air Quality Modeling (EPA 1993). Because the next nearest Class I area (Wolf Island Wilderness Area) is 63 miles north of Northside Generating Station (Section 3.2.2), any effects on visibility would be more pronounced at the Okefenokee Wilderness Area under similar meteorological conditions. The screening procedure used 24-hour concentrations obtained by applying the ISCST3 air dispersion model (in the same manner as for the criteria pollutants) to maximum hourly emissions of $\mathrm{SO}_{2}, \mathrm{NO}_{x}$, and PM-10 (Table 4.1.1). Calculations were made for existing emissions and expected emissions 
after the Unit 1 repowering (Table 4.1.1). The highest modeled 24-hour average concentrations for all 5 years (1984-88) were included in the analysis. A background visibility of 40 miles was used.

The results of the screening analysis indicate that the reduction in emissions of $\mathrm{SO}_{2}, \mathrm{NO}_{x}$, and PM-10 associated with the proposed project and the related action of repowering Unit 1 (Table 4.1.1) would lead to an increase in visibility of about 0.6 mile. This analysis exaggerates the effects on visibility of changes in concentrations of air pollutants; it is not likely that a change in visibility would be noticed at any Class I area as a result of the proposed project, either alone or in conjunction with the related action of repowering Unit 1. Nevertheless, the procedure does indicate that the net effect on visibility would be beneficial rather than detrimental.

\section{Acidic Deposition}

Acid rain, the popular name for acidic deposition, occurs when $\mathrm{SO}_{2}$ and $\mathrm{NO}_{x}$ are chemically transformed and transported in the atmosphere and deposited on the earth's surface in the form of wet (rain, snow, fog) or dry (particle, gas) deposition. $\mathrm{SO}_{2}$ and $\mathrm{NO}_{x}$ are readily oxidized in the atmosphere to form sulfates and nitrates. Subsequently, the sulfates and nitrates may form sulfuric acid and nitric acid when combined with water, unless neutralized by other chemicals present.

Acidic deposition may contribute to the acidification of lakes and subsequent damage to aquatic systems. Forests and agriculture are also potentially vulnerable because acidic deposition can cause leaching of nutrients from soils, inhibit microorganisms that convert atmospheric nitrogen into fertilizers for plants, and contribute to the release of toxic metals (EPA 1988). Acidic deposition also contributes to the corrosion of metals and deterioration of stone in buildings, statues, and other cultural resources. Sulfate particles and $\mathrm{NO}_{2}$ also reduce visibility by interfering with light transmission in the atmosphere. Whether a ton of $\mathrm{SO}_{2}$ or a ton of $\mathrm{NO}_{x}$ is more damaging depends on several factors, including the nature of the resource to be protected and the time scale under consideration. In general, however, there is no clear reason to consider either of these two precursors of acidic deposition as more damaging than the other on a ton-for-ton basis.

$\mathrm{SO}_{2}$ and $\mathrm{NO}_{x}$ can be transported by the wind for hundreds of miles from one region to another. Therefore, air over any given area will contain some residual emissions from distant areas and infusions received from nearby areas. This continuing depletion and replenishment of emissions along the path of an air mass makes it extremely difficult to determine relationships between specific sources of emissions and acidic deposition at any particular location.

As a consequence of JEA management's target of a $10 \%$ reduction in annual emissions of $\mathrm{SO}_{2}$ and $\mathrm{NO}_{x}$ from Northside Generating Station, annual $\mathrm{SO}_{2}$ emissions would decrease from 13,649 tons to 12,284 tons and annual $\mathrm{NO}_{x}$ emissions would decrease from 4,000 tons to 3,600 tons, effective for both the transition period after the Unit 2 repowering and after the Unit 1 repowering (Table 4.1.1). Table 4.1.6 compares these changes in annual emissions of $\mathrm{SO}_{2}$ and $\mathrm{NO}_{x}$ as a consequence of the proposed project with 1996 emissions from Florida (EPA 1997), which was chosen as an appropriate 
Table 4.1.6. Changes in emissions of acid-rain precursors as a consequence of the proposed project compared to emissions from all sources in Florida

\begin{tabular}{|c|c|c|c|}
\hline \multirow[b]{2}{*}{ Pollutant ${ }^{a}$} & \multirow[b]{2}{*}{$\begin{array}{c}1996 \text { Florida } \\
\text { emissions }^{b}\end{array}$} & \multicolumn{2}{|c|}{ Changes in emissions } \\
\hline & & Tons/year $^{c}$ & $\begin{array}{l}\text { As a percentage of } \\
\text { Florida emissions }\end{array}$ \\
\hline $\mathrm{SO}_{2}$ & 804,000 & $-1,365$ & -0.17 \\
\hline $\mathrm{NO}_{x}$ & 911,000 & -400 & -0.04 \\
\hline
\end{tabular}

${ }^{a} \mathrm{SO}_{2}=$ sulfur dioxide; $\mathrm{NO}_{x}=$ oxides of nitrogen.

${ }^{b}$ Florida emissions were obtained from EPA (1997).

'From Table 4.1.1.

area to represent emissions affecting acidic deposition. Emission decreases of $\mathrm{SO}_{2}$ and $\mathrm{NO}_{x}$ from Northside Generating Station would be only a small fraction of a percent of existing emissions from Florida. Thus, this beneficial reduction in emissions would probably not result in perceptible changes in acidic deposition.

\section{Global Climate Change}

A major worldwide environmental issue is the possibility of major changes in the global climate (e.g., global warming) as a consequence of increasing atmospheric concentrations of "greenhouse" gases (Mitchell 1989). The atmosphere allows a large percentage of incoming solar radiation to pass through to the earth's surface, where it is converted to heat energy (infrared radiation) that does not pass back through the atmosphere as easily as the solar radiation passes in. The result is that heat energy is "trapped" near the earth's surface. This phenomenon is commonly called the greenhouse effect because of an analogy with the glass in a greenhouse. However, the use of the term greenhouse effect to describe these radiative processes is somewhat of a misnomer because the main effect of the glass in a greenhouse is to act as a physical barrier that keeps the warm air inside.

Greenhouse gases include water vapor, $\mathrm{CO}_{2}$, methane, nitrous oxide, $\mathrm{O}_{3}$, and several chlorofluorocarbons. The greenhouse gases constitute a small percentage of the earth's atmosphere; however, their collective effect is to keep the temperature of the earth's surface about $60^{\circ} \mathrm{F}$ warmer, on average, than it would be if there were no atmosphere. Water vapor, a natural component of the atmosphere, is the most abundant greenhouse gas. The second-most abundant greenhouse gas is $\mathrm{CO}_{2}$, which has increased about $30 \%$ in concentration over the last century. It is generally agreed that fossil fuel burning is the primary contributor to increasing concentrations of $\mathrm{CO}_{2}$ (DOE 1989). The increasing $\mathrm{CO}_{2}$ concentrations may have contributed to a corresponding increase in globally averaged temperature in the lower atmosphere (IPCC 1992). 
Because $\mathrm{CO}_{2}$ is stable in the atmosphere and essentially uniformly mixed throughout the troposphere and stratosphere, the climatic impact does not depend on the geographic location of sources. Therefore, an increase in $\mathrm{CO}_{2}$ emissions at a specific source is effective in altering $\mathrm{CO}_{2}$ concentrations only to the extent that it contributes to the global total of fossil fuel burning that increases global $\mathrm{CO}_{2}$ concentrations.

The proposed project would increase global $\mathrm{CO}_{2}$ emissions by about 2,293,100 tons per year (Table 2.1.1), which is about $0.009 \%$ of annual global $\mathrm{CO}_{2}$ emissions from fossil fuel combustion (Table 4.1.7). The proposed project in conjunction with the related action of repowering Unit 1 (taking credit for the elimination of emissions from the existing Unit 1) would increase global $\mathrm{CO}_{2}$ emissions by about $3,842,800$ tons per year, or about $0.015 \%$. Increases expected from the proposed project alone or in conjunction with the related action are small in comparison with U.S. and global totals.

Table 4.1.7. Emissions of carbon dioxide $\left(\mathrm{CO}_{2}\right)$ from the proposed project by itself and in conjunction with the related action of repowering the existing Unit 1 compared to U.S. and global emissions from combustion of fossil fuels

\begin{tabular}{lccc}
\hline & \multicolumn{3}{c}{ Emissions } \\
\cline { 2 - 4 } \multicolumn{1}{c}{ Source } & $\begin{array}{c}\text { (As \% of U.S. total } \\
\text { of 5,643,991,000 } \\
\text { tons/year) }\end{array}$ & $\begin{array}{c}\text { (As \% of global total }_{\text {of } 25,128,900,000} \\
\text { tons/year) }\end{array}$ \\
\hline $\begin{array}{l}\text { Proposed project } \\
\text { Proposed project in }\end{array}$ & $2,293,100$ & 0.04 & 0.009 \\
$\begin{array}{l}\text { conjunction with } \\
\text { the related action }\end{array}$ & $3,842,800$ & 0.07 & 0.015 \\
\hline
\end{tabular}

National and global $\mathrm{CO}_{2}$ emissions were taken from Marland et al. (1998) and converted to tons of $\mathrm{CO}_{2}$ per year. Emissions from consumption of coal, oil, and gas and from gas flaring are included.

Airborne sulfates from fossil fuel combustion may be counteracting the greenhouse effect by increasing the reflection of incoming solar radiation (Mitchell et al. 1995). However, because annual $\mathrm{SO}_{2}$ emissions during the transition period after the Unit 2 repowering and after the Unit 1 repowering would decrease by $10 \%$ (1,365 tons) (Table 4.1.1), there would be less airborne sulfates to counteract the greenhouse effect. Assuming $\mathrm{SO}_{2}$ emissions are proportional to atmospheric sulfate loadings and global anthropogenic $\mathrm{SO}_{2}$ emissions are about 145 million tons per year (Hameed and Dignon 1992; Graedel and Crutzen 1993), then the proposed project in conjunction with the related action would decrease global anthropogenic sulfate loadings by about $0.001 \%$. This reduction would enhance any $\mathrm{CO}_{2}$-induced warming of the lower atmosphere, but it is not possible to provide a good estimate of the amount of the effect. In any case, the contribution of the proposed project and related action to global climate change would be small. 


\section{JEA EIS}

As an additional perspective, the following evaluation compares $\mathrm{CO}_{2}$ emissions to the amount of electricity generated at Northside Generating Station. As a consequence of the proposed project, $\mathrm{CO}_{2}$ emissions and power production would both increase. The ratio of $\mathrm{CO}_{2}$ emissions per $\mathrm{MWh}$ of electricity generated by the repowered units is estimated to be 0.98 tons per MWh (Table 2.1.1). Assuming that the ratio of $\mathrm{CO}_{2}$ emissions per $\mathrm{MWh}$ of electricity generated from the existing Unit 3 is the same as the ratio for the existing Unit 1 (calculated from Table 2.1.1), the current amount of $\mathrm{CO}_{2}$ emitted per $\mathrm{MWh}$ of electricity generated at Northside Generating Station is estimated to be 0.73 tons per MWh. Assuming that there would be no change in the existing capacity factors until the units are repowered and then the capacity factor for the repowered units would be $90 \%$, it is estimated that the amount of $\mathrm{CO}_{2}$ emitted per $\mathrm{MWh}$ of electricity generated would increase at Northside Generating Station to a ratio of 0.85 tons per $M W h$ during the transition period after the Unit 2 repowering. The expected ratio would further increase after the Unit I repowering to 0.91 tons per MWh. The combined result of the proposed project and the related action would thus be an approximate $25 \%$ increase in the amount of $\mathrm{CO}_{2}$ emitted per $\mathrm{MWh}$ generated at Northside Generating Station. This increase would be a result of using coal and petroleum coke in the repowered units whereas natural gas and fuel oil are currently used in the existing units.

\subsubsection{Surface Water Resources}

\subsubsection{Construction}

No change in the existing utilization or consumption of surface water would occur during the construction phase of the repowering of Units 1 and 2. All construction would be performed in accordance with an erosion and sedimentation control plan (JEA 1995; Foster Wheeler 1998b). Standard engineering practices such as straw berms, liners, cover materials, and grading would be implemented as required to minimize runoff, erosion, and sedimentation near the site. A Submerged Lands \& Environmental Resource Permit (SLERP) would be obtained from the FDEP for the construction and operation of the storm water treatment system. Impacts attributable to constructionrelated runoff, turbidity-causing agents, erosion, and sedimentation would be minimal.

Accidental spills of construction materials such as solvents, paint, caulk, oil, and grease that could contain hazardous substances would be cleaned up in a timely manner and in accordance with a spill prevention, control, and countermeasure plan (JEA 1992) and best management practices plan. The rapid cleanup would minimize the overland flow of accidental spills into San Carlos Creek or the back channel of the St. Johns River. 


\subsubsection{Operation \\ Hydrology}

Because Unit 2 has not operated since 1983, the proposed project (the repowering of Unit 2) would increase the demand for noncontact cooling water (however, not above permitted quantities). The current demand for cooling water by Units 1 and 3 combined is $620 \mathrm{Mgd}(430,700 \mathrm{gpm})$ (Figure 2.1.9). After Unit 2 is repowered, the entire 3-unit plant would use $827 \mathrm{Mgd}(574,000 \mathrm{gpm}$ ) (Figure 2.1.8). This would be approximately the same rate at which cooling water was used when the three units operated together from approximately 1978 until 1980 . The sustained flow of the back channel of the St. Johns River would not be depleted by this diversion because $815 \mathrm{Mgd}$ $(566,000 \mathrm{gpm})$ of the $827 \mathrm{Mgd}(574,000 \mathrm{gpm})$ of withdrawn cooling water would be returned to the river after passing through the condensers (Figure 2.1.8).

The tidal movement of seawater to and from the Atlantic Ocean ensures that Northside Generating Station would have a continuous supply of cooling water for the condensers even under conditions of prolonged drought. The tides would continue to occur twice daily even if the supply of fresh water flowing through the St. Johns River were reduced substantially by drought. The Atlantic Ocean serves as a virtually infinite source of cooling water for Northside Generating Station.

The rate at which heat would be rejected to the St. Johns River also would increase from the current operating level of $4 \times 10^{9} \mathrm{Btu} / \mathrm{hour}$ to $5.3 \times 10^{9} \mathrm{Btu} /$ hour after Unit 2 is repowered (EVSC 1983). However, the size of the thermal plume would not increase because the simultaneous operation of all three units would increase the discharge velocity, which would promote mixing and heat dissipation (Section 3.3.4). The thermal plume would be approximately the same size as when all three units operated at full capacity from 1978 until 1980.

With Northside Generating Station at full load, the related action of repowering Unit 1 would result in little or no change compared with facility operation after the proposed project is in operation because there would be little or no change in the rate at which cooling water would be required and the rate at which heat would be rejected to the river. However, because Unit 1's capacity factor would increase from about $30 \%$ (Table 4.1.1) to about $90 \%$ after its repowering, the annual volume of cooling water withdrawn from and returned to the river and the annual quantity of heat rejected to the river from Northside Generating Station would increase by approximately $40 \%$. The potential impacts to aquatic organisms resulting from this increased capacity factor are discussed in Section 4.1.6.2.

The permitted maximum total flow of $827 \mathrm{Mgd}(574,000 \mathrm{gpm})$ of noncontact cooling water for the three units at full load, which is specified in NPDES permit FL0001031 (JEA 1997b), would remain the same after the repowering. The temperature and total surface area of the thermal plume would not exceed the regulatory limits defined in the NPDES permit (Section 3.3.4) (JEA 1997b). The maximum width of the $2^{\circ} \mathrm{F}$ thermal discharge zone after repowering would not exceed the 275-yd NPDES permit limit. 


\section{JEA EIS}

There are no dams located near Northside Generating Station whose failure would induce a dambreak flood wave to jeopardize the structural integrity of the proposed CFB combustors. Rodman Dam is a low-head structure that is located approximately 80 miles upstream. The volume of water behind Rodman Dam is insufficient to sustain a dam-break flood wave over this distance that would inundate Northside Generating Station. The lakes of the St. Johns River are naturally formed bodies of water that were not created by manmade dams and would not endanger Northside Generating Station.

Runoff from facilities that would be built as part of the proposed project would be used in plant processes or routed through detention basins equipped with baffles or oil skimmers prior to being discharged at stormwater outfalls. The detention basins would reduce the maximum rate of stormwater discharge by increasing the length of time during which the discharge occurred. The baffles or oil skimmers would collect contaminants such as oil and grease that float on top of the stormwater. Environmental impacts associated with the runoff of stormwater would be minimized by the use of detention basins equipped with baffles or oil skimmers.

The existing Northside Generating Station stormwater discharges are regulated in accordance with a general permit (FLR00B341) issued by EPA (JEA 1997b). Coverage under a modified multisector general stormwater permit would be sought for the repowered Northside Generating Station.

Accidental spills from the proposed facility would be cleaned up in a timely manner in accordance with a spill prevention, control, and countermeasure plan (JEA 1992) and the best management practices plan for the facility (JEA 1995). The rapid cleanup of an accidental spill would minimize runoff into San Carlos Creek or the back channel of the St. Johns River and seepage into the groundwater. Two spills have occurred at Northside Generating Station during the unloading of fuel oil shipments. Corrective action was taken to prevent or mitigate further spills.

Tanks containing liquids such as fuel oils, waste oils, turbine lubrication oils, and fuel additives are either (1) surrounded by berms or dikes that would contain accidental leaks or spills, or (2) have controlled drainage areas whose runoff is routed to and collected in sumps (JEA 1992). The sumps are piped into the chemical wastewater treatment system. The berms or dikes and controlled drainage areas would prevent runoff from flowing overland into San Carlos Creek or the back channel of the St. Johns River if a tank failure released the stored liquid. Rapid cleanup of any liquid impounded by secondary containment that did not enter the wastewater treatment system would minimize seepage into the groundwater.

Power plant transfer piping is located above ground where practical and in areas protected by secondary containment or that drain to the wastewater treatment system (JEA 1992). Much of the remaining piping is located over paved or sandy areas that eventually flow overland into floor drains or drainage ditches. Guillotine failure (i.e., sheared off in a manner similar to the action of a paper cutter) of some portions of the transfer piping or undetected excess leakage at flange gaskets, pipe joints, or valve stem seals could cause an accidental spill with no secondary containment. The piping 
that connects the terminal unloading facility and the fuel oil storage tanks is not provided with secondary containment. Impacts associated with transfer piping failure or leakage would be minimized because (1) the piping is routinely inspected on a daily basis and more frequently while pumping is in progress, and (2) most pipeline failures manifest themselves as small-scale, gradually increasing leaks that would be detected during routine inspection before excess leakage would impact the environment.

\section{Water Quality}

Because of hydrodynamic processes and inputs of contaminants from a variety of sources into the lower St. Johns River, any incremental effects on water quality in this section of the river resulting from operation of the combined St. Johns River Power Park/Northside Generating Station facilities would be very difficult to detect or assess. The hydrodynamics of the lower St. Johns River are dominated by tidal processes which can create highly variable currents and tidal flow regimes. With an average of four tidal flow changes each day, contaminants in the lower St. Johns tend to be diluted and eventually flushed out of the system. The hydrology regimes of the lower St. Johns River system are primarily responsible for distributing and determining the fate of natural and anthropogenic sources of nutrients and pollutants (Brody 1993). Because of the low hydraulic gradient and the dominating tidal flow in this portion of the river, the net flow of the river can often be negative over a 24-hour period. Under certain conditions (such as during low rainfall periods), the river can actually flow upstream prolonging flushing and therefore having little effect on improving water quality in the vicinity of the site. In addition, because the St. Johns River in the site vicinity is downstream from the urban core of Jacksonville, the water quality in this section of the river is probably much more reflective of upstream inputs of industrial and domestic discharges than of inputs from the St. Johns River Power Park/Northside Generating Station facilities.

In addition to the effluent discharges from the power plant facilities, water quality in the St. Johns River in the site vicinity could also be potentially affected by dredging operations. Dredging for the new fuel unloading dock (Option 2) would occur between the edge of the present channel and the present dock facility. Approximately $150,000 \mathrm{yd}^{3}$ of sediment would be removed to expand the channel depth from an average of -25 to $-40 \mathrm{ft}$ amsl. Approximately one-third $(5 \mathrm{ft})$ of this dredge material would represent sediment in the upper layer that has been deposited since previous dredging operations, and the remaining two-thirds (10 ft) underneath would represent old or relatively clean sediment. These dredging activities, which are regulated under Section 404 of the Clean Water Act, would not be expected to have an adverse effect on local water quality except for brief periods during the operation itself. The only major water quality change would be localized increases in turbidity and fine suspended sediment. Dredge spoil from such operations is usually pumped to a dredge spoil holding pond on the site where slurry water in the pond slowly percolates through the sandy retention basin. Some discharges of decant from the dredge spoil holding pond 
into San Carlos Creek could occasionally occur, however, during periods of heavy use or rainfall. Even though this type of discharge is generally excluded from NPDES permitting, regulations pertaining to return water from upland contained disposal areas are addressed under Section 404 of the Clean Water Act. Utilization of the dredge spoil site and any discharges associated with the spoil site would be addressed in the SLERP, which would be jointly reviewed by the FDEP and the COE. .

\subsubsection{Geological Resources}

\subsubsection{Groundwater}

Water supply during construction of the proposed project would be obtained from the existing Northside Generating Station potable water supply pumped from groundwater. Water use during construction would include rinsing of equipment and structures as well as preparation of mixtures such as grout. Because concrete would be prepared off the site, groundwater use at Northside Generating Station would not be affected by concrete formulation. Water would be available to extinguish accidental fires that could occur during construction. The finite duration and size of the project as well as the intermittent use and consumption of water during construction would not cause the existing potable water wells to be overpumped.

The pipeline that delivers treated groundwater would be tapped and used to provide water for construction activities. The existing Northside Generating Station infrastructure would be used to supply drinking water and service lavatories and toilets. Drinking water for construction workers also would be provided using bottled water. Portable toilets would be provided to minimize requirements for additional sanitary water.

During operation of the proposed project, groundwater consumption by Northside Generating Station would be reduced by $10 \%$ from the upper Floridan aquifer, based on a comparison of the existing and proposed water balances in Figures 2.1.9 and Figure 2.1.8, respectively. A $10 \%$ reduction in groundwater consumption, which is the goal set by JEA, would decrease the rate of decline of the potentiometric surface of the upper Floridan aquifer. Stabilization of the potentiometric surface would result in two primary benefits: (1) more groundwater would be available to Northside Generating Station and other local users for a longer period of time and (2) the water quality would be stabilized because of the reduced influx of brackish water from the lower Floridan aquifer.

The impact to the surficial aquifer during operation of the proposed project would be considerably less than under existing conditions. The currently unlined settling ponds would be lined for the proposed project, and the supernatant from the settling ponds would be routed to the reuse tank. The overflow from the settling ponds would be directed to the existing percolation pond, and consequently to the surficial aquifer, only on an occasional basis when the reuse tank is full.

Following operation of the proposed project, the groundwater mound beneath the percolation pond would be reduced considerably in size and the impact on surrounding groundwater, wetlands, and 
streams would correspondingly be reduced. Although the proposed project's filter backwash water would be relatively rich in suspended solids that are removed from the main effluent by the filtration unit, its chemical character would be similar to the existing effluent in the percolation pond. Alkaline leachate from the uncovered limestone storage pile would percolate from the surface to the surficial aquifer, which would tend to neutralize the surficial aquifer's acidic nature [as indicated by routine analyses of samples from the background well (NS19)].

Contaminants would be unlikely to migrate downward from the surficial aquifer to the upper Floridan aquifer. As discussed in Section 3.4, the two aquifers are hydraulically isolated from one another and the upper Floridan aquifer has a higher potentiometric surface. Natural hydraulic isolation is provided by the confining strata in the Hawthorn Formation, and the production wells in the upper Floridan aquifer are cased-off from the surficial aquifer. The casing consists of steel tubing that has perforated walls only in the production zone and is completely surrounded by cement extending from the surface down to immediately above the production zone. Routine servicing of production wells helps maintain the integrity of the well casing and annular grout, thus reducing the chance for a breach between the surficial and upper Floridan aquifers.

The hydraulic pressure differential between the two aquifers would cause upward flow from the Floridan aquifer to the surficial aquifer in the event that hydraulic connection would be established between them. At present production rates in the upper Floridan aquifer at Northside Generating Station and the St. Johns River Power Park, the upper Floridan aquifer's potentiometric surface would be likely to remain higher than the surficial aquifer's potentiometric surface during the lifetime of the proposed project (Section 3.4).

\subsubsection{Subsidence}

Because the characteristics of the two small topographic depressions located on the south side of and immediately south of the dredge spoil site are not fully known (Section 3.4.6.1), subsidence from limestone solution cavities at a shallow depth on the site cannot be completely dismissed. However, such cavities are rare in the Jacksonville area because shallow limestone lenses are thin and discontinuous (Section 3.4.6.1). Sudden collapse or gradual subsidence at the surface does not generally occur unless the depth to the cavity is less than 6 or 30 times, respectively, the thickness of the cavity. For example, a 2-ft-thick cavity would need to be within $12 \mathrm{ft}$ of the surface to cause collapse or within $60 \mathrm{ft}$ of the surface to cause measurable subsidence. Large and extensive solution cavities in the Floridan aquifer would not be a concern because they are more than $800 \mathrm{ft}$ deep in the Jacksonville area.

One topographic depression is located at the proposed site for the covered fuel storage enclosure and the other topographic depression is located at the proposed site for the limestone storage pile (Figure 3.4.2) under Option 2 for the solid fuel and limestone delivery and handling system (Section 2.1.3). Because the overall weight of the covered fuel storage enclosure and its fuel would 
be less than the overall weight of dredge spoil previously stored at the first location, subsidence or structural collapse of a potential solution cavity as a result of the new storage enclosure would be unlikely. At the second location (south of the dredge spoil site), subsidence or collapse of the limestone storage pile into a thin cavity would not be a major concern because of the nonhazardous characteristics of limestone and the absence of structures associated with the pile.

Geotechnical site investigations would precede construction of any new major structures associated with the proposed project. Such investigations would be designed to reveal any solution cavities within $100 \mathrm{ft}$ of the surface that might cause the surface to collapse or subside appreciably. If a cavity were detected, collapse and subsidence at the surface would be prevented by filling the cavity.

\subsubsection{Settlement and Erosion}

Settlement and erosion potential were discussed in Section 3.4.6.2. Geotechnical site investigations would reveal any unusual settlement and erosion features prior to construction of major structures associated with the proposed project. Standard foundation preparation such as densification of unconsolidated sands and removal of soils mixed with decaying vegetation would be accomplished prior to construction of structures. Proper foundation preparation would prevent structural damage and reduce cosmetic damage during the lifetime of the proposed project. Site preparation and construction would also be preceded by development and implementation of an erosion and sedimentation control plan (ESCP) and a spill prevention, control, and countermeasures plan (SPCCP). Critical facilities would be protected from foundation erosion by protective layers of riprap, vegetation, or storm-surge energy deflectors, as appropriate.

\subsubsection{Earthquakes}

Section 3.4.6.3 discussed probabilities and consequences of earthquakes in northern Florida. Site-specific earthquake analyses have not been performed because such analyses are reserved for high-hazard facilities (e.g., nuclear power plants).

Earthquake design at the proposed site would be based on recommendations contained in the Uniform Building Code (UBC) (Section 3.4.6.3). UBC seismic design features are based on the regional seismic hazard analyses of Algermissen et al. (1990). Staub (1991) demonstrated that Algermissen's seismic hazard analyses are generally conservative with respect to site-specific analyses at U.S. nuclear power plants located east of the Rocky Mountains. The design ground motion of $0.075 \mathrm{~g}$ has a $10 \%$ probability of exceedance in 50 years. Because the proposed facilities have a design life of 30 years, the probability of exceedance would be less than $10 \%$. If a larger earthquake should occur, damage would range from slight to significant depending on the size of the earthquake. Onsite impacts would be similar to existing potential impacts from earthquakes except that the proposed higher stacks would be more likely to experience damage, and slope failures could 
occur along the steep sides of the 100-ft high ash storage pile. Impacts to offsite areas would include possible loss of electric power and damage to existing infrastructure until repairs could be completed.

The local faults postulated by Leve (1978) do not contribute to the earthquake hazard. If these faults exist, they do not reach the surface and do not displace Miocene and younger strata (strata that are less than 22 million years old).

\subsubsection{Floodplains, Storm Surge, and Wetlands}

The DOE regulation (10 CFR Part 1022) implementing Executive Order 11988 (Floodplain Management) and Executive Order 11990 (Protection of Wetlands) requires DOE to avoid direct and indirect support of development in floodplains and wetlands wherever there is a practical alternative. Where there is no practical alternative, DOE is required to prepare a floodplain and wetlands assessment discussing the effects on the floodplain and wetlands, and consideration of alternatives. DOE is also required to provide opportunity for public review of any plans or proposals for actions in floodplains (and new construction in wetlands). The floodplain and wetlands assessment discussing the effects on floodplain and wetlands anticipated from this proposed project has been prepared and included in this EIS, as required by DOE regulation [10 CFR Part 1022.12(b)]. For a full review of the floodplain and wetlands assessment, please refer to these parts of the EIS: Section 3.5.1 (Floodplains-Existing Environment), Section 3.5.3 (Wetlands-Existing Environment), Section 4.1.5.1 (Floodplains-Environmental Consequences), Section 4.1.5.3 (Wetlands-Environmental Consequences), and Section 7 (Regulatory Compliance and Permit Requirements). Opportunity for public comment and suggestions on the proposed scope of the EIS, including floodplain and wetlands issues and alternatives, was provided during the public scoping period announced by the Notice of Intent published by DOE on November 13, 1997

(62 FR 60889-92). Additional opportunity for public review of the proposed project's potential effects on floodplain and wetlands was provided during the public comment period on the draft EIS.

For actions that would be located in a floodplain, DOE regulations require a brief statement of findings describing the proposed action, location, alternatives considered, compliance of the proposed project with applicable state and local floodplain protection standards, and steps to be taken to minimize potential harm to or within the floodplain. The statement of findings for this proposed action has been incorporated into the EIS (Section 7.1), as provided by DOE regulation [10 CFR Part 1022.15(b)(5)].

The estuarine emergent wetlands in the project area have been identified by the National Marine Fisheries Service as Essential Fish Habitat (Letter No. 7 in Appendix G). DOE has consulted with the National Marine Fisheries Service on measures to protect Essential Fish Habitat. As part of the consultation, DOE prepared an Essential Fish Habitat Assessment dated January 24, 2000 (Appendix F), in which DOE determined that there would be no substantial 
adverse effect on Essential Fish Habitat in the project area as a consequence of the proposed project. After reviewing the Essential Fish Habitat Assessment, the National Marine Fisheries Service requested additional clarifying information regarding the wetlands in a letter dated February 23, 2000 (Appendix F). After receiving the additional information from $D O E$, the National Marine Fisheries Service sent a letter to DOE dated March 27, 2000 (Appendix F), in which they stated that they concur with DOE's determination that the project would not adversely affect Essential Fish Habitat and that they have no further objection to the project.

\subsubsection{Floodplains}

The main structure that houses the turbines for Units 1, 2, and 3 at Northside Generating Station resides on a graded, nearly level site with an approximate land elevation that-for the most part-slightly exceeds $10 \mathrm{ft}$ amsl (USGS 1992b). Flooding of the main structure would not be anticipated because the September 10,1964, flood of record that occurred during hurricane Dora rose to an elevation of only $7.9 \mathrm{ft}$ amsl at this location (Section 3.5.2).

Most of the land for the existing and proposed power blocks is located above the 500-year floodplain of $10 \mathrm{ft}$ amsl (Section 3.5.1). A small portion of this land along the southern edge of the existing and proposed structures could be inundated by an approximate 100 - to 500 -year flood to depths averaging less than $1 \mathrm{ft}$. Nuisance flooding of this type would not endanger the repowered units or the remaining Unit 3 because the boilers and major combustion equipment are located either on or above the second floor.

The covered fuel storage enclosure under Option 2 for the solid fuel and limestone delivery and handling system (Section 2.1.3) would be located along the southern edge of the dredge spoil site (Figure 3.4.2), lying above the 500-year floodplain. Contamination attributable to fuel pile runoff would not be anticipated because the enclosure would provide isolation from rainfall during an extreme precipitation event.

The surge buildings (that would be used to store petroleum coke and coal and to facilitate a steady supply to the conveyor) and the temporary limestone pile at the receiving facilities would be located on the 100-year floodplain along the St. Johns River. These facilities would be subjected to flooding during such an event. The surge buildings would partially protect and retain the petroleum coke and coal. The large quantities of water that would be present during an extreme flood would rapidly dilute any flood-induced seepage of dissolved petroleum coke or coal from the surge facilities to very low concentrations. Inundation and concomitant failure of the limestone pile would not be of concern. Limestone (Whitten and Brooks 1972) consists of the minerals calcite $\left(\mathrm{CaCO}_{3}\right)$ and dolomite $\left[\mathrm{CaMg}\left(\mathrm{CO}_{3}\right)_{2}\right]$. Both calcium (as $\mathrm{Ca}^{2+}$ ) and magnesium (as $\mathrm{Mg}^{2+}$ ) already are major contributors (i.e., the calcium and magnesium are pervasive) to the salinity of seawater (Duxbury 1971). 
The fuel unloading facilities that are part of the proposed project would not encroach measurably on the floodplain. The surge buildings for petroleum coke and coal, the limestone pile, and pilings associated with the conveyor would not be large enough to block the natural flow of the river and tides. The vast array of tidal marshlands, the relatively low topographic relief in the vicinity of Northside Generating Station, and the sparseness of prominent features ensure that excess water present during an extreme flood would have sufficient area in which to spread out.

Construction and operation of the proposed project would not result in any stream diversions that would be large enough to alter existing offsite drainage patterns. The surface water supplied to Northside Generating Station is approximately $10 \%$ of the average flow passing through the back channel of the St. Johns River (JEA 1976). Most of this noncontact cooling water would be returned to the river such that the average flow of the river would not be impacted. The land occupied by and immediately surrounding the repowered units would be sloped to promote drainage away from structures.

\subsubsection{Storm Surge}

With regard to storm surge, the occurrence of a hurricane similar to Dora would not flood the existing and proposed power block areas at Northside Generating Station (Section 3.5.2), and the repowered units would remain standing after the hurricane had passed. Wind speeds produced by Dora place the effects of this hurricane in category 3 at St. Augustine and category 1 at Jacksonville (Table 4.1.8). The major damage from Dora slightly inland at Jacksonville was caused by wind and not by storm surge. Although some wind damage (such as broken windows and torn roofing) probably would result from a hurricane similar to Dora, major structural damage would not be expected. Power lines that have not been designed to withstand hurricane-force winds would be destroyed. The fuel unloading facilities on the 100 -year floodplain would be more susceptible to hurricane-induced wave damage and would be a concern.

The predicted maximum storm surge heights in the vicinity of Northside Generating Station using the Sea, Lake, and Overland Surges from Hurricanes (SLOSH) model (NOAA 1992) are $21.7 \mathrm{ft}$ for a category 5 hurricane, $18.3 \mathrm{ft}$ for a category 4 hurricane, and $14.4 \mathrm{ft}$ for a category 3 hurricane. These predictions are slightly greater than the general guideline used to estimate storm surge based on hurricane category (Table 4.1.8). Because the site elevation at the base of the proposed power block is approximately $10 \mathrm{ft}$ amsl, the level of inundation based on the SLOSH model would be $11.7 \mathrm{ft}$ for a category 5 hurricane, $8.3 \mathrm{ft}$ for a category 4 hurricane, and $4.4 \mathrm{ft}$ for a category 3 hurricane.

A direct hit at Jacksonville of a category 3,4 , or 5 hurricane could jeopardize the structural integrity of the repowered units. Although the inland location of Northside Generating Station, the presence of the beach ridge along the dune line, and Blount Island would partially mitigate the effects of storm surge and waves that would occur along the beaches, the first floor of Northside 
Table 4.1.8. Categories of hurricane intensity

\begin{tabular}{|c|c|c|c|c|}
\hline Category & Description & $\begin{array}{l}\text { Wind speed } \\
\text { (mph) }\end{array}$ & $\begin{array}{l}\text { Storm surge } \\
(\mathrm{ft})^{a}\end{array}$ & Damage \\
\hline 1 & Minimal & $74-95$ & $4-5$ & $\begin{array}{l}\text { Damage primarily to shrubbery, tree foliage, } \\
\text { and unanchored mobile homes. Minor pier } \\
\text { damage, some small craft in exposed } \\
\text { anchorages torn from moorings. }\end{array}$ \\
\hline 2 & Moderate & $96-110$ & $6-8$ & $\begin{array}{l}\text { Some trees blown over. Major damage to } \\
\text { exposed mobile homes. Some damage to } \\
\text { roofing materials of buildings. Small craft in } \\
\text { unprotected anchorages tom from moorings. } \\
\text { Evacuation of some shoreline residences and } \\
\text { low-lying islands required. }\end{array}$ \\
\hline 3 & Extensive & $111-130$ & $9-12$ & $\begin{array}{l}\text { Foliage torn from trees, large trees blown } \\
\text { over. Some damage to roofing materials of } \\
\text { buildings; some window and door damage. } \\
\text { Some structural damage to small buildings. } \\
\text { Mobile homes destroyed. Serious flooding at } \\
\text { the coast. Low-lying inland escape routes cut } \\
\text { off by rising water } 3 \text { to } 5 \text { hours before } \\
\text { hurricane center arrives. Flooding of flat } \\
\text { terrain having an elevation less than or equal } \\
\text { to } 5 \mathrm{ft} \text { amsl }{ }^{b} \text { as far as } 8 \text { miles inland or more. }\end{array}$ \\
\hline 4 & Extreme & $131-155$ & $13-18$ & $\begin{array}{l}\text { Extensive damage to roofing materials, } \\
\text { windows, and doors. Complete failure of } \\
\text { roofs on many small residences. Flooding of } \\
\text { flat terrain having an elevation } \leq 10 \mathrm{ft} \text { amsl as } \\
\text { far as } 6 \text { miles inland. Major damage to lower } \\
\text { floors of near shore structures from flooding } \\
\text { and battering of waves and floating debris. } \\
\text { Major erosion of beaches. Massive evacuation } \\
\text { possibly required of residences within } 500 \text { yd } \\
\text { of shore and of single-story residences on low } \\
\text { ground within } 2 \text { miles of shore. }\end{array}$ \\
\hline 5 & Catastrophic & $>155$ & $>18$ & $\begin{array}{l}\text { Complete roof failure of many residences and } \\
\text { industrial buildings. Severe and extensive } \\
\text { damage to windows and doors. Some } \\
\text { complete building failures. Major damage to } \\
\text { lower floors of all structures less than } 15 \mathrm{ft} \\
\text { amsl within } 500 \text { yd of the shore. Massive } \\
\text { evacuation possibly required of residential } \\
\text { areas on low ground within } 5 \text { to } 10 \text { miles of } \\
\text { the shore. }\end{array}$ \\
\hline
\end{tabular}

\footnotetext{
${ }^{a}$ General guideline to estimate the depth of water above the normally occurring water level.

${ }^{b}$ Above mean sea level (amsl).

Source: Lutgens and Tarbuck 1998.
} 
Generating Station could be inundated. Wave-induced forces could destabilize the base of the structures while hurricane-force winds could simultaneously damage the structures. In a worst-case scenario, the repowered units could be toppled. The storm surge also could destroy the fuel unloading facilities. The propensity for hurricanes to bypass Jacksonville categorizes the occurrence of a category 3,4 , or 5 hurricane at Jacksonville as a low-probability, high-consequence event.

\subsubsection{Wetlands}

Ecological impacts to wetland areas from the proposed project would be minor because no more than 1.8 acres of isolated hardwood wetland habitat would be lost during construction of the ash storage area and disturbance of salt marsh habitats during construction of the solid fuel delivery system would be negligible. Wetlands associated with the upper salt marsh communities would not be measurably affected because nearly all of the conveyor system for solid fuel delivery associated with either unloading option would span these habitats using existing structures and would involve no clearing or earthmoving activities. Although some pilings may need to be installed at the upper fringes of the salt marsh and in San Carlos Creek, any impacts resulting from piling installation would be very localized and temporary and should not measurably affect the normal structural and functional dynamics of the salt marsh and nearby estuarine ecosystems.

Delineation of wetland boundaries near the site was particularly difficult during the winter of 1997-98 because of high rainfall and resulting high water levels. Consequently, the exact amount of wetland area to be disturbed by the ash storage area was difficult to determine. However, loss of only about 1 acre of hardwood wetlands south of Ostner Road and 0.8 acre north of Ostner Road would not measurably affect the ecological status of the wetland communities in the site vicinity because (1) 1.8 acres of hardwood wetlands represents no more than $2 \%$ of this type of ecological habitat that occurs within a 1-mile radius of the site and these wetland systems are prevalent throughout northern Florida and (2) some of the hardwood wetland communities in the site vicinity have experienced some deterioration over the past few years (even though they are still given the same consideration as undisturbed wetlands for ecological potential). Specifically, an old dirt road, which traverses through portions of the wooded area northeast of the site, functions as an impediment to natural hydraulic flow through a part of the wetland areas because the road is elevated a few feet above the ground and has no breaks or passages for water to flow from one side to the other. The wetland systems on opposite sides of the road are different: those on the downstream side of the road, including the 1 acre south of Ostner Road to be used for the ash storage area, have experienced some deterioration in their ecological character, perhaps because of altered hydraulic flow regimes in this area. Construction activities should not affect this situation because the primary restriction to water flow in this section of the wetlands system appears to be the existing dirt road.

Originally, another site was considered for the ash storage area, which included a 1-acre wetland site within the San Carlos Creek floodplain. However, after an alternative analysis was conducted 
under DOE regulations 10 CFR Part 1022, the current site was chosen because it minimizes potential impacts. The current site includes a 200 -ft buffer zone extending to the San Carlos Creek floodplain, which would minimize any impacts to the San Carlos Creek system.

As a mitigation measure to offset the loss of 1.8 acres of hardwood wetlands during construction of the ash storage area, JEA would purchase 3 credits (slightly greater than 3 acres) of wetlands from an offsite mitigation bank and restore 1 acre of salt marsh, resulting in a mitigation ratio of greater than 2.2 to 1 (more than 4 acres of wetlands gained to 1.8 acres lost). The 1.8 acres of hardwood wetlands are not high-quality habitats, as evaluated by the COE wetlands rapid assessment procedure. Both the COE and the FDEP approve of this mitigation plan. In addition, JEA plans to set aside and preserve 15 acres of undisturbed, uplands maritime oak hammock along the west bank of San Carlos Creek. By preserving the land, JEA would maintain habitat for wildlife, help protect the water quality of the creek, and leave a high-quality forested buffer area in a developing industrial area. Access to the preserve would be limited to a primitive walking path. Preservation of this land is considered a project enhancement rather than a mitigation measure.

\subsubsection{Ecological Resources}

\subsubsection{Terrestrial Ecology}

The ash storage area would require harvesting of approximately 28 acres of pine plantation and loss of 10 acres of upland hardwood/pine habitat. These areas are located immediately north of the 40-acre dredge spoil area. Disturbance or removal of this pine and hardwood acreage would not have a measurable effect on the ecological status of these terrestrial systems because of the prevalence of these communities in the vicinity of the site. Pine flatwood communities, in particular, are not only common in the area, but also make up a large percentage of terrestrial systems in northern Florida. Also, wildlife that frequent these habitats would not be measurably affected because sufficient similar habitat borders the disturbed area and wildlife species could easily relocate and/or recolonize these adjacent sites.

Gopher tortoises, a state protected species, frequent the pine flatwood areas, including the pine plantation, because of the availability of well-drained sandy soils for construction of their burrows. Loss of 28 acres of pine flatwood habitat would not measurably affect the distribution and success of the gopher tortoise populations because of the widespread availability of similar habitats in the site vicinity and the ability of this species to rapidly recolonize previously disturbed areas. Relocation of tortoises provides them a better chance of survival than taking no action. However, some mortality is still possible. Previous tortoise relocation efforts by JEA have apparently been successful and researchers at Jacksonville University have also successfully relocated tortoises on the university grounds. Any tortoises that are relocated on the Northside property because of construction activities would be moved only a few hundred yards and re-established in similar habitats of raised sandy berm areas. JEA personnel have noted that tortoises are relatively mobile and dig and abandon burrows 
frequently. In fact, recent excavation efforts found only one tortoise in six burrows excavated. JEA's permit from the Florida Game and Freshwater Fish Commission limits the number of tortoises to be relocated, specifies how they are to be captured, and indicates where they are to be relocated.

\subsubsection{Aquatic Ecology}

Potential impacts of the proposed project on the aquatic ecology in the site vicinity primarily are associated with the thermal discharge system, entrainment and impingement of organisms into the cooling water intake system, use of biocides, and dredging of the St. Johns River to expand the dock facilities for fuel unloading (Option 2). Because thermal, entrainment, impingement, and dredging related impacts directly involve the back channel of the St. Johns River, the following analysis focuses on the aquatic ecology in this section of the river.

\section{Thermal Effects}

The design criteria for the proposed project would maintain the circulating flow rates and condenser temperature rises that are currently authorized under NPDES Permit FL001031 (i.e., maximum withdrawal rate of $827 \mathrm{Mgd}$, maximum temperature rise of $19^{\circ} \mathrm{F}$, and maximum daily average of $104^{\circ} \mathrm{F}$ ). Additionally, the total area of the discharge plume would be regulated by limits currently specified in the NPDES permit renewal (Section 3.3.4). The thermal discharge limits were formulated using results from thermal plume mathematical modeling studies that assessed and substantiated the preoperational design of Northside Generating Station (JEA 1976), as well as results of an extensive biomonitoring program which was conducted over a 2-year period during the time when all 3 units were in operation (EVSC 1981b). Thermal plume mapping surveys demonstrated, however, that the extent of the Northside Generating Station thermal plume as defined by the area of the $2^{\circ} \mathrm{F}$ mixing zone was approximately one-tenth the size of the plume permitted by the NPDES limits (Section 3.3.4). The largest plume measured was 7 acres while the NPDES permit limit is 102 acres. Water temperature measurements recorded near the mouth of San Carlos Creek during this study also verified that the thermal plume did not penetrate into this system. During operation of the proposed project, the thermal discharge and the associated thermal plume from Northside Generating Station would be maintained within the constraints established in the NPDES permit, and conditions would be very similar to those experienced for the three-unit facility during the surveys.

Several factors suggest that thermal discharges associated with the proposed project would not have measurable effects on the biota of the St. Johns River and the surrounding tidal creek/salt marsh ecosystems. Because only about $35 \%$ of the flow of the St. Johns River passes through the back channel and only a portion of the back channel is thermally elevated, the thermal plume should not act as a barrier for normal or unrestricted passage of organisms up and down the river. In addition, there is no evidence that adult or juvenile fish or shellfish congregate in the zone of thermal 
influence during the winter. Any increase in number of free-swimming species in the site vicinity could be attributed more to manmade structures, such as pilings and rip-rap which attract organisms, than to other environmental factors in the site vicinity (EVSC 1981b).

Most species of fish would be unlikely to reside or congregate in the thermal discharge area for extended periods of time because of the relatively swift flows $(1-3 \mathrm{ft} / \mathrm{s})$ in the channel. Under these relatively high flow conditions, some species of fish would have difficulty maintaining position in the mid-channel area for extended periods of time. In addition, this section of the St. Johns River in the vicinity of the Northside Generating Station intake and discharge is not considered a spawning area for any ecologically important fish or shellfish species (JEA 1976). Unavailability of preferred spawning or feeding habitat would also tend to minimize the probability that fish species would frequent and reside in this area for extended periods of time. It is also unlikely that bottom-dwelling organisms such as macroinvertebrates would experience effects as a result of thermal discharges because the discharge plume is directed upward and is largely a surface phenomenon.

If, however, organisms such as fish would congregate in the thermal discharge area during the winter, it is very unlikely that a cold shock event would occur because all of Northside Generating Station's units would probably never be shut down simultaneously. The repowered Units 1 and 2 would operate at a capacity factor of about $90 \%$. In contrast, the existing Unit 1 operates at a capacity factor of about $40 \%$ (primarily during the summer and winter months to meet the larger demand for electricity resulting from the use of air conditioning and heating, respectively). Unit 3 is expected to continue its current mode of operating at a capacity factor of about $40 \%$. A more detailed analysis of the $40 \%$ capacity factors for the existing Units 1 and 3 indicates that they are operating at full or partial load about $70 \%$ of the time and they are not operating about $30 \%$ of the time. With regard to thermal discharge, the net result of this change in operations after the repowering of Units 1 and 2 would be an environment that would minimize the potential for thermal-related impacts on aquatic organisms because the thermal discharge would be relatively constant compared with the variability of current facility operations. Therefore, maintenance of this relatively constant thermal plume would reduce the potential for cold shock and thermal-related stress to aquatic organisms in the site vicinity.

In summary, thermal discharges from the proposed project would not be expected to have a measurable effect on the biota of the area because (1) the design flow rates and temperature rises would be maintained at or below the approved limits in the 316 demonstration (Section 3.3.4) and the NPDES permit for minimizing ecological impacts, (2) organisms would not be expected to reside or congregate in the thermal plume area because of factors that limit their occurrence, (3) the extent of the thermal plume would be relatively small and should not prevent organisms from avoiding the plume area or moving freely up and down the river, and (4) the design of the discharge is such that bottom-dwelling organisms would experience minimal thermal exposure. 


\section{Entrainment and Impingement}

The volume of cooling water withdrawn and water velocity at the intake screens for the proposed project would be identical to those originally evaluated in the Northside Generating Station 316 demonstration (Section 3.3.4) and would be limited as specified in the NPDES permit. The maximum water withdrawal for Northside Generating Station would be $574,000 \mathrm{gpm}$ and the design velocity at the cooling water intake structures in the St. Johns River would be approximately $3 \mathrm{ft} / \mathrm{s}$, which were found acceptable in the 316 studies for minimizing impacts to free-swimming species (JEA 1976).

On an annual basis, losses to the zooplankton population resulting from entrainment during cooling water withdrawal are predicted to be only $0.8 \%$ of the population that passes through the back channel of the St. Johns River (EVSC 1981a). Because approximately 35\% of the total tidal flow of the river passes through the back channel, only about $0.3 \%$ of the total zooplankton population of the river near the vicinity of the site would be lost assuming a through-plant mortality of $100 \%$. These relatively small losses, coupled with inherently high reproduction, recruitment, and turnover rates of small organisms such as zooplankton (Kremer and Nixon 1978), should not result in a measurable impact on the zooplankton population in the St. Johns River.

Entrainment of ichthyoplankton (finfish larvae) would impact a relatively larger percentage of its respective population than would entrainment of zooplankton in this section of the St. Johns River. Depending on the seasonal variation in the volume of water flowing in the St. Johns River, $1.0-6.5 \%$ of the ichthyoplankton population in the back channel would be subjected to entrainment. On an annual basis, an average of $2.3 \%$ of the population in the back channel would be affected. This fraction actually represents less than $1 \%$ of the total ichthyoplankton population in the river in the vicinity of the site because only about $35 \%$ of the total flow of the river passes through the back channel. About $60 \%$ of the entrained ichthyoplankton would consist of species with no appreciable commercial or recreational importance, such as croaker, spot, and silver perch, while about $40 \%$ would represent species of commercial and/or recreational value such as seatrout, weakfish, and menhaden. The effect of entrainment on the ichthyoplankton population in the St. Johns River in the vicinity of Northside Generating Station would be minor because the level of change or variability in the abundance of the population is indistinguishable from the natural variability that most fish populations experience year to year. Because most of the species represented at the site spawn offshore and in higher salinity areas, such as near the mouths of rivers, any small localized perturbations in their abundance and density resulting from entrainment would be overshadowed or masked by the natural offshore processes that influence ichthyoplankton dynamics and abundance.

Relative to impingement issues, free-swimming species should possess the swimming ability to escape the intake velocity of $3 \mathrm{ft} / \mathrm{s}$. Current speeds in the back channel typically range from 1 to $3 \mathrm{ft} / \mathrm{s}$, with a maximum recorded speed of $4 \mathrm{ft} / \mathrm{s}$. Most fish species which either pass through or frequent the back channel have regularly experienced and adapted to the current speeds that occur at 
the water intake structure (Blaxter and Dickson 1959). In addition, most fish species can swim in short-term bursts much higher than $3 \mathrm{ft} / \mathrm{s}$, which would usually allow them to escape impingement at the intake structure.

Impingement potential would also be minimized because the back channel in the vicinity of the site does not appear to be a preferred spawning or feeding area where important sport and commercial fish and shellfish species might congregate. The back channel is probably not a preferred feeding area because of the relatively swift currents, the relatively low density of prey such as bottom-dwelling macroinvertebrates (Section 3.6.2), and the general lack of preferred physical structures which tend to attract fish for food and shelter. The nearby tidal creeks and salt-marsh systems, however, are the preferred nursery and feeding sites for many fish and invertebrate species in the area. The general unavailability of preferred spawning and/or feeding habitat in the immediate vicinity of the intake structure would tend to minimize the probability that these species would reside in this area for extended periods of time, which would therefore decrease their long-term vulnerability to impingement.

To mitigate impingement, however, a fish return system has been in operation at Northside Generating Station since the late 1970s. This system, which was evaluated in accordance with the 316 provision and approved by the EPA as representing best available technology, consists of vertically rotating screens designed with cups and trays, low pressure sprays, and sluice water to convey free-swimming organisms unharmed to San Carlos Creek via two return troughs. In addition to the EPA evaluation and approval, associated state reviews and related permits have indicated that the facility complies with the cooling water criteria in Chapter 62-302.520 of the Florida Administrative Code. In 1981, a 1-year impingement study at Northside Generating Station found 78 species of fish impinged on the rotating screens (EVSC 1981b). Seven species (croaker, anchovy, weakfish, spotted seatrout, star drum, threadfin herring, and tonguefish) accounted for $85 \%$ of all fish impinged. Of these 7 species, croaker comprised $43.5 \%$, or $37 \%$ of all fish impinged. In addition, 22 species of invertebrates were found impinged during this study, with the blue crab and 3 species of shrimp being the most common and important species. Except for shrimp, which were found to have a $90-100 \%$ survival rate following impingement, estimates of survival for species of organisms impinged on the traveling screens could not be assessed reliably during the study because of the low statistical sample size (EVSC 1981b).

In March 1998, JEA initiated a study to determine how to optimize the operation and maintenance of the fish return system while maintaining the system's return efficiency and the survival rate of impinged organisms. As part of the study, quarterly reports summarized the findings regarding the immediate and long-term survivability of impinged fish and invertebrate species (Golder Associates 1998a,b). Results from the spring and summer quarters of 1998 indicated that the immediate survival rate of impinged organisms as a whole varied between 72 and $93 \%$. The long-term survival rate for seatrout was in the range of $40-100 \%$, while the range for shrimp, a 
relatively tolerant species, was $80-100 \%$. Thus, data collected to date indicate that the post-impingement survival of organisms varies as a function of the species involved and the length of time following impingement. In general, however, the long-term survival rate of most species would be at least $50 \%$.

In summary, loss of fish and shellfish resulting from entrainment and impingement during operation of the cooling water intake system would not be expected to have a detectable impact on the populations of biota in the site vicinity because (1) entrainment losses of zooplankton and ichthyoplankton would be less than $1 \%$ of their respective populations in the St. Johns River, which is well within the normal year-to-year natural variability experienced by these populations; (2) the cooling water intake system, including the fish return system, represents the best available technology for minimizing impacts as concluded by the EPA in 1994; and (3) many species of fish and shellfish would not be attracted or reside in this area of the back channel for extended periods of time because of a general lack of preferred spawning and feeding habitats.

\section{Dredging Activities}

Construction of a new solid fuel unloading dock (Option 2) would require dredging between the navigation channel and the present dock lane in the back channel. This activity would increase the depth of the present channel an average of $15 \mathrm{ft}$ by removing an estimated $150,000 \mathrm{yd}^{3}$ of sediment, which represents a surface area of approximately $30,000 \mathrm{yd}^{2}$. The elevation of the bottom of the channel currently varies between -30 and $-20 \mathrm{ft}$ amsl, with an average of $-25 \mathrm{ft}$ amsl. Because the new channel would be dredged to an elevation of $-40 \mathrm{ft}$ amsl, about $5 \mathrm{ft}$ of the dredged material would consist of newer and potentially contaminated sediment because the channel bottom has previously been dredged to $-30 \mathrm{ft}$ amsl. Approximately $10 \mathrm{ft}$ of the dredged material, however, would consist of old or potentially clean and uncontaminated sediment.

The two principal impacts that would occur from dredging activities are direct effects involving removal or disturbance of bottom-dwelling macroinvertebrates and indirect effects involving suspension of fine material such as silt and release of contaminants from disturbed sediment. Macroinvertebrate surveys conducted in the back channel revealed that their abundance and diversity are relatively low, consisting mainly of molluscs and in particular one species, the bivalve mollusc Mulina lateralis. Very few polychaetes and amphipods, which are more common in the tidal creeks, are present in the back channel area. During the spring and summer when the highest densities of macroinvertebrates occur in the back channel, Mulina comprises about $95 \%$ of the total population. Direct impacts on the macroinvertebrate population from dredging activities would be minor because (1) Mulina is abundant in this section of the river; (2) losses of organisms as a result of direct removal or replacement would be temporary because estuarine invertebrates could recolonize disturbed areas within a few months following dredging (Hanks 1968); and (3) temporary reductions in Mulina abundance should not affect the food availability of most finfish in the area because this 
organism is not an important food source for most finfish except possibly for drum. A temporary reduction in Mulina, however, should not affect the feeding ability of bottom foragers such as drum because this bivalve is very common in the St. Johns River.

A possible indirect effect of extended dredging operations would be an increase in suspended material, such as silt, and mobilization of contaminants from the disturbed sediments into the river water. Permanently attached organisms are usually the most vulnerable to silt and fine particles released from dredging because the filter feeding capacity of these organisms could be impaired. Indirect effects of dredging operations should be slight because (1) any increases in suspended material and turbidity would be localized and temporary; (2) very few of the more vulnerable permanently attached organisms occur in the vicinity of the site; and (3) the "zone" of turbidity or suspended material created by dredging operations would probably be small, which should allow free-swimming organisms to avoid these areas easily in their movements up and down the river. Previous maintenance dredging operations at the site have used hydraulic dredges or FDEP-approved clamshell buckets that cause minimal turbidity plumes. Turbidity from previous maintenance dredging activities has never exceeded the permitted level of 26 NTU (nephelometric turbidity units), and turbidity plumes have not been observed during these operations.

With respect to potential effects of contaminants mobilized from dredged sediments, studies conducted on oysters held for several months in cages near the Northside dock area showed that no appreciable uptake and bioaccumulation of metals occurred (Section 3.3.2.1). In addition, contaminant analysis of Florida coastal sediments by Seal, Calder, and Sloane (1994) demonstrated that heavy metal concentrations in the sediments of the back channel near the mouth of San Carlos Creek were at or near background levels. Even though organic contaminants, particularly polycyclic aromatic hydrocarbons, were elevated relative to background in the sediments near the mouth of San Carlos Creek, they were of equal or lower concentrations than those found at other sites in the St. Johns River near Jacksonville. Therefore, the concentration levels of pollutants mobilized from sediments during dredging operations for expansion of the Northside Generating Station dock (Section 4.1.3.2) would not be great enough to cause concern relative to their biotoxicity on resident biota.

\section{Use of Biocides}

Prior to circulating through the condensers, cooling water for the proposed project would be treated intermittently with sodium hypochlorite $(\mathrm{NaOCl})$ or sodium bromide $(\mathrm{NaBr})$ to control biological growth on heat exchanger tubes (Section 2.1.7.2). Sodium bromide is not expected to be used extensively because it is more expensive than sodium hypochlorite. The concentration of total residual chlorine (TRC) is limited in the NPDES permit to a maximum of $0.1 \mathrm{ppm}$ in the discharge canal. TRC levels of $0.1 \mathrm{ppm}$ and below have been demonstrated in laboratory toxicity testing to be safe levels for protecting aquatic organisms. Continuous TRC monitoring from the Northside 
discharge canal has indicated that TRC levels routinely occur at nondetectable (below $0.001 \mathrm{ppm}$ ) levels. During Northside operations, the period of chlorination would be limited to 2 hours per day per unit, and no two units would be chlorinated at the same time. When one unit is being chlorinated, discharge from the other units would be available for dilution. The Northside chlorination procedure would be coordinated with chlorination practices at the St. Johns River Power Park to minimize the total amount of TRC in the discharge. Because of the low levels of TRC being discharged and the dilution effects resulting from the sequenced chlorination schedules, no harm to aquatic organisms in the area of the discharge canal is expected from these chlorination practices. Because of the dilution provided by the St. Johns River, there would be no harm to aquatic organisms elsewhere in the river.

\subsubsection{Threatened and Endangered Species}

of the protected wildlife species that have been observed in the site vicinity (Section 3.6.3), the manatee is of most concern to environmental managers and regulators. Impacts on this species from construction of the new solid fuel and limestone unloading dock (Option 2) would be minimal because manatees probably would not regularly frequent the dock area due to the paucity of submerged vegetation such as seagrasses and emergent cordgrasses (Spartina sp.) in the immediate vicinity of the dock. Manatees were observed in the late 1980s near the southern shore of Blount Island, perhaps attracted there by emergent cordgrasses (Baugh, Valade, and Zoodsma 1989). However, this area currently has a scarcity of emergent cordgrasses and is rarely visited by manatees (observation by Dr. Pinto, Jacksonville University manatee research team). Since 1993, when the city of Jacksonville contracted Jacksonville University to conduct scientific surveys of manatees in the area, including their feeding behavior and habitat preference, aerial surveys have revealed that the majority of manatee feeding occurs south of the Fuller Warren Bridge. This area, which is separated from Northside Generating Station by Blount Island, is located in a different water channel than the one near the station.

In accordance with the conditions contained in the SLERP issued by the FDEP and the Section 404 Permit for Dredged or Fill Material issued by the COE, the following manatee precautions would be taken during all waterborne construction activities, including dredging and construction of the new dock (Option 2) and materials handling system:

- During all in-water construction activities, at least one experienced observer would be designated to watch for manatees. The observer would wear polarized sunglasses to aid in observation. The observer would advise personnel to stop work immediately if manatees were sighted within 50 ft of any in-water construction activity.

- In-water construction work and movement of vessels associated with the project (e.g., work barges) would not occur between sunset and sunrise, when it would be more difficult to spot manatees. The vessels would always operate at "idle speed/no wake" while in the construction 
area and while in waters where the vessel bottoms would be less than 4 ft from the bottom of the water body. All vessels would travel in deep water whenever possible.

- The construction contractor would instruct all personnel of the potential presence of manatees and the need to avoid collisions with manatees. Construction personnel would be advised of the civil and criminal penalties for harming, harassing, or killing manatees as outlined in the U.S. Marine Mammal Protection Act of 1972, as amended, the Endangered Species Act of 1973, and the Florida Manatee Sanctuary Act. Construction personnel would implement appropriate precautions to protect manatees.

- Prior to commencement of construction, the contractor would display at least two temporary signs concerning manatees.

- Siltation barriers would be properly secured so that manatees would not become entangled, and the barriers would be inspected at least once daily to avoid manatee entrapment. Barriers would not block manatee entry to or exit from essential habitat.

- The contractor would maintain a log during the contract period that documents any sightings, collisions, or injuries to manatees. Any collisions with and/or injuries to manatees would be reported immediately to the Florida Marine Patrol and the FDEP Office of Protected Species Management.

Potential impacts to manatees resulting from operational activities such as docking of vessels under either Option 1 or 2 would also be unlikely. For example, the potential for manatees to be trapped and pinned between the dock and a vessel would be minimal because the dock would be supported by widely spaced support pilings rather than consisting of one long continuous structure. This design would allow sufficient space between vessels and the dock structure such that manatees could easily avoid being trapped. In addition, a fender/bumper system would be installed at or above the mean high water level to minimize the risk of crushing manatees during vessel docking and mooring. Permanent signs would be installed to alert boaters using docking facilities of the potential presence of manatees, and two "Caution: Manatees" signs would be installed at the pier.

According to Brody (1993), the major threats to manatees in the lower St. Johns River appear to be wounds inflicted by boat propellers and by collisions with boats. The state of Florida has found during its examinations of manatee carcasses that an approximately equal number of manatees are killed by propeller injuries and by collisions, with a much smaller number killed by a combination of these two factors (Ackerman et al. 1995). To help reduce the probability of collisions with boats, several local governments have adopted speed restrictions on boating. While these speed restrictions may help reduce the number of watercraft collisions with fast-moving boats, some manatees are killed by large commercial vessels in the Jacksonville port area. These 
vessels rarely operate at high speeds and presumably injure these animals by "drawing" them into their propellers or by crushing them between the hull and river bottom.

Discharge of heated cooling water during operations could potentially impact manatees by subjecting them to cold shock during the winter if all units were to shut down simultaneously. However, the current discharge does not attract manatees because the discharge structure is located in the back channel of the St. Johns River where currents are relatively swift, while manatees generally avoid swift currents and prefer slow-moving or stagnant water. In addition, it is very unlikely that all units for both the St. Johns River Power Park and Northside Generating Station would be shut down simultaneously, thereby minimizing the probability that a cold shock event would occur. Moreover, the maximum size of the thermal discharge zone is relatively small (36 acres) for the $4^{\circ} \mathrm{F}$ temperature elevation (compared with ambient temperature) as specified in the NPDES permit (Section 3.3.4). The proposed project would not noticeably alter the characteristics of the thermal plume. Because of the above reasons, cold shock is not an issue of concern. In summary, impacts to manatees from the proposed project would be minimal or non-existent because of a lack of preferred foraging habitat such as submerged seagrasses and a scarcity of emergent cordgrasses in the immediate site vicinity, because of the construction design of the docking facilities, and because manatees are not attracted to the thermal discharge.

The only other protected species observed regularly on the site is the gopher tortoise, which is usually detected indirectly by its burrows. This species appears to be relatively opportunistic, utilizing a variety of habitats with well-drained soils for its burrows. Because water levels have

'declined in the wetland areas, the gopher tortoise's burrows have become common in upland areas, particularly in the pine flatwoods and on slopes or berms that are sandy and well drained.

Construction activities would be unlikely to occur where burrows have recently been observed. In addition, because a large population of this species exists in Florida (including the site vicinity) and because any dislocation of individuals from their burrows as a result of construction activities would be temporary, re-population would be expected to occur relatively rapidly. A permit would be required from the Florida Game and Freshwater Fish Commission for relocation of gopher tortoises from any impacted areas. Prior to construction, a gopher tortoise survey would be conducted to identify burrows that must be manually excavated, and the animals would be relocated according to conditions of the collecting permit. Section 4.1.6.1 contains additional information concerning relocation of gopher tortoises.

Four or five juvenile loggerhead, Kemps Ridley, and/or green sea turtles were sighted in the Northside Generating Station intake basin on one occasion during the summer of 1997. In order to prevent any further occurrences of juvenile turtles entering the intake structure and subsequently becoming trapped, JEA installed on the intake trash rakes a finer grid of mesh bars (welded wire screen on 6-in. centers contrasted to the old 12-in. centers). The denser grid has excluded turtles of sizes similar to those observed from entering the intake basin and becoming trapped. One potential 
problem with this change is that the finer grid could become more easily clogged with trash and attached marine organisms (e.g., barnacles and other biofouling organisms), effectively reducing the cross-sectional area and increasing the water velocity at the intake. In turn, this would increase the vulnerability of free-swimming organisms to entrainment and/or impingement. Therefore, JEA regularly inspects the intake trash rakes to monitor any increased clogging and increases the frequency of cleaning if necessary.

Except for the shortnose sturgeon that is rarely observed in the St. Johns River, the remaining protected organisms discussed in Section 3.6.3 are bird species that use the estuarine systems (i.e., the tidal creeks/salt marsh) adjacent to the site. There should not be observable impacts to these bird species because the proposed project would not adversely affect the ecology of the salt marsh/tidal creeks or the fish in the estuarine systems that are the principal food resource for these predatory birds.

\subsubsection{Biodiversity}

The three major ecosystem types that occur in the site vicinity (terrestrial systems including freshwater wetlands and creeks, salt marsh/tidal creek systems, and the St. Johns River estuary) would not be measurably affected by the proposed project. The St. Johns River estuary, which is the ecosystem most directly linked with the proposed project because it serves as a source of cooling water and is the receiving stream for discharge water, would not experience any appreciable ecological perturbations, including loss of natural shoreline resulting from the proposed project. No proposed construction or operational activities would have the potential to impinge on the normal functioning of the salt marsh/tidal creek system. Construction activities, however, would disturb or remove a small percentage of the existing terrestrial habitat in the site vicinity, primarily pine plantation and upland hardwood/pine. Only about 1.8 acres of hardwood wetland habitat would be affected. Because of the prevalence of these community types in the site vicinity and in northern Florida and the ability of disturbed wildlife species to successfully relocate and recolonize adjacent habitat, impacts of the proposed project on these terrestrial and wetland communities would also be minor. Because none of the ecosystems in the site vicinity would experience any substantial effects from the proposed project, the relatively high species richness and biodiversity would remain unchanged. The large influence of colonizing marine species from the Atlantic Ocean via the St. Johns River and the influx of terrestrial and avian species from surrounding communities would also help to stabilize and maintain a relatively high biodiversity in the site vicinity.

\subsubsection{Waste Management}

\subsubsection{Construction}

Construction rubble from the proposed project would be trucked off the site to one of two large landfill sites in northeastern Florida that are permitted to dispose of such waste. The landfills are an 
unnamed site in Nassau County, approximately 20 miles north of Northside Generating Station, and the Trail Ridge site near Baldwin, about 25 miles west of the station. Either of these landfills can easily accommodate the construction rubble.

Under Option 2 for the solid fuel delivery and handling system (Section 2.1.3), the proposed construction of a covered fuel storage enclosure on the south arm of the existing 40-acre dredge spoil storage area would reduce the future dredge spoil storage volume by approximately $114,000 \mathrm{yd}^{3}$. However, the fuel storage enclosure would not displace any existing dredge spoil. Construction of the solid fuel and limestone unloading terminal under Option 2 would require deepening the St. Johns River channel. The deepened channel would create $150,000 \mathrm{yd}^{3}$ of new dredge spoil. All new dredge spoil would be stored in the somewhat diminished area of the existing dredge spoil site.

At least 30 acres of the existing 40-acre dredge spoil site would remain after installation of the fuel storage enclosure. Storage of $150,000 \mathrm{yd}^{3}$ of new dredge spoil on the remaining acres would increase the height of the nearly flat-topped pile by an average of about $3.2 \mathrm{ft}$. The increased height would not appreciably decrease the stability of the dredge spoil pile. The new height of the dredge spoil pile would have much less visual impact than the proposed nearby $100-\mathrm{ft}$ high combustion ash storage pile.

Under Option 1 for the solid fuel delivery and handling system (Section 2.1.3), the existing dredge spoil area would be unaffected. No construction would occur within the area designated for dredge spoil storage, no existing dredge spoil would be displaced, and no new dredge spoil would be added to the site.

\subsubsection{Operation Combustion Ash Management}

Uncovered ash would be stored on a 40-acre area in the northwest corner of the Northside property located north of the existing dredge spoil site (Figure 3.4.2). The 40-acre site would consist of cell I ( 23 acres) in the southern portion and cell II (17 acres) in the northern portion, which are separated by Ostner Road running east-west. Cell I would be filled to its capacity of 2.2 million tons before cell II would be used. If ash marketing were successful, cell II likely would not be needed. If cell II were used, Ostner Road would be relocated around the northern perimeter of cell II, and the combustion ash storage pile in cell I would be extended to the north to form one elongated pile rather than two distinct piles.

The ash storage area would have a double liner, a leak detection system, and a runoff and leachate collection system to prevent impacts on nearby surface water and groundwater. If a leak were detected in the primary liner, a multi-step course of action would be employed, including increased groundwater surveillance and the use of a leachate collection and recovery system. The recovered leachate would be used in the hydration of fresh combustion ash. Because the material would be similar to other cementitious materials in composition and would be compacted, the 
permeability of the stored hydrated combustion ash would be fairly low. However, because of continued chemical changes (mostly hydration-dehydration reactions) within the ash, it is possible that cracking would occur, which would tend to channel leachate through the stored material. Nevertheless, any leak would be detected and corrected before it would reach the Northside Generating Station property boundary.

Conceptual plans for handling the waste streams expected at the storage area include commingling the leachate and runoff and directing the combined flow to the chemical waste treatment system. The treated effluent from the lined settling ponds would then be pumped to a reuse tank for utilization in the scrubber and ash conditioning processes. Any excess of treated effluent from the system which cannot be reused would overflow into the existing percolation pond for discharge to the surficial aquifer.

It is anticipated that cell I of the storage area would be accumulating combustion ash for at least 1 to 2 years while the market is being developed to match potential customers with one or more of the ash blends resulting from the different mixes of coal, petroleum coke, and limestone that would be used during the demonstration. If no ash were sold during the 2-year demonstration period, cell I would contain between 0.65 and 1.2 million tons of combustion ash from the two repowered units (depending on mixes between $100 \%$ coal and $100 \%$ petroleum coke, respectively). Because the 23-acre cell I would have a capacity of 2.2 million tons, it could easily accommodate all combustion ash during the demonstration period. Storage site characterization beyond the 2-year demonstration period is discussed in Section 5.

A nationwide survey of CFB ash and its uses indicates that $75 \%$ (4.4 million tons of nearly 6 million tons) was used in a variety of applications in 1995 (Svendsen and Bessette 1997). Nearly $82 \%$ of the successfully marketed ash was used in mining applications. Other major applications included use for structural fill, waste stabilization, and agriculture. Marketability of CFB ash in northeastern Florida and southeastern Georgia has yet to be determined. Although JEA has initiated a local study, marketing uncertainties would remain until ash characteristics are established.

Data obtained nationwide with regard to leachability and toxicity of CFB ash indicate that none of more than 450 sample analyses exceeded regulatory thresholds (Svendsen and Bessette 1997). EPA's toxic characteristic leaching procedure (TCLP), synthetic precipitation leaching procedure (SPLP), and extraction procedure toxicity test (EP Tox) were among the test analyses performed. EPA's regulatory determination under the Resource Conservation and Recovery Act of 1976 with respect to CFB ash is still pending.

EPA-approved TCLP tests would be performed on Northside Generating Station's CFB ash. Anhydrous and hydrated calcium sulfate (anhydrite and gypsum, respectively) would be the most common constituents of the ash. Anhydrite absorbs water (called water of hydration) to become gypsum. This process is called hydration, and it would take place in the polishing scrubber and an ash conditioner before placement of the ash in the storage area. Anhydrite is converted to gypsum at 
varying speeds, and some of the conversion would likely continue while the material is in the storage area. Some of the gypsum would leach because of the limited solubility of gypsum. Metals contained in the combustion ash would not be expected to leach because of the conversion of some of the compounds into ettringite, a compound that has the ability to trap many of the metals of environmental concern within its crystalline structure. Any water containing the leached material would be captured and delivered to the Northside Generating Station chemical wastewater treatment facility.

\section{Liquid Waste Management}

No major impacts would be expected from the liquid waste streams associated with the proposed project. In addition to the co-mingled stream from the ash storage runoff and leachate collection systems, the chemical waste treatment system would treat demineralizer and condensate polisher spent regenerant and rinse water (with total dissolved solids of approximately $14,500 \mathrm{mg} / \mathrm{L}$ and a pH of about 1.6), boiler and air preheater washes, boiler blowdown, and washdown water from equipment and floor drains. The average quantity of treated wastewater currently discharged through the evaporation/percolation ponds to the surficial aquifer is about $286 \mathrm{gpm}$ (Figure 2.1.9). For the proposed project, about $333 \mathrm{gpm}$ of chemical waste treatment water would be routed from the settling basins to a new reuse tank (Figure 2.1.8). A new filtration unit would receive this water in addition to any designated reuse water from the St. Johns River Power Park. Most of the wastewater from the filtration unit (213 gpm) would be directed to the new dry scrubbers, where it would either evaporate and exit through the stack to the atmosphere or combine with anhydrite to form gypsum combustion by-products. Only $48 \mathrm{gpm}$ of effluent from the chemical waste treatment system would be routed from the settling basins to the existing evaporation/percolation ponds unless the reuse tank becomes filled to capacity. An estimated $127 \mathrm{gpm}$ from the new ash storage area runoff and leachate collection systems would be directed to the chemical waste treatment system.

\subsubsection{Cultural Resources}

Because the area in the vicinity of the proposed project is rich in archaeological resources (Section 3.7) and the excavation of undisturbed land could affect important archaeological artifacts, a cultural resources assessment survey of the proposed project site and a follow-up Phase II investigation were conducted in the spring of 1999 (Florida Archeological Services 1999a,b). These studies found that there are no potentially significant historic or archaeological sites located in the area that would be disturbed by the proposed project. Consequently, no significant impacts to onsite cultural resources are expected to occur as a result of project construction.

The proposed project would require a SLERP that would be issued by the FDEP. Northside Generating Station is located within the St. Johns River Water Management District (SJRWMD), whose rules specify that SLERPs include a condition requiring the permittee (JEA in this case) to 
notify the district immediately upon the discovery of any archaeological artifacts on the project site [Rule 40C-4.381(1)(r), Florida Administrative Code]. As the FDEP is bound by SJRWMD rules in issuing the SLERP for the proposed project [Rule 62-330.200(2)(c), Florida Administrative Code], that permit would contain a condition requiring JEA to notify the appropriate agencies [the SJRWMD, the FDEP, and the State Historic Preservation Officer (SHPO)] immediately upon discovery of any archaeological artifacts on the project site.

Away from the immediate site, it is extremely unlikely that the project would result in the disturbance of major cultural or archaeological resources, because agricultural or vacant land or other unbuilt areas would not be converted to residential, commercial, industrial, or public facility uses (Section 4.1.1.1).

\subsubsection{Socioeconomic Resources}

At their own risk, JEA has begun initial construction activities without DOE funding. Construction would take approximately two years and, consistent with the original JEA schedule, would be completed in December 2001. Workforce projections provided by JEA cover the repowering of both Units 1 and 2 at Northside Generating Station. Work on both units would be ongoing during the same time period, but the activities at Unit 2 would precede the same activities at Unit 1 by 4 to 6 months. Approximately 820 construction workers would be employed onsite during the peak construction period, which would last for about 3 months in late 2000 and early 2001. Many different crafts would be required for project construction, with the largest numbers being boilermakers, pipefitters, plumbers, ironworkers, and electrical workers.

In addition to the jobs that would result directly from project construction, a number of indirect and induced jobs would be created as a result of the purchases of goods and services by JEA and the 820 construction workers. According to the RIMS II multipliers developed by the U.S. Bureau of Economic Analysis (1992), each direct job in new construction in Florida leads, on average, to the creation of 1.1 indirect and induced jobs, for a total of approximately 900 new workers (in addition to the 820 construction positions).

Because of the substantial size of the Duval County workforce (Section 3.8.2), it is likely that all or most of the workers needed for this project would come from the local area. However, to reflect the possibility that there could be some local shortages of particular crafts at the time of proposed construction, it is assumed that up to $25 \%$ of the direct workforce (205 workers at peak) could move to Duval County during the construction period. It is likely that the actual number of in-migrating construction workers would be substantially less than 205 , but that number is used throughout this analysis as a reasonable upper bound. Past experience (USNRC 1996) indicates that approximately $60 \%$ of inmovers (i.e., 123 workers) would be accompanied by families, while the remaining $40 \%$ ( 82 workers) would not be accompanied by family. If the inmoving construction workers have an 
average family size of 3.1-the average for Duval County (U.S. Bureau of the Census 1991)-the local population would increase by 463 residents in 205 households as a result of direct employment. Indirect jobs generally are less specialized than direct jobs and would be more likely to be filled by existing area residents. Accordingly, no more than $10 \%$ of the indirect workforce (i.e., 90 workers at peak) is assumed to move to the impact area during the construction period. Once again assuming that $60 \%$ of inmovers ( 54 workers) would bring families and that their average family size would be 3.1 , an upper bound estimate of 203 new residents in 90 households would result from indirect employment during the construction period.

Combining direct and indirect construction-period in-migration yields a total of 666 new residents in 295 households as an upper bound. Based on 177 new families (123 direct and 54 indirect) and the Duval County average of 0.74 school age children per family (U.S. Bureau of the Census 1991), about 131 additional children would be added to the local schools.

Plant operations would begin in early 2002, with a 2-year demonstration period. In 2004, commercial operations would ensue and would last until about 2032. The workforce required for plant operations would be substantially less than for project construction. A total of 74 operations workers and 64 maintenance workers would be required for Units 1 and 2 combined, plus another 12 employees for management, engineering, and administration. Existing employees would be used to operate and maintain the repowered units. Approximately one-half of these 150 workers would be required for each unit, meaning that Unit 2 would employ about 75 workers. Although operations workers would be required 24 hours a day, other employees would work primarily during the day shift. Approximately four contract truck drivers also would be needed to haul away plant byproducts. In addition to these year-round employees, about 100 to 200 contract workers per unit would be required for 3 to 4 weeks each year to perform maintenance duties associated with each unit's annual outage (outages would be scheduled so that they don't overlap), and the same number of contract workers per unit would be required for 9 to 16 weeks during each unit's major outage occurring every 5 to 10 years. No maintenance outages would be scheduled at Northside Generating Station during the peak construction period in late 2000 and early 2001.

As in the construction period, direct operations jobs would create indirect and induced employment. Because each direct job in the electric utility industry in Florida stimulates the creation of 2.5 indirect positions, on average (U.S. Bureau of Economic Analysis 1992), the 75 year-round operations and maintenance positions would normally result in about 188 new indirect and induced jobs. In actuality, this project probably would create fewer than 188 indirect and induced jobs because the 75 direct workers for Unit 2 are already employed at Northside Generating Station and are currently supporting some local service jobs. However, a substantial portion of the employment multiplier for the electric utility industry results from the purchase of equipment, materials, and support services that are necessary regardless of whether current plant workers are new to the 
community. Accordingly, this analysis assumes the need for 188 indirect and induced workers as an upper bound, acknowledging that the actual number of workers is likely to be somewhat less.

The four contract truck driving positions would sustain an additional four indirect jobs, reflecting the fact that the multiplier for direct transportation employment is substantially lower than for the utility sector. Another $\mathbf{5 0 0}$ indirect and induced jobs could theoretically be created during annual and major outages. In practice, however, these outages would be so brief that little, if any, local job creation would be likely to occur. Altogether, the number of direct and indirect jobs created during the operations period would be substantially less than during construction.

All 75 year-round jobs associated with Unit 2 would be filled by existing workers from JEA's employee pool, which is based at Northside Generating Station. Similarly, all four contract truck driver positions could easily be filled from the local labor pool. Accordingly, no year-round workers would be expected to move to the local area. Using $25 \%$ in-migration of new contract maintenance workers as an upper bound, up to $\mathbf{5 0}$ temporary employees could move to Duval County during annual and major outages. If $60 \%$ of these inmovers are accompanied by families with an average family size of 3.1, the local population would temporarily increase by 113 residents in 50 households as a result of direct employment during outages. These population increases would be very brief and much smaller than those experienced as a result of direct construction employment.

Assuming that $10 \%$ of the year-round indirect jobs created during the operations period could not be filled by current residents of Duval County, about 19 year-round workers could be added to the local population. Up to $75 \%$ of these could be accompanied by families (as opposed to $60 \%$ during construction) because the lengthier operations period would tend to encourage more workers to bring their families with them. Thus, the year-round local population could increase by 49 people in 19 households, and additional growth could theoretically occur during outages (although the brevity of these outages suggests that substantial indirect job creation would not occur). In actuality, no population growth would be expected to occur as the result of indirect employment during plant operations because the number of indirect jobs would be substantially fewer than during construction. The net effect of moving from construction to operations, therefore, would be a job loss and a slight population decline, unless the displaced workers find employment elsewhere in the local area.

The direct and indirect year-round jobs created during operation of the repowered Unit 2 could cause as many as 49 people in 19 households (with 11 school age children) to move to Duval County. Up to another 113 people in $\mathbf{5 0}$ households could come to Duval County briefly as a result of plant outages. Even with these temporary influxes, the number of project-related residents of Duval County would be substantially less during plant operations than at the time of construction. 


\subsubsection{Population}

The large majority of any in-migrating workers would probably settle in Duval County because of its abundance of available housing and services. The 666 new construction-period residents assumed in this analysis as an upper bound would represent an increase of only $0.09 \%$ to the population projected for Duval County in 2000. During the operations period, the 49 new year-round residents would account for only $0.006 \%$ of Duval County's population. Even during the periodic outages that would occur throughout the operations period, project-related residents would make up only $\mathbf{0 . 0 2 \%}$ of the Duval County population.

\subsubsection{Employment and Income}

During the peak of construction activity, the 1,720 additional jobs that would be generated by the proposed project represent $0.4 \%$ of the total number of jobs in Duval County in 1996. Year-round employment during the operations period would be substantially less, with the 271 positions associated with the Unit 2 repowering amounting to $0.07 \%$ of the 1996 Duval County workforce. Accordingly, construction of the proposed project would have a small positive effect on local employment, while a small net loss of employment would occur during project operations because the number of year-round operations jobs would be less than the number of construction jobs that would be lost.

Because the skilled craftspeople required during plant construction would probably earn more than the average worker in Duval County, mean income in the county could experience a slight increase. During the operations period, a continuation of this increase would be unlikely, because construction employment would end and all 75 workers required for plant operations would be expected to come from the existing pool of JEA workers.

\subsubsection{Housing}

The 295 new construction-period households assumed as an upper bound in this analysis would represent 1.7\% of the vacant housing units that were for sale or rent in Duval County in 1990 (the most recent year for which comprehensive data are available). During operations, the 19 new yearround housing units required by project-related workers would account for $0.1 \%$ of vacant sale and rental units, and this number would climb to only $0.4 \%$ during outages. Accordingly, any housing impacts would be very small during both the construction and operations periods.

\subsubsection{Local Government Revenues}

The amount of revenue received by the consolidated city of Jacksonville would increase with increased sales of electricity because JEA makes in-lieu-of-tax payments to the city based upon kilowatt hours sold. On a JEA systemwide basis, the increase in revenue to the city would be slight as the demand for electricity provided by JEA slowly increases with time. In addition, local 
purchases of materials needed during project construction and operations would result in additional sales tax receipts for the communities in which the purchases are made. The overall effect of these revenue increases, while positive, would be minor.

\subsubsection{Public Services \\ Education}

The addition of 131 new school-age children during the construction period would increase enrollment in Duval County's public schools by only 0.1\% (Section 3.8.5.1). Distributed evenly over all public schools in the county, such an increase would mean an average of 0.8 students per school. Accordingly, impacts to education would be very small. The impacts during the operations period, when there would be up to 11 new students, would be even less than during construction.

\section{Utilities}

The relatively small number of new households and residents that would come to Duval County as a result of construction and operation of the proposed project would not affect the ability of local water and sewer systems to provide adequate services, especially in light of the ongoing and planned improvements described in Section 3.8.5.2. Therefore, any impacts to utilities would be very small.

\section{Police and Fire Protection}

Local police and fire protection capabilities (Section 3.8.5.4) would not be strained by the relatively small number of new residents that would move to Duval County as a result of the proposed project. Accordingly, any impacts would be very small.

\subsubsection{Environmental Justice}

Section 3.8.6 indicates that the percentages of Blacks and Asians living in Duval County are greater than for the state as a whole, but that there are relatively few members of these ethnic groups living in the census tracts surrounding the proposed site. The percentage of people living below the poverty level is slightly less in Duval County than in all of Florida, and the percentage of the population living in poverty is substantially less in the census tracts surrounding the proposed site than it is for the county or the state. Accordingly, no disproportionately high and adverse impacts to minority or low-income populations would be expected from construction or operation of the proposed project. In particular, because of the relatively low number of minority and low-income residents in the vicinity of the proposed project, very few members of these groups would experience the adverse effects associated with increased road and rail traffic (Section 4.1.10.1) and related noise (Section 4.1.10.2). 


\subsubsection{Transportation and Noise}

\subsubsection{Transportation}

\section{Roads}

All 820 workers expected during the peak construction period would use the rear entrance to Northside Generating Station on Ostner Road, which is accessed from New Berlin Road (Figure 2.1.7). Construction activities would be conducted during a single shift during daylight hours. At peak, there may be $\mathbf{8 2 0}$ daily round-trips by passenger vehicles transporting construction workers to and from the site. In addition, concrete and small equipment would be brought to the site by truck. Most of these deliveries, which would normally occur between 9:00 a.m. and 3:00 p.m., would be made via the rear entrance. Concrete trucks would occasionally use the main entrance from Heckscher Drive.

Construction-induced traffic during the peak hour would not exceed available capacity for four of the five road segments shown in Table 3.9.1, although speed and maneuverability are likely to be substantially diminished on New Berlin Road. Available capacity is expected to be exceeded on the section of Heckscher Drive from State Route 9A to Drummond Point (just west of Eastport Road). This segment currently operates at an LOS of $\mathrm{E}$ and has an available capacity of 89 trips per hour during its peak period. A recent traffic impact analysis performed for JEA (Robinson Engineering Group 1998b) predicts that $19 \%$ of peak hour project-related traffic would use this road segment during the construction period. Using the conservative assumption that all 820 workers would drive themselves and would all leave the plant during the peak traffic hour, an additional 156 vehicles would use this segment during its time of highest use, thereby exceeding its remaining capacity. The congestion experienced on this segment would represent a significant impact during the peak construction period. Consequently, JEA has agreed to encourage carpooling and suggest alternate routes to and from the site (R. Comer, JEA, letter to J. Hebb, DOE, March 31, 1999).

The addition of 820 passenger vehicles carrying construction workers on New Berlin Road during the peak hour would use nearly all available capacity on the segment (Table 3.9.1) and would noticeably increase traffic congestion, especially at the intersection of Ostner and New Berlin Roads. To avoid a significant impact, JEA has agreed to monitor traffic at the abovementioned intersection and to place a police officer at the intersection to direct traffic during peak times, if needed. Should the presence of a police officer prove inadequate to control projectinduced traffic, JEA has further agreed to pursue authorization of a temporary traffic signal at that intersection (J. A. Leduc, JEA, personal communication to R. L. Miller, ORNL, January 28, 2000).

The additional number of vehicles on local roads during plant operations would be considerably less than during the construction period. As explained in the introduction to Section 4.1.9, the yearround workforce for Unit 2 would amount to only 75 operators and maintenance workers plus 4 contract truck drivers, in contrast to the 820 workers expected during the peak construction period. 
All workers would be expected to use the main entrance on Heckscher Drive; but only a portion of the total workforce would be on the site during any single shift, and most of these workers are already stationed at Northside. Even during plant outages, no more than 200 additional workers would be on the site, which would be less than $25 \%$ of the peak construction number of 820 . Because of the relatively few vehicles involved during plant operations, any impacts to traffic flow on Heckscher Drive, New Berlin Road, and other nearby roads would be very minor.

In addition to the passenger vehicles driven by operations workers, there could be up to 93 round-trips per day by heavy trucks carrying limestone from the waterfront area of Jacksonville to Northside to serve both repowered units. Although the limestone could be trucked to the St. Johns River Power Park and transported from there to the Northside facility by conveyor, it is more likely that the trucks would come directly to Northside's back entrance on Ostner Road. It is likely that fewer than 93 daily truck trips would be required because at least some portion of the limestone would probably be delivered via water. In fact, under Option 2 (Section 2.1.3), the limestone would be delivered entirely by ship. Up to another 56 truck trips per day could be required to remove ash generated by both repowered units from the site, and these trucks would also use the back entrance (Robinson Engineering Group 1998b). The anticipated volume of heavy truck traffic would increase the wear and tear on local roads and could accelerate the need for repairs. The maximum number of daily truck trips (i.e., for limestone and ash combined) would be well below the available capacity on New Berlin Road in the vicinity of the facility, but there could be some adverse effects to the rate and quality of flow on that road segment if all or most of those trips occurred during the periods of heaviest traffic. In actuality, those trips would more likely be spread out during the working day, so any impacts would probably be very small.

\section{Rail}

Based on current economic projections, marine transportation would be the primary means of delivering solid fuel and limestone for the proposed project. Consequently, no more than one 90 -car unit train per week would be required to transport coal for the proposed project, and this could be offset by decreased rail deliveries and corresponding increased waterborne deliveries for operations at the St. Johns River Power Park. However, in the less likely event that all necessary coal would be transported by rail, up to 3 additional trains per week would be required for a total of 6 new one-way trips by 90 -car unit trains. The coal would come initially to the St. Johns River Power Park and would be sent from there to Northside Generating Station by a new elevated conveyor. The short rail line that runs parallel to the eastern edge of the Northside property would not be used for fuel delivery because it is not near the proposed solid fuel storage area and because it lacks fuelunloading facilities. If all coal were transported by train, the 6 new one-way train trips per week could exacerbate the problems experienced by nearby residents with noise, vibration, and blocked roads at on-grade rail crossings resulting from existing train traffic. The 6 additional one-way trips 
per week would increase total movement on the CSX line paralleling U.S. 17 by about $5 \%$ and would increase traffic on the spur line from U.S. 17 to the St. John River Power Park and Blount Island by approximately 8\% (Robinson Engineering Group 1998a).

\section{Marine}

Based on current economic projections, most solid fuel and limestone for the proposed project would arrive by water. There are two options under consideration for moving waterborne solid fuel and limestone to Northside Generating Station. Option 1 is to bring these materials to the Power Park's unloading facility on the south side of Blount Island, transport them by existing conveyor to the Power Park, and send them on to Northside Generating Station by a new elevated conveyor. The existing unloading facility would have to be expanded to handle these additional shipments (Section 2.1.3). Option 2 is to ship these materials to an upgraded unloading facility that would replace Northside's existing oil unloading facility on the north shore of the St. Johns River back channel. From there, materials could be moved to the project site by a new elevated conveyor. Neither of these options would be likely to have adverse impacts on current marine traffic or unloading operations because existing waterways would be adequate to handle the increase in ship and barge traffic, and the construction of new or expanded unloading facilities would prevent existing operations from being degraded. However, excavation for new conveyors could potentially disturb archaeological resources (Section 4.1.8).

\subsubsection{Noise}

Northside Generating Station currently operates within the city's noise ordinance, which protects public health, comfort, and safety (Section 3.9.2). During construction of the proposed project, noise levels would increase from the present operational levels. Construction would primarily occur adjacent to the existing turbine building. The noisiest periods of construction would be during steam blowouts and during the operation of a pile driver and other construction equipment. If JEA conducts high-pressure steam blowouts without installing mufflers, noise from the blowouts could exceed the limitations of Rule 4, Noise Pollution Control, promulgated by the Jacksonville Environmental Protection Board (1995), which limits daytime construction noise levels to an Leq of $65 \mathrm{~dB}(\mathrm{~A})$ at residential property.

Steam blowout is a procedure in which the steam lines in the facility would be cleared of debris by blowing them out with steam prior to plant start-up. JEA likely would perform continuous, low-pressure, high-velocity steam blowouts. Although this activity would be conducted around the clock, noise levels at the nearest residences should be below levels of concern with this type of blowout that uses low-pressure steam rather than high-pressure steam. However, because JEA's steam blowout plan has not been finalized, JEA has committed to installing mufflers if high-pressure steam blowouts are conducted or, if mufflers are not installed, has committed to 
measuring the noise levels at the nearest residences to ensure that the levels would conform to the Noise Pollution Control ordinance limits (J. A. Leduc, JEA, personal communication to R. L. Miller, ORNL, February 10, 2000).

High-pressure steam blowouts without mufflers would generate the highest noise levels associated with plant construction, $129 \mathrm{~dB}(\mathrm{~A})$ at $50 \mathrm{ft}$ (EPA 1977). If JEA conducts high-pressure steam blowouts, they would be conducted for up to 10 days for each of the repowered units before start-up, and then would occur for up to several days only once every 5 to 10 years during major plant maintenance outages. A typical sequence would be to conduct several steam blowouts per day for several days during the period; the duration of each steam blowout would be about 3 min and the interval between blowouts would be no less than 30 min.

High-pressure steam blowouts produce noise that is directional. Along the direction of maximum noise, the level (without mufflers) should be reduced to about $99 \mathrm{~dB}(\mathrm{~A})$ at $1,600 \mathrm{ft}$ (the distance to the nearest residences) under normal atmospheric conditions. For other directions, noise levels would be substantially below $99 \mathrm{~dB}(\mathrm{~A})$ at $1,600 \mathrm{ft}$. Wind direction and speed and other atmospheric conditions can affect these noise levels. In addition, a face of a building or other structure can reflect noise and affect both the intensity and direction of noise. Short exposures to the highest anticipated levels should not result in permanent hearing loss, but they would be uncomfortable. Exposure to $3 \mathrm{~min}$ of noise at approximately $100 \mathrm{~dB}(\mathrm{~A})$ can result in a short-term threshold shift (a temporary shift in the hearing threshold, or lowering of sensitivity) of about $5 \mathrm{~dB}(\mathrm{~A})$; the time required for complete recovery ranges from a few hours to overnight (Kryter 1985).

Because of the noise associated with high-pressure steam blowouts without mufflers, JEA has historically implemented a public awareness program prior to implementation of steam blowouts and would do so during the proposed project, if necessary. The program includes advance notification to the media; police, fire, and rescue agencies; and local regulatory and governmental agencies. The program has generally been effective in alerting the public through newspaper and radio announcements, but some calls from concerned individuals are typically received by the above agencies and are anticipated during steam blowouts. The agencies, having been advised of an upcoming high-pressure steam blowout, would be able to describe the noise's source and projected duration and frequency to the concerned individuals. JEA would also notify beforehand all residences within 0.5 mile of the high-pressure steam cleaning operation. This advisory would alert people to go inside to reduce the effects of the noise. The number of residents affected within the 0.5-mile radius would be less than 100. As a mitigation measure, only daytime high-pressure steam blowouts would be permitted. No Sunday high-pressure steam blowouts would be allowed.

One pile driver operating intermittently would produce peak noise levels of about $101 \mathrm{~dB}(\mathrm{~A})$ at a distance of $50 \mathrm{ft}$ as the hammer impacts the pile (EPA 1971). This level would dissipate to about $.83 \mathrm{~dB}(\mathrm{~A})$ at $400 \mathrm{ft}$. For a brief period under Option 2 associated with constructing a new solid fuel 
This page cannot be converted.

Please view the native document

for the original page. 
sources (BBN 1984). Modeling results indicated that mitigation measures, including installing baffle silencers for the fans and enclosing the coal and limestone crushers in a sound-insulating building, would be necessary to reduce noise levels to comply with the city of Jacksonville noise ordinance level of $60 \mathrm{~dB}(\mathrm{~A})$ (Leq) at any residence (Foster Wheeler 1998c). The mitigation measures ensure that noise would not exceed $85 \mathrm{~dB}(\mathrm{~A})$ at a distance of $3 \mathrm{ft}$ from the equipment. The mitigation measures are conceptual because the design has not been finalized, but the analysis demonstrates that the proposed project could be designed so that noise ordinance levels would not be exceeded at any residence.

Based on implementing the mitigation measures, noise levels (in Leq) from the proposed project predicted by the model in each of four directions around the facility (at distances corresponding to the nearest residences) are as follows: $48 \mathrm{~dB}(\mathrm{~A})$ to the north, $50 \mathrm{~dB}(\mathrm{~A})$ to the east, $59 \mathrm{~dB}(\mathrm{~A})$ to the southeast, and $57 \mathrm{~dB}(\mathrm{~A})$ to the west. Because noise attenuates with distance, noise levels would be lower at other residences. The highest level would occur at the residences to the southeast, which are also the nearest residences overall (1,600 ft from the existing turbine building). Noise levels at the residences to the east would be reduced by shielding from the existing turbine building. Because the proposed facility would be used during commercial operation as a baseload unit operating 24 hours per day at the 297.5-MW level for 90\% of the time during the year, noise levels attributable to operation of the facility would be independent of time of day. The estimated levels are similar to and perhaps less than ambient levels (Section 3.9.2) because ambient levels are often dominated by other sources of noise, particularly from vehicles. The modeling results indicate that operation of the facility would comply with the city of Jacksonville noise ordinance level of $60 \mathrm{~dB}(\mathrm{~A})$ (Leq).

As noted in Section 3.9.2, the high decibel levels associated with rail traffic through the nearby area are a source of concern for residents of Panama Park, North Shore, and San Mateo. As discussed in Section 4.1.10.1, if all coal for the proposed project were transported by train, total movement on the CSX line paralleling U.S. 17 would increase by about $5 \%$ and traffic on the spur line from U.S. 17 to the St. Johns River Power Park and Blount Island would increase by approximately $8 \%$. Accordingly, the number of times that local residents would be subjected to loud noise from train whistles and rattling rail cars would increase by the same amount. Additional train traffic could be minimized by relying more heavily on barges and ships for coal transport. As mentioned earlier, economic projections indicate that this fuel delivery mode would be more likely.

\subsubsection{Electromagnetic Fields}

Over the past two decades there has been concern by some members of the scientific community and the public regarding human health effects from electromagnetic fields during the transmission of electrical current from power plants. In spite of efforts by the scientific community and funding from governmental agencies and private organizations, the issue is still clouded with much uncertainty. 
Small effects are indicated in some studies and none in others. Based on a comprehensive evaluation of published studies regarding the effects of electric and magnetic fields from power plants on cells, tissues, and organisms (including humans), there is no conclusive and consistent evidence that exposures to residential electric and magnetic fields produce cancer, adverse neurobehavioral effects, or reproductive and developmental effects (NRC 1997). An association between residential wiring configurations and childhood leukemia is evident in multiple studies, although the cause for that statistical association has not been identified. No evidence from recent measurements links magnetic fields to childhood leukemia (NRC 1997). Until more definitive answers become evident, little can be said with regard to the conclusions of these studies other than effects, if present, are small.

For the proposed project, electrical fields would not change from existing levels because the voltage would not change. However, magnetic fields within the transmission corridors would scale proportionally with the added transmitted power. The majority of consumers receiving electricity from the proposed facility would not experience any change in exposure levels to electromagnetic fields because the fields would be confined to areas along the transmission corridors.

\subsubsection{Human Health and Safety}

Potential health impacts to workers during construction of the proposed project would be limited to normal hazards associated with construction (i.e., no unusual situations would be anticipated that would make the proposed construction activities more hazardous than normal for a major industrial construction project). Most accidents in the construction industry result from overexertion, falls, or being struck by equipment (NSC 1994). Construction-related illnesses would also be possible (e.g., exposure to chemical substances from spills). Workers would be protected by JEA's Safety and Occupational Health Program, which incorporates the numerous health and safety procedures and policies required by OSHA, the state of Florida, and JEA.

The Bureau of Labor Statistics estimated that the 1992 incidence rate for total cases of occupational injury and illnesses resulting from construction activities was 13.1 per 100 workeryears (NSC 1994). Total cases include all work-related deaths and illnesses and those work-related injuries that result in loss of consciousness, medical treatment other than first aid, restriction of work or motion, or transfer to another job. In comparison, Foster Wheeler Constructors, Inc., recorded an annual rate of 2.2 per 100 worker-years for total cases during the 3-year period 1995-97 (Foster Wheeler 1998d). Based on this rate, the total number of cases of occupational injury and illnesses resulting from the proposed construction would be approximately 15 for the 650 person-years of construction.

Following the repowering of Unit 2 and the related action of repowering the existing Unit 1, the total number of employees at Northside Generating Station would decrease by about $10 \%$ through attrition from the current level of 265 to about 238 workers (Section 2.1.5). This change is relatively minor. The overall design, layout, and operation of the facilities would minimize human hazards. 
Compliance with the Federal Occupational Safety and Health Standards as well as safety standards specified by the Industrial Safety Section of the Florida Department of Commerce would maintain the current occupational safety record at Northside Generating Station. No substantial differences with respect to occupational safety or industrial hygiene would be expected between current operations and those of the proposed project. Thus, there should be a very similar occupational safety and health experience during future operations.

Potential health impacts to the public from the proposed project include fugitive dust typical of construction sites (Section 4.1.2.1), operational combustion emissions from the proposed facility (Section 4.1.2.2), blocked roads delaying emergency vehicles at on-grade rail crossings (Section 4.1.10.1), noise (Section 4.1.10.2), and electromagnetic fields (Section 4.1.11). Programs in place at JEA are designed to minimize public and employee health and safety risks during project construction and operation.

\subsection{POLLUTION PREVENTION AND MITIGATION MEASURES}

Pollution prevention and mitigation measures have been incorporated by JEA as part of the design of the proposed project. The CFB technology would remove up to $98 \%$ of $\mathrm{SO}_{2}$ emissions, reduce $\mathrm{NO}_{x}$ formation by approximately $60 \%$ compared with conventional coal-fired technologies, and remove more than $99 \%$ of particulate emissions. JEA plans to sell the proposed project's combustion ash as a by-product to offsite customers. In addition, mitigation measures have been developed to minimize potential environmental impacts associated with the construction and operation of the facilities. Table 4.2.1 lists the pollution prevention and mitigation measures that JEA would provide during the construction and operation of the proposed project.

\subsection{ENVIRONMENTAL IMPACTS OF NO ACTION}

Under the no-action alternative, DOE would not provide cost-shared funding for the proposed CFB combustor project. Consequently, three reasonably foreseeable scenarios could result (Section 2.3.1).

First, JEA could repower the existing Unit 2 steam turbine without DOE funding, thereby accepting more of the risks associated with demonstrating the CFB combustor. Construction materials and activities and project operations would be the same as for the proposed project. The same amount of electricity would be generated and environmental impacts would generally be very similar to those of the proposed project. Fuel requirements would be similar except that the blend of coal to petroleum coke might be slightly different, particularly during the first 2 years of operation. Under this scenario, more of the solid fuel used each year throughout the lifetime of the facility could be petroleum coke, which would be brought to the site by waterborne transport. Compared with the proposed project, the increased use of petroleum coke under this scenario would result in less train traffic and more ship traffic to deliver the fuel (particularly if current projections change 
Table 4.2.1. Pollution prevention and mitigation measures developed for the proposed project at Northside Generating Station

\begin{tabular}{l}
$\begin{array}{c}\text { Environmental } \\
\text { issue }\end{array}$ \\
\hline Land use \\
\\
Atmospheric \\
resources and air \\
quality
\end{tabular}

Pollution prevention or mitigation measure

The proposed project would be constructed to minimize impacts to the number, density, and species types of trees. As a mitigation measure, the planting of trees to replace those removed during construction is required under the city of Jacksonville's tree protection regulations. JEA would supply replacement trees from their tree farm to the local civic association for the latter to use wherever needed to implement the community's beautification program.

Atmospheric quality

During construction, vehicles and machinery would be equipped with standard pollution-control devices to minimize emissions. Dust suppression measures (i.e., watering) would be used to minimize the occurrence of fugitive dust during construction activities.

During operation, the handling and transfer of coal, petroleum coke, and limestone at the site would generate PM-10 emissions. To reduce these emissions to acceptable levels, the proposed project would minimize the number of handling and transfer points, enclose the conveyors and material unloading points, use wetting systems for particulate suppression, and install collection devices such as baghouses.

The circulating fluidized bed (CFB) combustor would use limestone injection to remove sulfur dioxide $\left(\mathrm{SO}_{2}\right)$. A polishing scrubber on the flue gas stream would further remove $\mathrm{SO}_{2}$.

Compared with conventional boilers, the CFB combustor would produce less amounts of oxides of nitrogen $\left(\mathrm{NO}_{x}\right)$ because of its lower flame temperature. Selective non-catalytic reduction technology would be incorporated in the proposed project to further reduce $\mathrm{NO}_{x}$ formation.

Emissions of particulate matter from the CFB combustor would be controlled using an electrostatic precipitator or a baghouse filter system.

JEA has committed to reduce maximum hourly $\mathrm{SO}_{2}$ emissions from the existing Unit 1 by nearly $93 \%$ when operations commence for the proposed project. This reduction would be accomplished by using a blend of natural gas and fuel oil with an $\mathrm{SO}_{2}$ emission rate averaging no more than $0.143 \mathrm{lb} / \mathrm{MBtu}$ (effectively, a blend with a sulfur content averaging no more than $0.13 \%$ ).

DOE is not proposing any project-specific mitigation measures for carbon dioxide emissions. In other programs, however, DOE is studying potential mitigation measures such as enhanced carbon sequestration. Further research and development are needed to determine the feasibility of such measures. 
Table 4.2.1. Continued

\begin{tabular}{|c|c|}
\hline $\begin{array}{l}\text { Environmental } \\
\text { issue }\end{array}$ & Pollution prevention or mitigation measure \\
\hline \multirow[t]{4}{*}{$\begin{array}{l}\text { Surface water } \\
\text { resources }\end{array}$} & $\begin{array}{l}\text { During construction, standard engineering practices such as straw berms, } \\
\text { liners, cover materials, and grading would be implemented as required to } \\
\text { minimize runoff, erosion, and sedimentation near the site. Accidental spills } \\
\text { of construction materials such as solvents, paint, caulk, oil, and grease that } \\
\text { could contain hazardous substances would be cleaned up in a timely } \\
\text { manner and in accordance with a spill prevention, control, and } \\
\text { countermeasure plan. }\end{array}$ \\
\hline & $\begin{array}{l}\text { Runoff from facilities that would be built as part of the proposed project } \\
\text { would be used in plant processes or routed through detention basins } \\
\text { equipped with baffles or oil skimmers before being discharged at } \\
\text { stormwater outfalls. The detention basins would reduce the maximum rate } \\
\text { of stormwater discharge by increasing the length of time during which the } \\
\text { discharge occurred. The baffles or oil skimmers would collect } \\
\text { contaminants such as oil and grease that float on top of the stormwater. }\end{array}$ \\
\hline & $\begin{array}{l}\text { Accidental spills from the proposed facility would be cleaned up in a } \\
\text { timely manner in accordance with a spill prevention, control, and } \\
\text { countermeasure plan and the best management practices plan for the } \\
\text { facility. Tanks containing liquids such as fuel oils, waste oils, turbine } \\
\text { lubrication oils, and fuel additives are either (1) surrounded by berms or } \\
\text { dikes that would contain accidental leaks or spills, or (2) have controlled } \\
\text { drainage areas whose runoff is routed to and collected in sumps. The } \\
\text { sumps are piped into the wastewater treatment system. Rapid cleanup of } \\
\text { any liquid impounded by secondary containment that did not enter the } \\
\text { wastewater treatment system would minimize seepage into the } \\
\text { groundwater. }\end{array}$ \\
\hline & $\begin{array}{l}\text { Impacts associated with transfer piping failure or leakage would be } \\
\text { minimized because (1) the piping is routinely inspected on a daily basis } \\
\text { and more frequently while pumping is in progress, and (2) most pipeline } \\
\text { failures manifest themselves as small-scale, gradually increasing leaks that } \\
\text { would be detected during routine inspection before excess leakage would } \\
\text { impact the environment. }\end{array}$ \\
\hline $\begin{array}{l}\text { Geological } \\
\text { resources, } \\
\text { groundwater }\end{array}$ & $\begin{array}{l}\text { The currently unlined settling basins would be lined for the proposed } \\
\text { project, and the supernatant from the settling basins would be routed to the } \\
\text { reuse tank. On an occasional basis when the reuse tank is full, the overflow } \\
\text { from the settling basins would be directed to the existing evaporation/ } \\
\text { percolation ponds and consequently to the surficial aquifer. }\end{array}$ \\
\hline
\end{tabular}


Table 4.2.1. Continued

\begin{tabular}{|c|c|}
\hline $\begin{array}{c}\text { vironme } \\
\text { issue }\end{array}$ & Pollution prevention or mitigation measure \\
\hline $\begin{array}{l}\text { Geological } \\
\text { resources, potential } \\
\text { for subsidence }\end{array}$ & $\begin{array}{l}\text { Geotechnical site investigations would precede construction of any new } \\
\text { major structures associated with the proposed project. Such investigations } \\
\text { would be designed to reveal any solution cavities within } 100 \mathrm{ft} \text { of the } \\
\text { surface that could cause the surface to collapse or subside appreciably. If a } \\
\text { cavity were detected, collapse and subsidence at the surface would be } \\
\text { prevented by filling the cavity. }\end{array}$ \\
\hline Floodplains & $\begin{array}{l}\text { The land occupied by and immediately surrounding the repowered units } \\
\text { would be sloped to promote drainage away from structures. }\end{array}$ \\
\hline \multirow[t]{2}{*}{ Wetlands } & $\begin{array}{l}\text { Judicious placement of facilities would minimize potential impacts on } \\
\text { wetlands. The site for the ash storage area includes a } 200 \text {-ft buffer zone } \\
\text { extending to the San Carlos Creek floodplain, which would minimize or } \\
\text { avoid any impacts to the San Carlos Creek system. }\end{array}$ \\
\hline & $\begin{array}{l}\text { To offset the loss of } 1.8 \text { acres of hardwood wetlands during construction of } \\
\text { the ash storage area, JEA would purchase } 3 \text { credits (slightly greater than } \\
3 \text { acres) of wetlands from an offsite mitigation bank and restore } 1 \text { acre of } \\
\text { salt marsh, resulting in a mitigation ratio of greater than } 2.2 \text { to } 1 \text { (more } \\
\text { than } 4 \text { acres of wetlands gained to } 1.8 \text { acres lost). Both the COE and the } \\
\text { FDEP approve of this mitigation plan. }\end{array}$ \\
\hline $\begin{array}{l}\text { Aquatic ecology, } \\
\text { thermal effects }\end{array}$ & $\begin{array}{l}\text { Thermal discharges would not be expected to have a measurable effect on } \\
\text { the biota of the area because the maximum circulating flow rates, } \\
\text { condenser temperature rises, and total area of the discharge plume that are } \\
\text { currently limited under a National Pollutant Discharge Elimination System } \\
\text { permit would be maintained. Bottom-dwelling organisms such as } \\
\text { macroinvertebrates would not experience effects as a result of thermal } \\
\text { discharges because the discharge plume is directed upward and is largely a } \\
\text { surface phenomenon. }\end{array}$ \\
\hline $\begin{array}{l}\text { Aquatic ecology, } \\
\text { entrainment and } \\
\text { impingement }\end{array}$ & $\begin{array}{l}\text { To mitigate impingement, a fish return system has been in operation at } \\
\text { Northside Generating Station since the late } 1970 \text { s. A } 1994 \text { study by the } \\
\text { U.S. Environmental Protection Agency concluded that this system } \\
\text { represents the best available technology for mitigating impingement. }\end{array}$ \\
\hline $\begin{array}{l}\text { Threatened and } \\
\text { endangered species }\end{array}$ & $\begin{array}{l}\text { The potential for manatees to be trapped and pinned between the dock and } \\
\text { a vessel would be minimal because the dock would be supported by widely } \\
\text { spaced support pilings rather than consisting of one long continuous } \\
\text { structure. This design would allow sufficient space between vessels and the } \\
\text { dock structure such that manatees could easily avoid being trapped. }\end{array}$ \\
\hline
\end{tabular}


Table 4.2.1. Continued

Environmental issue
Pollution prevention or mitigation measure
Threatened and endangered species (continued)
Socioeconomics, traffic and noise
Prior to construction, a gopher tortoise survey would be conducted to identify burrows that must be manually excavated, and the animals would be relocated according to conditions of the collecting permit from the Florida Game and Freshwater Fish Commission.

A few juvenile loggerhead, Kemps Ridley, and/or green sea turtles were observed swimming in the intake basin in 1997. To help prevent such future incidences, the intake trash racks were refitted with welded wire screens installed on 6-in. centers contrasted to the old 12-in. center grids. The closer grids have excluded turtles of sizes similar to those previously observed from entering the intake basin and becoming trapped.

Noise, vibration, and blocked roads at on-grade rail crossings caused by trains transporting coal would be minimized by relying more heavily on barges and ships for coal transport.

To reduce road congestion, JEA has agreed to encourage carpooling and suggest alternate routes to and from the site. JEA has also agreed to monitor traffic at the rear entrance to the site and to place a police officer at the intersection of Ostner and New Berlin Roads if necessary to reduce congestion during peak times. JEA also has agreed to pursue authorization of a temporary traffic signal at Ostner and New Berlin Roads if the presence of the police officer does not adequately control project-induced traffic.

JEA has committed to installing mufflers if high-pressure steam blowouts are conducted or, if mufflers are not installed, has committed to measuring noise levels at the nearest residences to ensure that the levels would conform to noise ordinance limits. JEA has historically implemented a public awareness program (e.g., advance notification) regarding high-pressure steam blowouts and would do so during the proposed project, if necessary. JEA would also notify beforehand all residences within 0.5 mile of the high-pressure steam cleaning operation. This advisory would alert people to go inside to reduce the effects of the noise. As a mitigation measure, only daytime high-pressure steam blowouts would be permitted and no Sunday high-pressure steam blowouts would be allowed. 
Table 4.2.1. Concluded

Environmental

issue

Pollution prevention or mitigation measure

Socioeconomics, traffic and noise (continued)

During pile driving, JEA would use an enclosure technology or a less noisy type of pile driving (e.g., the vibratory method), as necessary, to ensure that the daytime construction noise level would not exceed $65 \mathrm{~dB}(\mathrm{~A})$ at the nearest residences.

JEA would install baffle silencers for the fans of the proposed facility and enclose the coal and limestone crushers in a sound-insulating building to reduce noise levels during operation to comply with the city of Jacksonville noise ordinance level of $60 \mathrm{~dB}(\mathrm{~A})$ at any residence.

regarding the economic advantages of marine transportation for delivering coal so that rail transport becomes the primary means of delivering any coal to be used). As a result, there would be fewer train trips through the neighborhoods in the vicinity of Northside Generating Station (under this scenario compared with the proposed project), which would reduce potential problems with noise, vibration, and blocked roads at on-grade rail crossings. Thus, neighborhood concerns regarding the proposed project could be lessened.

Under the second scenario, rather than repowering Unit 2, JEA could construct and operate a new gas-fired combined cycle facility at Northside Generating Station or at one of their other existing power plants. The natural gas would drive a gas combustion turbine, and the heat from combustion would be used to produce steam to drive a steam turbine. The facility would be expected to generate approximately $230 \mathrm{MW}$ of electricity.

Construction activities and operations would be similar to the proposed project but with notable differences related to fuel, sorbent, and ash handling and storage facilities. Under this scenario, no coal, petroleum coke, limestone, or lime would be used. Because the natural gas would be delivered by pipeline and no sorbent would be used, there would be no train, ship, or truck traffic associated with fuel and sorbent delivery. No combustion ash would be generated and there would be no truck traffic to remove ash from the site. Consequently, community concerns related to traffic noise and disruptions would be minimized.

As discussed in Section 2.3.1, air emissions would be expected to increase compared with historical levels because of the operation of the combined cycle facility in addition to the existing Northside units operating at the same or higher capacity factors. Therefore, air emissions under this scenario would generally be greater than those for the proposed project. Changes in concentrations of pollutants in the ambient air would depend on the location and project-specific nature of the facility (e.g., stack height and exit temperature and velocity).

Although the size of the construction and operations workforce could be different than for the proposed facility, the difference would not be large enough to cause any noticeable socioeconomic or 
offsite land use impacts. These impacts likely would be the same for any site in the Jacksonville area. Traffic congestion during construction would depend on the project location. Compared to the proposed project, traffic congestion during the construction period could be reduced at Northside if a smaller workforce were required.

If a gas-fired combined cycle facility were constructed at Northside Generating Station, aesthetic impacts could vary slightly if its stack were a different height than the stack for the proposed project. However, the industrial nature of the project area makes it unlikely that any difference in aesthetic impacts would be substantial. Impacts to cultural resources could be less if there were less disruption to construct conveyors and other facilities on previously undisturbed land; conversely, impacts could be greater if more onsite and/or offsite land were disturbed because of a need to upgrade the pipeline supplying natural gas to the facility. If a gas-fired facility were constructed at another location, aesthetic and cultural impacts could be greater or less than at Northside Generating Station, depending on the nature of the site and the need to construct or upgrade a pipeline to supply natural gas to the facility.

Depending on the site, impacts to terrestrial ecological resources probably would be negligible because no solid fuel receiving and storage areas and no ash storage areas would be required. However, additional impacts might result from construction of an offsite pipeline to deliver natural gas. Depending on the site, ecological impacts to wetlands probably would be negligible. Floodplain impacts would be similar to those resulting from the proposed project. There would be no dredging activities that could temporarily affect water quality and mobilize contaminants.

Impacts resulting from electromagnetic fields would be similar to those resulting from the proposed project. The geographical distribution of impacts, if any, would be different if the facility were constructed at another site because the electricity would be transmitted on different transmission lines.

Under the third scenario, rather than repowering Unit 2, JEA could purchase electricity from other utilities to meet JEA's projected demand. Consequently, no construction activities or changes in operations would be expected to occur within the JEA system of power plants, including Northside Generating Station. There would be no change in current environmental conditions at the site, and the impacts would remain unchanged from the baseline conditions. It is possible that existing Units 1 and 3 might be required to operate at capacity factors greater than historical levels if JEA were unable to purchase sufficient electricity from other utilities. Consequently, annual air emissions and groundwater consumption might increase.

There could be construction activities or changes in operations at the other utilities providing electricity to JEA if the electricity were not readily available. Some impacts to resources could result in the geographical area of the other utilities, particularly if a new facility were built to meet the JEA demand or if additional fuel were transported to the other site or sites to generate additional 
electricity. The level of any such impacts would depend on the project-specific characteristics of any facility construction, the fuel required by the facility, and the affected resources in the area. 


\section{IMPACTS OF COMMERCIAL OPERATION}

Following the completion of the 24-month demonstration in March 2004, three scenarios are reasonably foreseeable: (1) a successful demonstration followed immediately by commercial operation of the facility at approximately the same power level using the CFB combustor and other equipment from the demonstration; (2) an unsuccessful demonstration followed by limited commercial operation of the facility to the extent possible, with the balance of JEA's projected demand being met by purchasing electricity from other utilities; and (3) an unsuccessful demonstration followed by conversion of the facility to a conventional coal- and petroleum cokefired power plant using best available control technology, including low- $\mathrm{NO}_{x}$ burners and a wet flue gas desulfurization system. A wet flue gas desulfurization system would be necessary to achieve a $98 \% \mathrm{SO}_{2}$ removal rate, comparable to that expected from the combination of the CFB combustor and the polishing scrubber for the proposed project. Under all three scenarios, the expected operating life of the facility would be 30 years.

Under the first scenario, the level of short-term impacts during commercial operation would not change from those described for the demonstration in Section 4 because the proposed facility would continue as a baseload power plant operating 24 hours per day with the same operating characteristics. For long-term effects, the level of impacts would be nearly identical to those discussed in Section 4, except for impacts that accumulate with time (i.e., ash disposal). As described in Section 4.1.7, the preferred alternative for management of the combustion ash would be to sell it as a by-product to offsite customers. An aggressive marketing program would be implemented to maximize the quantity sold. If more than approximately $70 \%$ of the ash could be sold over the 30-year lifetime of Northside Generating Station, the 40-acre storage site (cells I and II combined) described in Section 4.1.7 would be sufficient for complete containment, and disposal of the material would not be an issue. However, additional truck traffic would be associated with transporting the ash from Northside Generating Station to the offsite customers. Additional permanent disposal space would be required if JEA could not sell over $70 \%$ of the ash. In the unlikely event that none could be sold, an additional 80 to 100 acres of disposal space would be required over the 30 -year operating life of the facility.

The 40-acre combustion ash storage area would have the following appearance when filled to its capacity of 4.2 million tons. The 10 -acre central core would be nearly flat on top and reach a height of $100 \mathrm{ft}$. Approximately 2.1 million tons of ash would be contained in the central core when filled to capacity. A 30-acre perimeter containing the remaining 2.1 million tons of ash would slope away from the central core at an $18^{\circ}$ angle (1:3 vertical to horizontal).

The time required for the storage area to reach its capacity of 4.2 million tons would depend on several factors: (1) the percentages of coal and petroleum coke used in the combustion process, (2) their actual ash and sulfur contents, (3) the amount of lime and limestone required in the combustion process, and (4) the quantity of ash that could be sold before the site reaches its capacity. The time required to reach capacity can be bounded by assuming that either typical coal or petroleum 
coke would be burned $100 \%$ of the time. The annual two-unit total for generation of combustion ash would be 326,000 tons for coal or 560,000 tons for petroleum coke (Table 2.1.1). Assuming that none of the ash would be sold, the storage area would reach its capacity of 4.2 million tons in 13 years for coal ash or 7.5 years for petroleum coke ash. Although the actual percentages of coal and petroleum coke to be burned cannot be predicted over the long-term, a $10 \%$ variation on either side of an even mix would not be unreasonable. Thus, the 40 -acre storage site would likely be filled to capacity following 9 to 11 years of facility operation.

The length of time to reach capacity would increase as the rate of sale of ash increases. If the rate of sale eventually exceeds the rate of production, the storage capacity may be reached before falling below capacity or, alternatively, the capacity may never be reached (depending on the timing of successful marketing).

Slope failures would be unlikely because the hydrated ash is similar to other cementitious materials in composition with negligible loose material to erode. If erosion from torrential rain should occur along the $18^{\circ}$ angle side slopes of the pile, corrective action to prevent further erosion could include removal of part of the pile to decrease the steepness of the slope, which would reduce the amount of ash that could be stored on the site, and/or emplacement of riprap at locations that are vulnerable to erosion.

If additional disposal space were required in the future, the property directly north of the Northside property could be an option. JEA would need to purchase the property and receive a disposal permit. Another alternative would be to use additional landfill capacity available at the St. Johns River Power Park. Because the Power Park is a joint venture, JEA and Florida Power \& Light are discussing the use of the Power Park for disposal of the ash. In addition to the economic advantage of using the above properties, little or no additional offsite truck traffic would result. As another option, JEA could acquire other land that would be dedicated to disposing of the material.

As a last resort, existing offsite landfills could be used to dispose of the ash. Four large landfill sites that are permitted to dispose of nonhazardous industrial waste have been identified in northeastern Florida and southeastern Georgia. Ash from the CFB combustor at Northside Generating Station would require EPA-approved certification that it is nonhazardous before it would be accepted for disposal.

The two nearest offsite landfills are an unnamed site in Nassau County, Florida, and the Trail Ridge site near Baldwin, Florida (approximately 20 miles north and 25 miles west of Northside Generating Station, respectively). The Nassau County site currently has 60 permitted acres and about 3 million $\mathrm{yd}^{3}$ of space remaining. Because Northside Generating Station would produce about 0.775 million $\mathrm{yd}^{3}$ per year, the currently available space would be consumed by ash from Northside Generating Station alone in less than 4 years. Although this site's permit expires in 2004, there is an option to purchase an additional 350 acres.

The Trail Ridge site has 148 permitted acres and a remaining capacity for disposal of 19.2 million $\mathrm{yd}^{3}$ of waste. Ash from Northside Generating Station alone would consume the available 
capacity at Trail Ridge in 25 years. Similarly, municipal waste from the city of Jacksonville, Florida, currently a high volume customer of Trail Ridge, would also consume the available capacity of this landfill in 25 years. Together, these two sources would exhaust the available capacity in less than 13 years. Therefore, only a portion of Trail Ridge's remaining capacity would be available for ash disposal from Northside Generating Station. A permit would be required for the use of land at Trail Ridge in addition to the 148 acres already in use.

The two southeastern Georgia sites would not be economically attractive because their locations near Valdosta and Jessup are 130 and 100 miles from Northside Generating Station, respectively. Although no individual site appears to be capable of landfilling 25 years of ash from Northside Generating Station, a combination of several sites might be utilized. Additional truck traffic would result from transporting the ash to any of the offsite landfills.

The types of impacts associated with the second scenario (an unsuccessful demonstration followed by limited commercial operation of the CFB combustor facility, supplemented with electricity purchases from other utilities) would be similar to those in the first scenario. However, the level of impacts might be reduced slightly because the facility would not operate as often. On the other hand, Unit 3 might be required to operate at capacity factors greater than historical levels if JEA were unable to purchase sufficient electricity from other utilities. The net effect of these two offsetting factors would depend on the specific changes in levels of operation for the affected units.

Some impacts to resources could result in the vicinity of the utility or utilities providing electricity to JEA, particularly if a new facility were built to meet the JEA demand or if additional fuel were transported to the other site or sites to generate additional electricity. The level of any such impacts would depend on the project-specific characteristics of any facility construction, the fuel required by the facility, and the affected resources in the area.

Impacts associated with the third scenario (an unsuccessful demonstration followed by conversion of the facility to a conventional coal- and petroleum coke-fired power plant using best available control technology) would be similar to those in the first scenario, with the exception that (1) there would be minor impacts associated with dismantling and removing the CFB combustor and related equipment; (2) there would be minor impacts associated with construction and installation of the replacement equipment; (3) there would be a temporary period of time with fewer operational impacts because the CFB combustor would no longer be operating and the conventional facility would not yet be operating; and (4) the wet flue gas desulfurization system of the conventional facility would generate material in the form of bottom ash, fly ash, and wallboard-grade gypsum, all of which could be sold if a sufficient market were available. The amount of material produced would be somewhat less than the quantity of combustion ash under the first scenario because less sorbent would be required by the wet flue gas desulfurization system to remove sulfur. Therefore, the number of trucks transporting the material off the site would be less under this scenario than the number of trucks transporting combustion ash under the first scenario, unless much more of the first scenario's combustion ash were disposed of on the site or at the adjacent St. Johns River Power Park. 


\section{CUMULATIVE EFFECTS}

This section discusses potential impacts resulting from other facilities, operations, and activities that in combination with potential impacts from the proposed project may contribute to cumulative impacts. Cumulative impacts are impacts on the environment that result from the incremental impact of the proposed project when added to other past, present, and reasonably foreseeable future actions regardless of the agency (federal or non-federal) or person that undertakes such other actions (40 CFR Part 1508.7). An inherent part of the cumulative effects analysis is the uncertainty surrounding actions that have not yet been fully developed. The CEQ regulations provide for the inclusion of uncertainties in the EIS analysis, and state that "(w)hen an agency is evaluating reasonably foreseeable significant adverse effects on the human environment in an EIS and there is incomplete or unavailable information, the agency shall always make clear that such information is lacking" (40 CFR Part 1502.22). The CEQ regulations do not say that the analysis cannot be performed if the information is lacking. Consequently, the analysis contained in this section includes what could be reasonably anticipated to occur given the uncertainty created by the lack of detailed investigations to support all cause and effect linkages that may result from the proposed project, and the indirect effects related to construction and long-term operation of the facility.

Because cumulative impacts accrue to resources, it is important that the analysis of impacts focus on specific resources or impact areas as opposed to merely aggregating all of the actions occurring in and around the proposed facility and attempting to form some conclusions regarding the effects of the many unrelated actions. Narrowing the scope of the analysis to resources where there is a likelihood of reasonably foreseeable impacts accruing supports the intent of the NEPA process, which is "to reduce paperwork and the accumulation of extraneous background data; and to emphasize real environmental issues and alternatives" [40 CFR Part 1500.2(b)]. Each resource analyzed has its own spatial (geographic) boundary, although the temporal boundaries (time frame) can generally be assumed to equal the 30-year life expectancy of the proposed project.

The resources and impact areas that were identified are traffic and related issues such as noise, water quality, floodplain and wetlands, cultural resources, and socioeconomic resources including environmental justice. Except for atmospheric resources, the lack of linkage between cause and effect relationships and impacts to other resources directly affected by the proposed project precludes other resources from this cumulative effects analysis. For atmospheric resources, the cumulative impacts of regional and global sources of air emissions were discussed in Section 4 because of the logical sequence obtained by bridging the discussion from PSD increments to NAAQS. The findings indicate that the cumulative impacts of the proposed project in conjunction with other regional emission sources (within the spatial boundary of 31 miles from the proposed project that was used for atmospheric resources) would not be appreciably adverse; after implementation of the related action, impacts would be beneficial for most air pollutants and receptors (locations). For socioeconomic resources including environmental justice, Duval County was used as the spatial boundary in the analysis; for other resources, a spatial boundary of approximately 5 miles from the 
proposed project was used because of the inherent absence of potential cumulative impacts beyond this distance for these resources.

During the scoping process, the Notice of Intent identified cumulative impacts as an issue requiring assessment in the EIS and encouraged the public to assist in providing input for the assessment (Section 1.6). In addition, JEA provided input regarding existing and proposed facilities, operations, and activities that would contribute to cumulative impacts, and the Northeast Florida Regional Planning Council and the Jacksonville Comprehensive Planning Division were contacted. The following existing and proposed facilities, operations, and activities were identified as a consequence of this effort:

1. The Jacksonville Port Authority is improving the western shore of Dames Point, located about 2 miles to the southwest of Northside Generating Station on the St. Johns River, to accommodate the handling of cargo including bulk materials.

2. The Jacksonville Port Authority will add three new container cranes to the south shore wharf on Blount Island, located immediately to the southeast of Northside Generating Station. The cranes will begin service about the spring of 2000 . Increased truck traffic between Blount Island and Highway $9 \mathrm{~A}$ is anticipated.

3. A new wharf along the back channel near the northwestern tip of Blount Island was completed in late 1998. The project facilitates the unloading of foreign automobiles and other machinery at Blount Island for distribution in the southeastern United States.

4. The Florida Department of Transportation is considering widening Heckscher Drive from the Highway 9A interchange to the east of the Gulf Oil terminal facility. The improvements would provide four-lane access between Interstate 95 and Blount Island. This project is in the early stage of consideration and is at least 5 years away from completion.

5. American Environmental Systems is proposing to build a hazardous waste transfer facility west of the proposed project on New Berlin Road. The project has received the required zoning in spite of opposition from the community. Currently, the necessary environmental permitting has been denied by the FDEP because of concerns regarding the proposed evacuation plan in response to the unlikely event of a release of hazardous materials. An appeal by the developers may be made.

Because the cumulative effects of the proposed project, the related action, and the St. Johns River Power Park are so intertwined, these impacts were discussed in Section 4 rather than in this section. For example, the Power Park's water discharge system is integrated into the Northside Generating 
Station's system (i.e., make-up water needed by the Power Park's cooling towers is drawn from the Northside discharge and blowdown from the cooling towers is added to the Northside discharge).

Key findings from the cumulative effects analysis include that adverse cumulative impacts to existing traffic on local roadways could result from the increased vehicular traffic due to the new commercial and industrial facilities in the vicinity of the proposed project. Also, any increase in the number of trains through nearby areas as a result of additional commercial or industrial activities could intensify existing problems associated with noise, vibration, and road blockage and add to local residents' concerns. In particular, the improvements along the western shore of Dames Point to handle cargo are expected to increase train traffic. The improvements to Heckscher Drive, if made, would mitigate some of the concerns related to additional vehicular traffic because the road would be able to accommodate additional traffic.

Regarding water resources, more groundwater would be available to local users for a longer period of time because annual groundwater consumption at Northside Generating Station would decrease by $10 \%$ (compared to 1996 levels). This reduction would offset any strain on groundwater resources from other potential users. The demand for cooling water from the St. Johns River would be approximately the same as when all three units operated together from approximately 1978 until 1980. The sustained flow of the river would not be depleted by this diversion because nearly all of the cooling water would be returned to the river after passing through the condensers. Therefore, the cumulative impacts of the proposed project in conjunction with other potential users should not be measurably adverse.

Projects including improvements to the western shore of Dames Point, placement of additional cranes to the south shore wharf on Blount Island, and nearby planned road improvements would not cause enough floodplain encroachment to result in flooding at Northside Generating Station or other locations. Similarly, these projects would not alter the flow of the St. Johns River in such a way that Northside Generating Station would be threatened by diverted water. Because of the mitigation measure for the proposed project that would result in a net gain in the amount of wetlands (Section 4.1.5.3), the proposed project would not contribute to a cumulative loss of wetlands.

The proposed project would not contribute to any cumulative impacts to cultural resources because a cultural resources assessment survey and a follow-up Phase II investigation found that there are no potentially significant historic or archaeological sites located in the area that would be disturbed by the proposed project (Section 4.1.8). As an additional protection, JEA would be required to notify the appropriate agencies (the SJRWMD, the FDEP, and the SHPO) immediately upon discovery of any archaeological artifacts on the project site [Rule 62-330.200(2)(c), Florida Administrative Code].

Other construction projects in Duval County could theoretically have some effect on the number of construction workers available in the local area, and consequently the amount of in-migration that occurs. However, the local labor force is so large and the local infrastructure has such capacity that the simultaneous construction projects in Duval County would not have a noticeable effect on 
population, housing, public services, or offsite land use. Cumulative impacts to employment, income, and local government revenues would probably be minor as well.

There are relatively few members of minority ethnic groups living in the immediate vicinity of the proposed project, but the percentage of Blacks and Asians in Duval County overall is considerably higher than in the state as a whole. Although cumulative impacts to environmental justice could result if adverse effects from the proposed project extend beyond the immediate project area and other projects with negative environmental impacts were undertaken in the county, cumulative adverse impacts related to ethnic minorities would not be expected because many aspects of the proposed project result in beneficial effects. No cumulative adverse impacts in relation to low income persons would occur because the percentage of the Duval County population living below the poverty level is slightly less than for the state as a whole. 


\section{REGULATORY COMPLIANCE AND PERMIT REQUIREMENTS}

This section lists federal, state, and local regulatory compliance and permit requirements for the proposed project.

Under Section 7 of the Endangered Species Act of 1973 (Pub. L. 93-205, as amended), DOE must consult with the U.S. Fish and Wildlife Service to ensure that proposed actions are not likely to jeopardize the continued existence of any endangered species or threatened species or result in the destruction or adverse modification of the critical habitat of such species. Appendix A documents the findings of the U.S. Fish and Wildlife Service from such consultation and findings from consultation with the National Marine Fisheries Service regarding listed species of endangered and threatened marine life under their jurisdiction.

Under Section 106 of the National Historic Preservation Act (Pub. L. 89-665, as amended), DOE must consult with the Florida Historic Preservation Agency to ensure compliance with the act. Appendix B documents this agency's findings from such consultation.

Appendix $\mathrm{C}$ documents DOE's consultation with the Florida State Clearinghouse, which was contacted to solicit environmental issues of potential concern associated with the proposed project.

\subsection{FEDERAL REQUIREMENTS CLEAN AIR ACT (CAA)}

- Enacted by Pub. L. 90-148, Air Quality Act of 1967 (42 USC 7401 et seq.)

- Amended by Pub. L. 101-549, Clean Air Act Amendments of 1990

- Comprised of Titles I through VI

- Applicable titles

- Title I-Air Pollution Prevention and Control. This Title is the basis for air quality and emission limitations, PSD permitting program, State Implementation Plans, New Source Performance Standards, and National Emissions Standards for Hazardous Air Pollutants. The PSD permitting program serves as the basis for PSD Construction Permits which are required by this Title of the Act.

- Title IV-Acid Deposition Control. This Title establishes limitations on sulfur dioxide and nitrogen oxide emissions, permitting requirements, monitoring programs, reporting and record keeping requirements, and compliance plans for emission sources. This Title requires that emissions of sulfur dioxide from utility sources be limited to the amounts of allowances held by the sources.

- Title V-Permitting. This is the basis for the Operating Permit Program and it establishes permit conditions, including monitoring and analysis, inspections, certification, and reporting.

- Regulations implementing the CAA are found in 40 CFR Parts 50-95. 


\section{JEA EIS}

- In Florida, enforcement of the CAA has been delegated to the FDEP. JEA will submit all permit applications for the repowering project at Northside Generating Station to the FDEP (see Section 7.2).

\section{FEDERAL WATER POLLUTION CONTROL ACT}

- Enacted by Pub. L. 92-500 (33 USC 1251 et seq.)

- Amended by Pub. L. 95-217, Clean Water Act of 1977 (CWA) and Pub. L. 100-4, Water Quality Act of 1987

- Comprised of Titles I through IV

- Applicable titles

- Title III-Standards and Enforcement

Section 316-Thermal Discharges. Section 316 (a) addresses the permitting of thermal discharges that can allow alternative thermal effluent limitations that are less stringent than the limitations under Section 402(a) of the CWA. This section states that, if an owner of a discharge subject to Section 301 (Effluent Limitations) or Section 306 (National Standards of Performance) can demonstrate that an effluent limitation is ". . . more stringent than necessary to assure the protection and propagation of a balanced, indigenous population of shellfish, fish, and wildlife in and on the body of water into which the discharge is to be made. ..", then another effluent limitation may be imposed "... with respect to the thermal component of such discharge. .."

Section 316 (b) addresses the permitting of water intake structures and requires that "Any standard established pursuant to Section 301 or Section 306 of this Act and applicable to a point source shall require that the location, design, construction, and capacity of cooling water intake structures reflect best technology available for minimizing adverse environmental impact."

JEA will not be required to provide either of these demonstrations unless the thermal - characteristics of the cooling water discharge or the design or capacity of the cooling water intake structure at Northside Generating Station are altered as a result of the repowering project.

- Title IV-Permits and Licenses

Section 402, National Pollutant Discharge Elimination System (NPDES). This section regulates the discharge of pollutants to surface waters. Regulations implementing the NPDES program are found in 40 CFR Part 122.

Section 404, Permits for Dredged or Fill Material. This section regulates the discharge of dredged or fill material in the jurisdictional wetlands and waters of the United States. The $\mathrm{COE}$ has been delegated the responsibility for authorizing these actions. Therefore, as a result of construction activities which might occur in jurisdictional wetlands during this 
project, JEA will be required to apply to the COE for a Dredge and Fill Permit pursuant to the provisions of this section of the CWA.

- Regulations implementing the CWA are found in 40 CFR Parts 104-140. Regulations which affect the permitting of this project include

- 40 CFR Part 112-Oil Pollution Prevention. This regulation requires the preparation of a Spill Prevention, Control, and Countermeasure Plan. As a result of changes to the oil storage capacity at Northside Generating Station and, therefore, its potential for discharging oil to surface waters, JEA will be required to amend the existing Northside Generating Station Spill Prevention, Control, and Countermeasure Plan.

- 40 CFR Part 122-NPDES. This regulation requires the permitting and monitoring of any discharges to waters of the United States. The responsibility for issuing wastewater NPDES permits in the state of Florida has been delegated to the FDEP. Therefore, as a result of changes to the characteristics of the wastewater discharges at Northside Generating Station resulting from this project, JEA will apply to the FDEP for a modification of its existing NPDES permit \#FL00001031 (see Section 7.2).

EPA has retained the permitting authority for storm water NPDES permits in Florida. JEA is authorized to discharge storm water associated with industrial or construction activities at Northside Generating Station under the terms and conditions of an NPDES storm water general permit issued by the EPA for use in the state of Florida. However, because the Northside Generating Station repowering project will result in changes to existing storm water management practices at Northside Generating Station, JEA will be required to update the Storm Water Pollution Prevention Plan required by its NPDES Storm Water General Permit \#FLR00B341.

\section{EXECUTIVE ORDERS 11988 AND 11990}

Executive Order 11988, Floodplain Management, directs federal agencies to establish procedures to ensure that they consider potential effects of flood hazards and floodplain management for any action undertaken. Agencies are to avoid impacts to floodplains to the extent practical. Executive Order 11990, Protection of Wetlands, requires federal agencies to avoid short- and long-term impacts to wetlands if a practical alternative exists. DOE regulation 10 CFR Part 1022 establishes procedures for compliance with these Executive Orders. Where there is no practical alternative to development in floodplain and wetlands, DOE is required to prepare a floodplain and wetlands assessment discussing the effects on the floodplain and wetlands, and consideration of alternatives. In addition, these regulations require DOE to design or modify its actions to minimize potential damage in floodplains or harm to wetlands. DOE is also required to provide opportunity for public review of any plans or proposals for actions in floodplains (and new construction in wetlands).

The floodplain and wetlands assessment discussing the effects on floodplain and wetlands anticipated from this proposed project has been prepared and included in this EIS, as required by 
DOE regulation [10 CFR Part 1022.12(b)]. For a full review of the floodplain and wetlands assessment, please refer to these additional sections of the EIS: Section 3.5.1 (Floodplains-Existing Environment), Section 3.5.3 (Wetlands-Existing Environment), Section 4.1.5.1 (FloodplainsEnvironmental Consequences), and Section 4.1.5.3 (Wetlands-Environmental Consequences). Opportunity for public comment and suggestions on the proposed scope of the EIS, including floodplain and wetlands issues and alternatives, was provided during the public scoping period announced by the Notice of Intent published by DOE on November 13, 1997 (62 FR 60889-92). Additional opportunity for public review of the proposed project's potential effects on floodplain and wetlands was provided during the public comment period on the draft EIS.

As discussed in the previous section on the Federal Water Pollution Control Act, Section 404 of the Clean Water Act regulates the discharge of dredged or fill material in the jurisdictional wetlands and waters of the United States. The COE has been delegated the responsibility for authorizing these actions. In addition, according to provisions of Chapter 62-330 of the Florida Administrative Code, JEA will be required to apply to the FDEP for a Submerged Lands \& Environmental Resource Permit (SLERP) that addresses dredging and filling activities including excavation in surface waters or wetlands, excavation or creation of a water body that is or would be connected to surface waters or wetlands, and filling or deposition by any means of materials in surface waters or wetlands (see Section 7.2). The COE and FDEP have been notified of the proposed activities to determine the necessary permit submittal requirements.

For actions that would be located in a floodplain, DOE regulations require a brief statement of findings describing the proposed action, location, alternatives considered, compliance of the proposed project with applicable state and local floodplain protection standards, and steps to be taken to minimize potential harm to or within the floodplain. The statement of findings for this proposed action is given in the following discussion, as provided by DOE regulation [10 CFR Part 1022.15(b)(5)].

\section{STATEMENT OF FINDINGS-FLOODPLAINS}

Proposed Federal Action. The proposed action is for DOE to provide support through costshared funding for the design, construction, and demonstration of CFB combustion technology for electric power generation at a size sufficient to allow utilities to make decisions regarding commercialization of the technology. Specifically, DOE will decide on providing approximately $\$ 73$ million (about $24 \%$ of the total cost of approximately $\$ 309$ million) to demonstrate CFB technology at JEA's Northside Generating Station in Jacksonville, Florida. The new CFB combustor would use coal and petroleum coke to generate nearly $300 \mathrm{MW}$ of electricity by repowering the existing Unit 2 steam turbine, a 297.5-MW unit that has not operated since 1983. In doing so, the proposed project is expected to demonstrate emission levels following the combined removal of $\mathrm{SO}_{2}$, $\mathrm{NO}_{x}$ and particulate matter that would be lower than CAA limits while at the same time producing power more efficiently and at less cost. More detailed information on the proposed project is 
presented in Section 2. Environmental impact analysis for the proposed project is provided in Section 4.1.

Location. The site for the proposed project in Jacksonville, Florida, is located about 9 miles northeast of the downtown area. This 400 -acre industrial site at the existing Northside Generating Station is situated along the north shore of the St. Johns River, approximately 10 miles west of the Atlantic Ocean. The local terrain is flat and there is a mix of industrial, commercial, residential, and agricultural land use in the vicinity. The most striking environmental feature associated with the area is the nearby presence of estuarine salt marsh backwaters of the St. Johns River. The industrial 1,650-acre St. Johns River Power Park borders Northside Generating Station to the northeast, and the 46,000-acre Timucuan Ecological and Historic Preserve borders the site to the east. Blount Island, located immediately to the southeast in the St. Johns River, is a major port with facilities for docking, loading, and unloading large ocean-going vessels.

Alternatives Considered. In addition to the proposed project, the EIS has considered three scenarios reasonably expected as a consequence of the no-action alternative. First, JEA could repower the existing Unit 2 steam turbine without DOE funding, thereby accepting more of the risk associated with demonstrating the CFB combustor. JEA would also proceed with the related action of repowering Unit 1. Second, rather than repowering Unit 2, JEA could construct and operate a new gas-fired combined cycle facility at Northside Generating Station or at one of their other existing power plants. The natural gas would drive a gas combustion turbine and the heat from combustion would be used to produce steam that would drive a steam turbine. Based on modeling projections by JEA, the facility would be expected to generate approximately $230 \mathrm{MW}$ of electricity. Under this scenario, Northside Unit 1 would remain in its current oil- and gas-fired configuration, and JEA would not proceed with the related action of repowering Unit 1 . Third, rather than repowering Unit 2 , JEA could purchase electricity from other utilities to meet JEA's projected demand. Under this scenario, no construction activities or changes in current operations are expected to occur. JEA would not proceed with the related action of repowering Unit 1. More detailed information on alternatives considered is presented in Section 2.3. Environmental impact analysis for the three scenarios under no action is provided in Section 4.2.

Conformity with State and Local Floodplain Protection Standards. Only auxiliary facilities associated with the proposed project would be constructed on the 100-year floodplain, including (1) a second unloader and covered fuel storage at the existing St. Johns River coal terminal under Option 1, or (2) a solid fuel and limestone unloading terminal and pilings that support an elevated conveyor for solid fuel and limestone delivery to Northside Generating Station under Option 2. These facilities would not be large enough to block or encroach on the natural flow of rivers and tides near the shoreline, and excess water during an extreme flood would have sufficient area in which to spread out without endangering neighboring facilities because of the vast array of tidal marshlands, the relatively low topographic relief in the vicinity, and the lack of prominent features. 
JEA is planning to document and coordinate the results of floodplain evaluations with all appropriate federal, state, and local water resource agencies before the design of the proposed facilities is finalized. Contingent upon DOE approval of the proposed project through the Record of Decision, JEA would begin final project design and coordinate with the COE, FDEP, the Florida Department of Community Affairs [which makes Florida's final consistency determination with regard to the Coastal Management Act of 1978 (Sections 380.21-25, Florida Statutes)], and the city of Jacksonville (which regulates ordinance codes) to complete floodplain evaluations and submit permit applications.

Steps Taken to Minimize Potential Harm to or within the Floodplain. Only temporary access ways would be developed to allow for the entry and exit of personnel and equipment to construct the proposed facilities, including the pilings and elevated conveyor. Initial clearing would be accomplished by hand cutting to the greatest extent practical; mechanical equipment would be used when absolutely necessary. Some access by heavy equipment would be required to lift heavy objects, perform earthmoving activities, deliver concrete, and drive pilings. Construction activities would be scheduled to avoid wetter periods of the year, in order to minimize damage to vegetation and soil resources.

Any soils exposed by earth-disturbing activities would be restored through seeding and revegetation. Silt fencing also would be installed prior to construction to prevent sediment from washing into San Carlos Creek or the back channel of the St. Johns River.

\section{MAGNUSON-STEVENS FISHERY CONSERVATION AND MANAGEMENT ACT}

- The 1996 Amendments to the Magnuson Fishery Conservation and Management Act require the National Marine Fisheries Service to designate Essential Fish Habitat for species covered by a federal fisheries management plan. The renamed Magnuson-Stevens Act (16 USC 1801 et seq.) defines these habitats as "those waters and substrate necessary to fish for spawning, breeding, feeding, or growth to maturity." These habitats are in marine and estuarine areas as well as rivers that support federally managed anadromous fish (i.e, species that return from the sea to breed in rivers).

- Under the Act, federal agencies must consult with the National Marine Fisheries Service regarding any authorized, funded, undertaken, or proposed actions that may adversely affect Essential Fish Habitat. Although the concept of Essential Fish Habitat is similar to "critical habitat" under the Endangered Species Act, measures recommended by the National Marine Fisheries Service are advisory, not prescriptive. If a project would have adverse effects, the National Marine Fisheries Service must develop recommendations to avoid or offset the effects. Federal agencies have 30 days to respond in writing to those recommendations.

- National Marine Fisheries Service interim final implementing regulations 50 CFR 600 Subparts J and K, effective January 20, 1998 (62 FR 66531; December 19, 1997), specify that 
consultations on Essential Fish Habitat should be incorporated into environmental review procedures already established, including those for NEPA.

\section{RIVERS AND HARBORS ACT OF 1889}

- Enacted by Chapter 425, March 3, 1889 (33 USC 401 et seq.)

- Regulations implementing this Act are found in 33 CFR Parts 320-338. The following regulations are applicable to this project:

- 33 CFR Part 322-Permits for Structures or Work In or Affecting Navigable Water of the United States. Addresses permitting of construction activities in or over navigable waters, pursuant to the Act in Section 10, "Obstruction of excavations and filling in of navigable waters generally; wharves, piers, etc." JEA will apply to the COE for a "Section 10 " permit for the construction of a new fuel unloading dock and conveyor system pilings which will be part of the repowering project at Northside Generating Station.

- 33 CFR Part 330-Nationwide Permit Program. Nationwide permits are issued by the COE to regulate, with little delay or paperwork, activities having minimal impact. One of the categories of activities regulated by the Nationwide Permit Program is the release of "Return Water from Upland Contained Disposal Areas."

\section{RESOURCE CONSERVATION AND RECOVERY ACT OF 1976}

- Enacted by Pub. L. 94-580 (42 USC 6901 et seq.)

- Amended by Pub. L. 98-616, Hazardous and Solid Waste Amendments of 1984 and Pub. L. 99-499, Superfund Amendments and Reauthorization Act of 1986

- Applicable title

- Title II-Solid Waste Disposal (known as the Solid Waste Disposal Act) regulates the disposal of solid wastes. Under Title II, Subtitle D-State or Regional Solid Waste Plans, allows each state to develop a comprehensive plan for managing and permitting the disposal of solid wastes. In Florida, permitting of solid waste management facilities is the responsibility of the FDEP. As a result of the generation of combustion byproducts during the operation of the repowered units at Northside Generating Station, JEA will be required to apply to the FDEP for a solid waste disposal permit (see Section 7.2).

\section{ENDANGERED SPECIES ACT OF 1973}

- Enacted by Pub. L. 93-205 (16 USC 1531 et seq.)

- Section 7, "Interagency Cooperation," requires any federal agency authorizing, funding, or carrying out any action to ensure that the action is not likely to jeopardize the continued existence of any endangered species or threatened species or result in the destruction or adverse modification of critical habitat of such species. Consequently, the U.S. Fish and Wildlife Service will conduct a consultation, in compliance with Subsection (a)(2) of 
Section 7 of the Act, with regard to the impacts of the Northside Generating Station repowering project on threatened and endangered species listed by the Service and any critical habitat of such species in the vicinity of the project.

\section{COASTAL ZONE MANAGEMENT ACT OF 1972}

- Enacted by Pub. L. 92-583 (16 USC 1451 et seq.)

- This Act encourages states to develop comprehensive management programs which ensure the beneficial use, protection, and management of coastal resources and requires that all activities conducted by or on behalf of a federal agency, funded by a federal agency, or conducted pursuant to an Outer Continental Shelf Lands Act exploration lease, be consistent with the coastal zone management program established by the state in which the project is located.

- Regulations implementing this Act are found in 15 CFR Part 930.50.

- JEA is required to show consistency with the Florida Coastal Management Program (FCMP) (Section 7.2).

\section{FEDERAL AVIATION ACT OF 1958}

- 49 USC 1101 et seq., as amended

- Regulations implementing this Act are found in 14 CFR Part 77 and are enforced by the U.S. Department of Transportation, Federal Aviation Administration (FAA).

- These regulations require submittal of a notice identifying any structures which, because of construction or alteration, may be a hazard to air transportation. JEA will submit FAA Form 7460-1, Notice of Proposed Construction or Alteration, to the FAA.

\subsection{STATE REQUIREMENTS}

\section{AIR QUALITY}

- PSD Construction Permit. Pursuant to the Florida Administrative Code, Chapters 62-210, "Stationary Sources-General Requirements," and 62-212, "Stationary Sources-Pre-Construction Review," JEA will submit an application to the FDEP for a Title I PSD Permit which will serve as the construction permit for the new and modified sources of air emissions constructed as part of the repowering project at Northside Generating Station. In addition, JEA will be required to submit an application for modification of the existing PSD Permit (\# PSD-FL-010) for the St. Johns River Power Park as a result of construction and modifications to the Power Park resulting from the Northside Generating Station repowering project.

- Operating Permit. Pursuant to the Florida Administrative Code, Chapter 62-213, "Operation Permits for Major Sources of Air Pollution," and 62-214, "Requirements for Sources Subject to the Federal Acid Rain Program," JEA will be required to submit an application to the FDEP for modification of the existing Title V Permit for the combined Northside Generating Station and St. Johns River Power Park (No. 0310045-001-AV), including the acid rain section of this 
permit, as a result of modifications to these facilities resulting from the repowering project. The acid rain section of this permit is included in compliance with requirements of Title $I V$ of the CAA.

\section{WATER QUALITY}

- NPDES Wastewater Discharge Permit. Pursuant to Chapter 62-620, the Florida Administrative Code, "Wastewater Facility Permitting," JEA will be required to modify its existing NPDES Permit (No. FL00001031) for wastewater discharges to waters of the state. An application for renewal of this permit was submitted to the FDEP in April 1997. Modifications of this application for renewal will be submitted as changes are made to the Northside Generating Station wastewater management system resulting from the repowering project. As has been the case for the existing facility, the necessary coverage for point sources of storm water discharges associated with industrial activities will be obtained under general NPDES permits, as authorized by EPA, including a Modified Multisector General NPDES Permit and an NPDES General Permit for Construction Activities.

- Submerged Lands \& Environmental Resource Permit (SLERP). According to provisions of Chapter 62-330, the Florida Administrative Code, "Environmental Resource Permitting," JEA will be required to apply to the FDEP for a SLERP. This permit addresses surface water management systems including storm water management systems, dams, impoundments, reservoirs, and dredging and filling activities including excavation in surface waters or wetlands, excavation or creation of a water body which is, or is to be, connected to surface waters or wetlands, and filling or deposition by any means of materials in surface waters or wetlands.

- Consumptive Use Permit. This is a permit issued by the St. Johns River Water Management District (SJRWMD) which authorizes groundwater withdrawal. The current Northside Generating Station Consumptive Use Permit (No. 2-031-0108 US) does not expire until the year 2000 , and JEA will not need to apply for renewal until the summer of 2000 . There is no need to apply for renewal before then because Northside Generating Station is actually withdrawing less groundwater than permitted by the current permit.

\section{SOLID WASTE MANAGEMENT}

- Solid Waste Disposal Permit. Solid wastes, in the form of combustion byproducts, will be created as a result of the operation of the repowered Northside Generating Station Units 1 and 2. Therefore, in compliance with Chapter 62-701, the Florida Administrative Code, "Solid Waste Management Facilities," JEA will submit an application to the FDEP for a permit to construct and operate a solid waste disposal facility. 


\section{OTHER}

- Coastal Management Program. The Florida Coastal Management Act of 1978 (Sections 380.21-25, Florida Statutes) and the Federal Coastal Zone Management Act (16 USC 1456) require all activities that are undertaken, licensed, or permitted by federal agencies to be consistent with the FCMP. A number of state agencies review federal agency activities to ensure compliance with the FCMP statutes and authorities within their jurisdiction and submit comments on such compliance to the agency charged with making the state's final consistency determination. When the project is the subject of a state-issued permit that is analogous to the federal license or permit in question, however, the issuance or renewal of the state permit is the state's final determination that the federally permitted activity is consistent with the FCMP. Federal permits issued under the Rivers and Harbors Act and under Section 404 of the CWA are analogous to the SLERP issued by the state. Those aspects of the repowering project at Northside Generating Station that are governed by permits issued by federal agencies under these statutes will also be governed by the SLERP issued by the FDEP. FDEP's decision to issue or deny that permit will constitute the state's determination of compliance with the FCMP. All other permits for this project will be issued or renewed by state agencies.

\subsection{LOCAL REQUIREMENTS}

JEA will be required to comply with a number of local environmental and zoning regulations specified in the Ordinance Code of the city of Jacksonville for construction and operation of the Northside Generating Station repowering project. Following is a description of specific permits and certificates required for the repowering project at Northside Generating Station.

- Rezoning. If any new property is acquired by JEA for the Northside Generating Station repowering project, rezoning of the property will be required. (Ordinance Code Chapter 656, Zoning Codes, Section 332.)

- Zoning exception. Ordinance Code Chapter 656, Section 656.401 , requires a zoning exception for power generation facilities.

- Concurrency reservation certificate. Ordinance Code Chapter 655, Concurrency Management System, describes the system established to measure the potential impact of proposed developments on the adopted minimum levels of service for traffic circulation and mass transit, potable water and sanitary sewerage, solid waste, drainage, and recreation, as established in the 2010 Comprehensive Plan. A concurrency reservation certificate or Conditional Capacity Availability Statement is required prior to the issuance of all final development permits (such as a building permit) and final development orders (Section 655.111).

- Building permit. JEA will be required to obtain a Building Permit from the city of Jacksonville Building and Zoning Inspection Division. Requirements and procedures for obtaining this permit are described in the Ordinance Code, Title VIII-Construction Regulations and Building Codes, 
Subtitle A-Building Codes, Chapter 320, General Provisions, Part 4. Permits. As described in Section 320.403, in addition to an application for a building permit, JEA will be required to submit, and have approved, two sets of plans and specifications for the repowering project.

- Landscape and tree protection. Removal of protected trees and landscaping of newly developed property are addressed by the Ordinance Code, Chapter 656, Land Use, Part 12-Landscape and Tree Protection Regulations. These regulations require a survey of existing trees on the property, a site clearing and tree removal or relocation permit (for removal of protected trees), a mitigation plan addressing the replacement of trees removed during construction, and an approved landscape plan. These requirements must be met prior to issuance of a Building Permit.

The following requirements may apply. Their applicability is being determined on the basis of project design considerations and choices among alternatives within the proposed action.

- Engineering plan approval. Although this requirement does not result in a permit or certificate, approval of engineering plans is a requirement of Ordinance Code Chapter 654, Code of Subdivision Regulations.

- Development agreement. Ordinance Code Chapter 655, Concurrency Management System, Part 2. Jacksonville Development Regulations, defines the requirements for a development agreement. JEA may voluntarily enter into a development agreement with the city of Jacksonville. The agreement would address many of the concerns of the 2010 Comprehensive Plan and would include, among other things, a site development plan for the land subject to the development agreement (Section 655.206).

- Solid waste disposal or management facility certificate. JEA will construct a combustion byproducts disposal facility (landfill) on Northside Generating Station as part of the repowering project. Therefore, in addition to a state of Florida construction and operation permit, JEA will be required to obtain a certificate from the city for this solid waste disposal facility, according to Ordinance Code Chapter 380, Solid Waste Management, Section 380.103. 


\section{IRREVERSIBLE OR IRRETRIEVABLE COMMITMENTS OF RESOURCES}

For the proposed project, some of the resource commitments would be irreversible and irretrievable; that is, the resources would be neither renewable nor recoverable for future use. Resources that would be irreversibly or irretrievably committed by construction and demonstration of the proposed facility include a small amount of vegetation destroyed at the site, construction materials that could not be recovered or recycled, and fuel and sorbent consumed or reduced to unrecoverable forms of waste.

Resources used during construction of the proposed facility would include crushed stone, sand, water, diesel fuel, gasoline, and iron ore used to produce steel. Resources used during the demonstration would include coal, petroleum coke, limestone, lime, and water. None of these resources is in short supply relative to the size and location of the proposed project.

The proposed project requires a commitment of human and financial resources that could threaten or jeopardize the use of these resources for alternative projects or federal activities. However, the commitment is consistent with the purpose of and need for the proposed action (Section 1). 


\section{THE RELATIONSHIP BETWEEN SHORT-TERM USES OF THE ENVIRONMENT AND LONG-TERM PRODUCTIVITY}

The proposed project would occupy about 75 acres of the Northside Generating Station property (including the footprint for the new facilities associated with the repowered Unit 1) and consume resources including coal, limestone, natural gas, fuel oil, and water. Water for plant operation would be supplied from both the St. Johns River and four deep wells. However, groundwater consumption would decrease compared with current use because JEA's management has established a target of a $10 \%$ reduction in total annual groundwater consumption by Northside Generating Station compared to 1996 levels (Section 2.1.3). Following the Unit 1 repowering, natural gas and fuel oil consumption would also decrease because the existing Unit 1 combustor that uses natural gas and fuel oil would be replaced by the CFB combustor that uses coal and petroleum coke as its primary fuels. Wherever possible, existing facilities and infrastructure located at Northside Generating Station would be used for the proposed project. These include the discharge system for cooling water to the St. Johns River, the wastewater treatment system, and the electric transmission lines and towers.

The project would generate air emissions, liquid effluents, and solid wastes (unless all of the combustion ash were sold). JEA's management has established a target of a $10 \%$ reduction in total annual emissions of $\mathrm{SO}_{2}, \mathrm{NO}_{x}$, and particulate matter from Northside Generating Station compared to emissions during the most recent typical 2-year operating period (1994-95) of the station

(Section 2.1.3). These reductions would be accomplished while increasing the total annual energy output of the station from 2,320,000 MWh to 6,220,000 MWh. Discharges to the St. Johns River would include once-through cooling water and small amounts of liquid effluent (Section 2.1.7.2).

The long-term benefit of the proposed project would be to demonstrate an environmentally sound and innovative technology for the utilization of coal. CFB technology is an advanced method for burning coal and other fuels efficiently while removing air emissions inside the sophisticated combustor system. CFB technology provides flexibility in utility operations because a wide variety of solid fuels can be used, including high-sulfur, high-ash coal and petroleum coke. The technology is expected to remove up to $98 \%$ of $\mathrm{SO}_{2}$ emissions, reduce $\mathrm{NO}_{x}$ formation by approximately $60 \%$ compared with conventional coal-fired technologies, and remove more than $99 \%$ of particulate emissions. Unlike with many conventional technologies, the combustion ash is suitable for beneficial uses such as road construction material, agricultural fertilizer, and reclaiming surface mining areas. The technology also has lower operating and maintenance costs and a shorter "down time" for maintenance than conventional coal-fired technologies.

The design size for the proposed project was selected because it is large enough to convince utilities that the technology, once demonstrated at this scale, can be commercialized using similar sized or larger combustors, without further scale-up to verify operational or economic performance. Therefore, although the proposed project would consume resources and generate emissions, effluents, and perhaps solid wastes, it would demonstrate a technology that, once commercialized, 


\section{JEA EIS}

would reduce resource consumption and waste generation both domestically and abroad compared with conventional coal technologies. 


\section{REFERENCES}

Ackerman, B. B., S. D. Wright, R. K. Bonde, D. K. Odell, and D. J. Banowetz 1995. "Trends and Patterns in Mortality of Manatees in Florida, 1974-1992," pp. 223-258, in T. J. O'Shea, B. B. Ackerman, and H. F. Percival, eds., Population Biology of the Florida Manatee, National Biological Service Information and Technology Report 1.

ACGIH (American Conference of Governmental Industrial Hygienists) 1997. Threshold Limit Values and Biological Exposure Indices for Chemical Substances and Physical Agents. American Conference of Governmental Industrial Hygienists, Cincinnati.

Algermissen, S. T. et al. 1990. "Probabilistic Earthquake Acceleration and Velocity Maps for the United States and Puerto Rico," Miscellaneous Field Studies Map MF-2120, U.S. Geological Survey, Denver.

Baugh, T. M., J. A. Valade, and B. J. Zoodsma 1989. "Manatee Use of Spartina Alterniflora in Cumberland Sound," Marine Mammal Science by the Society for Marine Mammalogy, 5(1):88-90, Jan.

BBN (Bolt, Beranek and Newman, Inc.) 1984. Electric Power Plant Environmental Noise Guide, Volume 1, Cambridge, Mass. Prepared for Edison Electric Institute (EEI), New York.

Beck, B. F. and W. C. Sinclair 1986. "Sinkholes in Florida," The Florida Sinkhole Research Institute, University of Central Florida.

Blaxter, J. H. S. and W. Dickson 1959. "Observations on the Swimming Speeds of Fish," Journal of Conservation and Exploration of the Mer, 24:472-479.

Bollinger, G. A. 1986. "Reinterpretation of the Intensity Data for the 1886 Charleston, South Carolina, Earthquake," in The 1886 Charleston, South Carolina, Earthquake-A 1986 Perspective, O. W. Nuttli, G. A. Bollinger, and R. B. Herrmann, eds., U.S. Geological Survey Circular 985, Denver.

Brody, R. W. 1993. Lower St. Johns River Basin Reconnaisance Report, vol. 6, Environmental Sciences Division, St. Johns River Water Management District.

Bullock, O. R., K. A. Brehme, and G. R. Mapp 1998. Science Total Environment, 213:1.

Campbell, D., D. A. Munch, R. Johnson, M. P. Parker, B. Parker, D. V. Rao, R. Marella, and E. Albanesi 1984. "St. Johns River Water Management District," pp. 158-77 in Water Resources Atlas of Florida, E.A. Fernald and D. J. Patton, eds., Institute of Science and Public Affairs, Florida State University, Tallahassee, Fla.

Charles, L. J. and A. J. Rezaiyan 1997. Atmospheric Circulating Fluidized Bed, An Assessment of the Impact of a $300 \mathrm{MW}$ Class Demonstration Project on the Future Commercialization of Utility Scale ACFB Combustion Systems, Final Report, Energetics, Incorporated, Columbia, Md., prepared for the U.S. Department of Energy, Federal Energy Technology Center, Morgantown, W. Va., Sept. 
COE (U.S. Army Corps of Engineers) 1961. Survey Report-Analysis of Hurricane Problems in Coastal Areas of Florida, Jacksonville Office of the District Engineer, COE, Jacksonville, Fla, Sept 29.

Constantinou, E., X. A. Wu, and C. Seigneur 1995. Water, Air, and Soil Pollution, 80:325-335.

DeMort, C. L. 1991. "The St. Johns River System," in The Rivers of Florida, in Ecological Studies, 83:97-120, Springer-Verlag, New York.

DMC (DeLorme Mapping Co.) 1989. Florida Atlas \& Gazetteer, Freeport, Me.

DOE (U.S. Department of Energy) 1989. Clean Coal Technology Demonstration Program, Final

Programmatic Environmental Impact Statement, DOE/EIS-0146, Washington, D.C., Nov.

DOE (U.S. Department of Energy) 1995. Final Environmental Impact Statement for the Proposed

York County Energy Partners Cogeneration Facility, York County, Pennsylvania,

DOE/EIS-0221, Washington, D.C., May.

DOE (U.S. Department of Energy) 1996. Clean Coal Technology Demonstration Program Project

Fact Sheets, DOE/FE-0351, Washington, D.C., Sept.

DOE (U.S. Department of Energy) 1997. "Requested Site and Participant Change to Large-Scale

Circulating Fluidized Bed Combustion Demonstration Project, Clean Coal Technology

Cooperative Agreement DE-FC21-90MC27403," memorandum to Patricia Godley, Assistant

Secretary for Fossil Energy, from Rita Bajura, Director, Federal Energy Technology Center,

Morgantown, W. Va., Aug. 18.

Driscoll, D. A. 1985. NoiseCalc (A Computer Model for Noise Level Prediction), State of New York

Department of Public Service, Albany, N.Y.

EMCON 1995. "Limited Contamination Assessment Report," Jacksonville Electric Authority,

Northside Generating Station, Project 71268.001.043, Jacksonville, Fla.

EPA (U.S. Environmental Protection Agency) 1971. Noise from Construction and Operations,

Building Equipment and Home Appliances, NTID 300.1, Washington, D.C.

EPA (U.S. Environmental Protection Agency) 1977. Final Environmental Impact Statement for

George Neal Steam Electric Generating Station-Neal Unit 4, Region VII, Kansas City, Mo.

EPA (U.S. Environmental Protection Agency) 1981. Draft Environmental Impact Statement:

Jacksonville Electrical Authority, St. Johns River Power Park, EPA 904/9-81-088, Oct.

EPA (U.S. Environmental Protection Agency) 1985. Compilation of Air Pollutant Emission Factors,

Publication AP-42, Research Triangle Park, N.C.

EPA (U.S. Environmental Protection Agency) 1988. Environmental Progress and Challenges: EPA's

Update, EPA-230-07-88-033, Office of Policy Planning and Evaluation, Washington, D.C.

EPA (U.S. Environmental Protection Agency) 1989. "Interim Procedures for Estimating Risks

Associated with Exposures to Mixtures of Chlorinated Dibenzo-p-dioxins and -dibenzofurans

(CDDS and CDFS) and 1989 Update," EPA/625/3-89/016, Risk Assessment Forum,

Washington, D.C. 
EPA (U.S. Environmental Protection Agency) 1993. "Interagency Workgroup on Air Quality Modeling (IWAQM) Phase 1 Report: Interim Recommendation for Modeling Long-Range Transport on Impacts on Regional Visibility," EPA-454/R-93-015, Research Triangle Park, N.C. EPA (U.S. Environmental Protection Agency) 1994. Estimating Exposure to Dioxin-Like Compounds, Volume II: Properties, Sources, Occurrence and Background Exposures, Office of Health and Environmental Assessment, EPA/600/8-88/005Cb.

EPA (U.S. Environmental Protection Agency) 1995. User's Guide for the Industrial Source Complex (ISC3) Dispersion Models, EPA-454/B-95-003, Research Triangle Park, N.C.

EPA (U.S. Environmental Protection Agency) 1997. National Air Pollutant Emission Trends 1900-1996, EPA-454/R-97-011, Office of Air Quality Planning and Standards, Research Triangle Park, N.C.

EPA (U.S. Environmental Protection Agency) 1998a. EPA Region III Risk-Based Concentration

Table, Roy L. Smith, ed. URL http://www.epa.gov/reg3hwmd/risk/riskmenu.htm.

EPA (U.S. Environmental Protection Agency) 1998b. The Inventory of Sources of Dioxin in the United States, Office of Research and Development, EPA/600/P-98/002Aa, External Review Draft, April.

EPA (U.S. Environmental Protection Agency) 1999a. Appeals Court Statement by EPA Administrator Carol M. Browner, Headquarters Press Release, Oct. 29.

EPA (U.S. Environmental Protection Agency) 1999b. What is Radiation?, Radiation Protection Division, Office of Radiation and Indoor Air, Office of Air and Radiation, URL: http://www.epa.gov/radiation/rrpage/rrpage2.html, accessed Nov. 9.

EPRI (Electric Power Research Institute) 1992. Fly Ash Design Manual for Road and Site Applications, Volume 1: Dry or Conditioned Placement, EPRI-TR-100472, Research Project 2422-2, Final Report, prepared by GAI Consultants, Inc., Monroeville, Penn., April. EPRI (Electric Power Research Institute) 1994. Mercury Atmospheric Processes: A Synthesis Report, EPRI-TR-104214, Workshop Proceedings.

EPRI (Electric Power Research Institute) 1995a. Laboratory Characterization of Atmospheric

Fluidized-Bed Combustion By-Products, EPRI-TR-105527, Project 2708, Final Report, prepared by ICF Technology Incorporated, Richland, Wash., Sept.

EPRI (Electric Power Research Institute) 1995b. Coal Ash.Disposal Manual: Third Edition, EPRI-TR-104137, Project 3176-7, Final Report, prepared by GAI Consultants, Inc., Monroeville, Penn., Jan.

EPRI (Electric Power Research Institute) 1996. EGEAS-Electric Generation Expansion Analysis System, AP-111987, Palo Alto, Calif.

EVSC (Envirosphere Co.) 1981a. Site Certification Application Environmental Information

Document for Jacksonville Electric Authority, St. Johns River Power Park Units 1 \& 2. EVSC (Envirosphere Co.) 1981b. Northside Generation Station NPDES Permit Biomonitoring Program, Final Report for Jacksonville Electric Authority. 
EVSC (Envirosphere Co.) 1983. Hydrothermal Modeling at Existing Stations, Atlanta.

FDEP (Florida Department of Environmental Protection) 1994. 1994 Florida Sediment Quality Assessment Guidelines (SQAGs), Tallahassee, Fla.

FDER (Florida Department of Environmental Regulation). 1981. Modified Conditions of

Certification for Jacksonville Electric Authority's St. Johns River Power Park Units 1 and 2 as Determined by Testimony at the Public Hearing on December 1 and 3, 1981, PA 81-13, Conditions of Certification, Dec. 15 transmittal from H. S. Oven, Administrator, Power Plant Siting Section, FDER, Tallahassee, Fla., to C. H. Bentley, Division of Administrative Hearings, Oakland Office Building, Tallahassee, Fla.

FDR (Florida Department of Revenue) 1997. Florida Property Valuations and Tax Data, December 1996, Tallahassee, Fla.

FEMA (Federal Emergency Management Agency) 1989. Flood Insurance Rate Map (FIRM), City of Jacksonville, Florida, Duval County, Panel 167 of 310, Community-Panel No. 1200770167 E (map revised Aug. 15).

FLCIR (Florida Legislative Committee on Intergovernmental Relations) 1997. Local Government Finance Information Handbook, Tallahassee, Fla., July.

Florida Archeological Services 1999a. A Cultural Resources Assessment Survey of the Jacksonville Electric Authority Northside Units 1 and 2 Repowering Project, Duval County, Florida, Jacksonville, Fla., May.

Florida Archeological Services 1999b. A Phase II Archaeological Investigation of Site 8DU13923 at the Jacksonville Electric Authority Northside Generating Station, Duval County, Florida. Jacksonville, Fla., July.

Florence, B. L. and C. Moore 1997. Annual Water Use Survey: 1995, Tech. Pub. SJ97-4, St. Johns River Water Management District, Palatka, Fla.

Foster Wheeler (Foster Wheeler USA Corp.) 1998a. "JEA Northside Repowering" (a threatened and endangered species survey conducted in the vicinity of Northside Generating Station) Jan.

Foster Wheeler (Foster Wheeler USA Corp.) 1998b. Jacksonville Electric Authority, Jacksonville, Florida, Northside Units 1 \& 2 Repowering Project, Soil Erosion and Sediment Control Notes, Drawing No. 41715-1-41-010, Rev. A, drawn by JJG, Perryville Corporate Park, Clinton, N.J., Feb. 2.

Foster Wheeler (Foster Wheeler USA Corp.) 1998c. “Jacksonville Electric Authority Northside

Repowering Project, Operational Noise Analysis Results," Oct. 22.

Foster Wheeler (Foster Wheeler USA Corp.) 1998d. "Foster Wheeler Constructors, Inc., Safety

Rates" table, communicated from Lee Lamarre, Foster Wheeler USA Corporation, to P. T. Nielsen, Jacksonville Electric Authority, July 30.

German, E. R. 1997. "Potentiometric Surface of the Upper Floridan Aquifer in the St. Johns River Water Management District and Vicinity, Florida, September 1996," U.S. Geological Survey Open File Report FL97-353, Tallahassee, Fla. 
Golder Associates 1998a. Northside Generating Station Fish Return System Optimization Study, prepared for Jacksonville Electric Authority, Doc. No. 9837517B/R2, June.

Golder Associates 1998b. Northside Generating Station Fish Return System Optimization Study, prepared for Jacksonville Electric Authority, Doc. No. 9837517B/R3, September.

Graedel, T. E. and P. J. Crutzen 1993. Atmospheric Change: An Earth System Perspective, W. H. Freeman and Co., New York.

Grolier, Inc. 1993. "Saint Johns River," in The Encyclopedia Americana International Edition, vol. 24, Danbury, Conn.

Hameed, S. and J. Dignon 1992. "Global Emissions of Nitrogen and Sulfur Oxides in Fossil Fuel Combustion 1970-1986," Journal of the Air and Waste Management Association, 42:159-163.

Hanisch, Carola 1998. "Where is Mercury Deposition Coming From?" Environmental Science \& Technology, 32(7):176A-179A, April 1.

Hanks, R. W. 1968. "Benthic Community Formation in a "New Marine Environment," "Chesapeake Sci. 9:163-172.

Holzworth, G. C. 1972. Mixing Heights, Wind Speeds, and Potential for Urban Air Pollution Throughout the Contiguous United States, PB-207 103, U.S. Environmental Protection Agency, Research Triangle Park, N.C.

Huff, M. D. and M. McKenzie-Arenberg 1990. "Lower St. Johns and St. Marys Ground Water Basins Resource Availability Inventory," Tech. Pub. SJ 90-8, St. Johns River Water Management District, Palatka, Fla.

ICBO (International Conference of Building Officials) 1995. "Uniform Building Code," Whittier, Calif.

ICRP (International Commission on Radiological Protection) 1991. Recommendations of the International Commission on Radiological Protection, ICRP 60 1990, Pergamon Press, Oxford.

IPCC (Intergovernmental Panel on Climate Change) 1992. Climate Change 1992, the Supplementary Report to the IPCC Scientific Assessment, Cambridge University Press.

Jacksonville Environmental Protection Board 1995. Rule 4, Noise Pollution Control, Jacksonville, Fla.

Jacksonville Sheriff's Office 1998. Jacksonville Sheriff's Office web site,

URL: http: //www.itd.ci.jax.fl.us/pub/jso/sheriff.html, accessed Jan. 30.

JEA (Jacksonville Electric Authority) 1976. Northside Generating Station 316 Demonstration, Jacksonville, Florida, Mar.

JEA (Jacksonville Electric Authority) 1989. St. Johns River Power Park, Bioassay Test Program Summary. Report ESE No. 86-334-0200-2130.

JEA (Jacksonville Electric Authority) 1992. Oil Spill Prevention Control and Countermeasure Plan, Northside Generating Station, Jacksonville Electric Authority, Jacksonville, Florida, prepared by Alexander Whitmer, Inc., Jacksonville, Fla., May. 
JEA (Jacksonville Electric Authority) 1995. Northside Generating Station Best Management

Practices, BMP3 document, Jacksonville, Fla., Aug.

JEA (Jacksonville Electric Authority) 1996a. 1996 Integrated Resource Plan Jacksonville Electric

Authority, prepared by Black and Veatch, Jacksonville, Fla., Dec.

JEA (Jacksonville Electric Authority) 1996b. JEA Emergency Plan Book—Plan IV, Jacksonville, Fla, April 16 and May 8.

JEA (Jacksonville Electric Authority) 1996c. Storm Response Procedure, Generating Stations, JEA

Procedure No. PGD 108.0, rev. 1, No. 7, Jacksonville, Fla., April.

JEA (Jacksonville Electric Authority) 1997a. 1997 Integrated Resource Plan Jacksonville Electric

Authority, prepared by Black and Veatch, Jacksonville, Fla., Dec.

JEA (Jacksonville Electric Authority) 1997b. Northside Generating Station National Pollutant

Discharge Elimination System (NPDES) Permit Renewal No. FL0001031, Jacksonville, Fla.

JEA (Jacksonville Electric Authority) 1998a. Northside Generating Station Noise Survey Report, Jacksonville, Fla., March 10.

JEA (Jacksonville Electric Authority) 1998b. Northside Generating Station Supplemental Noise Survey Report, Jacksonville, Fla., May 26.

JEA (Jacksonville Electric Authority) 1999. Air Quality Permit Application, Northside Repowering

Project Circulating Fluidized Bed Combustion Technology, Jacksonville, Fla., Feb. 15.

JFRD (Jacksonville Fire and Rescue Department) 1998. Jacksonville Fire and Rescue Department

web site, URL: http: //www.ci.jax.fl.us/pub/citygov/fire/stats.html, accessed Jan. 30.

JPDD (Jacksonville Planning and Development Department) 1993a. Comprehensive Plan 2010:

Potable Water Sub-element, City of Jacksonville, Fla.

JPDD (Jacksonville Planning and Development Department) 1993b. Comprehensive Plan 2010:

Sanitary Sewer Sub-element, City of Jacksonville, Fla.

JPDD (Jacksonville Planning and Development Department) 1994. Comprehensive Plan 2010:

Historic Preservation Element, City of Jacksonville, Fla.

JPDD (Jacksonville Planning and Development Department) 1996a. Comprehensive Plan 2010:

Future Land Use Element, City of Jacksonville, Fla.

JPDD (Jacksonville Planning and Development Department) 1996b. Population Projection, Duval

County, Florida by Planning Districts, 1990-2020, City of Jacksonville, Fla.

JPDD (Jacksonville Planning and Development Department) 1997a. Building Permit Report for the

City of Jacksonville Semi-Annual 1997, City of Jacksonville, Fla.

JPDD (Jacksonville Planning and Development Department) 1997b. Population Matrix 1990-1997,

City of Jacksonville, Fla.

JPDD (Jacksonville Planning and Development Department) 1997c. Building Permit Report for the

City of Jacksonville Annual 1996, City of Jacksonville, Fla.

JPDD (Jacksonville Planning and Development Department) 1998. Jacksonville Concurrency

Management System Road Links Status Report, City of Jacksonville, Fla, Dec. 1. 
Keller, A. E. and J. D. Schell 1993. Lower St. Johns River Basin Reconnaissance: Sediment Characterization and Quality, vol. 5, St. Johns Water Management District, Tech.

Pub. SJ93-6.

Kinsey, J. C. and C. Cowherd, Jr. 1992. "Fugitive Dust," Air Pollution Engineering Monual,

A. J. Buonicore and W. T. Davis eds., Van Nostrand Reinhold, New York.

Kremer, J. N. and S. W. Nixon 1978. A Coastal Marine Ecosystem, Springer-Verlag, New York.

Kryter, K. D. 1985. The Effects of Noise on Man, Academic Press, Inc., New York.

Law Engineering 1992. "Groundwater Monitoring Plan," Jacksonville Electric Authority, Northside

Generating Station, Wastewater Sludge Application Area, Law Engineering Project

No. 444-06565.01, Jacksonville, Fla.

Leve, G. W. 1978. "Altitude and Configuration of the Top of the Floridan Aquifer, Duval County, Florida," U.S. Geological Survey Water Resources Investigation No. 77-114. Open File Report, Tallahassee, Fla.

Lindberg, S. E., and W. J. Stratton 1998. Environmental Science and Technology 32:49-57.

Lutgens, F. K. and E. J. Tarbuck 1998. The Atmosphere, An Introduction to Meteorology, 7th ed., Illinois Central College, Prentice Hall, Upper Saddle River, N.J.

MacDonald, D. D. 1993. Development of an Approach to the Assessment of Sediment Quality in Florida Coastal Waters, Florida Department of Environmental Protection, Tallahassee, Fla.

Marland, G., T. A. Boden, R. J. Andres, and C. Johnson 1998. Online Trends: A Compendium of Data on Global Change, Carbon Dioxide Information and Analysis Center, Oak Ridge National Laboratory, Oak Ridge, Tenn., http://cdiac.esd.ornl.gov/trends.

Mitchell, J. F. B. 1989. "The 'Greenhouse' Effect and Climatic Change," Reviews of Geophysics 27:115-139.

Mitchell, J. F. B., T. C. Johns, J. M. Gregory, and S. F. B. Tett 1995. "Climate Response to Increasing Levels of Greenhouse Gases and Sulphate Aerosols," Nature, 376:501-504.

NATO (North Atlantic Treaty Organization) 1988. Pilot Study on International Information Exchange on Dioxins and Related Compounds: Emissions of Dioxins and Related Compounds from Combustion and Incineration Sources, NATO, Committee on the Challenges of Modern Society, Report 172, 1988.

NOAA (National Oceanic and Atmospheric Administration) 1992. SLOSH: Sea, Lake, and Overland Surges from Hurricanes, NOAA Tech. Rpt. NWS-48, Silver Spring, Md., April.

NRC (National Research Council) 1997. Possible Health Effects of Exposure to Residential Electric and Magnetic Fields, National Academy Press, Washington, D.C.

NSC (National Safety Council) 1994. Accident Facts, 1994 Edition, Itasca, Ill.

Patrick, R. 1994a. "Estuaries," pp. 110-12 in Rivers of the United States, vol. I, John Wiley \& Sons, Inc., New York.

Patrick, D. R. 1994b. Toxic Air Pollution Handbook, Van Nostrand Reinhold, New York. 
Phelps, G. G. 1994. "Water Resources of Duval County,” U.S. Geological Survey Water Resources Investigations Report 93-4130, Tallahassee, Fla.

Phelps, G. G. and R. M. Spechler 1997. "The Relation Between Hydrogeology and Water Quality of the Lower Floridan Aquifer in Duval County, Florida, and Implications for Monitoring Movement of Saline Water," U.S. Geological Survey Water Resources Investigations Report 96-4242, Tallahassee, Fla.

Rabon, J. W. 1970. "Floods of September 9-13 in Central and Northern Florida and Southern Georgia Caused by Hurricane Dora," pp. C74-C81 in Summary of Floods in the United States During 1964, by J. O. Rostvedt et al., U.S. Geological Survey Water-Supply Paper 1840-C, Washington, D.C.

RBA (Robert Bates \& Associates) 1995. "Contamination Assessment Report, Fuel Tanks \#11 and \#12, JEA Northside Generating Station," RBA Project No. 94566, Jacksonville, Fla.

Robinson Engineering Group 1998a. Northside Units 1 and 2 Railroad Impact Analysis for the Jacksonville Electric Authority, Draft, Jacksonville, Fla., Nov.

Robinson Engineering Group 1998b. Northside Units 1 and 2 Traffic Impact Analysis for the Jacksonville Electric Authority, Jacksonville, Fla., Nov.

SBCC (Southern Buildings Code Conference) 1997. 1997 Standard Building Codes, Southern Building Code Congress International, Inc., Birmingham, Alabama.

Schropp, S. J. and H. L. Windom. 1988. A Guide to the Interpretation of Metal Concentrations in Estuarine Sediments, Florida Dept. Of Environmental Regulation, Tallahassee, Fla.

Seal, T. L., F. D. Calder and G. M. Sloane 1994. Florida Coastal Sediment Contaminants Atlas, Florida Department of Environmental Protection, Tallahassee, Fla.

Seed, H. B. and I. M. Idriss 1971. "Simplified Procedure for Evaluating Soil Liquefaction Potential," Journal of the Soil Mechanics and Foundation Division, Proceedings of the American Society of Civil Engineers, 97(9), 1249-74.

Sisler, J. F. 1996. Spatial and Seasonal Visibility Patterns and Long Term Variability of the Composition of the Haze in the United States: An Analysis of Data from the IMPROVE Network, Cooperative Institute for Research in the Atmosphere, Colorado State University, Fort Collins, Colo.

Staub, W. P. 1991. "Nuclear Power Station Seismic Hazard Curves and the Uniform Building Code," Association of Engineering Geologists, XXVII(1).

Svendsen, R. L. and R. D. Bessette 1997. The Council of Industrial Boiler Owners Special Project on Non-Utility Fossil Fuel Ash Classification, proceedings of the American Coal Ash Association, Workshop on Management and Use of Coal Combustion Products (CCPs), Minneapolis/St. Paul, July 15.

Toth, D. J. 1993. Lower St. Johns River Basin Reconnaissance: Hydrogeology, vol. 1, Tech. Pub. SJ 93-7, St.Johns River Water Management District, Palatka, Fla. 
TRB (Transportation Research Board) 1994. Highway Capacity Manual, Special Report 209,

3rd. ed., National Research Council, Washington, D.C.

University of Florida 1997. 1997 Florida Statistical Abstract, University of Florida, Bureau of Economic and Business Research, Gainesville, Fla.

U.S. Bureau of Economic Analysis 1992. Regional Multipliers: A User Handbook for the Regional Input-Output Modeling System (RIMS II), Second Edition.

U.S. Bureau of the Census 1981. 1980 Census of Population and Housing, Washington, D.C.

U.S. Bureau of the Census 1991. 1990 Census of Population and Housing, Washington, D.C.

U.S. Bureau of the Census 1996. Statistical Abstract of the United States, Washington, D.C.

U.S. Bureau of the Census 1997. Estimates of the Population of Counties by Race and Hispanic Origin: July 1, 1996, Washington, D.C.

U.S. Court of Appeals (D.C. Circuit) 1999a. American Trucking Associations, Inc, et al. v. U.S. Environmental Protection Agency, No. 97-1440, decided May 14, 1999. URL:

hittp://www.cadc.uscourts.gov/common/opinions/199905/97-1440a.txt, accessed Nov. 3, 1999.

U.S. Court of Appeals (D.C. Circuit) 1999b. American Trucking Associations, Inc, et al. v. U.S. Environmental Protection Agency, Nos. 97-1440 and 97-1441, filed Oct. 29, 1999. URL: http://www.cadc.uscourts.gov/common/opinions/199910/97-1440b.txt, accessed Nov. 3, 1999.

USGS (U.S. Geological Survey) 1980. “Water Resources Data, Florida Water Year 1979,"

U.S. Geological Survey Water Data Report FL-79-1B, Tallahassee, Fla.

USGS (U.S. Geological Survey) 1992a. Mayport Quadrangle Florida-Duval County 7.5 Minute

Series Topographic Map, scale 1:24,000, contour interval $10 \mathrm{ft}$, National Geodetic Vertical

Datum of 1929, DMA 4744 IV NW-Series V847, revision of original 1964 map, Reston, Va. USGS (U.S. Geological Survey) 1992b. Eastport Quadrangle Florida-Duval County 7.5 Minute

Series Topographic Map, scale 1:24,000, contour interval $10 \mathrm{ft}$, National Geodetic Vertical Datum of 1929, DMS 4644 I NE-Series V847, revision of original 1964 map, Reston, Va. USGS (U.S. Geological Survey) 1997. Water Resources Data-Florida, Water Year 1996,

Volume 1A, Northeast Florida-Surface Water, USGS/WDR-FL-96-1A, Water Resources Division, Altamonte Springs, Fla.

USNRC (U.S. Nuclear Regulatory Commission) 1996. Generic Environmental Impact Statement for License Renewal of Nuclear Plants, NUREG-1437, vol. 2, Appendix C, Washington, D.C.

Vergara, B. A. 1998. Water Supply Assessment 1998, Tech. Pub. SJ98-2, St. Johns River Water Management District, Palatka, Fla.

Weston, Roy F., Inc. 1995. Revised Radionuclides Emissions Report, prepared for York County Energy Partners, L.P., Feb.

Whitten, D. G. A., and J. R. V. Brooks 1972. A Dictionary of Geology, 1983 Reprint, Penguin Books Ltd., Harmondsworth, Middlesex, England.

Williams, J. M. and I. W. Duedall 1997. Florida Hurricanes and Tropical Storms, rev. ed., University of Florida Press, Gainesville, Fla. 


\section{LIST OF PREPARERS}

\section{U.S. Department of Energy}

Lisa K. Hollingsworth, NEPA Document Manager

Environmental, Safety and Health Division, National Energy Technology Laboratory

\section{Oak Ridge National Laboratory}

Robert L. Miller, Program Leader, Energy Division, Oak Ridge National Laboratory

Technical Responsibilities: Team Leader, Meteorology, Air Quality

Education: B.S., 1975, Meteorology, The Pennsylvania State University

M.S., 1977, Meteorology, The Pennsylvania State University

Years of Experience: 16

Total Publications: 35

S. Marshall Adams, Research Staff, Environmental Sciences Division, Oak Ridge National Laboratory

Technical Responsibilities: Surface Water Quality, Ecological Resources, Wetlands

Education: B.S., 1967, Wildlife Biology, North Carolina State University

M.S., 1969, Zoology, North Carolina State University

Ph.D., 1974, Marine Science, University of North Carolina

Years of Experience: 24

Total Publications: 75

Terence J. Blasing, Research Staff, Energy Division, Oak Ridge National Laboratory

Technical Responsibility: Meteorology, Air Quality

- Education: B.S., 1966, Meteorology, University of Wisconsin

M.S., 1968, Meteorology, University of Wisconsin

Ph.D., 1975, Meteorology, University of Wisconsin

Years of Experience: 16

Total Publications: 50 


\section{JEA EIS}

Clay Easterly, Research Staff, Life Sciences Division, Oak Ridge National Laboratory

Technical Responsibilities: Human Health, Safety, Noise

Education: B.S., 1966, Physics, Mississippi State University

Ph.D., 1972, Health Physics, University of Tennessee

Years of Experience: 25

Total Publications: 125

Robert O. Johnson, Development Staff, Energy Division, Oak Ridge National Laboratory Technical Responsibilities: Hydrology, Thermal Discharge, Floodplains, Storm Surge, Land Use, Groundwater, Solid Waste

Education: B.S., 1972, Mechanical Engineering, University of Evansville M.S., 1975, Mechanical Engineering, Purdue University Ph.D., 1984, Engineering Science and Mechanics, University of Tennessee

Years of Experience: 24

Total Publications: 82

Martin Schweitzer, Research Staff, Energy Division, Oak Ridge National Laboratory

Technical Responsibilities: Cultural Resources, Socioeconomic Resources, Transportation, Environmental Justice

Education: B.A., 1972, Psychology, University of Michigan

M.S., 1978, Planning, University of Tennessee

Years of Experience: 20

Total Publications: 90

William P. Staub, Consultant, Oak Ridge National Laboratory

Technical Responsibilities: Geology, Hydrogeology, and Solid Waste Management

Education: B.S., 1956, Geological Engineering, Washington University of St. Louis

M.S., 1961, Geology, Washington University of St. Louis

Ph.D., 1969, Geotechnical Engineering, Iowa State University

Years of Experience: 22

Total Publications: 60 


\section{LIST OF AGENCIES AND INDIVIDUALS CONTACTED}

Ms. Sara Aicher

Okefenokee National Wildlife Refuge

Route 2, Box 3330

Folkston, GA 31537

Ms. Keri L. Akers

Coordinator

Florida State Clearinghouse

Department of Community Affairs

2555 Shumard Oak Boulevard

Tallahassee, FL 32399-2100

Mr. Ralph Cantral

Executive Director

Florida Coastal Management Program

2555 Shumard Oak Boulevard

Tallahassee, FL 32399-2100

Mr. John H. Crofts

Chief

Comprehensive Planning Division

City of Jacksonville

Florida Theatre Building

Suite 700

128 East Forsyth Street

Jacksonville, FL 32202

Mr. Sam O. Drake, Jr.

Refuge Manager

U.S. Department of the Interior

Fish and Wildlife Service

Savannah Coastal Refuges

1000 Business Center Drive

Parkway Business Center, Suite 10

Savannah, GA 31405

Mr. Sam D. Hamilton

Regional Director

U.S. Department of the Interior

Fish and Wildlife Service

1875 Century Boulevard

Atlanta, GA 30345 
Mr. Brad Hartman

Director

Office of Environmental Services

Florida Game and Freshwater Fish Commission

620 South Meridian Street

Tallahassee, FL 32399-1600

Mr. Ted Holmes

Public Information Officer

Jacksonville Fire and Rescue Department

515 N. Julia Street

Jacksonville, FL 32202

Ms. Laura A. Kammerer

State Historic Preservation Office

Florida Department of State

500 South Bronough Street

Tallahassee, FL 32399-0250

Mr. James W. Killian

Florida Department of Transportation

P.O. Box 1089

Lake City, FL 32056-1089

Mr. D.F. Lewis

Commanding Officer

U.S. Coast Guard

Marine Safety Office

7820 Arlington Expressway, Suite 400

Jacksonville, FL 32211

Mr. Mark Musaus

U.S. Fish and Wildlife Service

1000 Business Center Drive

Suite 10

Savannah, GA 31405

Mr. Charles A. Oravetz

Office of Protected Resources

National Marine Fisheries Service

Southeast Region

9271 Executive Center Drive, North

St. Petersburg, FL 33702 
Mr. Robert S. Pace

Manager, Air Quality Branch

City of Jacksonville Regulatory \& Environmental Services Department

Air and Water Quality Division

117 West Duval Street, Suite 225

Jacksonville, FL 32202

Mr. Don Palmer

U.S. Fish and Wildlife Service

6620 Southpoint Drive, South

Suite 310

Jacksonville, FL 32216

Mr. George W. Percy

State Historic Preservation Officer

Florida Department of State

500 South Bronough Street

Tallahassee, FL 32399-0250

Mr. G. Steven Pfeiffer

Assistant Secretary

Florida Department of Community Affairs

2555 Shumard Oak Boulevard

Tallahassee, FL 32399-2100

Ms. Ellen Porter

National Park Service-AIR

P.O. Box 25287

Denver, CO 80225

Mr. Gustave A. Rappold

ICAR Coordinator

Northeast Florida Regional Planning Council

9143 Philips Highway

Suite 350

Jacksonville, FL 32256

Mr. Harry Reagan

Public Information Coordinator

Jacksonville Sheriff's Office

501 E. Bay Street

Jacksonville, FL 32202

Ms. April D. Williford

Office of Intergovernmental Programs

Florida Department of Environmental Protection

Marjory Stoneman Douglas Building

3900 Commonwealth Boulevard

Tallahassee, FL 32399-3000 


\section{LIST OF AGENCIES, ORGANIZATIONS, AND PERSONS TO WHOM COPIES OF THIS STATEMENT ARE SENT}

Ms. Sara Aicher

Okefenokee National Wildlife Refuge

Route 2, Box 3330

Folkston, GA 31537

The Honorable Warren Alvarez

117 West Duval Street

Suite 425

Jacksonville, FL 32202

Ms. Pat Anderson

Audubon Society

1275 Norwich Road

Jacksonville, FL 32207

Mr. John Austin

6356 Sundown Drive

Jacksonville, FL 32244

Ms. Sarah Bailey

Florida Wildlife Federation

2202 Bishop Estates

Jacksonville, FL 32223

The Honorable Joe Barton

Chairman

Subcommittee on Energy and Power

Committee on Commerce

United States House of Representatives

Washington, DC 20515

The Honorable Max Baucus

Ranking Minority Member

Subcommittee on Environment

and Public Works

Committee on Commerce, Science, and Transportation

United States Senate

Washington, DC 20510

Mr. Tom Beal

River Systems Preservation

5238 River Park Villa

St. Augustine, FL 32092 
Mr. Robert A. Beck

Executive Director

National Coal Council

2000 North $15^{\text {th }}$ Street, \#500

Arlington, VA 22201

Mr. Robert Bèndick

Regional Director

Florida Office

The Nature Conservancy

222 South Westmonte Drive

Suite 300

Altamonte Springs, FL 32714-4269

Mr. Richard Berry

President

Eden Group, Inc.

1106 Baisden Road

Jacksonville, FL 32218

Dr. Rosina Bierbaum

Associate Director for Environment

Office of Science and Technology Policy

Executive Office of the President

Old Executive Office Building

Room 443

$17^{\text {th }}$ and Pennsylvania Avenue, NW

Washington, DC 20502

The Honorable Michael Bilirakis

Chairman

Subcommittee on Health and Environment

Committee on Commerce

United States House of Representatives

Washington, DC 20515

The Honorable Tom Bliley

Chairman

Committee on Commerce

United States House of Representatives

Washington, DC 20515

Mr. Homer Bliss

President

Rotary Club of North Jacksonville

6 East Bay Street

Jacksonville, FL 32202 
Ms. Rebecca K. Blood

Senior Government Relations Representative

American Public Power Association

2301 M Street, NW

Washington, DC 20037

Mr. Art Bolling

2308 Fox Haven Drive

Jacksonville, FL 32224

Ms. Christine Boney

7643 North Laura Street

Jacksonville, FL 32208

Mr. Val Bostwick

President

Northside Civic Association

315 North $11^{\text {th }}$ Avenue

Jacksonville Beach, FL 32250

Ms. Barbara Broward

Chairperson

Environmental Protection Board

717 Cedar Bay Road

Jacksonville, FL 32218

The Honorable Corrine Brown

101 East Union Street

Suite 202

Jacksonville, FL 32202

Ms. Dana L. Brown

Manager

Regulatory Services Branch

City of Jacksonville

Regulatory and Environmental Services Department

Air and Water Quality Division

421 W. Church Street

Suite 422

Jacksonville, FL 32202

The Honorable George E. Brown, Jr.

Ranking Minority Member

Committee on Science

United States House of Representatives

Washington, DC 20515 
The Honorable Sherrod Brown

Ranking Minority Member

Subcommittee on Health and Environment

Committee on Commerce

United States House of Representatives

Washington, DC 20515

Mr. William Burnett

110 Canal Boulevard

Ponte Vedra, FL 32205

The Honorable Jeb Bush

Governor of Florida

The Capitol

Tallahassee, FL 32399-0001

The Honorable Robert Byrd

Ranking Minority Member

Committee on Appropriations

United States Senate

Washington, DC 20510

The Honorable Ken Calvert

Chairman

Subcommittee on Energy and Environment

Committee on Science

United States House of Representatives

Washington, DC 20515

Mr. Stafford Campbell

Greater Arlington Civic Council

3861 Wayland Street

Jacksonville, FL 32277

Ms. Ainsley Cardinal

American Lung Association of Florida, Inc.

Northeast Region

5526 Arlington Road

Jacksonville, FL 32239

The Honorable John Chafee

Chairman

Subcommittee on Environment and Public Works

Committee on Commerce, Science, and Transportation

United States Senate

Washington, DC 20510 
Mr. Maurice Coman

Sierra Club

4984 Harp Street

Jacksonville, FL 32258

The Honorable Jerry F. Costello

Ranking Minority Member

Subcommittee on Energy and Environment

Committee on Science

United States House of Representatives

Washington, DC 20515

Mr. Charles Crews

Northside Businessmen Association

1202 Dunn Avenue

Jacksonville, FL 32218

Mr. Kevin Daniels

Executive Director

Coastal Conservation Association

4801 Woodway Street

Suite 220 West

Houston, TX 77058

The Honorable Lad Daniels

117 West Duval Street

Suite 425

Jacksonville, FL 32202

Mr. Bryan De Boinville

5124 Bradley Boulevard

Chevy Chase, Maryland 20815

Mr. William Dickerson

Director

NEPA Compliance Division

Office of Federal Activities

U.S. Environmental Protection Agency

2252-A, 401 M Street, SW

Washington, DC 20460

The Honorable Norman Dicks

Ranking Minority Member

Subcommittee on Interior

Committee on Appropriations

United States House of Representatives

Washington, DC 20515 
Mr. Louis Dinah

Chairman

Northwest CPAC

1711 McMillan Street

Jacksonville, FL 32209

The Honorable John D. Dingell

Ranking Minority Member

Committee on Commerce

United States House of Representatives

Washington, DC 20515

Mr. James Dixon

7848 Laura Street N.

Jacksonville, FL 32208

The Honorable Pete Domenici

Chairman

Subcommittee on Energy and Water Development

Committee on Appropriations

United States Senate

Washington, DC 20510

Mr. Dan Donaldson

Sierra Club

1648 Seminole Road

Jacksonville, FL 32205

The Honorable Byron Dorgan

Ranking Minority Member

Subcommittee on Water and Power

Committee on Commerce, Science, and Transportation

United States Senate

Washington, DC 20510

Mr. Sam O. Drake, Jr.

Refuge Manager

U.S. Department of the Interior

Fish and Wildlife Service

Savannah Coastal Refuges

1000 Business Center Drive

Parkway Business Center

Suite 10

Savannah, GA 31405 
Mr. Alex Echols

Deputy Director

National Fish and Wildlife Foundation

1120 Connecticut Avenue, NW

Suite 900

Washington, DC 20036

Mr. A. Forester Einarsen

NEPA Coordinator

Office of Environmental Policy, CECW-AR-E

U.S. Army Corps of Engineers

U.S. Department of Defense

7701 Telegraph Road

Alexandria, VA 22315-3861

Mr. Guy Foster

President

North Council of Chamber of Commerce

P.O. Box 26998

Jacksonville, FL 32226

The Honorable Tillie Fowler

109 Cannon Building

Washington, DC 20515

Mr. Ernie Frey

Director

Northeast District

Florida Department of Environmental Protection

7825 Baymeadows Way

Suite B200

Jacksonville, FL 32256-7590

Mr. H. Paul Friesema

Institute for Policy Research

Northwestern University

2040 Sheridan Road

Evanston, IL 60208-4100

Ms. C. Elaine Furbish

National Park Service

Timucuan Ecological and Historic Preserve

13165 Mt. Pleasant Road

Jacksonville, FL 32225 
Ms. Leslie Goller

Environmental Protection Board

Air and Odor Committee

Brown Terrell Hogan, et al.

3644 Hendrick Street

Jacksonville, FL 32205

Ms. Barbara Goodman

Superintendent

National Park Service

Theodore Roosevelt

13165 Mount Pleasant Road

Jacksonville, FL 32225

The Honorable Slade Gorton

Chairman

Subcommittee on Interior

Committee on Appropriations

United States Senate

Washington, DC 20510

Mr. Michael Gosliner

General Counsel

Marine Mammal Commission

4340 East-West Highway

Suite 905

Bethesda, MD 20814

The Honorable Bob Graham

Ranking Minority Member

Subcommittee on Energy Research, Development,

Production, and Regulation

Committee on Commerce, Science, and Transportation

United States Senate

Washington, DC 20510

Mr. Steve Grimm

Senior Program Analyst, RRP-24

Office of Policy and Program Development

Federal Railroad Administration

U.S. Department of Transportation

Mail Stop 15

$4007^{\text {th }}$ Street, SW

Washington, DC 20590 
The Honorable Ralph M. Hall

Ranking Minority Member

Subcommittee on Energy and Power

Committee on Commerce

United States House of Representatives

Washington, DC 20515

Mr. Sam D. Hamilton

Regional Director

U.S. Department of the Interior

Fish and Wildlife Service

1875 Century Boulevard

Atlanta, GA 30345

Mr. Bill Hammill

Peoples Gas System

4040 Phillips Highway

Jacksonville, FL 32607

Mr. Brad Hartman

Director

Office of Environmental Services

Florida Game and Freshwater Fish Commission

620 South Meridian Street

Tallahassee, FL 32399-1600

Mr. Nelson Helmuth

Sierra Club

1738 Kingsley Avenue

Orange Park, FL 32073

Mr. Clay Henderson

President

Florida Audubon Society

National Audubon Society

1331 Palmetto Avenue

Suite 110

Winter Park, FL 32789

Mr. Robert L. Hill

Executive Director

American Association of Blacks in Energy

$92715^{\text {th }}$ Street, NW, \#200

Washington, DC 20005

Ms. Marion Hilliard

Florida Defenders of the Environment

2902 Greenridge Road

Orange Park, FL 32073 
The Honorable Alberta Hipps 117 West Duval Street Suite 425

Jacksonville, FL 32202

The Honorable Ernest Hollings

Ranking Minority Member

Committee on Commerce, Science, and Transportation

United States Senate

Washington, DC 20510

Mr. Kenneth W. Holt

Centers for Disease Control \& Prevention

National Center for Environmental Health

DEEHS/CDB (F16)

4770 Buford Hwy, NE

Atlanta, GA 30341-3724

Mr. George C. Jeffrey

P.O. Box 11622

Jacksonville, FL 32239

Mr. Walter R. Joba

President

Northside Rotary Club

c/o Owens Corning

1035 Talleyrand Avenue

Jacksonville, FL 32206-6019

Lt. Col. Julie Jones

Regional Director, Northeast Region

Florida Game and Freshwater Fish Commission

Route 7, Box 440

Lake City, FL 32055-8713

Ms. Laura Kammerer

Bureau of State Historic Preservation Office

500 South Bronough Street

Tallahassee, FL 32399-0250

Ms. Rosalyn Kilcollins

2555 Shumard Oak Boulevard

Tallahassee, FL 32399-2100 
Mr. Don Klima

Director

Office of Planning and Review

Advisory Council on Historic Preservation

Old Post Office Building

Suite 809

1100 Pennsylvania Avenue, NW

Washington, DC 20004

Ms. Chris Knezevich

7925 Merrill Road

Apt. 1503

Jacksonville, FL 32277

Mr. Fred Krupp

Executive Director

National Headquarters

Environmental Defense Fund, Inc.

257 Park Avenue South

New York, NY 10010

Dr. Daniel Lashof

Senior Scientist

Natural Resources Defense Council, Inc.

1200 New York Avenue, NW

Suite 400

Washington, DC 20005

Ms. Beverlee Lawrence

U.S. Army Corps of Engineers

Jacksonville District

400 West Bay Street

Jacksonville, FL 32202

Ms. Robin Leigh

6026 Heckscher Drive

Jacksonville, FL 32226

Mr. D.F. Lewis

Commanding Officer

U.S. Coast Guard

Marine Safety Office

7820 Arlington Expressway

Suite 400

Jacksonville, FL 32211 
Mr. Al Linero

Florida Department of Environmental Protection

Division of Air Resources Management

2600 Blair Stone Road

MS 5505

Tallahassee, FL 32399-2400

Mr. John A. Logan

10142 Haverford Road

Jacksonville, FL 32218

The Honorable Connie Mack

Chairman

Joint Economic Committee

United States Senate

Washington, DC 20510

Mr. James L. Manning, P.E.

Chief

Air \& Water Quality Division

Regulatory \& Environmental Services Department

421 West Church Street

Suite 412

Jacksonville, FL 32202

Ms. Dot Mathias

Northside Civic Association

341 Baisden Road

Jacksonville, FL 32218

The Honorable John McCain

Chairman

Committee on Commerce, Science, and Transportation

United States Senate

Washington, DC 20510

Ms. Cindy Moesling

BEAKS Bird Sanctuary

12084 Houston Avenue

Big Talbot Island, FL 32226

Mr. Damon Moglen

Greenpeace International

1436 U Street, NW

Washington, DC 20009 . 
Mr. W. Mercer and Ms. Maria Morris 7836 North Laura Street

Jacksonville, FL 32208

Mr. Heinz Mueller

Chief

Office of Environmental Assessment

Environmental Accountability Division

Region 4

U.S. Environmental Protection Agency

Atlanta Federal Center

61 Forsyth Street, SW

Atlanta, GA 30303

Mr. Mark Musaus

U.S. Fish and Wildlife Service

1000 Business Center Drive

Suite 10

Savannah, GA 31405

Ms. Sharon Myers

Post, Buckley, Schuh, \& Jernigan

4201 Northview Drive

Suite 302

Bowie, MD 20716

The Honorable Don Nickles

Chairman

Subcommittee on Energy Research, Development,

Production, and Regulation

Committee on Commerce, Science, and Transportation

United States Senate

Washington, DC 20510

The Honorable David R. Obey

Ranking Minority Member

Committee on Appropriations

United States House of Representatives

Washington, DC 20515

Mr. Charles A. Oravetz

Office of Protected Resources

National Marine Fisheries Service

Southeast Region

9271 Executive Center Drive, North

St. Petersburg, FL 33702 


\section{JEA EIS}

Mr. Hamilton B. Oven

Florida Department of Environmental Protection

2600 Blair Stone Road

MS 48

Tallahassee, FL 32399-2400

The Honorable Ron Packard

Chairman

Subcommittee on Energy and Water Development

Committee on Appropriations

United States House of Representatives

Washington, DC 20515

Mr. Don Palmer

U.S. Fish and Wildlife Service

6620 Southpoint Drive, South

Suite 310

Jacksonville, FL 32216

Mr. Brian Paradise

League of Conservation Voters

2831 Wood Valley Court

Jacksonville, FL 32217

Mr. Bruce Parker

2831 Talleyrand Avenue

Jacksonville, FL 32206

Mr. George W. Percy

State Historic Preservation Officer

Florida Department of State

500 South Bronough Street

Tallahassee, FL 32399-0250

Ms. Moya Phelleps

Executive Director

Coal Exporters Association of the United States

$113017^{\text {th }}$ Street, NW

Washington, DC 20036

Ms. Pat Pillmore

Stewards of the St. Johns

Mary L. Singleton Senior Center

150 East First Street

Jacksonville, FL 32206 
Ms. Ellen Porter

National Park Service-AIR

P.O. Box 25287

Denver, CO 80225

Ms. Peggy Powell

Duval Audubon Society

2965 Forest Circle

Jacksonville, FL 32257

Mr. Richard H. Powell

404 Irving Street

Olean, NY 14760

Mr. Jim Price

Senior Regional Staff Director

Southeast Office

Sierra Club

$133021^{\text {st }}$ Way, South

Suite 100

Birmingham, AL 35205

Ms. Madeline Reed

St. Johns Preservation Association

9209 Frederick Street

Jacksonville, FL 32226

The Honorable Ralph Regula

Chairman

Subcommittee on Interior

Committee on Appropriations

United States House of Representatives

Washington, DC 20515

The Honorable Harry Reid

Ranking Minority Member

Subcommittee on Energy

and Water Development

Committee on Appropriations

United States Senate

Washington, DC 20510

Ms. Sarah Robinson

Environmental Services

8711 Perimeter Park Boulevard

Suite 11

Jacksonville, Florida 32216 
Mr. Ronald Rohrer

3733 Pine Street

Jacksonville, FL 32205

Ms. Jessie Sammons

President

Heckscher Drive Community Club

9280 Heckscher Drive

Jacksonville, FL 32226

Ms. Ramona Schreiber

Environmental Program Specialist

Office of Policy and Strategic Planning

National Oceanic and Atmospheric Administration

U.S. Department of Commerce

Room 6117

Herbert Hoover Building

$14^{\text {th }}$ Street and Constitution Avenue, NW

Washington, DC 20230

Ms. Kelly Schultz

Jacksonville CPA Association

7136 Glendyne Drive North

Jacksonville, FL 32216

The Honorable F. James Sensenbrenner, Jr.

Chairman

Committee on Science

United States House of Representatives

Washington, DC 20515

Ms. Caroline Silvers

St. Johns River Water Management District

7775 Baymeadows Way

Suite 102

Jacksonville, FL 32256

The Honorable Gordon Smith

Chairman

Subcommittee on Water and Power

Committee on Commerce, Science, and Transportation

United States Senate

Washington, DC 20510

Mr. Gray C. Solomon

10011 Sawgrass Drive East

Ponte Vedra Beach, FL 32082 
Ms. Suzy Spencer

5440 Cedar Point Road

Jacksonville, FL 32226

Ms. Janet Stanko

Sierra Club

3417 Hermitage Road E.

Jacksonville, FL 32277

Congressman Cliff Stearns

115 SE 25th Avenue

Ocala, FL 34471

The Honorable Ted Stevens

Chairman

Committee on Appropriations

United States Senate

Washington, DC 20510

Mr. Edward Syrjala

P. O. Box 149

Centerville, MA 02632

Mr. Willie R. Taylor

Director

Office of Environmental Policy and Compliance

U.S. Department of the Interior

1849 C Street, NW

MS2340

Washington, DC 20240

Mr. Brian Teeple

Northeast Florida Regional Planning Council

9143 Phillips Highway

Suite 350

Jacksonville, FL 32256

Mr. Larry Thompson

Vice President

Florida Audubon Society

National Audubon Society

102 East $4^{\text {th }}$ Avenue

Tallahassee, FL 32303

Chief Peter G. Torres

Council Elder

Taino Tribal Council of Jatibonuco

703 S. Eighth Street

Vineland, NJ 08360 
Ms. Cherie Trainor

Coordinator

Florida State Clearinghouse

Department of Community Affairs

2555 Shumard Oak Boulevard

Tallahassee, FL 32399-2100

Ms. Connie Tucker

Southern Organizing Committee for

Economic and Social Justice

P. O. Box 10518

Atlanta, GA 30310

Mr. Samuel Tyson

Executive Director

American Coal Ash Association 6940 South Kings Highway

Suite 207

Alexandria, VA 22310-3344

Union of Concerned Scientists

1616 P Street, NW

Suite 310

Washington, DC 20036

U.S. Army Corps of Engineers

Jacksonville District

400 West Bay Street

Jacksonville, FL 32202

Mr. Jim Valade

U.S. Fish and Wildlife Service 6620 Southpoint Drive, South

Suite 310

Jacksonville, FL 32216

Ms. Christy Veleta

Program Administrator

Environmental Protection Board

117 West Duval Street

Jacksonville, FL 32202

Mr. Richard Vento

17438 Holmes Mill Avenue

Jacksonville, FL 32205 
Mr. Bruce Verhaaren

Environmental Assessment Division

Argonne National Lab

$\mathrm{EAD} / 900$

9700 S. Cass Avenue

Argonne, IL 60439-4812

The Honorable Peter J. Visclosky

Ranking Minority Member

Subcommittee on Energy and Water Development

Committee on Appropriations

United States House of Representatives

Washington, DC 20515

Mr. Harry Wagner

District Director

Lions Club

13659 Dunns Creek Road

Jacksonville, FL 32218

Mr. David Wheeley

7531 Wilder Avenue

Jacksonville, FL 32208

Mr. John Williams

12770 SW Foothill Drive

Portland, OR 97225

The Honorable C. W. Bill Young

Chairman

Committee on Appropriations

United States House of Representatives

Washington, DC 20515 


\section{INDEX}

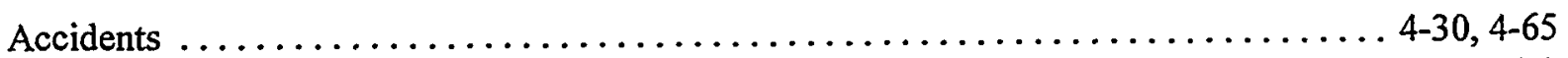

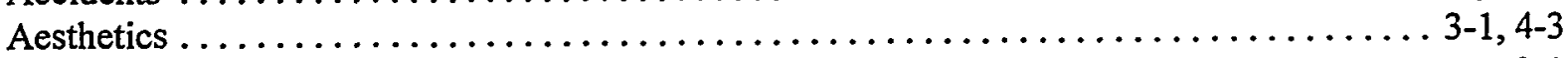

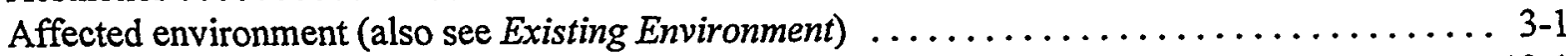

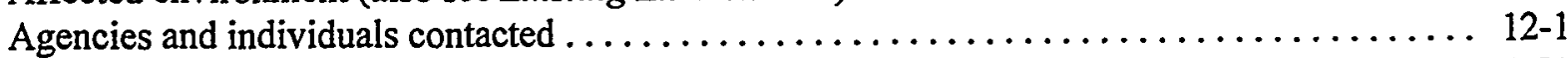

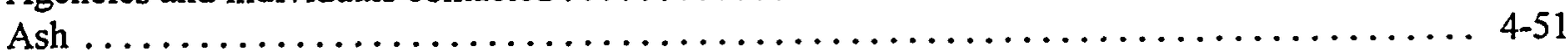

Air pollutants (see Air Quality)

Air quality

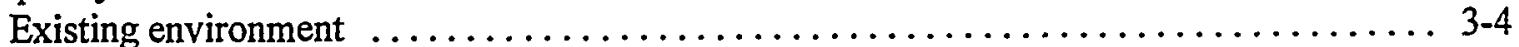

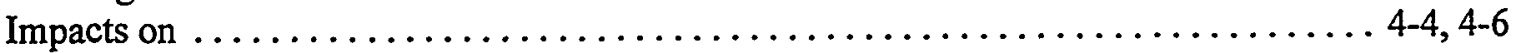

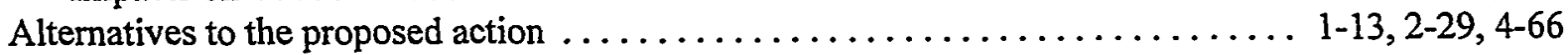

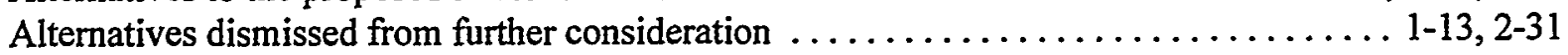

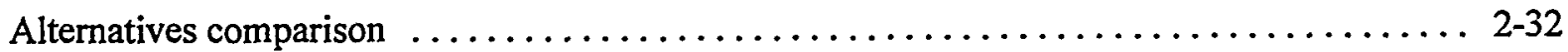

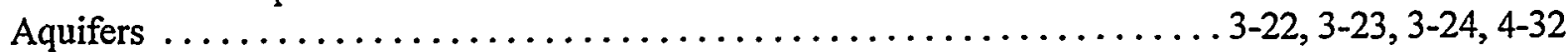

Aquatic resources

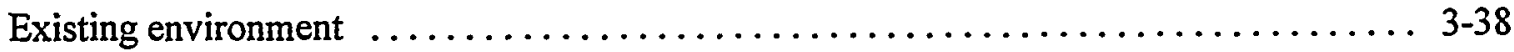

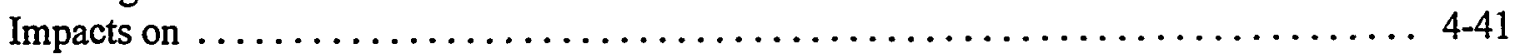

Archaeological resources (see Cultural Resources)

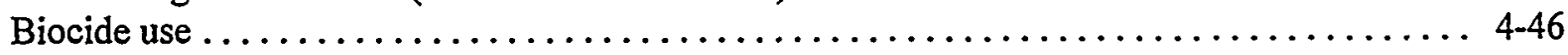

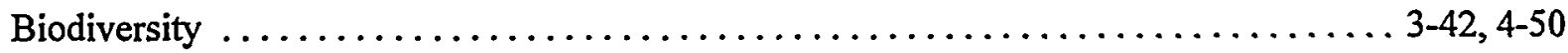

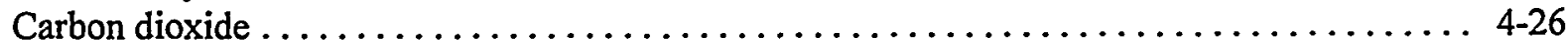

Circulating fluidized bed combustor $\ldots \ldots \ldots \ldots \ldots \ldots \ldots \ldots \ldots \ldots \ldots \ldots \ldots \ldots \ldots \ldots \ldots \ldots \ldots \ldots \ldots \ldots \ldots \ldots, 2-6$

Clean Coal Technology Program ................................ 1-1, 1-6

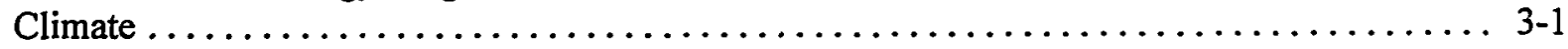

Coal (see Fuels)

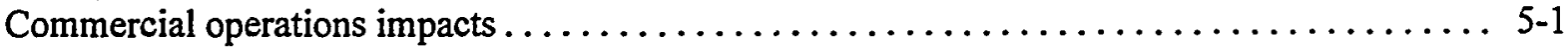

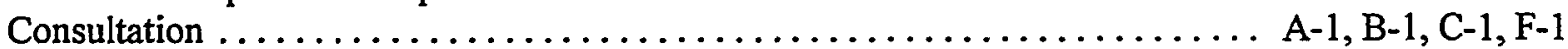

Cultural resources

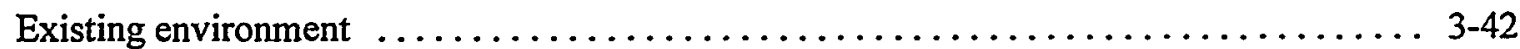

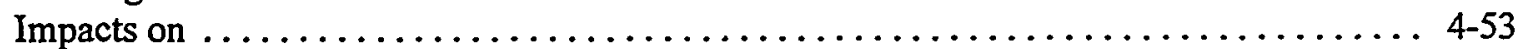

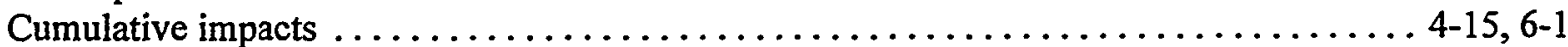

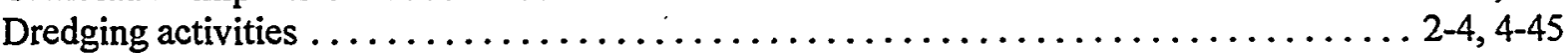

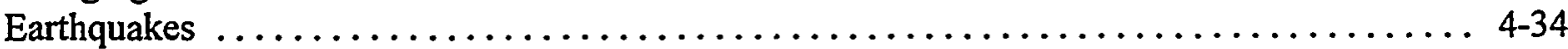

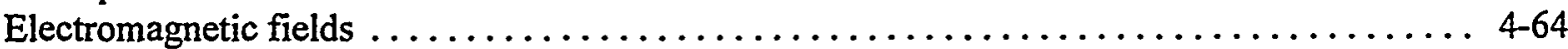

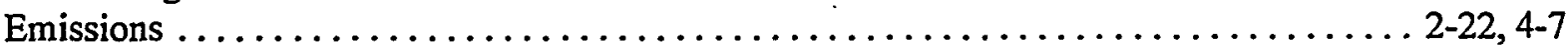

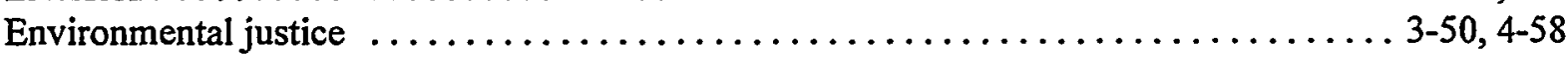

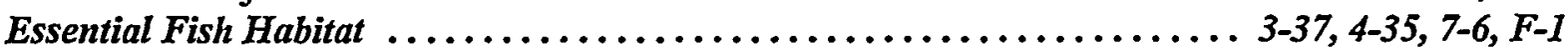

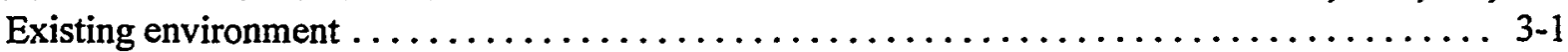

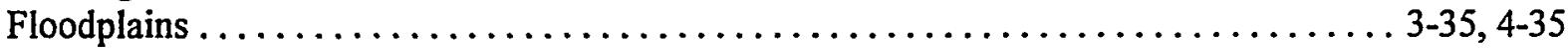

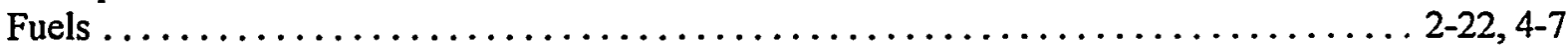

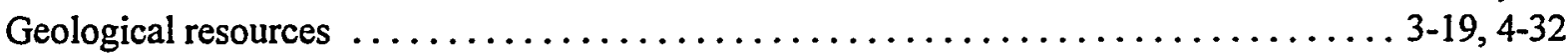

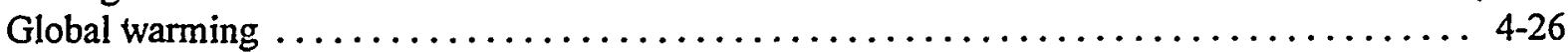

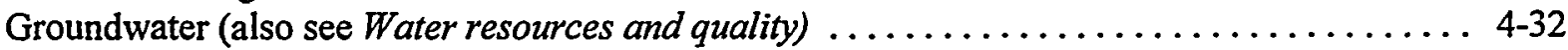

Hazardous materials .................................. 27, 4-18

Health and safety (see Human health)

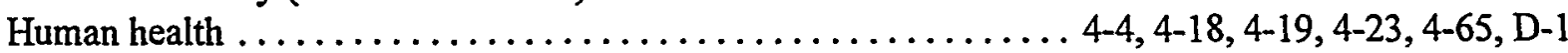

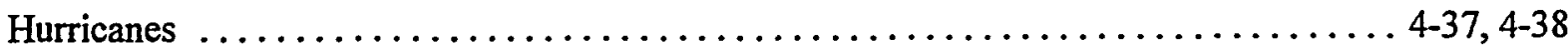

Hydrology (see Water resources and quality) 


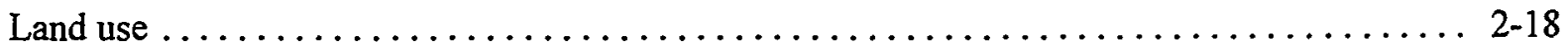

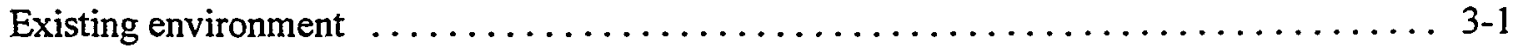

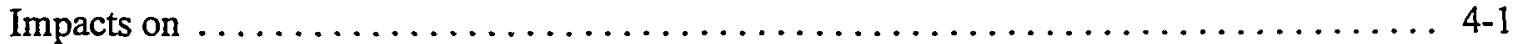

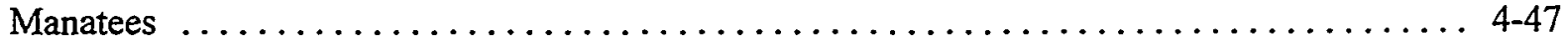

Mitigation measures ..................1-10, 4-1, 4-40, 4-61, 4-62, 4-63, 4-64, 4-66

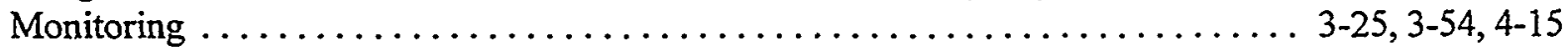

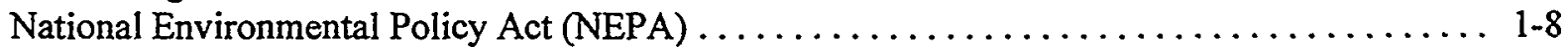

Natural gas (see Fuels)

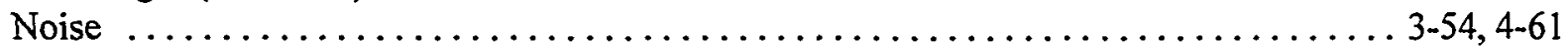

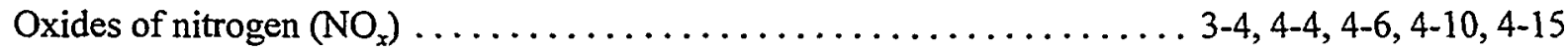

Ozone .............................................. . 4-14

Permits (see Regulatory compliance)

Petroleum coke (see Fuels)

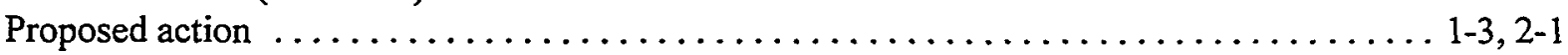

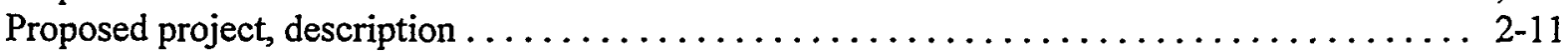

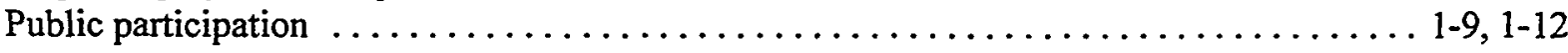

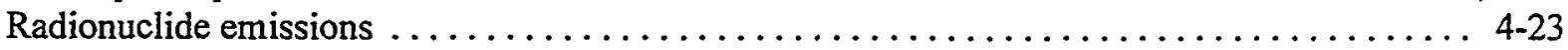

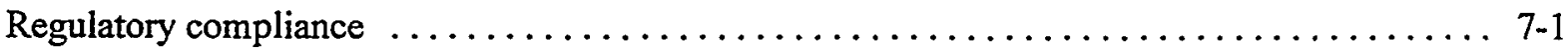

Related actions . ................................... 2-28, 4-10

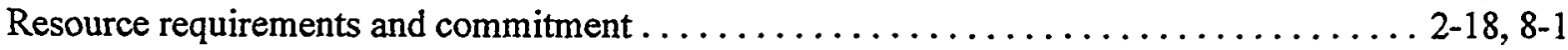

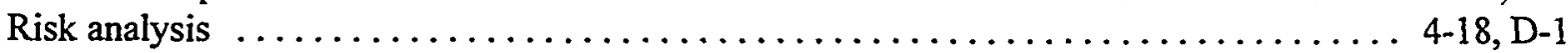

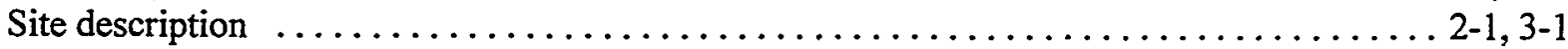

Socioeconomic resources

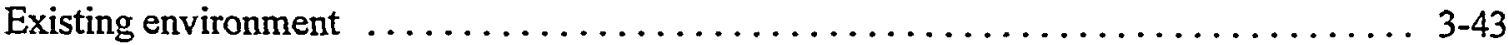

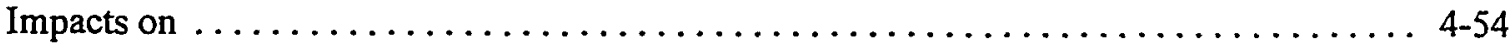

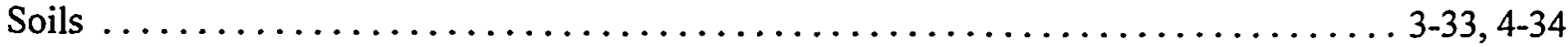

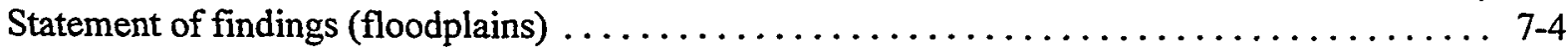

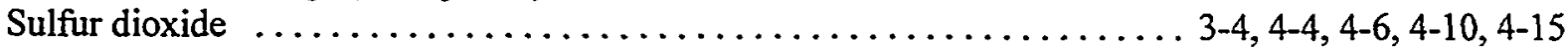

Surface water (see Water resources and quality)

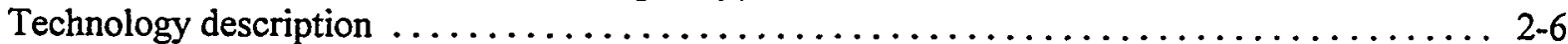

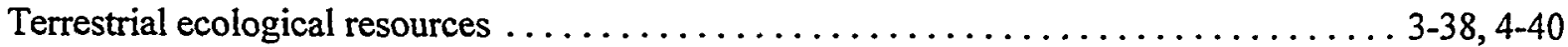

Threatened and endangered species . . . . . . . . . . . . . . . . . . . $3-40,4-47$

Traffic ................................................. $4-59$

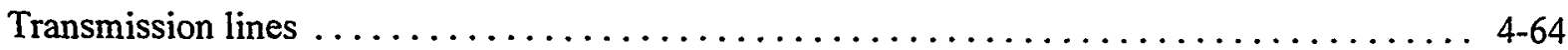

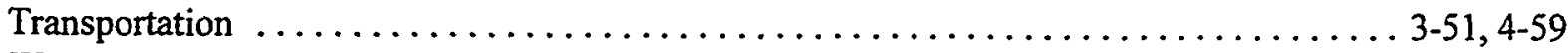

Waste management

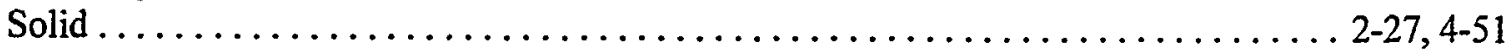

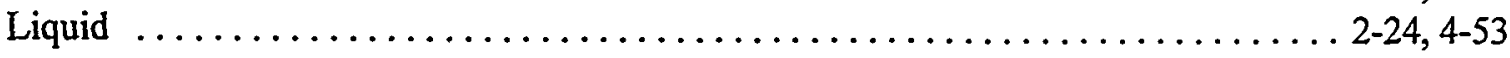

Water resources and quality

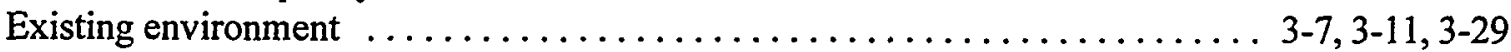

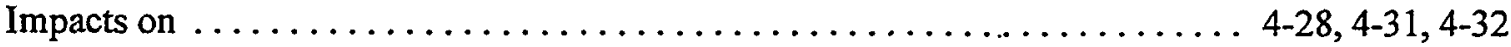

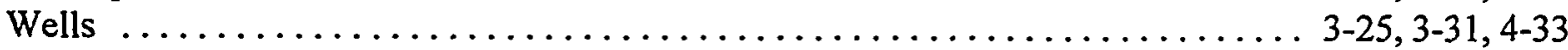

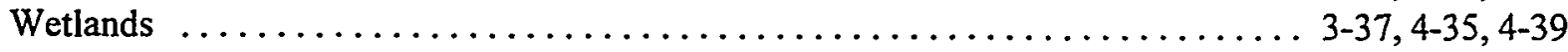




\section{APPENDIX A}

CONSULTATION LETTERS UNDER SECTION 7 OF THE ENDANGERED SPECIES ACT 


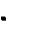




\title{
United States Department of the Interior
}

\author{
FISH AND WILDLIFE SERVICE \\ 6620 Southpoint Drive South \\ Suite 310 \\ Jacksonville, Florida 32216-0912
}

IN REPLY REFER TO:

JUN -91998

FWS/R4/ES-JAFL

Lisa K. Hollingsworth

NEPA Document Manager

Environmental, Safety \& Health Division

U.S. Department of Energy

3610 Collins Ferry Road

P.O. Box 88-

Morgantown, WV 26507-0880

Dear Ms. Hollingsworth:

This is in response to your letter of May 28,1998, requesting information on the threatened and endangered species that may occur in Duval County, the area of your proposed Jacksonville Electric Authority project. The Service does not have site-specific records for these species but depending on habitats found in the project area, some of these species may occur on-site.

If you have any further questions, you may call Don Palmer at (904) 232-2580 ex 115. Please reference the FWS log number 98-653E.

Sincerely,

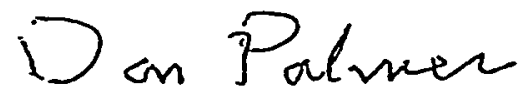

5u $\iota$ Michael M. Bentzien

Assistant Field Supervisor 


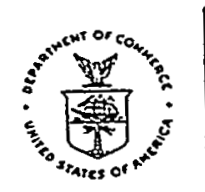

UNITED STATES DEPARTMENT OF COMMERCE

National Dceanic and Atmospheric Administration

NATIONAL MAFINE FISHERIES SERVICE

Southeast Regional Office

9721 Executive Center Drive North

St. Petersburg, FL 33702

JUN 251998

F/SER3:JBM

Ms. Lisa K. Hollingsworth NEPA Document Manager

Federal Energy Technology Center

U.S. Department of Energy

P.O. Box 880

Morgantown. WV 26507-0880

Dear Ms. Hollingsworth:

This is in response to your May 28, 1998 letter, concerning environmental impacts resulting from the Federally-funded circulating fluidized-bed combustors project proposed for the Jacksonville Electric Authority's Northside Generating Station, Jacksonville, Florida. Your preliminary list of identifiable environmental issues mentions sighting of green turtles near the cooling water intake structure. However, aside from green turtles, loggerhead and Kemp's ridley sea turtles may also be present in the project area. There is insufficient information to allow us to make a final determination regarding the extent of effects to listed species of endangered and threatened marine life under the jurisdiction of the National Marine Fisheries Service. We will again review the project for potential effects upon receipt of the Draft Environmental Impact Statement.

If you have any questions or we can be of further assistance, please contact Colleen Coogan at 813-570-5312.

Sincerely yours,

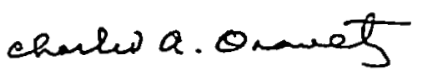

Charles A. Oravetz

Assistant Regional Administrator for Protected Resources Division 
APPENDIX B

CONSULTATION LETTERS UNDER SECTION 106 OF THE NATIONAL HISTORIC PRESERVATION ACT 


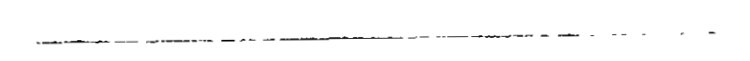




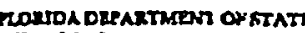

ceise of the socentry

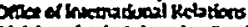

Divioion ol Adrainictratveservices

Direind Copperations.

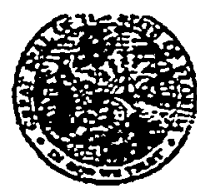

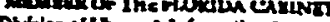

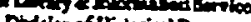
Lion af tridociol Remowe Rincling Herave of A Drtwian of tinction
FLORMOA DETARIMENT OF STATE

Sandra B. Mortham

Secretary of Stabe

DIVISTON OF HISTORICAL RESOURCES

December 22, 1997

Ms. Jan K. Wachter

Federal Energy Technology Center

U.S. Department of Energy

P.O. Box 880

Morgantowa West Virginia 26507-0880.
In Reply Refer To:

Frank J. Keel

Iistoric Preservation Planner

Project File No. 976219

RF: Culnurd Resource Assessment Request

Jacksonville Electric Authority (JEA) Circulating Fluidized Bed Combuster

Projoct - Narthside Generating Station

Duval County, Florida

Dear Ms. Wachter:

In accordance with the procedures contained in 36 C.FR, Part 800 ("Protection of Fintoric Properties"), wre have reviewed the referenced project (s) for posswile impset to historic propertio listed, or eligible for tisting in the National Register of Hisforic Places. The wuthority for this procedure is the National Historic Preservation Act of 1966 (Public Law 89-665), as ameaded.

It is the opinion of this agency that because of the project nature it is considered unlikely that archieological or historical sites will be affected. Therefore, it is the opinion of this office that the proposed project will have no effoct on any sites listed or efigible for tisting in the National Register. The project may proced without further involvement with this agency.

If you have any questions conceming our comments, please do not hesitate to contect us. Your interest in protecting Florida's historic properties is appreciated.

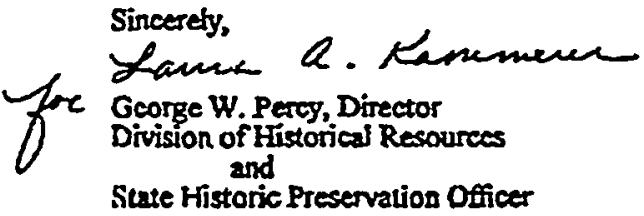

GWP/RfK

Stute Historic Preservalion Officer

\section{DIRECTORS OFIICE}

RA. Gray Bulding - 500 South Bronough Street - Tallaliasser, Forida $32399-0250$ - (85D) $188-1480$

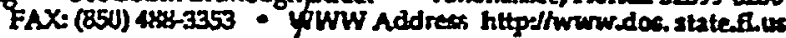

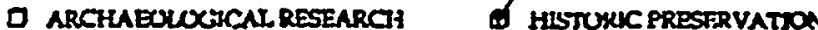
(250) $487-2299 \cdot F A \times: 1142297$ 
UTYSIONS OFFLRTDA DEPARTMENT OF STATE Ofsoce of the stareary

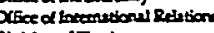

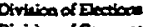

Divition or Coxpocetions

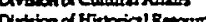

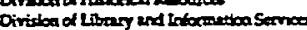

Division of Lementing

Divition of Adriniftretive Service

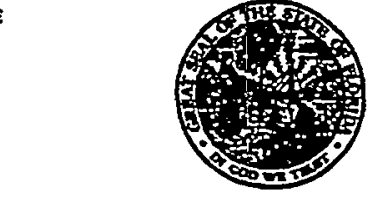

FLORIDA DEPARTMENT OF STATE
Katherine Harris
Secretary of State

DIVISION OF HISTORICAL RESOURCES
MECEER OF THEFLORDA CASDET

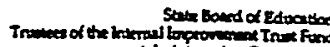

Theren

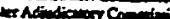

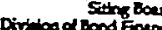

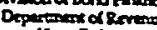

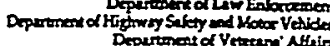

July 28, 1999

Mr. Robert Johnson

Florida Archaeological Services, Inc.

4250 Melrose Avenue

Jacksonville, FL 32210

RE: DHR Project File No. 994761

A Cultural Resource Assessment Survey of the Jacksonville Electric Authority Northside

Units I \& 2 Repowering Project. Duval County. Florida. By Florida Archaeological Services, Inc., May 1999.

Dear Mr. Johnson:

In accordance with the procedures contained in 36 C.F.R. Part 800 ("Protection of Historic Properties"), as well as Chapter 267.061, Florida Statues, implemented through 1A-46 Florida Administrative Code, we have reviewed the results of the referenced project and find them to be complete and sufficient.

Based on the information provided in the above report we note that four previously recorded sites, DU 91, DU 101, DU 102 and DU 105, and five newly recorded sites, DU13923 -

DU13927, were located and assessed as a result of the above survey. We concur with the conclusions and recommendations in the report that four of these sites, DU91, DU 13924 DU13925 and DU13927 are not eligible. We further concur that sites DU101, DU102, DU105 and DU13923 are potentially eligible. We recommended that these four sites (DU101, 102, 105 and (3923) be avoided by any development activities.

We note from the report that current plans would will place three of the potentially eligible sites DU101 (the San Cartos West Site), DU102 (the San Carlos West Burial Mound Site), and DU105 the Jacksonville Power Plant Site), within a conservation area. It is our understanding from the report that there have been problems with looting in the past at burial site DU102. We agree with the recommendations in the report for providing locked gates or some protection against looting for this site. A protection plan for this site should be coordinated with the project archaeologist and this agency to insure that the site is not affected by installation of fencing etc.

Regarding site DU 13923 the Light Bulb Site, we note that this potentially eligible site is not included in the proposed conservation ares. We therefore recommend avoidance of DU13923. If avoidance is not possible then Phase II testing will be necessary. We note from the report that when site DU13926 was found to be outside the current project area, work on it was suspended. There is therefore insufficient information to make a determination of its eligibility. Should project activities involve this site area in the future, it would need to be evaluated. If the above recommendations are followed, it is the opinion of this office that the proposed project will have no effect on sites listed, or eligible for listing, in the National Register of Historic Places, or otherwise of historic or archaeological value.

\footnotetext{
R.A. Gray Building - 500 South Bronough Street - Tallahassee, Florida 32399-0250 - htp://www flheritagecom a Director's Office a Archaeological Research

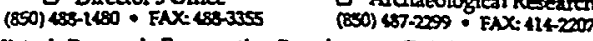
D Histocie Pensacola Preservation Boerd (850) 595-5775 - FAX: 595-5799 9 Palon Bcach Regionul Ofice

(t) 500) Historic Preservation St Soan Augustine Regional Office 850) Historical Muscums O Tampa Regional Office
(813) 272.3843 GAX:272-2310
} 
Mr. Johnson

July 28, 1999

Page 2

If you have any questions concerning our comments, please contact Ms. Robin Jackson, Historic Sites Specialist at (850) $487-2333$ or 1-(800) 847-7278. Your interest in protecting Florida's historic properties is appreciated.

Sincerely,

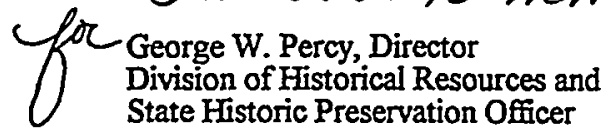

Laura A. Rammenes

State Historic Preservation Officer

GWP/Jrj 
DIVISIONS CF ELORTDA DEPAKTMENT OF STATE Otber ef thessocrary

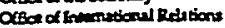
Dirstion of Eecolose Division ol Copporetion

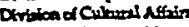

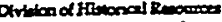

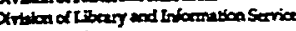
Diviten of Leoring

Divition of Adeninistive Serios

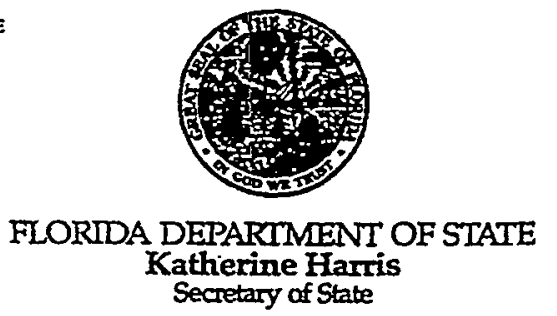

DIVISION OF HISTORICAL RESOURCES

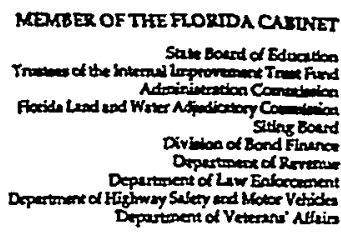

August 3, 1999

Mr. Robert Johnson

Florida Archaeological Services, Inc.

4250 Meirose Avemue

Jacksonville, FL 32210

RE: DHR Project File No. 995628

Cultural Resource Assessment Request

A Phase II Archaeological Imvestigation of Site $8 D U 13923$ at the Jacksomille Electric Authority Northside Generating Station. Duval County. Florida. By Florida Archaeological Services, Inc. July 1999.

Dear Mr. Johnson:

In accordance with the procedures contained in 36 C.F.R, Part 800 ("Protection of Historic Properties"), we have reviewed the results of the referenced project and find them to be complete and sufficient.

Based on the information provided in the above report, we note that a Phase II investigation was conducted for site 8DU13923. Based on the results of this investigation, the site was determined to not be eligible. We concur with the conclusions and recommendation in the report. We note from the Phase I survey of this project area that sites DU101, DU102 and DU105, were found to be potentially eligible. It is our understanding that these sites will be put in a conservation easement. It is therefore the opinion of this agency that the proposed project will have no effect on site s listed, or eligible for listing, in the National Register of Historic Places.

If you have any questions concerning our comments, please contact Ms. Robin Jackson, Historic Sites Specialist at (850) $487-2333$ or 1-(800) $847-7278$. Your interest in protecting Florida's historic properties is appreciated.

\section{Sincerely,}

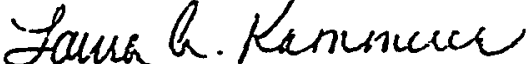

George W. Percy, Director

Division of Historical Resources and

State Historic Preservation Officer

GWP/Jrj

RA. Gray Building - 500 South Bronough Street - Tallahasses, Florida 32399-0250 - http://www.fheritagecom

a Director's Office (850) $183-1480$ - ENX:188-3355

D Historic Persocola Preservation Board (850) $595-5965$ - FAX $595-5989$
D Archaeological Reseanct (850) $437-2299$. FAX:411-2007

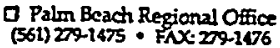

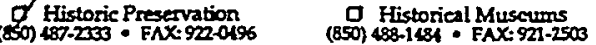

$$
\begin{aligned}
& \text { a St. Augustine Regional Office of Tampa Regional Office } \\
& \begin{array}{l}
\text { St. Augustine Regional Office } \\
\text { (901) } 825.5045 \text { - FNX: 825-5044 Tampa Regional Office } \\
\text { (813) 272.3843 }- \text { ERX:272.2340 }
\end{array}
\end{aligned}
$$


APPENDIX C

CONSULTATION LETTERS ASSOCIATED WITH THE FLORIDA STATE CLEARINGHOUSE 

United States Department of Energy

Federal Energy Technology Center

3610 Collins Eerry Road

Morgantown, Hest Virginia 26507-0880

RE: U.S. Department of Energy - Scoping Letter for Jacksonville Electric Authority Circulating Fluidized Bed Combustor Project - Duval County, Elorida SAI: EL9710020730C

Dear Mr. Lorenzi :

The Florida state Clearinghouse has received your notification of the above-described project, and has forwarded it to the appropriate state agencies for review. In order to receive comments from all agencies, an additional fifteen days is requested for completion of the review. Therefore, the clearance letter due date for this project will be extended from November 17, 1997, to December 2, 1997. If all comments are received prior to the extended date, every effort will be made to forward the clearance letter to you at an earlier date.

Thank you for your understanding. If you have any questions regarding this matter, please contact Ms. Cherie Trainor, clearinghouse Coordinator, at (850) 922-5438.

$\mathrm{RC} / \mathrm{Cc}$

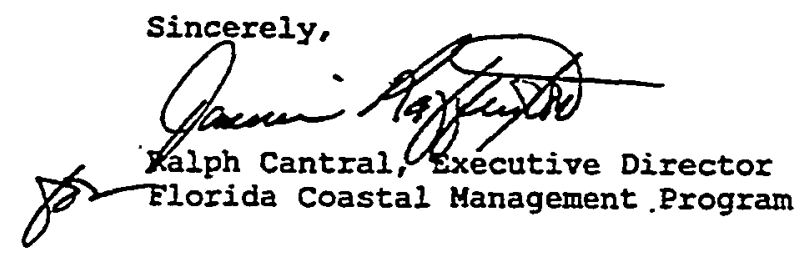

2555 SHUMARD OAK IOULEYARD DALLAHAS5EE, FLO2IDA 32359-2100

Phone: 850.488.8466/Suncom 278.8466 FAX: 850.921.0781/Suncom 291.0781 Internet address: hitp://www.state.fl.us/comaif/dea.html

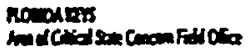

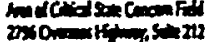

2now cormary

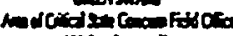

155t5

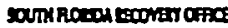

palom

coxx.3ins

cornosing 


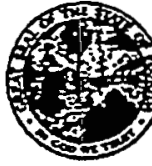

STATE OF FLORIDA

\section{DEPARTMENT OF COMMUNITY AFFAIRS \\ "Helping floridians create safe, vibrant, sustainable communities"}

UHTON CHILES

Covernor

JAMES F. MURLEY Secretary

December 2, 1997

Mr. Iloyd Lorenzi

United States Department of Energy

Federal Energy Technology Center

3610 Collins Ferry Road

Morgantown, West Virginia 26507-0880

RE: U.S. Department of Energy - Scoping Ietter for Jacksonville Electric Authority Circulating Fluidized Bed Combustor Project - Duval County, Florida SAI: FL9710020730C

Dear Mr. Lorenzi:

The Florida state Clearinghouse, pursuant to Presidential Executive Order 12372, Gubernatorial Executive Order 95-359, the Coastal Zone Management Act; 16 U.S.C. \$\$ 1451-1464, as amended, and the National Environmental Policy Act, 42 U.S.C. \$S 4321 , $4331-4335,4341-4347$, as amended, has coordinated a review of the above-referenced project.

The Department of Environmental Protection (DEP) offers coments addressing specific concerns that may arise during further development of the proposed Environmental Impact statement (EIS). Please refer to the enclosed DEP comments.

The Department of Community Affairs (Department) notes that the project is located in the 100 -year floodplain as well as a Category 1 to 3 hurricane storm surge zone. The Department has identified issues which should be included in the EIS. The applicant is also advised to coordinate the project design and construction activities with Duval County's emergency management office to ensure compliance with the county's floodplain and emergency planning requirements. Please refer to the enclosed DCA coments.

The Department of Transportation (DOT) indicates that the project will not impact the State Transportation system. However, a re-evaluation of the project will be conducted during the envirommental documentation or permitting stage. Please refer to the enclosed DOT comments.

2555 SHUMARD OAK IOULEVARD TALLAHASSEE, FLORIDA 32399-2100 Phone: 850.488.8466/Suncom 278.8466 FAX: 850.921.0781/Suncom 291.078 internet address: http://www.state.tl.us/comaf//dea.html 
Mr. Lloyd Lorenzi

December 2, 1997

Page Two

The referenced scoping notice is not subject to consistency review; however, the notice is provided by the applicant to ensure that the state's comnents and concerns are addressed in the draft and final Environmental Impact Statement (EIS). The draft and final EIS are subject to consistency review. The documents should be provided to the State clearinghouse prior to the decision to proceed to each subsequent stage of project development. The draft and final EIS should be accompanied by a federal consistency determination in accordance with 15 CFR 930 , Subpart $C$. The state appreciates the early coordination efforts. The applicant is also advised that based on our preliminary evaluation of the proposed action and the adoption of the recommendations provided by our reviewing agencies, at this stage, the state does not object to the continued development of the project. Comnents received from the Northeast Florida Regional planning Council are also enclosed for your review.

If you have any questions regarding this letter, please contact Ms. Cherie Trainor, Clearinghouse Coordinator, at (850) $922-5438$.

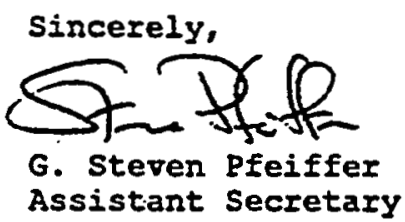

GSP/CC

Enclosures

cc: April Williford, Department of Environmental Protection Gustave Rappold, Northeast Elorida Regional Planning Council 


\section{DEPARTMENT OF COMMUNITY AFFAIRS}

"Helping Floridians create safe, vibrant, sustainable communities"

UWTON CAILES

JME F. MURLEY

Covenor

Secreary

\section{MEMORANDUM}

TO: Cherie Trainor, stffelearinghouse

FROM: G. Steven Pfgiferissistant secretary

SUBJECT: Scoping Let 19 Environmental Impact statement for Jacksonville Electric Authority Circulating Fluidized Bed Combustor Project - Duval County, Florida SAI: EL9710020730C

DATE: December 2, 1997

The Department of Comunity Affairs (Department), pursuant to its role as the state's land planning and emergency management agency, has reviewed the above-referenced project for consistency with its statutory responsibilities under the Florida Coastal Management Program (ECMP). The Department has determined that, at this stage, the project is consistent with its FCMP responsibilities. However, the Department has identified issues, as outlined below, which should be included in the Environmental Impact statement for the proposed project.

The Department notes that the project is located in the 100year floodplain and a Category 1 to 3 hurricane storm surge zone. Therefore, the EIS should include a thorough evaluation of the following:

1. The predicted maximum storm surge heights, using the sLOSH model, relative to the base elevation of the new power generating equipment:

2. The probability of storms and storm surge flooding at the site:

3. The probable damage to the new power generating equipment from hurricane-induced flooding and high winds for each category of hurricane;

4. The types of collateral offsite damage to persons and property that may result from hurricane-induced damage to the new power generating equipment and related facilities, and the estimated probability and severity of such damage;

5. The process, procedures, equipment and time required for the restoration and reconstruction of the plant from storm

2555 SHUMARD OAX BOULEYABD - TALLAHASSEE, FLORIDA 32395-2100 Phone: 850.488.8466/Suncom 278.8466 FAX: 850.921.0781/Suncom 291.0781 Internet address: http://www.stale.fl.us/comaff/dea.html

Acomons

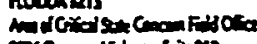

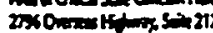

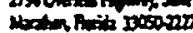

coarsme

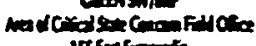

iss E $5 \mathrm{~S}$ Son

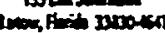

comnoms zonariona

Polatom

conver. 34 simifecis istsy 
Memorandum

December 2, 1997

Page Two

surge, freshwater flooding and wind related damage, as well as a detailed analysis of the expected costs for cleanup, restoration and reconstruction, proposed financing methods, and funding sources; and

6. Based on the foregoing, a description of the need for developing storm preparation and response plans, including

the identification of measures for the minimization of damage to the plant and the surrounding area, plans for the restoration of power after hurricanes, and identification of those responsible for the preparation of such plans.

In addition, the applicant is advised to coordinate the project design and construction activities with Duval County's emergency management office to ensure compliance with the County's floodplain and emergency planning requirements.

Thank you for the opportunity to comment on this project. If you require assistance or additional information, please contact Paul Darst, Division of Resource Planning and Management at (850) $487-4545$ or Rosalyn Kilcollins, Florida Coastal Management Program at (850) 414-6580 or at the address above.

GSP/IK 


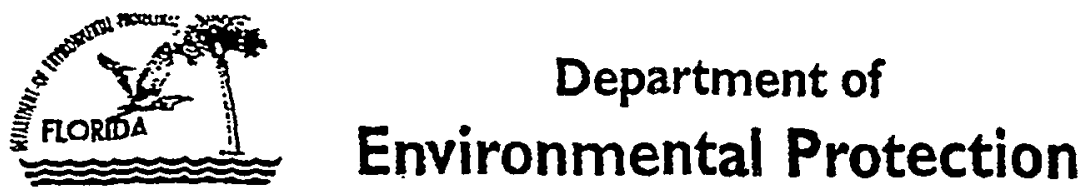

Lawoen Chites covernor

Marjory Stonerran Douglas Building Talbhassee. Fiorida 32399-3000

November 20, 1997

Cherie Trinor Seate Clearinghouse Departiont of Commity Affairs 2555 Stard Oak Booleverd Tallihessee, Florida 32399-2100

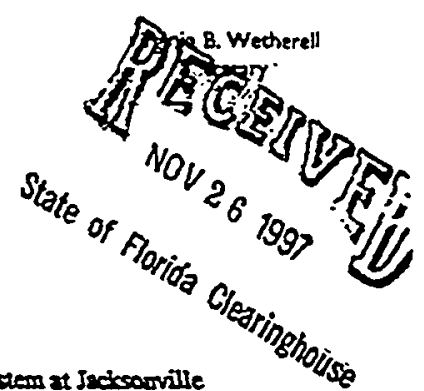

RE: DOE/Seoping Letter for Proposed EIS - Construction af Nere Combostion System at Jacksanville Electric Authority's Noxthside Genersting Station, Duvil Coury

\section{SAI: FL9710020730C}

\section{Dear MS. Trainor.}

The Department of Envirinmentel Procection has reviewed the refercoced scopingileter submitted by the U. S. Deparment of Enerty regarding tbe proposel to repower an existing stem urbine by construxting a new combustion syrem il the Jackcomville Electric Authority's Northside Generating Sution Tbe Department's Ofice of Siting, Division of Marine Recources, and Northease District Office bave provided the following comments to address specific conceros that andy arise duriag further development of the proposed EIS.

- The propoced repowering project is exempt from the mondutory provisions of the Flocida Elestrical Power PLant Sitiog Aat The JEA mary bee the provisions of 403.5175 to licence the cosversion.

- A NPDES permit adoriristered by the Deperment will address the proposed repowering.

- The project has a pocentill for ionpeting wellands and chenging consumptive use of pround vater. The appilionst stould contact the Departwent's Nortbest District and the St Johns River

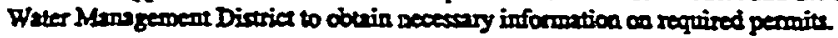

- The St. Johns River and its tributaries in the vicinity of the existing porter plant are documented

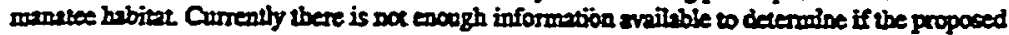

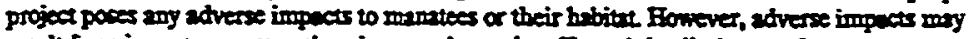
result from in-water consurction, incresed vesol trific and the disebarge of warm water eflivert ino waters that are accessible to memaves.

The following information is required to begin an asserement of the propoced project and to

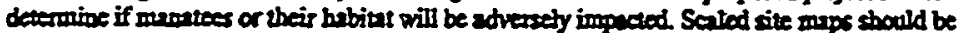
provided abowing the bation of any propoced sercemres and the location of any proposed inwater acoess sives and the roures to and from the eccess siter.

1. Will ary in-pater construction be raquired during the proposed project?

Proteca Conserve ond Monoge Forido's Emiroment and Neaural Resource" 
SAI 97-0730C

Page Two

2. Is there a canal connecting the project site to the St. Johns River? If not, will a canal be constructed?

3. Will any barge facilities be constructed along the St Johns River?

4. Is vessel traffic associated with the porrer plant expected to increase due to the proposed modifications (e.8., delivery of fiel via barges)?

5. In coajunction with the modifications, will the powrer plant discharge heated water into the St. Johns Rives or yaters connected to the St. Johns River?

We appreciate the opportunity to provide comments during the scoping phase of the proposed project. If you require additional information or have any questions, please contact me at (850) 487-2231.

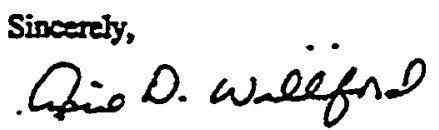

April D. Wiltiford

Environmental Specialist

Office of Intergoveramental Programs

Iadw

CC: Mark Latch, Recreation and Parks

Ron Mezich, Marine Resources

Hamilton Oven, Siting

Alisha Simpson, Northeast District

Fritz Wersein, Marine Resources 
coUNTY: Duval

Message:
Dars:

COMDniss DUE-2 WTS:

CTEATANCE DUE DAIS:

SAIt:
$10 / 03 / 97$

$10 / 18 / 97$

$11 / 17 / 97$

FL9710020730C

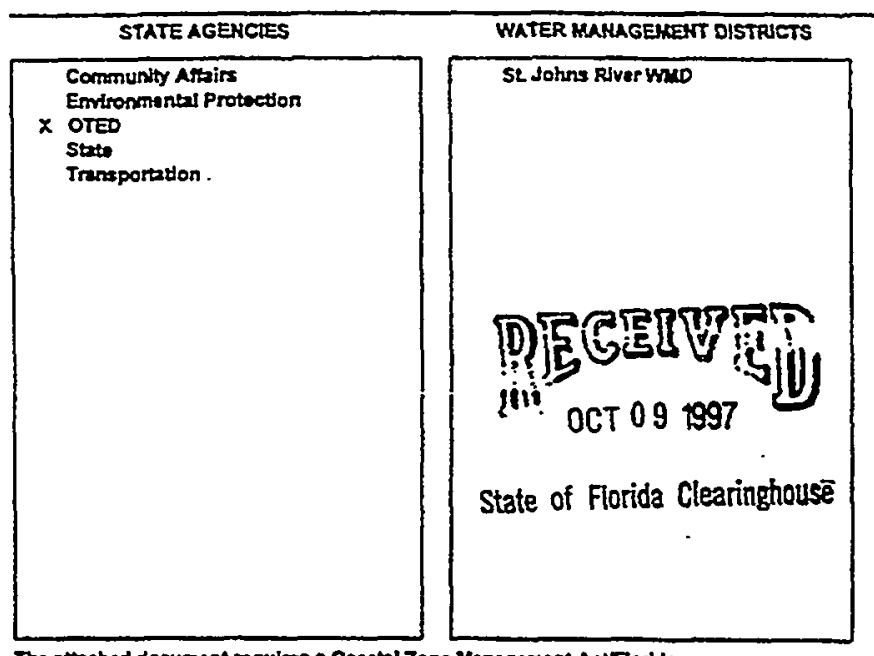

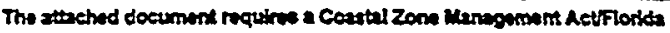

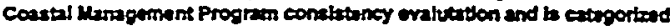
as one of the following:

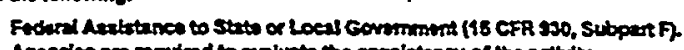

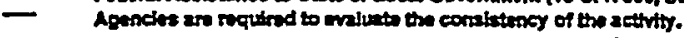

OPB POLCY UNTTS

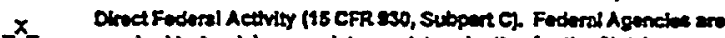

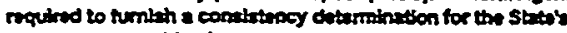
concutrence or objution.

Outer Conthental Shaif Exploretion, Denvloprent or Production Aethitise (1S CFR 250, Subpart E. Operators an requined to provide a

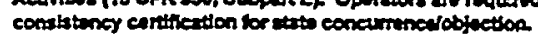

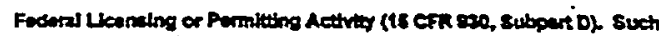

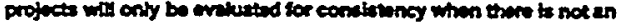

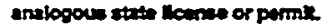

\section{Projuct Deseription:}

U.S. Departrant of Energy - Scoping Letter for

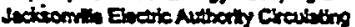
Futband and Combutor Proinct - Duval County. Forita.

\begin{tabular}{|c|c|c|c|}
\hline To: & $\begin{array}{l}\text { Florida State Clearinghouse } \\
\text { Department of Communily Afrairs } \\
2555 \text { Shumard Oak Boulevard } \\
\text { Tallahassee, FL } 32399-2100 \\
\text { (850) } 922-5438 \text { (SC 292-5438) } \\
\text { (904) 414-0479 (FAX) }\end{array}$ & $\begin{array}{l}\text { SNo Comment } \\
\square \text { Comments Attached } \\
\square \text { Not Applicable }\end{array}$ & $\begin{array}{l}\text { 6No Commenticonoistent } \\
\square \text { Consistenticomments Attached } \\
\square \text { InconsistentfComments Attached } \\
\square \text { NoL Applicable }\end{array}$ \\
\hline
\end{tabular}

From:

Divisionsurear $07 T E D$

Roviewe? 2 plakeles

Date: $10 / 4 / 97$ 
COUNTY: Duval

Message:
DATS:

CONEATS DUE-2 HKS:

CISARNACE DOE DATUE:
$10 / 03 / 97$

$10 / 18 / 97$

$11 / 17 / 97$

FL9710020730C

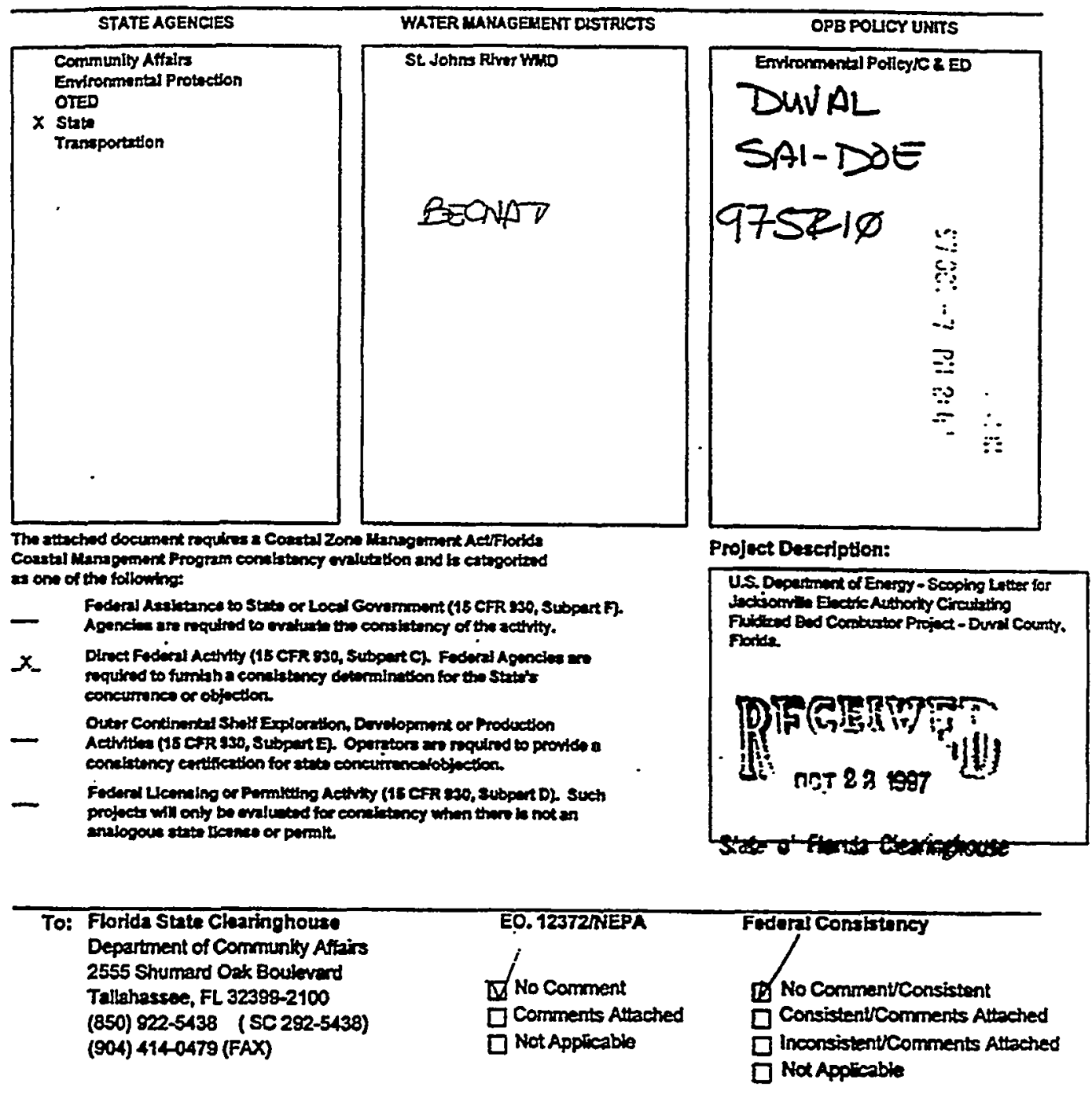

From:

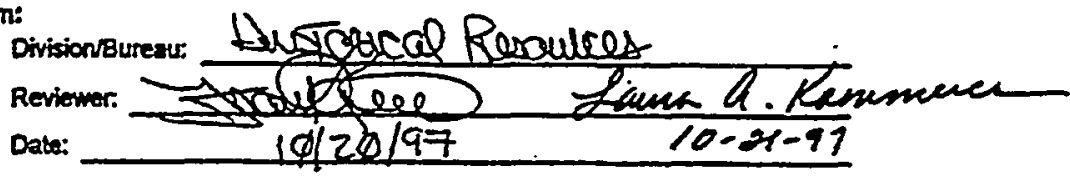




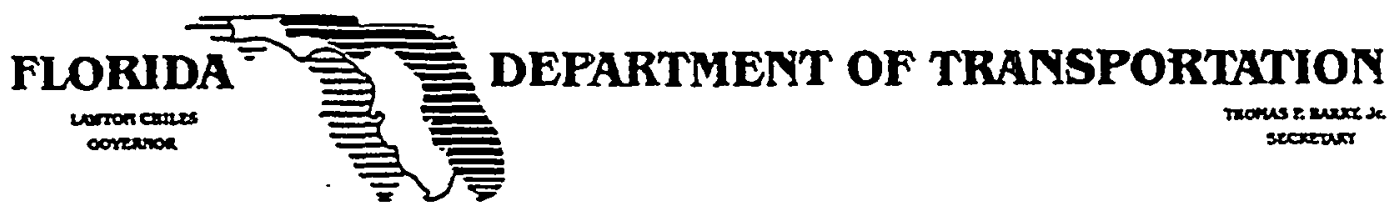

P.O. Box 1089

Lake City, F 32056-1089

October 13, 1997

Ms Keri Akers

Floridz Stre Clearinghouse

Deperment of Community Afteirs

2255 Sturd Out Blvt.

Tallehesecen F1 32399-2100

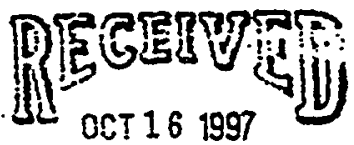

State of Florida Clearingtiousse.

Subject: SAN $*$ FL9710020730

JEA

Dear Ms Akers

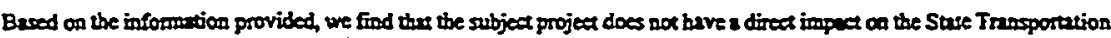

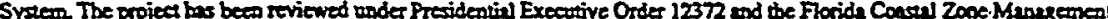

Program for consistency for the fallowing:

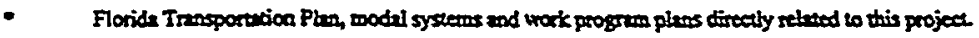

- Level of Service Stundends

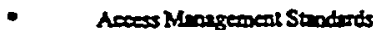

- Right-of-way coss and atremoed exquisition

- Interoverment condiantion

- Chapeers 334 and 339, Larrs of Florida

A re-evaluation of this project will be conctucted during the envincomental docrimenertion of perminting stage, as required Futare consistexcy of this project will be dependent upos the proper considerwion of our corments offered in this and subsequent reviews.

If you heve any questions regatiog this response, please coonec me at SC 881-3682

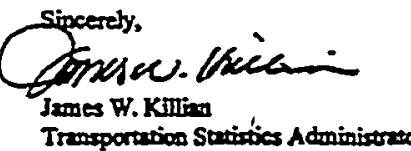

ce: Aage Schroder

Sendra Whitrive

Oremantan 
colnty: Duval

$\begin{aligned} \text { DATE: } & 10 / 03 / 97 \\ \text { CONDENTS DUE-2 HKS: } & 10 / 18 / 97 \\ \text { CTIARANCE DUE DATE: } & 11 / 17 / 97 \\ \text { SAII: } & \text { FL } 9710020730 C\end{aligned}$

Message:

SAI:

FL9710020730C

\begin{tabular}{|c|c|c|c|}
\hline & STATEAGENCIES & WATER HUKAGEHERT DISTRICTS & OPB POLLCY UAITS \\
\hline \multicolumn{2}{|c|}{$\begin{array}{l}\text { Conmunity Attairs } \\
\text { Emrronmontal Protuction } \\
\text { OTED } \\
\text { State } \\
\times \text { Transportation }\end{array}$} & St Jothes River Whid & Environmantal Polkeyrc E ED \\
\hline \multirow{2}{*}{\multicolumn{3}{|c|}{ 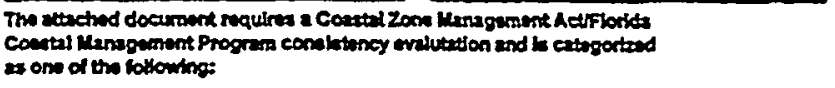 }} & \multirow{6}{*}{ 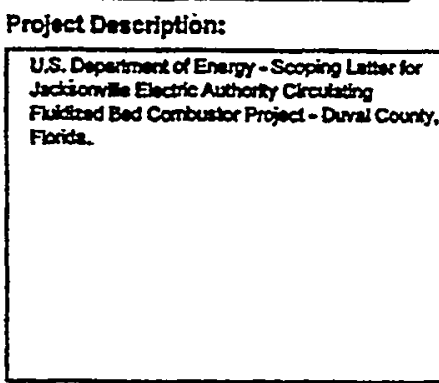 } \\
\hline & & & \\
\hline - & \multicolumn{2}{|c|}{ 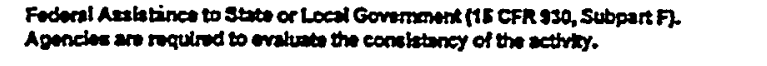 } & \\
\hline$-x$ & \multicolumn{2}{|c|}{ 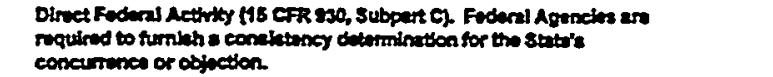 } & \\
\hline 一 & \multicolumn{2}{|c|}{ 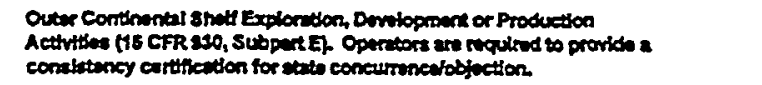 } & \\
\hline 一 & \multicolumn{2}{|c|}{ 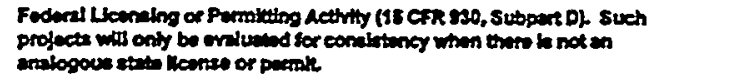 } & \\
\hline To: & \multicolumn{2}{|c|}{ 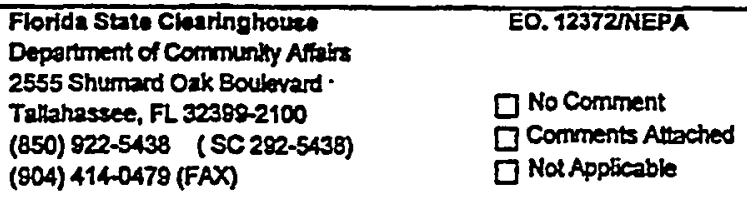 } & $\begin{array}{l}\square \text { No CommentiConsistent } \\
\square \text { ConstrientrComments Attached } \\
\square \text { InconsistentCComments Attectied } \\
\square \text { Not Appticoble }\end{array}$ \\
\hline
\end{tabular}

From:

Division Burears

- Reviewer

Date: 
COUNTY: Duval

DXII:

COADATS DUS-2 FRS:

CIDARANCE DUE DATE:

$20 / 03 / 970 / 4$

Message:

10/18/97 $\mathrm{Kb}$

$11 / 17 / 97$

SAII:

FL9710020730C

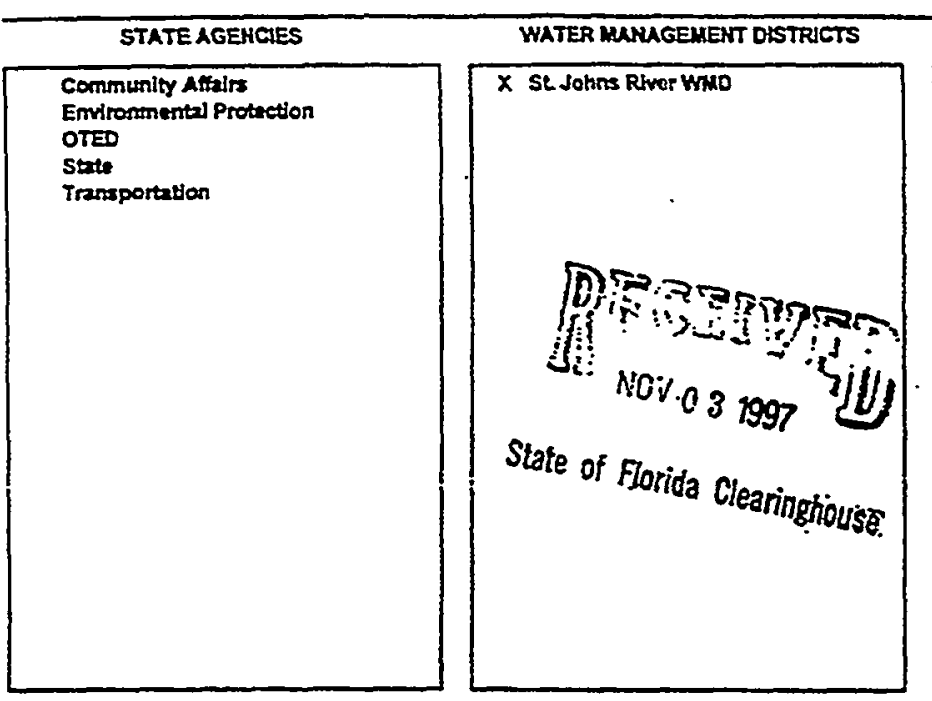

The atheched document requires a Cosctal Zone Management Actiflorida

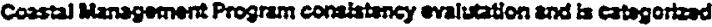
as one of the following:

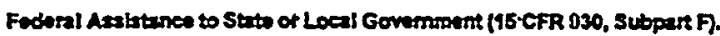

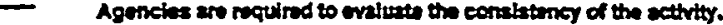

$x$ Dircet Federd Actitis (15 CFR 930, Subpart C). Federat Agoncies are

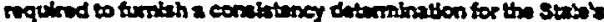
concurrance or objection.

Outer Continental shat Exploretion, Damiopment or Production

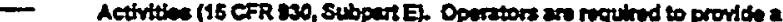

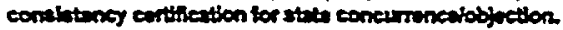

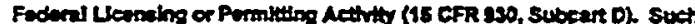
projects will only be waluated for constatency when there is not an aralopous tate liearine or permit.

\section{Project Description:}

U.S. Depatment of Enery + Scoping Letter for Jactwormilis Enetric Authority Creulating Fividzed Bed Conbuntor Projuct - Durat County. Forita.
To: Florida State Claringhouse Department of Community Avairs 2555 Shumard Oak Boulevard Tallahasseo, FL $32398-2100$ (B50) $922-5438$ (SC 282-5438) (904) 414-0479 (FAX)
EO. 12372/NEPA

$\square$ No Comment

$\square$ Comments Attached

$\square$ Not Applicable

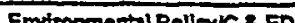

$n \pi T-28 s$

From:

DivisionBureau. Polley \& Planning

Reviewer. Hargaret $B$. Sportal

Date: $10-27-97$ 
COUNTY: Duval

DATr:

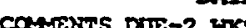

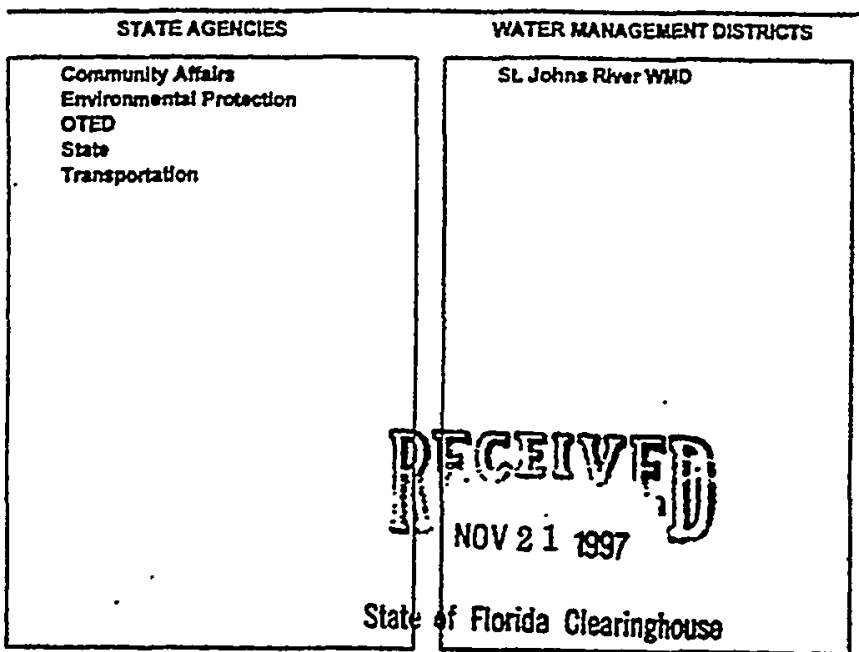

SAII:

FL9710020730C

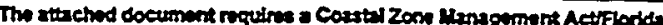

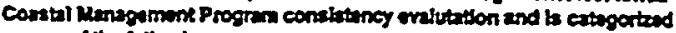
os one of the following:

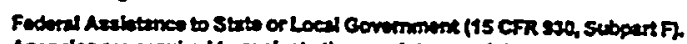

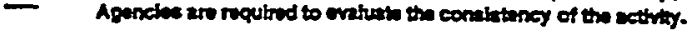

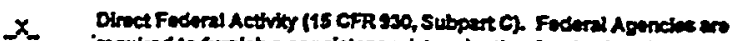
inquind to furninh a conliatancy deternination for the stato's concurneses or objectors

Outer Contionntal Shate Exploration, Demioponumt or Productios"

- Aethrties (15 CFR 290, Subpert E), Operators are roquired to provide

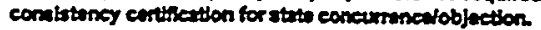

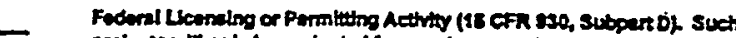

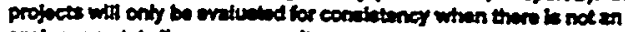

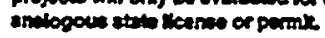

OPB POLICY UNTS

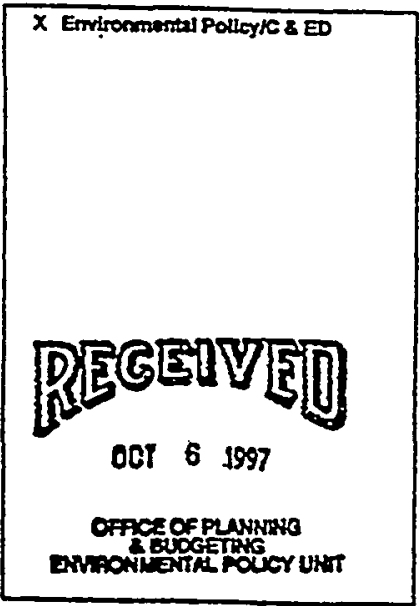

Project Deweription:

US. Deperrmant of Energy - Scoping Lobar for

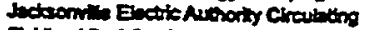
Fuldaed Bod Constudor Proinet - Dural County. Fioride.

To: Florida State Clearinghoute Department of Community Attins 2555 Shumand Oak Boulevard Tallahassee, FL 32309-2100 (850) $922-5438$ (SC292-5438) (804) 414-0478 (FAX) EO. 12372JNEPA

Fedoral Constatency

No Comment

$\square$ Comments Atteched

$\square$ Nol Appticable

G. No Commenveconsistent $\square$ Constenvecomments Altactred 0 inconsistentrcomments Altached $\square$ Not Appicioble

From:

Division/Bureau: EOG lop BENV

Revionef: Paven (M/a)

Date: Nos. Pilage 


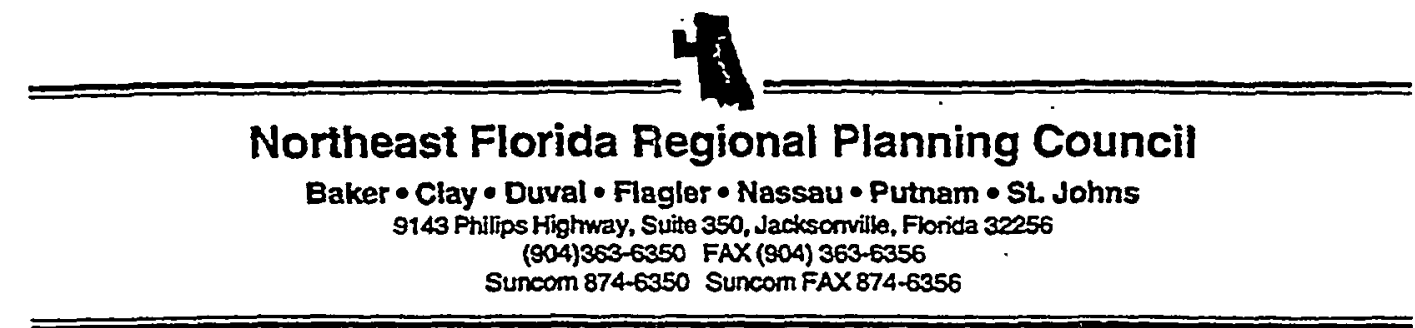

October 24, 1997

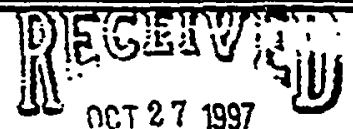

Florida Stare Clearinghouse

Deparment of Commumity Affairs

2555 Shumard Oak Bouleverd

Tallahasee, Florids 32399-2100

State of Florida Clearinghouse

All: Glean Church

SAI\# : FL9710020730C

Scoping Letter for Jacksonville Electric Authority Circulating Fluidized Bed Combustor Project - Duval County, Florida.

The Nontheast Flosida Regional Planning Council staff has reviewed the above cited Direct Federal Activity. The attrabed local response or comment was received.

Based on the information contained in the Project Deseription and after a review of the Comprebensive Regional Policy Plan (CRPP) goals and policies the NEFRPC staff finds the proposal to be "consistent" with the CRPP and in wecord with the foliowing policies:

Policy 17.1.13. Local governments should plan for the upgrading of existing public facilities where needed.

Policy: 17.2.1.2. Provisions for necessary public facilities should be made in advance of anticipated development to reduce the cost of such facilities.

This Federal Activity generally conforms with the other policies, plans, and programs of the Nortbeast Florida Regional Planning Council and the Northeast Fiorida Regional Planning Council starf has no objection to the above cited Direct Federal Activity.

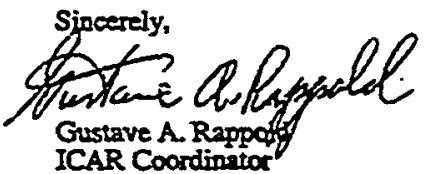

Enclosures

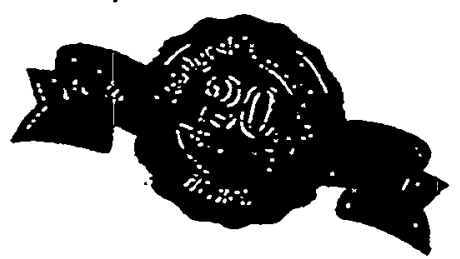




\section{FLOR:ASTATE CLEARINGHC: SE RPC INTERGOVERNMENTAL COORDINATION AND RESPONSE SHEET}

SAI H: FL9710020730C

COMMENTS DUE TO CLEARINGHOUSE: 1102/97

AREA OF PROPOSED ACTIVITY: COUNTY: DUval COUnTY

$\square$ FEDERAL ASSISTANCE

PROJECT DESCRIPTION

U.S. Department of Energy - Stoping Letter for Jacksonville Electric Authority Circulating Fuidibed Bed Combustor Project - Duval County, Floridz
DATE: $10 / 03 / 97$

CITY: Jxeksonville
[ג DIRECT FEDERAL ACTIVITY

FEDERAL, LICENSE OR PERMIT ocs $\frac{\text { RPC }}{\mathrm{X}}$

$X$ NE Florida RPC
ROUTING: 
Florida Thestre Buiding, Suite 700, 128 East Forsyth Street, Jacksonville, Fhoride 32202 Telephose (904) 630-1900 Fax (904) 630-2912

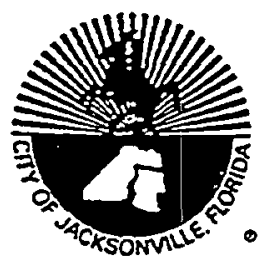

October 10, 1997

Mr. Michael Brown

Northeast Florida Regional Planning Council

9143 Philips Fighway, Suite 350

Jacksonville, Florida 32256

\section{RE: SAIA: FL9710020730C-DESIGN, CONSTRUCTION AND OPERATION OF A NE COMBUSTION SYSTEM TO REPOWER AN EXISTING STEAM TURBINE, UNIT 2, JACKSONVIITE ELECTRIC AUTHORITY'S NORTESIDE GENERATING SYSTEM}

Dear Mr. Brown:

In response to your recent request, please be advised that the Planning and Development Department endorses this project.

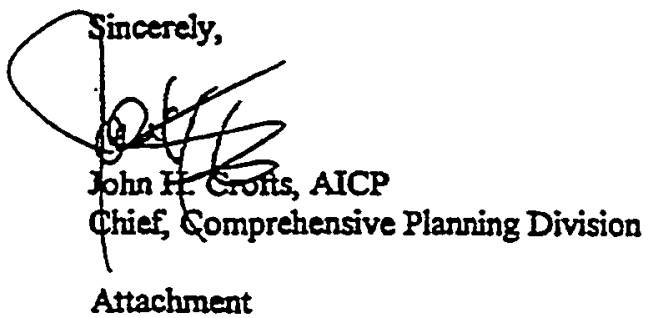

JiClads 


\section{APPENDIX D}

CALCULATIONS OF HUMAN HEALTH RISK FROM INHALATION OF TOXIC AND CARCINOGENIC SUBSTANCES 


\section{APPENDIX D}

\section{CALCULATIONS OF HUMAN HEALTH RISK FROM INHALATION OF TOXIC AND CARCINOGENIC SUBSTANCES}

Table D.1 uses EPA reference doses and carcinogenic potency to evaluate the human health risk from inhalation of toxic air pollutants from the proposed project. The first column of Table D.1 lists potential toxic air pollutants emitted from the stack of the proposed project. In the second and third columns, annual tons of pollutant emissions are given for one repowered unit assuming that only coal and only petroleum coke, respectively, were used as fuel. The fourth column is derived by taking the higher of the pollutant emissions in columns 2 and 3 and then converting the units to grams per second, which are the units required as input for the air dispersion modeling. The fifth column indicates maximum annual modeled ground-level concentrations in the ambient air for each of the toxic air pollutants (in units of milligrams per cubic meter), as calculated by the ISCST3 air dispersion model. The sixth column is the EPA reference dose (a no-effect dose set by the EPA for noncarcinogenic compounds) in units of milligrams of the substance taken into the body per kilogram of body weight per day. Based on the assumption that air is inhaled at a rate of $26 \mathrm{yd}^{\beta}$ per day by a person weighing $154 \mathrm{lb}$, the maximum modeled concentrations were converted to doses and compared with the EPA reference doses; the seventh column presents this comparison as the percentage of the EPA reference dose. The eighth column gives the carcinogenic potency in risk per milligram of the substance taken into the body per kilogram of body weight per day. The ninth column is the carcinogenic risk, which is derived from the maximum modeled concentrations (column 5) and the carcinogenic potency (column 8). 


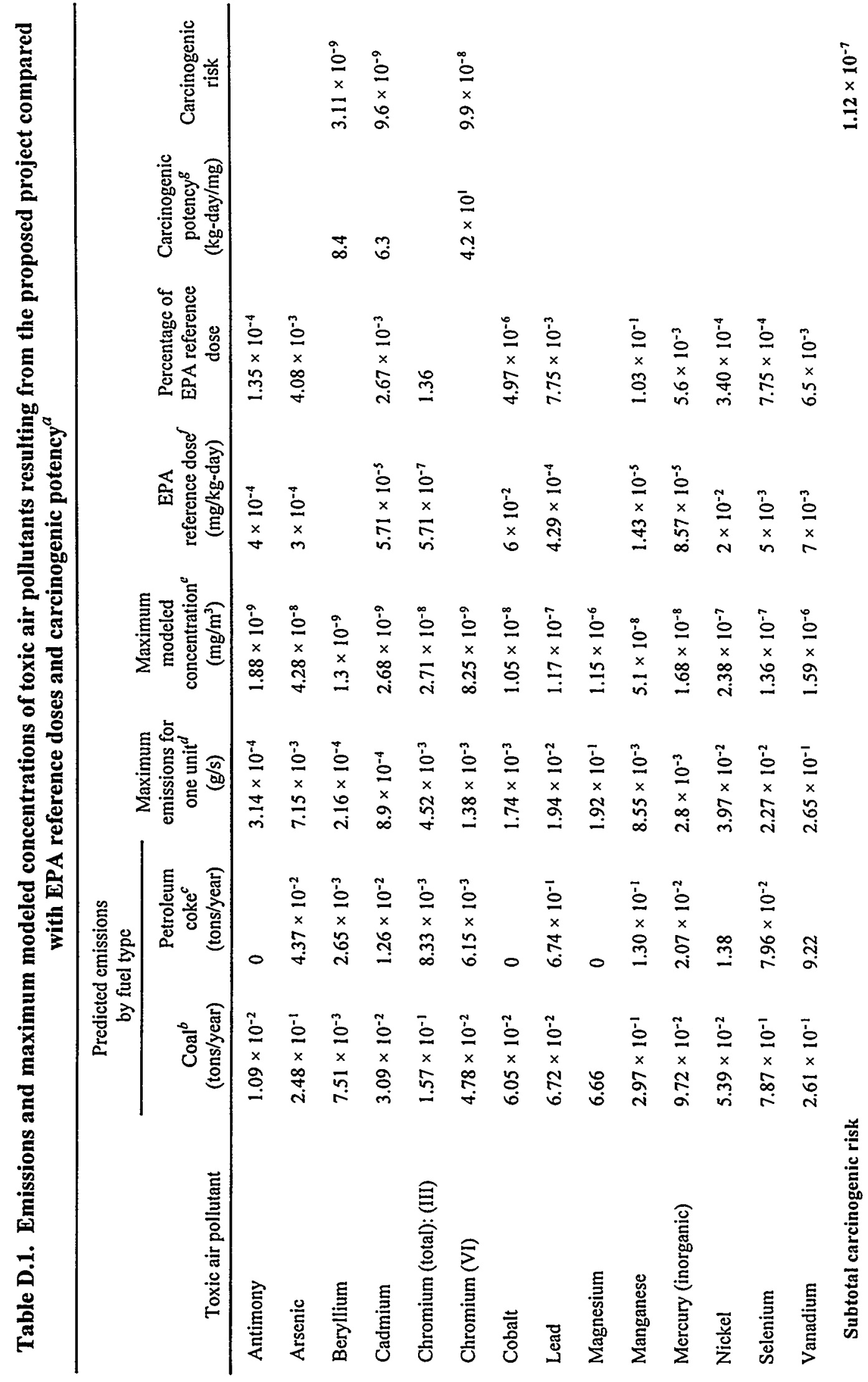




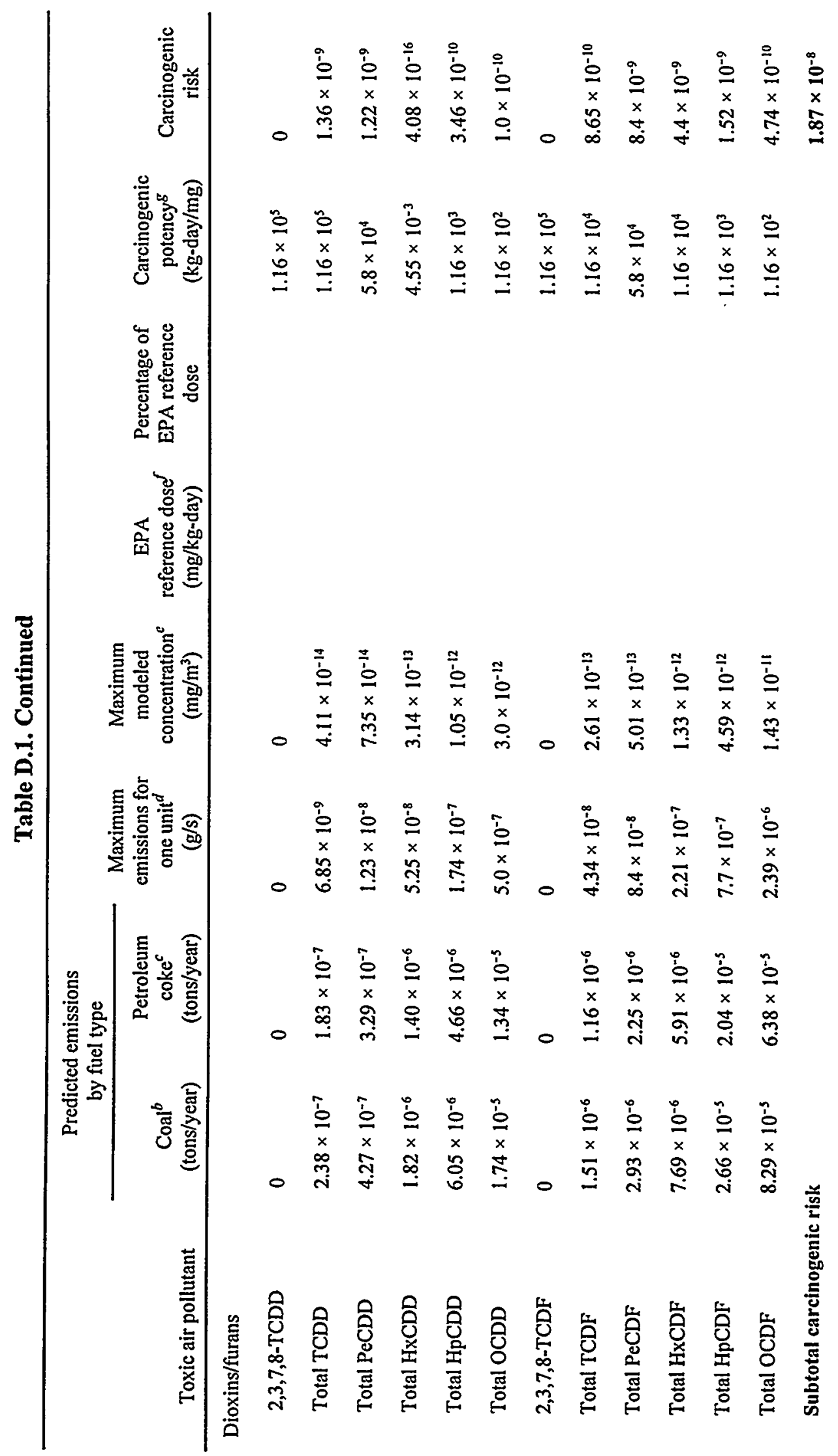




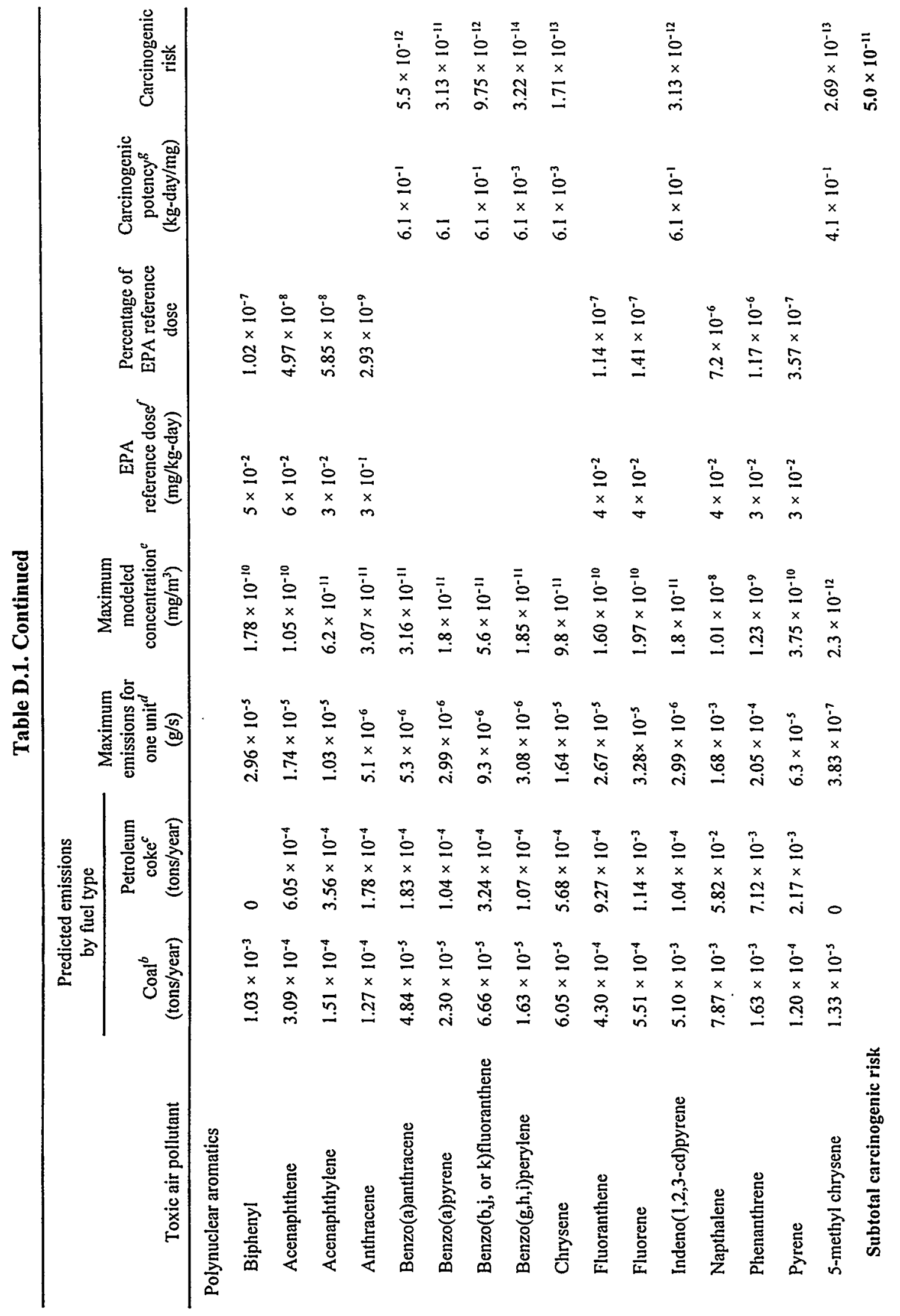




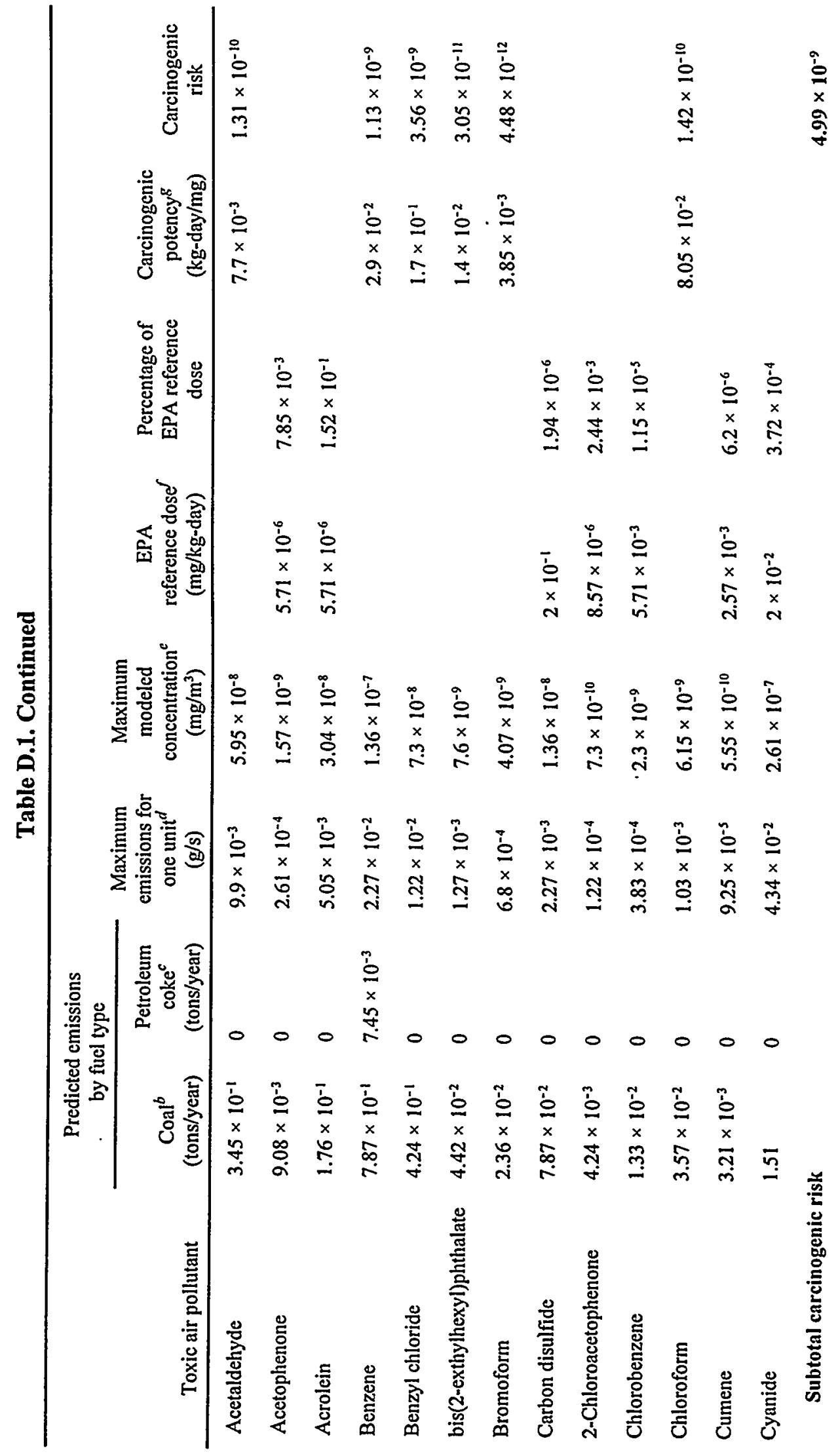




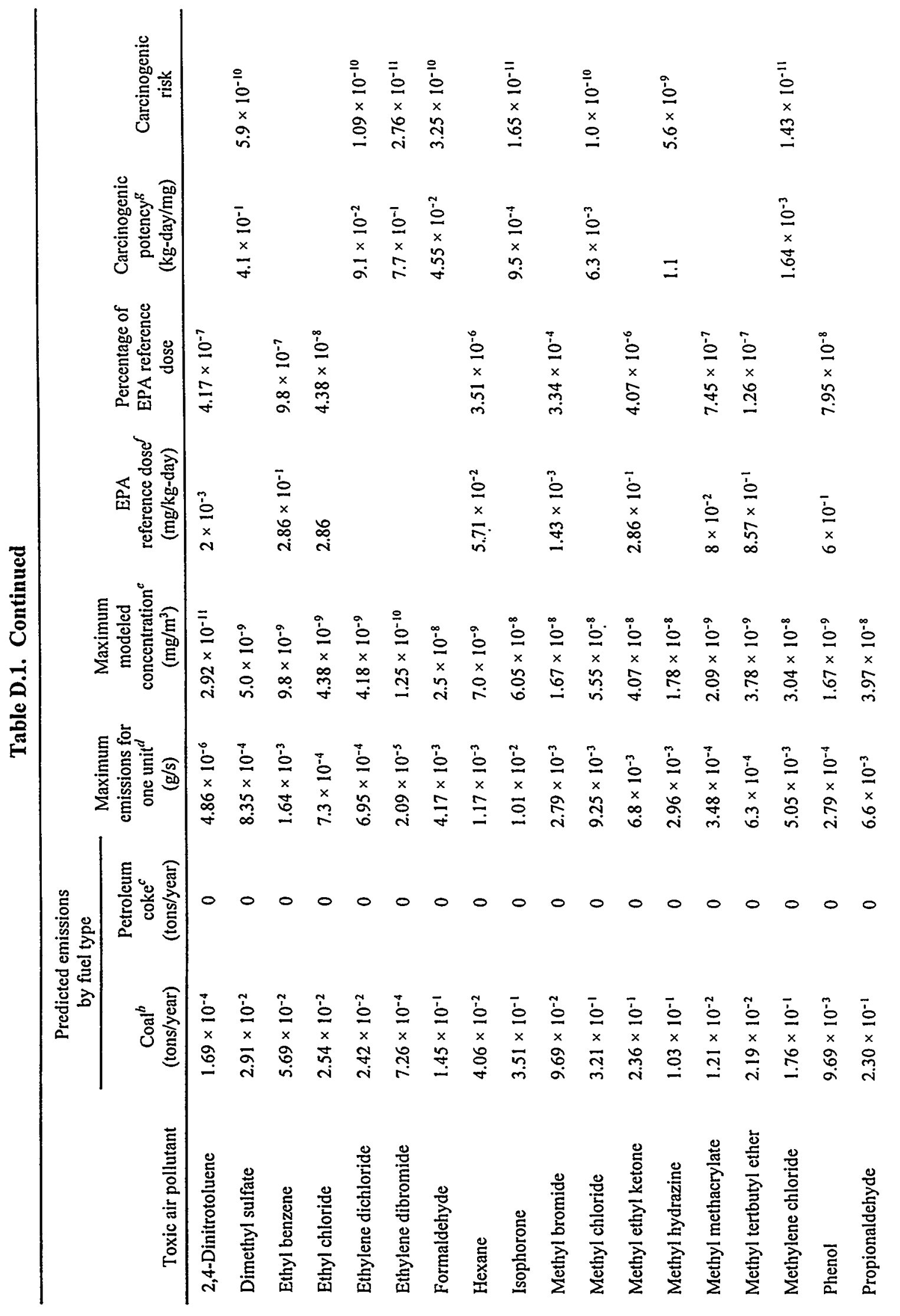




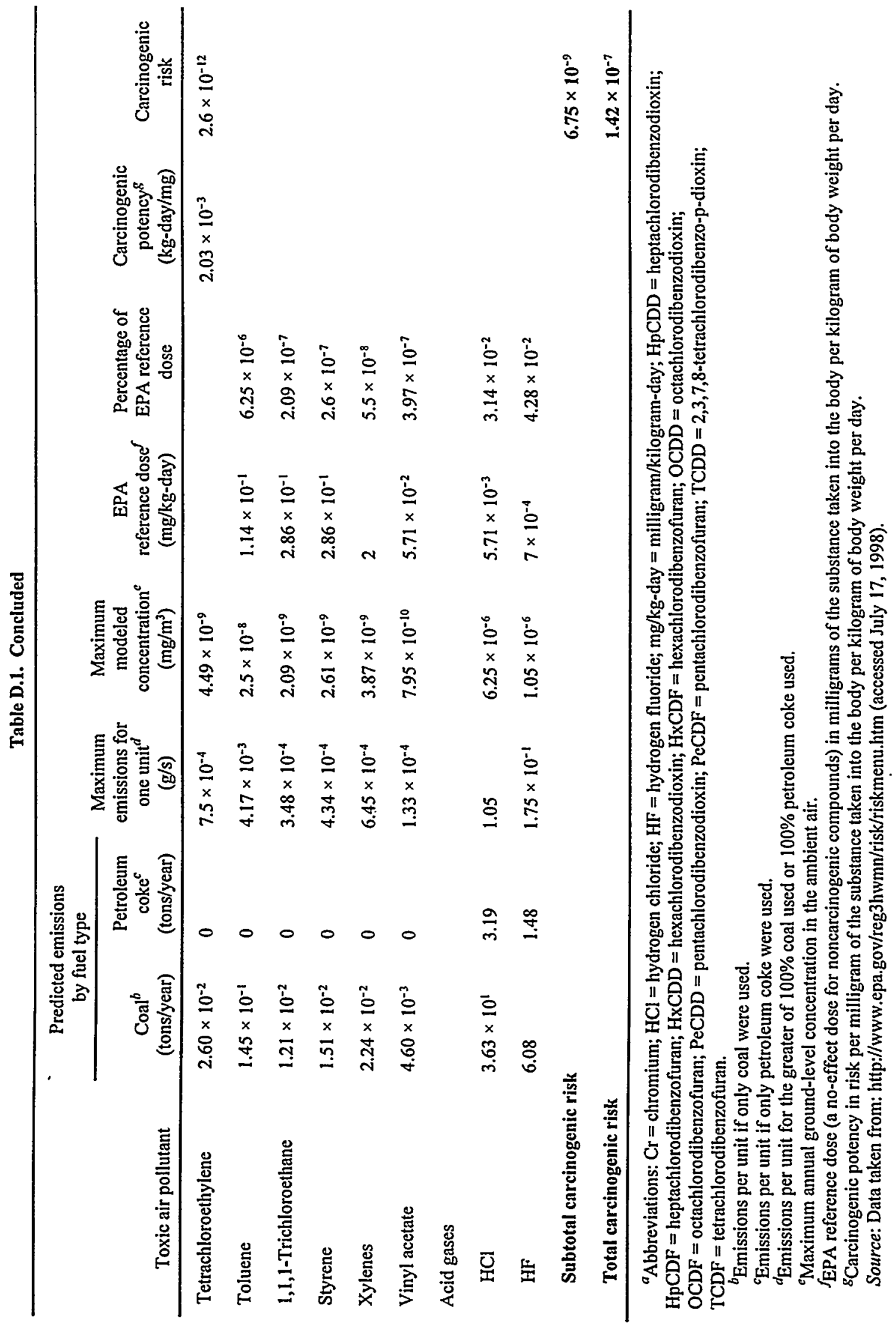




\section{APPENDIX E}

\section{ORGANIZATIONAL CONFLICT OF INTEREST STATEMENT}




\section{NEPA DISCLOSURE STATEMENT FOR PREPARING AN ENVIRONMENTAL IMPACT STATEMENT ON THE JEA CIRCUL ATING ELUIDIZED BED COMBUSTOR PROJECT}

CEQ Regulations at 40 CFR 1506.5 (c), which have been adopted by the DOE (10 CFR 1021), require contractors who will prepare an EIS to execute a disclosure specifying that they have no financial or other interest in the outcome of the project. The term "financial interest or other interest in the outcome of the project" for purposes of this disclosure is defined in the March 23, 1981 guidance "Forty Most Asked Questions Concenning CEQ's National Environmental Policy Act Regulations." 46 FR 18026-18038 at Questions 17a and b.

"Financial or other interest in the outcome of the project" includes "any financial benefit such as a promise of future construction or design work in the project, as well as indirect benefits the contractor is aware of (e.g., if the project would aid proposals sponsored by the firm's other clients)". 46 FR 18026-18038 at 1803 .

Lockheed Martin Energy

In accordance with these requirements Research Corporation

hereby certifies as follows:

Fill in either (a) or (b) COMPANY NAME

(a) Lockheed Martin Research Corp. COMPANY NAME

(b) COMPANY NAME

Einancial or Other Interests

1.

2.

3. has no financial or other interest in the outcome of the JEA Circulating Fluidized Bed Combustor Project.

has the following financial or other interest in the outcome of the JEA Circulating Fluidized Bed Combustor Project and hereby agrees to divest itself of such interest prior to initiating any technical analysis in support of this project.

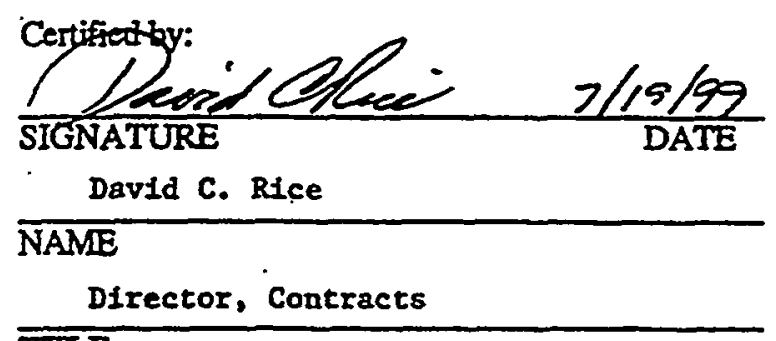

TILE . 
APPENDIX F

ESSENTIAL FISH HABITAT ASSESSMENT 


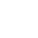




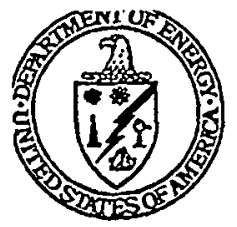

\section{U.S. Department of Energy} National Energy Technology Laboratory

3610 Collins Femy Road

P.O. Box 880

Morgantown, WV 26507-0880
626 Cochrans Mill Road

P.O. Box 10940

Piltsburgh, PA 15236-0940

\section{NETL}

We Solve National Energy and Envirommental Problems

January 24,2000

Andreas Mager, Jr.

Assistant Regional Administrator

Habitat Conservation Division

Southeast Regional Office

National Marine Fisheries Service

9721 Executive Center Drive N.

St. Petersburg, Florida 33702

Dear Mr. Mager,

In response to your letter of September 30, 1999, regarding your review of the Draft Environmental Impact Statement for the proposed JEA Circulating Fluidized Bed Combustor Project, please find attached our Essential Fish Habitat (EFH) Assessment for this project. The proposed project involves cost-shared funding for the demonstration of circulating fluidized bed combustion technology at JEA's existing Northside Generating Station in Jacksonville, Florida.

It is our assessment that the proposed project would not adversely.affect EFH and, therefore, no consultation is required. Please contact me at (304) 285-4992 or at the address shown above if you require additional information or if your findings should disagree. Please note that our Center, formerly the Federal Energy Technology Center, is now the National Energy Technology Laboratory. We are currently preparing the Final Environmental Impact Statement for the project, so we would appreciate a timely response should you have any concerns, so that we may address those concems as soon as possible. Thank you.

Sincerely,

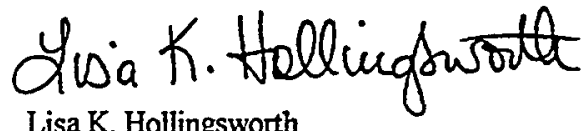

Lisa $\mathrm{K}$. Hollingsworth

NEPA Document Manager 


\section{JEA Circulating Fluidized Bed Combustor Project Jacksonville, Florida Essential Fish Habitat Assessment}

Proposed Project. The proposed project is to design, construct, and demonstrate a new circulating fluidized bed (CFB) combustor that would repower the existing Unit 2 steam turbine at JEA's (formerly the Jacksonville Electric Authority's) Northside Generating Station in Jacksonville, Florida. CFB technology is an advanced method for burning coal and other fuels efficiently while removing air emissions inside the sophisticated combustor system. By generating nearly $300 \mathrm{MW}$ of electricity, the proposed project would be built at a scale large enough to allow the power industry to assess technical, environmental, and financial data from the project and determine the potential of the technology for commercial application. DOE is preparing an environmental impact statement (EIS) as part of the National Environmental Policy Act (NEPA) process to assist in making a decision on whether to provide approximately $\$ 73$ million (about $24 \%$ of the total project cost of $\$ 309$ million) in cost-shared funding to design, construct, and demonstrate the CFB technology. JEA has indicated that construction may begin at their own risk without DOE funding prior to the completion of the NEPA process in early 2000 and would continue for more than 2 years. Demonstration of the proposed project would be conducted during a 2-year period from approximately March 2002 until March 2004. If the demonstration is successful, commercial operation would follow. The design life of the facility is 30 years. JEA also plans to repower the currently operating Unit 1 steam turbine without costshared finding from DOE. The Unit 1 steam turbine would be essentially identical to the turbine for Unit 2 and would be repowered about 6 to 12 months after the Unit 2 repowering.

The proposed CFB combustor would use bituminous coal and petroleum coke to produce steam to drive the existing Unit 2 steam turbine, a 297.5-MW unit that has been out of service since 1983, and generate electricity. Piping and related infrastructure would be constructed to link the new combustor with the existing steam turbine. During the demonstration, Unit 2 would be operated on several different types and blends of coal and petroleum coke to explore the flexibility of the CFB technology. The coal would be transported by ship (from areas such as Columbia and Venezuela), by train (primarily from the central Appalachian region such as West Virginia and eastern Kentucky), and by a combination of train and ship (train from West Virginia and eastern Kentucky to Newport News, Virginia, and ship from Newport News to Jacksonville). The petroleum coke would be transported by ship from oil refineries in Venezuela and the Caribbean region. Limestone for the CFB combustor probably would be transported by ship from the Caribbean region and the Yucatan Peninsula of Mexico. The proposed project is expected to demonstrate emission levels of sulfur dioxide $\left(\mathrm{SO}_{2}\right)$, oxides of nitrogen $\left(\mathrm{NO}_{x}\right)$, and particulate matter that would be lower than Clean Air Act limits while at the same time producing power more efficiently and at less cost than conventional coal utilization technologies. JEA's management has established a target of a $10 \%$ reduction in annual stack emissions of each of 3 pollutants ( $\mathrm{SO}_{2}, \mathrm{NO}_{x}$ and particulate matter) from Northside Generating Station (Units 1, 2, and 3), 
as compared to emissions during a recent typical 2-year operating period (1994-95) of the station (Units 1 . and 3). Also targeted for a $10 \%$ reduction is the total annual groundwater consumption of Northside Generating Station, as compared to 1996 levels. These reductions are to be accomplished while increasing the total annual energy output of the station.

Northside Generating Station occupies a 400-acre industrial site along the north shore of the St. Johns River about 9 miles northeast of the downtown area of Jacksonville. The local terrain is flat and there is a mix of industrial, commercial, residential, and agricultural land use in the vicinity. The property contains a number of wetland areas, especially in the perimeter areas. The industrial 1,650-acre St. Johns River Power Park borders Northside Generating Station to the northeast, and the 46,000-acre Timucuan Ecological and Historic Preserve borders the site to the east. Blount Island, located immediately to the southeast in the St. Johns River, is a major port with facilities for docking, loading, and unloading large ocean-going vessels. The proposed project would occupy a total of about 75 acres of land on the Northside Generating Station and St. Johns River Power Park property.

Analysis of EFH Effects. A Draft EIS was prepared for the project in accordance with the requirements of NEPA and was released for review in August 1999. The draft EIS examined potential project impacts on air quality, surface water, groundwater, floodplains and wetlands, ecological resources, noise, transportation, solid waste, and cultural and socioeconomic resources. Findings related to EFH are summarized below.

With regard to surface water resources, no change in the existing utilization or consumption of surface water would occur during the construction phase of the proposed project. All construction would be performed in accordance with an erosion and sedimentation control plan. Impacts attributable to construction-related runoff, turbidity-causing agents, erosion, and sedimentation would be negligible.

Because Unit 2 has not operated since 1983, the proposed project (the repowering of Unit 2) would increase the demand for noncontact cooling water. After Unit 2 is repowered, the demand by the entire 3-unit plant would be approximately the same as when the three units operated together from approximately 1978 until 1980. The sustained flow of the back channel of the St. Johns River would not be depleted by this diversion because nearly all of the withdrawn cooling water would be returned to the river after passing through the condensers. The amount of heat discharged to the St. Johns River would also increase as a consequence of the proposed project. However, modeling shows that the size of the thermal plume would not increase because simultaneous operation of all three units would increase the discharge velocity and enhance mixing. Bottom-dwelling organisms such as macroinvertebrates would not experience effects as a result of thermal discharges because the discharge plume is directed upward and is largely a surface phenomenon.

Construction and demonstration of the proposed project would not measurably affect estuarine emergent macrophytes identified as EFH. No more than 1.8 acres of isolated hardwood wetland habitat would be lost 
during construction of the ash storage area and disturbance of salt marsh habitats during construction of the solid fuel delivery system would be negligible. Wetlands associated with the upper salt marsh communities would not be measurably affected because nearly all of the conveyor system for solid fuel delivery associated with either unloading option would span these habitats (salt marsh systems) using existing structures and would involve no clearing or earthmoving activities. Option 1 is to construct a second unloader at the existing St. Johns River coal terminal that receives coal and petroleum coke delivered by ship and conveys the fuel to the St. Johns River Power Park. Option 2 is to construct a new unloading terminal to receive coal, petroleum coke, and limestone delivered by ship, as part of an upgraded unloading facility that would replace Northside's existing fuel oil unloading dock. Although some pilings could need to be installed at the upper firinges of the salt marsh and in San Carlos Creek, any impacts resulting from piling installation would be very localized and temporary and would not measureably affect the normal structural and functional dynamics of the salt marsh and nearby estuarine ecosystems. To offset the loss of 1.8 acres of hardwood wetlands during construction of the ash storage area, JEA would purchase 3 credits (slightly greater than 3 acres) of wetlands from an offsite mitigation bank and would restore 1 acre of salt marsh, which together would result in a mitigation ratio of greater than 2.2 to 1 (more than 4 acres of wetlands gained to 1.8 acres lost). The 1.8 acres of hardwood wetlands are not high quality habitats as evaluated by the Corps of Engineers WRAP (Wetlands Rapid Assessment Procedure). The site for the ash storage area includes a 200-ft buffer zone extending to the San Carlos Creek floodplain, which would minimize or avoid any impacts to the San Carlos Creek system. The project would result in a net increase of EFH compared with existing EFH. Both the Corps of Enginears and the Florida Department of Environmental Protection have given approval for this plan of action.

JEA plans to set aside and preserve 15 acres of undisturbed, uplands maritime oak hammock along the west bank of San Carlos Creek. By preserving the land, JEA would maintain habitat for wildlife, help protect the water quality of the creek, and leave a high-quality forested buffer area in a developing industrial area.

During construction, standard engineering practices such as straw berms, liners, cover materials, and grading would be implemented as required to minimize runoff, erosion, and sedimentation near the site. Accidental spills of construction materials such as solvents, paint, caulk, oil, and grease that could contain hazardous substances would be cleaned up in a timely manner and in accordance with a spill prevention, control, and countermeasure plan. Runoff from facilities that would be built as part of the proposed project would be used in plant processes or routed through detention basins equipped with baffles or oil skimmers before being discharged at stormwater outfalls. The detention basins would reduce the maximum rate of stormwater discharge by increasing the length of time during which the discharge occurred. The baffles or oil skimmers would collect contaminants such as oil and grease that float on top of the stormwater. Accidental spills from the proposed facility would be cleaned up in a timely manner in accordance with a spill prevention, control, and countermeasure plan and the best management practices plan for the facility. Tanks containing liquids 
such as fuel oils, waste oils, turbine lubrication oils, and fuel additives are either surrounded by berms or dikes that would contain accidental leaks or spills, or have controlled drainage areas whose runoff is routed to and collected in sumps that are piped into the wastewater treatment system. Impacts associated with transfer piping failure or leakage would be minimized because the piping is inspected on a daily basis and more frequently while pumping is in progress, and most pipeline failures manifest themselves as small-scale, gradually increasing leaks that would be detected during routine inspection before excess leakage would impact the environment.

Determination. Based on the scope and nature of impacts expected from the proposed project and the measures identified above, DOE has determined that there would be no measurable adverse individual or cumulative effects on $\mathrm{EFH}$ at the project location resulting from the proposed project. 


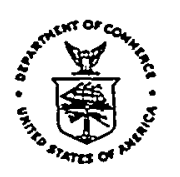

UNITED STATES DEPARTMENT OF COMMERCE

National Ocsanic and Atmospheric Administration NATIONAL MARINE FISHERIES SERVICE

Southeast Regional Office

9721 Executive Center Drive North

St. Petersburg, Florida 33702

February 23, 2000

Ms. Lisa K. Hollingsworth

National Environmental Policy Act Document Manager

U.S. Department of Energy, Federal Energy Technology Center

3610 Collins Ferry Road

P.O. Box 880

Morgantown, West Virginia 26507-0880

Dear Ms. Hollingsworth:

The National Marine Fisheries Service (NMFS) has reviewed your letter dated January 24, 2000, regarding the Draft Environmental Impact Statement regarding the JEA (formerly the Jacksonville Electric Authority) Circulating Fluidized Bed Combustor Project, in Jacksonville, Florida. The project is located adjacent to San Carlos Creek, St. Johns River, in Duval County, Florida.

The direct wetland impacts associated with this project include the filling of 1.8 acres of isolated hardwood wetlands from the construction of the ash storage area. To mitigate wetland impacts, the JEA would purchase approximately 3 acres of wetlands from an off-site mitigation bank and restore 1 acre of sait marsh In our letter, dated September 30,1999, the NMFS identified estuarine emergent wetlands as Essential Fish Habitat (EFH) and requested that any impacts to this habitat be identified. The NMFS is concerned about the secondary impact to tidal wetlands from the potential shading of the conveyor system associated with the two proposed unloading options.

The Department of Energy has determined that the construction and demonstration of the praposed project would not have an adverse effect on EFH. However, the NMFS would like mure information on the secondary impacts to tidal wetlands and those impacts quantified. The NMFS would also like specific information addressing the proposed tidal wetland restoration. Thank you for your consideration of our comments. If you have questions, please contact Jennifer Robinson of our Panama City Office at 850/234-5061.

Sincerely,

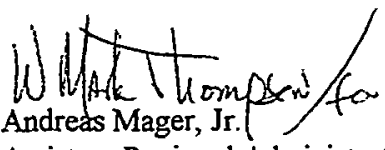

Assistant Regional Administrator

Habitat Conservation Division

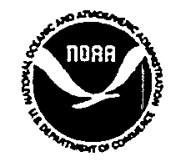




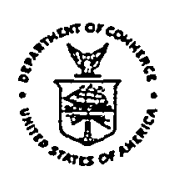

UNITED STATES DEPARTMENT OF COMMERCE

National Dceanic and Atmospheric Administration

NATIONAL MARINE FISHERIES SERVICE

Southeast Regional Office

9721 Executive Center Drive North

St. Petersburg, Florida 33702

$\operatorname{March} 27,2000$

Ms. Lisa $\mathrm{K}$. Hollingsworth

National Environmental Policy Act Document Manager

U.S. Department of Energy, Federal Energy Technology Center

3610 Collins Ferry Road

P.O. Box 880

Morgantown, West Virginia 26507-0880

Dear Ms. Hollingsworth:

The National Marine Fisheries Service (NMFS), per telephone conversation on March 1, 2000, with Robert Miller, Oak Ridge National Laboratories, was provided with additional information regarding the Draft Environmental Impact Statement for the JEA (formeriy the Jacksonville Electric Authority) Circulating FluidizedBed Combustor Project, in Jacksonville, Florida. The project is located adjacent to San Carlos Creek, St. Johns River, in Duval County, Florida.

The NMFS was concerned about the secondary impact to tidal wetlands from the potential shading of the conveyor system associated with the two proposed unloading options. Based upon our conversation, the conveyor system would be 10 feet wide, be elevated 7-8 feet above the marsh, and approximately 950 feet of length of the conveyor would cross tidal wetlands. Therefore, the conveyor system would shade approximately 0.22 acre of tidal wetlands. To mitigate wetland impacts, the applicant proposes to restore $l$ acre of tidal wetlands. The proposed mitigation site was filled in the 1960's for an equipment storage site and restoration activities involve scraping down the area and planting tidal vegetation.

The Department of Energy has determined that the construction and demonstration of the proposed project would not have an adverse effect on Fssential Fish Hahitat (EFH). The AMIFS concurs with this determination that the project would not adversely affect EFH. Therefore, the NMFS will have no further objection to this project. We appreciate working with your staff to resolve our concerns. If you have questions, please contact Jennifer Robinson of our Panama City Office at 850/234-5061.

Sincerely,

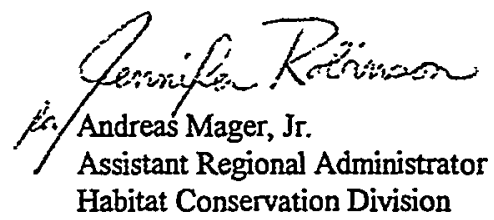




\title{
APPENDIX G
}

TRANSCRIPT OF AND RESPONSES TO THE PUBLIC HEARING

\author{
AND \\ PUBLIC COMMENT LETTERS AND RESPONSES
}





\section{TABLE OF CONTENTS}

Number Presenter

Page

\section{PART 1: PUBLIC HEARING TESTIMONY AND RESPONSES}

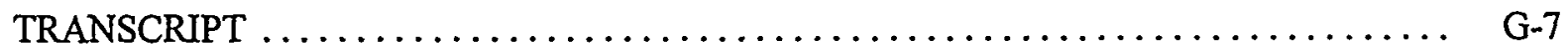

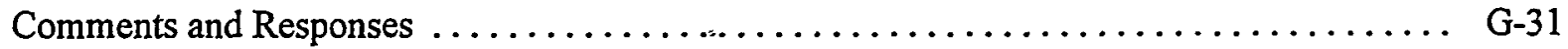

T-1 Dot Mathias, Northside Civic Association $\ldots \ldots \ldots \ldots \ldots \ldots \ldots \ldots$ G-31

\section{PART 2: WRITTEN COMMENTS AND RESPONSES}

Pat Pillmore.$\ldots \ldots \ldots \ldots \ldots \ldots \ldots \ldots \ldots \ldots \ldots \ldots \ldots \ldots$ G -35

2 Charles A. Oravetz, Chief, Protected Resources Division, National Marine Fisheries Service $\ldots \ldots \ldots \ldots \ldots \ldots \ldots \ldots \ldots \ldots \ldots$ G-40

Don Beattie, Geologist, Audubon Chapter and the Florida Wildlife Federation $\ldots \ldots \ldots \ldots \ldots \ldots \ldots \ldots \ldots \ldots \ldots \ldots$ G 44

Donivan Porterfield $\ldots \ldots \ldots \ldots \ldots \ldots \ldots \ldots \ldots \ldots \ldots \ldots \ldots \ldots \ldots \ldots \ldots$

Thomas H. Beal .............................. G-61

Janet Snyder Matthews, State Historic Preservation Officer, Florida Department of State, Division of Historic Resources ... . . . . . . G G-67 Andreas Mager, Jr., Assistant Regional Administrator, National Oceanic and Atmospheric Administration, National Marine Fisheries Service . . . . G-70

James H. Lee, Regional Environmental Officer, United States Department

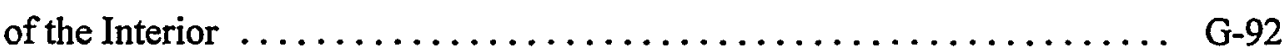

Heinz J. Mueller, Chief, Office of Environmental Assessment, U.S. Environmental Protection Agency, Region $4 \ldots \ldots \ldots \ldots \ldots \ldots$. . . . 102

Val Bostwick, President, Northside Civic Association, Inc. . . . . . . . . . . G-116 


\section{PART 1}

\section{PUBLIC HEARING TESTIMONY \\ AND \\ RESPONSES}


73417.0 FIEID
1

3

4

5

6

7

8

9

10

11

12

13

14

15

16

17

18

19

20

21

22
UNITED STATES DEPARTMENT OF ENERGY

FEDERAL ENERGY TECHNOLOGY CENTER

TRANSCRIPT OF PROCEEDINGS

Public Hearing

PROPOSED JEA CIRCULATING FLUIDIZED BED

COMBUSTOR PROJECT

1

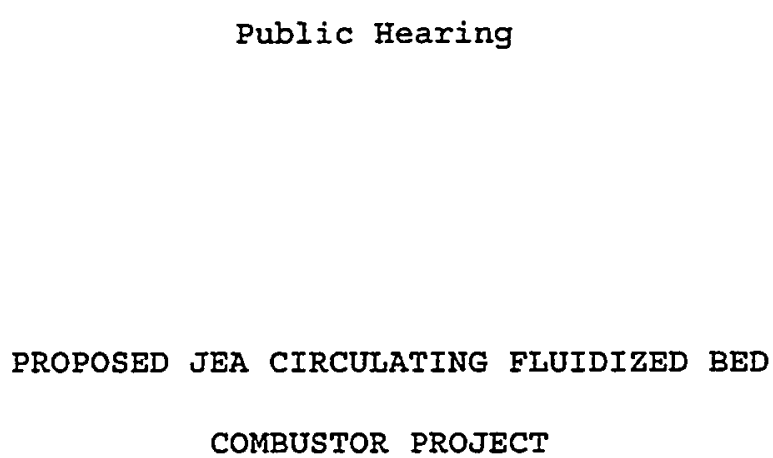

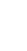

4

5

ACE-FEDERAL REPORTERS, INC.

$\begin{array}{lcl} & \text { Nationwide Coverage } \\ 202-347-3700 & 800-336-6646 & 410-684-2550\end{array}$


73417.0

ACE-FEDERAL REPORTERS, INC. $\begin{array}{lcc} & \text { Nationwide Coverage } \\ 202-347-3700 & 800-336-6646 & 410-684-2550\end{array}$ 
17
P R O C E E D IN G S

September 30, 1999

$7: 15$ p.m.

LISA HOLLINGSWORTH: GoOd evening. I

think I've met most of you. The room seems a little bigger than it was before (laughter), but, hopefully, you can all hear me well. Let me know if there's any problem at all.

I'm Lise Hollingsworth. I work for the Department of Energy at the Federal Energy Technology Center. We call that FETC. There's a FETC office in Pittsburgh, Pennsylvania. There's one in Morgantown, West Virginia. And that's where I'm from.

I'm supposed to tell you some facility info. You probably all already know it. And, if you go out these doors on either side to the next building, on your way there, there are restrooms on the ground floor.

In the unlikely event of a fire alarm or anything like that, you see the exits on. the side, and you can exit to safety. I don't think we're going to have anything like that tonight.

ACE-FEDERAL REPORTERS, INC.

$\begin{array}{lc}\text { 202-347-3700 } & \text { Nationwide Coverage } \\ \mathbf{8 0 0 - 3 3 6 - 6 6 4 6} & \mathbf{4 1 0 - 6 8 4 - 2 5 5 0}\end{array}$



details.

9
ACE-FedERAL REPORTERS, INC.

We'll talk a little about the National

Environmental Policy Act schedule, and we'll talk about how to provide comments and how you can speak at this hearing.

so I'm going to try to make this brief, since I think most of you are familiar with the project.

Nationwide Coverage

202-347-3700 $800-336-6646$

410-684-2550 
Okay. The purpose of this hearing. The National Environmental Policy Act, we call that NEPA, requires us to do several things. One is to evaluate the environmental impacts of our proposed actions, to identify alternatives to those actions, and to solicit input and comments from you, the public, regarding our proposed actions.

The main purpose of this hearing that we're here at tonight is to solicit your comments on the Draft Environmental Impact Statement.

I think many of you have a copy of that; if not, we do have some up front, or you can sign up. You can also sign up at the same time to get a copy of the final EIS.

I think most of you know that JEA was formerly the Jacksonville Electric Authority. Now we just refer to them as JEA. Okay.

The Proposed Action. In this case, the proposed action is to provide $\$ 73.1$ million in costshared funding to JEA to repower the Northside Station Unit 2 to demonstrate utility-scale circulating fluidized bed combustion technology. We ACE-FEDERAL REPORTERS, INC.
202-347-3700
$410-684-2550$ 
usually refer to that as CFB technology.

JEA also plans to repower the currently

operating Unit 1 with the same technology, but we wouldn't provide any funding for that. However, in the Draft EIS, we evaluate the effects of both as a related action.

Who's Who. The Department of Energy, wel1, we're the Eunding agency that's proposing to provide the cost-shared funding to repower Unit 2 .

We have a large system of checks and balances to help us implement the NEPA process correctly.

To my right here, first we have Jim Johnson. Wave, Jim. Good. Jim is from DOE headquarters in Washington.

He's the Fossil Energy NEPA Compliance Officer, and he gives us guidance and oversight on our documents that we do.

Next, I have Denise Freeman. Denise wasn't able to come, and, also, Lloyd Lorenzi, who works at the FETC. He wasn't able to come.

After that, we have Tom Sarkus. There's ACE-FEDERAL REPORTERS, INC. Nationwide Coverage 202-347-3700 $\quad 800-336-6646$ $410-684-2550$ 
1

2

3

4

5

6

7

8

9

10

11

12

13

Tom. He's the Director of the division at FETC in Pittsburgh, Pennsylvania, that manages this project for DOE.

And Jerry Hebb. He's also in that

division. And Jerry is the project manager for this project on the DOE side.

And I'm Iisa Hollingsworth. I am the NEPA

Document Manager. I am the person who is primarily

responsible for implementing the NEPA process for this project, and $I^{\prime} m$ also the main point of contact,

if you have any comments or want to receive any documents.

You have my name and address and everything all through here. And please contact me. I'Il get you whatever information I can or anything you need. Okay.

From JEA, JEA is the proposer of the new units at Northside Generating station. I only have a couple of names on here. We're lucky to have some more people.

Joey Duncan, who's the Project Manager on the JEA side. Susan Hughes, I have her here as

ACE-FEDERAL REPORTERS, INC. Nationwide Coverage $202-347-3700$ 800-336-6646 $410-684-2550$ 
1

2

3

4

5

6

7

8

9

10

11

12

13

21

22
Environmental Coordinator. I know she also handles most of the permitting stuff.

We also have P.T. Nielsen, Badie Hassan, and Jackie Leduc, at various places around here. I also noted on here that Foster wheeler is the designer for the units.

Next, I'd like to take a second just to tell you in brief about the clean coal Technology Program that DOE has.

It's a government-industry partnership program that Congress mandated back in 1985, and it involves cost sharing of different, innovative, fossil-fuel-based energy technologies.

The goal is to make available to the U.S. energy marketplace a number of advanced, more, efficient, and economically advantageous, and environmentally responsive technologies for coal utilization.

It includes 40 projects in 17 states, and federal funding of over $\$ 2$ billion, along with matching industrial funds well in excess of $\$ 2$ billion. So it's a big program.

ACE-FEDERAL REPORTERS, INC.

$\begin{aligned} & \text { Nationwide Coverage } \\ & \text { 202-347-3700 } \\ & 800-336-6646\end{aligned} \quad 410-684-2550$


The next thing I'd like to tell you about is just to give you a generic overview of CFB technology. This is a generic schematic, and this is something I did take from the Draft EIS.

I'm going to try and use the large-size laser pointer here. There we go. We have coal and Iimestone that gets injected into the combustor, along with -- this is where primary air goes in and secondary air goes in (indicating). And this air fluidizes the bed where the actual combustion takes place. The limestone removes something like 98 percent of the sulfur that comes in with the Euel.

Hot gases then move over into the cyclone,

where large particles are then returned to the bed. The hot gases continue on into some different heat exchangers, where more heat is removed from the hot gases.

Then it goes on into the cleanup or any polishing devices you have, where particulate is removed, and in some cases $\mathrm{NO}_{\mathrm{X}}$. Then it goes ahead to the atmosphere through the stack. Let's see now.

ACE-FEDERAL REPORTERS, INC.

202-347-3700 Nationwide Coverage

$410-684-2550$ 
Water is heated in the boiler tubes of the 
like at the station. And this is what the two new units would look like (indicating). okay.

The next overheard just kind of, I wanted to give you an idea of what the land requirements were for the proposed project.

Once again, this figure is in the Draft EIS and there's more details there. The Power Park would be in this area up here (indicating), just to orient you.

I just wanted to point out the existing Power Block and where the proposed Power Block would be (indicating), along with some of the storage that will be used for ash storage (indicating). Okay. Next, I'd like to give you some of the project characteristics, to give you an idea of the scale of the units we're talking about.

These are quantities that are input (indicating). And this is, like I said, just a brief summary.

You have your coal. We show numbers for the repowered Unit 2 and both units together -- it's just double of that -- and petroleum coke

ACE-FEDERAL REPORTERS, INC.

202-347-3700 Nationwide Coverage 800-336-6646 $410-684-2550$ 


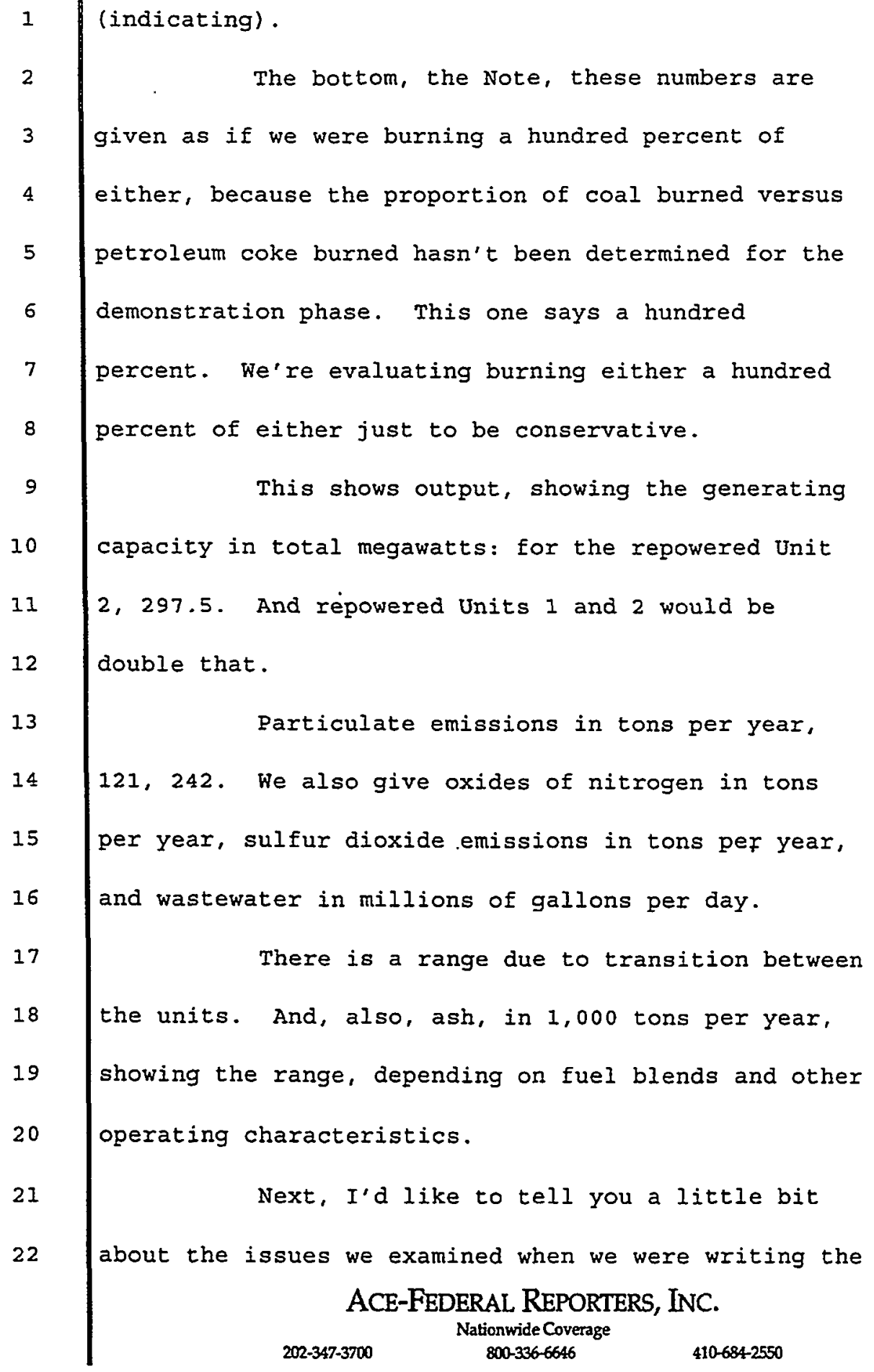

(indicating).

The bottom, the Note, these numbers are given as if we were burning a hundred percent of either, because the proportion of coal burned versus petroleum coke burned hasn't been determined for the demonstration phase. This one says a hundred percent. We're evaluating burning either a hundred percent of either just to be conservative. This shows output, showing the generating capacity in total megawatts: for the repowered unit 2, 297.5. And repowered Units 1 and 2 would be double that.

Particulate emissions in tons per year, 121,242 . We also give oxides of nitrogen in tons per year, sulfur dioxide emissions in tons pef year, and wastewater in millions of gallons per day.

There is a range due to transition between the units. And, also, ash, in 1,000 tons per year, showing the range, depending on fuel blends and other operating characteristics.

Next, I'd like to tell you a little bit about the issues we examined when we were writing the ACE-FEDERAL REPORTERS, INC. Nationwide Coverage $800-336-6646 \quad 410-684-2550$ 
Draft EIS, and some of these we did come up with based on input Erom the public at the scoping Meeting that was held here before.

We have air quality, water quality and use, including thermal discharges, groundwater usage, floodplains, wetlands, hydrogeology, storm surge, human health and safety, pollution prevention, waste management, ecological resources, including terrestrial and aquatic, biodiversity, threatened and endangered species, cultural resources, socioeconomics, including environmental justice, transportation, noise, and land use and aesthetics. Next, I'd like to do a quick summary of the expected environmental impacts if we were to implement our proposed action.

With air quality, temporary localized increases in gaseous pollutants and fugitive dust during construction would be expected. time for particulate, oxides of nitrogen and sulfur

ACE-FEDERAL REPORTERS, INC.

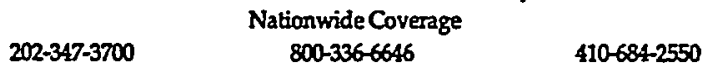




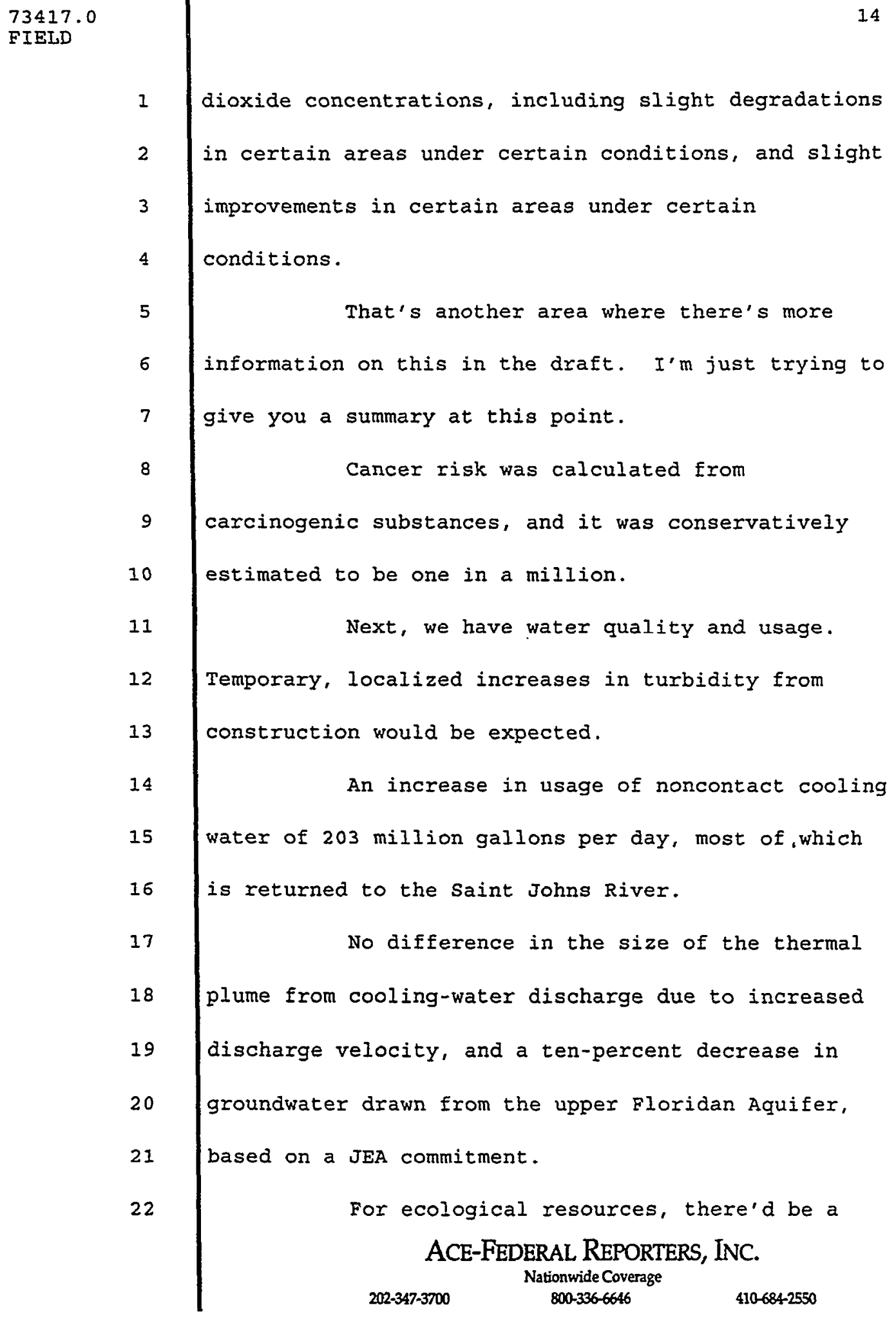

1

dioxide concentrations, including slight degradations in certain areas under certain conditions, and slight improvements in certain areas under certain conditions. information on this in the draft. I'm just trying to give you a summary at this point.

Cancer risk was calculated from carcinogenic substances, and it was conservatively estimated to be one in a million.

Next, we have water quality and usage. Temporary, localized increases in turbidity from construction would be expected.

An increase in usage of noncontact cooling water of 203 million gallons per day, most of which is returned to the Saint Johns River.

No difference in the size of the thermal plume from cooling-water discharge due to increased discharge velocity, and a ten-percent decrease in groundwater drawn from the upper Floridan Aquifer, based on a JEA commitment.

For ecological resources, there'd be a

ACE-FEDERAL REPORTERS, INC.

$\begin{aligned} & \text { Nationwide Coverage } \\ & \text { 202-347-3700 } \\ & 800-336-6646\end{aligned} \quad 410-684-2550$


1

2oss of 28 acres of pine plantation and 10 acres of upland hardwood-pine habitat, and a small net gain in wetlands area due to mitigative measures such as using wetlands credits. Biodiversity would not be measurably affected, based on our studies. Threatened and endangered species, our main species of concern is the manatee, but we also looked at the gopher tortoise, various sea turtles, and shortnose sturgeon.

Mitigative measures would eliminate or minimize any impacts to these. For example, the design of the dock would minimize the possibility of manatees being crushed, if there were a ship there and manatees happened to be there.

$$
\text { Cultural resources, there are culturaliy }
$$
significant sites that could be located near the proposed project.

We have here that JEA will conduct an archaeological survey prior to construction. I believe that's already been done at this point. And they're required to notify the appropriate agencies

ACE-FEDERAL REPORTERS, INC.

$\begin{aligned} & \text { 202-347-3700 } \\ & \text { Nationwide Coverage } \\ & 800-336-6646\end{aligned} \quad 410-684-2550$


upon discovery of any artifacts.

Socioeconomic Resources, no appreciable

impacts on local services are anticipated. And this

is what we're talking about when we say environmental

justice. No disproportionately high and adverse

impacts of low-income and minority populations are

expected, based on what we have seen.

Transportation. Localized traffic

congestion is anticipated during construction. Rail

traffic is not expected to increase, based on economic projections.

By this, we mean that the cost from

shipping by rail is not projected... we're not expecting to use rail, based on the costs that they have now.

Should economic conditions change, rail traffic could increase by up to three additional train deliveries per week, which could cause additional problems that some members of the public have mentioned, including noise, vibration, and blocked roads, access to emergency vehicles, that type of thing. No impacts to marine traffic are

ACE-FEDERAL REPORTERS, INC. Nationwide Coverage 202-347-3700 800-336-6646 $410-684-2550$ 
1

2

3

4

5

6

7

8

9

anticipated.

Next, we have noise. Some construction noise would exceed the city limits ordinance levels of 65 decibels.

99 decibels is possible at some nearby residences, based on our studies.

JEA has said that they would use a publicawareness plan to try to mitigate noise effects. Based on our analysis, operational noise would not be expected to be noticeably different than current noise levels if the project is implemented. Transportation noise from worker vehicles during construction or trains, if they were used for transporting fuel, could affect nearby residents.

That's the end of the summary of the environmental impacts. It is a very small summary, but, if you want more information, like I said, look to the draft or, you know, ask us.

$$
\text { Next, I wanted to go over the NEPA }
$$

schedule. A Notice of Intent to prepare an Environmental Impact statement was put in the Federal ACE-FEDERAL REPORTERS, INC.

\begin{tabular}{|c|c|}
\hline & Nationwide Coverage \\
\hline
\end{tabular}


73417.0

Register on November 13th, 1997.

2

3

4

5

6

7

8

9

10

II

12

13

14

15

16

17

18

19

20

21

22
And a Public Scoping Meeting was held in Jacksonville, Florida, on December 3rd,' 97 . As I said, we did receive several comments, which we've used in preparation of the Draft EIS.

The Draft EIS was released on August 27 th

of this year. And we tried to have a Public Hearing

on September $16 \mathrm{th}$, but Hurricane Floyd was against

it. So we rescheduled for today. I'm glad that some of you could still come.

There's a 45-day public comment period associated with the Draft EIS, and that comment period closes on October 15th of this year. So we need to have your comments by october 15 th, or to have them postmarked by october 15 th.

We will do our very best to address

comments received after that time, but, with our schedule, we may not be able to. So, if you want to be certain to have your comment addressed, get it to us or have it postmarked by october 15 th.

The Final EIS will be released later this year. When will depend a lot on the amount of ACE-FEDERAL REPORTERS, INC.

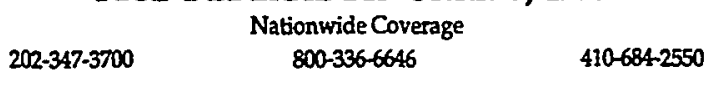


comments that we get.

So far, we've gotten about six written

comments from the public. And that's a relatively

small amount. It will depend on how long it will

take for us to address those.

7

8
We will address all comments received in

the Final EIS. They will be written out, with a response. Let's see.

The Record of Decision will then be published one month after the Final EIS is published. And, in that Record of Decision, DOE will make the decision whether or not we proceed with our proposed action, which is to provide the funding to JEA.

The next thing I have is how to provide comments. That's my name and address. This is my work 'phone number (indicating). I also have voice mail there. If you need it to get any of these documents or you just have some questions you want to talk about or give comments, that's the number to call.

There's also an 800 number. That has

voice mail only, but, if you leave comments there, we ACE-FEDERAL REPORTERS, INC.

$\begin{array}{lcc} & \text { Nationwide Coverage } \\ 202-347-3700 & 800-336-6646 & 410-684-2550\end{array}$


will transcribe them and put them in the EIS.

Fax, e-mail (indicating), comment in any way and we'll appreciate your comments and do our very best to address them. Next.

Next I want to tell you, if you want to speak at this hearing, how to do that. Speakers who have registered first get to speak first. Everyone else may speak on a first-come basis.

We haven't had anyone registered yet. So lucky you, whoever you are, you can be the very first one. We were going to limit people to ten minutes per speaking session just to make sure everyone gets a chance to talk. It looks like we may have plenty of time here. Anyway, if you want to speak, we'll stay as long as you want to speak.

We may answer limited questions in order to clarify issues, if you have specific questions. But I do want to make sure you understand that the expectation is that your comments will be studied, and we will address them, for the most part, in the Final EIS.

We will do our best to answer what

ACE-FEDERAL REPORTERS, INC.

$\begin{array}{lcc} & \text { Nationwide Coverage } \\ 202-347-3700 & 800-336-6646 & 410-684-2550\end{array}$


questions you have, if we can clarify something. But most of them will be addressed in the Final EIS.

Transcripts of this hearing will be available in the public reading rooms. Your local reading room is the Highlands Branch Library on Dunn Avenue. And we're being transcribed right now.

This is the end of my part of the presentation. I was told to keep it to thirty minutes or less, and I think I did that. I will ask, if you want to speak, we need you to state your name and then to spell your last name so that we can get it correct in the transcripts, and also to give your affiliation. I would say, still, that we do have several JEA people. If you didn't get to talk to someone you wanted to talk to out front, I think we'Il be able to, at the end of the hearing, also discuss things, if you want.

And there are also some other documents out front you might want to get a copy of.

So, with that, I'm going to turn the lights on, and then we'll see if anybody wants to

ACE-FEDERAL REPORTERS, INC. 202-347-3700 Nationwide Coverage $800-336-6646$ $410-684-2550$ 
talk. Here's the microphone for whoever wants to speak first (indicating). Anybody?

Is there anything anybody would like to make a comment on or needs clarification on? Because we're staying until nine $0^{\prime}$ clock, no matter what. of course, you don't all have to.

DOT MATHIAS: Well, I guess I have a comment. It's just a commendation, realiy. My name is Dot Mathias, $M-a-t-h-i-a-s$. And I reside at 341 Basin Road, here in Jacksonville. lot of our questions and our concerns. And that

\section{ACE-FEDERAL REPORTERS, INC.}

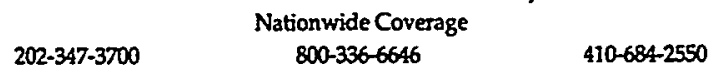


1

2

3

4

5

6

7

8

means a lot to a community, particularly when you're building a coal-fired plant in the area.

So we have been very, very grateful to them for meeting with us, because any questions that we had at that time, I think they have allayed our fears with them. And thank you so much.

IISA HOLLINGSWORTH: Thank you. I

appreciate that. And I'm sure they do, too.

If you can think of a question, we'd love

to hear it. Sometimes at these hearings, you know, you have a large number of people, a hundred or more, and sometimes you spend two hours or more fielding comments and questions, and sometimes you have two or three meetings. now 8:15. Since we don't have any new speakers, I'd like to thank you all for coming. And we're going to adjourn this Public Hearing. Thanks.

(Recess from $7: 40$ to $8: 15$ p.m.)

IISA HOLIINGSWORTH: Hi, everybody. It's (Whereupon, at $8: 15$ p.m., the Public Meeting was concluded.)

ACE-FEDERAL REPORTERS, INC.

$\begin{array}{lcc} & \text { Nationwide Coverage } \\ 202-347-3700 & 800-336-6646 & 410-684-2550\end{array}$




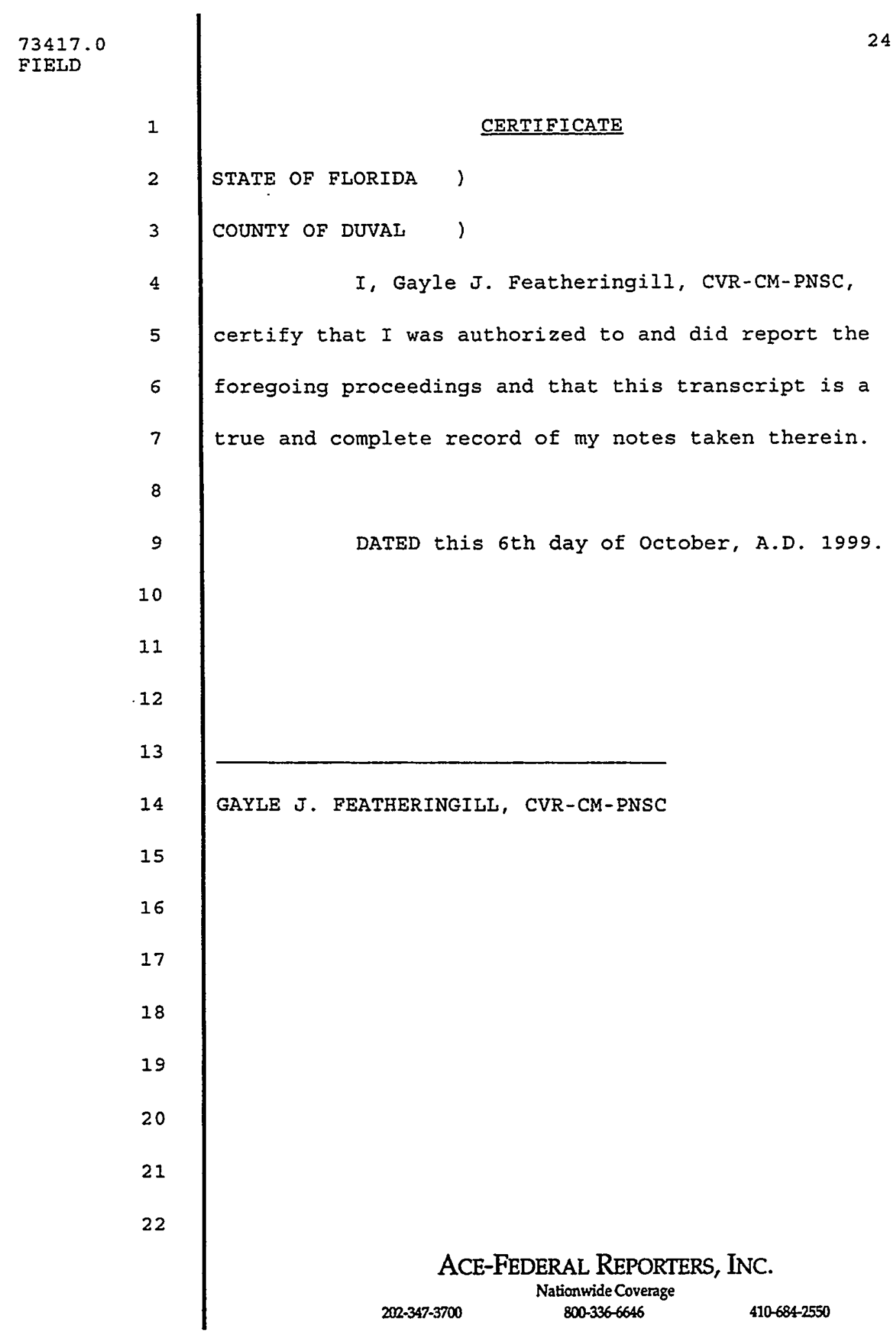




\section{COMMENTS AND RESPONSES \\ FROM THE PUBLIC HEARING \\ ON THE DRAFT EIS FOR THE \\ PROPOSED JEA CIRCULATING \\ FLUIDIZED BED COMBUSTOR PROJECT \\ JACKSONVILLE, FLORDA}

September 30, 1999

Commenter: Dot Mathias, Northside Civic Association, 341 Baisden Road, Jacksonville, FL 32218

\section{Comment T-1, pp. G-28-29:}

"Well, I guess I have a comment. It's just a commendation, really. My name is Dot Mathias, M-a-t-h-i-a-s. And I reside at 341 Basin [sic] Road, here in Jacksonville.

I'm the first vice-president for the Northside Civic Association, which is the governmental affairs chairman, also.

I would just like to say that probably the reason that we don't have any comments and that you're not having a hue and cry from the public is because JEA has worked so closely with the community, and we're very deeply appreciative, you know, of that.

We've had our meetings in the north Jacksonville area, and they have certainly answered a lot of our questions and our concerns. And that means a lot to a community, particularly when you're building a coal-fired plant in the area.

So we have been very, very grateful to them for meeting with us, because any questions that we had at that time, I think they have allayed our fears with them. And thank you so much."

\section{Response:}

Comments noted. 



\section{PART 2}

\section{WRITTEN COMMENTS}

AND

RESPONSES 


\section{Dear Lisa,}

thank you again for the opportunity to participate with the US Dept. of Energy.

The goal is of course to provide energy and to protect life. Life requires water and air, as clean as the day we used it. I will coincide we are not yet ready to do better than that.

It is unacceptable (expected response ha! ) to put anything in to the St. Johns River unless it is of a better quality than what you took it out. And because you are introducing water for energy exchange into an actuary, and at this time the chemistry of the organic matter is not stable in an industrialized water body, adding heat and possible refined levels of poison is unacceptable.

In the climate of political and human intervention to the impact of industrial co- ownership of the environment we should be striving to make a statement of a higher value of a foundation of expected behavior. It is unacceptable in 2000 t to be introduction any foreign bodies in to the river.

Water use should be considered a machine and it is owned and re-used until it needs replacing. The goal of steward-ship of water is to keep it usable.

Water at the proposed plant should be re-cycled and cooled with out the introduction or use of the river. It can be cooled by more water ground depth and you can use up some free units of power from Ga. Power and Light. If the re-fitting was done with the intent to be a front runner in technology.. there would have been gov. grants available. And the power grid would have been part of the plan.

In the future technology will be looked at as an all or nothing proposal for energy. All for the extension of a quality resource. Air and water are going to be protected first. Why spend more $\$$ later. You know the water and air standards are going to change. I hope this plant will continue to consider it's self a good neighbor.

Just a philosophical note: The Dept. Of Energy will be subservient to NASSA, unless that is the National Design, by limiting the concept of energy to all roads lead to ELECTRICITY.

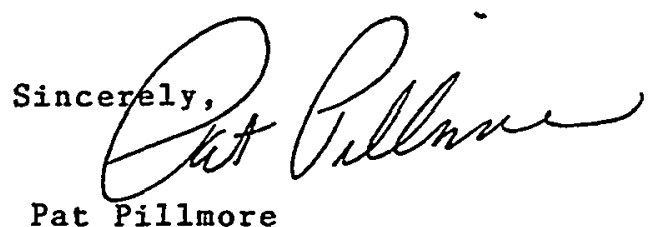

996 Camelia St., Atlantic Beach, Fla. 32233

cc: Don Donaldson

John Delaney, Mayor of Jacksonville Fla. 


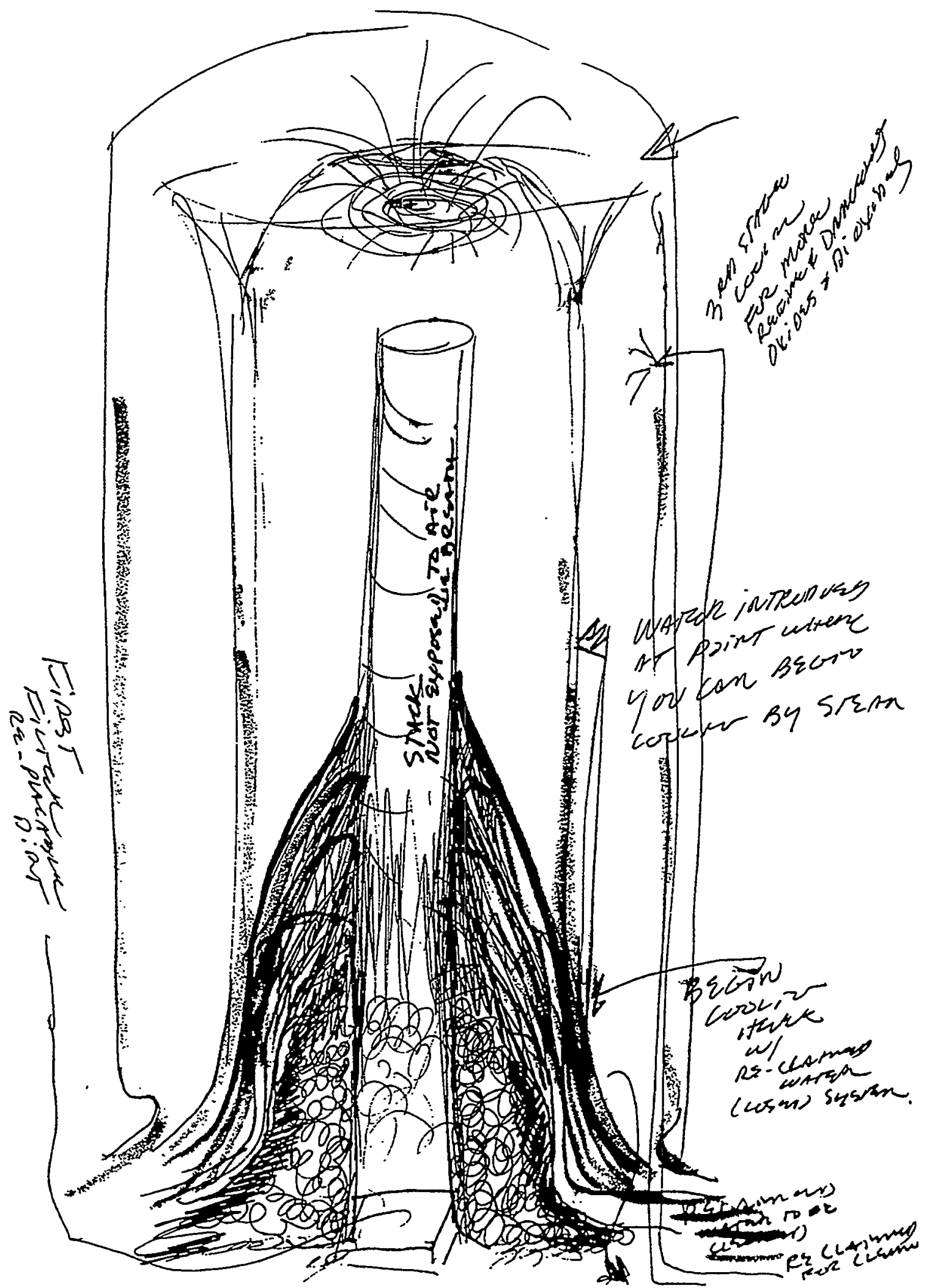




\section{Letter No. 1}

Pat Pillmore, 996 Camelia Street, Atlantic Beach, Florida 32233

\section{Comment 1-1:}

"It is unacceptable (expected response ha!) to put anything in to the St. Johns River unless it is of a better quality than what you took it out [sic]. And because you are introducing water for energy exchange into an actuary [sic], and at this time the chemistry of the organic matter is not stable in an industrialized water body, adding heat and possible refined levels of poison is unacceptable.

In the climate of political and human intervention to the impact of industrial co-ownership of the environment we should be striving to make a statement of a higher value of a foundation of expected behavior. It is unacceptable in $2000+$ to be introduction [sic] any foreign bodies in to the river.

Water use should be considered a machine and it is owned and re-used until it needs replacing. The goal of steward-ship of water is to keep it usable.

Water at the proposed plant should be re-cycled and cooled with out the introduction or use of the river."

\section{Response:}

As discussed in Section 4.1.3.2 of the EIS, the proposed project would increase the quantity of cooling water taken from the St. Johns River (however, not above permitted quantities). If Unit 2 is repowered, the entire 3-unit plant would withdraw $827 \mathrm{Mgd}(574,000 \mathrm{gpm})$ from the back channel of the river. This would be approximately the same rate at which cooling water was used when the three units operated together from approximately 1978 until 1980 . The sustained flow of the back channel would not be depleted by this diversion because $815 \mathrm{Mgd}(566,000 \mathrm{gpm})$ would be returned to the river after passing through the condensers. The tidal movement of seawater to and from the Atlantic Ocean, located about 10 miles east of Northside Generating Station, ensures that the facility would have a continuous supply of cooling water from the St. Johns River, even under conditions of prolonged drought.

Although the rate at which the cooling water would reject heat to the St. Johns River would increase from the current operating level, the size of the thermal plume would not increase because the simultaneous operation of all three units would increase the discharge velocity, which would promote mixing and heat dissipation. The thermal plume would be approximately the same size as when all three units operated at full capacity from 1978 until 1980 . The 
temperature and total surface area of the thermal plume would not exceed the regulatory limits defined in the NPDES permit.

Several measures are being implemented to minimize liquid discharges associated with the proposed project. Runoff from facilities that would be built for the proposed project would be used in plant processes or routed through detention basins equipped with baffles or oil skimmers prior to being discharged at stormwater outfalls. The detention basins would reduce the maximum rate of stormwater discharge by increasing the length of time during which the discharge occurred. The baffles or oil skimmers would collect contaminants such as oil and grease that float on top of the stormwater. Accidental spills from the proposed facility would be cleaned up in a timely manner in accordance with a spill prevention, control, and countermeasure plan and the best management practices plan for the facility. The rapid cleanup of an accidental spill would minimize runoff into San Carlos Creek or the back channel of the St. Johns River. Wastewater from processes such as demineralizer regeneration, boiler blowdown, and carbon purifier backwash would be routed to the chemical waste treatment facility. After being treated in this facility, most of the water would be reused within the scrubber and ash conditioning systems.

\section{Comment 1-2:}

"It can be cooled by more water ground depth [sic] and you can use up some free units of power from Ga. Power and Light. If the re-fitting was done with the intent to be a front runner in technology.. there would have been gov. grants available. And the power grid would have been part of the plan."

\section{Response:}

The suggested use of groundwater for cooling water would require expensive new infrastructure that would replace the existing infrastructure that withdraws water from the St. Johns River. The use of $827 \mathrm{Mgd}$ (574,000 gpm) of groundwater for cooling water would run counter to the target established by JEA's management to reduce the total annual groundwater consumption of Northside Generating Station by $10 \%$, as compared to 1996 levels. As discussed in Section 3.4.2.1 of the EIS, the potentiometric surface of the upper Floridan aquifer, from which Northside Generating Station currently withdraws groundwater from four deep wells, has been declining in northeastern Florida and is expected to continue to decline an additional 3 to $15 \mathrm{ft}$ between 1995 and 2020 (based on projected increased groundwater use). Groundwater resources likely would be strained severely by the large increase in groundwater use associated with the action suggested in the comment. The use of cooling towers or cooling ponds would reduce the quantity of water required but would be expensive and/or could result in potentially significant 
environmental impacts. Instead, cooling water for the proposed project would be drawn from the St. Johns River, as discussed in Section 4.1.3.2 of the EIS. Also, see response to Comment 1-1.

See response to Comment 5-3 for a discussion of the EIS's reasonably foreseeable scenario under the no-action alternative, in which JEA would purchase electricity from other utilities to meet JEA's projected demand rather than repowering Unit 2. Under the proposed action, DOE would provide approximately $\$ 73$ million (about $24 \%$ of the total cost of approximately $\$ 309$ million) to demonstrate CFB technology at Northside Generating Station. 


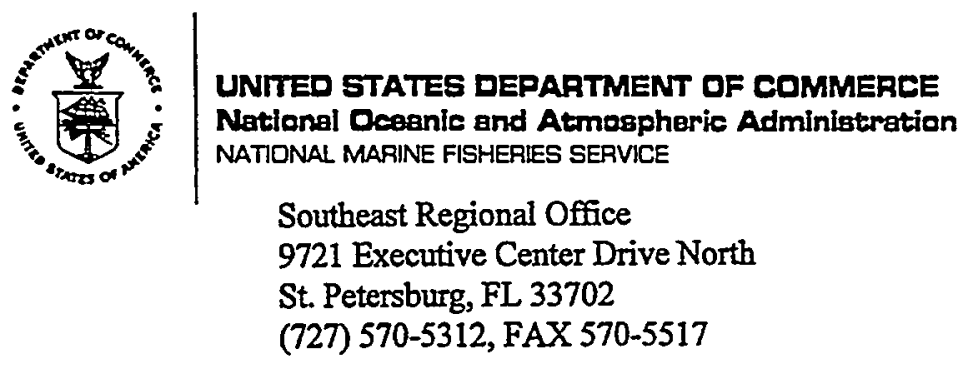

AUG $301999 \quad$ F/SER3:EGH

Ms. Lisa K. Hollingsworth NEPA Document Manager Federal Energy Technology Center 3610 Collins Ferry Road

P.O. Box 880

Morgantown, WV 26507 - 0880
Letter No. 2

Reproduced from copy submitted

Dear Ms. Hollingsworth:

This responds to your letter dated August 20, 1999 requesting review and comment on the U.S. Department of Energy's Draft Environmental Impact Statement (EIS) for the JEA Circulating Fluidized Bed Combustor Project, Jacksonville, Florida (DOE/EIS-0289). We previously commented on this project in June 1998.

The EIS acknowledges that "four or five juvenile (italics added for emphasis) loggerhead, Kemp's ridley, and/or green sea turtles were sighted. (in the back channel of the St. Johns River) in the intake basin of the Northside Generating. Station on one occasion during the summer of 1997." The EIS notes that Jacksonville Electric Authority (JEA) subsequently installed on the intake trash rakes a finer grid of mesh bars (welded wire screen on 6-inch centers contrasted to the old 12-inch centers) to reduce the possibility of sea turtle entrainment. We believe that the modification will exclude larger sea turtles, however, we believe that juvenile loggerheads and greens could still be entrained, and endangered Kemp's ridleys would very likely be entrained.

We suggest a further, small reduction (to 4-inch centers) in the size of the welded wire screen over the intake trash rakes. Turtle Excluder Devices (TEDs), required on shrimp trawlers operating in the Gulf of Mexico and Atlantic, use metal excluder grids (akin to trash rakes) with bar spacing not greater than 4 inches wide. This figure was arrived at based on statistical evidence that this minimum bar spacing would exclude (i.e., prevent from passing through the grid) most Kemp's ridley sea turtles which were inadvertently scooped up by shrimp trawl nets in the course of trawling operations. The turtles get out of the net through an escape opening cut into the net adjacent to the TED grid.

Since JEA has already indicated that it intends to regularly inspect the intake trash rakes to monitor any increased clogging and increase the frequency of cleaning if necessary, this seems like an eminently workable solution to the entrainment problem. We believe that the possibility that shortnose sturgeon may be entrained through a 4-inch grid is remote. Reducing the grid size to 4 inches would eliminate all our endangered species concerns. 
We appreciate the opportunity to comment. If you have any questions, please call Eric Hawk or Bob Hoffman at (727) 570-5312.

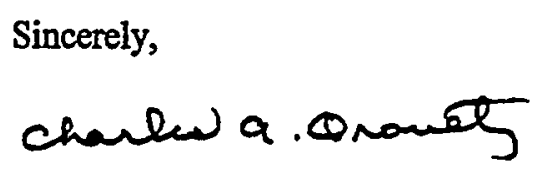

Charles A. Oravetz

Chief, Protected Resources Division

o:Isection7linformallfetc-sjr.doe

File: 1514-22 .m.3. DOE Florida 1999 


\section{Letter No. 2}

Charles A. Oravetz, Chief, Protected Resources Division, United States Department of Commerce, National Oceanic and Atmospheric Administration, National Marine Fisheries Service, Southeast Regional Office, 9721 Executive Center Drive North, St. Petersburg, Florida 33702

\section{Comment 2-1:}

"We believe that the modification will exclude larger sea turtles, however, we believe that juvenile loggerheads and greens could still be entrained, and endangered Kemp's ridleys would very likely be entrained.

We suggest a further, small reduction (to 4-inch centers) in the size of the welded wire screen over the intake trash rakes. Turtle Excluder Devices (TEDs), required on shrimp trawlers operating in the Gulf of Mexico and Atlantic, use metal excluder grids (akin to trash rakes) with bar spacing not greater than 4 inches wide. This figure was arrived at based on statistical evidence that this minimum bar spacing would exclude (i.e., prevent from passing through the grid) most Kemp's ridley sea turtles which were inadvertently scooped up by shrimp trawl nets in the course of trawling operations. The turtles get out of the net through an escape opening cut into the net adjacent to the TED grid.

Since JEA has already indicated that it intends to regularly inspect the intake trash rakes to monitor any increased clogging and increase the frequency of cleaning if necessary, this seems like an eminently workable solution to the entrainment problem. We believe that the possibility that shortnose sturgeon may be entrained through a 4-inch grid is remote. Reducing the grid size to 4 inches would eliminate all our endangered species concerns."

\section{Response:}

As part of the Northside Generating Station dredging permit (199500468) issued by the COE on July 21,1995 , a special condition was incorporated that requires JEA to fully inspect the intake gates prior to each dredging activity and replace the gates if corrosion has caused holes in the trash rakes. This condition in the COE permit was in response to a U.S. Fish and Wildlife Service comment upon their review of the permit application in which they expressed concern about sea turtles entering the intake flume and becoming trapped. Also in response to their concern, JEA offered to install new trash rakes with attached epoxy-coated fence screen with 6-in. square openings to prevent juvenile sea turtles from entering the intake. The design features of the intake structures, including installation of the 6-in. centers, were discussed with Mr. Marc Epstein of the U.S. Fish and Wildlife Service, who felt that the screen size was adequate to exclude the turtles, and with the COE's Ms. Lois Obenchain. An informal agreement 
was reached between JEA, the U.S. Fish and Wildlife Service, and the COE that resulted in the fabrication and installation of the new trash rakes and screen. JEA has committed to inspect and, if necessary, repair the screen consistent with the inspection requirements for the trash rakes in the COE permit (J. A. Leduc, JEA, personal communication to R. L. Miller, ORNL, February 10, 2000). JEA's commitment ensures that this equipment will be maintained in a condition adequate to exclude smaller turtles from entering the intake.

Even with the current 6-in. centers, the openings in the screens become rapidly clogged with biofouling marine organisms, resulting in a pressure drop across the intake. With three units operating using 4-in. screens, the pressure drop could limit the capability of the intake pumps. With a large pressure drop and during low tides, levels in the intake pump sumps could drop enough to cause a vortex condition, possibly resulting in pump damage or an inability to pump sufficient cooling water and/or causing overly elevated discharge temperatures. In addition, the water velocity at the intake would increase because the same amount of water would flow through a reduced area as a consequence of the marine growth buildup. Extensive maintenance would be required to prevent excessive marine growth buildup and the resultant pressure drop. Because of the above reasons and because there have been no observations or evidence that turtles have entered the intake after the installation of the 6 -in. screens, no plans exist to reduce the mesh size at the intakes to 4 in. 
LISA: Me. BEATTIE IS A PRETESTIMNAL,

PRACTEING GEOLOSAST ANA WAS HAPPY

TO REUTEW THO DEATT ENS FAR DUR AUOUAON CHAPTET

To: Sara Balley- $204-287-1763$ fax: $904.230-1187$

From: Don Beattie(904-287-0222)

Subject: Review of Draft EIS for JEA CFB combustor project Date: $9 \cdot 10-99$
TO: LISR K. HOLLINGSWORTH NEPA DOCUMENT MOR. FEDERAL ENERGY TECH CTR

FAX: $304285-4403$

Letter No. 3

Reproduced from
copy submitted

After a quick review of the subject EIS, here are some questions or concerns that 1 have.

1. Although the EIS indicates that a number of such power plants are operating or under construction (Table 1.3.1), all smaller than the proposed JEA plant, it does not provide any numbers based on operating experience to back up the claims that this plant will achieve the removal of SO2, NOx, and particulates as advertlsed. I belleve that due diligence requires JEA and other local, state and federal agencies to request and review the operating experience of these other plants and satisfy themselves that this technology will offer an improvement over other technologies that are available, probably at a lower cost and less risk than a CFB plant.

2. It should be noted that the proposed plant will burn a fuel mixture (Bituminous coal and petroleum coke) different than any of the existing or planned plants using this technology. The EIS does not address the question of the effect, if any, of this fuel mixture on the design and operating characteristics of the plant. Will this introduce new practices that are untested? Does the mixture of these two fuels have to be carefully controlled and monitored to be sure that the limestone mixture in the bed interacts correctly with the fuel? A similar question can be asked concerning the use of the ammonia injected into the exhaust gas to assure that excess emission of ammonia to the atmosphere does not occur. Is there past experience to justify any conclusions on these matters or is it based on bench scale experiments? If the latter, my experience with technologies of this type is that as they are scaled up to large commercial units they encounter a steep learning curve usually requiring a lot of "tinkering" to obtain desired operations. In the worse case, some redesign may be required. If needed, is JEA prepared for a breaking-in period that may result in downtime?

3. The EIS suggests that the bottom ash and fly ash that will be producod can be converted to useful products. I recommend that a careful analysis be made of the real potential of finding customers for the ash products. If they don't exist, or will be difficult to find, then JEA must develop a satisfactory plan for disposal of the ash products.

4. The schematic, Fig. 2.1.9, shows chemical waste products discharging to a settling basin(s). It indicates that there would be an emergency overflow to the St. Johns River. What type of emergency would result in such a discharge and what would be the effect on the River? Also, as for all power plants. the cooling water will be discharged into the Aiver at an elevated temperature. The impact of this discharge is discussed on page 4-28 and is stated to be "approximately the same size as when all three units operated at full capacity from 1978 until $1980^{\circ}$. I suggest that this impact be carefully examined; what may have been acceptable 20 years ago may not be today in view of more recent developments along the River and environmental concerns for the health of the River. 


\section{Letter No. 3}

Don Beattie, Geologist, Audubon Chapter and the Florida Wildlife Federation

\section{Comment 3-1:}

"Although the EIS indicates that a number of such power plants are operating or under construction (Table 1.3.1), all smaller than the proposed JEA plant, it does not provide any numbers based on operating experience to back up the claims that this plant will achieve the removal of $\mathrm{SO} 2, \mathrm{NOx}$, and particulates as advertised. I believe that due diligence requires JEA and other local, state and federal agencies to request and review the operating experience of these other plants and satisfy themselves that this technology will offer an improvement over other technologies that are available, probably at a lower cost and less risk than a CFB plant."

\section{Response:}

Foster Wheeler Corporation, which would perform the design, engineering, procurement, and construction of the CFB combustor for the proposed project, is one of the world's largest manufacturers of CFB equipment. Foster Wheeler's guarantees for the CFB technology are based on commercial-scale data. See response to Comment 3-2 for a general discussion of CFB commercial-scale operating experience.

With regard to $\mathrm{SO}_{2}$ emissions, there has been considerable operating experience with CFB technology at the $85-90 \%$ level of $\mathrm{SO}_{2}$ capture that is proposed for the project. The capture of the additional sulfur in the polishing scrubber to achieve an overall $\mathrm{SO}_{2}$ removal rate of $98 \%$ is expected to be readily attainable because scrubbers are commonly used alone for $90 \% \mathrm{SO}_{2}$ capture. The combined use of a CFB combustor with a polishing scrubber increases the overall ability of the system to meet $\mathrm{SO}_{2}$ emission limitations. For $\mathrm{NO}_{x}$ emissions, Foster Wheeler is confident that the guaranteed level can be met because test data show that $\mathrm{NO}_{\mathrm{x}}$ emissions are much less than $100 \mathrm{ppm}$ using ammonia injection. For particulate emissions, Wheelabrator Air Pollution Control has provided test data from a coal-fired power plant that utilizes a pulse-jet fabric filter similar to the design for the proposed project (if a fabric filter is used rather than an electrostatic precipitator). The test data substantiated the proposed design: stack emissions using EPA method 201A were below the detection level, and the actual emissions were less than allowed for the proposed project.

With regard to cost, in a comparison using low-quality fuels, CFB technology currently costs less than a conventional pulverized-coal unit with a scrubber. For high-quality fuels, CFB technology costs about the same as a conventional system. 


\section{Comment 3-2:}

"It should be noted that the proposed plant will burn a fuel mixture (Bituminous coal and petroleum coke) different than any of the existing or planned plants using this technology. The EIS does not address the question of the effect, if any, of this fuel mixture on the design and operating characteristics of the plant. Will this introduce new practices that are untested? Does the mixture of these two fuels have to be carefully controlled and monitored to be sure that the limestone mixture in the bed interacts correctly with the fuel? A similar question can be asked concerning the use of the ammonia injected into the exhaust gas to assure that excess emission of ammonia to the atmosphere does not occur. Is there past experience to justify any conclusions on these matters or is it based on bench scale experiments? If the latter, my experience with technologies of this type is that as they are scaled up to large commercial units they encounter a steep learning curve usually requiring a lot of "tinkering" to obtain desired operations. In the worse case, some redesign may be required. If needed, is JEA prepared for a breaking-in period that may result in downtime?"

\section{Response:}

Operation of the proposed project would draw upon Foster Wheeler's considerable experience with co-firing fuels, particularly coal and petroleum coke (e.g., a 30-MW CFB unit for the Ft. Howard Paper Company in Rincon, Georgia, that came on-line in 1988, a 20-MW CFB unit for the city of Manitowoc, Wisconsin, that began operation in 1991). No problems are anticipated with sulfur capture and it is not expected that the co-firing of fuels would introduce any major issues related to the distribution or mixing of fuels and limestone.

Additionally, it is not anticipated that the co-firing of fuels would increase the difficulty of using ammonia injection to limit $\mathrm{NO}_{x}$ emissions. As discussed in Section 2.1.3 of the EIS, the proposed project would use a selective non-catalytic reduction system to further reduce $\mathrm{NO}_{x}$ emissions. Aqueous ammonia, the reagent for this system, would be injected into the CFB combustor exhaust gas to convert $\mathrm{NO}_{x}$ emissions to nitrogen gas and water via a chemical reduction reaction. Atmospheric emissions of ammonia can occur if the amount supplied to reduce $\mathrm{NO}_{x}$ in the flue gas is not used up (ammonia slip). However, excess ammonia in the stack gas can typically be reduced to a level in the parts per million by optimizing the amount of ammonia that is injected. For the proposed project, stack emissions of ammonia slip would not exceed $40 \mathrm{ppm}$. Also, see response to Comment 3-1.

Over $100 \mathrm{CFB}$ combustion boilers have been installed and are operating throughout the world, primarily in Europe, Asia, and North America. The following discussion highlights the steady scale-up in the size of the units that has occurred with time. The first commercial-scale CFB boiler, which was $5 \mathrm{MW}$ in size, began operation in Finland in 1979 using wood waste and peat 
as fuel. During the early 1980s, CFB boilers increased in size and gained acceptance for power generation, particularly in cogeneration applications in which industries used both electricity and steam. For example, a 20-MW unit began cogeneration in Finland in 1981 using peat and coal as fuel. These smaller boilers proved the readiness of CFB technology for coal-fired boiler applications. The scale-up continued in the $1980 \mathrm{~s}$ to accommodate the interest of utilities in larger boilers. In 1987, a 110-MW coal-fired CFB unit began generating electricity in Colorado to demonstrate the technology at the smaller end of the utility scale. The unit demonstrated that the technology would burn coal efficiently, would accept variations in coal quality without lowering the boiler capacity, and would effectively control $\mathrm{SO}_{2}$ and $\mathrm{NO}_{\mathrm{x}}$ emissions. The next major scale-up occurred using a 165-MW coal-fired CFB unit in Nova Scotia in 1993. Then a 250-MW coal-fired CFB unit began operation in France in 1996, and two 235-MW lignite-fired CFB units came on-line in Poland in 1998. The proposed 297.5-MW project would take the next step in size by evaluating the viability of CFB combustion technology within the range that is most desired by utilities ( 250 to $400 \mathrm{MW}$ ). During the 2-year demonstration period, it is expected that the proposed project may encounter downtime as part of evaluating and improving its performance.

\section{Comment 3-3;}

"The EIS suggests that the bottom ash and fly ash that will be produced can be converted to useful products. I recommend that a careful analysis be made of the real potential of finding customers for the ash products. If they don't exist, or will be difficult to find, then JEA must develop a satisfactory plan for disposal of the ash products."

\section{Response:}

See response to Comment 11-6. Section 5 of the EIS discusses disposal options in the event that additional disposal space were required because of the 40-acre storage site (cells I and II combined) being filled to capacity.

\section{Comment 3-4:}

"The schematic, Fig. 2.1.9, shows chemical waste products discharging to a settling basin(s). It indicates that there would be an emergency overflow to the St. Johns River. What type of emergency would result in such a discharge and what would be the effect on the River?"

\section{Response:}

The water from the chemical waste treatment system currently discharges to settling basins and then most of it passes into evaporation/percolation ponds (Figure 2.1.9 of the EIS). The 
emergency overflow to the St. Johns River consists of a concrete spillway from the ponds. During periods of excessive rainfall, the spillway allows for overflow to prevent the size of the ponds from exceeding safe levels such that the earthen berms could be subject to failure. Although rarely used (e.g., not in the last 4 years), the overflow has been authorized in JEA permits since 1985 during construction of the chemical waste treatment system. During the infrequent discharges, relatively clean water is released because its composition is primarily rainwater. Consequently, the effect of these discharges on the St. Johns River is not detectable, especially because the runoff of excessive rainfall increases the volume of the river so that enhanced dilution of the discharges occurs.

After repowering both Units 1 and 2, the chemical waste treatment system and settling basins would be handling more water, but most of the water would be re-used and would not enter the evaporation/percolation ponds. Specifically, the average flow of water to the ponds would decrease from the current $286 \mathrm{gpm}$ (Figure 2.1.9) to $48 \mathrm{gpm}$ (Figure 2.1.8). Consequently, the probability of discharge from the spillway would be reduced compared to the existing probability.

For the NPDES permit, however, JEA was required to develop a scenario for overflow from the evaporation/percolation ponds. The scenario involved runoff from the proposed ash storage area to the chemical waste treatment system during a 24-hour storm event that would occur, on average, only once in 25 years. This scenario assumed that the re-use system could not handle all of the flow from the chemical waste treatment system and the excess would be discharged to the evaporation/percolation ponds, which would raise their level. Assuming rainy conditions persist, ground saturation would prevent the ponds from operating normally and an overflow from the spillway would occur if the rainfall were sufficiently heavy. In this unlikely event, the discharge water would be relatively clean because its composition primarily would be rainwater. Consequently, the effect of the discharge on the St. Johns River would not be detectable, particularly considering the reasons given earlier in this response regarding the increased volume of the river.

\section{Comment 3-5:}

"Also, as for all power plants, the cooling water will be discharged into the River at an elevated temperature. The impact of this discharge is discussed on page 4-28 and is stated to be 'approximately the same size as when all three units operated at full capacity from 1978 until 1980.' I suggest that this impact be carefully examined; what may have been acceptable 20 years ago may not be today in view of more recent developments along the River and environmental concerns for the health of the River." 


\section{Response:}

JEA was originally authorized by the EPA in January 1977 to discharge the once-through cooling water from the three units at Northside Generating Station into the back channel of the St. Johns River. The facility was subsequently re-evaluated and the EPA reissued NPDES permits in November 1983, June 1989, and September 1994. All of these permit renewals authorized the discharge of once-through cooling water from the three units, even though Unit 2 has been out of service since 1983. The NPDES permit was then delegated to the state of Florida in June 1995.

In April 1997, JEA submitted a permit renewal application to the FDEP requesting renewal of the authorization for discharge of once-through cooling water from the three units. Both FDEP and EPA personnel review permit applications prior to final issuance, assuring full evaluations are conducted by both state and federal agencies. The new NPDES permit was issued on February 15, 2000. The permit expires on February 17, 2005.

During each permit renewal, the thermal discharge from the facility has been re-examined. As stated in the EIS (Section 3.3:4), the size of the thermal plume would not increase during three-unit operation because the simultaneous operation of all three units would increase the discharge velocity, which would promote mixing and heat dissipation. The facility would continue to operate under the thermal discharge limitations specified in the NPDES permit.

The EIS addresses potential biological and ecological effects of the thermal discharge from the proposed project (Section 4.1.6.2). No measurable effect on the biota of the area would be expected from the temperature and total area of the thermal plume regulated by the limits specified in the NPDES permit (Section 3.3.4). 
Letter No. 4

Donivan Porterfield

PO Box 1417

Los Alamos, NM 87544

September 12, 1999

Ms. Lisa K. Hollingsworth

National Environmental Policy Act (NEPA) Document Manager

U.S. Department of Energy, Federal Energy Technology Center

3610 Collins Ferry Road

Morgantown, WV 26507-0880

\section{Re: DOE NEPA EIS-0289}

Dear Ms. Hollingsworth:

The comments below are in regard to EIS-0289, "Draft Environmental Impact Statement for the JEA Circulating Fluidized Bed Combustor Project". Before making conments specific to this draft ElS I would like to make three general comments.

\section{The Adobe PDF File}

In reading the Adobe PDF file for this EIS I encountered difficulty due to the fact that some text was lost in the conversion to the Adobe PDF format. This loss of text was due to the "Univers,Bold" font not being included in the Adobe PDF file. This loss primarily impacted document headings and page numbers. While I can understand this error in creation of the PDF file it is a little disappointing that it has not been caught or corrected as yet. I would hope in future that the Adobe PDF files be checked for this potential problem before being released to the public.

In the generation of Adobe PDF files it is possible to configure Adobe generating software to include the needed fonts in the resulting PDF file. While this can increase the Adobe PDF file size it insures the complete readability of the content. I would suggest that this practice be generally adopted in the generation of Adobe PDF files for public access. 


\section{Document Download}

While on a general theme I would also like to make a suggestion on how DOE makes these Adobe PDF files available over the internet. Having the document broken into several Adobe PDF files (20 in the case of this draft EIS) makes for easy on-line access to the content when using a continuous internet connection. However, for those of us limited to dial-up connections it makes the process of downloading the entire document somewhat tedious. In addition to making the PDF files individually available I would like to suggest also providing the alternate of downloading a single 'self-extracting zip' file representing the entire set of Adobe PDF files.

\section{Availability of References}

In reviewing this draft EIS I was hindered in lack of access to referenced documents. In the case of radionuclides two references are provided: Weston 1995 and DOE 1995. In the case of the first reference I would expect some difficulty in obtaining a copy of the report from a consulting firm to a private client. In the case of the second reference I was not able to readily find this reference on the DOE NEPA web page or through the DOE Information Bridge resource. I believe that where a DOE report is used to insure the availability of that report through the public section of the DOE Information Bridge. With respect to non-DOE judgment should be utilized in using sources that may not be readily accessible to the public.

\section{Radionuclide emissions (non-radon)}

I'm somewhat disaponited with the coverage of radionuclide emissions in section 4 of the draft EIS. I would like to suggest the following changes be realized in the final EIS:

a. Provide a table of estimated isotope specific radiomuclide emissions for this specific plant with reference to basis for these estimates.

b. Based on the mentioned modeling provide an estimate of both the maximum and median isotope specific activity (pCi/square meter) per year deposited at the 352 receptor locations within
6 miles of the CFB combustor stack.

c. Provide a table of estimated isotope specific radionuclide activity in the resulting ash by-product.

\section{Radionuclide emissions (radon)}

Beyond the resulting dose and lifetime risk quantity stated I believe the final EIS should also provide a measure of the resulting radon concentration in units of $\mathrm{pCi} / \mathrm{L}$ for direct comparison to the EPA action limit of $4 \mathrm{pCi} / \mathrm{L}$. This both in the maximum and medium for analyzed receptor sites. 
6. Ash by-product, radon emissions

The potential for adverse impact from ash by-product radon emissions does not appear to be addressed in the draft EIS. I would suggest that this additional pathway for radon exposure be addressed.

7. Ash by-product, TCLP analysis

As part of the mentioned TCLP analysis of Northside Generating Station's CFB ash I would suggest| the presence of radionuclides be determined in both the generic sense, gross alpha/beta, and isotope specific.

\section{Carbon dioxide emissions}

I believe it is mis-representative to minimize the carbon dioxide emissions of this plant be comparison to the amount emitted globally. I think a better perspective would be gained in comparison of the carbon dioxide emissions on a per capita basis to the population served. For example from the data provided in the EIS it appears that approximately 5 tons of carbon dioxide is emitted globally per person. Based on the anticipated carbon dioxide emissions of this plant it would represent approximately 400,000 persons. Is it anticipated that produced power would serve at least 400,000 persons?

I would also seem appropriate to address what if any mitigation could be undertaken to counter this amount of produced carbon dioxide. For example, by DOE and/or JEA acquiring additional credits of wetlands from the mentioned offiste mitigation bank or additional acres of the also mentioned undisturbed, uplands, maritime oak hammock. The amount acquired corresponding the area required to utilize the additional carbon dioxide emissions.

Sincerely yours,

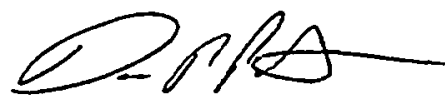

Mr. Donivan Porterfield 


\section{Letter No. 4}

Donivan Porterfield, P. O. Box 1417, Los Alamos, New Mexico 87544

\section{Comment 4-1:}

"In reading the Adobe PDF file for this EIS I encountered difficulty due to the fact that some text was lost in the conversion to the Adobe PDF format. This loss of text was due to the 'Univers,Bold' font not being included in the Adobe PDF file. This loss primarily impacted document headings and page numbers. While I can understand this error in creation of the PDF file it is a little disappointing that it has not been caught or corrected as yet. I would hope in future that the Adobe PDF files be checked for this potential problem before being released to the public.

In the generation of Adobe PDF files it is possible to configure Adobe generating software to include the needed fonts in the resulting PDF file. While this can increase the Adobe PDF file size it insures the complete readability of the content. I would suggest that this practice be generally adopted in the generation of Adobe PDF files for public access."

\section{Response:}

DOE regrets any inconvenience that online users may have experienced as a result of the problem described in the above comment that made the document more difficult to navigate and read. To make the draft EIS available to the.public quickly, DOE decided to proceed with electronic publication of the document on its NEPA Website with the Univers special font used on headings because (1) it was extremely difficult to convert the Univers font into a Webcompatible format, and (2) the Univers font did not impede users from reading the substantive content of the document. For the final JEA EIS, this problem has been avoided by changing the font to a Web-compatible format.

\section{Comment 4-2:}

"While on a general theme I would also like to make a suggestion on how DOE makes these Adobe PDF files available over the internet. Having the document broken into several Adobe PDF files (20 in the case of this draft EIS) makes for easy on-line access to the content when using a continuous internet connection. However, for those of us limited to dial-up connections it makes the process of downloading the entire document somewhat tedious. In addition to making the PDF files individually available I would like to suggest also providing the alternate of downloading a single 'self-extracting zip' file representing the entire set of Adobe PDF files." 


\section{Response:}

Because DOE NEPA documents frequently are very large, DOE has found that the needs of most users are best served when these documents are Web-published in smaller, more manageable files. The file lengths are selected to correspond with natural breaks (e.g., sections) in the documents. This approach of using multiple files prevents users from inadvertently exceeding the storage capacities of their computers. Depending on the users' preferred Portable Document Format viewer (e.g., Adobe Acrobat) and system configuration, the amount of time required to download a single large Portable Document Format file could prompt users to conclude that a selected document is not available. Nevertheless, DOE will consider the above suggestion of providing a single self-extracting zip file so that an entire EIS could be downloaded in one step. As another alternative for users who want a single electronic file, DOE often can provide documents in CD-ROM format upon request.

\section{Comment 4-3:}

"In reviewing this draft EIS I was hindered in lack of access to referenced documents. In the case of radionuclides two references are provided: Weston 1995 and DOE 1995. In the case of the first reference I would expect some difficulty in obtaining a copy of the report from a consulting firm to a private client. In the case of the second reference I was not able to readily find this reference on the DOE NEPA web page or through the DOE Information Bridge resource. I believe that where a DOE report is used to insure the availability of that report through the public section of the DOE Information Bridge [sic]. With respect to non-DOE [sic] judgment should be utilized in using sources that may not be readily accessible to the public."

\section{Response:}

DOE ensures that its EIS reference materials are reasonably available to the public by placing them in the public reading rooms listed in the EIS cover sheet, providing copies upon request, or assuring that the materials are generally available. In the EIS cover sheet and in the Notice of Availability for each EIS, DOE provides a contact person to whom requests for such information can be made. For the JEA EIS, the 1995 Weston report could have been and still can be obtained by submitting a request to the contact person, the JEA NEPA Document Manager. Regarding the second reference, DOE issued the Final Environmental Impact Statement for the Proposed York County Energy Partners Cogeneration Facility in May 1995, distributed it widely to interested parties, and placed it in the public reading rooms established for the project. An electronic version of this EIS is not available because it was published before DOE began to make NEPA documents available routinely on its NEPA Website. This EIS could have been and still can be obtained from the JEA NEPA Document Manager upon request. 


\section{Comment 4-4:}

"Provide a table of estimated isotope specific radionuclide emissions for this specific plant with reference to basis for these estimates."

\section{Response:}

Fossil fuels and limestone contain naturally occurring radionuclides and their decay products. The quantities of radionuclides emitted during combustion are dependent upon the characteristics of the fuels and limestone, as well as their processing prior to combustion. Isotope-specific radionuclide emissions for the proposed project have not been estimated because the estimates would be very uncertain and because the isotope-specific lifetime cancer risks derived from these estimates would be even less than the extremely low risk estimated for total radionuclide emissions. The total radionuclide emissions for the facility were calculated based on emission factors proposed by the Florida Electric Power Coordinating Group that were submitted to the FDEP in April 1995, when the latter agreed to consider industry proposals for industry-specific emission factors in the absence of EPA-approved factors. The total radionuclide emissions for the repowered Northside Generating Station were estimated at $6.378 \mathrm{mCi} /$ year using coal and petroleum coke (based on the proposed particulate limit of $0.011 \mathrm{lb} / \mathrm{MBtu}$ ) and $0.006 \mathrm{mCi} /$ year using No. 2 fuel oil.

As discussed in Section 4.1.2.2 of the EIS, detailed dose pathway analyses were performed (for a proposed facility very similar to the proposed project) for radionuclides in coal and limestone using two different approaches: measurement of radioactive species at an operating plant (Weston 1995) ${ }^{*}$ and calculations based on coal analysis coupled with emission factors (DOE 1995). The estimated radionuclide emission rates for the similar facility were approximately 10 times greater than the estimated radionuclide emission rates given above for the proposed Northside facility. Assuming that typical risks associated with the proposed project would correspondingly be 10 times less than for the similar facility, the lifetime cancer risk (excluding radon gas) from the proposed project for the maximum exposed person was estimated to be in the range of 2 in 100 million $\left(2 \times 10^{-8}\right)$ to 2 in 10 million $\left(2 \times 10^{-7}\right)$. For radon, the dose was estimated in Section 4.1.2.2 of the EIS to be approximately $3 \times 10^{-4} \mu$ rem per year, which is a lifetime risk of 1 in 100 billion $\left(1 \times 10^{-11}\right)$ (ICRP 1991).

*All references cited in this appendix are listed in Section 10. 


\section{Comment 4-5:}

"Based on the mentioned modeling provide an estimate of both the maximum and median isotope specific activity ( $\mathrm{pCi} / \mathrm{square}$ meter) per year deposited at the 352 receptor locations within 6 miles of the CFB combustor stack."

\section{Response:}

Because isotope-specific radionuclide emissions for the proposed project have not been estimated, estimates of the isotope-specific concentrations in the ambient air and deposition at the receptor locations cannot be obtained from modeling. Consequently, the maximum and median isotope-specific deposition cannot be given. However, as discussed in the response to Comment 4-4, the isotope-specific lifetime cancer risks would be even less than the extremely low risk estimated for total radionuclide emissions.

\section{Comment 4-6:}

"Provide a table of estimated isotope specific radionuclide activity in the resulting ash byproduct."

\section{Response:}

Limited data exist on radionuclide concentrations in coal combustion ash and isotope-specific radionuclide activity in the ash. One study that analyzed CFB by-products found gross alpha levels ranged from 0 to $17 \mathrm{pCi} / \mathrm{g}$, gross beta levels ranged from 1.6 to $55 \mathrm{pCi} / \mathrm{g}$, radium-226 levels ranged from 0.9 to $6.2 \mathrm{pCi} / \mathrm{g}$, and uranium-235 levels ranged from 0 to $4 \mathrm{pCi} / \mathrm{g}$ (EPRI 1995a). Gross alpha and gross beta activities were below or within the range found in conventional pulverized-coal fly ash from bituminous and subbituminous coals. Radium-226 was within or slightly higher than the conventional range. For uranium-235, no range from conventional pulverized-coal fly ash was given for comparison.

Two other studies evaluated coal fly ash for radioactivity (EPRI 1992). The first study found that 6 of 12 fly ashes from western subbituminous and lignite coal had radium-226 activity levels above $5 \mathrm{pCi} / \mathrm{g}$; the highest level measured was $10 \mathrm{pCi} / \mathrm{g}$. In the second study, 69 samples of eastern and western fly ash were evaluated. Seven had values greater than $5 \mathrm{pCi} / \mathrm{g}$; the highest level measured was $7 \mathrm{pCi} / \mathrm{g}$. The mean specific activity for the fly ash was $3.7 \mathrm{pCi} / \mathrm{g}$ for eastern coal, $2.6 \mathrm{pCi} / \mathrm{g}$ for western coal, and $3.9 \mathrm{pCi} / \mathrm{g}$ for eastern and western lignites.

The Nelson Industrial Steam Company in Westlake, Louisiana, has analyzed hydrated CFB ash material from its permitted landfill to seek approval of the ash's use as embankment and/or base material for highway construction. Analysis of the material revealed that radium-226 ranged 
from 3.1 to $4.3 \mathrm{pCi} / \mathrm{g}$, less than the $5 \mathrm{pCi} / \mathrm{g}$ level in which the material can be used without unreasonable risk, as specified in Louisiana radiation protection regulations.

\section{Comment 4-7:}

"Beyond the resulting dose and lifetime risk quantity stated I believe the final EIS should also provide a measure of the resulting radon concentration in units of $\mathrm{pCi} / \mathrm{L}$ for direct comparison to the EPA action limit of $4 \mathrm{pCi} / \mathrm{L}$. This both in the maximum and medium [sic] for analyzed receptor sites."

\section{Response:}

Using an upper limit for radon emissions of approximately $175 \mathrm{mCi} / y e a r(D O E ~ 1995)$ and an estimated dilution at the location of maximum exposure of about $6 \times 10^{-9} \mathrm{~s} / \mathrm{m}^{3}$ (the ratio of the maximum annual ground-level concentration in the ambient air calculated by the ISCST3 air dispersion model to the air emission rate), the maximum radon concentration would be approximately $3.3 \times 10^{-8} \mathrm{pCi} / \mathrm{L}$. This value is about a hundred-millionth of the EPA action limit of $4 \mathrm{pCi} / \mathrm{L}$. The median radon concentration for the ISCST3 receptors was estimated from the model results to be approximately $5.5 \times 10^{-9} \mathrm{pCi} / \mathrm{L}$, which is about one-sixth of the maximum concentration. Therefore, this value is slightly greater than a billionth of the EPA action limit of $4 \mathrm{pCi} / \mathrm{L}$.

\section{Comment 4-8:}

"The potential for adverse impact from ash by-product radon emissions does not appear to be addressed in the draft EIS. I would suggest that this additional pathway for radon exposure be addressed."

\section{Response:}

Because radon, which is a noble gas, is trapped within the matrix of the coal and petroleum coke, most of it would be released during the pulverizing operations. Small amounts would remain trapped in the fuel until combustion, when nearly all of the radon would be released into the exhaust gas stream rather than being collected in the ash.

Results from a study that analyzed 18 samples of fly ash from western and eastern coals indicated that all radon values obtained were below the federal EPA clean-up standard of $5 \mathrm{pCi} / \mathrm{g}$ (EPRI 1995b). This standard was established to limit the risk from inhalation of radon decay products and to limit gamma radiation exposure to members of the public in or near areas contaminated with uranium mill tailings. 
Another study assessed the potential radiation exposure resulting from activities at coal-fired power plants in which workers are exposed to combustion ash (e.g., ash silo operation, ash handling, and baghouse maintenance) (EPRI 1995b). The study also evaluated the exposure encountered by workers during planned facility outages, as well as non-occupational exposure resulting from road construction using ash for roadbed or asphalt filler, sandblasting using ash as grit, the manufacture of building materials using ash, the presence of residents near ash disposal areas, and residents living in homes constructed from ash by-products. The study calculated the radium concentration necessary to produce an individual exposure level of $25 \mathrm{mrem}$ per year. Radium, which is the parent of radon in the radioactive decay chain, is easier to measure because its half-life is 1,600 years while radon's half-life is less than 4 days. The level of 25 mrem was the draft exposure standard proposed by the Conference of Radiation Control Program Directors for naturally occurring radioactive material released to the environment. In all cases, to reach $25 \mathrm{mrem}$, the concentration of radium in coal combustion ash would need to be orders of magnitude greater than the highest radium concentration actually found. Therefore, even if the ash would contain a concentration equal to $5 \mathrm{pCi} / \mathrm{g}$ of radium, the dose received by those most exposed to the ash would be well below the health-based level of 25 mrem annual dose-equivalent to the whole body. The study focused on the annual dose-equivalent limit, rather than the concentration limit, because the model regulations are designed to protect public health, which is directly affected by the annual dose-equivalent limit.

\section{Comment 4-9:}

"As part of the mentioned TCLP analysis of Northside Generating Station's CFB ash I would suggest the presence of radionuclides be determined in both the generic sense, gross alpha/beta, and isotope specific."

\section{Response:}

As discussed in the response to Comment 4-6, radioactive characteristics of CFB combustion ash from the proposed project are expected to be similar to conventional pulverized-coal fly ash. Depending on the proportion of petroleum coke consumed, there could be lower concentrations of radionuclides in the ash because less uranium and thorium are present in the parent oil of petroleum coke than are present in coal. There currently is no regulatory requirement to evaluate the presence of radionuclides in CFB ash in a generic or isotope-specific sense. Gross alpha, radium-226, and radium-228 would be monitored for the ash storage area at the nearby surface water sampling location in accordance with the Class I landfill permit issued by the FDEP. 


\section{Comment 4-10:}

"I believe it is mis-representative to minimize the carbon dioxide emissions of this plant be [sic] comparison to the amount emitted globally. I think a better perspective would be gained in comparison of the carbon dioxide emissions on a per capita basis to the population served. For example from the data provided in the EIS it appears that approximately 5 tons of carbon dioxide is emitted globally per person. Based on the anticipated carbon dioxide emissions of this plant it would represent approximately 400,000 persons. Is it anticipated that produced power would serve at least 400,000 persons?"

\section{Response:}

The analysis in Section 4.1.2.2 of the EIS indicates that the proposed $\mathrm{CO}_{2}$ emissions are very large in terms of amounts released to the atmosphere (when compared with emissions of other gases), while the percentages are very small in comparison with U.S. and global $\mathrm{CO}_{2}$ emissions. A comparison of $\mathrm{CO}_{2}$ emissions on a per capita basis to the population served (Northside Generating Station would serve approximately 157,000 customers after both units are repowered) would be misleading because $\mathrm{CO}_{2}$ emissions in the United States are about five times the global average on a per capita basis and because generation of electricity accounts for only about a third of $\mathrm{CO}_{2}$ emissions from combustion of fossil fuels. However, based on the above comments, an additional evaluation is warranted that compares $\mathrm{CO}_{2}$ emissions to the amount of electricity generated.

As a consequence of the proposed project, $\mathrm{CO}_{2}$ emissions and power production would increase. The ratio of $\mathrm{CO}_{2}$ emissions per $\mathrm{MWh}$ of electricity generated by the repowered units is estimated to be 0.98 tons per $\mathrm{MWh}$ (Table 2.1.1). Assuming that the ratio of $\mathrm{CO}_{2}$ emissions per $\mathrm{MWh}$ of electricity generated from the existing Unit 3 is the same as the ratio for the existing Unit 1 (calculated from Table 2.1.1), the current amount of $\mathrm{CO}_{2}$ emitted per MWh of electricity generated at Northside Generating Station is estimated to be 0.73 tons per MWh. Assuming that there would be no change in the existing capacity factors until the units are repowered and then the capacity factor for the repowered units would be $90 \%$, it is estimated that the amount of $\mathrm{CO}_{2}$ emitted per MWh of electricity generated would increase at Northside Generating Station to a ratio of 0.85 tons per MWh during the transition period after the Unit 2 repowering. The expected ratio would further increase after the Unit 1 repowering to 0.91 tons per MWh. The combined result of the proposed project and the related action would thus be an approximate $25 \%$ increase in the amount of $\mathrm{CO}_{2}$ emitted per MWh generated at Northside Generating Station. This increase would be a result of using coal and petroleum coke in the repowered units whereas natural gas and fuel oil are currently used in the existing units.

This additional evaluation has been included in Section 4.1.2.2 of the EIS. 


\section{Comment 4-11:}

"I [sic] would also seem appropriate to address what if any mitigation could be undertaken to counter this amount of produced carbon dioxide. For example, by DOE and/or JEA acquiring additional credits of wetlands from the mentioned offsite mitigation bank or additional acres of the also mentioned undisturbed, uplands, maritime oak hammock. The amount acquired corresponding [sic] the area required to utilize the additional carbon dioxide emissions."

\section{Response:}

Although mitigating the additional $\mathrm{CO}_{2}$ emissions by acquiring additional land deserves consideration, a huge amount of land would be required to offset (to compensate entirely for) the additional $\mathrm{CO}_{2}$ emissions. Based on Table 4.1.7 of the EIS and a rough estimate of the amount of carbon capable of being sequestered (removed from the atmosphere) in wetlands, it is estimated that 70,000 acres of wetlands would be required to offset the $\mathrm{CO}_{2}$ emissions of the proposed project and 117,500 acres would be required to offset the $\mathrm{CO}_{2}$ emissions of the proposed project in conjunction with the related action (taking credit for the elimination of emissions from the existing Unit 1). In other programs, DOE is studying the potential of mitigation measures, such as enhanced carbon sequestration in the oceans and enhanced carbon sequestration on land, to offset global $\mathrm{CO}_{2}$ emissions but much more research and development are needed to determine the feasibility of these alternatives. 
Final: June 2000

6:

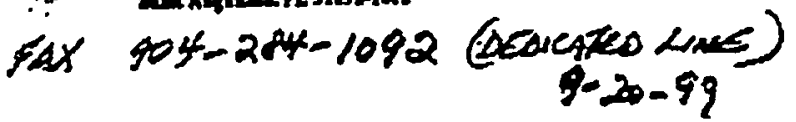

MI. NSA Hosuncruvas FAX 304-285-4403

H.S. DEST of Evenar (reTC)

360 Conur traser Rost

Pro, Bax 880

Letter No. 5

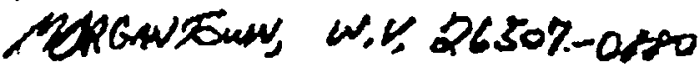

Reproduced from

copy submitted

RE: DEA EN

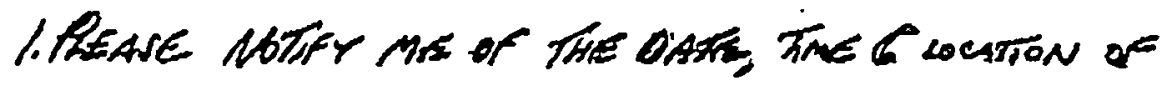
The Canceues 9-16-99 Prowe Hesence AT Feer in TACrsonume - Das To thepresnce Floyo.

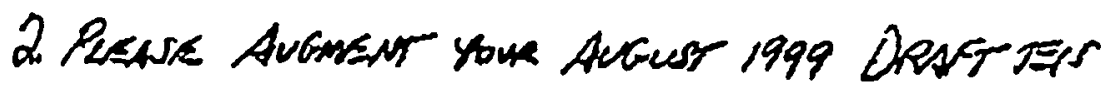

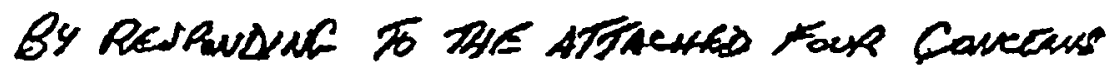
Prepared BY MR. Domend 1. CEAtife or tof Mus

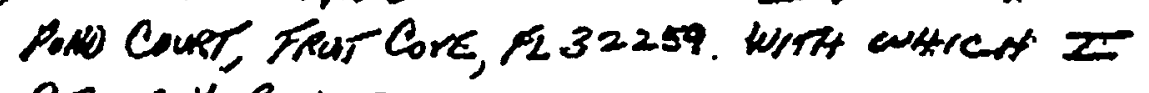
Mroukay Caven.

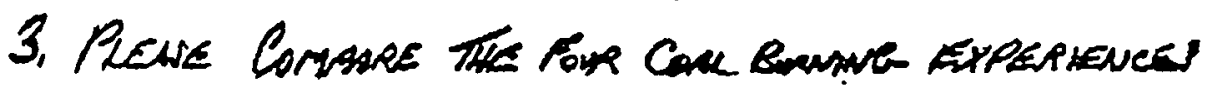

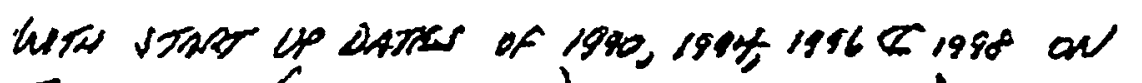

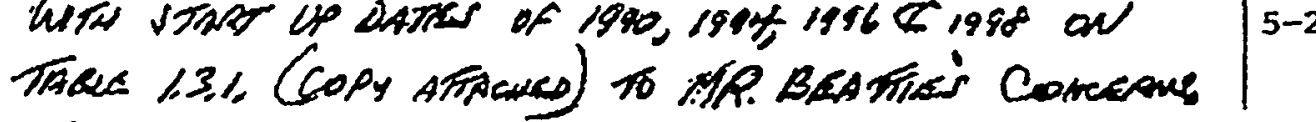

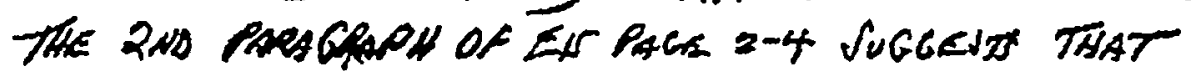

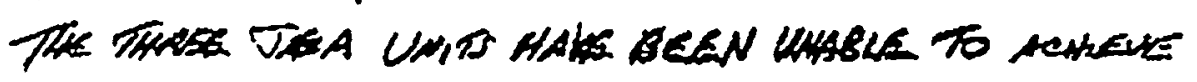

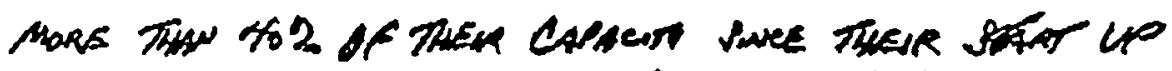

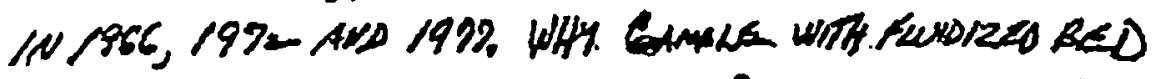

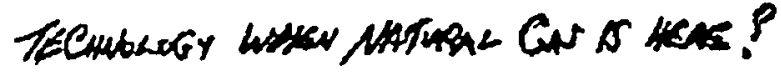

TOM BEA

PAGE, of 4 PAGES

G-61 


\section{PAGE 2 OF H PAGES}

1. Athough the EIS indicates that a number of such power plants are operating or under construction (Table 1.3.1), all smaller than the proposed JEA plant, it does not provide any numbers based on operating experience to back up the claims that this plant will achieve the removal of SO2, NOX, and particulates as advertised. I believe that due diligence requires JEA and other local, state and federal agencies to request and review the operating experience of these other plants and satisty themselves that this technology will offer an improvement over other tectnologies that are available, probably at a lower cost and less risk than a CFB plent.

2. It should be noted that the proposed plant will burn a fuel mixture (Bituminous coal and petroleum coke) different than any of the existing or planned plants using this technology. The ElS does not address the question of the effect, if any, of this fuel mixture on the design and operating characteristics of the plant. Will this introduce new practices that are untested? Does the mixture of these two fuels have to be carefully controlled and monitored to be sure that the limestone mixture in the bed interacts correctly with the fuel? A similar question can be asked concerning the use of the ammonia injected into the exhaust gas to assure that excess emission of ammonia to the atmosphere does not occur. Is there past experience to justify any conclusions on these matters or is it based on bench scale experiments? It the latter, my experience with technologies of this type is that as they are scaled up to large commercial units they encounter a steep learning curve usually requiring a lot of "tinkering" to abtain desired operations. In the worse case, some redesign may be required. If needed, is JEA prepared for a breaking-in period that may result in downtime?

3. The EIS suggests that the bottom ash and fly ash that will be produced can be converted to useful products. I recommend that a careful analysis be made of the real potential of finding customers for the ash products. If they don't exist, or will be difficult to find, then JEA must develop a satistactory plan for disposal of the ash products.

4. The schematic, Fig. 2.1.9, shows chemical waste products discharging to a settling basin(s). It indicates that there would be an emergency overflow to the St. Johns River. What type of emergency would result in such a discharge and what would be the effect on the River? Also, as for all power plants, the cooling water will be discharged into the River at an elevated temperature. The impact of this discharge is discussed on page 4-28 and is stated to be "approximately the same size as when all three units operated at full capacity from 1978 umil 1980". I suggest that thls impact be caretully examined; what may have been acceptable 20 years ago may not be today in view of more recent developments along the River and environmentel concerns for the health of the River. 


\section{PAge 3 or 4 Pages}

Draft: August 1990

Table 1.3.1. Chronobjeal lin of exinting and planned cireninting Huidized bed combutors within and outride the United States with an dectileal

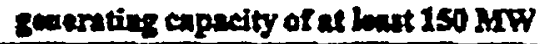

\begin{tabular}{|c|c|c|c|c|c|}
\hline Location & $\begin{array}{l}\text { Unit aix } \\
\text { (MrW) }\end{array}$ & $\begin{array}{l}\text { Number } \\
\text { of units }\end{array}$ & $\begin{array}{l}\text { Toti } \\
\text { chpoity } \\
\text { (MT) }\end{array}$ & Fual & $\begin{array}{c}\text { Sturt-up } \\
\text { dete }\end{array}$ \\
\hline
\end{tabular}

\begin{tabular}{|c|c|c|c|c|c|}
\hline \multicolumn{6}{|c|}{ Uniled Srates } \\
\hline Robation Co., Toxes & 150 & 2 & 300 & Lipnite & 1990 \\
\hline Taunton, Marsachusetts & 150 & 1 & 150 & Conl & 1998 \\
\hline Cumberlend, Mnyland & 210 & $\mathbf{l}$ & 210 & Bituminous coal & 1999 \\
\hline Jteksonville, Floridn & 297.5 & 2 & 595 & $\begin{array}{l}\text { Bituminous coll. } \\
\text { petroleurs colce }\end{array}$ & 2002 \\
\hline
\end{tabular}

\section{Onotide of ine Untied Srater}

\begin{tabular}{|c|c|c|c|c|c|}
\hline Orebro, Sweden & 165 & 1 & 165 & Can & $1990-$ \\
\hline Point Aconi, Cunude & 165 & 1 & 165 & Conl & 1994. \\
\hline Groable, France & 250 & 1 & 250 & Conl. & 1996 \\
\hline Turow, Polind & 235 & 2 & 470 & Brown coll, lignite & 1998 \\
\hline Tonghne, Kocea & 220 & 1 & 220 & Anthrocite & 1998 \\
\hline Toagher, Korea & 220 & 1 & 220 & Antbrucite & 1999 \\
\hline Guyams, Puento Rico & 250 & 2 & 500 & Btuminous conl & 2000 \\
\hline
\end{tabular}

Sonce: Cherles and Reailya 1997.

is co support the demonerstion of innovative, cont-besed tachnology, not for power production or meeting demends for electricity. The costeshured contribution by DOE for the demonstration would belp reduce the risk to the JEA team in dovoloping CFB technology to the level of maturity needed for decisions on commercielizetion.

\subsubsection{DOE's Noed}

Since the earty 1970s, DOE and fts predocassor orgnizutions hrve pursued a broadly based con R\&D propenm for ensuring avaituble and affordable energy mpplies while improving environmental quality. This R\&D program includes long-term activities the support the development of insovative, unproven concepts for a wide variety of coal tecbnologies twrough the proof-of-coscept stage. However, the availability of a rectuology at the proof-of-concept ange is not sufficient to ensure its 


JAGE \& OF HF PAGES

infrastructure would accupy about 75 acres of the property. The CPB combustor would be located inmediutely to the wast of the exirting Unit 3 on a rection of the proparty that currently consists primarily of a covered parking lot for employses (Figure 2.1.3). Piping and related infrastructure Hould be constructed to link tho new CFB combustor with the existing Unit 2 stem turbine.

Northside Generating Station hus operatod since November 1966 when the 297.5-MW Unit 1 came on-line. The 297.5-MW Unit 2 and the 564-MW Unit 3 started operation in Mareh 1972 and June 1977, respectively. Unit 2 has been out of service since 1973 because of mijor boiler problems 2ssociated with the volume of its furnace being inadequate 20 accommodute the beat genterated. The Unit 2 stem turbine is cumently idle and the Unit 2 funnese and tuck have recently been dismantled 2 and removed. Units 1 and 3 currenty operate at a capacity fretor of botween 30 and $40 \%$ because they are mose costly to operate than other unies in th: JEA symem. Northside Generating Stution exploys 265 people, including a pool of 105 operations workers and a pool of 126 maintenunce workers who are stutioned as Northside but are asigned daity racks at other JEA fucilinies in addition to Northside. The remuining 34 workers at Nerthalde are manaers, enginews, and administruors for the JEA system of power plants.

All throe units were devigned with the capability of using both oil and netural gas for fuel. However, all units began operation with infrantructure caphble of using No. 6 . fuel oil only, Units ? and 3 were modified hater so that they can burn both antural pes and oil No. 6 fivei oil or No. 2 fuel oil (diesel)]. Each unit hes multiple burners that are capuble of buming either numal gas or oil alone at any given time; fwel blonding flexibility for each unit is attrined by varying the number of bumers using each fuel. Blending is distated by ecosomis and uir enistion considentrions. Unins 1 and 3 have no air pollution control with the exceptica of low-NO $\mathrm{N}_{z}$ bumers on Unit 3. Oxco-through cooling water is withdrawn from and discherged into the St. Johns River. In addition to Units 1 and 3, 4 diesel-fited S2.5-MW comburtion turbines that opernute to meet peak demund un locted at Northside Genenting Station.

In the raid-1970s, the U.S. Army Corps of Engineess (COE) designed and constructed a 40-ecre dredge spoil ares on Northside Generating Stution property (Figure 3.4.2). The COE has ured this ares to dispose of sediment dredged from the bottom of the back chennel of the St. Johns River (Figure 2.1.2). Periodic dredging to maintein chunnel depth has been conducted at the existing Northside Generating Station fuel oil unlouding dock.

. The adjacent St. Johns River Power Purk (Figure 2.1.2) a power plant which has operated since 1986, is a joint venture between JEA and Floride Powar \& Light JEA and Florida Power \& Light each receive approximately so\% of the eloctricity genonted. The twin 660-MW units uro fueled with coni and petroleum soke, with coul comprising at lent $80 \%$ of the fuel blend. The units were designed to use conl with a $4 \%$ sulfur content, but they currently are using $1 \%$ sulfur conl. Wet limestone scrubbers are used for $\mathrm{SO}_{2}$ control, and electrostatic precipitators are used for particulate control. Curremtly, all of the gypsum (generated by the servbbers) and botrom ash (produced by the combustors) is sold, as is some of the fly ah (exptured by the electrostatic precipitators). The Power 


\section{Letter No. 5}

Thomas H. Beal, 5238 River Park Villa Drive, St. Augustine, Florida 32092

\section{Comment 5-1:}

"Please augment your August 1999 Draft EIS by responding to the attached four concerns prepared by Mr. Donald A. Beattie of 808 Mill Pond Court, Fruit Cove, FL 32259 with which I strongly concur."

\section{Response:}

Mr. Beattie's concerns are communicated in Letter No. 3. See responses to Comments 3-1, 3-2, 3-3, 3-4, and 3-5.

\section{Comment 5-2:}

"Please compare the four coal burning experiences with start up dates of 1990, 1994, 1996 \& 1998 on Table 1.3.1 (copy attached) to Mr. Beattie's concerns."

\section{Response:}

See response to Comment 3-2 for a general discussion of CFB commercial-scale operating experience, including the coal-fired units in Canada and France that are listed in Table 1.3.1 of the EIS.

\section{Comment 5-3:}

"The $2^{\text {nd }}$ paragraph of EIS page 2-4 suggests that the three JEA units have been unable to achieve more that $40 \%$ of their capacity since their start up in 1966,1972 and 1977 . Why gamble with fluidized bed technology when natural gas is here?"

\section{Response:}

Units 1 and 3 at Northside Generating Station currently operate at a capacity factor of only 30 to $40 \%$ because they are more costly to operate than other units in the JEA system. As discussed in Section 1.4.2, JEA performed a detailed analysis of 12 alternatives involving construction and operation of electrical generating facilities and 6 alternatives involving power purchased from other utilities. The alternatives were ranked according to cost, and environmental and land use issues were also considered to ensure that the least-cost plans were socially and environmentally responsible. Based on these considerations, the most favorable plan to meet the future demand 
for electricity was the repowering of Units 1 and 2 at Northside Generating Station. JEA has adopted this plan as their preferred approach to meet demand.

The proposed CFB combustor project was selected by DOE for demonstration in the Clean Coal Technology (CCT) Program as one of the projects that would best further the goals of the program. The primary goal of the CCT Program is to make available to the U.S. energy marketplace a number of advanced, more efficient, economically advantageous, and environmentally responsible technologies for coal utilization. Consequently, technologies using natural gas would not achieve this goal.

Two of the three reasonably foreseeable scenarios evaluated in the EIS under the no-action alternative (in which DOE would not provide cost-shared funding for the proposed CFB combustor project) involve using natural gas without repowering the existing Unit 2 . In the first scenario, JEA would construct and operate a new gas-fired combined cycle facility at Northside Generating Station or at one of their other existing power plants and would continue operating the existing natural gas- and oil-fired Northside units. In the second scenario, JEA would purchase electricity from other utilities to meet JEA's projected demand and would continue operating the existing natural gas- and oil-fired Northside units. Table 2.3.1 presents a comparison of potential impacts between the proposed project and the scenarios under the noaction alternative. 
DIVSIONS OF FLORIDA DEPARTMENT OF STATE

Office of the Secretasy

Ofice of Intemubionl Relitions

Division of Elections

Drvision ol Comportions

Division o Culnur] A Atsirs

Division of Histrical Resourres

Division ol Librisy and Intoration Servios

Division of lioensing

Division of Administrative Serricos

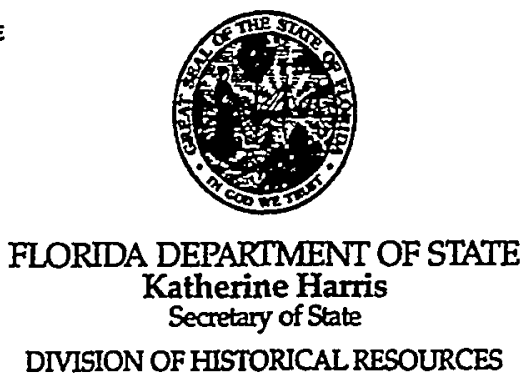

DIVISION OF HISTORICAL RESOURCES
MENBER OF THE FLORDA CABINET

Stak Bourd of Eduation

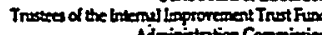

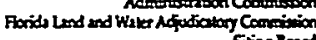

Drvition of Band Finenter Depertant of Reranes Departinent of Law Enforemet

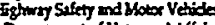

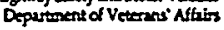

September 30, 1999

Ms. Lisa K. Hollingsworth

U.S. Department of Energy

Federal Energy Technology Center

P.O. Box 880

Morgantown, West Virginia 26507-0880

RE: DHR Project File No. 996239

Cultural Resource Assessment Request

Draft Environmental Impact Statement (DEIS) for the

JEA Circulating Fluidized Bed Combustor Project

Jacksonville, Durval County, Florida

Letter No. 6

Reproduced frow

copy submitted

Dear Ms. Hollingsworth:

In accordance with the procedures contained in 36 C.F.R., Part 800 "Protection of Historic Properties"), we have reviewed the referenced projects for possible impact to historic properties listed, or eligible for listing, in the National Regisier of Historic Places. The authority for this procedure is the National Historic Preservation Act of 1966 (Public Law 89-665), as amended.

We have reviewed the referenced draft environmental impact statement. We specifically reviewed sections 3.7 and 4.1 .8 , both dealing with Cultural Resources. We note that the project will have a cultural resource survey performed. The resultant survey report shall conform to the specifications set forth in Chapter 1A-46, Florida Administrative Code, and will need to be forwarded to this agency in order to complete the process of reviewing the impact of this proposed project on historic properties. Therefore, conditioned upon the JEA undertaking a cultural resource survey, and appropriately avoiding, minimizing, or mitigating project impacts to any identified significant archaeological or historic sites, the proposed project will have no effect on historic properties listed, or eligible for listing, in the National Register, or otherwise of historical or architectural value

If you have any questions concerning our comments, please contact Scott Edwards, Historic Preservation Planner, at 850-487-2333 or 800-847-7278. Your interest in protecting Florida's historic properties is appreciated.

Sincerely,

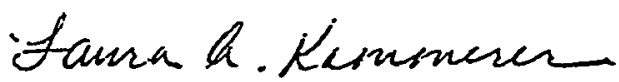

4h Janet Synder Matthews

State Historic Preservation Officer

JSM/Ese

RA. Gray Building - 500 South Bronough Street - Tallahassee, Flysta 32399-0250 - http://www. Aheritagecom
a Director's Office
a Archzeologieal Research
(850) 488-1450 - FAX: 488-3355 (850) 487.2099-FAX:414-2207
Historic Pensicola Preseniation Board
C Palm Beach Revional Office (561) 279.1475 - FAX:279.1476 (1) Historic Preservation
(850) $487-2333$ - FAX:922-0496 Historical Museums
(850) 488-1484 - FAX: $921-2500$
O St Aurustine Regional Office
- Tampa Regional Office (9)A) 5250045 - FAX $825-5044$ (813) $272-3843$ - FAX: 272-2340 


\section{JEA EIS}

Letter No. 6

Janet Snyder Matthews, State Historic Preservation Officer, Florida Department of State, Division of Historic Resources, 500 South Bronough Street, Tallahassee, Florida 32399-0250

\section{Comment 6-1:}

"We note that the project will have a cultural resource survey performed. The resultant survey report shall conform to the specifications set forth in Chapter 1A-46, Florida Administrative Code, and will need to be forwarded to this agency in order to complete the process of reviewing the impact of this proposed project on historic properties."

\section{Response:}

A cultural resources assessment survey of the proposed project site and a follow-up Phase II investigation were performed. Reports documenting their findings (Florida Archeological Services 1999a,b) that conformed to the specifications set forth in Chapter 1A-46, Florida Administrative Code, were sent to the State Historic Preservation Officer. In response, letters from the State Historic Preservation Officer dated July 28, 1999, and August 3, 1999 (Appendix B), describe the reports as complete and sufficient. The letters state that the proposed project would have no effect on culturally valuable sites if the potentially significant sites identified in the reports are avoided by any development activities. Because all potentially significant sites found on the JEA property are located outside the areas that would be disturbed by the proposed project, no adverse effect on culturally significant sites would be anticipated as a result of the proposed project. Sections 3.7 and 4.1 .8 of the EIS have been revised to include the findings of these studies. 


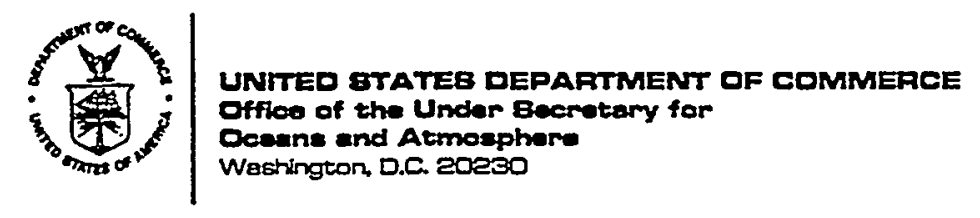

October 5, 1999

Ms. Lisa K. Hollingsworth

NEPA Document Manager

U.S. Department of Energy

Federal Energy Technology Center

3620 Collins Ferry Road

Morgantown, WV 26507-0880

Dear Ms. Hollingsworth:

Enclosed are comments on the Draft Environmental Impact statement for JEA Circulating Fluidized Bed Combustor Project Jacksonville, Florida. We hope our comments can assist you. Thank you for giving us an opportunity to review this document.

sincerely,

sucfo Tuchter

Susan B. Fruchter

Acting NEPA Coordinator

Enclosure 


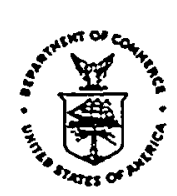

UNITED STATES DEPARTMENT DF COMMERCE

National Deaenic and Atmospheric Administration

NATIONAL MARINE FISHERIES SERVICE

Southeast Regional Office

9721 Executive Center Drive N.

St. Petersburg, Florida 33702

(727) 570-5317, FAX 570-5300

September 30, 1999 F/SER4:AM:rr

Ms. Lisa K. Hollingsworth

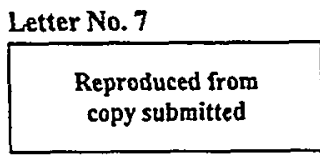

National Environmental Policy Act Document Manager

U.S. Department of Energy, Federal Energy Technology Center

3610 Collins Ferry Road

Morgantown, West Virginia 26507-0880

Dear Ms. Hollingsworth:

The National Marine Fisheries Service (NMFS) has reviewed the Draft Environmental Impact Statement (DEIS) for the JEA (formerly the Jacksonville Electric Authority) Circulating Fluidized Bed Combustor Project, in Jacksonville, Florida. The proposed project involves the Department of Energy providing cost-shared funding for the demonstration of circulating fluidized bed combustion technology at JEA's existing Northside Generating Station in Jacksonville, Florida.

Information contained in the DEIS indicates that the project area includes estuarine emergent wetlands. However, the NMFS cannot determine from the information contained in the DEIS regarding project construction and related mitigation whether there will be a net overall adverse affect to wetlands that support fishery resources of concern to the NMFS. Accordingly, we believe this is an opportune time to advise you of consultation requirements resulting from new legislation. In 1996, to further the conservation of marine fishery resources, Congress amended the MagnusonStevens Fishery Conservation and Management Act (Magnuson-Stevens Act). The amendment requires establishment of guidelines for the identification of Essential Fish Habitat (EFH) and the inclusion of EFH descriptions in fishery management plans. The Magnuson-Stevens Act also requires all Federal agencies to consult with the NMFS on measures to protect EFH when an agency proposes to authorize, fund, or undertake an activity which would adversely affect designated habitats.

The estuarine emergent wetlands in the project area have been identified as EFH. Accordingly, consultation is required pursuant to interagency coordination procedures specified by the NMFS in the 1997 Interim Final Rules to implement the EFH provisions of the Magnuson-Stevens Act (50 CFR Sections $600.805-600.930$ ) if the Federal action agency determines that their activity may adversely affect EFH. The DEIS would be an appropriate place to document the results of this determination and any subsequent consultation, if required. 
The amendments to the South Atlantic and Mid-Atlantic Fishery Management Plans, which identify EFH within the project area, have been approved by the Secretary of Commerce. With those approvals, the Department of Energy, and many other Federal agencies, became subject to the consultation requirements of the Magnuson-Stevens Act. To familiarize you and your staff with your consultation responsibilities, we are enclosing a document, prepared by the Southeast Region of the NMFS, entitled: Essential Fish Habitat: New Marine Fish Habitat Conservation Mandate for Federal Agencies. It provides background information, outlines consultation procedures, identifies $\mathrm{EFH}$ and managed fisheries, and references other data sources.

If you wish to discuss the attached document or have questions on consultation requirements or procedures, please call Mr. Rickey Ruebsamen of my staff at 727/570-5317.

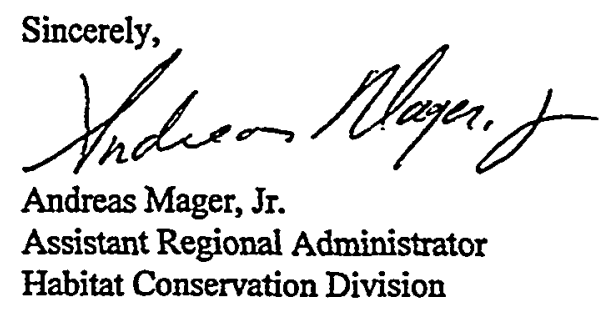

Enclosure 


\section{Essential Fish Habitat:}

New Marine Fish Habitat Conservation Mandate for Federal Agencies

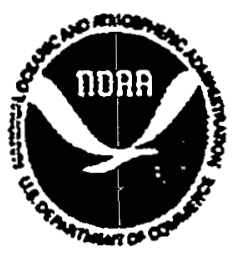

National Marine Fisheries Service Habitat Conservation Division

Southeast Regional Office

9721 Executive Center Drive North

St Petersburg, FL 33702

727/570-5317

February 1999

(revised 7/99) 


\section{Executive Summary}

The 1996 amendments to the Magnuson-Stevens Fishery Conservation and Management Act (MSFCMA) set forth a new mandate for the National Marine Fisheries Service (MMIFS), regional fishery management councils (FMC), and other Federal agencies to identify and protect important marine and anadromous fish habitat. The EFH provisions of the MSFCMA support one of the Nation's overall marine resource management goals maintaining sustainable fisheries. Essential to achieving this goal is the maintenance of suitable marine fishery habitat quality and quantity. The FMCs, with assistance from NMFS, have delineated "essential fish habitat" (EFH) for managed species. As new FMPs are developed, EFH for newly managed species rill be defined as well. Federal action agencies which fund, pernit, or carny out activities that may adversely impact EFH are required to consult with NMFS regarding the potential effects of their actions on EFH, and respond in writing to NMFS or FMC recommendations. In addition, NMFS and the FMCs may comment on and make recommendations to any state agency on their sctivities which may effect EFH.

On December 19, 1997, interim final nules were published in the Federal Register (Vol. 62, No. 244) which specify procedures for implementation of the EFH provisions of the MSFCMA. These rules address, in detail, the coordination, consultation, and recommendation requirements of the MSFCMA. Measures recommended by NMFS or an FMC to protect EFH are advisory, not proseriptive.

Within the area encompassed by the NMFS Southeast Region, EFH has been identified for hundreds of marine species covered by 20 fishery management plans (FMPs), under the auspices of the Gulf of Mevico, South Atlantic, or Caribbean FMC or the NMFS. Generic FMP amendments delineating EFH for species managed by the three FMCs were completed in early 2999.

Wherever possible, NMFS intends to use existing interagency coordination processes to fulfill EFH consultations for Federal ageney actions that may adversely affect EFH. Provided certain specifications are met, EFH consulations will be incorporated into interagency procedures established under the National Environmental Policy Act, Endangered Species Act, Clean Water Act, Fish and Wildlife Coordination Act, or other applicable statutes. If existing processes cannot adequately address EFH consultation requirements, appropriate new procedures should be developed in cooperation with the NMFS. Programmatic consultations may be implemented or General Concurrences may be developed when program or project impacts are individually and cumulatively minimal in mature. Moreover, NMFS will work closely with Federal agencies on programs requiring either expanded or abbreviated individual project consultations. An effective, interagency EFH consultation process is vital to ensuring that Federal actions are consistent with the MSFCMA resource management goals. 


\section{Essential Fish Habitat: \\ New Marine Fish Habitat Conservation Mandate for Federal Agencies}

\section{Introduction}

This document has been prepared by the Southeast Regional Office of the National Marine Fisheries Service (NMIFS) to provide an overview of the Essential Fish Habitat (EFH) provisions of the Magnuson-Stevens Fishery Conservation and Management Act (MSFCMA) and implementing rules. This primer provides a brief legislative and regulatory background, introduces the concept of EFH, and describes consultation requirements. Consistent with elements of the NMFS's National Habitat Plan, Strategic Plan, and Habitat Conservation Policy, this document is intended to: provide a mechanism for information exchange; foster interagency discussion and problem-solving; and enhance communication and coordination among the NMFS, regional fishery management councils (FMC), and affected state and Federal agencies. Ulimately, improved interagency coordination and consultation will enhance the ability of the agencies to sustain healthy and productive marine fishery habitats.

\section{Legislative and Regulatory Background}

The 1996 amendments to the MSFCMA (excerpied at Appendix 1) set forth a new mandate to identify and protect important marine and anadromous fisheries habitat. The FMCs, with assistance from NMFS, are required to delineate EFH in fishery management plans (FMP) or FMP amendments for all Federally managed fisheries. Federal action agencies which fund, permit, or carry out activities that may adversely impact EFH are required to consult with NMFS regarding potential adverse effects of their actions on EFH, and respond in writing to NMIFS and FMC recommendations. In addition, NMFS is directed to comment on any state agency activities that would impact EFH.

The purpose of addressing habitat in this act is to further one of the Nation's important marine resource management goals - maintaining oustainable fisheries. Achieving this goal requires the long-term maintenance of suitable marine fishery habitat quality and quantity. Measures recommended to protect EFH by NMFS or a FMC are advisory, not proseriptive. An effective EFH consultation process is vital to ensuring that Federal actions are consistent with the MSFCMA resource management goals.

Guidance and procedures for implementation of the 1996 amendments of the MSFCMA were provided through interim final rules established by the NMIFS in 1997 (50 CFR Sections 600.805 - 600.930). These rules specify that FMP amendments be prepared to deseribe and identify EFH and identify appropriate actions to conserve and enhance those habitats. In addition, the rules establish procedures to promote the protection of EFH through interagency coordination and consultation on proposed Federal and state actions.

\section{EFH Designation}

The MSFCMA requires that EFH be identified for all fisheries which are Federally managed. This includes species managed by the FMCs under Federal FMPs, as well as those managed by the NMFS under FMPs developed by the Secretary of Commerce. Applicable FMP authorities, along with some of the species covered by those FMPs, are listed in Appendices 2 - 5 for the major ecoregions of the NMFS Southeast Region. Species listed are those for which data were adequate to define and map EFH. The listed species under each FMC's authorities collectively occur throughout the areas managed by the respective FMCs, therefore, inclusion of species for which life history data are limited would not encompass a greater geographic area. Note that Appendix 3 lists species managed by the South Atlantic FMC, as well as some species managed by the Mid Atlantic FMC for which EFH has been identified to extend into the South Adlantic area. 
EFH is defined in the MSFCMA as“...those waters and substrate necessary to fish for sparning. breding. feding. or growth to maturity." The rules promulgated by the NMFS in 1997 further clarify EFH with the following definitions: waters - aquatic areas and their associated physial, chemical. and biological properies that are used by fish and may include aquatic areas historieally used by fish where appropriate; substrate - sediment. hard bottom, structures underlying the waters, and associated biological communities; pecessary - the habitat required to support a sustainable fishery and the managed species' contribution to a healthy ecosystem; and spanining, breeding, feeding, or gropth to maturity - stages representing a species' full life cycle. EFH may be a subset of all areas occipied by a species. Acknowledging that the amount of information available.for EFH determinations will vary for each species, the rules direct the FMCs to use the best information available, and to be increasingly specific and narrow in their delineations as more refined information becomes available.

The areas designated as EFH by the Gulf of Mexico, South Allantic, and Caribbean FMCs are generalized in Appendix 6. Additional sources of information, useful for preparing EFH assessments, and to further one's understanding of EFH designations and Federally managed fishery resources are available through the NMFS and FMCs. Appendix 8 provides citations for published Fishery Management Plan amendments and identifies reb sites containing information on the MSFCMA, the NMFS interim final mes for the implementation of EFH designation and consultation provisions, and data on specific managed fisheries and associated habitats. NMFS and FMC points of contact are identified in Appendix 9.

The rules also direet FMCs to consider a second, more limited habitat designation for each species in addition to EFH. Habitat Areas of Particular Concern (HAPCs) are described in the nules as subsets of ErF which are rare, particularly susceptible to human-induced degradation, especially ecologically important, or located in an environmentally stressed area. In general, HAPC include high value intertidal and estuarine habitats, offshore areas of high habitat value or vertical relief, and habitats used for migration, spawning, and rearing of fish and shellfish. Areas identified by each of the thre southeastern Fishery Management Councilsas HAPC are presented in Appendix 7. For a complete description of designated HAPCs the reader should reference the appropriate FMP amendment. HAPCs are not afforded any additional regulatory protection under the MSFCMA; however, Federal actions with potential adverse impacts to HAPC $s$ will be more carefully serutinized during the consulation process and will be subject to more stringent EFH conservation recommendations.

Designating the boundaries of EFH has taken careful and deliberate consideration by the FMCs. The effort to identify and delineate EFH in the various fishery management plans was a rigorous process that involved numerous state and Federal agencies and the public at large. The Gulf of Mexico, South Atlantic, and Caribbean FMCs have produced a generic management plan amendment to designate EFH for all fisheries managed by each FMC. For general planning purposes, Figures 1 - 3 depict boundaries as a consolidation of all identified EFH within the Southeast Region of the NMIFS. Reference should be made to each of the FMP amendments for a species-specific descriptions of EFH

Besides delineating EFH, the FMIP amendments produced by each of the three councils identify and describe potential threats to EFH, which includes threats from development, fishing, or any other sources. Also identified are recommend EFH conservation and enhancement measures. FMCs are required to implement management measures to minimize, to the extent practicable, any atverse impacts to EFH coused by fishing gear. Guidelines used in the development of EFH amendment sections for each of these issues are included in the EFH rules.

\section{EFH Consultations}

In the regulatory context, the most important provisions of the MSFCMA for conserving fish habitat are those which require Federal agencies to consult with NMFS when any sectivity proposed to be permitted, funded, or undertaken by a Federal .agency may have atverse impacts on designated EFH. The consultation requirements in the MSFCMA direct Federal agencies to consult with NMFS when any of their activities may have an actverse effect on EFH. The EFH rules define an adverse effect as "any impact which reduces quality and/or quanlity of EFH...[and] may include direct (e.g., contamination or physical disnuption), indirest (e.g., loss of prey, reduction in species' fecundity), site-specific or habitat wide impacts, including individual, cumulative, or synergistic consequences of actions." 
The consultation provisions have raised some concernamong Federal action agencies regarding potential increases in workload and the regulatory burden on the public. NMFS has addressed these concerns in the EFH nules by emphasizing the use of existing environmental review processes and time frames. Provided the specifications outlined in the rules are met, EFH consultations will be incorporated into interagency procedures previously established under the National Environmental Policy Act, Endangered Species Act, Clean Water Act, Fish and Wildlife Coordination Act, or other applicable statutes.

To incorporate EFH consultations into coordination, consultation and/or environmental review' procedures required by other statutes, three criteria must be met:

(1) The existing process must provide NMFS with timely notifieation of the action;

(2) Notification of the action must include an "EFH Assessment" of the impacts of the proposed action as outlined in the EFH rules;

(3) NMFS must have completed a written finding that the existing process satisfies the requirements of the MSFCMA.

An "EFH Assessment" is a review of the proposed project and its potential impacts to EFH. As set forth in the rules, EFH Assessments must include: (1) a description of the proposed action; (2) an analysis of the effects, including cumulative effects, of the action on EFH, the managed species, and associated species by life history stage; (3) the Federal agency's views regarding the effects of the action on EFH; and (4) proposed mitigation, if applicable. If appropriate, the assessment should also include the results of an on-site inspection, the views of recognized experts on the habitat or species affects, a literature review, an analysis of alternatives to the proposed action, and any other relevant information.

Once NMFS learns of a Federal or state activity that may have an adverse effect on EFH, NMFS is required to develop EFH conservation recommendations for the activity. These recommendations may include measures to avoid minimize, mitigate, or otherwise offset aciverse effects on EFH and are to be provided to the action agency in a timely manner. The MSFCMA also authorizes FMCs to comment on Federal and state projects, and directs FMCs to comment on any project which may substantially impact EFI. Federal agencies are required to respond 10 EFH conservation recommendations of the NMFS and FMCs in writing and within 30 days.

Consultations may be conducted through programmatic, general concurrence, or project specific mechanisms. Evaluation at a programmatic ievel may be appropriate when sufficient information is available to develop ErH conservation recommendations and address all reasonably foreseeable adverse impacts under a particular program area. General Concurrences ean be utilized for categories of similar activities having minimal individual and cumulative impacts. Programmatic and General Concurrence consultations minimize the need for individual project consultation in most cases because NMFS has determined that the actions will likely result in no more than minimal adverse effects, and conservation measures would be implemented. For example, NMFS might grant a General Concurrence for the construction of docks or piers which, with incorporation of design or siting constraints, would minimally affect Federally managed fishery resources or their habitats.

Consultations at a project-specific level are required when critical decisionsare madeat the project implementation stage, or when sufficiently detailed information for development of EFH conservation recommendations does not exist at the programmatic level. Project specific consultations must follow cither the abbreviated or expanded procedures. Abbreviated consultations allow NMFS to quickly determine whether, and to what degree, a Federal action may adversely impact EFH, and should be used when impacts to EFH are expected to be minos. For example, the abbreviated consultation procedure would be used when the adverse effect of an action or proposed action could be alleviated through minor design os operational modifications, or the inclusion of measures to offset unavoidable adverse impacts.

Expanded consultations allow NMFS and a Federal action agency the maximum opportunity to work together in the review of an activity's impact on EFH and the development of EFH conservation recommendations. Expanded 
consultation procedures must be used for Federal actions that would result in substantial adverse effects to EFH. Federal action agencies are encouraged to contact NMIFS at the earliest opportunity to diseuss whether the adverse effect of a proposed action makes expanded consultation appropriate. Expanded consultation procedures provide additional time for the development of conservation recommendations, and may be appropiriate for actions such as the construction of large marinas of port facilities.

The MSFCMA mandates that a Federal action agency must respond in uriting to ErH conservation recommendations from NMFS and FMCs rithin 30 days of receiving those recommendations. The rules require that such a response be provided at least 10 days prior to final approval of the action, if a decision by the Federal agency is required in fewer than 30 days. The response must include a description of measures proposed by the agency for avoiding, mitigating, or offsetting the impact of the activity on EFH. In the case of a response that is inconsistent with NMIF conservation recommendations, the agency mustexplain its reasons for not following the recommendations, including the scientific rationale for any disagreements with NMFS over the anticipated effects of the proposed action and the measures needed to offset such effects. When an agency decision is inconsistent with NMFS conservation recommendations, the NMFS Assistant Administrator may request a miecting with the head of the agency to further discuss the project.

\section{Conclusion}

The EFH mandates of the MSFCMA represent a new effort to integrate fishery management and habitat management by stressing the dependency of heal thy, productive fisheries on the maintenance of viable and diverse estuarine and marine ecosystems. The EFH consultation process will ensure that Federal agencies explicitly consider the effects of their actions on important habitats, with the goal of supporing the sustainable management of marine fisheries. The NMFS is commitred to working with Federal and state agencies to implement these mandates effectively and efficiently, with the ultimate goal of sustaining of the Nation's fishery resources.

Comments, questions, and suggested revisions may be directed to Rickey Ruebsamen (EFH Coordinator), 9721 Executive Center Drive, N. St. Petersburg, FL 33702; phone: 727/570-5317; email: ric.nuebsamen@noaz.gov. 
Appendix 1. Selected Tert from the Magauson-Stevens Fishery Conservation and Management Act (As Amended Through October 11, 1996)

16 U.S.C. 1854 note, 1855

M-S Act $\$ \$ 304$ note, $\$ 305$

SEC. 305. OTHER REQUIREMENTS AND AUTHORTYY

16 U.S.C. 1855 104-297

(b) FISH HABITAT.

(1) (A) The Secretary shall, within 6 months of the date of enactment of the Sustainable Fisheries Act, establish by regulation guidelines to assis the Councils in the description and identification of essential fish habitat in fishery management plans (including adverse impacts on steh habitat) and in the consideration of actions to ensure the conservation and entancement of such habitat. The Secretary shall set forth a schedule for the amendment of fishery management plans to include the identification of essential fish habitat and for the review and updating of such identifications based on new scientific evidence or other relevant information.

(B) The Secretary, in consultation rith participants in the fishery, shall provide each Council with recommendations and information regarding each fishery under that Council's authority to assist it in the identification of essential fish habitat, the adverse impacts on that habitat, and the actions that should be considered to ensure the conservation and enhancement of that habitat.

(C) The Secretary shall review programs administered by the Department of Commerce and ensure that any relevant programs further the conservation and enhancement of escential fish habitat.

(D) The Secretary shall coordinate with.and provide information to other Federal agencies to further the conservation and enhancement of essential fish habitat.

(2) Each Federal agency shall consult with the Secretary with respect to any action authorized, funded, or undertaken, or proposed to be authorized, funded, or undertaken, by such agency that may adversely affect any essential fish habitat identified under this Act.

(3) Each Council-

(A) may comment on and make recommendations to the Secretary and any Federal or State agency concerning any activity authorized, funded, or undertaken, or proposed to be authorized, funded, or underlaken, by any Federal or State agency that, in the view of the Council, may affect the habitat, including essential fish habitat, of a fishery resource under its authority, and

(B) shall comment on and make recommendations to the Secretary and any Federal or State agency concerning any such activity that, in the view of the Council, is likely to substantially affect the habitat, ineluding essential fish habitat, of an anadromous fishery resource under its authority.

(4) (A) If the Secretary receives information from a Council or Federal or State agency or determines from other sources that an action authorized, funded, or undertaken, or proposed to be authorized, funded, or undertaken, by any State or Federal agency would adversely affect any essential fish habitat identified under this Act, the Secretary shall recommend to such agency measures that can be taken by such agency to conserve such habilat.

(B) Within 30 days after receiving a recommendation under subparagraph (A), a Federal agency shall provide a detailed response in writing to any Council commenting undes paragraph (3) and the Secretary regarding the matter. The response shall include a description of measures proposed by the agency for avoiding, mitigating, or offsetting the impact of the activity on such habitat. In the case of a response that is inconsistent with the recommendations of the Secretary, the Federal agency shall explain its reasons for not following the recommendations. 
Appendix 2. Fishery Management Plans and Managed Species for the Gulf of Mexico.

\section{GULF OF MEXICQ FISHERY MANAGEMENT COUNCIL}

Shrimp Fishery Management Plan brown shrimp - Penaens aztecus pink shrimp - $P$. duorarum royal red shrimp - Pleoticus robustus white shrimp - Penaeus setiferus

Red Drum Fishery Management Plan red drum - Sciaenops ocellarus

Reef Fish Fishery Management Plan bluck grouper-Mycieroperca banaci Bag grouper-M. microlepis gray srapper - Lutjanus griseus gray triggefish - Belistes capriscus greater amberjack - Seriola dumerili lane snapper $-L$ synagris lesser amberjack -S. fasciata Ied grouper - Epinephelus morio red snepper - L compechanus scamp grouper $-M$, phentax tilefish - Lopholatilus chamoeleonticeps yellowtail mapper - Ocyurus chinssurus vermilion snspper - Rhomboplites aurorubens
Stone Crab Fishery Management Plan stone crab-Menippe spp.

Sp̣iny Lobster Fishery Management Plan spiny lobster - Panulines argus

Coral and Coral'Reef Fishery Management Plan

varied coral species and coral reer communities comprised of several hundred species

Coastal Migratory Pelagic Fishery Management Plan

bluefish - Panatomus saltatrix dolphin - Coryphoeno hippunus cobia - Rachycentron cansadum king msckerel - Scambenamorus conallo little tunny - Euthynus alleteratus Spanish mackerel -S. maculorus 
Appendix 3. Fishery Management Plans and Managed Species for the South Atlantic Region.

\section{SOUTH ATLANTIC FISHERY MANAGEMENT COUNCIL}

Shrimp Fishery Management Plan brown shrimp - Penaeus eztecks pink shrimp-P. duoraram rock shrimp - Sigrania brevirastris royal red sirimp - Pleoticus robustus white shrimp - Peraens setifenes

Red Drum Fishery Management Plan red drum - Scirenops acellatus

Snapper Grouper Fishery Management Plan blockfin snapper - Lutjanus buccanella blueline tilefish - Coulolatilus microps gray snapper - L griseus greater amberjack - Seriola dumerili jewfish -Epinephelus itojaro mutton snapper $-L$ analis Ied porgy - Pagniss pagrus red snipper - L campechanus scamp - hyoteroperea phenex sill srepper $-L$ vivamus sowy grouper $-E$, niveatus speckled hind - E drummondricost vermilion scapper - Rhomboplites auroribens yellowedge grouper $-E$. flavalimbatus warsaw grouper $-E$ nigritus white grunt - Heemulon plemient wrecicfish - Palyprion americonsus
Coastal Migratory Pelagies Fishery

Management Plan

dolphin - Cosyphaesa hippures cobis - Rachycentron canadum king mackerel - Scomberomonus conallo Spanish mackerel -S. mocularus

Golden Crab Fishery Management Plan golden crab - Chaceon fenneri

Spiny Lobster Fishery Management Plan spiny Lobster - Panulinus argus

Coral and Coral Reef Fishery Management Plan

varied coral species and coral reef communities comprised of several hundred species

Calico Scallop Fishery Management Plan calico scallop - Argopecten gibbus

Sargassum Habitat Fishery Management Plan Sargassum (and associated fauns) where it coevers in the EEZ and state waters

\section{MID-ATLANTIC FISHERY MANAGEMENT COUNCIL}

Summer Flounder, Scup, and Black Sea Bass Fishery Management Plan

Black sea bass - Centropristus striata Scup - Stenotanus chrysops Summer flounder-Paralichthys dertatus

Bluefish Fishery Management Plan Bluefish - Pomatomus salcarnix

Atlantic Surfelam and Ocean Quahog Fishery Management Plan

Ocean quahog - Artica islandica

Surfelam - Spisula solidissima
Atlantic Mackerel, Squid, and Butterfish Fishery Management Plan Atlentic butterfish - Peprilus triaconthus Allantic mackerel - Scamber scombrus Loog linned squidf - Loligo peoles Short finned squid - Illex illecebrarus

Dogfish Fishery Management Plan Spiny dogfish - Squalus acanthios 
Appendix 4. Fishery Management Plans and Managed Species for the Caribbean Region.

\section{CARIBBEAN FISHERY MANAGEMENT COUNCIL}

Reef Fish Fishery Management Plan banded butterflytish - Chaetodon striatus coney - Epinephelus fulves gray snspper - Lutjonus griseus queen triggerfish - Balistes vetulo mutton snspper $-L$ analis nassau grouper $-E$ striatus red hind $-E$ guttotus redtail partotish - Sparisama chrysopterum schoolmaster - L apodus silk mapper- $L$ vivanus squirrelfish - Holocentrus ascensionis sand tile fish-Malacanthus plumieri trunkfish - Lactophrys quadricomis yellowtail saupper - Ocyures chnysures white grunt - Haemulon plumieri
Spiny Lobster Fishery Management Plan spiny lobstex - Panulinus argus

Queen Conch Fishery Management Plan queen conch - Strambus gigas

Coral Fishery Management Plan varied coral species and coral reef communities comprised of several hundred species 
Appendix 5. Species Managed under the Federally-Implemented Fishery Management Plans.

\section{NATIONAL MARINE FISHERIES SERVICE}

Billfish

blue maslin - Makaira nigriocons longbill spearish - Temopturus pfluegeri sailfish - Istiophorus platypterus white marlin $-T$. albidus

Swordfish

swordfish - Xiphias gladius

Tuna

albacose - Thunnus alalungo

Atlantic bigeye $-T$. obesus

Allantic yellowin $-T$. albacares

skipjack - Kotsuwanus pelannis

Sharks

western Allantic bluefin - T. thynows

Atlantic angel shark - Squatine dumeril Atlantic sharpoose shark - Rhizoprionodon zerroenovae

basking shark - Cetorhinus maxinus bigeye sand tiger - Odontaspis naranhai bigeye sixgill shark - Hexanchus vitulus bigeye thresher shark - Alopies superciliosus bigrose shark - Carchartinus altimus blacknose shark - C. acranotus blacktip shark - C. limbotus blue shark - Prionace gloweo bonnethead - Sphyma tiburo bull shark - C. leuces
Caribbean reef shark - C. percai

Caribbean sharppose shark - $R$ porases common thresher shark $-A$. vulpinus dusky shark - C. obscunus

finetooth shark - C. iscodon

Gelapagos shark - C. golopogensis great hammerhead -S. moliarran lemon shark - Negaprion brevirastris longfin mako shark - Isurus paucus nstrowtooth shark - C. brachurerus night shark - $C$. signanus

nurse shark - Ginglymortama cirnatum oceanic whitetip shark - C. longimenus porbesgle shark - Lamna nasus sandbar shark - $C$. plumbers sand tiger shark - O. zaurus scalloped hammerhead -S. lewini sharpsose sevengill shark - Heptranchios perio

shortfin mako sharik - 1. axyrinchus silky shark - C. falcifomis sixgill shark - H. griseus smalltail shark - C. porosus smooth hammerthead - S. zygona spinner shark - C. brevipinna Tiger shark - Galeocerdo cuvien whale shark - Rhinocodon typus white shark - Cancharadon carcharias 
Appendix 6. Essential Fish Habitat Identified in Fishery Manggement Plan Amendments of the Gulf of Mexico, South Atlantic and Caribbean Fishery Mansgement Councils. (EFH for species managed under the NMFS Billish and Highly Migratory Species plans falls within the marine aress designated by three courcils)

\begin{tabular}{|c|c|c|}
\hline \multirow{4}{*}{$\begin{array}{l}\text { Gulf of Mexico FMC } \\
\text { Estuarine areas } \\
\text { Estuarine emergent } \\
\text { wetlands }\end{array}$} & \multirow{3}{*}{$\begin{array}{l}\text { South Aliantic FMC } \\
\text { Estuarixe areas } \\
\text { Estuarins energent } \\
\text { wethands }\end{array}$} & Caribbean FMC \\
\hline & & Estuarine areas \\
\hline & & Salt marshes \\
\hline & & Mangrove wetlands \\
\hline Mangrove wetlands & Estusrine scrub/shrub & \\
\hline Seagrass & mangroves & $\begin{array}{l}\text { Intertidal flats/salt } \\
\text { ponds }\end{array}$ \\
\hline & Seagrass & \\
\hline Algal nats & & Soft bottom lagoons \\
\hline & Oyster reefis \& shell & \\
\hline Mud, sand, shell, and & banks & Mud Dats \\
\hline & Intertidal fats & Sandy beaches \\
\hline Estuarine water column & & \\
\hline Marine areas & Palustrine entergent \& & Rocky shores \\
\hline Water column & & Marine areas \\
\hline & Aquatic beds & Water column \\
\hline Vegetated bottoms & & \\
\hline & Esturarine water column & Seagrass \\
\hline Nan-vegelated bottoms & Mrsine resess & Nom-reoctated bottoms \\
\hline Live bottoms & Live/tiard bottoms & Noit-Vegclated Dotdotas \\
\hline Coml mefe & Coml a mol nof & Coral rets \\
\hline 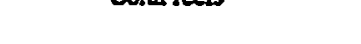 & 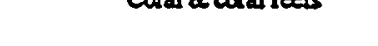 & Algal plains \\
\hline Artificial reefs & Artificial/manmade & \\
\hline Geolopic features & reefs & Geologic features \\
\hline & Sargassum & Live botroms \\
\hline $\begin{array}{l}\text { Continental Sbeif } \\
\text { features }\end{array}$ & & \\
\hline West Florida Shelf & & \\
\hline Mississippi/Alabema & & \\
\hline Shelf & & \\
\hline Louisiara/Texas Sbelf & & \\
\hline South Texss Shelf & & \\
\hline
\end{tabular}


Appendix 7. Geographically Defined Habitat Areas of Particular Concern Identified in Fishery Management Plan Amendments of the Gulf of Mexico; South Atlantic and Caribbean Fishery Management Councils.

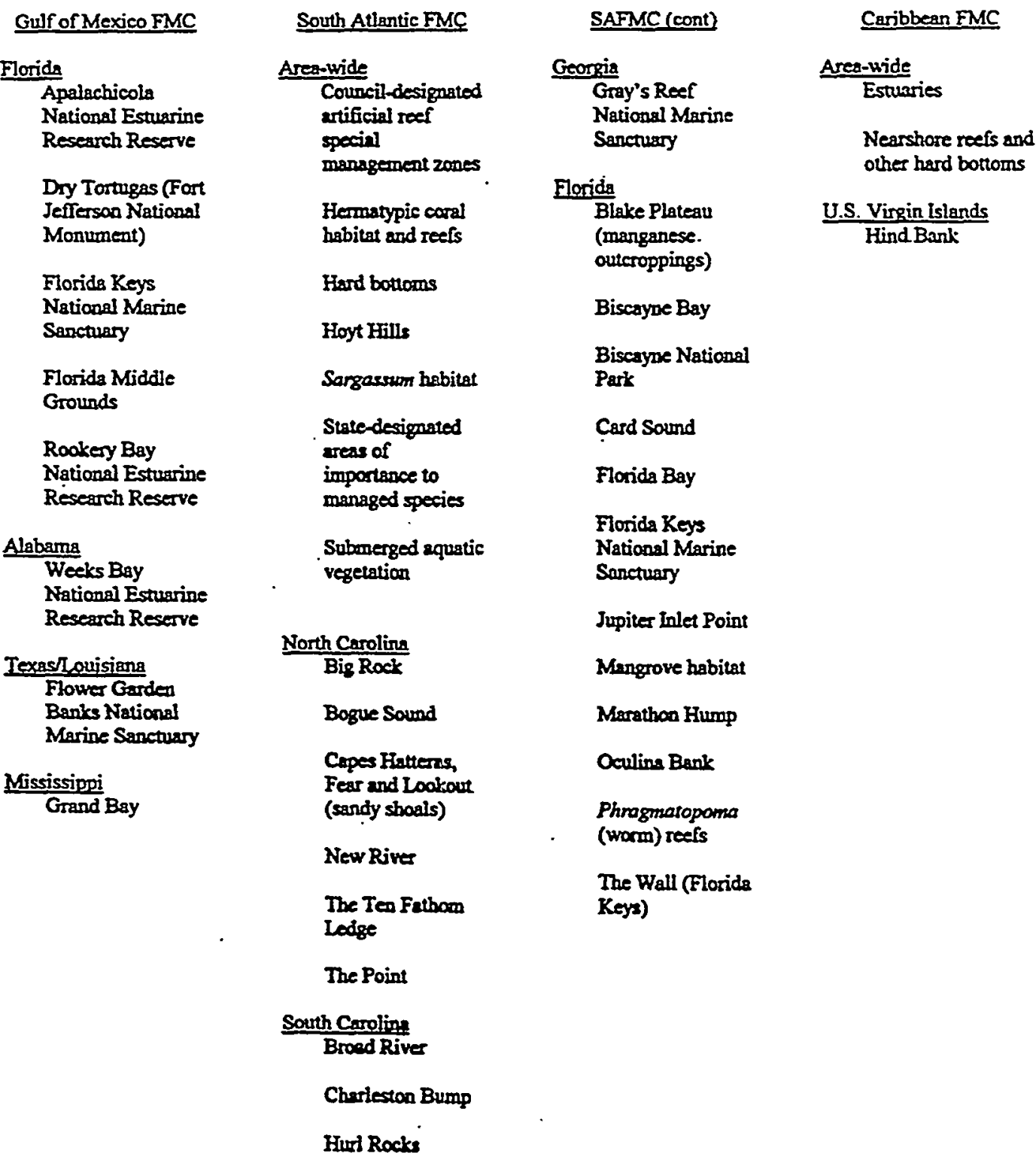


Appendix 8. Sources of EFH and Related Resource Information.

\section{Fishery Management Plan Amendments}

Caribbean Fishery Management Council. 1998. Essential Fish Habitat (EFH) generic amendment to the Fishery Management Plans (FMPS) of the U.S. Caribbean including a draft environmental assessment. Caribbean Fishery Management Council. San Juan, Puerto Rico. 2 vols.

Gulf of Mexico Fishery Management Council. 1998. Public hearing draft generic amendment for addressing Essential Fish Habitat requirements in the following fishery management plans of the Gulf of Mexico: Shrimp Fishery of the Gulf of Mexico, United States Waters, Red Drum Fishery of the Gulf of Mexico; Reef Fish Fishery of the Gulf of Mexico; Coastal Migratory Pelagic Resources (Mackerels) in the Gulf of Mexico and South Atlantic, Stone Crab Fishery of the Gulf of Mexico; Spiny Lobster in the Gulf of Mexico and South Atlantic; Coral and Coral Reefs of the Gulf of Mexico (includes environmental assessment). Gulf of Mexico Fishery Management Council. Tampa, FL.

Mid-Allantic Fishery Management Council. 1998. Amendment 1 to the bluefish fishery management plan. MidAllantic Fishery Management Council. Dover, DE. 2 vols.

Mid-Allantic Fishery Management Council 1998. Amendment 8 to the Atlantic mackerel, squid, and butterfish fishery management plan. Mid-Atlantic Fishery Management Council. Dover, DE.

Mid-Atlantic Fishery Management Council. 1998. Amendment 12 to the Atlantic surfilam and ocean quahog fishery management plan. Mid-Atlantic Fishery Managernent Council. Dover, DE.

Mid-Atlantic Fishery Management Council. 1998. Amendment 12 to the summer flounder, scup, and black sea bass fishery management plan. Mid-Atlantic Fishery Management Council. Dover, DE.

National Marine Fisheries Service. 1998. Billish essential fish habitat (EFH) pre-draft materials for the billfish fishery management plan amendment. National Marine Fisheries Service. Silver Spring, MD.

National Marine Fisheries Service. 1998. Highly migratory species essential fish habitat (EFH) pre-draft materials for the highly migratory species fishery management plan amendment. National Marine Fisheries Service. Silver Spring, MD.

South Atlantic Fishery Management Council. 1998. Final habitat plan for the South Atlantic region: Essential Fish Habitat requirements for Fishery Management Plans of the South Allantic fishery Management Council: The Shrimp Fishery Management Plan, The Red Drum Fishery Management Plan, The Snapper Grouper Fishery Management Plan, The Coastal Migratory Pelagies Fishery Management Plan, The Golden Crab Fishery Management Plan, The Spiny Lobster Fishery Management Plan, The Coral, Coral Reefs, and Live/Hard Bottom Habitat Fishery Management Plan, and The Calico Scallop Fishery Management Plan. South Atlantic Fishery Management Council. Charleston, SC.

\section{EFFH Related Web Sites}

South Allantic EFH

Gulf of Mexico FMC

Gulf of Mexico EFH

Caribbean EFH Resources

EFH Rules

NMFS Southeast Region

Highly migratory pelagic and

billfish resource EFH

\author{
htw:/hrux:safme.nezasov \\ hitp://wrww.gulfecouncil.org \\ hitn://galvesion, Ssp, nmfs. gov/efh/ \\ Ltup://christensenmac.nos.noan. gov/briefing.lutml \\ Intp://wruw.nmfs.gov/habitavefli \\ lill:/lealdera.sero.nmfs.gov \\ litup://unsw.nmfs.gov/sfa/hms/Final.heml
}


Appendix 9. Points of Contact for Essential Fish Habitat Activities within the Southeast Region of the National Marine Fisheries Service.

National Marine Fisheries Service Southeast Region

Andreas Mager, Jr. (Southeast Region) National Marine Fisheries Service 9721 Executive Center Drive, $N$. St. Petersburg, FL 33702 727/570-5317andi:maser:?anoza.sov

Rickey Ruebsamen (EFH Coordinator) National Marine Fisheries Service 9721 Executive Center Drive, N. St. Petersburg, FL 33702

727/570-5317 ric.nicbsamen:Rinoaa.gov

\section{Local Offices}

Russeil Swafford (Texas)

National Marine Fisheries Service

4700 Avenue $U$

Galveston, TX 77551

409/766-3699 nisfi:suaffordianoza.gov.

Richard Haruman (Louisiana)

National Marine Fisheries Service

clo Louisiana State University

Baton Rouge, LA 70803

225/389-0508 richard harmanionnca2.904

Marix Thompson (Forida, Alabama, Mississippi, Puerro Rico, U.S. Virgin Islands)

National Marine Fisheries Service

3500 Delwood Beach Rd.

Panama City, FL 32408-7499

850/234-5061 mark.thompson@moas.gov

David Rackley (South Carolina, Georgia)

National Marine Fisheries Service

Charleston Laboratory

219 Fort Johnson Road

Charleston, SC 29412-9110

(843) 762.8574 david.rakier@anoaa.gov

Larry Harty (North Carolina)

National Marine Fisheries Service

101 Pivers Island Road

Beaufor, NC 28516-9722

252/728-5090 lam:hardianoaa.gov
Gulf of Mexico Fisher: Management Council

Executive Director

Gulf of Mexico Fishery Management Council

The Commons at Rivergate

3018 U.S. Highway 301 N., Suite 1000

Tampa, FL 33619-2266

813/228-2815 gulf.councilidnoaa.gov

EFH Point of:Contact

Jeff Rester

(Gulf States Marine Fisheries Commission)

228/875-5912 jrester:agsmie.org

South Atlantic Fisherv Management Council

Executive Director

South Atlantic Fisherg Management Council

1 Southpark Circle

Southpark Building, Suite 306

Charleston, SC 29407-4699

843/571-4366_safme:ainosa.gov

EFH Point of Contact

Roger Pugliese

843/571-4366 roger.puglieseirinoaa.gov

Caribbean Fishery Management Council

Execulive Director

Caribbean Fishery Management Couneil

268 Avenue Rivera Avenue, Suite 1108

San Juan, Puerto Rico 00918-2577

787/ 766-5926 caribefish.auprl.upr.cluedu

EFH Point of Contact

Graciela Garcia-Moliner

787/766-5926 garibefisliauprt.upr.clu_edy

Mid-Atlantic Fishery Management Council

Execulive Director

Mid-Atlantic Fishery Management Council

Room 2115, Federal Building

Dover, Delaware 19901

Thomas B. Hoff EFH Point of Contact

302/674-2331 x15 tom.lioffanoza..gov 


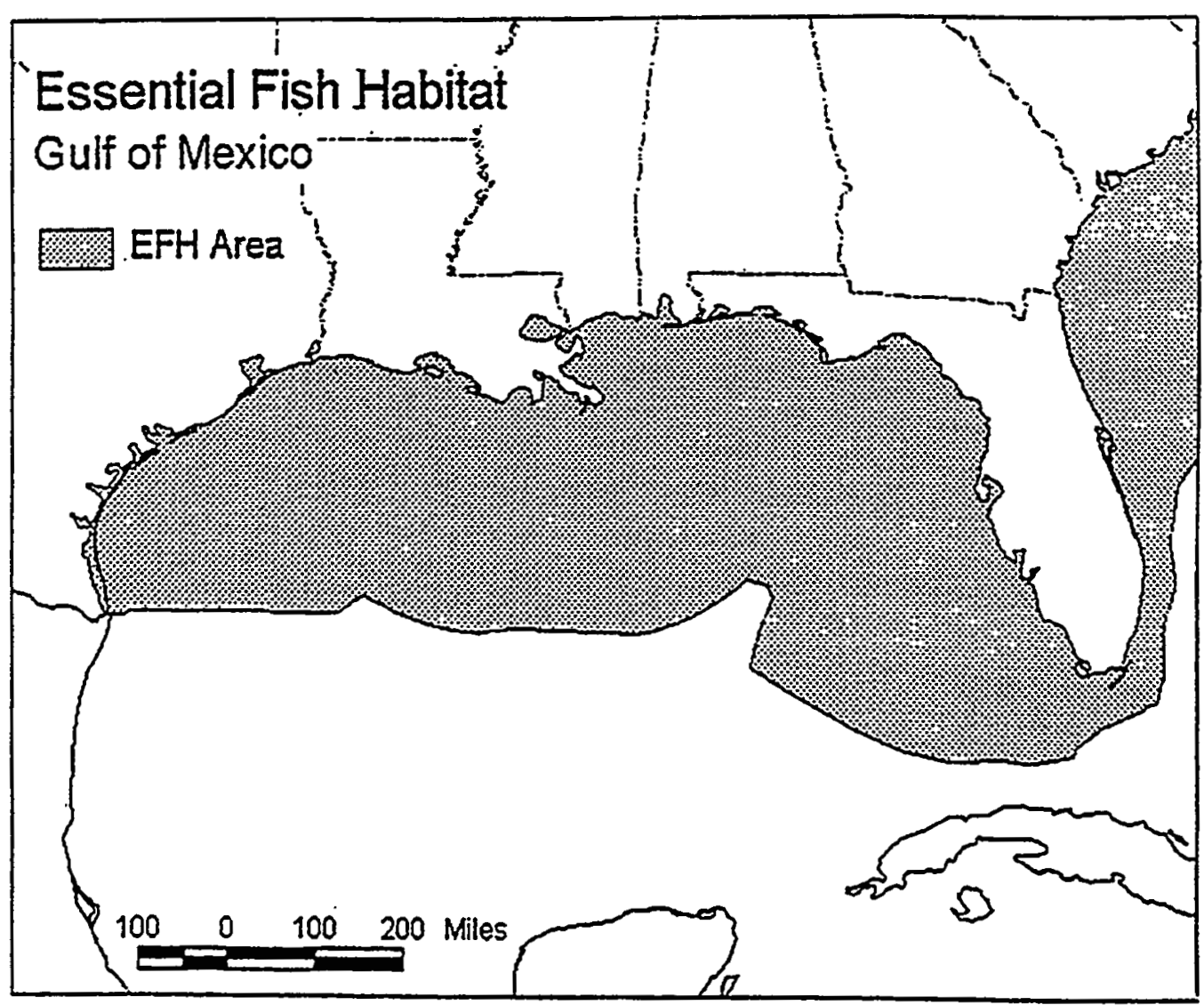

Figure 1. Map depicting the extent of Essential Fish Habitat in the Gulf of Mexico. 


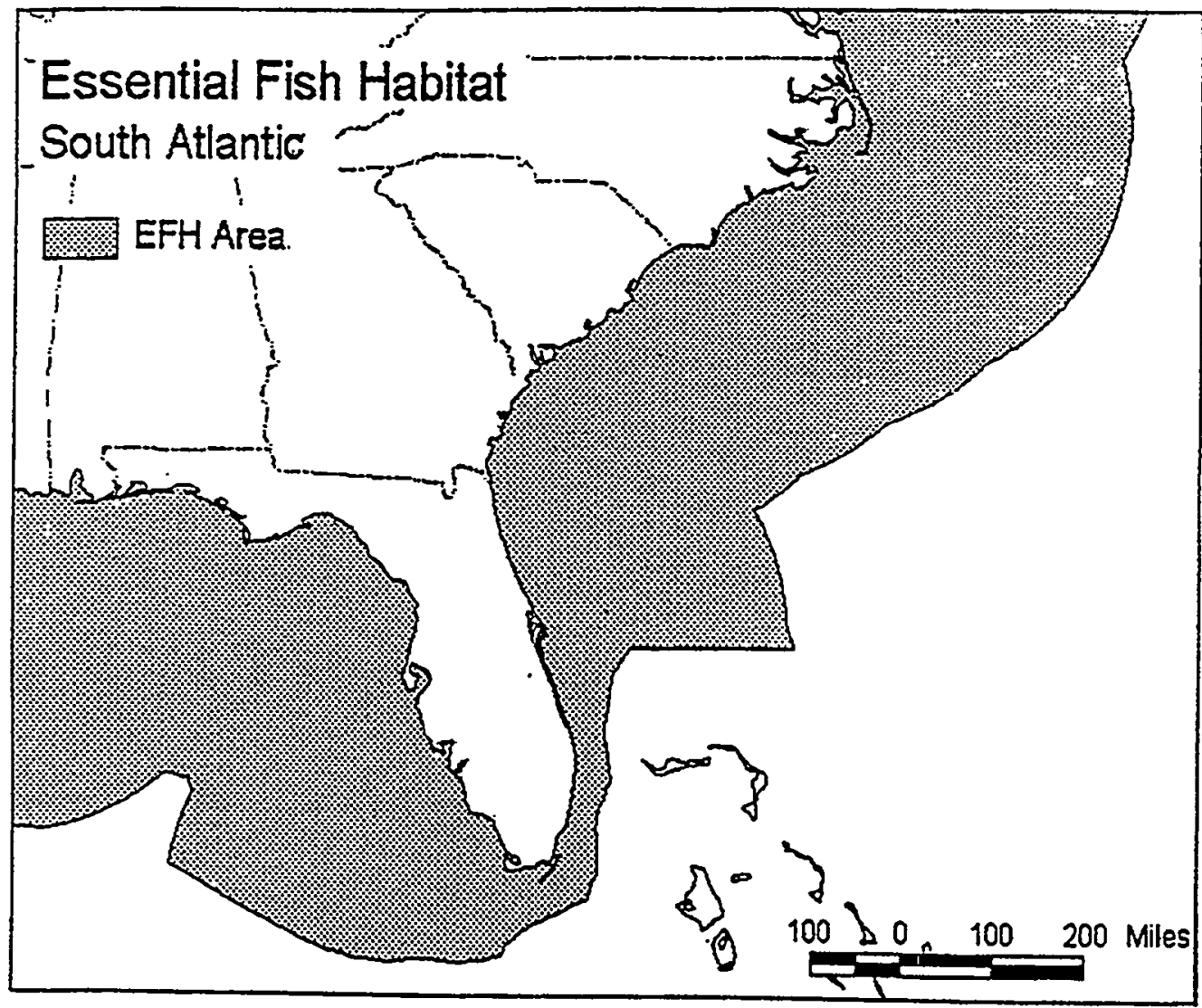

Figure 2. Map depicting Essential Fish Habitat in the south Atlantic region. 


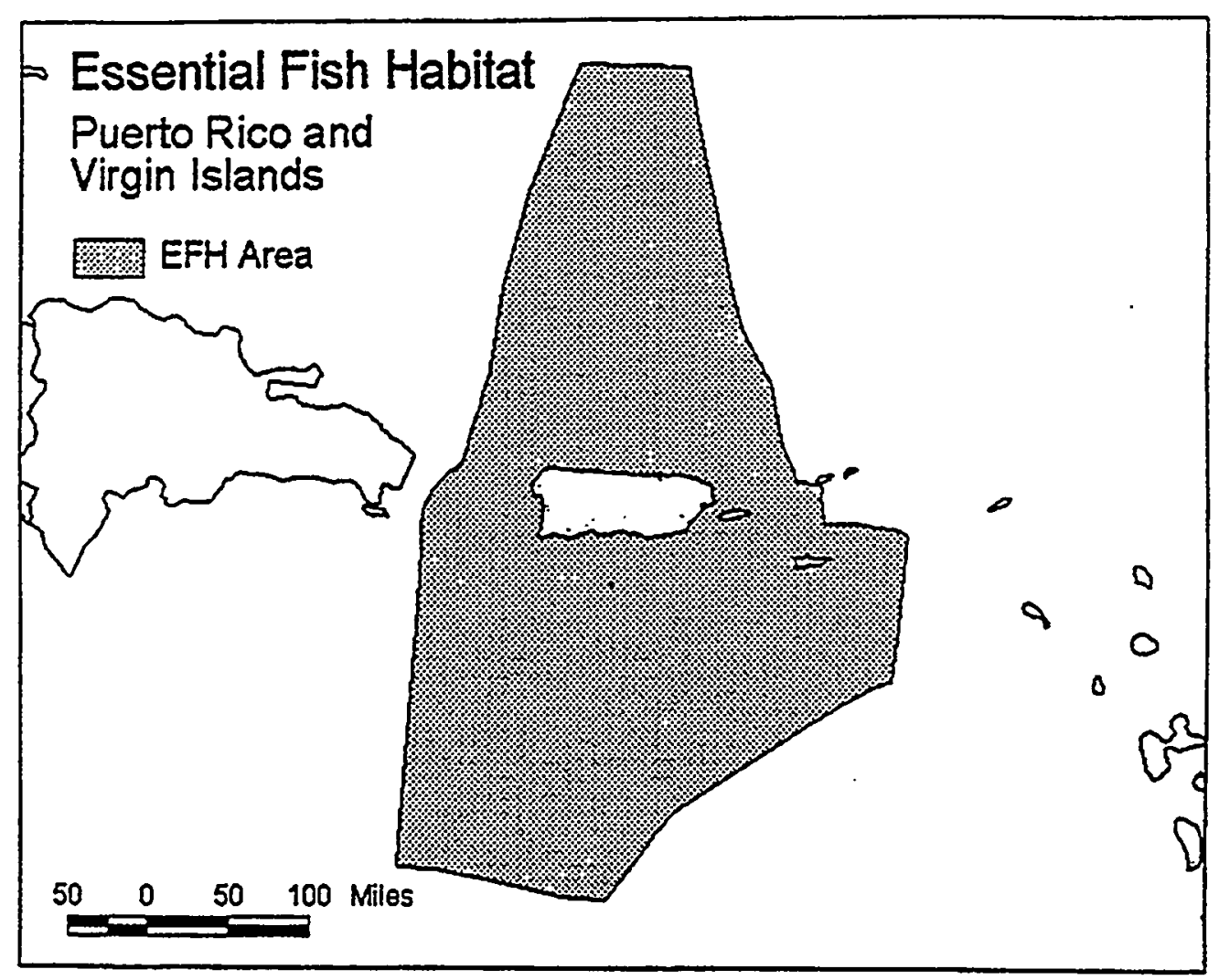

Figure 3. Map depicting Essential Fish Habitat in Puerto Rico and the U.S. Virgin Islands. 


\section{Letter No. 7}

Andreas Mager, Jr., Assistant Regional Administrator, Habitat Conservation Division, United States Department of Commerce, National Oceanic and Atmospheric Administration, National Marine Fisheries Service, Southeast Regional Office, 9721 Executive Center Drive N., St. Petersburg, Florida 33702

\section{Comment 7-1:}

"Information contained in the DEIS indicates that the project area includes estuarine emergent wetlands. However, the NMFS cannot determine from the information contained in the DEIS regarding project construction and related mitigation whether there will be a net overall adverse affect [sic] to wetlands that support fishery resources of concern to the NMFS. Accordingly, we believe this is an opportune time to advise you of consultation requirements resulting from new legislation. In 1996, to further the conservation of marine fishery resources, Congress amended the Magnuson-Stevens Fishery Conservation and Management Act (Magnuson-Stevens Act). The amendment requires establishment of guidelines for the identification of Essential Fish Habitat (EFH) and the inclusion of EFH descriptions in fishery management plans. The Magnuson-Stevens Act also requires all Federal agencies to consult with the NMFS on measures to protect EFH when an agency proposes to authorize, fund, or undertake an activity which would adversely affect designated habitats.

The estuarine emergent wetlands in the project area have been identified as EFH. Accordingly, consultation is required pursuant to interagency coordination procedures specified by the NMFS in the 1997 Interim Final Rules to implement the EFH provisions of the Magnuson-Stevens Act (50 CFR Sections 600.805-600.930) if the Federal action agency determines that their activity may adversely affect EFH. The DEIS would be an appropriate place to document the results of this determination and any subsequent consultation, if required."

\section{Response:}

DOE has consulted with the National Marine Fisheries Service on measures to protect Essential Fish Habitat. As part of the consultation, DOE prepared an Essential Fish Habitat Assessment dated January 24, 2000 (Appendix F), in which DOE determined that there would be no substantial adverse effect on Essential Fish Habitat in the project area as a consequence of the proposed project. After reviewing the Essential Fish Habitat Assessment, the National Marine Fisheries Service requested additional clarifying information regarding the wetlands in a letter dated February 23, 2000 (Appendix F). After receiving the additional information from DOE, the National Marine Fisheries Service sent a letter to DOE dated March 27, 2000 (Appendix F), in 
which they stated that they concur with DOE's determination that the project would not adversely affect Essential Fish Habitat and that they have no further objection to the project. 


\title{
United States Department of the Interior
}

\author{
OFFICE OF THE SECRETARY \\ OFFICE OF ENVIRONIIENTAL POLICY AND COMPLIANCE \\ Richard B. Russell Federal Building \\ 75 Spring Street, S.W. \\ Atlanta, Georgia 30303
}

October 8, 1999

Letter No. 8

ER-99/760

Reproduced from

copy submitted

Ms. Lisa K. Hollingsworth,

NEPA Document Manager

U.S. Department of Energy

Federal Energy Technology Center

3610 Collins Ferry Road

P. O. Box 880

Morgantown, WV 26507-0880

Dear Ms. Hollingsworth:

The Department of the Interior has reviewed the draft EIS for the JEA Circulating Fluidized Bed Combustor Project, Duval County, FL, as requested.

The NGS is located adjacent to Timucuan Ecological and Historic Preserve, a unit of the National Park Service.

The proposed unit would significantly reduce the emissions of sulfur dioxide, oxides of nitrogen and particulate matter. For these reductions, we highly commend the JEA. However, a review of the DEIS indicates a significant emission of heavy metals including mercury, vanadium and nickel. On page 3-12, the consideration of heavy metal impacts is treated in just a few paragraphs. These paragraphs indicate that heavy metal concentrations are or have exceeded water quality standards. The statement that metal levels exceeded state standards, but no longer do, is unclear. Did standards for heavy metals change or was a different sampling method used? This brief consideration of heavy metal concentrations is inadequaie to fully consider the poiential impacts to the marshes, flora and fauna of the Timucuan Preserve.

Timucuan Preserve was established by Congress "to protect the natural ecology of such lands and waters" within the boundaries of the Preserve. Emission of heavy metals will settle within a few miles of the stacks and will directly impact the Preserve. Since coal is a primary fuel, emission of mercury is a major concern. The ash from the combustion process will contain yanadium and nickel as well as other heavy metals.

The emissions of heavy metals and their impact on the resources of Timucuan Preserve are not adequately addressed in the DEIS. Recent research has shown the presence of heavy metals already present in the sediments from locations with 10 kilometers to the east of the NGS (USGS-BRD in preparation). We feel the final EIS must more fully address the impacts of heavy metals on the fora 
and fauna. The final EIS must also analyze the impacts of the addition of up to one-quarter ton of $\uparrow$ mercury per year, as well as other heavy metals, into an area already showing signs of heavy metal concentrations in excess of state water quality standards.

While we agree that with appropriate precautions the proposed project is not likely to adversely affect the Florida manatee (Trichechus manatus latirastris), some of the factual statements in the draft EIS regarding manatees are inaccurate or incorrect. We recommend that the final EIS be revised to reflect the following information. The headings below correspond to the headings in the draft EIS.

\subsubsection{Threatened and Endangered Species}

P. 3-41. The first sentence on this page references the "U. S. Marine Mammal Protection Act of 1992." The correct citation is the U.S. Marine Mammal Protection Act of 1972, as amended.

\subsubsection{Threatened and Endangered Species}

PQ 4-45,46. This section of the draft EIS states that manatees probably would not frequent the dock area because no submerged vegetation is available in the vicinity. Such statements are erroneous. Manatees are attracted to the southem shore of Blount Island (and the vicinity of the project site) by 8-4 emergent cordgrasses (Spartina sp.) (see Baugh, et al. 1989), and also use the shoreline area as a travel corridor.

When discussing the project's potential to "take" manatees, the draft EIS cites Brody (1993), who stated that "the major threats to manatees in the St. Johns River appear to be wounds inflicted by boat propellers, which are rarely fatal, and collisions with boats, which are more frequently fatal." While watercratt collisions are a major threat to manatees in this area, boat propellers are more than rarely fatal. The State of Florida, through its examination of manatee carcasses, has found that the number of manatees killed by watercraft are evenly divided between the number of animals killed by impacts versus propellers, and a small number of animals are killed by a combination of the two factors (Ackerman, et al., 1995). Furthermore, while it is true that locally adopted speed restrictions will help reduce the probability of watercratt collisions with fast-moving boats, a small number of manatees are killed by large commercial vessels in the Jacksonville port area. These vessels rarely operate at high speeds and presumably kill these animals by "drawing" them into their props or by crushing them between the hull and river bottom. Local speed restrictions will minimally affect vessel operations and their effects on manatees in the dock area.

In the discussion concerning the project's heated discharge, concerns about the manatees using the discharge and being subjected to "cold shock" in the event of a shut down are unfounded. Unless the proposed project alters the existing discharge in such a way as to attract manatees, data suggests.that the current discharge does not attract manatees and, as such, shut downs should have no effect on manatees. 
Given appropriate safeguards, the Fish and Wildlife (Service) believes that impacts to manatees from the proposed project will be negligible. In particular, precautions should be taken during any waterbome construction activities; vessel operators using the site should be educated about manatees and steps that should be taken to avoid collisions; and no changes should be made to the existing outfall that would attract manatees to the site.

Thank you for the opportunity to review and comment on the draft EIS. If there are questions regarding fish and wildlife resources, please contact Bruce Bell at 404/679-7089.

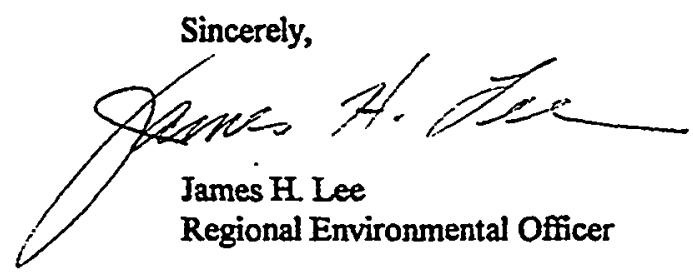




\section{Letter No. 8}

James H. Lee, Regional Environmental Officer, United States Department of the Interior, Office of the Secretary, Office of Environmental Policy and Compliance, Richard B. Russell Federal Building, 75 Spring Street, S.W., Atlanta, Georgia 30303

\section{Comment 8-1:}

"On page 3-12, the consideration of heavy metal impacts is treated in just a few paragraphs. These paragraphs indicate that heavy metal concentrations are or have exceeded water quality standards. The statement that metal levels exceeded state standards, but no longer do, is unclear. Did standards for heavy metals change or was a different sampling method used? This brief consideration of heavy metal concentrations is inadequate to fully consider the potential impacts to the marshes, flora and fauna of the Timucuan Preserve."

\section{Response:}

The state water quality standards have not changed, with the exception of the standard for silver. Sampling and analysis of heavy metals by the FDEP and JEA for the purpose of evaluating ambient water quality have been conducted in accordance with FDEP-approved methods and Standard Operating Procedures for laboratories with approved Comprehensive Quality Assurance Plans. The results indicate improvements in the actual water quality rather than a change in standards or the use of a different sampling or analytical technique.

Section 3.3.2.1 of the EIS provides results of tests that demonstrated that contaminants in effluent discharges from the St. Johns River Power Park/Northside Generating Station facilities are not toxic to aquatic biota. Studies conducted on oysters held in cages for several months near the Northside dock area showed no appreciable uptake and bioaccumulation of metals.

Section 4.1.6.2 discusses the finding that the concentration levels of pollutants mobilized from sediments during dredging operations for expansion of the Northside dock (Option 2) would not be great enough to cause concern relative to their biotoxicity on resident biota. A report by Seal, Calder, and Sloane (1994) indicated that heavy metal concentrations in the sediments of the back channel of the St. Johns River near the mouth of San Carlos Creek were at or near background levels. Also see response to Comment 8-2.

\section{Comment 8-2:}

"Timucuan Preserve was established by Congress 'to protect the natural ecology of such lands and waters' within the boundaries of the Preserve. Emission of heavy metals will settle within a few miles of the stacks and will directly impact the Preserve. Since coal is a primary fuel, 
emission of mercury is a major concern. The ash from the combustion process will contain vanadium and nickel as well as other heavy metals.

The emissions of heavy metals and their impact on the resources of Timucuan Preserve are not adequately addressed in the DEIS. Recent research has shown the presence of heavy metals already present in the sediments from locations with [sic] 10 kilometers to the east of the NGS (USGS-BRD in preparation). We feel the final EIS must more fully address the impacts of heavy metals on the flora and fauna. The final EIS must also analyze the impacts of the addition of up to one-quarter ton of mercury per year, as well as other heavy metals, into an area already showing signs of heavy metal concentrations in excess of state water quality standards."

\section{Response:}

Although the report cited in the comment is not yet available, several agencies previously have surveyed heavy metal concentrations in the sediments of the St. Johns River near Blount Island and the Timucuan Ecological and Historic Preserve. Seal, Calder, and Sloane (1994) have collated and summarized this information, including heavy metal data from two sites along the southern and western boundaries of the preserve. As shown in Table G.1, levels of

\begin{tabular}{lccc}
$\begin{array}{l}\text { Table G.1. Levels of heavy metals (mg/kg) measured in the sediments } \\
\text { at two sites (SJR 34 and SJR 35) } \\
\text { near the Timucuan Ecological and } \\
\text { Historic Preserve compared to their no observable effects levels. }\end{array}$ \\
\hline \multicolumn{2}{c}{$\begin{array}{l}\text { Pollutant } \\
\text { SJR 34 }\end{array}$} & SJR 35 & NOEL $^{a}$ \\
\hline Lead & 8.8 & 7.7 & 21 \\
Mercury & $\mathrm{BD}^{b}$ & $\mathrm{BD}^{b}$ & 0.1 \\
Chromium & 12.5 & 4.3 & 33 \\
Copper & 5.2 & 2.05 & 28 \\
Cadmium & 0.195 & 0.057 & 1 \\
Arsenic & 4.7 & $\mathrm{BD}^{b}$ & 8 \\
\hline
\end{tabular}

ano observable effects level.

${ }^{b}$ Below detection limits of analytical instrument.

lead, mercury, chromium, copper, cadmium, and arsenic measured at these two sites were well below their no observable effects levels (Keller and Schell 1993; MacDonald 1993). Mercury was not detected at either site. Although the detection limits of analytical instruments used to measure mercury can vary between laboratories, the detection limits are typically well below the no observable effects level of $0.1 \mathrm{mg} / \mathrm{kg}$ for mercury (T.L. Seal, FDEP, personal communication 
to S.M. Adams, ORNL, December 1, 1999). The heavy metal data reported from these two sites are considered to be at natural or background levels for areas characterized by sediments with relatively low clay and aluminum content (Schropp and Windom 1988; FDEP 1994). Therefore, if the levels of heavy metals measured in the sediments along the preserve boundaries represent those concentrations within the preserve, then the observed levels of these metals should pose no ecotoxicological risk to organisms of the preserve because all of the metal concentrations are well below their no observable effects levels.

With regard to the proposed project, the repowered Unit 2 would emit approximately 0.10 tons per year of mercury from burning entirely coal or 0.02 tons per year from burning entirely petroleum coke (Table 4.1.5 of the EIS). The repowered Unit 1 would also emit these quantities. A blend of these two fuels during operation of the units would result in mercury emissions between this range. The permitted limit for mercury emissions from each unit would be $0.03 \mathrm{lb} /$ hour for a 6 -hour average. In the unlikely event that measured emissions were higher than expected, the combustion process would be fine-tuned to ensure that the permitted limit would not be exceeded. The emissions of other heavy metals are given in Table D.1.

Much uncertainty exists regarding the spatial distribution of mercury deposition downwind of emissions sources. Likewise, source identification and attribution based on measurements of mercury deposition (i.e., working in the reverse direction to identify sources of measured deposition) have proven difficult. Moreover, not all emissions are produced by human activity, and lack of reliable data about the speciation of mercury in source emissions further contributes to assessment difficulties (Hanisch 1998). Controversy exists regarding the magnitude of the local impact from sources such as power plants. Few data are available about mercury concentrations in the vicinity of emissions point sources (Hanisch 1998). Global and regional models suggest that about $50 \%$ of manmade mercury emissions are transported globally, while the remaining 50\% deposit on a local or regional scale (EPRI 1994; Bullock, Brehme, and Mapp 1998). Another study has indicated that mercury is more of a global or regional problem than one of local concern because computer modeling has shown that most mercury emissions from power plants are transported over 60 miles away (Constantinou, Wu, and Seigneur 1995). However, some field measurements of oxidized, inorganic mercury appear to contradict this finding. This species normally represents only about $3 \%$ of total gaseous mercury, but is expected to account for a major portion of mercury dry deposition. On the basis of measurements near the ground in close vicinity to power plants, a study concluded that cutting a local emissions source of oxidized, inorganic mercury could result in some local reduction of deposition (Lindberg and Stratton 1998). Similar uncertainty exists for other heavy metals. 
While demonstration of the proposed project is not expected to evaluate specifically the impact of the project on the resources of the Timucuan Ecological and Historic Preserve, data obtained during the demonstration would characterize and quantify emissions of heavy metals. Heavy metals that would be measured in the flue gas from the firing of coal and petroleum coke during the demonstration include mercury, lead, antimony, arsenic, barium, beryllium, cadmium, chromium, cobalt, manganese, nickel, selenium, and vanadium. In addition to allowing prospective customers to assess the potential of CFB technology for commercial application, the data would be available for use in studies conducted by other agencies and organizations.

Section 4.1.2.2 of the EIS text has been modified to incorporate the above information.

\section{Comment 8-3:}

"While we agree that with appropriate precautions the proposed project is not likely to adversely affect the Florida manatee (Trichechus manatus latirostris), some of the factual statements in the draft EIS regarding manatees are inaccurate or incorrect. We recommend that the final EIS be revised to reflect the following information. The headings below correspond to the headings in the draft EIS.

\subsubsection{Threatened and Endangered Species}

P. 3-41. The first sentence on this page references the "U.S. Marine Mammal Protection Act of 1992.' The correct citation is the U.S. Marine Mammal Protection Act of 1972, as amended."

\section{Response:}

Section 3.6 .3 of the EIS text has been modified to indicate the correct citation.

\section{Comment 8-4:}

"Pp. 4-45, 46. This section of the draft EIS states that manatees probably would not frequent the dock area because no submerged vegetation is available in the vicinity. Such statements are erroneous. Manatees are attracted to the southern shore of Blount Island (and the vicinity of the project site) by emergent cordgrasses (Spartina sp.) (see Baugh, et al. 1989), and also use the shoreline area as a travel corridor."

\section{Response:}

Section 4.1.6.3 of the EIS text has been revised to incorporate the information in the comment. 


\section{Comment 8-5:}

"When discussing the project's potential to 'take' manatees, the draft EIS cites Brody (1993), who stated that 'the major threats to manatees in the St. Johns River appear to be wounds inflicted by boat propellers, which are rarely fatal, and collisions with boats, which are more frequently fatal.' While watercraft collisions are a major threat to manatees in this area, boat propellers are more than rarely fatal. The State of Florida, through its examination of manatee carcasses, has found that the number of manatees killed by watercraft are evenly divided between the number of animals killed by impacts versus propellers, and a small number of animals are killed by a combination of the two factors (Ackerman, et al., 1995). Furthermore, while it is true that locally adopted speed restrictions will help reduce the probability of watercraft collisions with fast-moving boats, a small number of manatees are killed by large commercial vessels in the Jacksonville port area. These vessels rarely operate at high speeds and presumably kill these animals by 'drawing' them into their props or by crushing them between the hull and river bottom. Local speed restrictions will minimally affect vessel operations and their effects on manatees in the dock area."

\section{Response:}

Section 4.1.6.3 of the EIS text has been revised to incorporate the information in the comment.

\section{Comment 8-6:}

"In the discussion concerning the project's heated discharge, concerns about the manatees using the discharge and being subjected to 'cold shock' in the event of a shut down are unfounded. Unless the proposed project alters the existing discharge in such a way as to attract manatees, data suggests that the current discharge does not attract manatees and, as such, shut downs should have no effect on manatees."

\section{Response:}

Section 4.1.6.3 of the EIS text has been revised to incorporate the information in the comment.

\section{Comment 8-7:}

"Given appropriate safeguards, the Fish and Wildlife (Service) believes that impacts to manatees from the proposed project will be negligible. In particular, precautions should be taken during any water borne construction activities; vessel operators using the site should be educated about manatees and steps that should be taken to avoid collisions; and no changes should be made to the existing outfall that would attract manatees to the site." 


\section{Response:}

In accordance with the conditions contained in the Submerged Lands \& Environmental Resource Permit (SLERP) issued by the FDEP and the Section 404 Permit for Dredged or Fill Material issued by the $\mathrm{COE}$, the following manatee precautions would be taken during all waterborne construction activities, including dredging and construction of the new dock (Option 2) and materials handling system:

- During all in-water construction activities, at least one experienced observer would be designated to watch for manatees. The observer would wear polarized sunglasses to aid in observation. The observer would advise personnel to stop work immediately if manatees were sighted within $50 \mathrm{ft}$ of any in-water construction activity.

- In-water construction work and movement of vessels associated with the project (e.g., work barges) would not occur between sunset and sunrise, when it would be more difficult to spot manatees. The vessels would always operate at "idle speed/no wake" while in the construction area and while in waters where the vessel bottoms would be less than $4 \mathrm{ft}$ from the bottom of the water body. All vessels would travel in deep water whenever possible.

- The construction contractor would instruct all personnel of the potential presence of manatees and the need to avoid collisions with manatees. Construction personnel would be advised of the civil and criminal penalties for harming, harassing, or killing manatees as outlined in the U.S. Marine Mammal Protection Act of 1972, as amended, the Endangered Species Act of 1973, and the Florida Manatee Sanctuary Act. Construction personnel would implement appropriate precautions to protect manatees.

- Prior to commencement of construction, the contractor would display at least two temporary signs concerning manatees.

- Siltation barriers would be properly secured so that manatees would not become entangled, and the barriers would be inspected at least once daily to avoid manatee entrapment. Barriers would not block manatee entry to or exit from essential habitat.

- The contractor would maintain a log during the contract period that documents any sightings, collisions, or injuries to manatees. Any collisions with and/or injuries to manatees would be reported immediately to the Florida Marine Patrol and the FDEP Office of Protected Species Management. 
In addition, prior to using the new dock, a fender/bumper system would be installed at or above the mean high water level to minimize the risk of crushing manatees during vessel docking and mooring. Permanent signs would be installed to alert boaters using docking facilities of the potential presence of manatees, and two "Caution: Manatees" signs would be installed at the pier. No changes that would attract manatees would be made to the existing outfall.

The information in this response has been included in Section 4.1.6.3 of the EIS. 


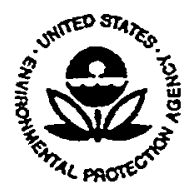

\author{
UNITED STATES ENVIRONMENTAL PROTECTION AGENCY \\ REGION 4 \\ ATLANTA FEDERAL CENTER \\ 61 FORSYTH STREET \\ ATLANTA, GEORGIA $30303-8960$
}

October 13, 1999

4EAD-OEA

Ms. Lisa K. Hollingsworth

NEPA Document Manager

U.S. Department of Energy

Federal Energy Technology Center

3610 Collins Ferry Road

P.O. Box 880

Morgantown, WV 26507-0880

\title{
RE: EPA Review and Comments on \\ Draft Environmental Impact Statement (DEIS) \\ JEA Circulating Fluidized Bed Combustor Project \\ CEQ No. 990300
}

Letter No. 9

Dear Ms. Hollingsworth:

Pursuant to Section 102(2)(C) of the National Environmental Policy Act (NEPA) and Section 309 of the Clean Air Act, the U.S. Environmental Protection Agency (EPA) has reviewed the subject Draft Environmental Impact Statement (DEIS). The document provides information to educate the public regarding general and project-specific environmental impacts and analysis procedures. We appreciate your consistency with the public review and disclosure aspects of the NEPA process. We also note that the Department of Energy held a public meeting concerning this project on September 16, 1999.

DOE's proposed action is to provide cost-shared funding to implement circulating fluidized bed (CFB) combustion technology under the Clean Coal Technology (CCT) Program This demonstration project would take place in Duval County, Florida, and would involve constructing and operating an electric, coal and petroleum coke-fired circulating fluidized bed combustor and boiler to repower an existing steam nurbine at JEA's Northside Geuerating Station in Jacksonville.

Based on our review, we rate the DEIS "EC-2", that is, we have environmental concerns about the project, and more information is needed to fulty assess the impacts. In particular, the issues of noise impact mitigation, air quality, and bealth-based criteria warrant further discussion in the Final EIS. Our detailed comments are attached. 
Thank you for the opportunity to comment on this project. If you have any questions or require technical assistance you may contact Ramona McConney of my staff at (404)562-9615.

Sincerely,

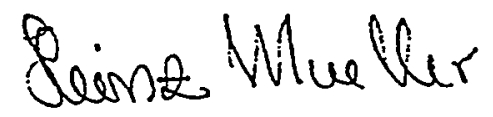

Heinz J. Mueller, Chief

Office of Environmental Assessment

Attachment 


\section{Comments on}

Draft Environmental Impact Statement (DEIS), May 1999

for JEA Circulating Fluidized Bed Combustor Project

CEQ No. 990300

\section{NOISE:}

Ambient Noise - We note that two noise surveys were conducted to determine ambient levels near the existing plant, and specifically that the supplemental survey detected plant effects and included monitoring stations proximal to residences near the plant. Page 3-56 indicates that ambient levels ranged approximately $41-46 \mathrm{dBA}$ at night and 55-60 dBA during the day. It is unclear, however, if these ambient measurements are in the Leq, L10, L50 or L90 metrics listed as being used (page 3-54). We assume that the Leq descriptor was used for the background noise surveys; however, the FEIS should clarify. We note that the Jacksonville city noise ordinance limits nighttime noise levels at residences to $60 \mathrm{dBA}$.

If the Leq metric was used, it is an average level over a given period of time. It should be noted that certain project-related single-event noise levels that are much greater than average levels also occur under ambient conditions such as steam blowout noises and some of the train whistles due to the operation of the existing plant.

Construction Noise - We appreciate that examples of noisy construction equipment were listed in the DEIS (such as pile drivers) and predictions of their noise attenuations over distance (pages 4-58 and 4-59). The FEIS should clarify if the documented noise attenuation levels were determined by calculation (based on distance from source), by model, or by another method.

The expected length of the time of construction should be included in the FEIS in order to gain a perspective of the magnitude of the construction noise.

Operational Noise - Residents would be affected by intrusive noise levels resulting from steam blowouts and other operations. The FEIS should document the number of such residents affected within the prescribed 0.5 mile radius (what is the basis for selection of a 0.5 -mi radius?).

Since trains, trucks and barges would be used to haul in coal and limestone, the FEIS should estimate the number of residences affected along such routes within a 5-mile radius of the plant. The noise levels at the nearest residences should also be disclosed. It should also be noted that while barges may have less noise effects than other modes, there could be greater effects for other forms of pollution, such as wetland impacts (unloading dock construction or expansion) and water quality pollution (spills). These impact tradeoffs should be considered and discussed in the FEIS. 
Noise Mitigation - We note that some mitigative measures are apparently proposed. These are listed on page 4-59 as 1) installing baffle silencers for fans, 2) enclosing coal and limestone crushers, and 3) installing sound insulation in buildings. This mitigation is intended for compliance with the city ordinance. JEA should commit to such mitigation in the FEIS and verify its effectiveness after prospective project construction.

Page 4-59 states that the mitigation measures would "...ensure that noise would not exceed 85 $\mathrm{dB}(\mathrm{A})$ at a distance of $3 \mathrm{ft}$ from equipment." We assume, however, that steam blowouts would exceed such a level (but that steam piping is apparently not included here as "equipment"). However, JEA should consider some "source reduction" or "at-source" noise mitigation of such intrusive noise emissions. Could JEA perhaps devise some enclosure technology to attenuate steam blowout noise?

If steam blowouts and other intrusive noise events cannot be mitigated at the source or otherwise, we agree that at a minimum, proposed public notification of such events should be provided to nearby residents (page 4-58). The FEIS should indicate what form(s) of notification will be provided (e.g., newspapers, fliers, phone calls, etc.) and the expected frequency of such blowouts should be estimated in the FEIS and be included in the notifications. Finally, a noise complaint line should be established by JEA, with JEA responses to reasonable complaints being provided in a timely fashion. Procedural/mitigative modifications should be considered based on these complaints.

Page 4-60 indicates that mitigative measures are predicted to attenuate operational noises to 48 , 50,59 and $57 \mathrm{dBA}$ in the four directions of the proposed project. We assume that these levels are daytime average levels; the FEIS should clarify. We also note that these levels are quite similar to or even less than the ambient levels noted above for the daytime background (55-60 dBA). As such, the attenuated levels (or ambient levels) are somewhat questionable and should be verified in the FEIS. Also, as indicated above, JEA should verify whatever final predictions are made (for mitigated noise levels incorporated in the FEIS) after prospective project construction and use adaptive management to further minimize noise as needed.

\section{Air Quality:}

We note the mention of traffic congestion (pg. 4-56) during construction of the facility. To what extent is this expected to affect local air quality?

\section{Electromagnetic Fields:}

Page 4-61 states that "[t]he majority of customers receiving electricity from the proposed facility would not experience any change in exposure levels due to electromagnetic fields because the fields would be confined to areas along the transmission lines." The FEIS should verify that the widths of the rights-of-way are in compliance with state of Florida law relative to the line voltage transmitted and the breadth of the associated magnetic fields. Will expansion of the ROWs be , required after project construction and operation in order to maintain/achieve compliance? 


\section{Health-based Criteria:}

Health-based criteria for carcinogens, commonly referred to as virtually safe dose, may be used as the action level of a carcinogenic chemical constituent. A virtually safe daily dose of a carcinogenic chemical over a lifetime will result in an incidence of cancer equal to a specified risk level. This corresponds to environmental concentrations that, under case specific intake assumptions, yield a specified excess lifetime cancer risk (e.g., $10^{-6}$ for Class A and B carcinogens). Based on the information provided on page 4-20 under the dioxin and furans sections, it appears as though the cancer risk associated with dioxin, furans and other carcinogenic substances was calculated on a "per year basis." The risk calculations should be reported as the excess carcinogenic risk instead. This should increase the calculated cancer risk documented in this DEIS.

Furthermore, please provide additional information regarding the underlying health-based criteria and any risk levels associated with Florida's Ambient Air Reference Concentrations (FAARCs). 


\section{Letter No. 9}

Heinz J. Mueller, Chief, Office of Environmental Assessment, U.S. Environmental Protection Agency, Region 4, Atlanta Federal Center, 61 Forsyth Street, S.W., Atlanta, Georgia 30303-8960

\section{Comment 9-1:}

"Page 3-56 indicates that ambient levels ranged approximately 41-46 dBA at night and 55-60 dBA during the day. It is unclear, however, if these ambient measurements are in the Leq, L10, L50 or L90 metrics listed as being used (page 3-54). We assume that the Leq descriptor was used for the background noise surveys; however, the FEIS should clarify. We note that the Jacksonville city noise ordinance limits nighttime noise levels at residences to $60 \mathrm{dBA}$."

\section{Response:}

The ambient levels are expressed as Leq. Section 3.9.2 of the EIS text has been modified to reflect this metric.

\section{Comment 9-2:}

"If the Leq metric was used, it is an average level over a given period of time. It should be noted that certain project-related single-event noise levels that are much greater than average levels also occur under ambient conditions such as steam blowout noises and some of the train whistles due to the operation of the existing plant."

\section{Response:}

The information in the comment has been included in Section 3.9.2 of the EIS text.

\section{Comment 9-3:}

"Construction Noise - We appreciate that examples of noisy construction equipment were listed in the DEIS (such as pile drivers) and predictions of their noise attenuations over distance (pages 4-58 and 4-59). The FEIS should clarify if the documented noise attenuation levels were determined by calculation (based on distance from source), by model, or by another method."

\section{Response:}

The documented noise attenuation levels were determined by calculation (based on distance from source) from initial noise levels of construction equipment at $50 \mathrm{ft}$ (EPA 1971). 


\section{Comment 9-4:}

"The expected length of the time of construction should be included in the FEIS in order to gain a perspective of the magnitude of the construction noise."

\section{Response:}

Section 4.1.10.2 of the EIS, which discusses the potential impacts of construction noise, notes that the peak construction period would occur for about 3 months in late 2000 and early 2001 . Section 2.1.4 indicates that JEA has begun initial construction activities at their own risk (without DOE funding). Construction would take approximately two years and, consistent with the original JEA schedule, would be completed in December 2001. Section 2.1.4 also notes that construction crews would probably work five 8-hour days with the option for four 10-hours days, and that construction deliveries would normally be made by truck between 9 a.m. and 3 p.m.

\section{Comment 9-5:}

"Operational Noise - Residents would be affected by intrusive noise levels resulting from steam blowouts and other operations. The FEIS should document the number of such residents affected within the prescribed 0.5 mile radius (what is the basis for selection of a 0.5 -mi radius?)."

\section{Response:}

Because noise attenuates as it propagates from its source, residents within a 0.5 -mile radius would be most affected by intrusive noise levels resulting from steam blowouts and other operations. The number of residents affected within the 0.5 -mile radius would be less than 100 . The general public, including residents affected outside the prescribed 0.5 -mile radius, would be targeted in the public awareness program through newspaper and radio announcements.

\section{Comment 9-6:}

"Since trains, trucks and barges would be used to haul in coal and limestone, the FEIS should estimate the number of residences affected along such routes within a 5-mile radius of the plant. The noise levels at the nearest residences should also be disclosed."

\section{Response:}

The issue of noise impacts resulting from rail traffic was raised at the public scoping meeting. Impacts associated with truck and barge traffic are expected to be measurably less. The distance from the location where the CSX rail line crosses 44th Street (about a mile and a quarter south of the Trout River) to the St. Johns River Power Park is slightly more than 10 miles. Along this route, the planned land use in the vicinity of the rail line is about one-half industrial, one-third 
residential, and one-eighth commercial, with a very small amount of land devoted to public facilities. Of the industrial land-the largest single usage-about three-fifths is dedicated to light industry and the remainder to heavy industry. Nearly all of the residential land is zoned for lowdensity occupation. As mentioned in Section 3.9.1.2 of the EIS, the rail line runs through the residential communities of Panama Park and North Shore and passes along the northern edge of San Mateo.

Section 3.9.1.2 indicates that a total of about 115 one-way trips per week are currently made on the CSX line paralleling U.S. 17 and that there are about 78 one-way trips per week on the spur line that runs from U.S. 17 to the St. Johns River Power Park and Blount Island. Section 4.1.10.1 states that, in the event that all coal for the proposed project would be transported by rail, three additional trains per week (six new one-way trips) would be required. This would increase total movement on the CSX line paralleling U.S. 17 by about $5 \%$ and would increase the spur line traffic by about $8 \%$. However, the decibel-level of the noise would remain the same. As discussed in Section 1.6, a speaker at the public scoping meeting noted that the train passages are routinely punctuated by high-decibel train whistles [which the speaker said he had measured at $108 \mathrm{~dB}(\mathrm{~A})$ at his property line] and loud rattling of the cars themselves [up to $85 \mathrm{~dB}(\mathrm{~A})$ ]. In the more likely event that barges and ships would be the primary means of coal transport, no more than one additional train per week would be required and the relatively small percentage increases in train traffic described above would be substantially reduced.

\section{Comment 9-7:}

"It should also be noted that while barges may have less noise effects than other modes, there could be greater effects for other forms of pollution, such as wetland impacts (unloading dock construction or expansion) and water quality pollution (spills). These impact tradeoffs should be considered and discussed in the FEIS."

\section{Response:}

The EIS discusses potential impacts associated with waterborne delivery of solid fuel and limestone. Section 4.1.5.3 states that disturbance of salt marsh habitats would be negligible during construction of the system for unloading and handling waterborne deliveries. Wetlands associated with the upper salt marsh communities would not be measurably affected because nearly all of the conveyor system for delivery associated with either unloading option would span these habitats using existing structures and would involve no clearing or earthmoving activities. Although some pilings may need to be installed at the upper fringes of the salt marsh and in San Carlos Creek, any impacts resulting from piling installation would be very localized and 
temporary and would not measurably affect the normal structural and functional dynamics of the salt marsh and nearby estuarine ecosystems.

As discussed in Section 4.1.3.2, accidental spills from the proposed facility would be cleaned up in a timely manner in accordance with a spill prevention, control, and countermeasure plan and the best management practices plan for the facility. The rapid cleanup of an accidental overland spill of solid fuel or limestone would minimize runoff into San Carlos Creek or the back channel of the St. Johns River. Two spills have occurred at Northside Generating Station during the unloading of fuel oil shipments. Corrective action was taken to prevent or mitigate further spills. Spills of solid fuel or limestone would be easier to handle and remediate than liquid spills. The transport of fuel or limestone to Northside Generating Station would be the responsibility of the supplier until the vessels dock to unload their cargo. In accordance with the conditions contained in the SLERP issued by the FDEP, JEA would maintain a fuel spill and response plan for fuel unloading activities. In addition, best management practices would be implemented during all fuel unloading operations, including booms for temporary containment around the unloading area and a vacuum/collection system to remove any material inadvertently deposited on the dock. Transfer stations along the conveyor would be equipped with washdown or wet suppression collection and containment systems. The wastewater in these containment systems would be routinely emptied and transported for treatment at the chemical waste treatment facility.

\section{Comment 9-8:}

"Noise Mitigation - We note that some mitigative measures are apparently proposed. These are listed on page 4-59 as 1) installing baffle silencers for fans, 2) enclosing coal and limestone crushers, and 3) installing sound insulation in buildings. This mitigation is intended for compliance with the city ordinance. JEA should commit to such mitigation in the FEIS and verify its effectiveness after prospective project construction."

\section{Response:}

JEA would implement mitigation measures as required to comply with the city of Jacksonville noise ordinance level of $60 \mathrm{~dB}(\mathrm{~A})$ at any residence. Should concerns be raised by nearby residents who question JEA's compliance with the Noise Pollution Control ordinance limits, JEA would verify the effectiveness of the mitigation measures.

\section{Comment 9-9:}

"Page 4-59 states that the mitigation measures would '...ensure that noise would not exceed $85 \mathrm{~dB}(\mathrm{~A})$ at a distance of $3 \mathrm{ft}$ from equipment.' We assume, however, that steam blowouts would 
exceed such a level (but that steam piping is apparently not included here as 'equipment'). However, JEA should consider some 'source reduction' or 'at-source' noise mitigation of such intrusive noise emissions. Could JEA perhaps devise some enclosure technology to attenuate steam blowout noise?"

\section{Response:}

JEA likely would perform continuous, low-pressure, high-velocity steam blowouts. Although this activity would be conducted around the clock, noise levels at the nearest residences should be below levels of concern with this type of blowout that uses low-pressure steam rather than highpressure steam. However, because JEA's steam blowout plan has not been finalized, JEA has committed to installing mufflers if high-pressure steam blowouts are conducted or, if mufflers are not installed, has committed to measuring the noise levels at the nearest residences to ensure that the levels would conform to the Noise Pollution Control ordinance limits (J. A. Leduc, JEA, personal communication to R. L. Miller, ORNL, February 10, 2000). Section 4.1.10.2 of the EIS has been modified to incorporate this information.

\section{Comment 9-10:}

"If steam blowouts and other intrusive noise events cannot be mitigated at the source or otherwise, we agree that at a minimum, proposed public notification of such events should be provided to nearby residents (page 4-58). The FEIS should indicate what form(s) of notification will be provided (e.g., newspapers, fliers, phone calls, etc.) and the expected frequency of such blowouts should be estimated in the FEIS and be included in the notifications. Finally, a noise complaint line should be established by JEA, with JEA responses to reasonable complaints being provided in a timely fashion. Procedural/mitigative modifications should be considered based on these complaints."

\section{Response:}

See response to Comment 9-9, which discusses JEA's options for steam blowouts. If necessary, the awareness program for high-pressure steam blowouts would include public notification through newspaper and radio announcements and phone calls to appropriate emergency response, regulatory, and other governmental agencies. If JEA conducts high-pressure steam blowouts, they would be conducted for up to 10 days for each of the repowered units before start-up, and then would occur for up to several days only once every 5 to 10 years during major plant maintenance outages. A typical sequence would be to conduct several steam blowouts per day for several days during the period; the duration of each steam blowout would be about $3 \mathrm{~min}$ and the interval between blowouts would be no less than $30 \mathrm{~min}$. Section 4.1 .10 .2 of the EIS has been 
modified to include this information. To register a complaint regarding noise levels, residents should contact JEA Customer Service at (904) 632-5200 or toll free at (800) 683-5542.

\section{Comment 9-11:}

"Page 4-60 indicates that mitigative measures are predicted to attenuate operational noises to 48, 50,59 and $57 \mathrm{dBA}$ in the four directions of the proposed project. We assume that these levels are daytime average levels; the FEIS should clarify. We also note that these levels are quite similar to or even less than the ambient levels noted above for the daytime background (55-60 dBA). As such, the attenuated levels (or ambient levels) are somewhat questionable and should be verified in the FEIS. Also, as indicated above, JEA should verify whatever final predictions are made (for mitigated noise levels incorporated in the FEIS) after prospective project construction and use adaptive management to further minimize noise as needed."

\section{Response:}

Because the proposed facility would be used during commercial operation as a baseload unit operating 24 hours per day at the $297.5-\mathrm{MW}$ level for $90 \%$ of the time during the year, noise levels attributable to operation of the facility would be independent of time of day. The estimated levels are similar to and perhaps less than ambient levels because ambient levels are often dominated by other sources of noise, particularly from vehicles. This information has been added to Section 4.1.10.2 of the EIS. See response to Comment 9-8 for a discussion of noise verification by JEA.

\section{Comment 9-12:}

"We note the mention of traffic congestion (pg. 4-56) during construction of the facility. To what extent is this expected to affect local air quality?"

\section{Response:}

As discussed in Section 4.1.2.1, exhaust emissions from workers' vehicles during facility construction, including during periods of traffic congestion, would be very small compared to regulatory thresholds typically used to determine whether further air quality impact analysis is necessary. For example, as discussed in Section 4.1.2.2, although a conformity determination is not required because the precursors of $\mathrm{O}_{3}$ (VOCs and $\mathrm{NO}_{\mathrm{x}}$ ) are evaluated in the PSD permit application, the exhaust emissions from workers' vehicles would be much less than the levels that trigger a conformity determination (i.e., 100 tons per year for VOCs and $\mathrm{NO}_{x}$ in maintenance areas outside an $\mathrm{O}_{3}$ transport region). Duval County is a maintenance area for $\mathrm{O}_{3}$. Similarly, $\mathrm{CO}$ and particulate emissions from workers' vehicles would not be expected to contribute to 
exceedances in ambient air quality standards because current $\mathrm{CO}$ and particulate levels are less than $50 \%$ and $70 \%$ of the standards, respectively (Table 3.2 .1 ).

\section{Comment 9-13:}

"Page 4-61 states that ' $[\mathrm{t}]$ he majority of customers receiving electricity from the proposed facility would not experience any change in exposure levels due to electromagnetic fields because the fields would be confined to areas along the transmission lines.' The FEIS should verify that the widths of the rights-of-way are in compliance with state of Florida law relative to the line voltage transmitted and the breadth of the associated magnetic fields. Will expansion of the ROWs be required after project construction and operation in order to maintain/achieve compliance?"

\section{Response:}

The widths of the existing rights-of-way are in compliance with state of Florida law and were designed in accordance with the applicable standards that applied at the time of construction of the lines. Expansion of the rights-of-way exiting the plant would not be required because the voltage on the lines would not change and any increases in magnetic fields would not exceed maximum values that the lines were originally designed to handle.

\section{Comment 9-14}

"Based on the information provided on page 4-20 under the dioxin and furans sections, it appears as though the cancer risk associated with dioxin, furans and other carcinogenic substances was calculated on a 'per year basis.' The risk calculations should be reported as the excess carcinogenic risk instead. This should increase the calculated cancer risk documented in this DEIS."

\section{Response:}

Cancer risk is consistently discussed in the EIS on a "per year" basis. Because the facility would be designed for a lifetime of 30 years, the risk from a 30-year period of exposure during the lifetime of the facility can be approximated by multiplying each corresponding annual risk by 30 . This statement has been added to Section 4.1.2.2 of the EIS. 


\section{Comment 9-15}

"Furthermore, please provide additional information regarding the underlying health-based criteria and any risk levels associated with Florida's Ambient Air Reference Concentrations (FAARCs)."

\section{Response:}

The FAARCs for each pollutant are derived to minimize health risk to the general population. However, some individuals who are hypersensitive due to a combination of genetic factors, previous exposures, personal habits (e.g., smoking), age, medication, or other factors, may experience effects at concentrations at or below the FAARCs. The health-based criteria for deriving reference concentrations are obtained from professional literature by professional hygienists. For example, for the two elements (beryllium and mercury) considered in detail in the EIS, the 24-hour FAARCs are derived from guideline values developed by the American Conference of Governmental Industrial Hygienists (ACGIH) that are adjusted to apply to the general public, as discussed in Section 4.1.2.2 of the EIS. The following reports provide more detailed information about mercury:

EPA (U.S. Environmental Protection Agency) 1997. Mercury Study Report to Congress, Volume V, Health Effects of Mercury and Mercury Compounds, EPA-452/R-97-007.

EPA (U.S. Environmental Protection Agency) 1996. Study of Hazardous Air Pollutant Emissions from Electric Utility Steam Generating Units--Interim Final Report, EPA-453/R-96-013a-c (3 volumes).

The following report provides more detailed information about beryllium:

EPA (U.S. Environmental Protection Agency) 1987. Health Assessment Document for Beryllium, EPA/600/8-84/026F. 


\section{NORTHSIDE CIVIC ASSOCIATION, INC.}

Post Office Box 26234

Jacksonville, Florida 32226

\section{FAX \\ COVER SHEET}

DATE: 15 October 99

TO: Lisa K. Hollingsworth

FAX NUMBER: $\quad$ (304) $285-4403$

FROM: Val Bostwick, President

Northside Civic Association, Inc.

\# OF PAGES TRANSMITED: 2

SUBJECT: COMMENTS / PUBLIC HEARING

September 30, 1999

JEA Circulating Fluidized Bed Combustor Project

The attached letter raises concerns over the possibility of increased rail traffic. Please review and address the issue raised. Thank you.

Telephone (904) 246-1658 Fax (904) 270-0021 


\section{NORTHSIDE CIVIC ASSOCIATION, INC.}

Post Office Box 26234

Jacksonville, Florida 32226

October 15,1999

\begin{tabular}{|c|} 
Letter No. 10 \\
$\begin{array}{c}\text { Reproduced from } \\
\text { copy submitted }\end{array}$
\end{tabular}

Ms. Lisa K. Hollingsworth

VLA- BAX

Federal Enerey Technology Center

P.O. Box 880

Morgantown, WV 26505

Re: Public Comments/Concerns

Proposed JEA Circulating Fluidized Bed Combustor Project

Dear Ms. Hollingsworth:

In connection with the recent Public Hearing on the Proposed JEA Circulating Fluidized Bed Combustor Project on September 30, 1999, NCA would like to raise the following concern based on a statement made in the "Summary of Expected Environmental Impacts" Transportation Section.

The statement reads "Should economic conditions change, rail traffic could increase by un to 3 additional train deliveries per week, exacertbating some existing community concerns with noise, vibrations, and blocked roads," The last, 'Blocked Roads', is of great concern because existing rall traffic already cuts off neighborhoods from essential services such as Fire \& Rescue when coal deliveries are made to the St. Johns River Power Park and the U.S. Generating/Cedar Bay Facility.

Any possible increase in rail traffic should be carefully examined. JEA has here-to-now, indicated coal deliveries would be made by water. Because of only having one way in, the estimated increase of three (3) trips would equate to six (6) trains because every trip in requires a trip out.

NCA requests your careful review of this issue. We are avallable to meet with you and can provide you with documentation as may be necessary.

cc: Susan Hughes / JEA

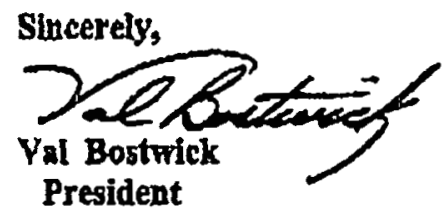




\section{Letter No. 10}

Val Bostwick, President, Northside Civic Association, Inc., P. O. Box 26234, Jacksonville, Florida 32226

\section{Comment 10-1:}

"The statement reads 'Should economic conditions change, rail traffic could increase by up to 3 additional train deliveries per week, exacerbating some existing community concerns with noise, vibrations, and blocked roads.' The last, 'Blocked Roads', is of great concern because existing rail traffic already cuts off neighborhoods from essential services such as Fire \& Rescue when coal deliveries are made to the St. Johns River Power Park and the U.S. Generating/Cedar Bay Facility.

Any possible increase in rail traffic should be carefully examined. JEA has here-to-now, indicated coal deliveries would be made by water. Because of only having one way in, the estimated increase of three (3) trips would equate to six (6) trains because every trip in requires a trip out."

\section{Response:}

Current community concern with blocked roads and other effects of rail traffic is described in Section 1.6, and the phenomenon of road blockage is described in Sections 3.9.1.1 and 4.1.10.1. An explanation that three additional train deliveries would mean an increase of six one-way trips is provided in Section 4.1.10.1. These six additional trips would represent an increase of about $5 \%$ in total movement on the CSX rail line paralleling U.S. 17 and an increase of $8 \%$ on the spur line that runs from U.S. 17 to the St. Johns River Power Park and Blount Island. 


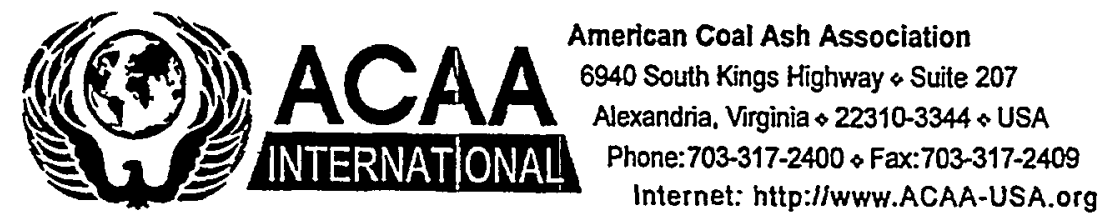

October 15,1999

Ms. Lisa K. Hollingsworth

NEPA Document Manager

Letter No. 11

U.S. Department of Energy

Federal Energy Technology Center

3610 Collins Ferry Road

P.O. Box 880

Morgantown, WV 26507-0880

RE: U.S. Department of Energy (DOE) Draft Environmental Impact Statement (EIS) for the JEA Circulating Fluidized Bed Combustor Project, Jacksonville, Florida [DOE/EIS-0289, August 1999]

Dear Ms. Hollingsworth:

The American Coal Ash Association (ACAA) appreciates the opportunity to review the above referenced document, Draft Environmental Impact Statement (EIS) for the JEA Circulating Fluidized Bed Combustor Project, Jacksonville, Florida [U.S. Department of Energy (DOE), DOE/EIS-0289, August 1999], and is pleased to offer comments.

The EIS indicates that the circulating fluidized bed (CFB) combustion technology to be demonstrated under DOE's Clean Coal Technology Program at Northside Generating Station, a site owned by JEA (former Jacksonville Electric Authority) about nine miles northeast of the downtown area of Jacksonville, Florida. The fuels to be used would be both coal and petroleum coke for generation of 300 megawatts of electricity; and the combustion residues would be some 57,000 tons per year of coal fly ash and 106,000 tons of bottom ash, if coal were used alone for an entire year; and alternatively, if petroleum coke were used alone for an entire year, 109,000 tons of fly ash and 170,000 tons of bottom ash annually.

ACAA's comments focus on managing the combustion residues in ways that are technically sound and environmentally safe, thereby maximizing their potential for use. The positive record for the use of coal combustion products (CCPs), covering more than 30 years, provides positive guidance for developing such uses. Similarly, this record of experience raises cautions against potentially inappropriate uses of such materials. 
Lisa K. Hollingsworth

Page 2 of 6

NEPA Document Manager

RE: DOE/EIS-0289

October 15, 1999

ACAA's comments are presented in the following paragraphs with reference to numbered sections within the subject EIS document.

2.1.7.3 - Solid Waste - Both coal and petroleum coke are to be used during the course of a year. The document states that combustion residues (fly ash and bottom ash) from each fuel source will be collected in silos and subsequently commingled for potential use.

We ask if there is a distinction to be made between the residues from coal and those from the coke, and for varying fuel combinations in between $100 \%$ of either fuel, based on the physical and chemical characteristics of the residues?

Also, if excess material is disposed, either on-site or off-site, will the combustion residues from each fuel be placed in separate areas to allow for the potentially different management practices that may be needed for each of these materials? Such management practices could significantly enhance the marketability of the combustion residues.

Furthermore, if unforseen circumstance develop with respect to the performance of the disposal site, such as occurrences of runoff or movement of leachate, can the contribution of each combustion residue be distinguished?

4.1.7.2 Operation - Combustion Ash Management - As an alternative to the stated plan, the storage cells (I and II) for uncovered ash could be developed concurrently with separate areas for the combustion residues from each of the two fuel sources (and perhaps an area for fuel mixes between the two). The added cost of operating the two sites might be more than offset by revenues from additional marketing opportunities that could be developed.

By capitalizing on the tendency of these CFB combustion residues to selfharden due to hydration reactions, it may be feasible to manufacture certain products such as roadbase material and synthetic aggregates. These products might be stockpiled in the cells and used at later dates, as needed, with the seasonal fluctuations in demand for highway construction and commercial building markets. 
Lisa K. Hollingsworth

Page 3 of 6

NEPA Document Manager

RE: DOE/EIS-0289

October 15, 1999

7. - Regulatory Compliance and Permit Requirements - Opportunities to utilize the CFB combustion residues, in lieu of disposal, should be developed and pursued simultaneously with the review of regulatory compliance and permit requirements. This early action, in harmony with all federal, state and local requirements, will dramatically improve the likelihood of developing successful marketing programs.

The federal government has promoted CCP reuse through a variety of initiatives. In 1983, EPA promulgated the first federal procurement guideline that required agencies using federal funds to implement a preference program favoring the purchase of cement and concrete containing fly ash. 40 C.F.R. Part 249. The EPA endorses the use of pozzolans, such as coal ash, as the preferred method for stabilizing certain metal bearing wastes. 52 Federal Register 29992.

EPA also has published a summary of information pertaining to CCP use in an "environmental fact sheet," Guideline for Purchasing Cement and Concrete Containing Fly Ash [EPA/530-SW-91-086, January 1992]; however, the CFB combustion residues from the JEA project would almost certainly not meet the requirements of this specification.

Similarly, cautions should be raised against the use of the CFB materials in any engineering or manufacturing application where volume stability, either expansion or shrinkage, would be a factor in their successful performance.

Additionally, Executive Order 13101, Greening the Government Through Waste Prevention, Recycling, and Federal Acquisition, signed on September 14, 1998 , directs federal agencies to develop affirmative procurement programs for environmentally preferable products and requires EPA to issue guidance on the principles agencies should use in making determinations for the preference and purchase of environmentally preferable products. Executive Order 13101 supercedes Executive Order 12873 of October 20, 1993.

EPA originally had proposed a Comprehensive Procurement Guideline (CPG), in response to Executive Order 12873, designating items that can be made with recovered materials, including fly ash. 59 Federal Register 18852 (April 20, 1994). The scope of recovered materials encompassed by the CPG has continued to grow in subsequent years. As applications for the CFB 
Lisa K. Hollingsworth

Page 4 of 6

NEPA Document Manager

RE: DOE/EIS-0289

October 15, 1999

combustion residues from the JEA project are developed, they too could be submitted to U.S. EPA for evaluation and possible inclusion in the CPG.

The proximity of the project site to the Jacksonvilie metropolitan area, and its access to the port facilities of the St. Johns River, would be very positive factors in the development of a marketing plan for the CFB combustion residues. There could be substantial local demand for the materials, depending on the actual applications for which they are found to be suitable; and, the distances over which cost-effective shipments of the combustion residues, or products made from them, could be significantly increased.

8. - Irreversible or Irretrievable Commitments of Resources - The fuel and sorbent reduced to unrecoverable forms of waste can be minimized by developing an early plan for their management and use in accordance with the comments presented above.

\section{9. - Relationship Between Short-Term Uses of the Environmental and Long-}

Term Productivity - As stated, the long-term benefit of the proposed project is to demonstrate an environmentally sound and innovative technology for the utilization of coal. The CFB technology is expected to remove up to $98 \%$ of $\mathrm{SO}_{2}$ emissions, reduce $\mathrm{NO}_{x}$ formation by approximately $60 \%$ compared with conventional coal-fired technologies, and remove more than $99 \%$ of particulate emissions. The similar long-term benefit of the project should be to demonstrate environmentally sound and innovative uses for the combustion residues.

In recent comments to U.S. EPA, in response to the Request for Information Concerning Transfrontier Movements of Wastes Destined for Recovery Operations Within the OECD Area [Federal Register, August 17, 1999], ACAA noted that the overall goal of the Basel Convention is to protect human health and the environment against the adverse effects from the generation and management of hazardous wastes and "other wastes." "

'American Coal Ash Association, Comments to U.S. EPA Request for Information Conceming Transfrontier Movements of Wastes Destined for Recovery Operations Within the OECD Area, September 30, 1999, 48 pages, EPA Docket Number F-1999-TMWA-FFFFF. 
Lisa K. Hollingsworth

NEPA Document Manager

RE: DOE/EIS-0289

October 15, 1999

As one of the "other wastes", coal combustion residues that are used in lieu of portland cement, not only in concrete but also in other cementing applications, provide significant environmental benefits that frequently are overlooked. In applications where portland cement can be partially replaced, and in some cases totally replaced, by fly ash, the resulting decrease in $\mathrm{CO}_{2}$ emissions from the avoided manufacture of cement is substantial.

Opportunities for using fly ash to achieve this important environmental benefit were addressed initially by ACAA in a paper published in $1995^{2}$, and in a subsequent paper and report ${ }^{3}$, where the topic was extensively developed.

The cementing applications of fly ash that replace portland cement and avoid $\mathrm{CO}_{2}$ emissions are not limited to fly ash in concrete. Specifically, with respect to EPA's RTC, the use of fly ash in many mining applications, particularly where flowable fill requiring low strengths are required, can eliminate most of all of the cement that would have been used.

10. - References - ACAA is pleased that one of its publications "was found to be useful in the development of the EIS document for the JEA project. The ACAA document is a collection of five papers that were presented at a regional workshop sponsored by ACAA in Minneapolis/St. Paul in July 1997.

2 "Climate Change and New Opportunities for Coal Combustion Byproducts", Published in Proceedings of the $11^{\text {th }}$ International Symposium on Management and Use of Coal Combustion Byproducts, American Coal Ash Association, January 1995, 15 pages.

${ }^{3}$ Increased Fly Ash Use Under the Climate Challenge Program: A Summary of Participation Accords Between the Electric Utilities and the U.S. Department of Energy, American Coal Ash Association, Prepared by: Daniel E. Klein, Twenty-First Strategies, L.L.C., March 1996, 52 pages (including appendices).

${ }^{4}$ Workshop on Management and Use of Coal Combustion Products, American Coal Ash Association, Minneapolis/St. Paul, July 15, 1997 (Collection of five papers presented at the workshop). 
Lisa K. Hollingsworth

Page 6 of 6

NEPA Document Manager

RE: DOE/EIS-0289

October 15, 1999

The method used in citing the ACAA reference in section 4.1.7.2

Operation - Combustion Ash Management of the EIS document may give the impression that the nationwide survey of CFB ash and its variety of applications was conducted by ACAA; however, that survey was conducted by the Council of Industrial Boiler Owners (CIBO), a cosponsor of the July 1997 workshop. The survey of CFB ash was described in a paper ${ }^{5}$ that was presented at the ACAA workshop and that paper subsequently was included in the ACAA publication ${ }^{4}$ that was cited in the EIS document.

Similarly, the EIS document appears to attribute the following statement to ACAA: "Data obtained nationwide with regard to leachability and toxicity of CFB ash indicates that none of more than 450 sample analyses exceeded regulatory thresholds." This information also came from the paper ${ }^{5}$ presented at ACAA's July 1997 workshop, which subsequently was published by ACAA 4 .

Respectfully submitted,

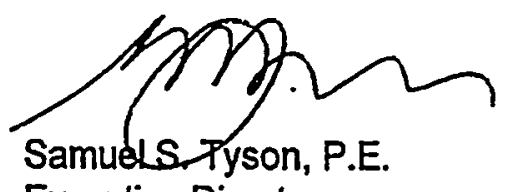

Executive Director

s Svendsen and Bessette, The Council of Industrial Boiler Owners Special Project on Non-Utility Fossil Fuel Ash Classification, 13 pages, Proceedings: Workshop on Management and Use of Coal Combustion Products (CCPs), Minneapolis/St. Paul, American Coal Ash Association, July 15, 1999. 


\section{Letter No. 11}

Samuel S. Tyson, P.E., Executive Director, American Coal Ash Association, 6940 South Kings Highway, Suite 207, Alexandria, Virginia 22310-3344

\section{Comment 11-1:}

"We ask if there is a distinction to be made between the residues from coal and those from the coke, and for varying fuel combinations in between $100 \%$ of either fuel, based on the physical and chemical characteristics of the residues?"

\section{Response:}

No distinction would be made between residues from coal and those from petroleum coke. Ash from coal and petroleum coke would be commingled in the ash storage area, in accordance with the fill sequence established in the Class I landfill permit currently under review by the state of Florida. Characteristics of the commingled ash would be considered during its marketing.

\section{Comment 11-2:}

"Also, if excess material is disposed, either on-site or off-site, will the combustion residues from each fuel be placed in separate areas to allow for the potentially different management practices that may be needed for each of these materials? Such management practices could significantly enhance the marketability of the combustion residues."

\section{Response:}

Residues generated from the combustion of coal and petroleum coke would be commingled and stored initially in cell I of the ash storage area. Ash would require EPA-approved certification that it is nonhazardous before it would be accepted for disposal. JEA would consider segregating the ash should it become necessary for its marketing and sale.

\section{Comment 11-3:}

"Furthermore, if unforseen circumstance [sic] develop with respect to the performance of the disposal site, such as occurrences of runoff or movement of leachate, can the contribution of each combustion residue be distinguished?"

\section{Response:}

The ash storage area is being permitted based on the requirements for Class I landfills in the state of Florida. The runoff and leachate collection system is designed to accommodate the 25 -year, 
24-hour storm event. Runoff and leachate collected in this system would be discharged to the onsite chemical waste treatment system and commingled with other wastewater streams generated on the site. Therefore, the contribution of each combustion residue would not be distinguishable. However, groundwater and surface water monitoring would be implemented to ensure continued proper operation of the permitted systems.

\section{Comment 11-4:}

"4.1.7.2 Operation - Combustion Ash Management - As an alternative to the stated plan, the storage cells (I and II) for uncovered ash could be developed concurrently with separate areas for the combustion residues from each of the two fuel sources (and perhaps an area for fuel mixes between the two). The added cost of operating the two sites might be more than offset by revenues from additional marketing opportunities that could be developed."

\section{Response:}

It is JEA's intention to develop cell I alone for ash storage. By implementing an aggressive marketing program for this commingled residue, JEA intends to be able to prevent development of cell II. Cell II would only be developed if additional storage space is required or if marketing dictates that the ash should be stored separately.'

\section{Comment 11-5:}

"By capitalizing on the tendency of these CFB combustion residues to self-harden due to hydration reactions, it may be feasible to manufacture certain products such as roadbase material and synthetic aggregates. These products might be stockpiled in the cells and used at later dates, as needed, with the seasonal fluctuations in demand for highway construction and commercial building markets."

\section{Response:}

Opportunities including those described are being considered by JEA.

\section{Comment 11-6:}

"7.-Regulatory Compliance and Permit Requirements - Opportunities to utilize the CFB combustion residues, in lieu of disposal, should be developed and pursued simultaneously with the review of regulatory compliance and permit requirements. This early action, in harmony with all federal, state and local requirements, will dramatically improve the likelihood of developing successful marketing programs." 


\section{Response:}

Opportunities to utilize the ash, in lieu of disposal, are being developed by JEA concurrently with the state of Florida's review of the Class I landfill permit for the ash storage area. JEA intends to pursue these opportunities upon selection of the contractor to manage the ash storage area and market the ash.

\section{Comment 11-7:}

"Similarly, cautions should be raised against the use of the CFB materials in any engineering or manufacturing application where volume stability, either expansion or shrinkage, would be a factor in their successful performance."

\section{Response:}

JEA intends to consider these concerns during research conducted by the selected marketing firm to determine suitable applications for the ash.

\section{Comment 11-8:}

"The similar long-term benefit of the project should be to demonstrate environmentally sound and innovative uses for the combustion residues."

\section{Response:}

DOE agrees that a long-term benefit of the proposed project is to demonstrate environmentally sound and innovative uses for the combustion ash. Section 9 of the EIS states that, unlike with many conventional technologies, the combustion ash from the proposed project is suitable for beneficial uses such as road construction material, agricultural fertilizer, and reclaiming surface mining areas.

\section{Comment 11-9:}

"The method used in citing the ACAA reference in section 4.1.7.2 Operation - Combustion Ash Management of the EIS document may give the impression that the nationwide survey of CFB ash and its variety of applications was conducted by ACAA; however, that survey was conducted by the Council of Industrial Boiler Owners (CIBO), a cosponsor of the July 1997 workshop. The survey of CFB ash was described in a paper ${ }^{5}$ that was presented at the ACAA workshop and that paper subsequently was included in the ACAA publication ${ }^{4}$ that was cited in the EIS document. 
Similarly, the EIS document appears to attribute the following statement to ACAA: 'Data obtained nationwide with regard to leachability and toxicity of CFB ash indicates that none of more than 450 sample analyses exceeded regulatory thresholds.' This information also came from the paper ${ }^{5}$ presented at ACAA's July 1997 workshop, which subsequently was published by ACAA $^{4}$."

\section{Response:}

In both cases, Section 4.1.7.2 of the EIS text has been modified to indicate the correct citation. 
Mr. Lloyd Lorenzi

U.S. Department of Energy

Federai Energy Tecinnology Center

3610 Coilins Ferry Road

Morgantown, West Virginia 26507-0880

RE: J.S. Department of Energy - Draft Environmental Impact Statement (EIS) for JEA (formerly Jacksonville Electric Authority) Circulating Fluidized Bed Combustor Project - Jacksonville, Duval County, Florida SAI： EI9710020730CR

Dear Mr. Lorenzi:

The Florida State Clearinghouse, pursuant to Presidential Executive order 12372, Gubernatorial Executive order 95-359, the Coastal Zone Management Act, 16 U.S.C. \$\$ 1451-1464, as amended, and the National Environmental Policy Act, 42 U.S.C. \$\$ 4321, $4331-4335,4341-4347$, as amended, has coordinated a review of the above-referenced project.

The Department of Environmental Protection (DEP) indicates that permits will be required prior to the start of construction. Early coorainarion with DEP may help to eijminate problems in the permitting process. Please refer to the enclosed DEP comments.

The Department of Transportation (DOT) notes that the propcsed project may directly impact the State Transportation system. The applicant should submit all site plans and access plans to the DOT's Jacksonville Urban office in order to secure the proper permits. A re-evaluation of the project will be conducted during the environmental documentation or permitting stage. Please refer to the enclosed DOT corments.

The Department of State (DOS) notes that the proposed project will have a cultural resource survey performed. Provided

2555 SHUMARD OAKBOULEVARD - TALLAHASSEE, FLORIDA $32399-2100$

Phone: (850) 488-8466/Suncom 278.8466 FAX: (850)921-0781/Suncom 291-0781 Internet address: hitp://www.state.fl.us/comalf/

Foridex kers Ares of Cihcal sule Coroem fietd ontice $27 \%$ Oversers Highwory, Suite 212
Masation. Floxida 33050-2227 
Mr. Lloyd Lorenzi

November 15,1999

Page Two

that the applicant completes the survey and appropriately avoids, minimizes, or mitigates impacts to any significant archaeological or historic sites identified in the survey, the above project will have no adverse effect. Please refer to the enclosed DOS comments.

Based on the information contained in the draft environmental impact statement and the applicant's satisfactory compliance with all conditions stipulated by the Dos, as enclosed, the state has determined that the above-referenced project is consistent with the Florida Coastal Management Program. Enclosed are all comments received to date from our reviewing agencies. Comments subsequently received by the state clearinghouse will be forwarded for your review and consideration.

Thank you for the opportunity to review the environmental impact statement. If you have any questions regarding this letter, please contact Ms. Cherie Trainor, Clearinghouse Coordinator, at (850) 414-5495.

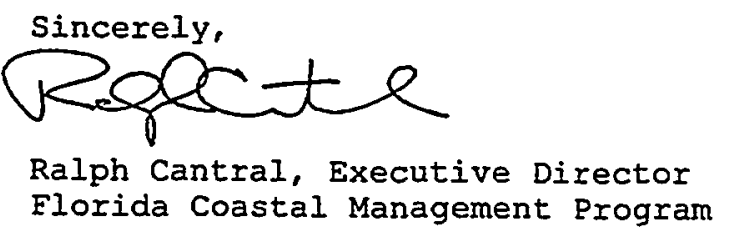

$\mathrm{RC} / \mathrm{CC}$

\section{Enclosures}

cc: April Williford, Department of Environmental Protection P. Ward Swisher, Department of Transportation

Janet Snyder Matthews, Department of State 
COUNTY: Duval

Message:
DATE:

COMENTS DUE-2 FTS:

CLSARANCE DUE DATE:

SAIH:
$08 / 26 / 1999$

$09 / 09 / 1999$

$10 / 11 / 1999$

FL $9710020730 \mathrm{CR}$

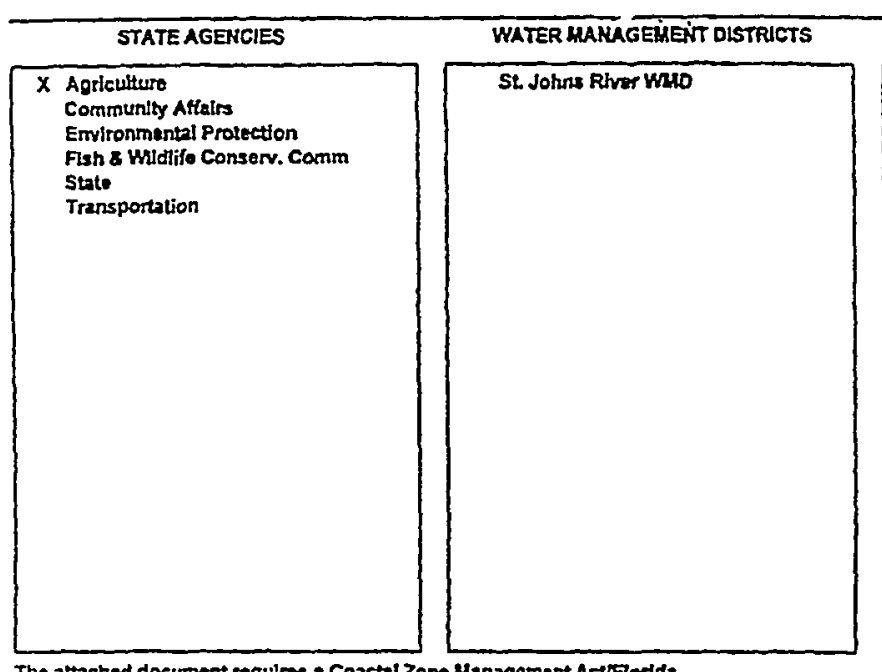

The athehad document requires a Coastat Zorn Mamagement Aceflorida Coastal Management Program consisteney svalutation and is eotogorized as one of the following:

Fedoral husistanco to State or Local Government (15 CFR \$30, Subpast f).

- Agencies are required to evaluale the consistancy of tho activity.

$x$ Diroct Foderal Acttrly (15 CFR 930, Subpert C). Fodera A Aeneies an requind to furnish a condatency deternination for the State's concurrence ot abjector

Outar Continantal Shall Exploration, Devilopment of Production

- Aetivities (15 CFR 930, Subpart E). Operators ane required to provido a consistency cortfication for state concurrencelobjectlor.

Federal Licensing or Permilting Actlity (15 CFR 930, Subpart O). Sueh projects will onty be ovaluatod for consisteney when thare is not an ariogous tate licanse or purmit.

\section{Project Description:}

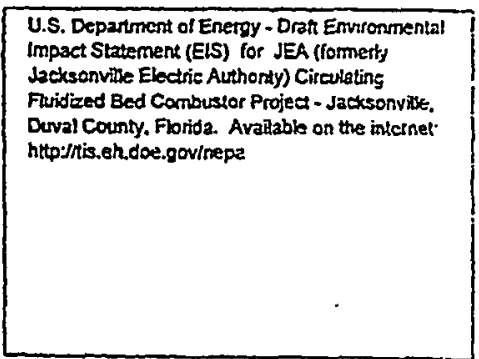

U.S. Department of Energy - Drat Envronmental impact Statement (ELS) for JEA (formerts zexsonvitie Electrie Authorty) Cireriating

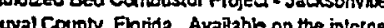
hitoj/tis.ehodoe.gov/sepa
To: Florida State Cloaringhouse Department of Community Affairs 2555 Shumard Oak Boulevard Tallahassee, FL 32399-2100 (850) $922-5438$ (SC 292-5438) (850) 414-0479 (FAX)

\section{EO. 12372 NEPA

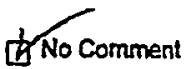 \\ $\square$ Comments Attached \\ $\square$ Not Applicable}

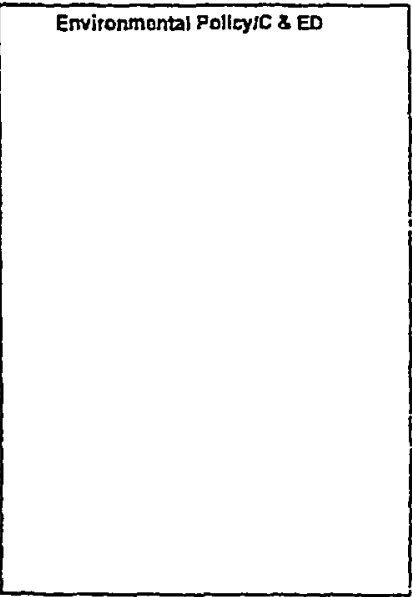

Division of Forestry
Forest Resoure Planning
\& Support Senices Bureau
3125 Conner Btvd., Main Stop C23
Tallahassee, FL 32399-1650
Division/Bureau:
Reviewer:




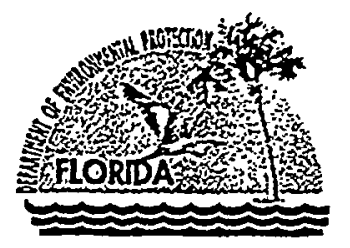

\section{Department of Environmental Protection}

Marjory Stoneman Douglas Building
3900 Commonwealth Boulevard 3900 Commonwealth Boulevard

Tallahassee, Florida 32399-3000

October 1, 1999
David B. Struhs

Secreany

Cherie Trainor

State Clearinghouse

Department of Cormmunity Affairs

2555 Shumard Oak Boulevard

Tallahassee, Florida 32399-2100

RE: DOE/Draft EIS for the JEA Circulating Fluidized Bed Combustor Project in Jacksonville, Duval County

SAI: FL9710020730CR

Dear Ms. Trainor:

The Department of Environmental Protection has reviewed the above-referenced Draft Environmental Impact Statement for the JEA Circulating Fluidized Bed Combustor Project. Based on the information provided, the Department finds the proposed project to be consistent with its statutory authorities in the Florida Coastal Management Program, provided all necessary permits are oblained prior to construction activities.

We appreciate the opportunity to provide comments on the proposed project. If you have any questions or require additional information, please contact me at (850) 487-2231 or SunCom 277-2231.

Sincerely,

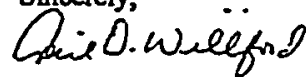

April D. Williford

Office of Intergovernmental Programs

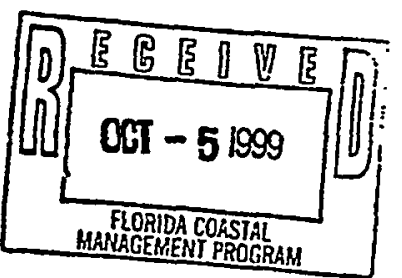

"Proteca, Conserve and Manoge Forida's Envisorment and Naturol Resources"

Printed an recosed poper. 
DIVISIONS OF FLORIDA DEPARTMENT OF STATE

Olfixe o the Secresing

Olfeer hesendions Relations

Divienn af Extions

Divioin of Culturel A ItLi

Division of Historiel Roowres

Division of Litraty and hromstion Service

Drvistor of Liemesing

Division of Administrative Servize:

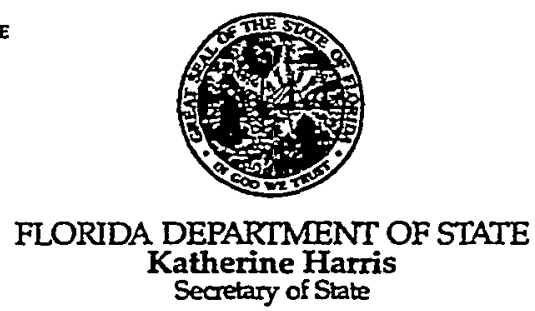

DIVISION OF HISTORICAL RESOURCES
MEMBER OF THE FLORIDA CABINET

Serse Bowrs of Edvation

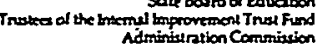

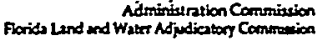
Divtion of Bond Finents

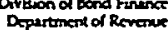

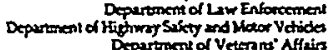
Depras

Ms. Cherie Trainor

State Clearinghouse

November 3. 1999

Department of Community Affairs

2555 Shumard Oak Boulevard

Tallahassee, Florida 32399-2100

RE: DHR Project File No. 997940

SAI\# FL9710020730CR

Draft Environmental Impact Statement (DEIS) for the

JEA Circulating Fluidized Bed Combustor Project

Jacksonville, Duval County, Florida

Dear Ms. Trainor:

In accordance with the provisions of Florida's Coastal Zone Management Act and Chapter 267,

Florida Statutes, as well as the procedures contained in 36 C.F.R, Part 800 ("Protection of

Historic Properties"), we have reviewed the referenced project for possible impact to historic properties listed, or eligible for listing, in the National Register of Historic Places, or otherwise of historic or architectural value.

We have reviewed the referenced draft environmental impact statement. We specifically reviewed sections 3.7 and 4.1.8, both dealing with Cultural Resources. We note that the project will have a cultural resource survey performed. The resultant survey report shall conform to the specifications set forth in Chapter 1A-46, Florida Administrative Code, and will need to be forwarded to this agency in order to complete the process of reviewing the impact of this proposed project on historic properties. Therefore, conditioned upon the JEA undertaking a cuitural resource survey, and appropriately avoiding minimizing or mitigating project impacts to any identified significant archaeological or historic sites, the proposed project will have no effect on historic properties listed, or eligible for listing, in the National Register, or otherwise of historical or architectural value.

If you have any questions concerning our comments, please contact Scott Edwards, Historic Preservation Planner, at 850-487-2333 or 800-847-7278. Your interest in protecting Florida's historic properties is appreciated.

Sincerely,

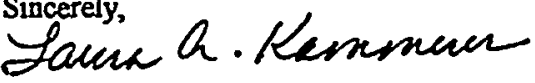

fre Janet Synder Matthews, Ph.D. State Historic Preservation Officer

\section{JSM/Ese}

xc: Jasmin Raffington, FCMP-DCA

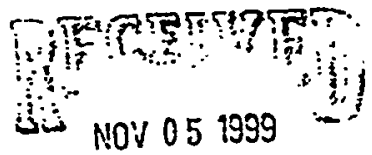

\section{Siate of Florida Clearinghouse}

R.A. Gray Building - 500 South Bronough Street - Tallahassee, Flofida 323990250 - http://www Aheritagecom (850) $488-1450$ - FN $x_{i} 483-3355$

O Archatological Research

Histarie Pensacola Praxervation Bond

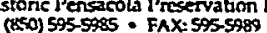

A Palm Bcach Regional Office

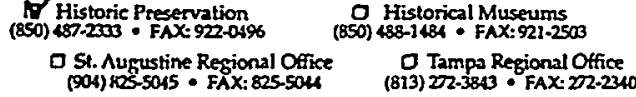




\section{T) \\ Florida Department of Transportation \\ 12007002007}

JEB BUSH
GOVERNOR

P.O. Box 1089

Lake City, FI 32056-1089

September 2, 1999

Ms. Cherie Trainor

Florida State Clearinghouse

Department of Community Affairs

2255 Shumand Oak BIvd.

Tallahassee, F1 32399-2100

THOMAS F. BARRY, JR SECRETARY

Subject: $\quad$ SAI NO. FL9710020730CR

JEA

Dear Ms. Trainor:

Based on the information provided, we find that the subject project may have a direct impact on the State Transportation System. It is requested that the applicant submit all site plans and access plans to Mrs. Carol Wright, Jecksonville Permit Engineer, Jacksonville Uban Office, Post Office Box6669, Jacksonville, Florida 32236-6669 Telephone (904) 360-5433 in order to secure proper permits. The project has been reviewed under Presidential Executive Order 12372 and the Florida Coastal Zone Management Program for consistency for the following:

- Florida Transportation Plan, modal systems and work program plans directly related to this project.

- Level of Service Standards

- Access Management Standards

- Right-of-way costs and advanced acquisition

- Intergovemmental coordination

- Chapters 334 and 338, Laws of Florida

Are-evaluation of this project will be conducted during the environmental documentation orpermitting stage, as required. Future consistency of this project will be dependent upon the proper consideration of our comments offered in this and subsequent reviews.

www.dot.state.fl.us 


\section{JEA EIS}

If you have any questions regarding this response, please contact me at SC 881-3678.

Sincerely,

Survatsurthen

P. Ward Swisher

Asst. Transportation Statistics Administrator

cc: Aage Schroder

Sandra Whitmire

Carol Wright

Tom Dyal

99-069.ws 


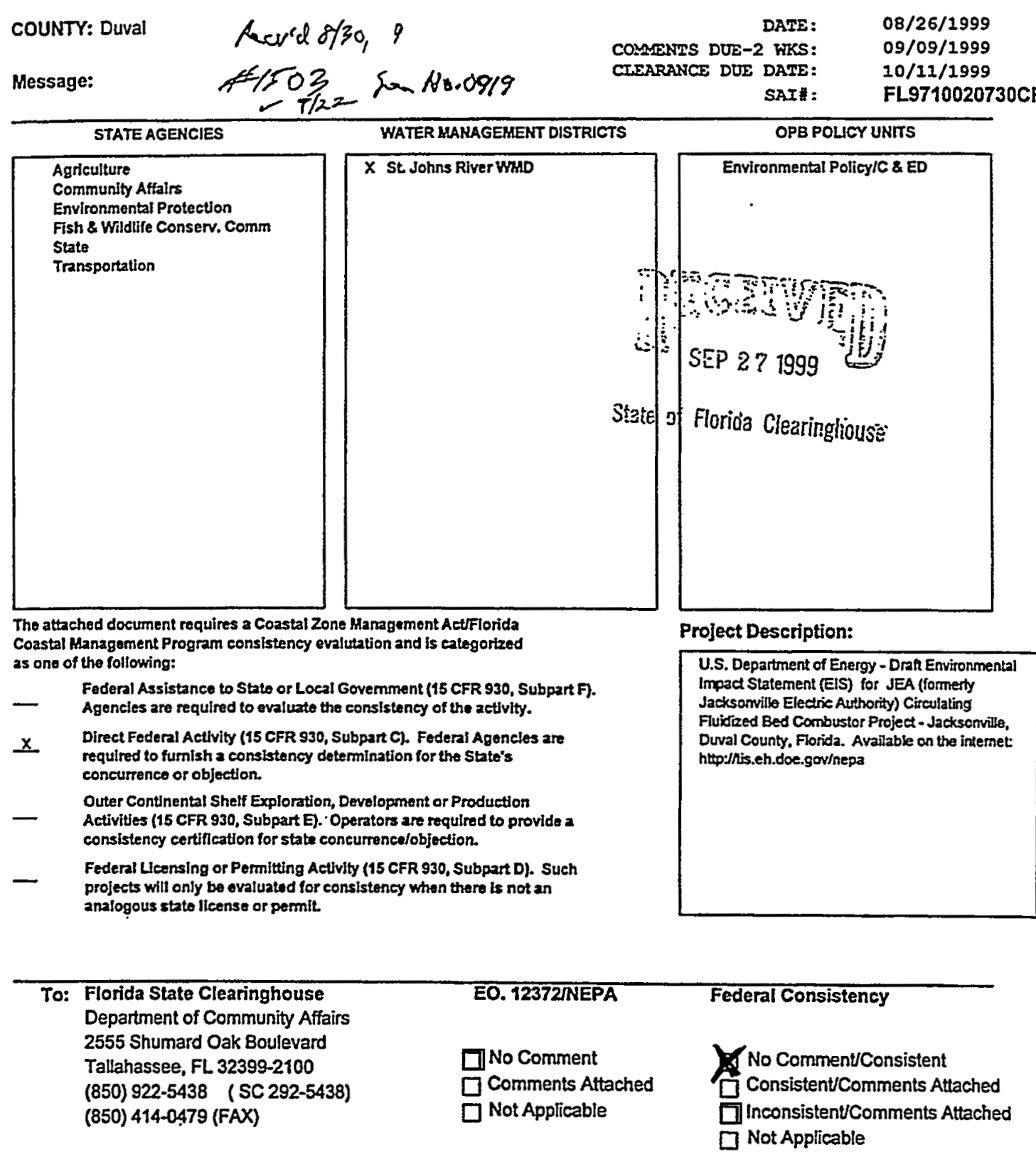

From:

Division/Bureau: SURWMD /OPP

Reviewer. Mspoxtre $9 / 22 \% 99$

Date: 
COUNTY: Duval

Message:
JATE:

COMENTS DUE- $\alpha$ WKS:

CLEARANCE DUE DATE:

SAI" :
$08 / 26 / 1999$

$09 / 09 / 1999$

$10 / 11 / 1999$

FL.9710020730CR

\begin{tabular}{|l|l|}
\hline \multicolumn{1}{|c|}{ STATE AGENCIES } & WATER MLANAGEMENT DISTRICTS \\
\hline $\begin{array}{l}\text { Agriculture } \\
\text { Community Aftalrs } \\
\text { Environmental Protection } \\
\text { Fish \& Whdtife Conserv. Comm River WMD } \\
\text { State } \\
\text { Transportation }\end{array}$ & \\
\hline
\end{tabular}

The altached document requires a Coxstal Zone Kanagement Act/Florida Coastal Management Program conslstency evalutation and is catogorized as one of the following:

Federal Assistance to State or Local Govemment (15 CFR 930, Subpart F). Agencies are required to evaluate the consistency of the activity.

$x$ Direct Federal Activity (15 CFR 930, Subpart C). Federal Agencies aro required to furnish a consistency determination for the State's concurrence or objection.

Outer Continental Shelf Exploration, Dovelopment or Production Activities (15 CFR 930, Subpart E). Operators are required to provide a consistency cartfication for state concurrencelobjection.

Federal Licensing or Permitting Activity (15 CFR 930, Subpart D). Such projects will only be evaluated for consistoncy when there is not an analogous state license or permit.

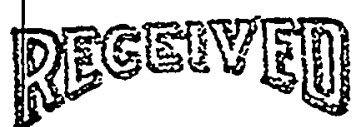

AUG 50 icra

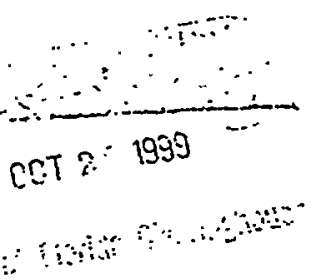

\section{Project Description:}

U.S. Department of Energy - Draft Environmenta Impact Statement (EIS) for JEA (formenty Jacksonville Electric Authority) Circulating Fluidized Bed Combustor Project - Jacksonvilte. Duval County, Florida. Available on the inteme: http:/his.eh.doe.gov/nepa

From:

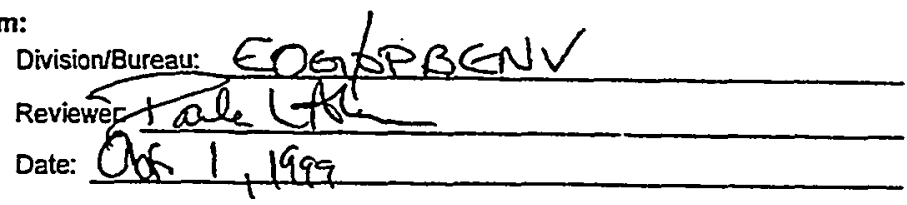




\section{Letter No. 12}

Ralph Cantral, Executive Director, Florida Coastal Management Program, State of Florida

Department of Community Affairs, 2555 Shumard Oak Boulevard, Tallahassee, Florida 32399-2100

\section{Comment 12-1:}

"Based on the information provided, the Department finds the proposed project to be consistent with its statutory authorities in the Florida Coastal Management Program, provided all necessary permits are obtained prior to construction activities."

\section{Response:}

All necessary permits for the proposed project would be obtained as required by the permitting agencies.

\section{Comment 12-2:}

"We note that the project will have a cultural resource survey performed. The resultant survey report shall conform to the specifications set forth in Chapter 1A-46, Florida Administrative Code, and will need to be forwarded to this agency in order to complete the process of reviewing the impact of this proposed project on historic properties."

\section{Response:}

See response to Comment 6-1.

\section{Comment 12-3:}

"Based on the information provided, we find that the subject project may have a direct impact on the State Transportation System. It is requested that the applicant submit all site plans and access plans to Mrs. Carol Wright, Jacksonville Permit Engineer, Jacksonville Urban Office, Post Office Box 6669, Jacksonville, Florida 32236-6669 Telephone (904) 360-5433 in order to secure proper permits."

\section{Response:}

This comment was based on the assumption that there would be construction associated with the proposed project on Heckscher Drive, which is a state road. JEA has contacted Carol Wright to discuss this concern and both parties agree that, because project-related construction would not occur along Heckscher Drive and because the only access for construction personnel would be located at the New Berlin Road entrance to the facility, JEA is not required to submit site plans 


\section{JEA EIS}

and access plans for the proposed project to the Florida Department of Transportation (C. A. Wright, Florida Department of Transportation, personal communication to J. A. Leduc, JEA, January 7, 2000). 